\title{
De omwenteling die niet kwam: verkenning van het bestuursbeleid bij het ministerie van Binnenlandse Zaken, 1969-2009
}

Citation for published version (APA):

Schrijver, J. F. (2015). De omwenteling die niet kwam: verkenning van het bestuursbeleid bij het ministerie van Binnenlandse Zaken, 1969-2009. [Doctoral Thesis, Maastricht University]. Boom. https://doi.org/10.26481/dis.20150408js

Document status and date:

Published: 01/01/2015

DOI:

10.26481/dis.20150408js

Document Version:

Publisher's PDF, also known as Version of record

Please check the document version of this publication:

- A submitted manuscript is the version of the article upon submission and before peer-review. There can be important differences between the submitted version and the official published version of record.

People interested in the research are advised to contact the author for the final version of the publication, or visit the DOI to the publisher's website.

- The final author version and the galley proof are versions of the publication after peer review.

- The final published version features the final layout of the paper including the volume, issue and page numbers.

Link to publication

\footnotetext{
General rights rights.

- You may freely distribute the URL identifying the publication in the public portal. please follow below link for the End User Agreement:

www.umlib.nl/taverne-license

Take down policy

If you believe that this document breaches copyright please contact us at:

repository@maastrichtuniversity.nl

providing details and we will investigate your claim.
}

Copyright and moral rights for the publications made accessible in the public portal are retained by the authors and/or other copyright owners and it is a condition of accessing publications that users recognise and abide by the legal requirements associated with these

- Users may download and print one copy of any publication from the public portal for the purpose of private study or research.

- You may not further distribute the material or use it for any profit-making activity or commercial gain

If the publication is distributed under the terms of Article $25 \mathrm{fa}$ of the Dutch Copyright Act, indicated by the "Taverne" license above, 
De omwenteling die niet kwam 


\title{
De omwenteling die niet kwam
}

\author{
Verkenning van het bestuursbeleid \\ bij het ministerie van Binnenlandse Zaken \\ 1969-2009
}

Jan Schrijver

Boom Lemma uitgevers

Den Haag

2015 
Foto omslag: Het kantoorgebouw aan de Schedeldoekshaven in Den Haag, waar het ministerie van Binnenlandse Zaken tussen 1978 en 2013 zetelde.

(ㅇ) 2015 J.F. (Jan) Schrijver | Boom Lemma uitgevers

Behoudens de in of krachtens de Auteurswet gestelde uitzonderingen mag niets uit deze uitgave worden verveelvoudigd, opgeslagen in een geautomatiseerd gegevens- bestand, of openbaar gemaakt, in enige vorm of op enige wijze, hetzij elektronisch, mechanisch, door fotokopieën, opnamen of enige andere manier, zonder voorafgaande schriftelijke toestemming van de uitgever.

Voor zover het maken van reprografische vervee/voudigingen uit deze uitgave is toegestaan op grond van artikel $16 \mathrm{~h}$ Auteurswet dient men de daarvoor wettelijk verschuldigde vergoedingen te voldoen aan de Stichting Reprorecht (Postbus 3051, 2130 KB Hoofddorp, www.reprorecht.nl). Voor het overnemen van (een) gedeelte(n) uit deze uit- gave in bloemlezingen, readers en andere compilatiewerken (art. 16 Auteurswet) kan men zich wenden tot de Stichting PRO (Stichting Publicatie- en Reproductierechten Organisatie, Postbus 3060, 2130 KB Hoofddorp, www.cedar.nl/pro).

No part of this book may be reproduced in any form, by print, photoprint, microfilm or any other means without written permission from the publisher.

ISBN 978-94-6236-534-6

NUR 80

www.boomlemma.nl 


\title{
De omwenteling
}

\section{die niet kwam}

Verkenning van het bestuursbeleid

bij het ministerie van Binnenlandse Zaken

1969-2009

\section{PROEFSCHRIFT}

ter verkrijging van de graad van doctor aan de Universiteit Maastricht op gezag van de Rector Magnificus prof. dr. L.L.G. Soete, volgens het besluit van het College van Decanen in het openbaar te verdedigen

\author{
op 2015 \\ om uur \\ door \\ Jan Frans Schrijver
}




\section{Promotor}

Prof. dr. A.F.A. Korsten (Universiteit Maastricht/Open Universiteit)

Leden beoordelingscommissie

Prof. dr. K. Peters (voorzitter)

Prof. dr. H.M.J. van den Bosch (Open Universiteit)

Prof. dr. F. Fleurke (Vrije Universiteit)

Prof. dr. P. Glasbergen (Universiteit Utrecht/Universiteit Maastricht)

Prof. dr. B.J.S. Hoetjes 


\section{Voorwoord}

$\mathrm{Na} 25$ jaar beleidsambtenaar te zijn geweest bij Binnenlandse Zaken ${ }^{1}$ werd ik gedetacheerd bij het interdepartementale Expertisebureau voor Innovatieve Beleidsvorming XPIN. ${ }^{2}$ Dat bood mij de gelegenheid om verschillende nieuwe benaderingen van het openbaar bestuur en de verhouding met de samenleving te bestuderen. Dat thema boeide me al jaren, ook toen ik nog 'in het vooronder' zat voor het bestuursbeleid dat zich richtte op de interbestuurlijke betrekkingen tussen ministeries, gemeenten en provincies. Na XPIN gaf directeur-generaal Leon van Halder mij een functie die me in staat stelde om mijn kennis te verdiepen als Verkenner van Governance.

Met steun van prof. Maarten Hajer kon ik een deel van mijn werktijd besteden aan een gastdocentschap en -onderzoek bij de Universiteit van Amsterdam. Daar heb ik werkcolleges gegeven, scripties begeleid, contacten gelegd tussen de universiteit en de rijksoverheid en eigen onderzoek kunnen doen.

Gedurende mijn loopbaan heb ik herhaaldelijk gelegenheid gezocht om te reflecteren op de ontwikkelingen in het openbaar bestuur. Via publicaties in vakbladen verkende ik in de jaren tachtig vooral mechanismen die de balans tussen centralisatie en decentralisatie beïnvloeden (Schrijver 1980, 1983, 1984, 1985, 1986, 1987, 1989, 1990, 1991). Sinds de jaren negentig reflecteerde ik op de verhouding tussen overheid en samenleving, eerst nog nadruk leggend op de afhankelijkheidsrelaties binnen de overheid, na 2000 vooral daarbuiten. In een artikel over besluitvorming in een innovatief project (Schrijver, 1992) verbaasde ik me, terugblikkend op het zogeheten D'project, over de rol van het toeval en over de problemen die ontstaan door de botsing van 'sturingsinstrumenten van de tweede generatie' (netwerksturing) met de klassieke sturingsinstrumenten (wetgeving). Een ander artikel in hetzelfde blad Openbaar Bestuur (Schrijver, 1998) gaat in op paradoxale tendensen in de besluitvormingsprocessen, de organisatie en de verhouding met de samenleving, die de overheid en de volksvertegenwoordiging dwingen per geval op maat procesmanagement toe te passen om in het complexe speelveld van vele participanten resultaten te kunnen boeken. In een hoofdstuk voor het 'Handboek voor

Overheidsmanagement' (Lemstra cum suis, 1996) beschreef ik de relaties tussen de overheden als een resultante van de keuzen in vijf spanningsvelden: de perceptie van de maatschappelijke opgave, de taakverdeling tussen bestuurseenheden, de keuze van sturingsinstrumenten, de inrichting en toerusting van de organisatie met oog op zelfregulerend vermogen en de manier waarop informatievoorziening en feedback zijn georganiseerd. Sinds 2000 gaan mijn publicaties vrijwel uitsluitend over de verhouding met de burger en participatieve vormen van democratie (Schrijver et al. 2002, 2005, 2008, 2010).

In dit boek vraag ik me af hoe het ministerie van Binnenlandse Zaken, de organisatie waar ik al die tijd heb gewerkt, reageerde op zijn omgeving. Is er over een lange waarnemingsperiode van circa veertig jaar bestuursbeleid een uitspraak te doen over een eigensoortige benadering van het eigen

\footnotetext{
${ }^{1}$ Hoewel het ministerie op 3 augustus 1998 naamsuitbreiding heeft gekregen door de toevoeging van Koninkrijksrelaties, gebruik ik in dit boek consequent de toepasselijke aanduiding Binnenlandse Zaken.

2 Het Expertisebureau voor Innovatieve Beleidsvorming (2001-2005) was een kenniscentrum voor de publieke sector en is ontstaan uit de behoefte om kennis en ervaring over de gevarieerde praktijk met betrekking tot innovatieve beleidsvorming te bundelen, verbindingen te maken tussen kennis en organisaties en deze kennis te laten stromen naar de gehele overheidsorganisatie. XPIN is ingesteld door het beraad van Secretarissen-generaal van alle departementen. XPIN had tot doel: verzamelen, verwerven en verspreiden van kennis over best practices, verbinding tot stand brengen en samenwerking bevorderen tussen bestuurders en ambtenaren en betrokkenen bij innovatieve beleidsvorming, kennis verzamelen en geconsolideerd inzicht verwerven. Hierbij de ontwikkeling van ICT zo goed mogelijk benutten.

Het begrip innovatieve beleidsvorming is gaandeweg uiteengevallen in verschillende werkvormen, zoals empowerment van het maatschappelijk middenveld, vraagsturing, burgerparticipatie, doelzoekend beleid en coproductie van publiek en privaat. Voorbeelden van XPIN-producten waren brainstormgesprekken, adviesgesprekken, koppelgesprekken om ervaringen van anderen te horen, workshops, conferenties, checklists, adviesrapporten, publicaties, een jaarlijks werkbezoek Out of Office en de website www.xpin.nl met praktijkvoorbeelden, nieuws, forum, en publicaties
} 
beleidsobject door dit ministerie? Bepaalt de manier waarop generaties van ambtenaren binnen het ministerie reageerden op de bestuurlijke werkelijkheid de natuurlijke richting waarin oplossingen werden gezocht? Is er sprake van een dergelijke ingebouwde reflex? Kunnen we spreken van een typische Haagse werkelijkheid, van het discours binnen Binnenlandse Zaken, dat zich onderscheidt van dat binnen andere ministeries en binnen decentrale overheden? Dit zijn vragen die mij bezig houden en waarop ik een antwoord hoop te vinden.

Deze studie heeft ook tot doel om de strategische reflectie binnen het ministerie te bevorderen en het collectieve geheugen van Binnenlandse Zaken vast te leggen. Met het oog hierop is het ministerie zo ruimhartig geweest om in 2013 een voorstudie van dit boek te publiceren onder de titel 'Wachten op het Omslagpunt'.

Vanaf het moment dat ik me ging bezighouden met bestuursbeleid, groeide het besef dat bestuursvormen zich op een organische manier hadden ontwikkeld en dat bij elk onderwerp de betrokkenen zich als in de bedding van een rivier hadden laten leiden naar voor hen passende organisatievormen en werkwijzen. Wat Binnenlandse Zaken steeds weer probeert, is deze verscheidenheid in zekere mate terug te trimmen tot een ordelijk patroon, zoals dat past in het constitutioneel bestel van Thorbecke. Het uitgangspunt is dan een strakke scheiding van publiek en private domeinen, een duidelijke verdeling van verantwoordelijkheden over verschillende bestuurslagen en een financiële en bestuurlijke organisatie die aan minimale eisen van doeltreffendheid en doelmatigheid voldoet.

In de loop van de jaren negentig werd mij duidelijk dat deze bestuurscentrische benadering onoverkomelijke beperkingen meebracht.

In de eerste plaats werd duidelijk dat de stuurbaarheid van de bestuurlijke inrichting van ons land, evenals veel andere beleidsdoelstellingen, beperkt was. De pogingen tot herstructurering van het middenbestuur maakten dit het meest duidelijk.

In de tweede plaats werd de concurrentie tussen doelstellingen ten aanzien van de bestuurlijke organisatie en maatschappelijke beleidsdoelstellingen steeds sterker. De inspanningen bij hetzelfde beleidsonderdeel van Binnenlandse Zaken om effectief grotestedenbeleid te voeren of etnische minderheden te integreren in de samenleving maakten het dilemma duidelijk. Wat moest prevaleren: het oplossen van deze maatschappelijke vraagstukken of het respecteren van bestuurlijke randvoorwaarden?

In de derde plaats deed zich in het bestuur zelf een aantal ingrijpende maatschappelijke ontwikkelingen gevoelen, zoals individualisering, globalisering, de vervaging van ideologische scheidslijnen, de mondigheid van burgers en informatisering. Deze trends maakten oude opvattingen over hiërarchie, over staatsgezag en over rechttoe rechtaan beleidsvoering obsoleet. Politieke articulatie van behoeften en doelstellingen werd meer en meer door incidentele opportuniteit geregeerd in plaats van door langetermijnvisies. Het besturen verliep steeds meer 'op de tast', in wederzijdse afhankelijkheid met maatschappelijke partners en in grote onzekerheid over de invloed van externe factoren.

In delen van de bestuurskundige literatuur werd de nadruk verlegd van projectmanagement naar procesmanagement, de rationele beleidsanalyse vervangen door argumentatieve of deliberatieve vormen van beleidsvorming en het aantal actoren dat in de beleidsarena werd toegelaten werd verbreed, tot gewone burgers toe. Er werd gesproken over een verschuiving van government, waarbij de overheid duidelijk de touwtjes in handen hield, naar governance, waarbij publieke aangelegenheden werden behartigd in een gecompliceerde wisselwerking tussen overheidsinstanties en maatschappelijke organisaties, burgers en bedrijven.

Mijn politicologische opleiding en het interdepartementale en interbestuurlijke overzicht over beleidspraktijken maakten me ontvankelijk voor het waarnemen van contexten en institutionele verbanden. Het werk bij XPIN had als rode draad het gegeven van de horizontalisering van de 
relaties tussen overheid en samenleving en de behoefte aan het versterken van de externe oriëntatie van overheidsbeleid, in het bijzonder op rijksniveau. Dit verklaart mijn idee om na terugkeer binnen de beleidsorganisatie de functiebenaming Verkenner van Governance aan te nemen. Eigenlijk is het tegen deze achtergrond opvallend dat ik pas na geruime tijd met vingeroefeningen voor verschillende onderzoeksrichtingen op het idee kwam om de tegenstelling tussen government en governance als optiek te kiezen voor het onderzoek naar de beleidsontwikkeling bij Binnenlandse Zaken.

Deze keuze leek mij aantrekkelijk, omdat zij een goed te operationaliseren ingang biedt voor het categoriseren van beleidskeuzen en naar mijn indruk een treffende typering levert van de trendmatige ontwikkelingen in het openbaar bestuur aan het eind van de twintigste eeuw. Ik zal dit laatste punt hierna verduidelijken aan de hand van de relevante bestuurskundige literatuur, maar nu eerst aan de hand van een anekdote uit de praktijk. Typerend is het verhaal van staatssecretaris Tonny van de Vondervoort. Zij had tijdens het eerste paarse kabinet (1994-1998) gemeentelijk bestuur en gemeentefinanciën in haar portefeuille en voelde aan het eind van haar zittingsperiode behoefte zich wat meer te profileren. Daarom koos zij ervoor in het najaar van 1997 het land in te trekken, veel gesprekken te voeren en discussies te houden in gemeenten over de vraag wat in deze tijd de rol en missie van gemeenten zou kunnen en moeten zijn. Die vraag kwam op door de algemeen erkende tendens dat de positie van het openbaar bestuur, en ook van de gemeente aan een verandering en vermaatschappelijking onderhevig was. De Raad voor het Binnenlands Bestuur had als afsluitend advies het beschouwende rapport 'Besturen op de Tast' afgescheiden en er werd in de vakbladen en in wetenschappelijke publicaties veel geschreven over interactief bestuur en over de regierol van de gemeente te midden van talrijke partners die ieder op hun manier kunnen bijdragen aan het oplossen van maatschappelijke problemen. Daarom was het niet vreemd dat de staatssecretaris een publiek debat entameerde, waarbij zelfs burgers werden uitgenodigd om mee te denken over de toekomstige rol van gemeenten. Opvallend is in dit verband echter wel weer de titel die voor deze campagne werd gekozen: 'Daar gaat de gemeente over'. Een analyse die was gebaseerd op gesignaleerde horizontalisering en vervlechting van functies mondt uit in een zoektocht naar verticale en ondubbelzinnige verantwoordelijkheden van gemeenten.

In een notendop illustreert dit verhaal de stelling van dit boek: Binnenlandse Zaken is niet blind voor maatschappelijke ontwikkelingen en complexe verhoudingen, maar bij het scheiden van de markt kiest het ministerie voor klassiek overheidsbestuur (government).

Dit werk was niet tot stand gekomen zonder de medewerking van velen. Ik noem hier de belangrijkste personen: Leon van Halder, Herman Scholten en Jan Andries Wolthuis, die mij de ruimte gaven voor detachering bij de Universiteit van Amsterdam. Maarten Hajer, Jaap Boonstra en Arno Korsten, die me bij de hand namen op het voor mij glibberige pad van wetenschappelijk onderzoek. Laatstgenoemde bleef dit volhouden toen ik er zelf al nauwelijks meer in geloofde. Aan hem als promotor dank ik nog het meest. Streng en bemoedigend was hij, precies in de juiste dosering en met zijn enorme eruditie een schatkamer voor elk bestuurskundig onderzoek. De veertig geïnterviewde helden uit de verhalen over de beleidsprojecten worden in bijlage 1 genoemd. Hun bereidheid een openhartig gesprek te voeren was hartverwarmend. Jan Andries Wolthuis, Hans Wilmink, Paul Pestman, Jornt van Zuylen, Aart van Dam, Merel de Groot, Meine Henk Klijnsma, Roel in 't Veld, Arthur Ringeling, Fred Fleurke, Frans Leeuw, Klaartje Peters, Frank Hendriks, Piet Glasbergen, Herman van den Bosch en Ben Hoetjes waren bereid het concept te lezen en voorzagen het van waardevol commentaar. Hun allen ben ik grote dank verschuldigd. Dat geldt ook voor de velen die mij hebben bemoedigd om door te gaan, zoals de leden van de promovendikring rond Arno Korsten en vele collega's als zij hoorden waar ik mee bezig was. 


\section{Inhoud}

$\begin{array}{ll}\text { DEEL I Onderzoeksopzet } & 17\end{array}$

$\begin{array}{ll}1 . & \text { Probleemstelling en werkwijze }\end{array}$

$\begin{array}{ll}\text { 1.1. Inhoudelijke thematiek, probleemstelling } & 17\end{array}$

$\begin{array}{ll}\text { 1.1.1. Overwegingen voor de keuze van optiek } & 17\end{array}$

1.1.2. Probleemstelling, deelvragen $\quad 21$

1.1.3. Verwachte uitkomsten $\quad 23$

1.2. Afbakening onderzoeksobject 29

1.2.1. Bestuursbeleid $\quad 29$

1.2.2. Verbijzondering in beleidsdossiers 30

1.2.3. Keuze van casusmateriaal voor analyse van het bestuursbeleid 31

1.3. Resumé en vooruitblik 33

2. De bestuurstheorieën 35

2.1. Inleiding 35

2.2. Bestuurswetenschappelijk discours: van government naar governance 35

2.2.1. De ontwikkeling van het vak bestuurskunde in Nederland 35

2.2.2. Omslag in de bestuurskunde 36

2.3. Kernbegrippen in de bestuurswetenschap 38

$\begin{array}{ll}\text { 2.3.1. Begrip governance } & 38\end{array}$

2.3.2. Complexe netwerkrelaties versus eenduidige vaste verhoudingen 41

2.3.3. Keuze van relevante concepten 43

2.3.4. Specifieke aspecten van de nieuwe benaderingswijze 48

2.4. Conclusies 52

3. Methode van beleidsonderzoek 53

3.1. Inleiding 53

3.2. Wetenschapsopvatting 53

3.3. Interpretatieve benaderingen van beleid $\quad 55$

3.3.1. Gelaagdheid van beleidsideeën $\quad 55$

3.3.2. Denken in termen van de beleidstheorie $\quad 57$

3.3.3. Verhalen als vehikel van discours $\quad 58$

3.3.4. Keuze van begrippen in dit onderzoek 60

3.4. Analysemethode voor het begrijpen van de inhoud van bestuursbeleid 61

3.4.1. Kernbegrippen 61

3.4.2. Operationalisering van onderzoek naar discours: verhaallijnen 62

3.4.3. Onderzoeksopzet voor het zoeken van een dominant discours 64

3.5. Operationele werkwijze voor onderzoek in het bestuursbeleid 65

3.5.1. Onderzoeksopgave 66

$\begin{array}{ll}\text { 3.5.2. Benodigde informatie } & 67\end{array}$

3.5.3. Onderzoeksmethode, gegevensverzameling 69

$\begin{array}{ll}\text { 3.6. } & \text { Resumé en vooruitblik } \\ \end{array}$ 
4. Historische schets van het ministerie in de onderzochte periode $\mathbf{7 5}$

$\begin{array}{ll}\text { 4.1. Inleiding } & 75\end{array}$

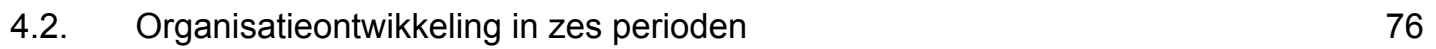

4.2.1. Prehistorie: ontstaan van bestuursbeleid 76

4.2.2. Vroegste periode, tot 1980: 'Biza verzet de bakens' 77

4.2.3. Directoraat-generaal Binnenlands Bestuur 1980-1987 79

4.2.4. Directoraat-generaal Openbaar Bestuur 1987-1994 81

4.2.5. Opsplitsing van Interbestuurlijke Betrekkingen en Informatievoorziening 82 1994-2002

4.2.6. Directoraat-generaal Koninkrijksrelaties en Bestuur 2002-2008 84

4.2.7. Directoraat-generaal Bestuur en Koninkrijksrelaties 2008 - 85

$\begin{array}{lll}\text { 4.3. } & \text { Organisatiecultuur } & 86\end{array}$

4.4. De invloed van politieke bazen en kabinetsperioden 88

4.5. Hoogtepunten van beleid 90

$\begin{array}{ll}\text { 4.6. Conclusies } & 91\end{array}$

5. Dossier Bestuurlijke Organisatie 93

5.1. Inleiding 93

5.2. Algemene ontwikkeling van dit dossier 93

5.2.1. Selectie van cases 93

5.2.2. Alternatieve benaderingen 95

5.3. Reorganisatie van het binnenlands bestuur 96

5.3.1. Inleiding 96

5.3.2. Projectbeschrijving en verhalen 96

5.3.3. Aanwijzingen voor de gehanteerde bestuurstheorie 100

5.3.4. Typering van dit project volgens overige onderzoekscriteria 102

5.3.5. Conclusies 103

$\begin{array}{ll}\text { 5.4. Complementair bestuur } & 103\end{array}$

5.4.1. Inleiding 103

5.4.2. Projectbeschrijving en verhalen 105

5.4.3. Aanwijzingen voor de gehanteerde bestuurstheorie 111

5.4.4. Typering van dit project volgens overige onderzoekscriteria 112

$\begin{array}{ll}\text { 5.4.5. Conclusies } & 113\end{array}$

$\begin{array}{lll}5.5 & \text { Bestuur op niveau, stadsprovincies } & 114\end{array}$

$\begin{array}{ll}\text { 5.5.1. Inleiding } & 114\end{array}$

5.5.2. Projectbeschrijving en verhalen 114

5.5.3 Aanwijzingen voor de gehanteerde bestuurstheorie 118

5.5.4. Typering van dit project volgens overige onderzoekscriteria 119

$\begin{array}{ll}\text { 5.5.5. Conclusies } & 120\end{array}$

$\begin{array}{ll}\text { 5.6. Project middenbestuur } & 120\end{array}$

5.6.1. Inleiding 120

$\begin{array}{ll}\text { 5.6.2. Projectbeschrijving en verhalen } & 121\end{array}$

$\begin{array}{ll}\text { 5.6.3. Aanwijzingen voor de gehanteerde bestuurstheorie } & 123\end{array}$

5.6.4. Typering van dit project volgens overige onderzoekscriteria $\quad 124$

$\begin{array}{ll}\text { 5.6.5. Conclusies } & 124\end{array}$ 
$\begin{array}{ll}\text { 5.7. Dualisering van het gemeentebestuur } & 125\end{array}$

$\begin{array}{ll}\text { 5.7.1. Inleiding } & 125\end{array}$

$\begin{array}{ll}\text { 5.7.2. Projectbeschrijving en verhalen } & 126\end{array}$

5.7.3. Aanwijzingen voor de gehanteerde bestuurstheorie 127

5.7.4. Typering van dit project volgens overige onderzoekscriteria 128

5.7.5. Conclusies 129

5.8. Conclusies over de bestuurstheorie bij bestuurlijke organisatie 129

5.8.1. Resumé van dit dossier in de loop van de tijd 129

5.8.2. Gemeenschappelijke bestuurstheorie 130

5.8.3. Conclusies 132

6. Dossier interbestuurlijke betrekkingen en decentralisatie 134

$\begin{array}{ll}\text { 6.1. Inleiding } & 134\end{array}$

6.2. De ontwikkeling van de interbestuurlijke betrekkingen en decentralisatiebeleid 134

6.2.1. Typering van de projecten 135

6.2.2. Coördineren ten behoeve van decentraal bestuur 136

$\begin{array}{ll}\text { 6.3. Coördinerende taak } & 137\end{array}$

$\begin{array}{ll}\text { 6.3.1. Inleiding } & 137\end{array}$

$\begin{array}{ll}\text { 6.3.2. Projectbeschrijving en verhalen } & 138\end{array}$

6.3.3. Aanwijzingen voor de gehanteerde bestuurstheorie 141

6.3.4. Typering van dit project volgens overige onderzoekscriteria 142

6.3.5. Conclusies 143

$\begin{array}{ll}\text { 6.4. Offensief decentralisatiebeleid } & 143\end{array}$

6.4.1. Inleiding 143

6.4.2. Projectbeschrijving en verhalen $\quad 145$

6.4.3. Aanwijzingen voor de gehanteerde bestuurstheorie 145

6.4.4. Typering van dit project volgens overige onderzoekscriteria 146

$\begin{array}{ll}\text { 6.4.5. Conclusies } & 146\end{array}$

$\begin{array}{lr}\text { 6.5. Sanering van specifieke uitkeringen } & 147\end{array}$

$\begin{array}{ll}\text { 6.5.1. Inleiding } & 147\end{array}$

6.5.2. Projectbeschrijving en verhalen 148

6.5.3. Aanwijzingen voor de gehanteerde bestuurstheorie 150

6.5.4. Typering van dit project volgens overige onderzoekscriteria 150

6.5.5. Conclusies 151

$\begin{array}{ll}\text { 6.6. Bestuursakkoorden } & 151\end{array}$

6.6.1. Inleiding 151

6.6.2. Projectbeschrijving en verhalen 153

6.6.3. Aanwijzingen voor de gehanteerde bestuurstheorie 153

6.6.4. Typering van dit project volgens overige onderzoekscriteria 154

6.6.5. Conclusies 154

$\begin{array}{ll}\text { 6.7. D'project } & 155\end{array}$

$\begin{array}{ll}\text { 6.7.1. Inleiding } & 155\end{array}$

6.7.2. Projectbeschrijving en verhalen 155

6.7.3. Aanwijzingen voor de gehanteerde bestuurstheorie 156

6.7.4. Typering van dit project volgens overige onderzoekscriteria 156

6.7.5. Conclusies 157

$\begin{array}{lll}\text { 6.8. Decentralisatie-impuls } & 158\end{array}$

$\begin{array}{ll}\text { 6.8.1. Inleiding } & 158\end{array}$ 
6.8.2. Projectbeschrijving en verhalen 158

6.8.3. Aanwijzingen voor de gehanteerde bestuurstheorie 160

6.8.4. Typering van dit project volgens overige onderzoekscriteria 160

6.8.5. Conclusies 161

6.9. Decentraliseren met beleid 161

6.9.1. Inleiding 161

6.9.2. Projectbeschrijving en verhalen 163

6.9.3. Aanwijzingen voor de gehanteerde bestuurstheorie 164

6.9.4. Typering van dit project volgens overige onderzoekscriteria 164

6.9.5. Conclusies 165

6.10. Gedifferentieerde contracten met gemeenten 165

6.10.1. Inleiding 165

6.10.2. Projectbeschrijving en verhalen 165

6.10.3. Aanwijzingen voor de gehanteerde bestuurstheorie 168

6.10.4. Typering van dit project volgens overige onderzoekscriteria 168

6.10.5. Conclusies 169

6.11. Conclusies over bestuurstheorie bij interbestuurlijke betrekkingen en 169 decentralisatiebeleid

7. Dossier Achterstandsproblemenbeleid 172

$\begin{array}{ll}\text { 7.1. Inleiding } & 172\end{array}$

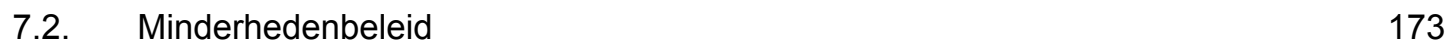

$\begin{array}{ll}\text { 7.2.1. Inleiding } & 173\end{array}$

7.2.2. De verhalen: geboorte van een nieuwe taak 174

7.2.3. Inrichting van de Directie Coördinatie Minderhedenbeleid (DCM) 176

7.2.4. Beleid voor probleemcumulatiegebieden 179

7.2.5. Aanwijzingen voor de gehanteerde bestuurstheorie 182

7.2.6. Typering van dit project volgens overige onderzoekscriteria 183

7.2.7. Conclusies 184

$\begin{array}{ll}\text { 7.3. Sociale vernieuwing } & 185\end{array}$

$\begin{array}{ll}\text { 7.3.1. Inleiding } & 185\end{array}$

7.3.2. De verhalen: geboorte van een nieuwe taak 187

$\begin{array}{ll}\text { 7.3.3. Ontwikkeling van het project } & 189\end{array}$

7.3.4. Aanwijzingen voor de gehanteerde bestuurstheorie 189

7.3.5. Typering van dit project volgens overige onderzoekscriteria 190

$\begin{array}{ll}\text { 7.3.6. Conclusies } & 191\end{array}$

7.4. Grotestedenbeleid 192

$\begin{array}{ll}\text { 7.4.1. Inleiding } & 192\end{array}$

7.4.2. Projectbeschrijving en verhalen 192

7.4.3. Aanwijzingen voor de gehanteerde bestuurstheorie 200

7.4.4. Typering van dit project volgens overige onderzoekscriteria 201

7.4.5. Conclusies 202

\begin{tabular}{ll} 
7.5. & Project bedrijfsbetrokkenheid \\
\hline
\end{tabular}

7.5.1. Inleiding 203

7.5.2. Projectbeschrijving en verhalen 203

7.5.3. Aanwijzingen voor de gehanteerde bestuurstheorie 205

7.5.4. Typering van dit project volgens overige onderzoekscriteria 206

7.5.5. Conclusies 206 
8. Dossier Interbestuurlijke informatievoorziening 208

$\begin{array}{ll}\text { 8.1. Inleiding } 208 & 208\end{array}$

8.2. BBI en single information, single audit 208

8.2.1. Inleiding 208

8.2.2. Projectbeschrijving en verhalen 209

8.2.3. Aanwijzingen voor de gehanteerde bestuurstheorie 213

8.2.4. Typering van dit project volgens overige onderzoekscriteria 215

8.2.5. Conclusies 216

8.3. ICT doorbreekt bestuurslagen: de gemeentelijke basisadministratie (GBA) 216

$\begin{array}{ll}\text { 8.3.1. Inleiding } & 216\end{array}$

$\begin{array}{ll}\text { 8.3.2. Projectbeschrijving en verhalen } & 216\end{array}$

8.3.3. Aanwijzingen voor de gehanteerde bestuurstheorie 219

8.3.4. Typering van dit project volgens overige onderzoekscriteria 220

8.3.5. Conclusies 220

8.4. Kwaliteitsinstrumentarium en bestuurlijke vernieuwing 220

$\begin{array}{ll}\text { 8.4.1. Inleiding } & 220\end{array}$

8.4.2. Projectbeschrijving en verhalen 221

8.4.3. Aanwijzingen voor de gehanteerde bestuurstheorie 225

8.4.4. Typering van dit project volgens overige onderzoekscriteria 226

$\begin{array}{ll}\text { 8.4.5. Conclusies } & 227\end{array}$

$\begin{array}{lll}\text { 8.5. Ketenregie } & 228\end{array}$

8.5.1. Inleiding 228

8.5.2. Projectbeschrijving en verhalen 228

8.5.3. Aanwijzingen voor de gehanteerde bestuurstheorie 231

8.5.4. Typering van dit project volgens overige onderzoekscriteria 231

8.5.5. Conclusies 232

8.6. Conclusies over de bestuurstheorie bij de versterking van bestuurskracht 232

9. Dossier organisatie en werkwijze van de rijksdienst 235

9.1. Inleiding 235

9.2. Reorganisatie van de rijksdienst en de grote efficiency-operatie 235

9.2.1. Inleiding 235

9.2.2. De ontwikkeling van het project 235

9.2.3. Aanwijzingen voor de gehanteerde bestuurstheorie 236

9.2.4. Typering van dit project volgens overige onderzoekscriteria 237

$\begin{array}{ll}\text { 9.2.5. Conclusies } & 237\end{array}$

\begin{tabular}{ll} 
9.3. & Scheiding beleid en uitvoering \\
\hline
\end{tabular}

$\begin{array}{ll}\text { 9.3.1. Inleiding } & 237\end{array}$

9.3.2. Ontwikkeling van dit project, verhalen 237

9.3.3. Aanwijzingen voor de gehanteerde bestuurstheorie 243

9.3.4. Typering van dit project volgens overige onderzoekscriteria 243

9.3.5. Conclusies 243

9.4. Procesmanagement en interactief bestuur 243

9.4.1. Inleiding 243

9.4.2. Projectbeschrijving en verhalen 244

9.4.3. Aanwijzingen voor de gehanteerde bestuurstheorie 252

9.4.4. Typering van dit project volgens overige onderzoekscriteria 252

9.4.5. Conclusies 253

9.5 Resumé en conclusies 253 
10. Constateringen over het totale bestuursbeleid in de periode 1969-2009 256

10.1. Inleiding 256

10.2. Verzamelde resultaten met betrekking tot de hoofdvraag 256

10.2.1. Inleiding 256

10.2.2. Ontwikkeling en onderhoud van de bestuurstheorie 257

10.2.3. Gevonden patronen: shift of geen shift? 257

10.3. Overige conclusies, 'bijvangst' 263

10.4. Concurrerende verklaringen voor het gevonden patroon 266

10.4.1. Inleiding 266

10.4.2. Discussie over alternatieve verklaringen 266

10.5. Reflectie: op zoek naar het Grote Verhaal achter het bestuursbeleid 269

10.5.1. Impressie uit de verhalen 269

10.5.2. Mogelijk patroon in de golfbeweging 269

DEEL III Bestuurstheorie in de bestuurlijke omgeving van Binnenlandse Zaken 273

11. Vergelijking met de Tweede Kamer 273

$\begin{array}{ll}\text { 11.1. Inleiding } 273 & 273\end{array}$

11.2. Literatuuronderzoek over bestuursopvattingen in de Tweede Kamer 274

11.2.1. Algemene politieke uitingen die wijzen op een bepaalde bestuurstheorie 274

11.2.2. Houding van de VC-Binnenlandse Zaken in het bestuursbeleid 279

11.3. Conclusie over de bestuurstheorie van de Tweede Kamer 281

12 Vergelijking met een vakdepartement: Landbouw 283

$\begin{array}{ll}\text { 12.1. Inleiding } 283 & 283\end{array}$

12.2. Literatuurverkenning over de bestuurstheorie van LNV 284

12.2.1. De corporatistische traditie, neo-corporatistische staatsopvatting 284

12.2.2. De salto mortale 286

12.2.3. Drie paradigma's in de landbouwnetwerken 287

12.2.4. Hoe is de landing na de salto mortale verlopen? 288

12.2.5. Voorbeeld mestbeleid 290

12.3. Conclusies 292

12.3.1. Ontwikkeling van Landbouw in het licht van dit onderzoek 292

12.3.2. Vraagtekens bij de 'shift' op rijksniveau 293

13 Vergelijking met het lokaal bestuur 295

$\begin{array}{ll}\text { 13.1. Inleiding } 295 & 295\end{array}$

13.2. Literatuurverkenning over governance bij gemeenten 295

13.2.1. Ons thema binnen de bestuurskundige literatuur over lokaal bestuur 295

13.2.2. Aanwijzingen voor een omslag 296

13.2.3. Contra-indicaties 302

13.3. Conclusies over bestuurstheorie van het lokaal bestuur 308

$\begin{array}{ll}\text { DEEL IV Concluderende beschouwingen } & 311\end{array}$

14. Samenvatting, conclusies, verklaringen en reflectie 311 
14.1. Samenvatting en conclusies $\quad 311$

14.2. Mogelijke verklaringen van de bevindingen 311

14.2.1. Hypothesen naar aanleiding van de uitkomsten bij Binnenlandse Zaken 316

14.2.2. Hypothesen naar aanleiding van de uitkomsten buiten Binnenlandse 321 Zaken

14.2.3. Weging $\quad 322$

14.3. Hoe nu verder? 323

14.3.1. Wat kan het bestuursbeleid met deze uitkomsten? 323

14.3.2. Wat kan de bestuurskunde met deze uitkomsten? 326

$\begin{array}{ll}\text { Literatuur } & 328\end{array}$

$\begin{array}{lr}\text { Summary } & 349\end{array}$

BIJLAGE 1 Lijst van geïnterviewde personen 363

BIJLAGE 2 Opzet interviews bij verhalen over bestuursbeleid 365

BIJLAGE 3 Lijst van afkortingen $\quad 367$

$\begin{array}{lr}\text { Curriculum vitae } & 369\end{array}$

$\begin{array}{lr}\text { Valorisatie } & 370\end{array}$ 


\section{Lijst van figuren}

Figuur 2.1 De matrix van Wildavsky

Figuur 2.2 Aspecten van meervoudig bestuur

Figuur 3.1 Over diepgang en locus van ideeën die beleidsinhoud bepalen

Figuur 3.2 Invloed van projecten op de bestuurstheorie van Binnenlandse Zaken

Figuur 3.3 Tabelstructuur voor analyse van de 24 casussen

Figuur 4.1 Wisseling van onderwerpen over verschillende directies

Figuur 4.2 Twee denkpatronen naast elkaar

Figuur 8.1 Vier werelden van besturing volgens Aardema

Figuur 9.1 Overzicht van pogingen tot reorganisatie van de rijksdienst

Figuur 10.1 Analyse van de 24 casussen in tabelvorm

Figuur 10.2 Projecten, getypeerd als A- of B-modus, uitgezet op een tijdbalk

Figuur 10.3 Perioden waarin werd geïntervenieerd in de kwaliteit van het lokaal bestuur

Figuur 12.1 Configuratie-onderzoek fixaties en verandering

Figuur 13.1 Perspectieven en interventiemechanismen

Figuur 14.1 Relaties tussen overheid en burger volgens de commissie-Docters van Leeuwen 


\section{Probleemstelling en werkwijze}

\section{Inhoudelijke thematiek, probleemstelling}

\section{Overwegingen voor de keuze van optiek}

Politieke besluitvorming is een boeiend onderwerp. Het gaat uiteindelijk over afwegingen, machtsverhoudingen en over de werking van democratie. Maar het proces om tot besluiten te komen is mensenwerk, een wisselwerking tussen discoursen: beelden, ideeën, verhalen enerzijds en de werkelijkheid anderzijds: ervaringen, macht, effecten. En dat laatste altijd ook weer alleen door middel van communicatie van beelden, ideeën, verhalen over die werkelijkheid. Dat discours staat in dit onderzoek centraal. Is in de loop van de tijd een constante dominante opvatting te traceren achter het beleid of heeft zich daarin een majeure verandering voltrokken?

Het gaat ook altijd over een onderwerp van maatschappelijke problematiek of van beleid. Hier betreft het de sturing van de inrichting en werkwijze van het openbaar bestuur, het bestuursbeleid. Dit 'metabeleid' is bij uitstek een relevant onderwerp omdat het zo fundamenteel is voor de bewerktuiging van de politiek zelf. De organisatie van de staatsorganen bepaalt immers in belangrijke mate wat de politiek vermag. Toch is de bewuste ontwikkeling van beleid op dit terrein nog niet erg oud, zoals we zullen zien. Daarom is het mogelijk om bijna de hele periode waarop dit beleidsveld functioneert binnen één ambtelijke loopbaan te overzien.

De rol van het bestuursdepartement binnen de politieke besluitvorming, de ideeën van de ambtelijke organisatie en haar directe (politieke) omgeving die de inhoud van het beleid bepalen, zijn onderwerp van deze studie. Deze studie bestrijkt de periode vanaf 1969 tot 2009. Het onderzoek sluit dus af enkele jaren voor publicatie, waardoor ook de doorwerking van het beleid kan worden waargenomen.

Dit onderzoek is gebaseerd op een meervoudige casestudy. Want in de eerste plaats is de casus Binnenlandse Zaken (BiZa) opgebouwd uit een groot aantal deeldossiers. In de tweede plaats wordt de bestuursopvatting van dit ministerie vergeleken met die van andere beleidsarena's in zijn omgeving, die ook eigen beleidstheorieën over het bestuur hebben: de Haagse politiek, een vakdepartement, en de gemeentelijke overheden.

\section{Waarom en waartoe dit onderwerp?}

De keuze van dit onderwerp vloeit voort uit de voortdurende discussie binnen het ministerie van Binnenlandse Zaken (waar de auteur gedurende het grootste deel van de onderzoeksperiode werkzaam was) over de kern van zijn opdracht: wat is goed openbaar bestuur en wat is de bijdrage van het ministerie daaraan? Dat laatste zou ook ten dele kunnen worden ingevuld met een vraag naar de mate van invloed van het ministerie, op basis van een machtsanalyse, maar dat is hier niet aan de orde, omdat de nadruk ligt op de inhoud. Dat is al lastig genoeg.

Discours is niet hetzelfde als koekoek één zang. Er is juist voortdurend discussie. Alleen komt, zo is de veronderstelling, één zienswijze - de klassieke - steeds als dominant boven drijven. Dat wordt verderop uitgewerkt. Dat er discussie was, blijkt uit de vele Jaarberichten van de regeringscommissaris voor reorganisatie van de rijksdienst, Herman Tjeenk Willink. Hij wees op de 
hoofdstroom binnen de reorganisatie van de rijksdienst, en hamerde voortdurend op verbindingen op de grensvlakken tussen politiek, ambtelijke dienst en samenleving (zie verder paragraaf 9.2).

Een ander voorbeeld is de indruk dat er een permanent debat is tussen de ambtenaren met een coördinerende taak ten opzichte van de vakdepartementen op het terrein van de interbestuurlijke betrekkingen, en de ambtenaren die de systemen van de Gemeentewet en van de bestuurlijke organisatie bewaakten. De eersten tonen steeds gevoel voor contingentie en voor afwijkende ontwikkelingen in de (beleids)sectoren gericht op specifieke problematiek, de tweede categorie was meer van de strenge standaardoplossingen voor het hele binnenlands bestuur in onze gedecentraliseerde eenheidsstaat.

Dit debat tussen deze twee 'stromingen' binnen de ambtelijke organisatie van Binnenlandse Zaken kwam het scherpst naar voren in de verhouding tussen twee departementsonderdelen: Bestuurlijke en Financiële Organisatie (BFO) en Interbestuurlijke Betrekkingen (IB). De eerste was belast met het ontwikkelen en bewaken van de organisatorische en financiële structuren van het binnenlands bestuur. De tweede had een coördinerende rol om de verschillende arrangementen binnen de vakdepartementale sectoren zo goed mogelijk af te stemmen op de behoeften van het lokaal bestuur. Hiervoor kan alvast een vergelijkingstabel uit hoofdstuk 4 naar voren gehaald worden.

Figuur 4.2 Twee denkpatronen naast elkaar

\begin{tabular}{|c|c|}
\hline 'BFO’ (Bestuurlijke en Financiële Organisatie) & 'IB' (Interbestuurlijke Betrekkingen) \\
\hline Uitgaand van bestuursmodel of doctrine & Uitgaand van pluriforme bestuurspraktijk \\
\hline $\begin{array}{l}\text { Coherentie tussen verschijnselen geattribueerd } \\
\text { door het model }\end{array}$ & $\begin{array}{l}\text { Coherentie tussen verschijnselen ervaren door } \\
\text { betrokkenen }\end{array}$ \\
\hline $\begin{array}{l}\text { Onzekerheids- en complexiteitsreductie als } \\
\text { hoofdactiviteit ter wille van beheersbaarheid } \\
\text { doelrealisatie }\end{array}$ & $\begin{array}{l}\text { Onzekerheid en complexiteit als weldadig } \\
\text { gegeven; beheersbaarheid alleen op niveau van } \\
\text { waarden en oogmerken }\end{array}$ \\
\hline $\begin{array}{l}\text { Planmatig voorbereiden van welomschreven } \\
\text { product; VBTB-proof }\end{array}$ & $\begin{array}{l}\text { Open zoektocht vanuit probleemdefinitie en } \\
\text { timeframe, laat je verrassen. VBTB moet worden } \\
\text { gecontenteerd door taaltrucs }\end{array}$ \\
\hline Laat je niet afleiden & $\begin{array}{l}\text { Side-effects zijn minstens zo leerzaam als } \\
\text { hoofdspoor }\end{array}$ \\
\hline Rationeel-causaal sturingsmodel & Constructivistische sturingsopvatting \\
\hline Voeding door uitbesteed onderzoek & Eigen onderzoek en waarneming voorop \\
\hline $\begin{array}{l}\text { Politiek primaat: instructie komt van de leiding, } \\
\text { ambtenaren werken uit en voeren uit }\end{array}$ & $\begin{array}{l}\text { Politiek 'ultimaat': ambtenaren verkennen } \\
\text { alternatieve oplossingen; politiek kiest uiteindelijk } \\
\text { de meest wenselijke optie }\end{array}$ \\
\hline $\begin{array}{l}\text { Individuele ambtenaar ondergeschikt en } \\
\text { uitwisselbaar }\end{array}$ & $\begin{array}{l}\text { Individuele ambtenaar en zijn/haar persoonlijke } \\
\text { motivatie, netwerk en beleving zijn bepalend voor } \\
\text { resultaat }\end{array}$ \\
\hline $\begin{array}{l}\text { Organisatie spreekt met één mond, is als een } \\
\text { piramide }\end{array}$ & $\begin{array}{l}\text { Organisatie is meervoudig netwerk, werkt samen } \\
\text { naar binnen en naar buiten }\end{array}$ \\
\hline Aan de top van de organisatie 'gebeurt het' & Aan de grens van de organisatie 'gebeurt het' \\
\hline
\end{tabular}


Dergelijke interne discussies zoals uit deze tabel spreken, vormen een aanleiding voor deze studie.

Achterliggende opvattingen over de kerntaak van het openbaar bestuur en over de rol van een bestuursdepartement als Binnenlandse Zaken zijn steeds zeer actueel en bepalen de beleidskeuzen van de bewindslieden op dit ministerie tot op grote hoogte.

De analyse van deze opvattingen is tot nu toe zelden voorwerp geweest van wetenschappelijk onderzoek. Uitzonderingen zijn wellicht de dissertaties van Van der Heijden (1990) en Koppenjan (1991).

Voor deze analyse is de reconstructie van het discours en van de dominantie die daarin valt te onderkennen, de voor de hand liggende methode. Verderop komt dit onderwerp nader aan de orde.

Dat er veel interne discussie op het departement plaatsvond, wil niet zeggen dat er in termen van 'het dominant discours' over wordt gesproken. Het discours moet met enige moeite uit de materie gereconstrueerd worden. De verwachting is echter gerechtvaardigd dat de uitkomst van dit onderzoek in vruchtbare bodem zal vallen, omdat ambtenaren van Binnenlandse Zaken en belangstellenden eromheen hierdoor het inzicht in hun positie en in de alternatieve benaderingswijzen van het openbaar bestuur kunnen scherpen. Dat te bereiken is tevens een belangrijke doelstelling van dit onderzoek en bepaalt ook de beleidsrelevantie ervan.

\section{Binnenlandse Zaken een geval apart?}

Verschillende bronnen (Koppenjan 1993: 234; Peters 1999: 29) suggereren dat bij Binnenlandse Zaken een specifiek eigen discours heerst, anders dan elders in de overheid. Het woord discours duidt hier op de manier waarop bepaalde gemeenschappelijke ideeën binnen de organisatie zich manifesteren (namelijk via taal). Het gaat hierbij om vrij diep verankerde, steeds terugkerende denkbeelden over de werkelijkheid waarmee het ministerie zich bezighoudt, de wijze waarop de organisatie zich verhoudt tot haar omgeving, in dit geval het openbaar bestuur en de Nederlandse samenleving. Zo'n discours, dus zo'n manier van benaderen van het eigen beleidsobject (het bestuur), zou over een lange reeks van jaren vrij hardnekkig moeten zijn om te kunnen spreken van een eigen geluid. Het discours zou zich ook moeten onderscheiden van de omgeving en een eigen dynamiek moeten vertonen. Het is interessant om te onderzoeken in hoeverre het ministerie van Binnenlandse Zaken met zijn directe satellieten en gesprekspartners opereert als eigenstandig politiek subsysteem. Is er zoiets als een 'Haagse' werkelijkheid binnen de bestuurlijke wereld met Binnenlandse Zaken als organisatorische locus?

Een ministerie als Binnenlandse Zaken wordt wel eens opgevat als een bolwerk, een ivoren toren. ${ }^{3}$ Tegenover dit weinig vleiende beeld kan worden aangevoerd dat zo'n ministerie bestaat uit honderden individuele ambtenaren met elk hun relatienetwerken in de samenleving, dat er ook organisatorisch veel dwarsverbanden en afhankelijkheidsrelaties tussen de beleidsonderdelen en de omgeving bestaan. Afhankelijkheid van de diversiteit van die omgeving zou eerder doen verwachten dat er sprake is van 'osmose' aan de buitengrenzen en van steeds nieuwe discoursen.

Gebruikelijker is uit te gaan van het bestaan van een vrij homogene ontwikkeling in de verhaallijnen binnen organisaties als zo'n ministerie. De interactie met de buitenwereld doet daar relatief weinig aan af, omdat deze buitenwereld veelal zo is geselecteerd dat gelijkgestemden elkaar ontmoeten en bevestiqen.

\footnotetext{
${ }^{3}$ Zie bijvoorbeeld http://retro.nrc.nl/W2/Lab/Om/980429bin.html. De nieuwste kantoorbehuizing op de Turfmarkt heeft overigens wel wat weg van een ivoren toren.
} 
De organisatiewetenschappen (organisatiesociologie en -psychologie, organisatiekunde, bestuurskunde) hebben lang genoeg convergerende processen binnen organisaties en beleidsdomeinen vastgesteld om te mogen stellen dat duurzame aparte eenheden met eigen discours te onderscheiden zijn. Daarom is het gebruikelijk in de politicologie een ministerie als dat van Binnenlandse Zaken als een apart subsysteem te beschouwen. Het is aldus mogelijk te spreken over een subsysteem Binnenlandse Zaken dat ook een aantal 'satellieten' en gesprekspartners van het ministerie omvat, zoals de Vereniging van Nederlandse Gemeenten, de Vaste Kamercommissie Binnenlandse Zaken, de Raad voor het openbaar bestuur (Rob) en de Raad voor de Gemeentefinanciën, later opgevolgd door de Raad voor de financiële verhoudingen (Rfv), de commissarissen van de Koningin in de provincies, et cetera. Vanuit die veronderstelling gaat deze studie op zoek naar de dominante visie op het bestuur van het ministerie van Binnenlandse Zaken cum annexis (politieke leiding, beleidsbepalende stemmen, clientèle). Die visie hoeft natuurlijk geen veertig jaar dezelfde te blijven. Aannemelijk is, opnieuw volgens organisatiewetenschappelijke inzichten, dat die meebeweegt met de omstandigheden. Verandering in het discours of de verschillende discoursen binnen het beleidsveld is interessant, omdat er dan kennelijk iets gebeurt in de spanningsvelden tussen beleid en werkelijkheid.

Joop Koppenjan (1991) zocht naar de manier waarop de beleidsagenda zich bij het ministerie van Binnenlandse Zaken ontwikkelde. Daartoe heeft hij een aangepaste versie van Kingdons 'stromenmodel' ontworpen, dat hij Arenamodel noemde. Hij neemt in zijn model afstand van het toeval als relevante factor. In plaats daarvan noemt hij een lange reeks bepalende factoren die van invloed zijn op het procesverloop en resultaat van het beleid. Dat zijn zowel factoren in de omgeving van het beleid, zoals het politiek bestuur, organisatie en management en probleembepalende omstandigheden, alsook de manier waarop de arena is ingericht ('samengesteld'): probleemformulering, aangedragen oplossingen, participanten en de beschikbare tijd (tijdsdruk). Met zoveel variabelen valt er hoogstens te spreken van 'regie van het toeval' (Schrijver, 1992), in de zin dat beleidsmakers contingenties creëren voor de samenkomst van factoren die opeens een doorbraak, een nieuwe agenda mogelijk maken.

In plaats van de benadering waarin de heersende ideeën en 'groupthink' passen, koos Koppenjan dus voor de institutionele invalshoek als verklaringsmodel. Hij volgde drie 'projecten' van vrij onbepaalde tijd, waar via slepende processen tussen 1960 en 1990 gezichtsbepalend beleid van Binnenlandse Zaken werd ontwikkeld. Het betrof het ontwerp van een nieuwe Gemeentewet, de aanpak van de grotestedenproblematiek en de bestuurlijke organisatie in verband met het regionale gat. Aan het eind van zijn boek komt Koppenjan tot de conclusie dat dergelijke zeer lange beleidsprocessen een grillig verloop kennen (Koppenjan, 1991: 230). Zelfs de probleemstelling en de percepties van de actoren over de mogelijke oplossingsrichtingen verschuiven in de tijd. De manier waarop het probleem aanvankelijk vanuit het ministerie wordt geagendeerd, roept sterke reacties op vanuit de relevante omgeving. Die reacties en andere maatschappelijke ontwikkelingen bieden vervolgens aanleiding voor het ministerie om een nieuwe invalshoek te kiezen, omdat verantwoordelijke bewindslieden daar kansen zien om vooruitgang te boeken, enzovoort. Zo begon het grotestedenbeleid met de begrotingstekorten van de vier steden als breekijzer voor de agenda, maar later kwamen slogans als stedelijke vernieuwing, sociale vernieuwing en Europese concurrentie tussen stedelijke regio's van pas om politieke besluitvormers te mobiliseren. Het ministerie deint dus mee op de golven. Al te rigide eigen denkmodellen staan flexibiliteit in de weg. Alleen wanneer de tijdsdruk als extreem hoog wordt waargenomen (of zo wordt gecreëerd), signaleert Koppenjan op sommige momenten verschijnselen die lijken op 'groupthink' (fuikdenken), waardoor de 'werkelijkheid' (enigszins) uit het oog wordt verloren. Hij noemt als voorbeelden het werk van de Werkgroep Grote Steden aan het rapport 'De Schuyt die tegen stroom wordt opgeroeyt' en de Wet reorganisatie van het binnenlands bestuur (het voorstel om te komen tot 26 provincies). Men zou daaraan het latere project Stadsprovincies kunnen toevoegen. Dat zijn 
incidentele situaties van een collectief perspectief (lees collectieve 'framing') waardoor ernstige misrekeningen kunnen optreden.

\section{Bestuurstheorie}

Toch zou een algemener overkoepelende continue factor bij dit soort mega-projecten gevonden kunnen worden die niet aan de aard van de problemen kan worden toegeschreven, maar die is gekoppeld aan het 'algemeen bestuurlijke denken', dat lange tijd binnen Binnenlandse Zaken en daarnaast wellicht ook bij zijn vaste gesprekspartners, zoals de Vaste Kamercommissie en bij de Vereniging van Nederlandse Gemeenten (VNG) en het Interprovinciaal Overleg (IPO), dominant is geweest. Ook Koppenjan (1993: 238) spreekt hierover impliciet door de aandacht te vestigen op bepaalde gevoeligheden, voorkeuren en antipathieën als het gaat om oplossingsrichtingen en taboes. Hiervoor bestaat het begrip bestuurstheorie.

Een bestuurstheorie is een species van een beleidstheorie. Een beleidstheorie is het geheel van veronderstellingen dat aan een beleid ten grondslag ligt (Hoogerwerf, 1984). De beleidstheorie (achterliggende veronderstellingen) over de inrichting en werking van het bestuur heet dan bestuurstheorie. Er zou dan - zo is hier de veronderstelling - niet alleen sprake zijn van een bepaalde bestuurstheorie, maar deze zou ook sterk levende heftige reacties oproepen, min of meer te vergelijken met reacties op voorstellen om de verzuiling op onderwijsgebied te doorbreken. Koppenjan verklaart deze waarden-geladenheid door de ingrijpendheid van beleidsvoorstellen op het terrein van het binnenlands bestuur. Het gaat vrijwel altijd om machtsposities, waarbij de verbetering van de positie van de één ten koste gaat van die van de ander (taakverdeling, grensafbakening, financiële verhouding).

Koppenjan (1993: 239) noemt een aantal begrippen die hij is tegengekomen in zijn onderzoek, waar Binnenlandse Zaken alle heil van verwacht of die een zwaar positieve lading vertegenwoordigen: wettelijke regelingen, planning, coördinatie, overleg, decentralisatie, reorganisatie, et cetera. ${ }^{4}$ Negatieve tegenpolen zijn dan specifieke uitkeringen, circulaires (informele regelingen), verkokering en functionele decentralisatie. Ook begrippen als partnerschap, complementair bestuur en medebewind noemt hij, zonder dat die in hun gevoelswaarde ook zo sterk positief of negatief te duiden zijn.

Als het klopt dat het ministerie een eigen culturele identiteit vormt, dan zouden we aan dit 'subsysteem' ook aparte kenmerken moeten kunnen toeschrijven, als een Haagse enclave in de wereld van beleid en bestuur. Dat zou licht werpen op de manier waarop politieke besluitvorming plaatsvindt, die traditioneel wordt opgevat als politiek-democratisch voortkomend uit de opvatting van de meerderheid van de kiezers. In werkelijkheid ligt dat ingewikkelder, maar hoe dan? Hier wordt een zelfstandige invloed verondersteld van ideeën die hardnekkig zijn bij een departementale organisatie als Binnenlandse Zaken, zeker als het gaat over kernbegrippen als bestuur en beleid. Deze denkbeelden kunnen worden afgezet tegen die welke gangbaar zijn in de wetenschap en in andere domeinen met betrekking tot die thema's. Die vergelijking zou overeenkomsten of verschillen aan het licht kunnen brengen, die zowel voor de wetenschap als voor het beleid interessant zijn.

\subsubsection{Probleemstelling, deelvragen}

\section{Probleemstelling en onderzoeksbenadering}

Om in deze maatschappelijk belangwekkende kwestie van de kracht en dynamiek van ideeën meer klaarheid te brengen is de volgende algemene probleemstelling gekozen:

\footnotetext{
${ }^{4}$ Later zou een aantal van deze begrippen, zoals planning, coördinatie en reorganisatie, minder positief klinken dan in de jaren tachtig.
} 
Heeft zich binnen het subsysteem van het 'bestuursbeleid' van het ministerie van Binnenlandse Zaken in de periode van 1969 tot 2009 een dominant discours over de verhouding tussen bestuur en samenleving ontwikkeld?; zijn daarin verschuivingen opgetreden en hoe is die (eventuele) ontwikkeling te verklaren?

In plaats van het woord discours over de verhouding tussen bestuur en samenleving kan hier ook 'bestuurstheorie' worden gelezen (Hoogerwerf, 1984).

Deze probleemstelling valt voor dit onderzoek uiteen in twee specifieke hoofdvragen:

A. Is de bestuurstheorie van Binnenlandse Zaken in deze periode stelselmatig ontwikkeld door middel van ijking aan de bestuurspraktijk en de maatschappelijke ontwikkeling? Van belang hiervoor is dat het ministerie zijn beleid ontwikkelt in wisselwerking met de omgeving, dat in lijn met maatschappelijke veranderingen innovaties plaatsvinden die voortbouwen op voorgaande ervaringen met behulp van feedforward- en feedbackmechanismen en dat daarbij gebruikgemaakt wordt van evaluaties van het gevoerde beleid en van de gehanteerde beleidsprocessen.

B. Is de bestuurstheorie van Binnenlandse Zaken in overeenstemming met het dominante discours binnen de integrerende bestuurswetenschap (lees: bestuurskunde), die zoals in hoofdstuk 2 zal blijken, kan worden samengevat als: er vindt een verschuiving (shift) plaats van government naar governance of netwerkbestuur? ${ }^{5}$

Om de inhoudelijke typering van dit politieke subsysteem te beschrijven is een bepaalde vorm van discoursanalyse als methode gebruikt. Over de periode 1969-2009 worden door middel van de gebruikte verhaallijnen de daaraan te relateren bestuurstheorieën binnen een aantal dossiers vergeleken en vervolgens tussen deze dossiers onderling. Zit daar voldoende overeenkomst in, is er sprake van een consistente denklijn? Wijkt die af van de discoursontwikkeling buiten deze dossiers? De auteur heeft dat al eens geprobeerd in een vingeroefening rond het decentralisatiebeleid van het ministerie (Schrijver, 2009). Daar kwam uit dat er weliswaar voortdurend pogingen zijn geweest om alternatieve benaderingen uit te proberen, maar dat het beleid uiteindelijk steeds terugviel op een constante voorkeursoptie, die kennelijk dominant was. Dus ja, er zou wel iets te vinden moeten zijn als een consistente bestuurstheorie van Binnenlandse Zaken. Die denklijn is vervolgens vergeleken met bestuurstheorieën van andere actoren in de omgeving (departementen, gemeenten, politiek en wetenschap).

Behalve een beleidskern kent ook de wetenschap zijn vaste denkpatronen, paradigma's genaamd. Zo heeft de bestuurswetenschap bepaalde kenmerkende redeneerwijzen en preoccupaties. Je zou verwachten dat de denkwijzen in de bestuurskunde over haar kenobject zich weerspiegelen in het beleid van het ministerie dat gaat over het openbaar bestuur. Onderscheidt de bestuurstheorie van Binnenlandse Zaken zich van de inzichten in de bestuurswetenschap? En onderscheidt het discours van bestuursbeleid zich van die van de omgeving (de bestuurstheorie van andere ministeries, gemeenten, politiek in de Tweede Kamer)?

\section{Deelvragen}

Deelvragen zijn logisch uit de probleemstelling en de hoofdvragen af te leiden:

1. Wat wordt tot het bestuursbeleid gerekend, welke dossiers vallen hieronder, welke projecten zijn interessant om de discoursontwikkeling te volgen, bijvoorbeeld omdat hier sprake lijkt van beleidsvernieuwing? Deze deelvraag komt nog in dit hoofdstuk aan de orde.

2. Hoe is te onderbouwen dat de dominante verhaallijn over het openbaar bestuur binnen de desbetreffende tak van wetenschap, de bestuurskunde, gaat over de shift van government naar governance? Zie hiervoor hoofdstuk 2 over de relevante bestuurskundige theorie.

\footnotetext{
${ }^{5}$ Ingevolge de aanbeveling van Hajer (2009) om misverstanden over het meervoudig gebruik van het woord governance te voorkomen, wordt in dit boek regelmatig de aanduiding netwerkbestuur aan governance gekoppeld.
} 
3. Wat is een passende methode om inhoudelijke typering en vergelijking van bestuursbeleid vast te stellen? Wat is de verhouding tussen taaluitingen (discours) en feitelijk handelen bij dit onderzoek? Hiervoor is een methodologisch derde hoofdstuk ingeruimd.

4. Kan met behulp van het postulaat uit de bestuurskunde over de shift van government naar governance een operationele ideeëndichotomie worden gedestilleerd waarmee het bestuursbeleid kan worden getypeerd? Zie hiervoor het laatste deel van hoofdstuk 3.

5. Zijn bij de bestudeerde dossiers de verhaallijnen veranderd, is tussen de verschillende dossiers sprake van samenhang en inhoudelijke verwantschap, die een aanwijzing vormen voor de aanwezigheid van een dominante verhaallijn? Hoe verhoudt deze zich tot de genoemde bestuurskundige kijk op de werkelijkheid? En, annex hiermee:

6. Zijn er aanwijzingen dat Binnenlandse Zaken lering heeft getrokken uit de confrontaties met de bestuurspraktijk en daarmee bewust een bestuurstheorie heeft ontwikkeld en bijgehouden? En heeft de dominante bestuurstheorie in de afgelopen veertig jaar een shift van government naar governance laten zien? In hoofdstuk 4 tot en met 9 zijn de bevindingen in een 25-tal casussen (projecten) verwerkt. Hoofdstuk 10 vat de bevindingen samen over de bestuurstheorie in het bestuursbeleid.

7. Is er aanwijzing voor een dominant discours bij het parlement en bij politieke partijen op hetzelfde terrein van de verhouding tussen openbaar bestuur en samenleving en wijkt dat af van het gevonden resultaat bij Binnenlandse Zaken? Wat kunnen we zeggen over mogelijk nauwe banden tussen het denken binnen Binnenlandse Zaken en de representatieve politiek? Hoofdstuk 11 gaat hierover.

8. Is er aanwijzing voor een dominant discours bij een of meer andere ministeries als het gaat om de verhouding tussen openbaar bestuur en samenleving en wijkt dat af van het gevonden resultaat bij Binnenlandse Zaken? Voor deze vergelijking is de keus gevallen op het ministerie van Landbouw (wisselende benamingen, laatstelijk LNV) in hoofdstuk 12.

9. Is er aanwijzing voor een dominant discours bij de decentrale overheden op hetzelfde terrein van de verhouding tussen openbaar bestuur en samenleving en wijkt dat af van het gevonden resultaat bij Binnenlandse Zaken? Hoofdstuk 13 is hieraan gewijd.

10. Wat zijn mogelijke hypothesen ter verklaring van de opgedane bevindingen? Welke reflecties zijn tijdens de verkenning van deze materie opgekomen die nadere doordenking verlangen zowel over de politieke besluitvorming en het bestuursbeleid alsook voor de bestuurswetenschap? Dat is voer voor het slothoofdstuk 14.

In hoofdstuk 14 zal worden teruggekomen op de vraag of de bestuurswetenschap de aanspraak op een hoog aanzien voor de beleidsvorming kan waarmaken, in dit onderzoek in het bijzonder of de aan de bestuurskunde ontleende dichotomie tussen government en governance bruikbaar is gebleken.

Nu wordt eerst beschreven welke verwachte antwoorden op de genoemde vragen of uitkomsten op voorhand aan bestaande literatuur ontleend kunnen worden. Met andere woorden: welke hypothesen kunnen op basis van de theorie worden geformuleerd over de empirische kwesties (4t/ m 10) die zojuist zijn genoemd?

Hoewel deze studie niet pretendeert een beleidsevaluatief karakter te hebben, kan uit de feiten en passant worden afgeleid in hoeverre het beleid 'succesvol' was, dat wil zeggen impact had op de bestuurlijke werkelijkheid en ook een doorwerking had, waarop binnen het eigen beleidssysteem werd voortgebouwd.

\subsubsection{Verwachte uitkomsten}

\section{Verandering en verandering zijn twee}

Een van de deelvragen (5) is of de bestuurstheorie van de verschillende dossiers van bestuursbeleid in de loop van veertig jaar is veranderd. De empirische invulling heeft Schrijver al eens laten zien in het artikel over decentralisatie in Bestuurswetenschappen (Schrijver, 2009). Daar 
bleek dat Binnenlandse Zaken een duidelijke voorkeur etaleerde voor de government-modus. Weliswaar waren er aanvechtingen vanuit het governance-denken, maar die werden niet doorgezet. Dat maakt dat de veronderstelling voor het hele terrein in dezelfde richting gaat. Dat netwerkbestuur/governance ergens in het bestuursbeleid zou zijn doorgebroken in de periode 1969-2009 lijkt onwaarschijnlijk. 'Nee' moet hier de hypothese zijn.

Beleidsverandering is zeldzaam, zoals ook Hogwood en Peters (1983: 131-134) aantonen. Zij analyseren in hun boek 'Policy dynamics' langetermijnontwikkelingen in beleidssectoren op continuïteit en verandering. Daarbij valt te denken aan een periode van circa vijftig jaar. Zij construeren hierbij vier typen van verandering:

1. beleidsaanpassing ('policy maintenance');

2. beleidsinnovatie;

3. beleidsopvolging ('policy succession'); en

4. beleidsbeëindiging.

Bij beleidsaanpassing wordt het bestaande beleid met dezelfde doelstellingen voortgezet. Het is dat zij de categorie volstrekte stabiliteit niet als aparte categorie onderscheiden, maar deze komt daar het dichtste bij. Het beleid wordt licht gewijzigd, bijvoorbeeld door een drempelverlaging voor de toegang tot een voorziening, waardoor bijvoorbeeld het aantal gebruikers toeneemt. Bij beleidsaanpassing staat voorop om het beleid tot zijn recht te laten komen, niet om wezenlijk ander beleid te voeren.

Beleidsinnovatie houdt bij Hogwood en Peters in dat een overheidsorganisatie zich begeeft op een nieuw terrein, waarop ze zich nog niet eerder bewoog. Van bestaande institutionele voorwaarden, zoals wetgeving, organisaties en financiële beleidsmiddelen, is nog amper of niet sprake. Voorbeelden daarvan zijn in Nederland steeds minder te vinden, omdat de overheid zich al decennia lang op vrijwel alle terreinen beweegt. De ontwikkeling van het emancipatiebeleid vanaf het midden van de jaren zeventig kan als een voorbeeld dienen en ook de onderwerpen binnen het bestuursbeleid, voorwerp van dit onderzoek, zijn stuk voor stuk pas vanaf de jaren zeventig ontstaan.

Beleidsopvolging, een derde type, wordt door de genoemde auteurs omschreven als 'de gehele of gedeeltelijke vervanging (replacement) van een bestaand beleid, beleidsprogramma of organisatie door een ander beleid dat gericht is op dezelfde problemen en/of doelgroep(en)'. Het nieuwe beleid kan als functioneel equivalent voor het oude worden beschreven. Er kan sprake zijn van nieuwe doelstellingen. Het aandachtsveld blijft globaal hetzelfde. De vervanging van sectorale wetten op het terrein van het milieubeleid door de Wet algemene bepalingen milieubeleid, en later de Wet milieubeheer, kan als zodanig worden beschouwd. Ook de vervanging van normerende wetgeving op het terrein van bepaalde milieudoelstellingen door convenanten met het bedrijfsleven is een vorm van opvolging. Volgens Hogwood en Peters komt deze variant verreweg het meeste voor. Veel beleid is in feite de voortzetting van een vorig beleid en zelden een origineel begin van iets geheel nieuws. Ook voor de volgende categorie betekent deze waarneming veel.

Beleidsbeëindiging is bij deze auteurs "the abolition of a policy, program or organization with no replacement being established" (Hogwood \& Peters, 1983: 62). Beleidsbeëindiging vatten ze op als volledige beëindiging. Partiële beëindiging is bij hen een vorm van beleidsopvolging, omdat dan een deel van het beleid blijt bestaan. 'Oud voor nieuw' rekenen ze ook tot beleidsopvolging, en daarmee partiële beëindiging die gepaard gaat met nieuw beleid. Zij kiezen dus een enge omschrijving en beschouwen alleen volledige beëindiging zonder het alternatief van nieuw beleid als beëindiging. Het afschaffen van de Wet investeringsrekening en inzet van een ander (beleids)instrument in de plaats daarvan is in hun ogen beleidsopvolging (Korsten, 2008a: 3-6). 
Het is niet eenvoudig om in het beleidsdichte Nederland voorbeelden van beleidsbeëindiging te vinden, maar ze zijn er wel (Korsten, 2008b). Op het terrein van bestuursbeleid kan men denken aan de rigoureuze streep die na het vertrek van D66 uit het kabinet in 2007 onder staatkundige vernieuwing is geplaatst. Maar dat onderwerp kan spoedig weer de kop opsteken (correctief referendum, kiesrechtverandering) en bovendien kunnen andere accenten in het beleid ('dialoog met de samenleving') al gauw als functionele alternatieven voor staatkundige vernieuwing worden gezien. Dan gaat het om een wederopstanding van beleid dat, zoals een pc, enige tijd in de slaapstand verkeerde. De verplaatsing van het minderhedenbeleid en later ook van het grotestedenbeleid van Binnenlandse Zaken naar een ander departement betekende voor dit ministerie een rigoureuze vorm van beleidsbeëindiging, maar het is de vraag of dit voor Hogwood en Peters meetelt. Het beleid is immers elders voortgezet en bovendien hebben binnen Binnenlandse Zaken rudimentaire elementen van dat beleid de kop opgestoken.

\section{Echt fundamentele verandering onwaarschijnlijk}

Dit denkschema voor het aanduiden van beleidsinhoudelijke veranderingen zal in de empirische hoofdstukken van dit boek aan de orde komen. Hogwood en Peters nuanceren hun categorieindeling verder door het begrip 'policy split' te introduceren (Hogwood \& Peters, 1983: 70-73). Zover gaat deze studie niet. Ook mogen we niet vergeten dat hun empirisch materiaal stamt uit een Engelse context en dus niet zonder meer te transponeren is. Hogwood en Peters leggen de nadruk op het incrementele karakter van de meeste beleidsveranderingen en beargumenteren dat overtuigend. Dat gaat zeker ook voor Nederland op.

Het onderzoek naar bestuursbeleid is uiteindelijk niet zozeer op zoek naar (dis)continuïteit in het beleid dat allerlei vormen aanneemt, maar volgens Hogwood en Peters zelden een breuk met het verleden vormt. Hier zoeken we de stille vervanging van bepaalde inhoudelijke voorkeursredeneringen achter het beleid. De discontinue momenten zullen wel opgezocht worden om deze te gebruiken voor de beschrijving van de beleidsontwikkeling, maar uiteindelijk moeten inhoudelijk dieper gravende typeringen van het beleid op tafel komen om te kunnen spreken van een eventuele paradigmawisseling.

Er past nog een kanttekening bij het lenen van het begrippenapparaat van Hogwood en Peters voor dit onderzoek. Zij spreken pas over iets nieuws als beleid daadwerkelijk is gerealiseerd, met wetgeving en al. In dit onderzoek kan een nieuw project al als discontinu worden aangemerkt als een bestuurlijk en ambtelijk gedragen voorstel radicaal breekt met het bestaande beleid. In het voorliggende onderzoek, waar het gaat om de ontwikkeling van ideeën die in ieder geval door de ambtelijke en bestuurlijke top worden gedragen, is het welslagen van een nieuw idee een afzonderlijke kwestie, die aan de orde komt bij de doorwerking, het beklijven van een initiatief. Merk in ieder geval op dat er een aanzienlijk spanningsveld bestaat tussen de algemene macrothese binnen de bestuurskunde over een paradigmawijziging in opvattingen over de verhoudingen tussen bestuur en samenleving en de opvattingen binnen diezelfde bestuurskunde over veranderingen in beleidsprogramma's, dus in micro-opzicht. De eerste stelling binnen de bestuurskunde praat erg gemakkelijk, bijna clichématig, over paradigmashifts; de tweede stelling noemt een ingrijpende verandering in denkwijze binnen bestuur en beleid eigenlijk onwaarschijnlijk.

Conclusie: de analyse van Hogwood en Peters en Schrijvers vingeroefening in het tijdschrift Bestuurswetenschappen leveren de verwachte uitkomst voor deze deelvraag op: op het eerste gezicht ambivalent, maar dominant is een stabiele verhaallijn (die bovendien meer op government dan op governance lijkt).

Homogeniteit van denken binnen het bestuursbeleid Deelvraag 5 stelt onder meer aan de orde of we wel kunnen spreken over eenzelfde bestuurstheorie binnen het bestuursbeleid. De veronderstelling is dat binnen één organisatie op het 
niveau van de basisgedachten die aan het beleid ten grondslag liggen, de neuzen dezelfde kant op wijzen. Hiervoor is een uitstapje naar de organisatieleer nodig.

Ralph Stacey is een organisatiekundige met eigentijdse opvattingen. Hij laat systeemgrenzen los (organisatie als ding). En hij introduceert interne en externe conversatie als basis van ontwikkeling. Daarmee is werk in organisaties principieel overgeleverd aan onvoorspelbare intermenselijke processen. Het beleidsdiscours zal altijd een eigen leven leiden, waar managers zich niet boven of buiten kunnen plaatsen. Als zij dat toch doen door controlegedrag en subtiele repressie, bereiken zij veelal een averechts resultaat, namelijk isolatie van de omgeving. Dat wil niet zeggen dat management zinloos is of dat sommige medewerkers niet over meer middelen en invloed beschikken dan andere. Zij kunnen die hulpbronnen ten goede aanwenden door goede conversaties te bevorderen, door te monitoren en daardoor wellicht eerder en meer gegevens uit de omgeving te halen. De organisatie kan echter door niemand als een 'ding' worden bestuurd. Een combinatie met onder meer de psychoanalyse levert interessante inzichten op voor de verklaring van het gedrag van mensen en organisaties om te leren en hun overlevingskans aanmerkelijk te vergroten (Stacey, 1996: 140-164).

Elk individueel of collectief menselijk organisme wordt gekenmerkt door een harde kern met een kenmerkend dominant en manifest denkschema en een latent schaduwsysteem daaromheen, dat in contact staat met de buitenwereld en dat rivaliserende denkbeelden binnenbrengt.

Dominante systemen kunnen in extreme gevallen grote stabiliteit vertonen, door met succes weerstand te bieden tegen signalen van buiten. Tegenovergesteld zijn situaties waarin rivaliserende ideeën de overhand hebben, wat leidt tot anarchie en chaos en neurotische symptomen in een werkomgeving.

De aanbevolen toestand zit volgens Stacey daartussenin. De tussenvorm waarbij organisaties creatieve ontwikkeling laten zien, is die waarin voldoende centripetale kracht bestaat om een voortdurende staat van onzekerheid en nervositeit in de periferie te dempen, maar anderzijds voldoende gelegenheid wordt geboden om grenservaringen te laten doordringen en die te incorporeren in de dominante 'ideologie' door middel van creatieve destructie.

Dat impliceert in combinatie met de bovengenoemde opvatting over management dat de verbindingen tussen top en werkvloer open en vloeiend moeten zijn.

Stacey noemt vijf factoren die bepalen of een organisatie op het scherp van de snede opereert, tussen de luie zekerheid van de comfortzone en chaotische anarchie:

- de kwaliteit van informatiestromen;

- voldoende, maar niet overmatige diversiteit in de organisatie;

- de kwaliteit van verbindingen;

- gecontroleerde nieuwsgierigheid en scoringsdrift;

- ervaren machtsverschillen binnen de organisatie.

Het komt aan op het vinden van het heilzame midden: regelkramp en onderdanigheid zijn net zo schadelijk als ongebreidelde fantasie en hobbyisme. Werkrelaties mogen niet te vluchtig zijn en ook niet te hecht, maar voldoende intensief om vertrouwen te genereren.

Ook in die zin wordt het bestaan van een departementale groepsidentiteit algemeen aannemelijk geacht (zie G.H. Scholten in: 't Hart et al., 1991: 198; Hoogerwerf, 1989: 326). Het is toch een vreemd, maar onmiskenbaar verschijnsel dat ambtenaren die van ministerie wisselen, binnen enkele maanden denkwijze(n) uit hun nieuwe omgeving hebben aangenomen. Dit wijst behalve op de kameleontische aanpassingseigenschap van mensen ook op het bestaan van zoiets als departementale (culturele) identiteit. Die adaptatie is ook functioneel, omdat het bestaan van een gemeenschappelijke identiteit de interne coördinatie en het optreden naar buiten toe vergemakkelijkt. 
De keerzijde is dus het risico van eenzijdige waarneming, waardoor blinde vlekken ontstaan. Tegenover de veronderstelde vrije influx van ideeën staat dat de ambtelijke organisatie wel degelijk vatbaar is voor sociaalpsychologische verschijnselen die worden aangeduid als groepsdenken ('groupthink'). In de eerste plaats worden veel besluiten genomen in relatief kleine en homogene afdelingen of projectteams, waar de gevaren van groupthink op de loer liggen ('t Hart et al., 1991: 36). Ten opzichte van andere organisaties is een ministerie bij uitstek hiërarchisch georganiseerd. Dan is de werkelijke besluitvorming te projecteren op een kleine groep, de Algemene Leiding. De kans is aanwezig dat in die kleine elite groepsdynamische processen optreden die tot oogkleppen leiden: selectie op basis van co-optatie, homogene samenstelling, groepscohesie, sturend leiderschap van enkelen, zelfoverschatting en superioriteitsgevoel ten opzichte van de buitenwereld, jaknikkers- en duikgedrag van deelnemers. Dit alles is moeilijk te onderzoeken en speelt vooral in bepaalde crisisachtige episoden, waarin onder grote druk een bepaald specifiek besluit genomen moet worden. De groupthink-theorie is er vooral op gericht om treffende beleidsfiasco's te verklaren uit groepsdynamische processen in betrekkelijk homogene op besluitvorming gerichte groepen. Deze studie richt zich echter op grotere denkprocessen dan een enkel besluit, de aanwezigheid van een bepaalde hardnekkige cultuur of ideologie; het (denk)kader waarbinnen de besluitvorming zich afspeelt in een heel ministerie.

Wat betreft Binnenlandse Zaken wijzen de signalen verschillende kanten op. Het ministerie als geheel staat, ondanks verwoede pogingen tot het ontwikkelen van 'corporate identity', juist te boek als een heterogene organisatie, soms zelfs een verzameling van restanten. Dit is anders bij de vakministeries, die met een samenhangende maatschappelijke sector van het moederdepartement konden worden afgesplitst. ${ }^{6}$ Toch is de centripetale kracht van de hiërarchie en de aanwezigheid van een kern van managers die erop uit is de bestaande koers te verdedigen, ook hier manifest aanwezig, wat een consistente denklijn over de verschillende dossiers heen aannemelijk maakt.

\section{Bijzondere verhouding tussen Binnenlandse Zaken en de politieke besluitvorming} In deelvraag 5 (en 6 tot en met 7) komt de kwestie naar voren of Binnenlandse Zaken misschien een aparte positie inneemt op het punt van zijn bestuurstheorie. Klaartje Peters stelt in haar proefschrift (1999: 29) dat het binnenlands bestuur zich van andere onderwerpen onderscheidt doordat de invloed van het politieke bedrijf hier groter zou zijn dan die op andere beleidsterreinen. Die stelling zou nog eens goed onder de loep genomen moeten worden voor de langere periode die dit onderzoek bestrijkt. Zij citeert onder meer de eerdere dissertatie van Koppenjan (1993) over een drietal grote dossiers: grotestedenbeleid, de vorming van een nieuwe Gemeentewet en de bestuurlijke reorganisatie. Koppenjan stelt onder meer vast dat de Tweede Kamer belangrijke invloed wist uit te oefenen op het beleid (Koppenjan, 1991: 324). Dat zou volgens Van Putten (1980: 274-275) wel eens kunnen samenhangen met het gegeven dat op de 'klassieke' beleidsterreinen zoals binnenlands bestuur, justitie en buitenlands beleid het instrument wetgeving nog in ere wordt gehouden, zodat daar het parlement als medewetgever relatief veel invloed heeft.

Hoe het zij, de politieke agenda zou volgens deze opvattingen onevenredig sterk doorwerken in het domein van het bestuursbeleid. Dat betekent dat in het discours van volksvertegenwoordigers en politieke partijen dezelfde opvattingen over de positie van het bestuur ten opzichte van de samenleving zou heersen als binnen het ministerie. Los van de nauwe betrokkenheid en de herkenbare verticale gerichtheid van het ministerie op het parlement zijn er ook zelfstandige aanwijzingen dat het parlement zich nog weinig bewust toont van de afhankelijkheid van de samenleving en van horizontalisering in het publieke domein. Het voert wellicht te ver om ook de mate waarin politieke partijen de genoemde shift omarmd hebben te onderzoeken, maar zelfs in het brede politieke spectrum dat wij in Nederland kennen, lijkt de dominante lijn: we rule this country. Of: stem op ons en al uw problemen worden opgelost. De verwachte uitkomst is daarom dat politiek en ministerie verregaand op één lijn zitten als het gaat om de dominante verhaallijn.

\footnotetext{
${ }^{6}$ Tenzij deze zelf ook weer door fusies en afsplitsingen een heterogeen fundament kregen, zoals bijvoorbeeld VROM.
} 
Theorie over vertogen binnen het openbaar bestuur

Nog een ander proefschrift, van Hein-Anton van der Heijden (1990: 165-234), analyseert het discours ('vertoog') in de beleidsdomeinen van de bestuurlijke reorganisatie, de organisatie van de rijksdienst en de 'grote operaties' in de periode 1973-1989. Hij gebruikt dus dezelfde methodiek als in dit boek voorzien wordt, namelijk proberen te doorgronden welke impliciete opvatting over het openbaar bestuur dominant was. Welnu, hij stelt vast dat deze opvatting overwegend het zogenoemde neo-corporatistische beheersperspectief volgde (Van der Heijden, 1990: 332). Binnen deze dominante filosofie hadden andere vertogen ook wel enige invloed, zoals het neopluralisme met zijn netwerkidee en issuegerichte burgerparticipatie en het nieuw-rechtse gedachtegoed van privatisering en deregulering. Opmerkelijk is volgens Van der Heijden het ontbreken van invloed van het pluralisme op het discours binnen de bestuurlijke wereld. Het pluralistisch paradigma gaat uit van een fundamenteel tekort aan sturingsvermogen van de staat door een grote fragmentatie en door grote onderlinge afhankelijkheid van de spelers. Hoewel dit pluralisme de feitelijke vormgeving van de bestuurlijke verhoudingen permanent kenmerkte, waren het wereldbeeld en het taalgebruik van de beleidsmakers vervuld van het tegendeel, dat wil zeggen zij geven lippendienst aan de veelvormigheid van het bestuur, maar streven in feite voortdurend naar stroomlijning en beheersing (Van der Heijden, 1990: 333).

Dit werk draagt dus wel bij aan het scheppen van een verwachting omtrent de denkpatronen binnen Binnenlandse Zaken, maar er moet bij worden opgemerkt dat het dateert van 1990 en dus een belangrijk deel van de periode mist, juist de periode waarin binnen de Nederlandse bestuurskunde de bovengenoemde paradigmashift (van government naar governance) 'ontdekt' werd.

Vergelijking met andere bestuurseenheden

Deelvraag 6 zoekt naar overeenkomsten en verschillen tussen de bestuurstheorie van

Binnenlandse Zaken en die van een vakdepartement. Waar kunnen gegevens voor die vergelijking vandaan komen?

In plaats van eigen onderzoek kan gebruikgemaakt worden van bestaande studies. Vooral het ministerie van Landbouw is onderwerp van dit soort analyses geweest (Termeer, 1993; Wielenga 2001; Bekke et al., 1994; Kickert en Van der Meer, 2007). Misschien moet dat ministerie dan ook maar het referentiepunt worden voor de vergelijking om met behulp van secundaire analyse te bepalen of er een eigen bestuurstheorie wordt gehanteerd, afwijkend van die welke bij Binnenlandse Zaken is gevonden. De vooraf verwachte uitkomst van deze vergelijking is dat een dergelijk vakministerie, dat de hete adem van de samenleving direct ondervindt, wel degelijk een shift van government naar governance heeft doorgemaakt, maar kennisnemen van wetenschappelijke literatuur doet hieromtrent ook weer twijfel rijzen.

Er is veel literatuur over lokaal bestuur (zie de literatuurlijst, nauwgezet bijeengebracht op de website van Korsten.nl/downloads), maar daaronder zit opvallend weinig empirisch onderzoek met kwantitatieve indicaties over ingrijpende veranderingen in de kijk van bestuur op samenleving. Dus in hoeveel gemeenten en in welke breedte van het lokale bestuursdomein is nu werkelijk een kanteling vast te stellen? Enerzijds is er veel casus-beschrijvende en beredenerende kwalitatieve literatuur die op een shift wijst, misschien ook een proefschrift als dat van Erik Gerritsen (2011). Anderzijds is er ook nogal wat materiaal dat indiceert dat bij de meeste gemeenten nog weinig ingrijpend is veranderd, bijvoorbeeld het essay 'Bestuurskracht' op het terrein van Welzijn, zelfs na de WMO (De Boer en Van der Lans, 2011). Ook het proefschrift van Abma (2012), een van de weinigen die het gedrag van gemeenten meet, wijst niet in de richting van een shift van government naar governance.

Verwachte antwoorden 
De vanuit de literatuur te verwachten uitkomsten voor de eerste deelvragen in de genoemde onderzoeksperiode zijn dus, in de meest simpele beantwoording met 'ja of nee':

- De verhaallijn in dossiers van bestuursbeleid weerspiegelt een shift van government naar governance: nee.

- $\quad$ Onderlinge verwevenheid (hiërarchie) tussen de verschillende dossiers: ja.

- $\quad$ Verwevenheid van Binnenlandse Zaken met parlement en politiek maken dat het bestuursbeleid dicht tegen de daar heersende opvattingen aankruipt: ja.

- $\quad$ Hetzelfde geldt voor de opvattingen binnen een groot deel van het lokaal bestuur, dat in hetzelfde subsysteem (binnenlands bestuur) beweegt.

- $\quad$ Shift in vakdepartementen? Ministerie van LNV: ja.

Als deze uitkomsten worden bevestigd, kan de nieuwe stelling worden geponeerd dat een bepaald deel van het openbaar bestuur (Binnenlandse Zaken, Vaste Commissie Binnenlandse Zaken, een deel van het lokaal bestuur) een eigen discours in stand houdt, dat er inderdaad op basis van inhoudelijke verwantschap sprake lijkt te zijn van een discourscoalitie, die zich onderscheidt van andere; is dat dan het zogeheten bestuurlijk circuit?

Voor de verklaringen (deelvraag 10) van de gevonden resultaten kunnen vervolgens weer nieuwe hypothesen worden geformuleerd, die in dit onderzoek niet meer beoordeeld kunnen worden.

\subsection{Afbakening onderzoeksobject}

\subsubsection{Bestuursbeleid}

Ontstaan van de term

Het woord bestuursbeleid zal men tevergeefs in een woordenboek zoeken. En als het al wordt aangetroffen, bijvoorbeeld in een zoekmachine op internet, dan duidt het doorgaans op het beleid van een bepaald bestuur. Binnen Binnenlandse Zaken is het echter een redelijk gangbaar begrip.

Bij de oprichting van de directie Coördinatie Bestuursbeleid (CB) in 1987 werd nagedacht over een geschikte naam van de eenheid die tot dan toe met de werktitel Externe Coördinatie werd aangeduid. lemand kwam met het neologisme bestuursbeleid, naar analogie van talloze andere vormen van beleid (minderhedenbeleid, milieubeleid, veiligheidsbeleid, et cetera). Een directie die zichzelf respecteerde, moest toentertijd het woord beleid in de naam hebben staan. Dat scheelde tenminste twee schalen in de functiewaarderingen.

En bestuur was inderdaad het object van het beleid. Daarmee onderscheidde het ministerie zich van alle andere onderdelen in de rijksdienst: $\mathrm{CB}$ zou aan de andere ministeries gefundeerd richting kunnen geven aan de inrichting van het bestuursinstrumentarium en de bestuurlijke verhoudingen. Eerder had de commissie-Vonhoff, en daarvoor de commissie-De Wolff, het gehele domein van rijksbeleid ingedeeld in vijf hoofdbeleidsgebieden (internationaal, ruimtelijk, sociaaleconomisch, sociaal-cultureel en bestuurlijk-juridisch). De laatste van deze facetten had nog het meest het karakter van een restpost. Valt veiligheid er ook onder? In ieder geval erkende men het functioneren van het openbaar bestuur als doeltreffend, doelmatig en democratisch systeem als zelfstandig aandachtsgebied van rijksbeleid.

\section{Definities}

De term bestuursbeleid wordt tegen deze achtergrond gezien als het samenstel van maatregelen dat betrekking heeft op de verbetering van de inrichting en werking van het openbaar bestuur als zodanig. Het betreft dus reflexief beleid binnen het openbaar bestuur, dat op metaniveau het eigen functioneren als object kiest. Departementale indeling, de organieke wetsbepalingen voor gemeenten en provincies, de staatkundige procedures en bestuursinstrumenten zijn onderwerpen van zorg zolang openbaar bestuur bestaat, maar dat zijn losse bouwstenen die nog geen bestuursbeleid vormen. 
Het 'bestuursdepartement' is voor de ambtenaren daar zonder meer synoniem voor Binnenlandse Zaken, het ministerie dat in bovengenoemde betekenis bestuursbeleid voert. Het is verrassend dat bij deze term in Google vrijwel alleen andere betekenissen van bestuursdepartement naar voren komen. Bestuursdepartement is overal buiten Binnenlandse Zaken kennelijk synoniem met de beleidskern in Den Haag, in contrast met de uitvoerende diensten. Vooral bij Justitie wordt steevast in die betekenis over het bestuursdepartement gesproken. Vreemd, omdat het slechts een deel van het departement betreft en misschien beter de beleidskern of desnoods bestuursdienst zou kunnen heten. Maar goed, ieder zijn taal. Hier wordt met de term bestuursdepartement gedoeld op het enige ministerie dat claimt als het bestuurlijke geweten van het openbaar bestuur op te treden. Hoewel Binnenlandse Zaken ook wel het moederdepartement wordt genoemd, daarmee een gemeenschappelijke stam tot uitdrukking brengend, is in het bestuursbeleid een eigensoortige opgave ontstaan die haar van alle andere ministeries onderscheidt. In hoeverre de claim om bestuurlijk richtpunt voor de hele overheid te zijn wordt waargemaakt, zal verderop blijken.

Het ontstaan van het bestuursbeleid is te positioneren omstreeks 1970 (Nota Bestuurlijke Organisatie, 1969; de commissie-Van Veen over de reorganisatie van de rijksdienst, 1971). In hoofdstuk 4 staat meer informatie over de geschiedenis van het bestuursbeleid en dus ook over de afbakening van (de start van) het onderzoeksobject in de tijd. Het onderzoek beslaat een periode van veertig jaar, die eindigt met de reorganisatie van eind 2008. Dat lijkt een mooie cesuur om een punt te zetten achter de gegevensverzameling, met het risico dat de lezer zal zeggen dat sindsdien alles anders is geworden. Dat risico lijkt overzienbaar.

\subsubsection{Verbijzondering in beleidsdossiers}

\section{Afbakening bestuursbeleid}

De vraag die nu aan de orde is, luidt: wat valt vanaf 1969 allemaal onder het bestuursbeleid van Binnenlandse Zaken en wat wordt wel of niet meegenomen in het onderzoek? Niet alle denkbare bestuurlijke onderwerpen hebben de status van beleid bereikt. Het leerstuk van de hybride organisatie, de informatie-overload van bestuurders en volksvertegenwoordigers en de rekrutering en training van politieke ambtsdragers zijn in zekere zin witte plekken. Verwacht van bestuursbeleid geen quasi-complete wetenschappelijk-deductieve bewerking. De beleidsagenda van het departement is in feite een reeks van capita selecta; het zijn krenten uit de pap. De selectie van onderwerpen zou een interessant studieobject op zichzelf zijn, dat hier nu blijft liggen.

En niet alle bestuursbeleid was in handen van Binnenlandse Zaken. Zo zijn beleidsanalyse en publiek-private samenwerking bestuurlijke thema's die zijn opgepakt door het ministerie van Financiën; zelfregulering en mediation als bestuursinstrument werden ontwikkeld door Justitie (bijna twintig jaar later). Maatschappelijk verantwoord ondernemen kwam in handen van Economische Zaken. Duurzame ontwikkeling (het voorkomen van alle vormen van afwenteling) werd uiteindelijk ter hand genomen door het ministerie van Volkshuisvesting, Ruimtelijke Ordening en Milieubeheer (VROM). Interactieve beleidsvorming en procesmanagement werden door VROM en het ministerie van Verkeer en Waterstaat (V\&W) verder ontwikkeld: respectievelijk in het bureau Pegasus en de Adviesunit Resultaatgericht Beleid (ARB), later Inspraakpunt; thans Centrum voor Publieksparticipatie; sinds 2013 is dit centrum onderdeel van de directie Participatie van het ministerie van Infrastructuur en Milieu.

Wat valt er wel onder bestuursbeleid als onderzoekbare thema's ('dossiers')? Een dossier is binnen het raam van deze studie een samenhangend cluster van onderwerpen dat door het ministerie gedurende de onderzoeksperiode min of meer permanent wordt behartigd. Binnen het domein van bestuursbeleid kan (ongeacht reorganisaties die in de loop der tijd wisselende organisatorische indelingen opleverden) onderscheid gemaakt worden tussen zes dossiers:

- $\quad$ Bestuurlijke organisatie; 
- $\quad$ Financiële verhouding(en);

- Decentralisatie;

- $\quad$ Achterstandsgebiedenbeleid (= PCG, sociale vernieuwing, grotestedenbeleid);

- Interbestuurlijke informatievoorziening;

- $\quad$ Organisatie rijksdienst.

Hier komt het empirisch materiaal voor deze studie vandaan.

Binnen deze dossiers is gezocht naar cases, projecten die allemaal een zekere beleidsinnovatie introduceerden: een inhoudelijk nieuw inzicht of een geheel nieuwe sturingsaanpak. Bij deze voorbeeldprojecten kon steeds een trekker worden geïdentificeerd, die als 'held' in het beleidsverhaal figureert. De lotgevallen van deze projecten en hun typering volgens de onderscheiden bestuurstheorieën maken duidelijk hoe het ministerie zich daadwerkelijk opstelt in de loop van de tijd.

\subsubsection{Keuze van casusmateriaal voor analyse van het bestuursbeleid}

\section{Dossiers en projecten}

Een relevante casus voor dit onderzoek is elk nieuw project, hier gedefinieerd als uitgewerkt voornemen voor nieuw beleid, waartoe door de politieke of ambtelijke leiding (op minimaal DGniveau) van het ministerie wordt besloten. Besluiten op dit niveau mogen worden geacht de heersende visie van het moment te weerspiegelen. In ieder geval is de instemming van het ministerie met beleidsinitiatieven vereist. Dus niet elk ideetje of initiatief op werkvloerniveau wordt meegenomen. Het gaat immers om de typering van de bestuurstheorie van het ministerie en niet om de grillen van individuele medewerkers of afdelingen. De instemming van de leiding met een nieuwe beleidsactiviteit kan nog een uiting van repressieve tolerantie zijn. Daarmee laat zij nog niet haar ware gezicht zien.

De lotgevallen van de projecten moeten vervolgens een indicatie geven over de dieperliggende voorkeuren van het ministerie. Sommige projecten vallen al na korte tijd plat voor de kast, andere zijn niet weg te krijgen. Het is interessant om te zien of deze praktijk inhoudelijk een bepaald voorkeurspatroon laat zien.

Uit eigen herinnering is eerst een lijst van voorbeelden samengesteld en deze is na rondvraag onder collega's aangevuld tot de volgende voor Binnenlandse Zaken nieuwe ideeën en projecten, in chronologische volgorde, per dossier. Het dossier Financiële Verhouding(en) blijkt hierbij geen stand te kunnen houden als afzonderlijk thema; het valt grotendeels weg onder de paraplu van het decentralisatiestreven, onder het motto 'financiën zijn volgend'. Er blijven zo nog vijf dossiers over waarin in chronologische volgorde nieuwe beeldbepalende projecten zijn te rangschikken:

- $\quad$ Bestuurlijke organisatie

1. Reorganisatie binnenlands bestuur 1974-1983 (met vervolgacties tot na 2009)

De eerste systematische pogingen om het zogeheten 'regionale gat' te dichten;

2. Complementair bestuur 1978-1982

Verkenning van horizontale samenwerking tussen verschillende bestuursorganen; (+ Voorstel om Binnenlandse Zaken bij complexe vraagstukken in te schakelen als bemiddelaar tussen verschillende bestuursorganen, 1982-1985);

3. Stadsprovincies 1992-1994

Tweede poging om het zogenoemde regionale gat te dichten, selectief in stedelijke agglomeraties;

4. Middenbestuur 2005-2007

Verkenning naar nieuwe vorm van middenbestuur, uitmondend in poging tot structuurverandering naar landsdelige provincies;

5. Dualisering gemeentebestuur 1998-2002 
Aanpak van de monistische structuur van het gemeentebestuur;

- Interbestuurlijke betrekkingen, decentralisatie

6. Coördinerende taak binnenlands bestuur 1973-2009

Poging om financiële sturing en later alle overige bestuursrelaties van vakdepartementen jegens decentrale overheden te stroomlijnen;

7. Offensief decentralisatiebeleid vanuit Binnenlandse Zaken 1980-1994 (en 2004-2007) Overgang van vrijwillige taakoverdracht naar taakstellingen van bovenaf, geregisseerd door Binnenlandse Zaken;

8. Sanering specifieke uitkeringen 1978-2003 (en weer na 2007)

Streven om specifieke uitkeringen systematisch af te schaffen, door bundeling of overheveling naar het Gemeentefonds, impact op inrichting van dat Fonds;

9. Bestuursakkoorden 1980-2009

Normaliseren van betrekkingen tussen Rijk en gemeenten door gedragscode, later gevolgd door inhoudelijke prioriteitsafspraken (Bestuursakkoord-nieuwe stijl, BANS);

10. D'project 1987-1993

Decentralisatievoorstellen van onderaf, naar Scandinavisch voorbeeld (Frikommuner), inclusief mogelijkheid om te experimenteren met gedereguleerde arrangementen;

11. Decentralisatie-impuls, 1991-1993

Decentralisatie in ruil voor geld: onderhandelingen BiZa, Algemene Zaken (AZ) en

Financiën (Fin) met VNG en IPO over efficiencykorting bij decentralisatie;

12. Decentraliseren met beleid 1998-2001

Decentralisatie voortaan met in acht nemen van de context, contingentie van de beleidsontwikkeling en kwaliteiten van de ontvangende bestuurseenheden;

13. Gedifferentieerde verantwoordelijkhedentoedeling aan gemeenten 1998-2006

Voorstel om financiële relaties en taakverdeling te differentiëren aan de hand van

output-afspraken;

- Achterstandsproblemenbeleid (minderhedenbeleid, sociale vernieuwing, grotestedenbeleid)

14. Minderhedenbeleid 1980-2001

Coördinerende taak voor de opvang van nieuwkomers bij Binnenlandse Zaken

ondergebracht; eerste aanzet voor beleid gericht op achterstandswijken:

Probleemcumulatiegebiedenbeleid (PCG);

15. Sociale vernieuwing 1990-1993

Impuls voor samenlevingsopbouw door bewoners in (achterstands)wijken te mobiliseren voor wonen, werk en weten;

16. Grotestedenbeleid, Meerjarige Ontwikkelingsplannen 1994-2009

Langdurig volgehouden gezamenlijke inspanning om stedelijke problematiek te lijf te gaan en kansen voor stedelijke dynamiek uit te bouwen;

17. Bedrijfsbetrokkenheid, verantwoord ondernemen 1995-1996

Inschakelen van lokaal bedrijfsleven bij de versterking van de leefbaarheid in stadswijken, aanjagen vanuit Binnenlandse Zaken;

- Interbestuurlijke informatievoorziening

18. Beleids- en beheersinformatiesysteem (BBI), single audit 1985-1990 (en 2005-2007) Impuls om gemeentelijke jaarstukken op orde te krijgen, primair ten behoeve van het inzicht van raadsleden, maar dan ook als basisinformatie voor hogere overheden;

19. ICT doorbreekt bestuurslagen: Gemeentelijke BevolkingsAdministratie (GBA) 1986-2002 Moderne informatietechniek maakt modernisering van bevolkingsadministratie mogelijk tot basisinformatiesysteem persoonsgegevens ten behoeve van alle overheidsgebruikers op verschillende niveaus;

20. Kwaliteitsinstrumenten 1992-2009 
Toepassing van ICT maakt dienstverlening klantgerichter en doeltreffender en verticaal toezicht minder nodig, diverse projecten ter stimulering van innovatie bij gemeenten;

21. Ketenregie 1999-2001

Ontwikkeling van kenniscentrum voor bestuursaanpak om de inzet van de betrokken publieke diensten rond een concreet probleemgeval (de keten) optimaal te organiseren;

- Organisatie en werkwijze Rijksdienst

1. Reorganisatie Rijksdienst 1971-1985

Dwarsverbanden tussen sterk verkokerde departementen in hoofdbeleidsgebieden met coördinatie-instrumenten; massieve poging vanuit Binnenlandse Zaken tot het versterken van de taakverdeling en coördinatie, sturingskracht en beheerskwaliteit van de rijksoverheid;

23. Verzelfstandiging en ministeriële verantwoordelijkheid 1993-2006

Scheiding van beleid en uitvoering, aanvankelijk vooral uit oogpunt van efficiënte bedrijfsvoering, wordt vanuit Binnenlandse Zaken gepusht om de uitoefening van de ministeriële verantwoordelijkheid te verbeteren;

24. Procesmanagement, interactief bestuur 1996-2006 (en na 2008)

Besluitvorming over grote infrastructurele projecten vergt vooral goed procesmanagement, waarbij belanghebbenden vroegtijdig in overleg (onderhandeling) worden betrokken, diverse projecten hierna op het terrein van burgerparticipatie.

\subsection{Resumé en vooruitblik}

\section{Resumé}

De nieuwsgierigheid van de onderzoeker gaat uit naar de mate waarin het ministerie van Binnenlandse Zaken en zijn satellieten zich in zijn inhoudelijk denken over het openbaar bestuur laat leiden door vaak verborgen grondideeën. Deze grondslagen van denkwijzen herkent men aan het taalgebruik van de actoren, redeneerlijnen, symboliek en metaforen.

Een eerste opgave hierbij is het vinden van een manier om 'mainstream'-opvattingen te onderscheiden van toevallige tijdelijke oprispingen. Als ijkpunt voor contrasterende bestuurstheorieën in de laatste decennia wordt gekeken naar de bestuurswetenschap (lees; bestuurskunde). Het gaat daar steeds over de benadering van de verhouding tussen overheid en samenleving, verticaal sturen en verantwoordelijkheden verdelen enerzijds of samenwerken in horizontale coproductie en verantwoordelijkheden delen anderzijds. Hoe zit Binnenlandse Zaken in dat discours en hoe staat het in de andere genoemde arena's of beleidssferen met de bestuurstheorie?

Vooraf werd aan de literatuur een aantal verwachte uitkomsten ontleend, die inderdaad wijzen in de richting van verschillen. Binnenlandse Zaken en zijn politieke opdrachtgevers hellen over naar het verdelen van verantwoordelijkheden, terwijl de wetenschap nadruk legt op het delen daarvan. De kans dat vakdepartementen en gemeenten diezelfde nadruk leggen als de wetenschap, in afwijking van het bestuursdepartement, wordt reëel geacht, maar is onzeker.

Als uit feitenonderzoek zou blijken dat deze laatste stellingen niet houdbaar zijn, is de eindconclusie dat de (bestuurs)wetenschap alleen staat of te ver voor de troepen uitloopt of eenzijdigheden kent. Mochten de verwachtingen over de tendensen in de vakdepartementen en het decentraal bestuur wel worden bevestigd, dan vormen Binnenlandse Zaken en de Vaste Commissie binnen de Tweede Kamer een eiland te midden van verschuivende bestuurstheorieën.

Het kernobject binnen Binnenlandse Zaken is het bestuursbeleid, de systematische verzameling van maatregelen gericht op de verbetering van inrichting en werking van het openbaar bestuur als 
zodanig. Daarvan wordt de oorsprong als georganiseerd beleid geprojecteerd omstreeks 1969 . Om het dominante discours op de genoemde as te kunnen vaststellen binnen het bestuursbeleid van het ministerie, zijn toonaangevende beleidsprojecten geïnventariseerd binnen bepaalde clusters (dossiers).

Om het anders te stellen: onderzoek doen komt in belangrijke mate neer op het vergelijken van twee of meer gegevensbestanden. In dit onderzoek zullen we vier van dergelijke vergelijkingen terugvinden:

- de vergelijking van de bestuursopvattingen binnen de onderzochte periode zoals die zich manifesteren in de verschillende (aan Binnenlandse Zaken gerelateerde) projecten, alsmede de consistentie of veranderlijkheid van de bestuurstheorie;

- $\quad$ de vergelijking van de dominante bestuurstheorie van Binnenlandse Zaken met het gekozen ankerpunt, een dominante theorie binnen de Nederlandse bestuurskunde;

- $\quad$ de vergelijking van de dominante bestuurstheorie van Binnenlandse Zaken met de bestuurstheorie in andere bestuursdomeinen (politiek, vakdepartement, lokaal bestuur);

- $\quad$ de verhouding tussen de bestuurstheorie van Binnenlandse Zaken (visie), opgevat als instrumentele leidraad voor het beleidshandelen, en een aantal daaraan te stellen kwaliteitseisen: consistentie, langetermijngerichtheid, aansluiting op de ontwikkeling in de samenleving en dus 'passendheid' ter wille van de effectiviteit ervan.

Wat volgt

Het inhoudelijke keuzeschema om de inhoud van bestuursbeleid te typeren richt zich op de manier waarop wordt aangekeken tegen de verhouding tussen overheid en samenleving. De bestuurswetenschap reikt hiervoor (in ieder geval in Nederland) de dichotomie in opvattingen aan: (klassiek) government of governance. Dat vormt de hoofdgedachtelijn in hoofdstuk 2.

In het daarop volgende hoofdstuk volgt een methodisch gefundeerde beschouwing over de analyse van de inhoud van beleid, in casu dus bestuursbeleid. Daarbij valt de beredeneerde keuze op een vorm van discoursanalyse.

De daaropvolgende stap betreft de werkwijze die nodig is om een dominant discours te traceren en te bepalen. Die methode staat in het tweede deel van hoofdstuk 3 beschreven. Aan het eind van dat hoofdstuk wordt ook geoperationaliseerd hoe discours passend in de government-lijn onderscheiden kan worden van de governance-lijn. In dit methodologische hoofdstuk is een verantwoording opgenomen van de onderzoeksopzet en van de waarborgen voor de betrouwbaarheid van dit onderzoek.

Daarmee zal het eind van het theoretische gedeelte van dit boek bereikt zijn en gaat het relaas over naar het empirische deel. Eerst wordt het speelveld van het bestuursbeleid geschetst in een overzichtshoofdstuk 4. Daarna komen eerst vijf hoofdstukken over de dossiers van bestuursbeleid aan de orde $(5 \mathrm{t} / \mathrm{m} 10)$, gevolgd door beschrijvingen met hetzelfde zoeklicht over de nationale politiek (beperkt tot de Tweede Kamer) in hoofdstuk 11, een vakdepartement als Landbouw, Natuurbeleid en Visserij (LNV) (hoofdstuk 12), en het veld van de gemeentebesturen (hoofdstuk 13). In hoofdstuk 14 wordt het onderzoek afgesloten met conclusies en een reflectie op de bevindingen in de vorm van mogelijke verklaringen. 


\section{De bestuurstheorieën}

\subsection{Inleiding}

Dit hoofdstuk begint met een verkenning van het discours binnen de bestuurswetenschap. De bedoeling is hieruit een ijkpunt te destilleren voor het zoeken naar verhaallijnen binnen het bestuursbeleid. Weerspiegelt het beleid met betrekking tot het bestuur eenzelfde denklijn over de verhouding tussen overheid en samenleving als de toegepaste wetenschap van het bestuur (bestuurskunde), was immers de vraag. Die denklijn is wel te vinden, maar moet voor het doel van dit onderzoek nog worden toegespitst tot een operationele dichotomie, tot twee storylines, die herkend kunnen worden in de bestuurspraktijk.

Het gevonden begrippenapparaat uit de bestuurswetenschap wordt voor het empirische deel van dit onderzoek een leidraad voor het zoeken naar de bestuurstheorie van de beleidsmakers in het bestuursbeleid. Daarna zal in het tweede deel van dit hoofdstuk een onderzoeksstrategie worden uitgestippeld, waarmee de vraag beantwoord moet kunnen worden hoe verhaallijnen per project te typeren zijn, hoe deze verhaallijn zich verder heeft ontwikkeld in volgende projecten en of over de volle breedte van het bestuursbeleid hegemonie van een van deze verhaallijnen kan worden bepaald.

\subsection{Bestuurswetenschappelijk discours: van government naar governance}

De eerste vergelijkingseenheid voor het bestuursbeleid van Binnenlandse Zaken is voor dit onderzoek de dominante kijk van de wetenschap op de ontwikkeling in het openbaar bestuur. De relevante tak van wetenschap noemt zich bestuurswetenschap of bestuurskunde. Daar gaan we dus te rade voor het vinden van het denkkader dat we projecteren op het bestuursbeleid van 1969-2009. Men zou immers mogen verwachten dat kennisontwikkeling (in de bestuurskunde) en beleidsontwikkeling (bij het bestuursdepartement Binnenlandse Zaken) over hetzelfde object verwantschap vertonen.

\subsubsection{De ontwikkeling van het vak bestuurskunde in Nederland}

\section{Overzicht}

Het vak bestuurskunde als zelfstandige studierichting bestaat in Nederland, toevallig of niet, ongeveer even lang als het bestuursbeleid waarvan de start hierboven omstreeks 1970 werd gedateerd (Korsten, 1992: 17). Beschouw het maar als teken van emancipatie van het openbaar bestuur als zelfstandig probleemgebied. Vanuit een positie als bijvak of maximaal hoofdrichting onder politicologie (UvA, VU, Nijmegen) werd in 1976 onder leiding van Andries Hoogerwerf de eerste zelfstandige opleiding gestart aan de Universiteit van Twente. Sindsdien heeft bestuurskunde in Nederland een gestage opmars beleefd en is nu in vrijwel alle universiteiten (en hogescholen) present.

We beschikken over verschillende overzichtsdocumenten die proberen deze geschiedenis te typeren. De belangrijkste zijn de rapportage van de visitatiecommissie Public Administration onder leiding van de Leuvense hoogleraar Maes in het kader van de Quality Assurance van Nederlandse Universiteiten (QANU, 2005) en een themanummer van het blad Bestuurskunde ter gelegenheid van het afscheid van Arno Korsten als eindredacteur (Boin et al., 2004). De laatstgenoemde heeft samen met Rob Hoppe ook een duit in het zakje gedaan waar het gaat om beleidswetenschap (Korsten en Hoppe, 2006). Uit het genoemde themanummer van Bestuurskunde zijn de artikelen 
van Walter Kickert en Theo Toonen, die een aantal interessante lijnen trekken, bruikbaar. Hieronder wordt nog verwezen naar een boek van Ig Snellen (2007) over de 'Grondslagen van de bestuurskunde' en wordt een aantal opeenvolgende drukken van het meest gangbare leerboek voor de bestuurskundeopleidingen vergeleken (Rosenthal et al., 1996; Bovens et al., 2001, 2007 en 2012).

\section{Ontstaan van het vak}

In de eerste plaats komt de bestuurskunde in Nederland oorspronkelijk voort uit het bestuderen van instellingen en de formeel-juridische structuur van het openbaar bestuur. Dat was de bestuurskundige prehistorie, waarbij de Amsterdamse hoogleraar G.A. van Poelje doorgaans als pionier wordt genoemd.

De start van de zelfstandige discipline is vooral te danken aan de introductie van beleidswetenschap (Lasswell, 1971) door Kuypers en Hoogerwerf om de groeiende sturingsbehoefte van de Nederlandse overheid te laten vergezellen door rationele planning en evaluatie. Ook Korsten (1992: 17) positioneert een cesuur in de tijd rond 1968 als het vak bestuurskunde zich onder de vleugels van de rechtswetenschappen uitwerkt en relaties aangaat met politicologie (Amsterdam en Nijmegen) en sociologie (Rotterdam). Het institutionalisme van de oertijd is in de loop van de jaren tachtig vervangen door neo-institutionele benaderingen, waarmee ook het beleid werd ingebed in een bredere context. Niet alleen de formele structuren en ook niet puur rationele analyses van effecten, maar ook de gebruiken, culturen en routines van organisaties bepalen de uitkomst van beleid volgens deze stroming, die in Nederland tegenwoordig sterk is vertegenwoordigd.

\subsubsection{Omslag in de bestuurskunde}

\section{In Rotterdam begint de vernieuwing}

De grote cesuur die in de jaren negentig herkenbaar wordt, ontstaat als men zich bewust wordt van de beperkingen die complexiteit stelt aan sturing en beleidsvorming. Er waren ook voorlopers die al eerder blijk gaven van het besef dat bestuursverantwoordelijkheid gespreid was (o.m. Van Mierlo, 1988) en dat nieuwe, participatieve vormen van democratie serieus genomen moesten worden (o.m. Korsten, 1979). Buiten de bestuurskunde had onder sociologische vlag de Utrechtse vakgroep Planning en Beleid al uitgebreid gepubliceerd over interactief beleid en de netwerkbenadering, maar de fundamentele betekenis van fragmentatie in het openbaar bestuur en van verplaatsing van de politiek in termen van een shift daagde pas in de jaren negentig. Vooral de bestuurskunde-afdeling van de Erasmus Universiteit gaf hier de toon aan (Ringeling, Kooiman, Kickert, Klijn, Koppenjan, In 't Veld, Teisman), op de voet gevolgd door Delft (De Bruijn, Ten Heuvelhof). Volgens de wet van de remmende voorsprong werden zij spoedig door andere universiteiten ingehaald.

Het 'New Public Management' (NPM), dat alle overheden in zijn greep kreeg sinds de jaren negentig, liet in de bestuurskunde ook zijn sporen na, maar de interesse van de onderzoekers ging vooral uit naar het proces van hervormingen in de overheidsorganisaties en naar internationale vergelijking op dat punt. De inhoudelijke pretenties van deze managementstroming NPM, dat een bedrijfsmatige benadering tot betere dienstverlening zou leiden, werden minder geprofeteerd. De meeste bestuurskundigen waren nog bezig te bekomen van de schok dat sturing minder rationeel mogelijk was dan lange tijd was verondersteld. Toonen stelt niet zonder ironie vast dat "soms dezelfde onderzoekers die het bestuurlijke vraagstuk in de jaren zeventig en tachtig enthousiast bestudeerden vanuit de 'systeemtheoretische' optiek van 'het sturende en het te besturen systeem' in de jaren negentig hemel en aarde hebben bewogen om vooral de grenzen van bestuur, de onbestuurbaarheid van de samenleving, de zelfreferentialiteit van bestuurlijke organen en het interactieve afhankelijkheidskarakter van het bestuurlijk proces te beklemtonen" (Toonen, 2004: 35). 
Karakterisering van de verschuiving binnen de bestuurswetenschap

Veel van de bestuurskundige benaderingswijzen uit de jaren negentig - waaronder

netwerkbenaderingen, incentivesturing, postmoderne stromingen - zijn in feite voorbeelden van een procesmatige kijk op het openbaar bestuur. Daar ligt in dit kader de omslag. Men wilde weg van een te overheidsinterne oriëntatie, omdat die te veel zou suggereren dat de overheid zelf als centrale actor het stuur in handen had (de overheid als cockpit). Het kabinet-Den Uyl fungeerde als karikatuur van de maakbaarheidsgedachte waartegen (post)moderne bestuurskundigen zich afzetten.

De erkenning van het ontstaan van een kennissamenleving met een veelheid van relevante en niet te miskennen actoren en de adoptie van de complexiteit van de interacties tussen overheid en samenleving als probleemveld, bepalen de focus van de hedendaagse bestuurskunde.

Wellicht is governance ('besturen') niet meer dan een modeterm, die op zichzelf nog weinig oplost, maar op de achtergrond is het voor de meeste wetenschappers duidelijk dat de overheidsorganisatie zelf niet meer in staat is wat complexere maatschappelijke vraagstukken op te lossen en dat rationele top-downsturing steeds minder realistisch is. Het kenobject van de meeste bestuurskundigen is overduidelijk de wisselwerking, het samenspel tussen publieke organisaties en de samenleving geworden. Voor zover organisaties zelf het onderzoeksonderwerp vormen, gebeurt dat vanuit interesse voor hun cultuur en werkwijze, vanuit historisch gegroeide contingenties, niet als weerslag van een rationeel sturingsontwerp of normatieve staatkunde.

\section{Positionering in de tijd}

Deze omslag wordt het meest pregnant weergegeven door de these dat er sprake is van een 'shift van government naar governance', van verticale top-downsturing naar horizontale cocreatie van beleid, toenemende maatschappelijke zelforganisatie en meer meta-sturende en faciliterende rollen van de overheid.

In het midden van de jaren negentig kwamen er handboeken over netwerkmanagement en governance (Kickert et al., 1997; Kooiman, 1993). De verschijning daarvan past bij een positionering van de genoemde omslag in het denken in de tijd omstreeks 1995.

Wie verwacht dat het bestuurskundig onderwijs hiermee gelijke tred houdt, moet voor de aardigheid eens een aantal opeenvolgende drukken van het bekende inleidende handboek 'Openbaar Bestuur' bekijken. Dit leidt tot de conclusie dat het onderwijs wel tien jaar na-ijlt op het discours in de academische bestuurswetenschap. De vijfde druk van 1996 rept met geen woord over netwerken of governance. Ja, het woord netwerk wordt gebruikt in de betekenis van borrelcircuit. In de zesde druk van 2001 sluipen termen als coproductie en concurrentie wel binnen. Complexiteit van beleidsvorming wordt nog in verband gebracht met de veelheid van adviesorganen, commissies, bestuursorganen en dergelijke. Het gaat dus over de ingewikkeldheid van de overheidsorganisatie, niet over de afhankelijkheid van maatschappelijke partners en stakeholder. Pas in de zevende druk van 2007 gaat de redactie voluit over tot het thematiseren van de beweging 'Van zorgen voor naar zorgen dat' en van netwerkbestuur/governance. Kennelijk worden de jeugdige studenten dan eindelijk in staat geacht deze uitbreiding van het speelveld van de bestuurskunde te kunnen verwerken. De achtste druk (2012) van 'Openbaar Bestuur' gaat voort op deze lijn (Bovens et al., 2012: 43).

Snellen beschrijft in zijn boek 'Grondslagen van de bestuurskunde' (2007) maar liefst vijf paradigma's (rationaliteiten) die in beschouwingen over de verhoudingen tussen bestuur en politiek (let wel: niet samenleving) te onderscheiden zijn. Maar uiteindelijk is volgens deze auteur alleen de vijfde (de postmoderne) op te vatten als een omvattende benadering, de andere zijn perspectivische benaderingen of deelbenaderingen (Snellen, 2007: 93). Zo kan ook Snellen worden geschaard onder de Nederlandse bestuurskundigen die een tegenstelling waarnemen 
tussen klassieke government- en meer actuele governance-benaderingen. Alleen heeft die postmoderne rationaliteit als belangrijk bezwaar dat hierin zoveel factoren variabel zijn dat de spanningsboog van de wetenschap hier niet tegen is opgewassen. Dit maakt dat met het governance-denken niet het laatste woord in de bestuurskunde is gezegd, dat er niet een soort 'Einde van de Bestuurskunde' is bereikt. Hier gaat het erom dat de mainstream op enig moment rond de jaren negentig in die bedding belandde.

\section{Internationaal perspectief}

Van belang is nog te vermelden dat de zeer nadrukkelijke focus van de bestuurskunde op deze beweging ten dele een typisch Nederlands verschijnsel is. Kickert zegt hier het volgende over:

"After long following the American example finally in the 1990s the Dutch field of public administration and management developed some distinct approaches, such as the approach of 'managing complex networks' and 'public governance'. Management in complex and dynamic interorganisational networks, more or less resembling the British approach of networks and governance, became a Dutch specialty." (Kickert, 2008: 229)

Kjaer schrijft over de 'Dutch School' (Kjaer, 2004: 41), die zoveel nadruk legt op netwerkmanagement (ibidem: 45), en hoe de overheid omgaat met het gegeven dat de tegenspeler geen vaste actor is.

Dus, hoewel er vergelijkbare literatuur in de Verenigde Staten en Groot-Brittannië, evenals in het Duitse taalgebied (Benz et al., 2005), is te vinden, hebben Nederlandse bestuurskundigen wel bij uitstek oog voor de governance-benadering.

Deze kanttekening relativeert de hier gehanteerde tegenstelling in internationaal perspectief, al komt ook uit de Verenigde Staten het volgende citaat: "The shift from government to governance represents one of the important theoretical developments in political science and sociology during the past decades." Aldus begint Frank Fischer (2006) een artikel, waarin hij verwijst naar uitspraken van Jon Pierre uit 2000. Een afwijkend Amerikaans geluid is afkomstig van Frederickson (2005), die het gebruik van het begrip governance, vooral bij Europeanen, erg vaag vindt en voorstelt het te beperken tot drie verschijnselen:

1. inter-jurisdictional governance (interbestuurlijke samenwerking);

2. third-party governance (contractueel naar de (semi-)private sector gedelegeerde bestuursbevoegdheden);

3. public non-governmental governance, waar non-gouvernementele organisaties publieke belangen behartigen (Frederickson, 2005; 300-301).

Het is echter duidelijk dat met dit voorstel de impact op het reguliere bestuur wordt gemist. Dat vinden wij in Nederland juist interessant.

Voor dit onderzoek is de interpretatie van de hoofdvraag niet gericht op de bestuurstheorie van de hele wereld. Het is al heel wat als het Nederlandse bestuursbeleid ongeveer gelijke tred houdt met de Nederlandse bestuurskunde.

Hieronder wordt aangegeven wat deze begrippen in deze context betekenen en hoe deze kunnen worden geoperationaliseerd om ze in het discours van Binnenlandse Zaken te kunnen herkennen.

\subsection{Kernbegrippen in de bestuurswetenschap}

\subsubsection{Begrip governance}

\section{Een verwarrend begrip}


Het is niet zonder meer duidelijk wat met governance wordt bedoeld, omdat het gebruik van het woord niet eenduidig is. Die verwarring wordt bevorderd doordat het begrip te pas en te onpas wordt gebruikt en in nogal verschillende betekenissen. Rhodes (1997: 47-53) onderscheidt zes verschillende betekenissen van het woord governance met elk hun eigen literatuur:

- $\quad$ corporate governance (bestuurskwaliteit in het particulier bedrijfsleven);

- good governance, of government governance, waar de interne kwaliteit van het openbaar bestuur centraal staat;

- $\quad$ het streven naar een minimale staat, en maximale toepassing van marktwerking bij de levering van publieke diensten;

- $\quad$ bestuur volgens de idealen van het New Public Management, dat de verhouding tussen overheid en burgers afmeet naar maatstaven van klanttevredenheid en dat managementmethoden uit de particuliere sector overplant naar het openbaar bestuur;

- bestuur volgens de sociocybernetische systeemleer, waarbij de afhankelijkheid tussen talrijke actoren wordt gepostuleerd. Hier vormt interactie het mechanisme dat sociaal-politieke bestuursresultaten genereert;

- de studie van zelfregulerende netwerken, waarbij vrijwel niets van tevoren is gegeven, maar spelregels en context door netwerken zelf worden bepaald.

Bressers en Kuks (2000: 4) voegen hieraan nog een zevende categorie governance-publicaties toe:

- $\quad$ international governance (verkeer tussen staten, waar de verticale gezagsverhouding ontbreekt).

In de combinaties corporate governance en good governance betekent het doorgaans gewoon 'bestuur' (de activiteit in plaats van het instituut).

De Wereldbank introduceerde het woord governance in 1989 het eerst om daarmee een aanduiding te creëren voor het besturen als proceskwaliteit als voorwaarde voor steunverlening aan (ontwikkelings)landen en ten behoeve van internationale vergelijking. Zo ook Kettl (2002: xi). leder land heeft een bestuur, maar hoe dat werkt, kan tot uiting worden gebracht in gegevens over government governance. Een verschuiving van government naar governance zou in deze context zelfs kunnen worden uitgelegd als een verschuiving van aandacht voor instellingen naar de kwaliteit van bestuur.

Governance: uiteenlopende visies op bestuur

Good governance, corporate governance en international governance hebben eigenlijk weinig andere connotatie dan het woord bestuur in een bepaalde sector. Maar de andere vier stapels literatuur van de zeven die Bressers en Kuks noemen (2000: 4), onderscheiden zich door een eigen, vaak normatieve, visie op het bestuur.

Het contrasterende begrippenpaar government versus governance duidt in bestuurskundig jargon op de horizontaliserende verhouding tussen overheid en samenleving, een verschijnsel dat aandacht vraagt voor complexiteit en interactie. Beide begrippen slaan dan op een bepaalde wijze van besturen, maar met een verschillende perceptie van het speelveld en van de beleidsbepalende actoren. Hierbij ligt de nadruk op de interactie en de relationele kant van het besturen.

Verschillende betekenissen sluiten meer aan bij hiërarchische sturingsmodellen of bij verhoudingen in de markt dan bij de specifieke derde weg, die van het netwerkbestuur. Meuleman, die in zijn dissertatie zoekt naar manieren waarop managers gebruikmaken van de drie hoofdrepertoires van publieke sturing om problemen aan te pakken: hiërarchie, markt en netwerkbestuur, opteert voor een brede definitie van governance, die ook de hiërarchische aanpak en de toepassing van marktprincipes omvat (Meuleman, 2008: 11). Dan is er helemaal geen sprake van een shift, maar van verschillende accenten, geregeerd door een al dan niet expliciet gehanteerde vorm van metagovernance. 


\section{Drie hoofdstromen}

In deze discussie zijn drie hoofdstromen te onderscheiden bij het gebruik van het begrip governance.

1. een overkoepelend begrip dat de werkelijkheid van het bestuur probeert te beschrijven in al zijn verscheidenheid, met gebruikmaking van zowel hiërarchische, markt- als netwerkmethoden (Meuleman, 2008);

2. een specifiek onderdeel van de bestuurlijke werkelijkheid, waarin de civil society een belangrijke bijdrage levert aan het oplossen van maatschappelijke problemen. Als bijkomend verschijnsel is hier in het bijzonder netwerkbestuur als werkwijze toepasbaar. De hoofdzaak is dat het georganiseerde middenveld en het zelforganiserend vermogen van de samenleving een bepalende rol speelt bij het realiseren van bestuursresultaat. De tweede hoofdstroom betreft dus een derde weg náást hiërarchie en markt. Voor zover de overheid hier partij is, gelden horizontale verhoudingen, afspraken en convenanten, maar eigenlijk is de impliciete boodschap dat de samenleving het behartigen van collectieve belangen in hoge mate zelf afkan;

3. een nieuwe benaderingswijze van bestuur die de nadruk legt op de wederzijdse afhankelijkheid van veel actoren, de meervoudigheid van arena's voor politiek handelen, radicale onzekerheid en verscheidenheid en de menselijke communicatie en interactie als belangrijkste hulpmiddel om gemeenschappelijke betekenis te genereren. Hierbij is de herkomst van de actoren (overheid, markt, maatschappelijke organisaties) niet bepalend voor het gebruik van het begrip governance, maar veeleer de complexiteit van de relaties. In de meeste gevallen zal er sprake zijn van een of andere combinatie van actoren uit de publieke en private sector, omdat de problematiek erom vraagt en omdat dit de specifieke dynamiek van bestuurlijke verhoudingen verklaart. Wezenlijk is dat er ten opzichte van de klassieke overheid verbreding van het speelveld optreedt, waarbij de scheiding tussen bestuurssubject en bestuursobject vervalt.

In dit boek wordt de laatste benadering gehanteerd, een keuze die hierna zal worden toegelicht. Definities zijn rekbaar en een kwestie van smaak en afspraak. In dit onderzoek ligt de nadruk op het contrast tussen bepaalde percepties van besturen en daarom wordt hier aangesloten bij de school binnen de bestuurskunde die governance associeert met horizontaal netwerkbestuur en government met de meer verticale vormen van bestuur. De belangrijkste representanten van deze school komen oorspronkelijk uit Delft en Rotterdam (Kooiman, Van Twist, Klijn, Teisman), maar geleidelijk aan hebben ze bij de meeste Nederlandse bestuurskundigen in Amsterdam, Nijmegen, Leiden, Twente en Tilburg wel gehoor gevonden, daarbij Rotterdam en Delft spoedig overvleugelend in het nog meer loslaten van het institutiegebonden onderzoek. Vrijwel alle Nederlandse universitaire bestuurskundeafdelingen publiceren in deze denklijn (Denters, Hoppe, Bressers, Kickert, Klijn, Teisman, Ten Heuvelhof, De Bruin, Grin, Hajer, Van Twist, Frissen, Hendriks, Van den Brink, Termeer, In 't Veld en vele anderen).

Eerlijkheidshalve zij vermeld dat er ook bestuurskundigen zijn die hierop niet betrapt kunnen worden (onder meer Hoogerwerf, Rosenthal, Denters, Fleurke, De Ridder), maar zij zijn in de minderheid en hebben zich ook zelden uitdrukkelijk gekeerd tegen deze gedachtegang.

Over de betekenis van deze begrippen bestaat weinig verschil van mening meer, wel over de mate waarop zij in de empirie bepalend zijn voor het gedrag van bestuurders en ambtenaren en in hoeverre de kanteling naar governance ook beter bestuur oplevert. Over het tegendeel, namelijk dat dit niet per se het geval is, is overigens voldoende literatuur te vinden. Zo leidde 'dialogisch bestuur' in de ruimtelijke ordening (een vorm van interactieve netwerksturing) tot oeverloze deliberatie totdat het woord oeverloos bij een overstroming letterlijk werkelijkheid werd en men zich door crisis gedwongen voelde om tot actie over te gaan (Cörvers et al., 2003: 221). Uiteraard bewijst dit nog niet of het tekortschieten ligt aan de bestuurstheorie van in dit geval dialogisch 
bestuur of aan de toepassing ervan, maar deficiënties van op governance gebaseerde aanpakken zijn in de praktijk vanzelfsprekend niet uitgesloten.

\subsubsection{Complexe netwerkrelaties versus eenduidige vaste verhoudingen}

\section{Essentie van government}

Government is een grondgedachte van besturen waarbij de scheiding tussen besturend orgaan en bestuurd systeem (de samenleving) strak is en de beslissing over beleid en uitvoering in één hand ligt, doorgaans die van de verantwoordelijke bestuurder. Het is het monocentrisch cockpitdenken. Dit model is toepasbaar in domeinen waar taken, doelen en middelen goed zijn af te bakenen en een overheid die niet hoeft te delen met andere organisaties. Als een overheid (bij een taak of opdracht) alle doorzettingsmacht heeft, is government soms een toepasbaar model.

Het departementaliseren van onderwerpen in hiërarchisch aangestuurde afdelingen en diensten is functioneel voor een effectieve en efficiënte dienstverlening door de overheid bij niet al te complexe onderwerpen. De beoordeling van de situatie, waaronder de complexiteit van overheidsactiviteiten, is overigens een uitkomst van politieke perceptie. Men kan hetzelfde onderwerp met de hele wereld in verband brengen of, als hierover politieke consensus bestaat, die verbanden grotendeels veronachtzamen.

Merk verder op dat vergaande departementalisering en specialisatie binnen en buiten het openbaar bestuur tegelijkertijd de kiem legt voor het ontstaan van netwerken en onmisbare afhankelijkheidsrelaties en samenwerkingsverbanden en daarmee voor het ontwikkelen van vormen van governance. Immers, hoe meer eenheden door specialisatie functioneel zijn versnipperd, des te sneller zullen ad hoc verbindingen en combinaties van verschillende eenheden nodig zijn om een probleem op te lossen of een product te leveren.

\section{Essentie van governance}

De ontwikkeling van het bestuur kenmerkt zich in deze tijd volgens een ruim aanbod aan bestuurskundige literatuur door de overgang van government naar governance (Kooiman, 1993; Scharpf,1994; March \& Olsen, 1995; Rhodes, 1997; Hoekema et al., 1998; Mayntz, 1999; Peters \& Pierre, 2000; Salamon, 2002; Hajer \& Wagenaar, 2003; Kjaer, 2004; Van der Heijden et al., 2005; Bevir \& Rhodes, 2006; Schuppert, 2007; Hoppe, 2011).

In de bestuurskunde werd vanaf de jaren zeventig de aandacht voor de bestuurbaarheid van moderne samenlevingen steeds belangrijker (Van Gunsteren, 1974). De zoektocht begon naar alternatieve sturingsvormen naast de klassieke overheidshiërarchie en de markt. Ingewikkelde maatschappelijke problemen zouden uiteindelijk door vormen van netwerkmanagement of zelforganisatie beter kunnen worden aangepakt dan door top-down staatsinterventie. Daarvoor was het nodig de schijnwerper te verplaatsen van bestuursstructuren en instituties naar beleidsprocessen en netwerken. De opkomst van nieuwe samenwerkingsvormen buiten klassieke staatsmachten, zoals de Europese Unie, versterkte die aandacht nog verder. Uiteindelijk komt de bestuurskunde uit bij 'de nieuwe onoverzichtelijkheid' (Habermas, 1989).

De vraag is of de klassieke bestuursparadigma's dan nog passen dan wel moeten worden vervangen door een algemene theorie over sociale dynamiek. Mayntz (1999) meent dat het zo'n vaart nog niet loopt, tenzij de globalisering zover voortschrijdt dat graduele aanpassingen van het klassieke bestuursmodel niet meer voldoen. Hoewel zij elders schrijft dat modern bestuur geconfronteerd wordt met ongrijpbare complexe systemen, met onverwachte tegenspelers die zichzelf spontaan organiseren en in staat zijn beleid te dwarsbomen en dat regeringen dus nieuwe onderhandelings- en coördinatietechnieken moeten beheersen (Kjaer, 2004: 36). Dat is nogal wat.

Het is een semantische discussie of een bestuursparadigma moet worden aangepast. Enerzijds kan men stellen dat de enkele verschuiving van perceptiewijze die uitgaat van een centrale actor 
naar een wijze van zien die uitgaat van de wederzijdse afhankelijkheid van verschillende actoren al een totaal ander redeneermodel vergt. In het tweede geval is immers de uitkomst van de wisselwerking principieel niet meer voorspelbaar (Zuijderhoudt, 2007: 19). Anderzijds blijft ook veel hetzelfde, omdat ook in processen met een onzekere uitkomst een gezaghebbende overheid een belangrijke, zij het minder beheersbare, rol zal blijven spelen

\section{Afhankelijkheid tussen en verscheidenheid van actoren}

Is dus government in één beeld te vangen met het woord cockpit, zo is bij governance afhankelijkheid de centrale term. De vraag is dan of de onderlinge afhankelijkheid van actoren gecombineerd moet worden met de overschrijding van de grens tussen publieke en private sector. Een perceptiewijze die overheidshandelen opvat als resultante van de wisselwerking tussen vele actoren zou ook toepasbaar zijn op een complex van actoren binnen één overheidsorganisatie, waarbij bijvoorbeeld de overheid is opgebouwd uit verschillende quasi-autonome eenheden, zoals het Nederlandse collegiaal bestuur, de intergemeentelijke samenwerking of de relatie tussen beleids- en uitvoeringseenheden wel kunnen worden beschreven.

Aldus toegespitst op het optreden van meerdere actoren is dit denkmodel ook relevant als men denkt aan de verhoudingen tussen verschillende overheidsorganisaties, zoals gemeenten, provincies en rijksministeries. Daarvoor is onder meer de term complementair bestuur (Werkgroep, 1977 ) in het leven geroepen. In de wetenschap spreekt men van multi-level governance (tenzij alleen gemeenten onderling met elkaar samenwerken). In deze situaties worden samenwerkingsrelaties formeel vastgelegd in kaderwetten (denk aan planverplichtingen), convenanten of bestuursakkoorden. Knap voorspelbaar en statisch kunnen dergelijke contracten zoals akkoorden nog steeds zijn. Een nieuw paradigma is er nauwelijks voor nodig. Interessant wordt het pas als dynamiek, verandering in de tijd en leereffecten in het spel worden betrokken. Dat is aan de orde als de verhoudingen grensoverschrijdend én variabel zijn. Een gestolde afhankelijkheidsrelatie binnen één sector, bijvoorbeeld tussen ministerie, inspectie en scholen, ministerie en energiebedrijven, tussen gemeenten en marktpartijen bij uitbesteding van diensten en zo verder, is uit oogpunt van bestuurlijke dynamiek niet wezenlijk anders dan een gemeenschappelijke regeling met verschillende openbare besturen. Het gegeven dat overheden met private partijen samenwerken, is dus misschien wel een noodzakelijke, maar nog geen voldoende voorwaarde om van de governance-benadering te kunnen spreken. Er is meer voor nodig. Meestal wordt daarom het begrip governance verbonden met flexibele netwerkrelaties tussen publieke en particuliere actoren, die tot stand komen op grond van functionele afhankelijkheden bij de aanpak van een complex maatschappelijk probleem. Het nieuwe of problematische in dergelijke afhankelijkheidsrelaties is dat, anders dan in een klassiek governmentpatroon, de hegemonie, de gezags- en verantwoordingsrelaties niet op voorhand vastliggen (Hajer en Wagenaar, 2003: 9) en afhankelijk zijn van het specifieke probleem en de specifieke context. Geen enkele actor heeft alleen alle doorzettingsmacht of de benodigde kennis in huis.

Tot zover typeringen van de begrippen op hoofdlijnen. Het is waarschijnlijk dat zich bínnen het governance-denken ook bepaalde verschuivingen en ontwikkelingen hebben voorgedaan. Zo is in de samenspraak en coproductie tussen overheid en samenleving wel onderscheid te maken tussen procesmanagement, burgerparticipatie en zelforganisatie (doe-democratie), maar dat zijn toch accentverschillen die hier verder buiten beschouwing blijven.

\section{Sturen of samenwerken}

In geval van governance is de rol van de overheid anders dan bij government. De ontwikkeling van beleid ligt niet in één hand, maar is afhankelijk van de samenwerking van vele actoren. Complexiteit is hier de kenmerkende factor en menselijke interactie vervangt de top-down bevelsrelatie. Verkokering in de betekenis van eenkennigheid van overheidsorganisaties is in dit geval disfunctioneel. Nederlandse equivalenten voor beide begrippen zijn klassieke overheidsorganisatie en netwerkbestuur. 
Er zijn veel auteurs die de overgang van government naar governance op een normatieve manier beschrijven: de klassieke top-down werkwijze is niet meer bruikbaar voor het oplossen van bepaalde maatschappelijke problemen, dus dient de overheid zijn rol aan te passen aan de noodzakelijke coproductie in netwerken (Pierre \& Peters, 2000: 223). Daarnaast is er een meer empirisch georiënteerde benadering van de begrippen mogelijk, die eenvoudig vaststelt dat zich nieuwe sturingsvormen ontwikkelen als reactie op maatschappelijke ontwikkelingen zoals individualisering, toenemende mondigheid van burgers, informatisering, et cetera. De waarde van die bestuursvormen kan in het midden blijven. Als in de bestuurlijke werkelijkheid er toenemend gebruik van wordt gemaakt, is dat ook voor de overheid en voor het politieke circuit een gegeven. Empirisch kan er een ingrijpende verstrengeling worden waargenomen tussen overheid en samenleving, tussen publieke en private domeinen. De overheid heeft een aantal taken afgestoten aan de particuliere sector en daarmee haar eigen afhankelijkheid van bedrijven en maatschappelijke organisaties zoals ziekenhuizen en woningcorporaties vergroot. Aan de kant van bedrijven en maatschappelijke organisaties is het publieke verantwoordelijkheidsbesef vergroot en kijkt niemand meer vreemd op van consortia van zeer gemengde samenstelling, waarin politie, sportkledingfabrikanten, woningcorporaties, stadsbestuurders en charitatieve instellingen een project opzetten om achterstandsjeugd op te vangen.

De nuchtere vaststelling van het praktisch nut van nieuwe samenwerkingsarrangementen voor het aanpakken van maatschappelijke problemen betekent niet dat de werkelijkheid in alle domeinen van het openbaar bestuur aan de kenmerken van governance hoeft te voldoen. Dat zal zeker niet het geval zijn binnen terreinen waar de overheid haar hiërarchisch bovengeschikte rol speelt, zoals bij de uitoefening van het geweldsmonopolie. Die rol en alle voorbeelden waarbij de burgers als onderdaan figureren, kunnen het discours over het hele openbaar bestuur als government kleuren. Discoursen in de trant van government of governance zijn dus geen pogingen om de werkelijkheid van het openbaar bestuur in haar geheel te typeren, maar leggen accenten die passen bij een bepaalde probleemanalyse die in delen van het openbaar bestuur op dat moment dominant wordt geacht. Is men geneigd complexiteit te reduceren tot centrale sturing of complexiteit te omarmen door meervoudige sturing in netwerkcontexten als uitgangspunt te nemen? Die accenten kunnen voor jaren de actualiteit van de beleidsontwikkeling bepalen als het gaat om het beleid dat gericht is op verbetering van het openbaar bestuur als zodanig, het bestuursbeleid.

\subsubsection{Keuze van relevante concepten}

Op een andere manier kijken naar hetzelfde bestuur

Het hele betoog zou ook herleid kunnen worden tot een perceptieverschuiving; men zet tegenwoordig een andere bril op om het openbaar bestuur te beschrijven: governance zou dan vooral een werkelijkheidsgetrouwer, meer sociologisch, beeld van het bestuur opleveren dan het modelmatige sjabloon van government. De Weberiaanse ambtenaar bestaat niet echt, evenmin als de voor maatschappij-invloeden inerte politicus, noch die stabiele gemeenschap met afgebakende grenzen (één publiek, één mediageluid), noch een strikte hiërarchie of de door veel burgers kennelijk ${ }^{7}$ verlangde al bedillende presterende (dienstverlenende) verzorgingsstaat, waarvan vooral de output bijdraagt aan de legitimatie van het bestuur.

Governance erkent op al deze modelmatige kenmerken dat de praktijk vooral het tegendeel laat zien of dat government misschien nooit aan dit ideaalbeeld heeft voldaan (Zimmer, 2007: 3). Let wel: in dat geval hoeft ook niet in termen van een shift gedacht te worden.

\section{'Moeilijke en makkelijke' onderwerpen}

\footnotetext{
${ }^{7}$ Zie onder meer de uitkomsten van 21 minuten.nl (De Publieke Zaak, 2007), waar het contrast opvalt tussen massieve kritiek op de overheid enerzijds en zeer hooggespannen verwachtingen jegens diezelfde overheid anderzijds voor het oplossen van alle maatschappelijke problemen.
} 
In de praktijk is het in veel gevallen uitstekend mogelijk om de rationalistische, beheersgerichte benadering te hanteren. Die werkt immers vooral als een probleem en de bijbehorende oplossing voldoende duidelijk zijn en de materie relatief onomstreden is. Dat zijn de 'makkelijke onderwerpen' die aangepakt kunnen worden door een overheid die alle doorzettingsmacht heeft. Moeilijke onderwerpen voor een ministerie zijn daarentegen die taken die te maken hebben met onzekerheden, met meervoudige percepties, die afhankelijk zijn van samenwerking met verschillende actoren (met eigen taken en/of doelen en/of middelen) en die organisatie- en sectoroverstijgende werkwijzen vergen. Soms is dat wel duidelijk. Een straatnamenplan maken is over het algemeen in Nederland geen complex probleem. Het is echter niet altijd op voorhand gegeven welke taken moeilijk en welke makkelijk zullen zijn. Dat is ten dele een politieke keuze, een kwestie van waardering. Zelfs het grotestedenbeleid kan de politiek 'makkelijk' maken, zoals in een bepaalde periode het geval was toen dit onderwerp synoniem werd beschouwd aan het opknappen van oude woningen met behulp van stadsvernieuwing. Anderzijds kan zelfs het ontwikkelen van model voor een paspoort een moeilijke en zwaar politieke opgave zijn als er maar genoeg verschillende eisen en aspecten aan verbonden worden. Tot op zekere hoogte is de ingewikkeldheid (moeilijkheid) van een probleem uitkomst van politieke processen, maar vaak is op het eerste gezicht wel duidelijk dat een onderwerp zich eerder leent voor een makkelijke aanpak dan andere: het maken van een straatnamenplan, het onderhoud van straten en wegen, et cetera.

De aan een probleem verbonden eisen en aspecten kunnen onzekerheden meebrengen op het niveau van waarden of van feiten en kennis. Van Wildavsky (Douglas \& Wildavsky, 1982) is de volgende bekende matrix afkomstig die de categorisering van beleidsonderwerpen naargelang de mate van controverse in schema brengt (Hisschemöller, 1993: 28).

Figuur 2.1 De matrix van Wildavsky

\begin{tabular}{|l|l|l|}
\hline & $\begin{array}{l}\text { Geen verschil van inzicht over in } \\
\text { geding zijnde waarden }\end{array}$ & $\begin{array}{l}\text { Onduidelijkheid of onenigheid } \\
\text { over in geding zijnde waarden }\end{array}$ \\
\hline $\begin{array}{l}\text { Geen verschil van inzicht over } \\
\text { van belang zijnde feiten }\end{array}$ & $\begin{array}{l}\text { Technisch oplosbaar } \\
\text { gestructureerd probleem }\end{array}$ & $\begin{array}{l}\text { Politiek conflict, slecht } \\
\text { gestructureerd probleem }\end{array}$ \\
\hline $\begin{array}{l}\text { Onduidelijkheid of onenigheid } \\
\text { over van belang zijnde } \\
\text { feiten }\end{array}$ & $\begin{array}{l}\text { Nader onderzoek nodig } \\
\text { Matig gestructureerd probleem }\end{array}$ & $\begin{array}{l}\text { Weerbarstig probleem, } \\
\text { 'wicked problem' }\end{array}$ \\
\hline
\end{tabular}

Ook Hoppe (1989) heeft veel over dit onderwerp geschreven. Hij spreekt over ongetemde problemen. In grote lijnen lenen de onderwerpen in de cel linksboven in figuur 2.1 zich bij uitstek voor een government-benadering en die in de cel rechtsonder kunnen zeker alleen met behulp van netwerkbestuur/governance (interactieve netwerkaanpak) worden benaderd.

Een samenleving casu quo het bestuur heeft een zekere marge om individuele kwesties als makkelijk/duidelijk of moeilijk/controversieel te behandelen, bijvoorbeeld door verschillen te negeren of te overrulen. Over de ideologische verschillen die in de cel rechtsboven overblijven, kan men uiteindelijk wellicht uitruil plegen, maar bij bijna alle cellen is veel communicatie van belang, tenzij men de kortste weg kiest, maar dat zal in toenemende mate niet ongestraft blijven. Zelfs straatnamen kun je in samenspraak met de buurt vaststellen en klimaatproblemen laten zich wellicht alleen 'dictatoriaal' oplossen (dus niet?). Hier volgen we de stelling dat steeds meer 
interactie en netwerkvorming nodig is om op de as van betekenisgeving of op de as van kennisvergaring de zaken op een rijtje te krijgen. Het onderscheid tussen de cellen is dan gradueel.

Of elk vraagstuk zich uiteindelijk leent om in governance-modus aan te pakken en in welke mate, lijkt een academisch discussiepunt te blijven. Het is mogelijk over de keuze van elke straatnaam een discussie te starten met tal van actoren maar dat zal al snel als overdreven legitimiteit zoekend en ondoelmatig beschouwd worden. Mogelijk treedt ook inertie op doordat niet alle aangezochte actoren daarvoor interesse hebben.

Hier gaat het om een relatieve tendens die wordt afgeleid uit maatschappelijke ontwikkelingen. De feitelijke ontwikkelingen in de samenleving met bekende trends als individualisering en fragmentatie wijzen in de richting van steeds meer weerbarstigheid, onzekerheid en afhankelijkheid. Geen actor beschikt over alle taken, bevoegdheden en middelen om de belangrijkste maatschappelijke problemen alléén op te lossen. Verknoping met taken, bevoegdheden en middelen van anderen is daardoor onvermijdelijk. Minstens zo belangrijk is dat niemand de benodigde lokale of andere kennis in huis heeft, waar Hoppe en anderen nadruk op leggen. Het maakt niet veel uit of de feiten onzeker zijn of ook de waarden uiteenlopen. Zowel in geval van een verschillende perceptie en/of beoordeling van feiten als in geval van verschil in waardenoriëntatie zal er de noodzaak bestaan tot interactie tussen van elkaar afhankelijke actoren. Ze gaan op zoek naar gemeenschappelijke beeldvorming en zo mogelijk ook naar doelverbinding en/of middelenbundeling.

In alle gevallen zal het bestuur van buiten naar binnen moeten werken om problemen aan te pakken.

Wat is dan die shift?

De literatuur is niet eenstemmig over de vraag of er werkelijk een fundamentele verandering is opgetreden in de aard en context van openbaar bestuur of dat alleen de perceptie en het inzicht over de werkelijkheid zijn veranderd. Voor dit moment kunnen we het antwoord op die vraag in het midden laten, omdat in beide gevallen van het bestuur een ander handelingspatroon verlangd wordt. Wel kan hier al volmondig worden beaamd dat een zogenoemde shift niet moet worden opgevat als vervanging van alle bestuur van modus A (government) door bestuur van modus $\mathrm{B}$ (netwerkbestuur/governance). Dat zou feitelijk onmogelijk en ook onwenselijk zijn. Strakke regels inclusief 'verticale' handhaving en heldere kaders blijven onontbeerlijk in de Nederlandse context van politieke democratie en rechtsstaat. Het gegeven dat een zeer groot deel van ons bestuurlijke werkelijkheid nog wordt geregeerd door juridische kaders en bindende regels (zoals onder meer geboden en verboden), dwingt bestuurders, ook al zouden zij anders willen, tot een bestuurscentrisch, gehoorzaam en gehoorzaamheid vereisend handelen. Uitvoering, handhaving en toezichtsarrangementen zijn hier meer toepasselijke codewoorden dan bijvoorbeeld probleemverkenning of coproductie in netwerken, laat staan zelfsturing. Alleen de samenwerkingsmodus in netwerkverband krijgt relatief steeds meer accent in een complexe gefragmenteerde samenleving. Zo ook Hendriks en Drosterij (2012: 21), die schrijven over goed bestuur in de stad en daarbij erkennen dat het repertoire van gemeentebesturen de laatste jaren grotere diversiteit vertoont en steeds meer nadruk geeft aan vormen van overleg met de 'echte beslissers' enerzijds en met gewone burgers anderzijds, met gebruikmaking van communicatievormen in een stedelijk platform of van vrije concurrentie tussen maatschappelijke initiatieven. Deze laatste markt-achtige werkwijze, die vanuit variëteit toewerkt naar selectie in plaats van vanuit rationele analyse naar dirigistische instructie, komt in paragraaf 3.5 .2 uitgebreider terug.

Samenvattend is het begrip governance in de frase 'overgang van government naar governance' aldus te definiëren: 
Governance is de grondvorm van openbaar bestuur die zich voordoet wanneer de ontwikkeling van beleid en beleidsrealisatie niet in één hand ligt, maar 'in het midden'. Dat wil zeggen dat het resultaat afhankelijk is van de samenwerking en gedachtewisseling van vele actoren. In het Nederlands spreekt men dan doorgaans van netwerkbestuur.

Voor government geldt dan een tegengestelde omschrijving:

Government is de grondvorm van openbaar bestuur die erop is gericht om in de samenleving convergentie te bewerkstelligen naar eenheid in locus en focus van collectieve besluiten, waarbij een publieke actor in staat wordt gesteld gezaghebbende besluiten te nemen die voor andere actoren bindend zijn.

Hoe komt de verschillende benadering tot uiting?

De genoemde overgang van government naar governance manifesteert zich op verschillende aspecten (zie figuur 2.2).

Figuur 2.2 Aspecten van meervoudig bestuur

\begin{tabular}{|l|l|l|}
\hline & Modus 1: Government & Modus 2: Governance \\
\hline waar (niveau) & Gescheiden bestuurslagen & $\begin{array}{l}\text { Multi-level, samenhang verschillende } \\
\text { niveaus (o.a. beleid en uitvoering) }\end{array}$ \\
\hline wie & Centrale sturende actor & $\begin{array}{l}\text { Multi-actor (niet één actor is zonder meer de } \\
\text { baas) }\end{array}$ \\
\hline wat & $\begin{array}{l}\text { Politieke oplossingen (producten) } \\
\text { centraal }\end{array}$ & $\begin{array}{l}\text { Maatschappelijk probleem centraal: multi- } \\
\text { facet. Proces genereert op voorhand } \\
\text { onbekende uitkomst }\end{array}$ \\
\hline hoe & Regels, subsidie en preek & $\begin{array}{l}\text { Multi-strategie en -instrumenten } \\
\text { sturingsinterventies beïnvloeden elkaar } \\
\text { wederzijds }\end{array}$ \\
\hline waarmee & $\begin{array}{l}\text { Algemene middelen, ambtelijke } \\
\text { capaciteit }\end{array}$ & $\begin{array}{l}\text { Multi-resources: combinatie van middelen } \\
\text { bepaalt de mogelijkheden }\end{array}$ \\
\hline
\end{tabular}

Bron: Bressers en Kuks, 2000: 10

Meest genoemd is de erkenning van bestuur als multi-actor- en multi-level-sturing, met wederzijdse afhankelijkheid van de partners om tot resultaat te komen, tegenover de klassieke opvatting waar de sturingsverantwoordelijkheid en het prestatievermogen bij één centrale actor zijn gelegd, die hoogstens met anderen afstemt of anderen 'inhuurt' om tot beslissingen en implementatie te komen.

De aanleiding die het inschakelen van verschillende lagen en actoren nodig maakt, is de definitie van het probleem dat men wil aanpakken: maatschappelijke problemen zijn meestal complex en meerzijdig, de oplossingen hebben talrijke effecten en neveneffecten, waardoor vrijwel altijd verschillende stakeholders (met onverwachte inzichten en belangen) geraakt worden. Bovendien is zelden één aanpak voor de oplossing toereikend, maar verscheidene oplossingsstrategieën werken weer op elkaar in. Ten slotte kan bij deze complexe problemen alleen door de doelverknoping en bundeling van middelen met verschillende partners een passend resultaat worden bereikt. 
Overheden hebben zelden voldoende macht en capaciteit in huis om zelf de klus te klaren; ze zullen krachten moeten bundelen en hefboomwerking moeten inzetten om het verschil te maken.

Met deze kijk op de bestuursopgave zijn nog andere kenmerken verbonden die maken dat van een paradigmawisseling gesproken kan worden:

- Er zijn specifieke proceskenmerken die horen bij de erkenning van de genoemde afhankelijkheidsrelatie. De dynamiek van beleidsprocessen valt niet meer te beschrijven in lineair-rationele termen. Leren kan niet meer uit een boekje, maar vloeit voort uit de feedback van handelen en dialoog.

- Als gevolg van grote onzekerheid en verwevenheid zijn klassieke benaderingen ontoereikend om de werkelijkheid van governance te beschrijven. Pas in het gesprek leert men de werkelijkheid kennen, of zelfs: er bestaat geen werkelijkheid buiten de conversatie tussen mensen. Die werkelijkheid beantwoordt aan veel grilliger patronen dan directe oorzaak-gevolgrelaties.

- Nieuwe sturingsbenaderingen zijn nodig om zaken voor elkaar te krijgen: horizontale netwerksturing is naast het verticaal hiërarchisch sturingsmodel nodig in de bestuurlijke methodiek van beleidsontwikkeling.

\section{Valkuil}

Onze stelling over de shift maakt het lastig om neutraal van twee modaliteiten te blijven spreken, omdat de theorie veronderstelt dat er een niet te negeren maatschappelijke trend in de richting van governance plaatsvindt. Als het bestuursbeleid deze omwenteling niet zou weerspiegelen (wat hier ook wordt verwacht als uitkomst), zou dit beleid bij voorbaat als obsoleet bestempeld kunnen worden. Hiertegen moet de onderzoeker waken om de volgende redenen:

1. In de eerste plaats is het geheel niet zeker dat de bestuurswetenschap het bij het rechte eind heeft. Dat een bepaalde stelling breed wordt aangehangen, is niet hetzelfde als dat zij ook bewezen is. Dat hier de bestuurswetenschap als 'ankerpunt' wordt gebruikt voor het beleid, is bij gebrek aan beter. Hierop wordt in hoofdstuk 14 teruggekomen.

2. In de tweede plaats kan het voor (onderdelen van) het bestuursbeleid altijd nog een legitieme keuze zijn om 'tegen de stroom in' centraliteit, ordening en standaardisatie na te streven. Het (micro) bestuursbeleid is niet gelijk te stellen aan de totale (macro) ontwikkeling (megatrend) van de verhouding tussen overheid en samenleving. Als die ontwikkeling al een nettoverschuiving in de richting van netwerkbestuur laat zien, zou een aanpassing in de bestuurstheorie verwacht mogen worden die recht doet aan die verschuiving, maar die hoeft niet per se meebuigen in dezelfde richting te impliceren. Een bestuurstheorie is geen windvaan. Continuiteit in de bestuurstheorie en in de positie van een betrouwbaar bestuur is ook veel waard, zo stellen ook bestuurskundigen (Bekke, 1990), maar juist als ontwikkelingen in de samenleving zeer dynamisch zijn, is het nodig veranderingen tijdig, maar weloverwogen te incorporeren in de bestuurstheorie. Vandaar dat deze studie zo op verandering en vernieuwing is gefocust.

3. In de derde plaats is al meermalen gesteld dat de shift niet absoluut kan worden opgevat. Het is niet zo dat alles van government-denken kan worden ingewisseld voor alles van een governance-benadering. Het is eerder een kwestie van meer of minder (contingentie), maar verwacht mag worden dat het beleidsdenken over het bestuur de sporen vertoont van een dergelijke accentverschuiving als de bestuurspraktijk daar om vraagt. In dat licht zijn bij de hier ondernomen verkenningen de onderweg opgedane inzichten over de werking van de bestuurstheorie minstens zo interessant als de 'absolute scores' op de schaal tussen government en governance. De verhalen in deze studie kunnen blijk geven van de mate waarin een op de lange termijn gerichte visie op het openbaar bestuur in een veranderende samenleving bestaat en effect sorteert op het beleid.

Daarom hebben resultaten van de voorgenomen analyse een relatieve betekenis. Zij zijn vooral te duiden als een vaststelling van de mate waarin het bestuursbeleid daadwerkelijk in deze twee 
termen (die in de Nederlandse bestuurskunde zo spreekwoordelijk zijn) te typeren is. In ieder geval is het niet zo dat de keuze voor meer government of governance als grondslag van een bestuurstheorie op zichzelf verontrustend hoeft te zijn. Ten opzichte van de turbulente maatschappelijke veranderingen in de afgelopen veertig jaar (megatrends met individualisering voorop) zou vooral het ontbreken van een merkbare verandering in de visie op de verhouding tussen overheid en samenleving bevreemding wekken. Maar zowel de bestuurstheorie (visie) van het ministerie als de mainstream-theorie van de wetenschap kunnen op de weegschaal gelegd worden als vervolg op uitkomsten van dit onderzoek.

\subsubsection{Specifieke aspecten van de nieuwe benaderingswijze}

\section{Reflectie op complexiteit in organisatieleer}

Opmerkelijk is dat de governance-literatuur steeds terugkomt op complexiteit als het belangrijkste kenmerk van de ontwikkeling in het bestuur, maar slechts sporadisch de complexiteitstheorie aanroept als analysemodel. Een uitzondering is de natuurkundig opgeleide Kickert (1993: 191 e.v.), die althans het verband legt, evenals Wagenaar (2007: 31-38) en Teisman (2005). Omgekeerd blijft het studieobject van de literatuur die de complexiteitstheorie aanmerkelijk nauwkeuriger toepast in de organisatiekunde, angstvallig binnen de grenzen van organisaties (Stacey, 2007; Zuijderhoudt, 2004). Concepten als adaptie, attractor, doorbreker, emergentie, zelfordening, synergie zijn niet of nauwelijks terug te vinden in de context van netwerken of samenwerkingsverbanden.

Weliswaar is de definitie die Mastenbroek geeft voor organisatie (Mastenbroek, 1996: 29) netwerken van interdependente groepen, maar daarmee benadrukt hij vooral dat betrekkingen binnen organisaties meervoudige doelen dienen. Zijn definitie beoogt niet een verbreding van het organisatiebegrip tot tijdelijke samenwerkingsrelaties tussen organisaties, over de grenzen van organisaties heen tot stand te brengen.

\section{Reflectie op dialoog, sociaal constructivisme}

Een minstens zo belangrijk aspect als de fragmentatie in het veld is het discursieve karakter van de werkelijkheid dat direct samenhangt met de governance-benadering met haar vele actoren. Omdat de doelstellingen en belangen, maar ook de waarnemingen en opvattingen bij horizontale bestuursverhoudingen 'in het midden liggen' en naar hun aard worden gekleurd door de positie van de verschillende actoren, is een gezamenlijk beeld van de werkelijkheid niet objectief gegeven, zelfs niet door 'wetenschappelijke feiten'. Een dergelijke gemeenschappelijke werkelijkheid kan hoogstens de resultante zijn van een dialoog.

De epistemologische basis van de grondvorm governance wijkt af van de klassiek-rationele werkelijkheidsvinding. Dus parallel met een nieuwe kijk op bestuursstructuren en instituties die passen in een netwerksamenleving, is ook een bijbehorende benadering van beleidsanalyse ontstaan (Dryzek, 1997; Yanov, 1993 en 1999; Fischer \& Forester, 1993; Hoppe en Peterse, 1998; de latere In 't Veld, 2010). Het betreft een beleidsanalyse die niet zozeer de feiten centraal stelt, maar de argumentatie en interpretatie van de feiten door deelnemers in het beleidsproces, tot uiting komend in hun taal, in hun communicatie. Deze omslag in de beleidswetenschap wordt aangeduid als de Argumentative of Interpretative Turn. Zelfs de feiten zijn niet onomstreden, zoals talloze beleidsprocessen rondom complexe onderwerpen laten zien. Of het nu gaat over de toekomst van de Nederlandse luchtvaart, olieboringen in de Waddenzee of de noodzaak van een Tweede Maasvlakte, steeds bestrijden de partijen elkaar met hun eigen rapporten die, met even verantwoorde onderzoeksmethoden, tot tegenstrijdige conclusies komen. Dit bekende gegeven heeft hier en daar aanleiding gegeven tot de ontwikkeling van een praktijk die zich louter richt op het bereiken van overeenstemming over de feitenverzameling en het te verrichten onderzoek (Susskind et al., 2005). In Nederland zijn Hoppe en Yanov de bekendste epigonen van argumentatieve beleidsanalyse.

\section{Problemen bij beleidsevaluatie}


Een soortgelijke ontwikkeling is te zien als het gaat om de evaluatie van het beleid. Ook dat is ingewikkelder geworden dan het op een rij zetten van effecten, af te zetten tegen de beoogde doelen. Welke effecten en welke doelen? Welke beleving en waardering van de feiten? De 'Vierde generatie beleidsevaluatie' biedt een opzet van evaluatiestudies in de vorm van een multi-actor dialoog. Guba en Lincoln hanteren bij evaluaties een sociaal-constructivistisch paradigma. De percepties van de deelnemers worden expliciet betrokken in de evaluatie, die ten dele verrassende nieuwe inzichten en probleemstellingen oplevert als begin van een volgende beleidscyclus (Guba \& Lincoln, 1989: 226). Hoewel het hierdoor moeilijker is om consensus te bereiken, is het in een open samenleving van essentieel belang dat de verschillen naar voren komen. Dit betekent in plaats van tevoren vastgestelde uitkomsten, gesloten vragen en gestandaardiseerde antwoorden een open proces dat veel weg heeft van een onderhandelingssituatie. Door dit proces krijgen de deelnemers meer zicht op hun eigen 'geconstrueerde werkelijkheid'. Deze vierde generatie van evalueren biedt in theorie de mogelijkheid om de claims, concerns en issues die bij de verschillende stakeholders leven in kaart te brengen. De praktijk blijkt echter nog weerbarstiger, want deze responsieve vorm van evaluatie wordt zelden toegepast (Korsten, 2013). Is dit de vooraankondiging van een bevinding dat de bestuurskunde soms ook te hard wil lopen?

Relatie tussen de uitdagingen van beleidsproblemen en behoefte aan een andere bestuurstheorie In de vorige paragraaf werd het onderscheid tussen 'moeilijke' en 'makkelijke' taken en problemen geïntroduceerd. Bij moeilijke, weerbarstige problemen is vaak sprake van verschil van mening over de feiten en percepties, de weging van waarden en de aanpak. Denk hier bijvoorbeeld aan bepaalde milieuvraagstukken, aan jeugdproblematiek, et cetera. Andere, makkelijke(re), maatschappelijke problemen kenmerken zich door voldoende kennis over de feiten en eenstemmigheid van waarden. Denk aan het onderhoud van wegen. De samenleving is sinds de jaren zestig van de vorige eeuw zozeer verbrokkeld en burgers en organisaties zijn zoveel beter toegerust om toe te treden tot de politieke arena dat vaak al onzeker is welke actoren voor een bepaalde kwestie van belang zijn en waar de grenzen van een probleem ophouden (Bestuurskunde, 2014). Van Gunsteren sprak in 1995 al over De Ongekende Samenleving (Van Gunsteren en Van Ruyven, 1995). Naast de moeilijkheid van de vaststelling van het probleem en de oplossing is er ook de afhankelijkheid van verschillende partijen om een oplossing te kunnen effectueren. Een huisvrouw met een computer kan een routinematig ingezette vaccinatiecampagne voor baarmoederhalskanker doorkruisen. Burgers nemen de risico's van opslag van $\mathrm{CO}_{2}$ heel anders waar dan energiebedrijven en overheden en kunnen deze ook tegenhouden. Voor de houdbaarheid van hypotheekrenteaftrek in Nederland blijkt opeens niet het verkiezingsprogramma van Nederlandse politieke partijen, maar de bankencrisis op Wallstreet van grote invloed. Onzekerheid en afhankelijkheid zijn bepalende factoren voor de aanpak van publieke vraagstukken. De rationales voor beleidskeuzes houden zich bij complexe problemen niet meer aan de conventies van sectoren en soms ook niet aan grenzen van territoriale eenheden. Dit zijn gegevenheden die maken dat in deze periode de uitdagingen voor het bestuur verder gaan dan wat de Nederlandse traditie van 'schikken en plooien' en het poldermodel geacht wordt van oudsher te bieden.

De betekenis van netwerkbestuur/governance is dan ook voor het Nederlandse bestuur ingrijpend. De tegenstelling tussen government en governance is in dit onderzoek scherper dan die tussen een autoritaire bestuurshouding en consensusbereidheid met de bekende gesprekspartners in steeds dezelfde vertrouwde sector. Er wordt in toenemende mate een beroep gedaan op avontuurlijke en experimenterende bestuurskwaliteiten. Het is evident dat naarmate de maatschappelijke werkelijkheid complexer en pluriformer wordt, er meer behoefte ontstaat aan een bestuur dat in staat is om te gaan met verscheidenheid en onzekerheid. De veronderstelling van de bestuurskunde en andere sociale wetenschappen is dat de maatschappelijke werkelijkheid die kenmerken in toenemende mate vertoont en daarbij past de stelling dat er sprake is van een (relatieve) verschuiving in het karakter van het openbaar bestuur van government naar 
governance. Aan het eind van deze paragraaf volgt nog een korte uiteenzetting wat dit 'relatieve' voor dit onderzoek betekent.

\section{Reflectie op integraliteit en maakbaarheidspretenties}

$E r$ is één thema waar de dichotomie tussen government en governance niet eenduidig is. Dat betreft het gebruik van het begrip 'integraal' in het openbaar bestuur. Enerzijds kan dit worden geassocieerd met een vergaande sturingspretentie van de overheid, die in staat zou moeten zijn om samenhang tussen een breed veld van doelstellingen en middelen aan te brengen om rationele besluiten te richten op optimalisering van alle te verwachten effecten en neveneffecten. Deze maakbaarheidspretentie past bij het government-denken voor zover het een vergaand geloof in rationele besluitvorming deelt, en bij governance als nadruk wordt gelegd op meervoudigheid en complexiteit. Naar zijn aard overkoepelt de governance-benadering de hele sfeer van overheid en samenleving. Al doet zij dat niet met totalitaire pretentie, er zit iets holistisch in, terwijl een government-aanpak heel goed te rijmen is met een bescheidener taakopvatting: deze krenten uit de pap lenen zich voor overheidssturing en de rest, daar blijven we buiten. Zo stelt Frissen in een recente kritiek op governance, dat bestuurskundige auteurs in hun streven naar isomorfie tussen bestuur en maatschappij niet berusten in complexiteit, maar oplossingen voor alle problemen blijven zoeken in de veronderstelde integraliteit van de problematiek (Frissen, 2013: 95).

Wegens de ambiguïteit van dit begrip is er vanaf gezien om de 'integrale aanpak' te gebruiken als bouwsteen bij de operationalisering van het hier gehanteerde begrippenpaar. $\mathrm{Er}$ is ook wel een meer sophisticated variant van governance-denken mogelijk, waarbij de complexiteit en principiële onstuurbaarheid van maatschappelijke processen vooropstaat, maar omdat die niet gemakkelijk te onderscheiden is van de primitieve 'wij-besturen-met-elkaar-de-samenleving-versie', kunnen we het begrip integraal beter buiten de vergelijking houden. In hun gemeenschappelijke ijver om alle problemen uiteindelijk, over grenzen van sectoren en machtsbolwerken heen op te lossen - door een super-effectieve overheid of door slimme netwerkcombinaties - raken government en governance elkaar in het woord integraliteit.

\section{Reflectie op democratie, pluralisme}

Ten slotte heeft de governance-benadering ook zijn weerslag op de democratieopvatting. De dialoog tussen deze actoren bepaalt of een aanvaardbaar besluit of aanvaardbare actie mogelijk is en geeft daarmee van onderaf invulling aan legitimiteit en aan (deliberatieve) democratie.

Pas als de fundamentele pluriformiteit van de samenleving als uitgangspunt wordt geaccepteerd, ontstaat ruimte voor andere democratie-opvattingen (Dewey, 1927; Frissen, 2007; Dijstelbloem, 2008) waarin wisselende 'publieken' levensvatbare plannen genereren na een uitvoerige dialoog. In de klassieke democratie-opvatting wordt de voorkeur van het volk (de demos) geconstrueerd door eerst een relevante representatie van de bevolking te bepalen via verkiezingen. Vervolgens wordt verondersteld dat de meerderheid van de gekozen representanten bepaalt welke voorkeuren de doorslag geven. Deze democratieopvatting is inmiddels zo ingeburgerd dat de talloze denkstappen en fictieve veronderstellingen die tot deze preferentiebepaling leiden, zelden meer ter discussie worden gesteld. Een uitzondering vormt In 't Veld $(2007,2010)$. De volgende veronderstelde voorwaarden voor een representatieve democratie berusten volgens hem evident op een fictie:

- $\quad$ vooraf bekende voorkeuren van kiezers;

- $\quad$ helder weerspiegeld in de opvattingen van politieke partijen;

- gemakkelijk te herleiden tot duidelijke opties voor het oplossen van specifieke maatschappelijke vraagstukken (ook tussentijds opkomende nieuwe kwesties);

- $\quad$ het belang van elke kiezer in alle collectieve vraagstukken is gelijk;

- $\quad$ eenduidige preferentievolgorde tussen de issues (Arrow-paradox).

Participatieve democratieopvattingen of corporatistische modellen proberen de tekortkomingen te compenseren door per issue aanvullende representatiemethoden toe te passen. 
Absolute of relatieve dichotomie?

Voordat de praktische aanpak van dit onderzoek aan de orde komt, zijn nog enkele zinnen nodig over de vraag hoe scherp de 'shift' nu moet worden opgevat. Eerst de vraag naar de kip of het ei. De opvattingen in de bestuurswetenschap over haar kenobject zijn hier als ijkpunt gehanteerd voor de bestuurstheorie in het bestuursbeleid. Is dat ook de volgorde der dingen? Moet reflectie in de bestuurskunde eerst hebben geleid tot een heel andere literatuur alvorens verwacht mag worden dat de beleidspraktijk de nieuwe opvattingen oppakt? In dat geval zou elke ontwikkeling in het bestuursbeleid van vóór ongeveer 1995 buiten beschouwing kunnen blijven. Hierboven werd al duidelijk dat ook binnen de bestuurskunde een periodisering van de shift niet eenduidig is. De literatuur ten behoeve van het onderwijs aan eerstejaars bestuurskundigen blijkt bijvoorbeeld wel zo'n tien jaar na te ijlen. Anderzijds is er ook al veel eerder dan 1995 sprake van gespecialiseerde literatuur over bijvoorbeeld besluitvorming in een fuzzy omgeving (Kickert, 1979), gebrekkige beleidseffectiviteit (In 't Veld, 1984) en bestuurlijke vernieuwing en participatieve democratie (Korsten, 1979).

Daarnaast mag verwacht worden dat ook bestuurskundig onderzoek de praktijk van het openbaar bestuur weerspiegelt, dus dat de onderliggende empirische processen al van eerder dateren. Dat kan ook pas weer alleen als in de hoofden van de beleidsmakers de knoppen al eerder zijn omgezet.

Bovendien is onder verwijzing naar 'makkelijke en moeilijke' taken al gesteld dat de shift niet op alle onderwerpen in gelijke mate van toepassing is. Er zal dus naar alle waarschijnlijkheid sprake zijn van een grijs gebied tussen wit (government) en zwart (governance). Om de zaak nog verder te compliceren, zullen ook niet alle knoppen tegelijk zijn omgezet. Bijvoorbeeld: meervoudig bestuur in termen van Bressers cum suis (figuur 2.2) met multi-level en multi-actor bestuur is zeer wel denkbaar binnen de bestuurskolom met al zijn lagen en instellingen. Dan is een benadering die het ontwerpen van nieuwe bestuurseenheden (regionale provincies) vervangt door modellen van interbestuurlijke samenwerking al een stap in de richting van governance. Ook kan bestuursbeleid wel gericht zijn op de versterking van samenwerking en daarbij ook wel horizontale sturingsmodellen hanteren, maar nog niet de stap hebben gemaakt om ook de probleemformulering en leerprocessen volledig open van onderop te laten komen en zich experimenteel te laten ontwikkelen. Kortom, deze erkenning laat ruimte voor proto-shift verschijningsvormen van governance of mengvormen.

Toch wordt in dit onderzoek gekozen voor een scherpe begrenzing tussen beide begrippen. Mengvormen binnen eenzelfde dossier of project worden gesignaleerd als er sprake is van alternerende toepassing van de beide contrasterende denkwijzen, nu eens government, en daarna bij een ander deelonderwerp governance. Halfbakken stappen in de gezochte richting zijn niet overtuigend genoeg om te spreken van een omslag of shift.

Ten slotte kan de vraag worden gesteld of governance uiteindelijk niet altijd uitmondt in gestolde regelingen en sturing (government). Dan zou het gewoon een kwestie van faseverschil zijn. Ook de open verkenningen tussen overheid en samenleving over bijvoorbeeld de afvalproblematiek monden uiteindelijk uit in convenanten of regelingen. Dat is ook zo, met dien verstande dat het bestuur de verkenningsfase zou kunnen overslaan als men het zo al weet of als het probleem supersimpel en uitgekristalliseerd is (politieke analyse -> instructie). Maar we hebben het hier over (bestuurs)beleid en beleidsontwikkeling, niet over implementatie. Bij beleidsontwikkeling maakt de aanpak een wereld van verschil. In de implementatiefase minder, met dien verstande dat in alle gevallen regels en instructies nodig zijn. Niet voor niets associeerden we de ontwikkeling van de bestuurskunde met de start van de beleidswetenschap (Lasswell). Als het kenobject vooral beleidsontwikkeling is (en eventueel de weerbarstigheid van de uitvoering), wordt ook duidelijk waarom de hier bedoelde shift een bruikbaar concept is. Dan nog kan ook de wijze waarop de 
uitvoering wordt aangepakt een duidelijke governance-benadering verraden. Denk aan de toepassing van pilotprojecten en experimenten, aan kaderregelingen die maatwerk ter plaatse mogelijk maken en soortgelijk instrumentarium dat blijk geeft van het besef dat de werkelijkheid niet op voorhand gekend en beheerst kan worden. Bij het project Dualisering (paragraaf 5.7) zullen we een duidelijk voorbeeld hiervan tegenkomen in de Vernieuwingsimpuls. Government-uitvoering ('uitrollen') is anders dan governance-uitvoering. Dus enerzijds zijn in de praktijk genoeg aanleidingen om beide modaliteiten naast elkaar aan te treffen. Toch is de mindset achter government en governance zo verschillend dat het voor onderzoekers niet moeilijk is het onderscheid in de praktijk te herkennen. Over de manier waarop dat hier gebeurt, gaat het laatste deel van het volgende hoofdstuk.

\subsection{Conclusies}

In dit hoofdstuk kwam naar voren dat in het bijzonder de hoofdstroom in de Nederlandse bestuurskunde gedurende de onderzoeksperiode een omslag heeft doorgemaakt die op zichzelf ook weer een verschuiving (shift) postuleert in de bestuurspraktijk. Het theoretisch kader voor dit onderzoek is gebaseerd op het begrippenpaar government en governance (of netwerkbestuur) dat hier tegenover elkaar wordt geplaatst als exponenten van verschillende paradigma's over de positie en taakopdracht van overheidsbesturen en hun organisaties. Dit gebeurt in het besef dat de bestuurspraktijk zich nimmer tot één van beide benaderingen kan beperken. Hoogstens is aannemelijk dat de accenten bij de toenemende complexiteit van de samenleving en van de bestuursinstellingen zodanig worden verlegd dat de tradities van de klassieke overheid beginnen te kraken. Vandaar de veronderstelde aandachtsverschuiving naar netwerkbestuur, omdat deze werkwijze de veronderstellingen achter het geïntegreerde en relatief overzichtelijke bestuur op de proef stelt. Met een dergelijke uitdaging zou de opdracht van het bestuursbeleid een grote bijdrage kunnen leveren om het bestuur toe te rusten voor zijn maatschappelijke taak.

In dit boek wordt governance duidelijk scherper afgebakend dan in sommige publicaties gebeurt, waar ook al eeuwenoude vormen van consensusdemocratie en polderoverleg tot het netwerkbestuur worden gerekend. We leven nu volgens Van Gunsteren in De Ongekende Samenleving (Van Gunsteren en Van Ruyven, 1995). Dat stelt het bestuur voor de uitdagingen die met governance zouden worden aangepakt. De afhankelijkheid van onzekere, onvoorspelbare factoren en actoren zijn de werkelijk nieuwe en onderscheidende elementen van het gekozen begrip netwerkbestuur/governance. Dat betekent dat in netwerkcontexten altijd meerdere actoren samen handelen en zelfstandig handelen. Wie goed rondkijkt, ziet dat ook. Een voorbeeld: de beperking van voetbalvandalisme in preventief, procesmatig en repressief opzicht is een zaak van de minister van Justitie en Veiligheid, de Europese en nationale voetbalbond, burgemeesters, politie, besturen van voetbalclubs, scheidsrechters enzovoort.

Besturen is in deze tijd steeds vaker synoniem met samenwerken. Als dat waar is, zou bestuursbeleid ook duurzaam (maar dus niet uitsluitend) gericht moeten zijn op de kunst van het samenwerken.

Zo leidt het overwegend redeneren aan de hand van het begrip governance tot zichtbaar andere keuzen in het openbaar bestuur dan wanneer het government-denken dominant blijft, ook al is dat laatste soms nodig. Het zijn botsende rationaliteiten, waarvan beleidsmakers zich bewust moeten zijn. Voor Binnenlandse Zaken kunnen andere overwegingen gelden om enig tegenwicht te bieden tegen de relatieve volatiliteit van de governance-benadering, maar als het ministerie zich onaangedaan zou tonen ten opzichte van grote maatschappelijke trends die de wetenschap signaleert, zou dat merkwaardig zijn. 


\section{Methode van beleidsonderzoek}

\subsection{Inleiding}

In dit hoofdstuk gaat het over de methode(n) van onderzoek. Er wordt literatuur verkend die behulpzaam kan zijn bij de vraag waarom in dit boek voor een bepaalde kijk op de werkelijkheid en de daarbij passende onderzoeksmethode wordt gekozen. Aan het eind van dit derde hoofdstuk moet het methodologische en methodisch fundament onder het onderzoek zijn gelegd. Hierbij worden eigen keuzen voor een onderzoeksaanpak in de trant van Hajer (1993) en Dicke (2001) gemaakt en verdedigd, die past voor een zo breed onderwerp als in dit boek aan de orde is.

Bij de vragen die in het vorig hoofdstuk zijn gesteld, komt de manier waarop de werkelijkheid wordt gepercipieerd en geanalyseerd steeds terug als van bepalend belang. Dit past bij een stroming in de bestuurswetenschap die doorgaans wordt aangeduid als de 'interpretative turn': de interpretatie van de werkelijkheid krijgt het volle gewicht, bij gebrek aan 'objectieve' werkelijkheid die sociale wetenschappers nu eenmaal niet zonder tussenkomst van taal en menselijke perceptie kunnen benaderen. Daarom wordt een groot deel van dit theoretische hoofdstuk gewijd aan de keuze voor de discoursanalyse, die helpt bij het systematisch zoeken van inhoudelijke betekenisgeving aan beleid. In het eerste deel van dit hoofdstuk wordt uiteengezet welke benadering hier het beste past; in het tweede deel volgen de consequenties voor dit onderzoek.

\subsection{Wetenschapsopvatting}

De aard van sociale wetenschap

Het inleidend hoofdstuk begon al met de constatering dat in de sociale wetenschappen de werkelijkheid zich manifesteert in vertogen. We kunnen niet meer van de maatschappelijke werkelijkheid te weten te komen dan wat zich via intermenselijke communicatie openbaart. Daarom bestuderen we de inhoud van het bestuursbeleid van Binnenlandse Zaken aan de hand van de typering van taaluitingen (o.a. Dryzek, 1997; Frouws, 1998; Dicke, 2001; Goverde, 2001; Hajer, 2000, 2001; Hajer \& Laws, 2006; Tennekes, 2005; Van der Arend, 2007).

Aan deze eenvoudige kanttekeningen vooraf kunnen veel diepgravende conclusies van epistemologische aard worden verbonden. Discoursanalyse breekt in bepaalde visies radicaal met de klassieke benadering waarin taal refereert aan een andere werkelijkheid buiten onszelf die met behulp van taal wordt beschreven. Uitgangspunt bij de hardcore discoursanalyse is dat taal een eigen werkelijkheid creëert. Taal representeert sociaal gedrag. Taal is in deze visie niet een afgeleide van een objectieve werkelijkheid. Met andere woorden: de expressieve en referentiële functies van taal staan niet meer los van elkaar, maar vormen samen manieren waarop de werkelijkheid gerepresenteerd wordt. Discoursanalyse is onderzoek naar de manier waarop meningen en werkelijkheden discursief - dat wil zeggen in taal - geconstrueerd worden.

Een implicatie van deze definitie van taal als sociaal gedrag is dat voor taalhandelingen hetzelfde geldt als voor sociale handelingen in het algemeen: taalgedrag bestaat niet alleen uit de uitdrukking van intenties en bedoelingen van de taalgebruiker. Taalhandelingen produceren betekenissen dus een werkelijkheid - waarvan de gebruikers zich lang niet altijd bewust zijn. Taalgebruikers hebben de neiging taal op te vatten als een 'vorm' waarmee zij een boodschap overdragen aan anderen. Daarbij miskennen zij dat die 'vorm' zelf - het taalgebruik - niet neutraal is en allerlei betekenissen herbergt die door hen meestal niet meer als zodanig worden herkend. Met andere woorden: bij communicatie worden niet alleen 'boodschappen' uitgewisseld, maar ook metaboodschappen die inherent zijn aan het taalgebruik. Een voorbeeld van eigen leven leidende taaluitingen is het mechanisme van de selffulfilling prophecy: het ontwikkelen van definities van de 
situatie en verwachtingen kan ertoe leiden dat men zich zodanig gaat gedragen dat de verwachtingen ook gerealiseerd worden. Als bijvoorbeeld verhalen over een dreigende botsing tussen culturen als hoofdthema worden opgevoerd in berichten over onveiligheid en sociale conflicten, zullen inderdaad conflicten ontstaan die een overeenkomstig karakter krijgen.

\section{Methodologische valkuil}

Wetenschappelijke strengheid komt al gauw in de knoop met het gebruik van discoursanalyse in de bovenstaande strikt constructivistische betekenis, want wie probeert taalgedrag te duiden, komt meteen zichzelf tegen. Als discoursanalyse één op één wordt verbonden met sociaal constructivisme, loopt de onderzoeker op tegen de vraag met welk recht hij betekenis toeschrijft aan uitlatingen. $\mathrm{Er}$ is geen objectieve werkelijkheid meer om aan te toetsen. Helemaal op glad ijs komt hij als gebruikgemaakt wordt van interviews over situaties in het verleden, die per definitie buiten de oorspronkelijke context plaatsvinden. Daar worden immers nieuwe referentiekaders geschapen.

Het lijkt beter om deze strenge redeneerlijnen te omzeilen. Het is goed mogelijk om bepaald beleid te duiden als passend in een bepaalde betekenis, zolang dat voor de lezer overtuigend gebeurt. De collectiviteit van lezers is uiteindelijk de maat der dingen en als er veel verschillende lezers zijn die niet overtuigd worden, is daarmee de poging van de onderzoeker mislukt. Combinatie van discoursanalyse met andere methoden van onderzoek kunnen helpen om de argumentatie te ondersteunen en zoiets moet niet meteen als spelbederf worden gekwalificeerd. Met een conclusie dat sociaal constructivisme elk streven naar objectiviteit (transsubjectiviteit) en wetenschappelijkheid relativeert, komt niemand verder.

\section{Houvast voor wetenschappelijke analyse}

Interpretatie van taaluitingen is dus inherent lastig, maar er is ook een lichtpunt. Omdat taal de uitingsvorm is van sociale wezens, zijn er juist veel regelmatigheden te verwachten. Menselijke communicatie moet fungeren als manier om gedrag onderling af te stemmen. Dat betekent dat taaluitingen niet alleen individuele eigenaardigheden, maar vooral vaste betekenissen en herkenningspunten weergeven. Ook als we ons er niet van bewust zijn, verraadt ons taalgebruik regelmatigheden en opvattingen over wat hoort en wat niet hoort. Dit is voor de wetenschap een zegen, want zo kunnen door nadere analyse uit taaluitingen dergelijke regelmatigheden worden gereconstrueerd. Sociale regels spelen daarbij een belangrijke rol, want evenals andere sociale handelingen wordt taalgedrag gereguleerd door sociale regels. Niet iedereen mag alles tegen iedereen zeggen. Er zijn sociale regels voor wie wat wanneer en waar mag zeggen en er zijn regels voor hoe iets gezegd behoort te worden en ook het hoe is tijd-, plaats- en positiegebonden.

Dat taalgebruik gezien kan worden als een vorm van sociaal handelen, was overigens niet helemaal onbekend in de sociale wetenschappen. Survey-onderzoekers worstelen bijvoorbeeld al heel lang met het fenomeen dat sociale wenselijkheid een belangrijke rol kan spelen in het antwoordgedrag van respondenten. Maar de neiging bestaat om dit soort fenomenen te beschouwen als 'ruis', die het zicht op de 'ware meningen' verstoort. Vanuit het perspectief van discoursanalyse is dit soort ruis nu juist een van de interessante aspecten van vraaggesprekken. Bovendien gaat discoursanalyse ervan uit dat de door kwantitatieve survey-onderzoekers bedoelde ruis geen bijverschijnsel maar een principieel kenmerk is van vraaggesprekken: antwoordgedrag van respondenten is situatieafhankelijk. En de diversiteit van antwoordgedrag is in het perspectief van discoursanalyse een interessant onderzoeksthema in plaats van een barrière voor het 'meten' van een hypothetische werkelijkheid die 'weerspiegeld' zou worden in het antwoordgedrag (Van den Berg, 2004: 34).

\section{Discours met een grote $D$}

Volgens sommigen gaat het bij een discours niet alleen om taal (wat je kunt opschrijven), maar om alles wat bijdraagt aan betekenisverlening (beelden, rituelen, mimiek, et cetera). Het totaal zou Discours met een grote $D$ genoemd kunnen worden, te onderscheiden van discours (met een 
kleine d), dat duidt op betekenissystemen die via taalgebruik geconstrueerd worden (Gee, 1999: 20-34). In de onderzoekspraktijk gaat het vrijwel altijd om discours met een kleine 'd', ook als de theoretische pretenties eigenlijk gericht zijn op Discours met een grote 'D'. In zijn latere werk heeft Hajer wel aandacht besteed aan de kracht van beelden en context in het mediatijdperk (Hajer, 2009).

In dit boek zal een eigen methodiek worden gepresenteerd die ook praktijken en vervolgacties in de analyse betrekt. De analyse omvat dus meer dan taaluitingen, maar daalt niet zozeer af naar het microniveau van non-verbale communicatie als juist naar de context van verhalen.

\section{Analyse van de inhoud van beleid}

Beleid is een specifieke gesystematiseerde variant van menselijk gedrag en communicatie. Het gaat daarbij in vrijwel alle definities over een combinatie van doelen, middelen en tijdsplanning (Hoogerwerf, 1984, 1989, 1993a; Hoogerwerf en Herweijer, 2003). Beleidstaal bevat altijd een bepaalde betekenis die verwijst naar de inhoud van middelen en doelen. Soms is die inhoud een beetje verborgen '(tussen de regels'), soms ligt die er bewust dik bovenop, omdat de beleidsmakers zich willen verbinden met bepaalde krachtige symbolen en metaforen die hun argumentatie kracht bij zetten. Ook hier is dus de gehanteerde argumentatie een vindplaats voor de denkwereld van de beleidsmakers, ook als zij hun zielenroerselen nergens expliciet hebben gemaakt.

Hieronder passeren verschillende theoretische benaderingen met betrekking tot de inhoudsanalyse van beleid de revue: beleidstheorie (= bestuurstheorie in dit onderzoek), systeemtheorie, frameanalyse, discoursanalyse. Allemaal erkennen ze de kracht van betekenisverlening als zelfstandige factor in het menselijk handelen (naast bijvoorbeeld macht en middelen). Wij kiezen uiteindelijk voor een eigen variant op een al eerder toegepaste vorm van discoursanalyse, op basis van storylines.

\subsection{Interpretatieve benaderingen van beleid}

\subsubsection{Gelaagdheid van beleidsideeën}

\section{Diepgang en verstrekkendheid van ideeën}

Elk beleid of beleidsvoorstel bevat bepaalde redeneringen en verwijst naar herkenbare betekenis. De inhoud van de denkkaders van de beleidsmakers kan meer of minder diep gaan en meer of minder verborgen zijn, dat wil zeggen: als bekend en vanzelfsprekend worden aangenomen. In de wetenschappelijke discussie treft men weinig aan over niveauverschil in beleidsopvattingen. Het lijkt zinnig om een soortgelijke hiërarchie in waarden en opvattingen te onderscheiden als Frank Fischer aanbrengt ten behoeve van de discoursanalyse (Fischer, 2003: hoofdstuk 3). Naast technische gesprekken over feiten houdt hij drie niveaus van waarderingen en percepties zorgvuldig uit elkaar:

- situationele oordelen, die bijvoorbeeld in NIMBY-uitspraken naar voren komen: dit voorstel is niet wenselijk, omdat het in deze omstandigheden strijdigheid is met erkende belangen;

- waardeoordelen over wenselijkheid of onwenselijkheid van voorstellen binnen het bestaande systeem;

- meta-oordelen over het systeem zelf, bijvoorbeeld de gehanteerde doelen.

Zo zou men ook een gelaagdheid in bestuurstheorieën kunnen veronderstellen. Ideeën in het beleid kunnen meer operationeel of meer strategisch beleid betreffen en daarom het 'systeem' zelf raken dan wel ongemoeid laten. Dit boek gaat over fundamentele ideeën over het bestuur. We zijn niet zomaar op zoek naar toevallige ideetjes, maar naar opvattingen die

- vrij hardnekkig voorkomen en een zekere duurzaamheid vertonen,

- krachtig genoeg zijn om een dominante positie in de ministeriële organisatie te verwerven; 
- betrekking hebben op de inrichting en werking van beleid en bestuur in het algemeen.

Daarmee mogen we aannemen dat de gezochte veronderstellingen zich vrij hoog in de cognitieve hiërarchie van de organisatie bevinden, wellicht op het niveau van waarden of beginselen. We spreken in dat geval van paradigma's.

Figuur 3.1 Over diepgang en locus van ideeën die beleidsinhoud bepalen

\begin{tabular}{|l|l|l|}
\hline & \multicolumn{2}{|l|}{ Beleidsdebat dat wordt beïnvloed } \\
\hline Diepgang van ideeën & Op de voorgrond & Op de achtergrond \\
\hline Cognitief (causaliteit) & $\begin{array}{l}\text { 1. Programmatische } \\
\text { veronderstellingen }\end{array}$ & 2. Beleidsparadigma's \\
\hline Normatief (waarden) & $\begin{array}{l}\text { 3. Symbolische connotaties } \\
\text { (frames) }\end{array}$ & 4. Politieke sentimenten \\
\hline & & \\
\hline Bron: Campbell, 2002: 385 & & \\
\hline
\end{tabular}

Er zijn volgens Campbell verschillende typen ideeën die een rol spelen in het beleidsdebat. Ideeën die expliciet gemaakt worden of juist altijd op de achtergrond blijven. En ideeën die in de cognitieve sfeer leven en die zich meer op het niveau van waardepatronen bewegen. Als we op zoek gaan naar beleidstheorieën, moeten we ons behelpen met de ideeën die, op de voorgrond, expliciet gemaakt zijn, al kunnen die als symptoom worden uitgelegd voor paradigma's op de achtergrond. We doen weliswaar onderzoek in een politiek bestuurlijk veld, maar zijn minder geïnteresseerd in politiek met het bijbehorende sentiment. Het gaat ons om de beleidsredeneringen van een ministerie, over een lange periode, dus individuele politieke bestuurders overstijgend.

De ideeënveranderingen in cel 1 zijn voor dit onderzoek aangrijpingspunten voor het signaleren van eventuele verschuivingen in paradigma's van cel 2 .

\section{Vrijwel synonieme begrippen}

Er zijn veel begrippen die qua betekenis dicht in de buurt komen van het begrip beleidstheorie of bestuurstheorie. Mentale kaart, denkkader, waarderingssysteem, perceptiewijze of gewoon 'bril'. Meer gericht op (overheids)organisaties duiken nog andere begrippen op. Vickers presenteerde al in 1965 'appreciative systems' in zijn baanbrekende werk 'The art of judgment'. Discours is al genoemd. Dat is de meest algemene aanduiding van een mechanisme dat betekenis toekent aan verschijnselen (een meer uitgebreide definitie volgt). Alleen beleidstheorie lijkt een meer technische term. Vrijwel uitwisselbaar is het begrip 'frame', maar denk ook aan sturingsfilosofie,

bestuursmodel, paradigma of ('stille') waarden. Discours verhoudt zich tot de andere begrippen als de communicatie van een idee tot het idee zelf. Hajer zegt hierover:

"Aangezien de grens tussen de wereld van percepties en beelden en die van reële verschijnselen niet duidelijk is, geef ik er de voorkeur aan om beleidstheorieën en frames te beschouwen als representaties van opvattingen over de gepercipieerde werkelijkheid, tot uiting komend in de beleidscommunicatie, het discours. Dit is inclusief de daarin vervatte machtsverhoudingen, die immers weerspiegeld worden in 'het samenstel van talige en niet talige handelingen en praktijken, dat beïnvloedt wat gedacht, begrepen en gezegd wordt, wat met invloed kan worden gezegd en op welke wijze dit gebeurt." (Hajer, 1999: 248-249) 
Hierna wordt nader ingegaan op een aantal van deze begrippen om wat meer idee te krijgen van de toepasbaarheid, van wat je ermee kunt.

\subsubsection{Denken in termen van de beleidstheorie}

Beleidstheorie als toetsinstrument voor de realiteitswaarde van beleid In 1984 introduceerde Andries Hoogerwerf in een artikel in Acta Politica het begrip beleidstheorie, voortbouwend op binnen- en buitenlandse literatuur op het terrein van beleidsonderzoek (o.m. Van Doorn al in 1955; Vickers, 1965; Argyris \& Schön, 1974; Axelrod, 1976; Lindblom \& Cohen, 1979). $\mathrm{Hij}$ definieerde dit als "het geheel van veronderstellingen die aan een beleid ten grondslag liggen". Deze veronderstellingen kunnen van verschillende aard zijn:

kenmerken van verschijnselen; dit zijn descriptieve elementen van de beleidstheorie, in tegenstelling tot de relaties tussen verschijnselen en begrippen:

- $\quad$ finale relaties (doel - middel);

- $\quad$ causale relaties (oorzaak - gevolg);

- $\quad$ normatieve relaties (norm, beginsel - bestaande of te verwachten situaties).

De gedachte is dat een expliciete of impliciete beleidstheorie (mentale kaart) kan worden gereconstrueerd uit documenten of uitspraken van beleidsmakers. Daarna is vergelijking mogelijk met de wetenschappelijke theorieën en daarmee zou volgens Hoogerwerf de 'onjuistheid' van beleid aan het licht gebracht kunnen worden. Zoals in het vorige hoofdstuk is gesteld, zal hier in navolging van Hoogerwerf worden gesproken in plaats van beleidstheorie over de bestuurstheorie van Binnenlandse Zaken. In Engelse vertaling wordt hiervoor de term polity-theory gekozen.

In een volgend overzichtsartikel heeft Hoogerwerf de reikwijdte van het begrip beleidstheorie ingeperkt uit oogpunt van onderzoekbaarheid. Men moet een beleidstheorie altijd koppelen aan een bepaald beleid(sprogramma) en aan een bepaalde actor (Hoogerwerf, 1989: 326). Daarbij is het belangrijk te beseffen dat er meerdere actoren zijn die zich met het beleid bezighouden en die dus ook verschillende beleidstheorieën hebben. Van Doorn had de definitie van beleidstheorie gekoppeld aan een beleid en erop gewezen dat op dit resultaat doorgaans door zoveel actoren wordt ingespeeld dat beleidsanalytisch onderzoek van een van de achterliggende veronderstellingen onmogelijk is, tenzij er sprake is van "beperkte, overzichtelijke en uit één beleidskoker voortkomende beleidsprojecten" (Van Doorn, 1985: 109). Beleid wordt soms inderdaad beïnvloed door een brede context, de inbreng van pressiegroepen, de uitkomst van opiniepolls en nog veel meer. Het moet daarom gaan om de opvattingen van een bepaalde actor over een specifiek onderwerp. In dit geval dus het ministerie van Binnenlandse Zaken over het openbaar bestuur.

\section{Beleidstheorie op het niveau van organisaties}

Dat leidt meteen tot de vraag of je wel zo makkelijk een grote organisatie als actor van beleidstheorieën kunt opvatten. Volgens Hoogerwerf is dat geen enkel probleem: "men kan bijvoorbeeld spreken van de beleidstheorie van het ministerie van onderwijs ten aanzien van het basisonderwijs, maar ook van de beleidstheorie van een minister, een ambtenaar, een Kamerfractie of een belangengroep" (Hoogerwerf, 1989: 326).

ledereen die in een grote organisatie heeft gewerkt, zal het beamen. Inderdaad heerst er een bepaalde centripetale kracht in organisaties die maakt dat er een herkenbare sfeer, ideeënwereld en cultuur heerst. Het is natuurlijke eigenlijk een mysterie dat dit zo werkt; je zou willen weten hoe dat wordt overgedragen op een voortdurend wisselend bestand van personen, maar dat vergt een andere studie. Vermeld werd al het verschijnsel dat ambtenaren die van een ander ministerie komen, als een kameleon de identiteit van de nieuwe plek hebben overgenomen. Als de vorige werkgever hen nog als vijfde colonne zou willen inzetten in een beleidscoalitie, komt die 
waarschijnlijk voor teleurstellingen te staan. Het zal iets te maken hebben met de mimetische behoefte van mensen, de drang tot navolging en tot identificatie.

Anderzijds is het ook niet allemaal 'koekoek één zang' binnen een ministerie. Als we al spreken over de beleidstheorie (bestuurstheorie) van een organisatie, dan zou zeker een kwalificatie passen dat het gaat om de 'dominante' bestuurstheorie of die van de leiding (zie ook Idenburg, 1999: 11-17 en 214). Het is op zichzelf een interessante onderzoeksvraag om na te gaan hoeveel unisono er nu werkelijk in zo'n ministerie klinkt en zo ja, welke mechanismen hieraan ten grondslag liggen. Dat zal te maken hebben met macht en met de werking van hiërarchie. Ook als afwijkende geluiden opgevangen kunnen worden, is de herkomst daarvan te onderzoeken. Is dat de behoefte zich te onderscheiden, liggen er bepaalde belangen (tegenmacht) aan ten grondslag? Maar hier wordt aan de verleiding weerstand geboden om dit zijpad te betreden. Het zou veel ingewikkeld onderzoek vergen als er al ooit een vinger achter te krijgen is.

\section{Verschillende rationaliteiten}

Beleidstheorieën zijn op het eerste gezicht niet moeilijk te reconstrueren. De causale redeneringen en normatieve verbanden zijn meestal wel expliciet gemaakt. Hoewel men moet beseffen dat lang niet alle doelstellingen achter beleid zomaar gecommuniceerd kunnen worden. Het is bijvoorbeeld wat lastig te verkopen dat een medezeggenschapsregeling in universiteiten erop gericht is om de inspraak van studenten klein te houden, ook al is dat wel degelijk mede beoogd. En doelstellingen achter beleid kunnen in de loop van de tijd veranderen.

Onwaarschijnlijker is het om van de evaluatieve kracht van beleidstheorieën zoveel te verwachten dat men zou kunnen spreken van 'onjuist' beleid, want er is doorgaans wel enige werking en soms zijn neveneffecten bij nader inzien positief. Het komt ook voor dat wetenschappelijke studies die gebruikmaken van het begrip beleidstheorie de vergelijking zoeken met wetenschappelijke uitspraken en theorieën, wellicht in de hoop falen van beleid te kunnen toeschrijven aan het veronachtzamen van wetenschappelijke inzichten. Die pretentie ontbreekt hier.

Sowieso zijn er meer rationaliteiten die op het beleidsproces inwerken (Korsten, 1988). Snellen (1987) onderkent naast de technisch-wetenschappelijke rationaliteit (doelrationaliteit toegespitst op effectiviteit), economische rationaliteit (doelrationaliteit toegespitst op efficiëntie), politieke rationaliteit, die naast het aanpakken van maatschappelijke problemen ook het behartigen van machtsposities omvat, en juridische rationaliteit, dat wil zeggen het funderen van het vertrouwen in het recht op basis van beginselen als duidelijkheid, consistentie, rechtszekerheid en vrijheid van willekeur.

In het algemeen is de pretentie van wetenschappelijke beleidsvorming ook volgens positivisten niet overeind te houden, tenzij het gaat om onderzoeksobjecten (beleidsprojecten) van beperkte omvang, waar de actor de effecten in belangrijke mate in eigen hand heeft (Veldheer en Van Kalmthout, 1989). Dat is vrij zeldzaam en zeker op het beleidsterrein van Binnenlandse Zaken. De argumentatie in de wereld van beleid en bestuur kan niet worden los gezien van andere dan louter logische en rationele overwegingen. Inderdaad zijn er andere dan wetenschappelijke argumenten in het spel bij beleidsvorming, maar dat heeft Hoogerwerf al in zijn concept inbegrepen. Dat omvat immers ook normatieve relaties (Hoogerwerf, 1989: 322, in debat met Hoppe, die hem eerder een 'sciëntistische benadering' had verweten). Alle relativering van wetenschappelijke beleidsonderbouwing daargelaten, komt het andere uiterste veel voor: beleid dat een greep in de lucht is. Ook daar hebben we het niet verder over.

\subsubsection{Verhalen als vehikel van discours}

\section{Storylines}


De hier verder gevolgde definitie van discours luidt: "een specifiek samenstel van ideeën, begrippen en categoriseringen dat wordt geproduceerd, gereproduceerd en getransformeerd in bepaalde praktijken waardoor betekenis wordt toegekend aan fysieke en sociale verschijnselen" (Hajer, 1995: 44, 264). Dit is een overkoepelend begrip. Een krachtige bouwsteen van het discours, die in staat is mensen te verenigen op een gemeenschappelijke denklijn, is de storyline: verhaallijnen (narratives) over de sociale werkelijkheid die elementen van vele verschillende domeinen combineren en de actoren voorzien van een stel symbolische verwijzingen die een gemeenschappelijk begrip van de werkelijkheid suggereren (Hajer, 1995: 62). Doordat mensen zich achter een dergelijke storyline scharen, kan enkel taal beleidsverandering teweegbrengen.

Verhalen hebben grote suggestieve kracht. Storylines (zoals 'zure regen' of 'tropisch regenwoud') zijn het cement van discursieve coalities, en verhaallijnen zijn aldus de krachtigste motor voor continuïteit of verandering in beleid. Voor ons onderzoek lijkt het nuttig om op dit begrip storyline voort te borduren.

\section{Voorbeeld uit Hajers dissertatie}

Hajer onderscheidt in zijn boek 'The politics of environmental discourse' in grote lijnen twee hoofdvertogen op het terrein van milieuproblemen in Groot-Brittannië. De eerste categorie reacties in het debat over een plotselinge milieukwestie zoals 'zure regen' is te typeren als 'traditioneel pragmatisme'. Dit pragmatisme verwijst naar manieren om te ontkennen dat zich iets nieuws of ingrijpends voordoet dat systeemingrepen zou rechtvaardigen, zoals de oorzaak buiten het eigen (Britse) handelen zoeken, verwijzen naar onderzoek, vertrouwen op wetenschap voor oplossingen of het afdoen van verschijnselen als incidentele vervuiling die met end-of-pipe technologie bestreden moet worden. Daartegenover staat wat Hajer het 'ecologische moderniseringsvertoog' noemt: zure regen als symptoom van de ecologische crisis, noodzaak van een transitie in menselijk gedrag, geen tijd om te wachten op het laatste onomstotelijke bewijs uit onderzoek, milieu als integraal handelingsperspectief, bijvoorbeeld om kosten te internaliseren en onherstelbare schadetoebrenging aan de natuur te voorkomen.

Storylines vergemakkelijken in beide vertogen het communiceren, want zij klinken aannemelijk en passen in reeds aanwezige referentiekaders. In het geval van zure regen zijn de bruikbare storylines verwijzingen naar dode vissen, kale bomen. De milieu-griezelverhalen zijn zo krachtig, dat ze zelfs in staat zijn de aanvankelijk positieve connotatie van rokende schoorstenen (= welvaart) te doen omslaan in weerzin en angst en onmiddellijk doen terugverwijzen naar de eigen verantwoordelijkheid van mensen voor de effecten van hun gedrag, urgentie van ingrijpen, et cetera. Storylines kunnen putten uit een groot reservoir van beschikbare geschiedenissen, zegswijzen en 'wijsheden'. Zo lag het voor de hand om met zure regen aan te sluiten bij reeds aanwezige noties van luchtvervuiling door de industriële samenleving. Milieu-activisten konden dit gebruiken om te betogen: "Zie je wel, de maatregelen om luchtvervuiling te voorkomen zijn ten enen male onvoldoende." Aan de andere kant konden belanghebbenden de zure regen gebruiken om dit te kwalificeren als een bijzonderheid, die losstond van de algehele chemische cocktail die niet de specifieke effecten sorteerde als met zure regen plotseling aan de orde leken te zijn. Storylines zijn dus als zodanig niet ondubbelzinnig te plaatsen als indicator voor deze of gene beleidsinhoud. Men moet ze met verstand in hun context interpreteren om ze op de juiste manier te kunnen plaatsen.

\section{Voorbeeld uit bestuursbeleid}

Op het eigen terrein van het bestuursbeleid past bijvoorbeeld het discours over de stadsprovincies of regiobesturen in een traditie van zoeken naar de optimale bestuursschaal, die zich ergens bevindt tussen de huidige gemeenten en de huidige provincies. Zonder orde in het bestuur in de vorm van een gemeenschappelijke locus voor besluitvorming kan democratische belangenafweging niet plaatsvinden en zullen deelbelangen de overhand hebben. Daartegenover 
staat de stellingname dat elke samenwerkingseenheid in zijn eigen historische contingentie passend is, maar niet zomaar straffeloos kan worden ingepast in een grootste gemeenschappelijke eenheid. Belangrijker dan het scheppen van een kunstmatig gestandaardiseerde bestuursstructuur is in deze visie de kunst van het samenwerken en van het verbinden van verschillende belangen, ook al zijn deze als een lappendeken op en over elkaar heen georganiseerd. Stukjes storyline die in deze vertogen terugkeren, zijn die van het democratische gat, de bestuurlijke drukte, de netwerksamenleving, de contingentie, maatwerk, et cetera. Sommige storylines zijn populair in bepaalde argumentatielijnen en minder bij andere (bijvoorbeeld democratisch gat en bestuurlijke drukte of bestuurlijke spaghetti passen typisch bij de ambitie om een 'optimale' bestuursstructuur te creëren), maar komen ook bij de tegengestelde visie terug, al was het maar om het belang van deze kwesties te relativeren (beperktheid van de representatieve democratie in deze tijd, bestuurlijke drukte 'zit tussen de oren'8).

Kortom, storylines kunnen niet worden gebruikt als lakmoes voor het scheiden van bokken en schapen in het beleid. Zij suggereren een gemeenschappelijk begrip van de situatie, passend in een vertoog (discours), waarbij via een reeks van stappen (ideeën, praktijken) betekenis wordt verleend aan de werkelijkheid.

\section{Verhaal als heuristisch instrument}

Narratieven (verhalen) zijn ook voertuigen waarin discoursen ontdekt kunnen worden. Storytelling is in bestuurskundig onderzoek een steeds populairder onderzoeksmethode (Roe 1994; Abma 1996). Door mensen aan het vertellen te zetten, krijg je meer informatie dan sec hun feitenrelaas. Analyse van hun taalgebruik, houding en gedrag verraadt ook hun gevoelens, ambities en benaderingswijze ten aanzien van de kwestie. Aangezien discoursen ook identiteitsgestuurde verschijnselen zijn, is het nog beter als er tegelijkertijd beelden beschikbaar zijn waardoor de ambiance, non-verbale communicatie, dramaturgie en andere 'performatieve' kenmerken in het onderzoek kunnen worden betrokken. Zo toonde Hajer aan zijn studenten de videobeelden van gezagsdragers als Cohen en Aboutaleb na de moord op Theo van Gogh en het optreden van Colin Powell in de Veiligheidsraad van de Verenigde Naties, waar hij de aanwezige gedelegeerden en de televisiekijkers moest overtuigen van de noodzaak om Irak binnen te vallen.

\subsubsection{Keuze van begrippen in dit onderzoek}

\section{Keuze voor discours en verhaallijn}

Het begrippenapparaat van Schön en Rein (1994), die met hun boek 'Frame reflection' nadruk leggen op de condities waaronder mensen in onderlinge communicatie opeens van standpunt kunnen veranderen, sluit minder goed dan discours en 'verhaallijn' van Hajer aan bij onze zoektocht naar duidelijk contrasterende denkbeelden achter beleidsprogramma's. De oneindig diverse belevingswerelden van burgers, groepen en organisaties bepalen hoe deze actoren tegen bepaalde politieke kwesties aankijken. Onderliggende geloofsopvattingen, perceptiewijzen en waarderingsgrondslagen bepalen ieders positie in een bepaalde politieke controverse. Uit de voorbeelden in het boek van Schön en Rein blijkt dat de beleidsrelevante gezichtspunten soms uit de meest onverwachte hoek kunnen komen. Deze auteurs verwijzen naar het voorbeeld van stadsvernieuwing om hun begrip 'frames' te verduidelijken (Schön \& Rein, 1994: 23 e.v.). Sommige actoren zien hierbij grootschalige sloop en nieuwbouw voor ogen, anderen denken juist aan het zorgvuldig behoud van de fysieke structuur van buurten en wijken en richten zich meer op de voorwaarden voor een gezonde gemeenschapsontwikkeling van de bewoners. Er zijn waarschijnlijk nog veel meer gezichtspunten (frames) aanwezig, afhankelijk van de vraag of men een architect, een wijkagent, een student, een sociaal werker of een middenstander naar zijn verhaal over de vernieuwing en leefbaarheid van de stad vraagt. De student zal zich afvragen hoe het staat met

\footnotetext{
${ }^{8}$ Een mooie uitspraak in dit verband van de oud-gemeentesecretaris van Amsterdam Henk de Jong is: 'Leer spaghetti eten!'
} 
uitgaansgelegenheden, goedkope kamers, et cetera, een oudere bewoner denkt wellicht met weemoed terug aan nachtrust, veiligheid en behoud van vertrouwde ontmoetingspunten.

Het gaat Schön en Rein vooral om het proces van consensusvorming, terwijl in dit onderzoek de nadruk ligt op dominantie van één bepaalde opvatting of paradigma én het tegendeel ervan, en niet zozeer op het proces waardoor actoren van een andere opvatting worden overtuigd. Omdat het onderzoek naar bestuursbeleid bovendien niet te maken krijgt met een vrijwel oneindig aantal perspectieven van allerlei relevante actoren, maar de duidelijk contrasterende redeneerlijnen binnen een bepaalde organisatie en op een bepaald beleidsterrein naast elkaar zet, is het begrippenapparaat van Schön en Rein hier minder toepasselijk.

Discours als voertuig voor plotselinge omslag in denken

Discours- en frame-analyse kunnen ook licht werpen op het verschijnsel beleidsverandering. Deze sociaal-constructivistische benaderingswijzen weerspiegelen een kijk op de werkelijkheid, een ontologie, waarbij de werkelijkheid zelf betekenis krijgt door taaluitingen en denkbeelden. Omdat deze elementen naar hun aard zeer fluïde zijn, is verandering een direct effect van het omarmen van een ander verhaal onder een bepaalde beleidsredenering. Verandering kan daarom volgens deze theoretici dus zo wendbaar zijn als een vlucht spreeuwen of zoals Hajer stelt: "Political change may therefore well take place through the emergence of new story-lines that re-order understandings." (Hajer, 1995: 56)

\section{Beperkingen van deze begrippen}

Het is zeer de vraag of uitingen op het niveau van waarden en paradigma's in een beleidsdebat ook de diepgevoelde opvattingen van de sprekers reflecteren. Het gebruik van een bepaalde verhaallijn is volgens Hajer zeker niet een noodzakelijke aanwijzing voor het bestaan van de diepste overtuigingen van de spreker. Beleidsmensen kunnen vrijmoedig met storylines spelen, als dat zo uitkomt. Zo komt ook hier het onderzoeksobject over het voetlicht. Ambtenaren van Binnenlandse Zaken (en hun bondgenoten) zijn uiterst flexibel in hun taaluitingen en ook de beleidsredeneringen kunnen alle kanten uit. Dieper liggende geneigdheden van de beleidsmakers moeten uit andere analyses blijken dan uit de louter serieus genomen retorische uitingen. Die analyse zal in dit onderzoek dan ook een plaats krijgen. Dat neemt niet weg dat we de typering van het beleid nodig hebben en daarvoor de gehanteerde storylines kunnen gebruiken als herkenningsteken.

In de volgende paragraaf zullen we zien hoe dat in de praktijk gedaan kan worden.

In deze categorie zijn de verschillende publicaties te vinden die gebruikmaken van discoursanalyse om Nederlands beleid te analyseren (Aarts en Te Molder, 1998; Dicke, 2001; Eberg, 1997; Frouws, 1998; Hajer, 1995; Goverde, 2000; Pestman, 2001; Smaal, 2012; Van der Steen, 2009; Tennekes, 2005; Termeer,1993; Van der Valk, 2001; Zwanikken, 2001; zie ook Korsten en Leers, 2005). Stuk voor stuk betreft het onderzoeken over complexe vraagstukken, zoals de onderdelen van bestuursbeleid dat vrijwel zonder uitzondering eveneens zijn, omdat de actoren, effecten en neveneffecten doorgaans meervoudig zijn. Die laatste constatering maakt dit onderzoek zo relevant.

\subsection{Analysemethode voor het begrijpen van de inhoud van bestuursbeleid}

\subsubsection{Kernbegrippen}

De algemene probleemstelling in dit onderzoek is:

Heeft zich binnen het subsysteem van het 'bestuursbeleid' van het ministerie van Binnenlandse Zaken in de periode van 1969 tot 2009 een dominant discours over de verhouding tussen bestuur 
en samenleving ontwikkeld? Zijn daarin verschuivingen opgetreden en hoe is die (eventuele) ontwikkeling te verklaren?

In deze probleemstelling zitten drie kernbegrippen besloten die operationalisering behoeven: discours, dominantie en als beleidsthema: de gepercipieerde verhouding tussen bestuur en samenleving. Over de operationalisering van de eerste twee van deze drie kernbegrippen in onderzoekstermen gaat deze paragraaf. Het derde (de focus op een bepaald discours) komt in het volgende hoofdstuk aan de orde.

De vraagstelling veronderstelt dat er sprake is van een dominante bestuurstheorie gedurende de gehele periode. Het zou natuurlijk ook kunnen zijn dat het dominante discours tussentijds is veranderd. In dat geval zou de vergelijking meervoudig worden, maar is het nog steeds mogelijk om een vergelijking te maken met de ontwikkelingen bij andere actoren ten aanzien van hetzelfde onderwerp.

Het kan dan zijn dat de gesignaleerde shift zich elders niet of eerder of later heeft voorgedaan. Ingewikkelder is het als de feiten tot de conclusie leiden dat op een of meer dossiers een andere bestuurstheorie is gaan gelden dan op de overige. De verwachting is echter dat de bestuurstheorie tussen verschillende dossiers redelijk consistent is. De integrerende rol van de ambtelijke en politieke leiding maakt dit aannemelijk, tenzij dit ministerie als los zand opereerde. Daarvoor is het van belang om de verschillende dossiers naast elkaar te onderzoeken.

In alle gevallen blijt de vraag: Hoe stel je de beleidsinhoud vast op moment 1, 2, 3 en 4 ? En hoe breng je eventuele verandering of stabiliteit in kaart? Welke bestaande methode is voor dit onderzoek het meest geschikt?

De vraag is dus tweeërlei:

- $\quad$ Hoe vinden we de inhoudelijke opvatting die achter elk nieuw beleidsinitiatief schuilgaat?

- $\quad$ Hoe bepalen we welke opvatting structureel als dominant kan worden gekenmerkt?

Wat betreft de eerste vraag ontlenen we het antwoord in de volgende paragraaf aan Hajer en Dicke. De tweede vraag komt terug in de beschrijving van de onderzoeksopzet (paragraaf 3.4.3).

\subsubsection{Operationalisering van onderzoek naar discours: verhaallijnen}

\section{Indicator voor de aanwezigheid van storylines}

Discoursanalyse kent vele verschijningsvormen (Van der Arend, 2007: 27 e.v.). Hajer introduceert een extra vertaalslag tussen 'beleid' en de achterliggende opvattingen. Hij koppelt de paradigma's (discours) aan rivaliserende groepen, een mechanisme voor machtsvorming waarop we hierna ingaan, maar ook hanteert hij het begrip storyline om de groepen te kunnen typeren naar hun inhoudelijke oriëntatie. Discours definieert Hajer (zie hiervoor) als "een specifiek samenstel van ideeën, begrippen en categoriseringen dat wordt geproduceerd, gereproduceerd en getransformeerd in bepaalde praktijken waardoor betekenis wordt toegekend aan fysieke en sociale verschijnselen" (Hajer, 1995: 264). Dat komt zeker in de buurt van wat we zoeken voor dit onderzoek, maar is nog behoorlijk abstract. We hebben behoefte aan praktische indicatoren. Daarvoor kiezen we het hierboven omschreven begrip storyline als verwijzing naar een gemeenschappelijk aanvaarde redeneerketen. Vaak is dit een metafoor. Door te verwijzen naar dat gezamenlijk stukje ingezonken leerervaring, kunnen hele stukken argumentatie worden overgeslagen. Dat is heel vaak nodig omdat het vertoog (discours) in politiek en beleid zelden helemaal logisch sluitend is. Metaforen en verwijzingen naar andere bekende domeinen des levens zijn dus nodig om enerzijds gaten in de redenering op te vullen of te maskeren, en anderzijds om mensen te verleiden zich bij het discours aan te sluiten. Een soort steno voor beleidsmensen die zo aan een half woord genoeg hebben. Dat 'halve woord' is dan voor de onderzoeker het signaal voor 
de aanwezigheid van een bepaalde lijn van redeneren. Hier komt het van pas dat de onderzoeker zelf ook een ingewijde is in de beleidstaal van het ministerie en dus de teksten kan plaatsen.

Vier stappen in de analyse

Bij de beschrijving van zijn methode van analyse onderscheidt Hajer vier stappen. In de eerste stap is op basis van een analyse van artikelen uit een viertal bladen en dagbladen over zure regen een gedetailleerde contextuele geschiedenis beschreven. Vervolgens is een analyse gemaakt van alle relevante beleidsdocumenten over en rondom het onderwerp zure regen. In de derde stap zijn parlementaire debatten en uitspraken op symposia en conferenties, en de verschillende reacties daarop uit de media, onderzocht. Aan de hand hiervan beschrijft Hajer de argumentatieve interactie tussen actoren. In de vierde stap is een serie van interviews gehouden met de actoren die uit de eerdere stappen naar voren kwamen als sleutelactoren. Aan de hand van deze vier stappen heeft Hajer een beeld verkregen van de verschillende aspecten van de discours-coalities die hij wilde onderzoeken.

De onderzoeker, die doorgaans buitenstaander is, maar in dit geval niet, zal in beide gevallen uit de stukken, uit interviews met de sleutelactoren en uit waarnemingen van beleidscommunicatie de relevante redeneerlijnen en de verandering daarin moeten vinden. Taalinterpretatie is zijn belangrijkste instrument. Bij discoursanalyse wordt de grote lijn vaak ontleend aan vooraf gegeven kennis over de programmatische veronderstellingen (vergelijk figuur 3.1). Zo categoriseert Dicke in haar onderzoek denkbeelden uit de modernistische en de postmoderne traditie. In ons onderzoek wordt vooraf vanuit de bestuurswetenschap gedefinieerd waar de discussie om draait. Voor dit boek is discoursanalyse nader te definiëren als: de typering van taaluitingen en praktijken binnen een vooraf geconstrueerde dichotomie van denkwijzen, waarmee betekenis wordt verleend aan het handelen van beleidsmakers.

\section{Werkwijze van Dicke}

Willemijn Dicke geeft een vrij nauwkeurige beschrijving van de manier waarop narratieven gereconstrueerd kunnen worden. Ze analyseert een bepaalde beleidsredenering naar zeven kenmerken (Dicke, 2000: 152):

1. Ontologie: hoe ziet men de werkelijkheid? Bijvoorbeeld: markt is beter dan overheid.

2. Wat is de redeneerlijn? Bijvoorbeeld: private organisatie van watervoorziening is het meest doelmatig; staatstoezicht is uit oogpunt van volksgezondheid weliswaar onvermijdbaar, maar hoe meer marktmechanismen kunnen worden geïntroduceerd, hoe beter.

3. Wat zijn de belangrijkste gebeurtenissen? Bijvoorbeeld: de privatisering in 1989.

4. Welke thema's spelen er? Zoals klantgerichtheid, transparantie, doelmatigheid, productkwaliteit.

5. Theorieën, waarmee ze kennelijk doelt op grote academische tradities, ze noemt bijvoorbeeld 'economisch rationalisme'.

6. Belangrijkste metaforen en retorische hulpmiddelen: klant, keuzevrijheid, product.

7. Dominantie in het beleidsveld: in casu de geprivatiseerde waterbedrijfstak.

Dicke verbindt een aldus uit beleidsstukken gevonden verhaallijn vervolgens aan drie aan de literatuur ontleende contrasterende meta-verhalen (modernisme of postmodernisme). Het is in haar onderzoeksveld van het watermanagement niet moeilijk de narratieven te typeren als hetzij passend in het vooruitgangsgeloof (modernisme) of in het postmodernisme. Alleen voor de laatste periode kwam ze met deze dichotomie niet uit en was het nodig een ander meta-verhaal te construeren: het ecologisch duurzaamheidsdenken.

Overigens blijven de zeven punten van Dicke in haar studie nogal impliciet. Er worden niet steeds zeven stappen doorlopen. In ons onderzoek zal dat ook niet zo gebeuren, al komen soortgelijke kenmerken ook regelmatig naar voren en wordt wel degelijk per casus systematisch gerapporteerd over vaste kenmerken. 
Ambiguïteit of duidelijke omslag?

De meeste theoretici met betrekking tot deze materie gaan uit van een duidelijk dominante of zelfs uniforme beleidstheorie die in één grote beweging kan omklappen. Hall (1993) beschrijft de omslag van het Keynesiaanse denken naar de economie van de Oostenrijkse en Chicago-school, bij meerderheidsstelsels als dat van de Verenigde Staten en het Verenigd Koninkrijk. Daar maakte het hele beleid in korte tijd volte-face.

Het onderhavige onderzoek naar bestuursbeleid problematiseert die omslag meer. Men kan daar mogelijk heen-en-weer-bewegingen aantreffen tussen verschillende vernieuwingsprojecten, waarbij contrasterende beleidstheorieën en verhaallijnen herkenbaar zijn. Denk aan het omarmen van het project sociale vernieuwing in 1991, waarmee het ministerie een geheel andere bottom-up denkrichting leek in te slaan, maar al gauw een zoveelste variant op decentralisatiebeleid bleek gevonden te hebben en de nieuwe wijkaanpak ook al gauw weer aan de wilgen hing. Op de achtergrond lijkt er gedurende lange tijd sprake te zijn van conflicterende inhoudelijke opvattingen over de kernthema's van bestuursbeleid, hier samengevat onder de verhouding tussen overheid en samenleving, zonder dat deze spanning duidelijk wordt beslecht.

Samenvattend is het herkennen van inhoudelijke betekenis in beleidsgeschiedenissen geen kwestie van elementen turven of van chemische analyse zoals bij de lakmoesproef. Mits toegepast overeenkomstig hun definitie kan men vertogen en storylines op het spoor komen door begrijpend lezen.

We constateren dat inhoudsanalyse een zekere dosis 'verstehen' met zich meebrengt, maar dat sluit niet uit dat intersubjectief overtuigende analyses van de bedoeling van teksten en beleid kunnen worden gepresenteerd. Dicke probeert de werkwijze om met zeven stappen het beleidsverhaal uit teksten te halen nog te expliciteren, maar een instructie voor een betrouwbare en herhaalbare interpretatie is dit nog niet. Het blijt een kwestie van interpreteren. Wat wel helpt, is dat de verhaallijnen (storylines) zo scherp contrasterend zijn gekozen dat plaatsing van taaluitingen in dichotome categorieën doorgaans niet moeilijk is.

\subsubsection{Onderzoeksopzet voor het zoeken van een dominant discours}

\section{Eigen onderzoeksaanpak kijkend naar gedrag}

Wat is vernieuwing, verandering? Op het eerste gezicht is het tekenend als je bepaalde verhalen ziet waarvan je denkt 'dat had het bestuur in de jaren zeventig nooit zo gezegd', maar eerlijker is het als je alle daden van het bestuur analyseert en daarin ook tegenstrijdigheden meeneemt. Tellen? Wegen? Inderdaad, hier wordt niet volstaan met het reconstrueren van een dominant discours gedurende een bepaalde periode.

Aanvullende methoden zijn nodig om vast te stellen hoe dominantie ook uit gedrag blijkt in plaats van alleen uit retoriek. Bijvoorbeeld door na te gaan wat er van de verschillende verhalen is terechtgekomen (doorwerking). Daarom wordt in dit onderzoek een eigen werkwijze ontwikkeld voor een navolgbare exegese. Aan het eind van het volgende hoofdstuk wordt dit verder uitgewerkt. Op deze plaats alvast het volgende over deze benadering.

\section{Institutionalisering}

Hajer spreekt niet over dominantie, maar over institutionalisering en over de hegemonie van een discours. Dat laatste begrip is als synoniem op te vatten voor de vraag of een discours dominant is. Welnu, volgens Hajer is dat het geval als aan twee voorwaarden wordt voldaan:

- $\quad$ structurering van het betoog: zonder gebruikmaking van de ideeën en begrippen uit een bepaald discours kan men geen geloofwaardig beleid formuleren;

- $\quad$ institutionalisering, dat wil zeggen het vertalen van een discours of verhaallijn in institutionele arrangementen, geëffectueerd beleid en maatregelen in de institutionele sfeer (herkenbare keuze die past binnen het bepaalde discours). 
Dit betekent dat we niet alleen of zelfs bij voorrang kijken naar het gevoerde discours, maar vooral ook naar de duurzame verwerking in het beleid. Wat beklijft? In verband met onze organisatorische gerichtheid is de vraag of de gehanteerde opvattingen over het bestuur zodanig doorwerken dat het ministerie in het vervolg hier ook nog wat mee moet. In het geval van verankering in wetgeving zal de wetgever gehouden zijn verdere uitwerking en uitvoering in de gekozen richting te verzorgen. Bij continuering van de in een vernieuwend project gekozen beleidsfocus vraagt de gekozen benadering verdere doordenking, kennisontwikkeling en concretisering, misschien wel inrichting van een organisatie-eenheid, kortom institutionalisering.

Voor de analyse van het discours in termen van de gekozen dichotomie, die de bestuurswetenschap aanreikt, is de onderzoeker afhankelijk van interpretatie. Per project (of traject) is dus uitgezocht wat er vervolgens van terecht is gekomen. Daarbij kon veelal volstaan worden met algemeen bekende gegevens (bijvoorbeeld wet ingetrokken, systeemwijziging geïmplementeerd, nieuwe organisatie-indeling of werkwijze ingevoerd, of: beleid mislukt). Als dan blijkt dat het ministerie bij volgende beleidsprojecten systematisch overgaat op een ander voorkeursdiscours, kunnen we spreken van een paradigmawisseling of shift.

\section{Verhaal als epos}

Om aan een bepaald beleidsproject de betekenis te ontfutselen, is het behulpzaam om zo dicht mogelijk bij de verhaalvorm te blijven. De gebeurtenissen worden geplaatst in een herkenbaar patroon, dat gemakkelijk de plot verraadt. Een held ontmoet een uitdaging, gaat de strijd aan met het kwaad, weet uiteindelijk te overwinnen, al was het maar in morele zin en leeft nog lang en gelukkig. Hoe het kwaad wordt gedefinieerd, hoe de strijd wordt gestreden, wat voor persoon de held is en zijn of haar tegenstander, dit alles maakt duidelijk hoe betekenis wordt verleend aan de situatie.

De opgetekende verhalen spelen allemaal rond bestaande personen die binnen het ministerie als projectleider of auctor intellectualis een vernieuwing hebben geïntroduceerd of daartoe een poging hebben verricht. Dat is bij alle 24 geselecteerde onderzoekscasussen het geval. Het is mogelijk veel van deze personen te kwalificeren als 'public heroes' in de betekenis van Idenburgs boekje 'Het gaat om mensen' (1999), omdat zij allen als publiek ondernemers te boek staan en grote flexibiliteit ten toon moesten spreiden om een innovatief project te leiden. Korsten heeft verschillende kenmerken van excellent leiderschap onderscheiden in zijn boek 'Grote klasse!' (2005). Corifeeën of excellente leiders hoeven de in dit onderzoek opgevoerde helden geen van allen te zijn; de meesten bleven inderdaad buiten 'hun' project overwegend in de schaduw opereren en kwamen op enkele uitzonderingen na niet verder dan de middenechelons van de ambtelijke hiërarchie. Hoewel het woord 'held' hier tussen aanhalingstekens moet worden gebruikt, is het treffend dat deze figuur in de archetypische verhaalvorm niet gemist kan worden. Het is vooral als innovatiedrager in een weerbarstige omgeving dat hun verhaal hier goed past. Interviews met deze personen geven extra kleur aan hun belevenissen, maken duidelijk welke wind er toen waaide of welke gure tegenwind zij intern soms moesten trotseren, wat in een enkel geval weer kan verraden wat de dominante verhaallijn was.

\section{Herleiden tot een Groot Verhaal}

Al deze afzonderlijke verhalen kunnen, volgens de werkwijze van Hajer en Dicke, worden herleid tot een groot verhaal of storyline. In ons geval is dat de gestileerde bestuurstheorie, de vraag tot één trefwoord gereduceerd, of government of governance schuil gaat achter het desbetreffende project. Als het gaat om bestuursbeleid, zit de verhaallijn in de gereconstrueerde perceptie van de verhouding tussen overheid en samenleving.

De discursieve analyse hier betreft vergelijking tussen het verhaal en de achtergrondinformatie over het project met de kenmerken van verticaal government of horizontaal governance. In het 
vorige hoofdstuk is duidelijk gemaakt waar dit onderscheid vandaan komt, namelijk uit wetenschappelijke reflectie op bestuurlijke ontwikkelingen. Hierna wordt de nadere operationalisering van de criteria voor deze toetsing uiteengezet.

\subsection{Operationele werkwijze voor onderzoek in het bestuursbeleid}

\subsubsection{Onderzoeksopgave}

Van project naar dossier naar bestuursbeleid

In hoofdstuk 1 zijn dossiers onderscheiden en projecten geselecteerd die het bestuursbeleid in de periode 1969-2009 inhoud en kleur hebben gegeven. Daar, in die projecten, gebeurde wat. Als men op zoek wil naar inhoudelijke typering van het bestuursbeleid en vooral van de dynamiek daarin, dan zal het daar te vinden zijn. In de voorafgaande paragrafen zijn de lenzen geslepen waarmee naar de verhalen in die projecten gekeken zal worden. De wetenschap reikt het begrippenpaar government-governance aan, en spreekt daarbij over een omslag of shift. Nu is het zaak om binnen het bestuursbeleid de ontwikkelingen in dat licht te analyseren.

Uiteindelijk wordt voor het bestuursbeleid in zijn totaliteit gezocht naar algemene conclusies:

- Hoe wordt hier doorgaans gewerkt? Incrementeel, experimenteel, met pilots, als een verkenningstocht? Dat is een aanwijzing dat men zich bewust is van bestuurlijke onzekerheid.

- Welk discours, welke verhaallijn komt als hegemoniaal naar voren: government of governance?

- Is er in de loop van de tijd iets fundamenteel veranderd (shift)?

Om daarover uitspraken te kunnen doen wordt een vrij breed beleidsterrein-dekkend aantal projecten bekeken, geclusterd in vijf dossiers. Per dossier is een globale typering van de beleidsopgave en van de beleidsaanpak nodig. Per dossier (hoofdstuk) zullen ook aan het eind van elk hoofdstuk overkoepelende conclusies worden getrokken over het geheel van beleidsinitiatieven/ projecten die daaraan voorafgaand zijn behandeld.

Om de genoemde eindconclusies te kunnen trekken moeten per project gegevens worden verzameld om na te gaan:

- Wat was hier nieuw, was er überhaupt sprake van vernieuwing?

- $\quad$ Hoe is het beleid te typeren op de as government-governance?

- Welke actoren, trekkers waren bepalend voor keuzen en vooral innovaties in het project?

- Wat is er van het beleid terechtgekomen? Dit laatste is nodig om de impact van het beleid te bepalen. Dat beïnvloedt vervolgens weer de duurzame bijdrage aan de bestuurstheorie, al dan niet in de vorm van een koerswending.

- Is er geëvalueerd, is er lering getrokken in een cumulatief proces van groeiend inzicht en zich steeds verdiepende bestuurstheorie? In hoeverre heeft het project een stempel gedrukt op het vervolg door leerervaringen of doordat de aandacht werd opgeëist voor uitwerking en implementatie?

In de komende hoofdstukken zal, een enkel ornament of weglating daargelaten, overal het volgende stramien te herkennen zijn:

1. Inleiding op het hele dossier;

2. Projecten; per project achtereenvolgens:

- totstandkoming, context;

- iets over de trekker, de innovator, de 'held' van het verhaal;

- de lotgevallen van het project aan de hand van het verhaal van de trekker en soms ook van anderen;

- de typering van de doelstelling achter het project en de beleidsredenering;

- de typering van de sturingsaanpak;

- de typering van de democratie-opvatting;

- de typering van de wijze van informatievergaring; 
- de typering van het vernieuwend gehalte van het project;

- de vraag of evaluatie heeft plaatsgevonden;

- de vraag of het project heeft bijgedragen aan de bestuurstheorie van Binnenlandse Zaken, zo mogelijk geactualiseerd aan de praktijk en met een opgaande leercurve;

- typering van de doorwerking, institutionalisering (het beklijven) in het bestuursbeleid.

3. Score per project als A, A -, B of B - (government- of governance-oriëntatie) en aan het eind een conclusie over het hele dossier in het licht van de beantwoording van de hoofdvraag over de omwenteling van government naar governance.

Nu volgt de uitwerking van deze opgave op het niveau van dossiers en cases/projecten, die tevens het onderzoeksplan oplevert, maar eerst in paragraaf 3.5.2 nog een verdere definiëring van de gezochte informatie, en daarna in paragraaf 3.5.3 een beeld van nog concretere gegevens die deze informatie kunnen opleveren.

\subsubsection{Benodigde informatie}

Algemene beleidskarakterisering op dossierniveau, afdalend naar projectniveau

Per dossier start elk hoofdstuk met een korte beleidsgeschiedenis. Uiteraard wordt daarvoor gebruikgemaakt van beschikbare documenten, archiefmateriaal en monografieën. Bij oudere perioden zijn er archiefstudies om te raadplegen. Maar ook de interviews met betrokken ambtenaren zullen bijdragen aan het algemene feitenrelaas.

De meeste beschrijving zal echter gewijd worden aan de ontwikkeling van de afzonderlijke projecten. De cases zijn in paragraaf 1.2.3 al genoemd. Hiervoor is hetzelfde type bronnenmateriaal beschikbaar, al zal er meer nadruk liggen op de verhalen die naar voren komen uit de interviews met de meest betrokken projecttrekkers (de helden) en soms ook hun helpers.

- $\quad$ Eerst wordt het project gekwalificeerd naar zijn vernieuwende gehalte, waarbij gebruikgemaakt wordt van de onderscheidingen van Hogwood en Peters (beleidsaanpassing, beleidsinnovatie, beleidsopvolging, beleidsbeëindiging), met de kanttekeningen daarover in paragraaf 1.1.3. Dat is nodig om besef te krijgen van de ingrijpendheid van een project en van de kans op vernieuwing in de bestuurstheorie.

- Ook zal steeds nagegaan worden of er is geëvalueerd. Gegevens over evaluatie van de beleidsprojecten zijn veelzeggend over de vraag of bestuurstheorie en de verdieping ervan een zwaarwegend element vormen in het (bestuurs)beleid. Immers, om inrichting en werking van het openbaar bestuur te verbeteren, de ambitie van het bestuursbeleid, zal men zich een gefundeerd beeld moeten vormen van de effecten van de eigen interventies en over de passendheid van de daarachter gelegen veronderstellingen.

- Belangrijk is ook dat duidelijk wordt in hoeverre het beleid doorwerking heeft gekregen. Uiteraard kan dat doordat het beleid succesvol is geweest en daarom zijn neerslag heeft gevonden in wet- en regelgeving of in andere sturingsmaatregelen. Als dat het geval is, zal het ministerie en zijn directe omgeving per definitie blijven werken aan het onderwerp van het project. Maar doorwerking kan ook indirect zijn doordat de lessen uit het project in de volgende fase merkbaar invloed hebben, zodat men het juist anders gaat doen of een ondervonden knelpunt met voorrang gaat aanpakken.

Hoe de cases te typeren op de schaal van government naar governance?

Uiteindelijk moeten bij de analyse van de cases, met behulp van interviews en documenten, indicaties te vinden zijn of er sprake is van denken in het patroon van government of van governance.

Daarbij zal onderscheid gemaakt worden tussen uitspraken van vier categorieën:

\section{Doelstelling van beleid}


Natuurlijk kijken we bij de projecten eerst naar de strekking van het streven achter het beleid(svoornemen) met betrekking tot het object bestuur. Indien dat is gericht op het versterken van de centraliteit van het bestuur, op de scheiding van verantwoordelijkheden, op uniformiteit in de toepassing en standaardisatie is dat te beschouwen als aanwijzing van government-denken. Voor zover echter samenwerking tussen van elkaar afhankelijke organisaties, het delen van verantwoordelijkheden, contingentie en maatwerk vooropstaan, is de werking van een governance-benadering zichtbaar. De eerste opvatting gaat ervan uit dat bestuursopgaven ordelijk volgens vooraf aangegeven procedures kunnen worden toegedeeld en opgelost. De tweede opvatting ziet de bestuursopgaven vooral als een avontuur, dat noopt tot het leggen van verbindingen tussen verschillende organisaties en partijen om tot een oplossing te komen. Onmiddellijk hierbij aansluitend past een bepaalde sturingsaanpak.

\section{Sturingsaanpak bij de beleidsvoering}

Behalve uit de oogmerken van het beleid komen al dan niet impliciete inhoudelijke opvattingen van de beleidsmakers ook naar voren uit hun gebleken voorkeuren voor een aanpak. Waar die voorkeur tendeert naar een hiërarchische command and control-benadering, planmatige fasering, sterke reductie van complexiteit, het ontkennen van afhankelijkheden, afwezigheid van interactie met 'partners' en scheiding tussen beleid en uitvoering, herkennen we daarin de government-aanpak. 'Wij gaan erover.'

Het tegendeel, omgaan met complexiteit, beleidsprocessen opvatten als avontuur, zoeken naar ad hoc coalities, open communicatie en dergelijke, wijst op de invloed van governancedenken. De institutionele setting is hier in wezen meervoudig en ambigu. Machtsposities zijn zwak en omstreden ('coördinerend, faciliterend'). In sommige gevallen is, in navolging van Koffijberg (2005: 274-308), te zien dat beide sturingsbenaderingen allebei aanwezig zijn, dat ze moeilijk te scheiden lijken of elkaar afwisselen. Met deze 'derde weg' wordt rekening gehouden.

\section{Democratieopvatting}

Uit het discours komt vaak een bepaalde democratieopvatting naar voren. Aan de ene kant van het spectrum wordt beleid democratisch genoemd dat steunt op de meerderheidsbesluiten van de representatieve democratie. Daartegenover staat de opvatting dat democratie meervoudig is, dat naast de steun van de gekozen volksvertegenwoordiging directe participatie van betrokkenen onmisbaar is om tot een gedragen en behoorlijk besluit te komen. De tegenstelling tussen government en governance komt bij deze dimensie scherper naar voren als niet alle 'polderoverleg' vanzelf tot de tweede categorie wordt gerekend. Dat zijn nog redelijk voorspelbare rituelen die passen binnen de procedures van de representatieve democratie. Hier behoeft de lezer dus geen beschouwingen te verwachten waarin netwerkbestuur-governance wordt doorgetrokken tot de zeventiende-eeuwse traditie van schikken en plooien, die de vaderlandse consensusdemocratie kenmerkt (Kickert, 2004). De cesuur wordt in dit onderzoek gelegd bij de radicale aanpassingen die van het openbaar bestuur worden gevergd als bij de besluitvorming niet meer vastligt welke aspecten, actoren en kennisdomeinen uiteindelijk het resultaat zullen bepalen. Dit is waar het een substantieel aandeel in de bestuurspraktijk gaat beslaan, een relatief recent fenomeen. De meest open en improviserende vorm van beleidslegitimering is vereist als vanuit onverwachte hoek opkomende actoren zich in de besluitvorming mengen. Bestuur dat zich daarop instelt (door open platforms in te richten en door zich maximaal flexibel in te stellen jegens elke relevante inbreng van buiten), zal als netwerkbestuur worden aangemerkt.

\section{Informatievergaring}

Een laatste voor de hand liggende indicator voor een van beide paradigma's is epistemologisch van aard. Hoe komen betrokken BZK-ambtenaren aan hun informatie over de werkelijkheid? 
In de government-aanpak past de klassieke rationele volgorde Analyse -> Instructie (eerst grondig analyseren achter het bureau en met de vertrouwde gesprekspartners, dan daadkrachtig besluiten op basis van de analyse en implementeren). Projectmanagement zoekt orde door te leren van vorige projecten en fouten uit het verleden te vermijden.

Een indicatie van governance-denken is in deze dimensie het besef dat analyse van achter het bureau door de complexiteit van de materie geen soelaas meer biedt. In zijn uiterste vorm levert dit een voorkeur op voor creatieve concurrentie waarbij consortia van betrokkenen worden uitgenodigd de beste probleem-oplossingscombinatie te ontwerpen, voor de metafoor van beleid als expeditie met de erkenning van onbekendheid van terrein en van de waarschijnlijkheid dat ergens op een onverwacht moment een moeras zal opdoemen waar de karavaan in vast dreigt te raken, respectievelijk dat men er meestal ook weer uit kan komen. Improviserend bestuur, waarbij leren dus vooral een kwestie van trial and error wordt. Verscheidenheid van contacten vergroot de kans op succes. Dit levert de aanpak Variëteit -> Selectie op, die begint met een grote verscheidenheid aan verschijningsvormen en waaruit dan de best werkende overblijft. De begrippenparen van Analyse naar Instructie en van Variëteit naar Selectie zijn afkomstig van Van Gunsteren (1994: 105). De evolutie is het meest bekende voorbeeld waar het mechanisme van Variëteit en Selectie werkzaam is.

Deze vier criteria zijn via inductieve weg gevonden, maar liefhebbers van een meer deductieve aanpak zullen er wel een matrix in herkennen, met op de ene as interne en extern gegenereerde factoren en op de andere as inhoudelijke en instrumentele (machtsbepalende) kenmerken. ${ }^{9}$ Gemeenschappelijke noemer van al deze criteria is het onderscheid tussen meer of minder interactiviteit tussen beleidsmakers en betrokkenen. Bij het eerste criterium (doelstelling binnen de bestuurlijke organisatie) geldt dit procesmatige kenmerk nog het minst, maar ook daar is de noodzaak tot communicatie-op-maat (interactie) het directe gevolg van het erkennen van diversiteit en meervoudigheid in taakverdeling.

\subsubsection{Onderzoeksmethode, gegevensverzameling}

Elk onderzoek met empirische pretenties kent een of meer waarnemingsmethoden. In het voorgaande is daarover al iets gesteld. Omdat er projecten op het vlak van bestuursbeleid aan de orde komen, zal het raadplegen van de inhoud van overheidsdocumenten een belangrijke informatiebron zijn.

\section{Verantwoording}

De interviews vormen een andere belangrijke informatiebron. Hier volgt een verantwoording van de gevoerde gesprekken. Per casus zijn enkele direct betrokkenen geïnterviewd. De lijst van geïnterviewden is bijgevoegd in bijlage 1. Meestal waren dit de 'helden' zelf, projectleiders of de innovatiedragers. Soms was dat niet mogelijk, bijvoorbeeld omdat ze inmiddels waren overleden (Charles de Menthon Bake, Johan van de Poel, Henk van Ruller, Gert-Jan Uhl) of omdat ze niet bereikbaar waren (Bert van Vliet, Marianne Sint, Louis Berger, Jan Post). In dat geval is een betrouwbare nabije informant geïnterviewd, zoals Hessel Boerboom, Frans van Bork, Tony Kristallijn en Grada Lautenbach.

Voor de beschrijving en analyse van projecten geldt uiteraard de eis van geldigheid en betrouwbaarheid. Daarom is de weergave van de verhalen aan alle geïnterviewden toegestuurd met het verzoek om accordering of correctie. Deze feedbackmogelijkheid was nuttig. Daarnaast is het manuscript als geheel zorgvuldig op juistheid gecontroleerd door enkele personen die al lang meelopen in het ministerie en vanuit verschillende posities aan de vorming van het bestuursbeleid hebben deelgenomen. Het betreft Jan Andries Wolthuis (medewerker Interbestuurlijke betrekkingen, Strategische Kennisontwikkeling, Programma Krachtig Bestuur en Burgerschap en Informatiebeleid) en Hans Wilmink (Minderhedenbeleid, Decentralisatie, Sociale vernieuwing,

${ }^{9}$ Er is zelfs een verband te leggen met het AGIL-schema van Talcott Parsons (Adriaanssens, 1983: 107-115). 
Formatiezaken personeelsbeleid rijksdienst en Strategische kennisontwikkeling). Daarnaast hebben vele medewerkers de voorstudie 'Wachten op het Omslagpunt' gelezen en hebben zij de moeite genomen commentaar te leveren, waarbij niet meer de opmerking "dit klopt niet" naar voren kwam. De onderzoeker voelt zich hierdoor gesterkt in zijn stelling dat hij ten minste een intersubjectief beeld van het bestuursbeleid heeft neergezet.

\section{Redeneerlijn voor het bereiken van onderzoeksresultaten}

Al dit materiaal moet ertoe leiden dat we elk project kunnen plaatsen op de hierboven beschreven as government - governance. Per project (of traject) is vervolgens uitgezocht wat er van is terechtgekomen. Daarbij zijn weer dezelfde bronnen gebruikt, met dien verstande dat veelal volstaan kon worden met algemeen bekende gegevens (bijvoorbeeld wet ingetrokken, systeemwijziging geïmplementeerd, beleid mislukt). Als het ministerie bij volgende beleidsprojecten stelselmatig en langdurig overgaat op een ander beleidsmodel, vormt dit een indicatie voor een eventuele discoursverandering. De interpretatie van het materiaal vindt plaats met behulp van de aspecten (criteria) uit paragraaf 3.5.2.

De typering van de gehanteerde werkwijze als government- of governance-gericht is dus een meervoudige variabele, gebaseerd op vier criteria of indicatoren. In theorie is het denkbaar dat de criteria tegengestelde richtingen indiceren. Indien dat het geval is, zal geconcludeerd worden dat er een mengvorm is opgetreden, met elementen van de tegengestelde storyline. Ter wille van de leesbaarheid is er in de empirische hoofdstukken vanaf gezien om tabellen met de uitkomsten per criterium op te stellen, laat staan om hier schijnexacte kwantitatieve scores aan toe te kennen. De omschrijvingen moeten voldoende overtuigend duidelijk maken welke bestuursmodus hier aan de orde is. Wel zal steeds concluderend afgesloten worden met een totaaloordeel.

Steeds is per project, dat is getypeerd als type A (government-denken) of type B (governancedenken) of een mengvorm (A - of B -: government met elementen van governance, respectievelijk governance met een vleugje government), vastgesteld welke bestuurstheorie herkenbaar is. Het eindsaldo A, B of A -, B - komt terug in een totaal scoringsschema, waarin nog meer elementen zijn opgenomen die tezamen de indicatie voor het optreden van een omslag in dominante denkwijzen vormen.

Misschien vinden we als uitkomst veel heen-en-weer-bewegen tussen contrasterende verhaallijnen. Ambiguïteit en interne tegenspraak zijn binnen een beleidsomgeving immers niet uitzonderlijk. Mocht de uitkomst te veel dubbelzinnigheden vertonen, dan is de gekozen polariteit misschien niet geschikt om een voorkeurparadigma te vinden. Ook dat is een leerzaam resultaat. Het kan natuurlijk zijn dat een of meer van de gekozen scoringscriteria 'door de mand valt' omdat er te veel gemengde uitkomsten voorkomen. Bij de volkshuisvesting constateerde Koffijberg (2005: 274-308) bijvoorbeeld al dat de sturingsaanpak zich juist kenmerkt door het wisselend gebruik van hiërarchische en horizontale instrumenten. Dat zou ook bij bestuursbeleid de praktijk kunnen zijn.

Het gegeven dat in dit hoofdstuk meermalen naar voren is gekomen dat er een grijs gebied bestaat, dat de denkbeelden in een ministerie en zijn omgeving vaak ambivalent zijn, lijkt spanning op te leveren met een zoektocht naar een dichotome tegenstelling tussen twee diametraal verschillende verhaallijnen. Naar verwachting is het uiteindelijk niet moeilijk om conclusies te trekken over het geaggregeerde beeld van alle projecten in een dossier of het hele bestuursbeleid. Moet om van een shift te kunnen spreken, er immers een duidelijk herkenbare dominantie zichtbaar zijn? Niet elke stap of elk idee hoeft in dezelfde lijn te passen, als de grootste gemene deler maar vergelijkbaar is.

Daarbij is vooral van belang dat wordt bekeken of het project is beklijfd, dat wil zeggen of institutionalisering heeft plaatsgevonden. Heeft het beleid neerslag gekregen in wetten en structuren, is het in de organisatiestructuur van het ministerie (afdelingsnaam, nieuwe taak) herkenbaar opgenomen? 
Door het combineren van de typeringen van elk project langs steeds dezelfde criteria en de uitkomsten van de beleidsresultaten (beklijft het project of niet) zal worden afgeleid wat de hegemoniale denkwijze van het ministerie blijkt te zijn. Niet alleen de eigen kwalificatie van de betrokkenen en de interpretatie daarvan door de onderzoeker, maar ook het waargenomen gedrag weegt hierbij mee. In de eerste plaats behelst onze discoursanalyse overeenkomstig de in paragraaf 3.4.2 genoemde definitie niet alleen taaluitingen, maar ook praktijken. In de tweede plaats is de vraag wat er van de projecten is beklijfd en geïnstitutionaliseerd, een apart meetpunt in dit onderzoek en dat impliceert dat ook naar de feiten wordt gekeken. Naarmate ideeën en projecten van het type government of het type governance meer beklijven dan wel zonder doorwerking blijven, zal de ene of de andere denkwijze als heersend worden aangemerkt. Het eventuele alternatieve denktype dat niet leidt tot doorwerking van beleid, zal worden opgevat als een serieuze aanvechting van het heersende paradigma. Een dergelijk project dat met een alternatief type basisgedachte is ingezet, heeft het immers wel tot beleid geschopt, maar het is na korte tijd weer in de la beland of niet opnieuw (in aangepaste vorm) geprobeerd.

Dit zijn de bouwstenen voor een conclusie, per project, per dossier en ook over de dossiers heen. Bepalend is uiteindelijk of in de meerderheid van de gevallen binnen een bepaald tijdvak zowel de typering van de modaliteit als de institutionele doorwerking van projecten wijst op een omslag of omwenteling.

\section{Bijdrage aan een geactualiseerde bestuurstheorie}

Naast de plaatsing op de as tussen government en governance is de bijdrage van elk project aan de bestuurstheorie van Binnenlandse Zaken een apart aandachtspunt. Daarvoor wordt allereerst ingezoomd op de op leereffect gerichte procesgang binnen en de eventuele evaluatie na elk project. Veel evaluaties zijn strikt gericht op de mate van doelbereiking, maar hier gaat het meer om de vraag wat Binnenlandse Zaken zelf van het project heeft geleerd. Ook een belangrijke indicatie is de mate waarin feedback en feedforward deel uitmaakten van de casus, of wisselwerking heeft plaatsgevonden met de bestuurlijke en maatschappelijke praktijk. In dat geval spreken we van een dynamische bijdrage aan de bestuurstheorie. Als de beleidsontwikkeling door de jaren heen relatief ongevoelig is voor nieuwe invloeden van buiten, noemen we het beleid statisch.

Voor de duurzame impact van een project aan de bestuurstheorie is het nodig verder te kijken naar het vervolg op het beleid. Sommige ideeën achter projecten hebben een duidelijke weerslag op de daarna volgende acties, soms nog decennia lang, terwijl andere al dood en begraven lijken op het moment dat het project wordt afgesloten.

Over de bijdrage van projecten aan de duurzame en aan de praktijk geijkte bestuurstheorie van Binnenlandse Zaken kan dus iets gezegd worden aan de hand van twee criteria:

- is het idee achter het project op termijn invloedrijk gebleken of niet;

- is de ontwikkeling van dit idee in de loop van de tijd statisch of dynamisch, al dan niet getoetst aan de bestuurspraktijk door middel van evaluaties en feedback.

Dit levert de volgende eenvoudige matrix op:

Figuur 3.2 Invloed van projecten op de bestuurstheorie van Binnenlandse Zaken

\begin{tabular}{|l|l|l|}
\hline Actualisering & Dynamisch, geijkt aan de praktijk & Statisch, vaste beleidslijn \\
\hline Mate van invloed & 1. Ontwikkelde bestuurstheorie & 2. Vaste doctrine \\
\hline Invloedrijk & & \\
\hline
\end{tabular}




\subsection{Resumé en vooruitblik}

\section{Resumé}

Aan het begin van dit hoofdstuk werd beloofd het methodologisch fundament van het onderzoek te leggen dat het best past bij de vraagstellingen uit hoofdstuk 1.

Na een vrij uitgebreide literatuurverkenning zijn discours en verhaallijn (storyline) van Hajer en Dicke gekozen als methodologische kernbegrippen voor dit onderzoek. We zijn immers op zoek naar de bestuurstheorieën die schuilgaan achter het bestuursbeleid. Verhalen zijn hiervoor bruikbare bronnen. Verderop zal de lezer zelfs verhalen in de oorspronkelijke betekenis van lotgevallen van een held in een strijdperk met al dan niet happy end tegenkomen.

Een kanttekening is dat, anders dan de studies van Hajer en Dicke suggereren, bepaalde beleidsopvattingen (bestuurstheorieën) niet vaak in onversneden vorm worden volgehouden. Er is veel heen-en-weer-bewegen tussen contrasterende verhaallijnen. Ambiguïteit en interne tegenspraak zijn binnen een beleidsomgeving een realiteit.

Discours is hier gedefinieerd als de typering van taaluitingen en praktijken binnen een vooraf geconstrueerde dichotomie van denkwijzen, waarmee betekenis wordt verleend aan het handelen van beleidsmakers.

Een belangrijke toevoeging aan de discoursanalyse is dat hier niet wordt volstaan met het typeren van een enkel beleidsproject, maar gewogen wordt hoe de verhaallijn van een veelheid van nieuwe beleidsinitiatieven zich ontwikkelde en vooral in hoeverre die verhaallijnen leidden tot institutionele verankering. Daardoor kan immers pas worden vastgesteld welke, in termen van Hajer, hegemoniaal genoemd mag worden.

Storylines zijn compacte verhaallijnen ('steno') over de sociale werkelijkheid die elementen van verschillende domeinen combineren en de actoren voorzien van een stel symbolische verwijzingen die een gemeenschappelijk begrip van de werkelijkheid suggereren, vaak in contrast met de tegengestelde verhaallijn.

In dit onderzoek zijn de storylines ontleend aan de bestuurskunde, waar het begrippenpaar government en governance tegenover elkaar zijn gesteld.

De begrippentegenstelling tussen governance en governance is voor de herkenning van bestuursopvattingen in de verhalen van het praktische bestuursbeleid nader geoperationaliseerd in vier criteria:

- doelstelling achter het beleid;

- $\quad$ de sturingsbenadering die ten grondslag ligt aan een project;

- $\quad$ de democratieopvatting die opgesloten zit in een project;

- $\quad$ de wijze van informatieverwerving ten behoeve van een project.

We plaatsen deze criteria in de context van eigentijdse maatschappelijke ontwikkelingen en zijn strikt bij de definitie van het begrip netwerkbestuur, zodat voorspelbaar 'polderen' erbuiten valt.

Per casus (project) zal op basis van de vier operationele criteria vastgesteld kunnen worden in hoeverre er sprake is van een governance-aanpak. Daarnaast zal de aandacht uitgaan naar de vraag of institutionele doorwerking heeft plaatsgevonden. Als bij meer dan de helft van de projecten in een bepaald tijdvak aan beide voorwaarden is voldaan, wordt besloten tot een shift van government naar governance. 
Onderweg zal steeds ook aandacht worden besteed aan aanwijzingen voor het überhaupt werkzaam zijn van een bestuursvisie en vooral op de doorwerking ervan in het beleid. Daarbij zal bij alle projecten worden vastgesteld hoeveel invloed is uitgeoefend op de bestuurstheorie van het ministerie en in hoeverre de ideeënontwikkeling in dynamische wisselwerking met de bestuurspraktijk en met maatschappelijke ontwikkelingen heeft plaatsgevonden.

De typering van projecten in de terminologie van Hogwood en Peters (beleidsinnovatie, beleidsopvolging, beleidsaanpassing, beleidsbeëindiging) is nuttig om een indruk te krijgen van de mate waarin het ministerie open stond voor beleidsvernieuwing en de ingrijpendheid van die innovaties. De vraag of de effecten van deze projecten zijn geëvalueerd, zegt iets over de mate waarin het ministerie erop is gericht van zijn nieuwe ervaringen te leren. Als men 'maar wat doet' en niet verder omkijkt naar lessen voor de toekomst, is dat een belangrijke aanwijzing voor de mate waarin innovaties passen in een voortschrijdende en bewuste ontwikkeling van beleid en organisatie.

\section{Wat volgt}

In de empirische hoofdstukken 5 tot en met 9 staan uitgebreide beschrijvingen van een reeks voorbeelden van de introductie van nieuwe benaderingen in het beleidsveld van Binnenlandse Zaken, waarbij de belangstelling vooral uitgaat naar de relatie van de vernieuwingspogingen met de veronderstelde verschuiving (shift) van government naar governance. Voor zover de genoemde relatie herkenbaar is, onderzoeken we de condities waaronder deze ontwikkelingen konden plaatsvinden en al dan niet structurele doorwerking vonden in de organisatie en het beleid. Omdat er geen beleidsanalyse wordt toegepast op de mogelijke effecten buiten het onderzoekssubject Binnenlandse Zaken, ligt de nadruk bij doorwerking op de merkbare follow-up binnen het ministerie. Zo is van thema's als sociale vernieuwing, Ketenregie en Procesmanagement bekend dat deze een bloeiende ontwikkeling hebben doorgemaakt nadat ze binnen Binnenlandse Zaken allang in de spreekwoordelijke la waren beland. Dat is dan voor de bestuurstheorie van Binnenlandse Zaken verder zonder betekenis.

In hoofdstuk 10 vat een figuur de elementen samen die in 24 relevante casussen het zoekproces leiden dat is gericht op aanwijzingen voor de doorbraak van nieuwe bestuursopvattingen. In figuur 3.3 staat het format waarmee dat schema is opgebouwd.

Figuur 3.3 Tabelstructuur voor analyse van de 24 casussen

\begin{tabular}{|l|l|l|l|l|l|l|}
\hline & $\begin{array}{l}\text { I } \\
\text { Mate } \\
\text { van } \\
\text { beleids- } \\
\text { veran- } \\
\text { dering 1) }\end{array}$ & $\begin{array}{l}\text { II } \\
\text { Evalu- } \\
\text { atie }\end{array}$ & $\begin{array}{l}\text { III } \\
\text { Typering van } \\
\text { bestuurs- } \\
\text { theorie 2) }\end{array}$ & $\begin{array}{l}\text { IV } \\
\text { Doorwer- } \\
\text { king } \\
\text { institutionali- } \\
\text { sering } \\
\text { Casus }\end{array}$ & $\begin{array}{l}\text { V } \\
\text { Indicatie } \\
\text { voor } \\
\text { omslag/ } \\
\text { shift }\end{array}$ & $\begin{array}{l}\text { VI } \\
\text { Indicatie } \\
\text { voor } \\
\text { duurzame } \\
\text { invloed op } \\
\text { bestuurs- } \\
\text { theorie 3) }\end{array}$ \\
\hline 1 & & & Ja of nee & $\begin{array}{l}\text { (combinatie } \\
\text { van } \\
\text { kolommen } \\
\text { I, Il en III) }\end{array}$ & \\
3 & & & & & & \\
$\ldots$ & & & & & & \\
24 & & & & & & \\
\hline
\end{tabular}


1) Typering volgens Hogwood en Peters:

Beleidsinnovatie - Beleidsaanpassing - Beleidsopvolging

2) Typering beleidsbenadering overeenkomstig dit onderzoek:

A = government-aanpak

$\mathrm{B}=$ governance-aanpak

A - = overwegend government-modus met enkele governance-elementen

B - = overwegend governance-modus met enkele government-elementen

3) Invloed op bestuurstheorie van Binnenlandse Zaken, overeenkomstig figuur 3.2:

1. veel/dynamisch

2. veel/statisch

3. gering/dynamisch

4. gering/statisch

Vervolgens worden deze conclusies in het tweede deel van dit boek (hoofdstukken 11 tot en met 13) door middel van een literatuurverkenning naast drie andere domeinen gelegd waaraan de bestuurstheorie van Binnenlandse Zaken kan worden gespiegeld: de politieke arena, een vakdepartement en het lokaal bestuur. Is daar de dominante bestuurstheorie soms anders gekleurd dan bij Binnenlandse Zaken, bijvoorbeeld omdat de invloed van de samenleving daar anders of intenser werd of wordt gevoeld?

De stelling in dit onderzoek is dat het van vitaal belang is voor het gedrag van de organisatie en voor de uitkomsten van het beleid hoe in overwegende mate tegen bestuursprocessen wordt aangekeken.

Dit mogelijke effect kan worden versterkt als een gelijk denkend subsysteem zich verder uitstrekt dan de organisatiegrenzen. We zullen hier bezien in hoeverre Binnenlandse Zaken zich in een gelijkgestemd gezelschap bevindt en daarmee eenzelfde bestuurstheorie deelt.

Voordat we aan de verhalen over de empirie toekomen, volgt eerst nog een historisch overzicht van de ontwikkeling van het beleid van Binnenlandse Zaken vanaf 1969 om de lezer enig houvast te bieden voor de gedetailleerde dossierbeschrijvingen. 


\section{Dee| || Bestuurstheorie binnen het beleidssysteem van Binnenlandse Zaken}

\section{Historische schets van het ministerie in de onderzochte periode}

\subsection{Inleiding}

Om de lezer gevoel te geven voor het onderzoeksobject volgt hier een schets op hoofdlijnen van de historische ontwikkeling van het bestuursbeleid. Dat gebeurt allereerst door een beschrijving van de organisatorische ontwikkeling, de organisatiestructuur van het organisatieonderdeel van Binnenlandse Zaken waar de verantwoordelijkheid voor het bestuursbeleid was belegd. De organisatie van de beleidsdossiers die in dit onderzoek aan de orde komen, wisselt nogal en de organisatorische setting is uiteraard van belang voor de inhoud van het beleid. Periodisering vindt plaats aan de hand van reorganisaties, omdat dit tevens bezinningsmomenten waren voor de missie en inrichting van het bestuursbeleid, waarbij nieuwe accenten werden gelegd. Die momenten markeren, meer dan kabinetsperioden, de koers ten aanzien van het bestuursbeleid. Elke paragraaf tussen twee reorganisaties beginnen we met een lijst van de zes thema's, waarbij het organisatieonderdeel wordt genoemd dat er in de desbetreffende periode verantwoordelijk voor was. Alle zes gekozen terreinen hebben in enige periode wel een eigen directie gehad. Maar we hebben ook alle mogelijke combinaties van deze terreinen in dezelfde directie gezien. Dit laatste is opmerkelijk en toont aan dat er grote inhoudelijke samenhang tussen de onderwerpen moet zitten. In schema ziet dit er als volgt uit:

Figuur 4.1 Wisseling van onderwerpen over verschillende directies

\begin{tabular}{|l|l|l|l|l|l|l|}
\hline (Re)organisatiemoment & $\mathbf{1 9 8 0}$ & $\mathbf{1 9 8 4}$ & $\mathbf{1 9 8 7}$ & $\mathbf{1 9 9 4}$ & $\mathbf{2 0 0 2}$ & $\mathbf{2 0 0 8}$ \\
\hline 1.Bestuurlijke organisatie & BB & BFO & BFO & BFO & BFO & OBD \\
\hline 2. Financiële verhouding(en) & FBB & & & & & \\
\hline 3. Decentralisatie & -- & DCB & IBI & GSIB & GSIB & OBD \\
\hline 4. Achterstandsgebieden & -- & DCM & DCM & GSIB & GSIB & -- \\
\hline 5. Informatievoorziening & -- & DB & IBI & IOS & IIOS & DRI+OBD \\
\hline 6. Organisatie rijksdienst & O\&A & O\&A & IBI & GSIB & POIR & POIR \\
\hline Legenda: zie lijst van afkortingen, bijlage 3 & & & & & &
\end{tabular}


Minstens zo belangrijk is een typering van de organisatiecultuur (paragraaf 4.3), die een belangrijke weerslag heeft op de aanpak en werkwijze in de verschillende onderdelen. Daarna wordt in paragraaf 4.4 iets gezegd over de personen die een hoofdrol speelden, de bewindspersonen en de ambtelijke top. Ten slotte volgen in paragraaf 4.5 de belangrijkste highlights van het beleid in chronologische volgorde, dus nog niet per dossier, waarmee een lijst van wetten en nota's wordt gepresenteerd.

De bedoeling van dit nogal feitelijk beschrijvende hoofdstuk is om enig overzicht en ordening tot stand te brengen in het belangrijkste kenobject van dit boek.

\subsection{Organisatieontwikkeling in zes perioden}

\subsubsection{Prehistorie: ontstaan van bestuursbeleid}

Institutionele geschiedenis van de organisatie van de rijksdienst

Ondanks de lange geschiedenis van de staatsinrichting zijn binnen het openbaar bestuur systematische reflectie en beleidsvorming over het instrumentarium en de taakverdeling nog niet zo heel oud (Winsemius, 1945; Van IJsselmuiden, 1988; Breunese en Roborgh, 1992). De aandacht hiervoor nam sterk toe na 1965 uit zorg voor de doeltreffendheid en democratische kwaliteit van het bestuur toen in de jaren na de Tweede Wereldoorlog de verzorgingsstaat een grote vlucht nam en de beperkingen van een groot en verkaveld staatsapparaat begonnen te knellen (Nota Bestuurlijke Organisatie, 1969; Commissie-Van Veen, 1971; Knelpuntennota, 1974; Commissie-Vonhoff, 1980). Voor die tijd lag de nadruk op doelmatigheid en op de invoering van moderne boekhoudsystemen en dergelijke. De coördinerende functie voor rijksorganisatie lag, zonder overigens die woorden te gebruiken, bij de minister van Financiën.

Sinds het kabinet-Cals-Vondeling in 1965 werd de zorg voor de doelmatige organisatie van de rijksdienst toevertrouwd aan de minister van Binnenlandse Zaken (Van IJsselmuiden, 1988). Als gevolg hiervan werd het bureau van de Adviseur voor de Organisatie Rijksdienst per 1 september van dat jaar overgebracht van het ministerie van Financiën naar dat van Binnenlandse Zaken. Maar de vakminister bleef verantwoordelijk voor de organisatie op het eigen departement, terwijl de supra-departementale activiteiten op dit gebied in handen van de Ministerraad bleven. Voor het eerst werd nu in de toelichting op de rijksbegroting expliciet aandacht aan het beleidsterrein geschonken; de organisatie van de (rijks)overheid was op de politieke agenda gezet. In de regeringsverklaring werd bijzondere aandacht geschonken aan de 'onvermijdelijkheid' om overheidstaken in te perken of te beëindigen. Dit was nieuw. Daarnaast bleef de nadruk liggen op efficiencyvergroting en stroomlijning, waarbij automatisering van het routinewerk een belangrijk aandachtspunt werd.

De centrale directie ging vanaf 1970/1971 als Directie Overheidsorganisatie en -Automatisering (O\&A) door het leven. Daarmee was de organisatie van de rijksdienst samengebracht met het overkoepelend personeelsbeleid (PIVOT 143, 2003).

Binnenlands bestuur als thema voor bestuursbeleid In bestuurlijk-politieke zin was de zorg voor het binnenlands bestuur, die van oudsher bij Binnenlandse Zaken berustte, interessanter dan de organisatie van de rijksdienst. Althans toen eind jaren zeventig daar het besef ontstond dat ingrijpen in het departementaal beleid ter inperking van de ongebreidelde regelzucht noodzakelijk was om de autonomie en democratische levensvatbaarheid van het decentraal bestuur overeind te houden. Het zou overigens nog tot 1994 duren voordat deze twee onderdelen ook in organisatorische zin tot een eenheid werden samengebracht. Toch werd in de bestuurswereld vanaf het begin van de jaren tachtig (de periode van de zogeheten 'Grote Operaties') de organisatie en taakuitoefening van de vakdepartementen als de sleutelfactor beschouwd voor het functioneren van het gehele openbaar bestuur, de gemeenten en provincies inbegrepen. Daarom was het vooral vanuit het binnenlands bestuur dat 
begrippen als bestuursbeleid en bestuursdepartement opkwamen. Dit boek kiest de eerste Nota Bestuurlijke Organisatie met sturingspretentie van 1969 als beginpunt. Sommig beleid is al veel ouder, ander wat jonger.

De onderzochte periode wordt afgesloten met de grote reorganisatie van 2008, waarbij voor het eerst een beleidseenheid voor democratie werd opgericht. Bij de volgende reshuffle in 2011, die voortvloeide uit de departementale herindeling na de kabinetsformatie voor het kabinet-Rutte I in 2010, kwamen grotestedenbeleid en minderhedenbeleid (wat daarvan over was) terug in het moederdepartement en werd een aparte directie rond 'de burger' opgericht (Burgerschap en Informatiebeleid). De gevolgen hiervan op de bestuurstheorie van het ministerie moeten zich nog uitkristalliseren. Laat de veertig jaar tussen 1969 en 2009 hier als onderzoeksperiode dienen.

\subsubsection{Vroegste periode, tot 1980 : 'Biza verzet de bakens'}

Zoals het voor elke periode zal gaan, volgt aan het begin de aanduiding van de directies en eventueel afdelingen waar de zes onderwerpen gelokaliseerd moeten worden.

$\begin{array}{lll}\text { - } & \text { Bestuurlijke organisatie } & \text { Directie Binnenlands Bestuur (BB) } \\ \text { - } & \text { Financiële verhouding(en) } & \text { Directie Financiën Binnenlands Bestuur (FBB) } \\ \text { - } & \text { Decentralisatie } & \text { niet aanwezig of in statu nascendi vooral bij FBB } \\ \text { - } & \text { Achterstandsgebiedenbeleid } & \text { niet aanwezig } \\ \text { - } & \text { Interbestuurlijke informatievoorziening } & \text { Directie Organisatie en Automatisering (O\&A) } \\ \text { - } & \text { Organisatie rijksdienst } & \text { Directie O\&A }\end{array}$

Organisatieverschillen, cultuurverschillen

Omstreeks 1975 bestond er bij Binnenlandse Zaken geen overkoepelende beleidseenheid (directoraat-generaal) voor Binnenlands Bestuur of voor Openbaar Bestuur. Wel waren er twee min of meer samenwerkende directies, Binnenlands Bestuur en Financiën Binnenlands Bestuur, elk met onderscheiden cultuurtrekken, daarbij cultuur opgevat als het geheel van werkwijzen, informele manieren van doen en gewoonten. Zij opereerden rechtstreeks onder de secretaris-generaal. Daarnaast bestond er een derde zelfstandige directie, Organisatie en Automatisering, waar de rijksbrede organisatie-ontwikkeling werd ondersteund, bijvoorbeeld de commissies voor de reorganisatie van de rijksdienst, de commissie-Van Veen, de Mitaco (ministeriële commissie Taakverdeling en Coördinatie) en de bekendste, de commissie-Vonhoff. Ook weer met een eigen organisatiecultuur.

De directie Binnenlands Bestuur (BB) bestond voor een groot deel uit Leidse juristen. De directie Financiën Binnenlands Bestuur (FBB) was vrijwel uitsluitend samengesteld uit selfmade hoofdambtenaren uit de gemeentelijke praktijk, die in de avonduren aan de bestuursacademie diploma's (GA I, GA II, GF) hadden gehaald. De directie Organisatie en Automatisering werd gedomineerd door academische hoogvliegers, sociologen en bestuurskundigen (Organisatie) en bèta-wetenschappers en ingenieurs (Automatisering).

Als de directie Financiën Binnenlands Bestuur al belast was met een zeker minderwaardigheidsgevoel ten opzichte van de collega's-van-goede-komaf, dan compenseerde zij dit ruimschoots door blijk te geven van sterker ontwikkeld praktisch inzicht over wat gemeenten beweegt en door relatief frequente deelname aan interdepartementaal overleg, waardoor men meer voeling hield met de actuele ontwikkelingen in het rijksbeleid dan de andere directies. Dit soort gevoelens zal men niet gauw in documenten terugvinden. De noodzaak om zich met sectoraal beleid bezig te houden kwam door de dringende urgentie die Binnenlandse Zaken in die periode voelde vanuit de omgeving met betrekking tot de noodlijdende gemeentefinanciën. De begrotingen van relatief veel gemeenten stonden in het rood en zij werden onder curatele gesteld op basis van de zogeheten artikel 12-procedure uit de Financiële Verhoudingswet (Havermans, 1984). De vier grote steden vielen in een aparte categorie, maar waren nagenoeg virtueel bankroet behoudens redding vanuit het Rijk door dit artikel 12. De oorzaak van dit kwaad werd unaniem 
toegeschreven aan het beleid van de vakministeries die met hun beleidsdrang en regeldrift de molens van de verzorgingsstaat aanbliezen en de gemeenten via medebewind en onvoldoende dekkende specifieke uitkeringen op kosten jaagden. Het was dan ook geen toeval dat als vertegenwoordigers vanuit Binnenlandse Zaken in interdepartementale overleggremia twee ambtenaren optraden die een functie vervulden als stoffer en blik van de gemeentefinanciën. Het waren de heer A. Eveleens, ${ }^{10}$ hoofd van de Inspectie Gemeentefinanciën, waar de artikel-12maatregelen werden uitgevoerd en Johan Hoff van Bureau Bijzondere Adviezen, waar de problemen van de grote steden werden behandeld. Het laatstgenoemde bijzondere bureau komt verderop in hoofdstuk 5 en 6 nog terug. Daarnaast was binnen de directie Binnenlands Bestuur één medewerker, jhr. Alexander van Sonsbeeck, aangewezen die contacten met de vakdepartementen onderhield. Ook al betrof het de hoogste interdepartementale commissies als de Rijksplanologische Commissie, de directeuren Jan Mulder (FBB) en Charles de Menthon Bake (BB) vertoonden zich weinig buiten hun burelen. De grote veranderingen kwamen met de komst van een bijzondere staatssecretaris bij Binnenlandse Zaken, tijdens het kabinet-Den Uyl, Wim Polak. Deze visionaire bewindsman werd belast met de coördinerende taak voor de gemeentefinanciën. Daarmee werd alles anders. Binnenlandse Zaken moest zijn blikveld richten op het beleid van de andere departementen.

\section{Organisatieverandering}

Dit was de organisatorische context waarin Henk van Ruller omstreeks 1974 als Raadsadviseur voor Coördinatievraagstukken onder secretaris-generaal Van Dijke aantrad. In de tweede helft van de jaren zeventig werden in rap tempo academici aangetrokken in de beide directies BB en FBB, die beleidsambities ontwikkelden om de bestuurlijke wildgroei van de verzorgingsstaat met alle risico's van dien voor het Huis van Thorbecke en zelfs voor de politieke democratie te gaan indammen. Zo werd de tijd rijp voor een ingrijpende reorganisatie, begeleid door een zwaar aangezet extern advies van bureau Berenschot om de onontkoombaarheid ervan kracht bij te zetten. De twee directies die al die jaren na de oorlog hun zelfstandigheid hadden kunnen behouden, moesten eraan geloven en werden onder de overkoepelende leiding van een directeurgeneraal geplaatst. Deze moest de organisatie klaarmaken voor twee bewegingen:

- $\quad$ in plaats van defensief inpassen van externe ontwikkelingen in de bestaande hoofdstructuur van het binnenlands bestuur meer offensief vormgeven aan het bestuur van Nederland; - $\quad$ in plaats van zich te beperken tot de inrichting en werking van de gemeenten en provincies ingevolge artikel 24 van de Grondwet, het blikveld verbreden naar de indirecte effecten van het beleid van de vakdepartementen op de kwaliteit van het bestuur.

Op zichzelf was de wending van een volgend, legalistisch beleidsdenken naar meer sturende eigen modellering van de werkelijkheid niet nieuw. Immers, de directie Binnenlands Bestuur had al enige jaren gewerkt aan het megaproject Reorganisatie binnenlands bestuur ( 26 'doe-provincies'). En ook enige bemoeienis met het beleid van vakdepartementen was al eerder vertoond, bijvoorbeeld vanuit de Inspectie voor de Gemeentefinanciën van FBB zoals hiervoor vermeld. Nieuw was dat de prioriteiten van dit onderdeel nu werden gekanteld, al kwam dit onder de nieuwe directeur-generaal (DG) Elco Brinkman nog niet meteen tot uiting in een nieuwe organisatiestructuur.

In plaats van het dominante onderscheid tussen de twee aspecten (en disciplines) bestuurlijkjuridisch en financieel ontstond geleidelijk ruimte voor een nieuw onderscheid: intern bestuurlijk en extern beleidsmatig gericht of liever: de wettelijke en organisatorische structuur van het binnenlands bestuur versus de feitelijke werking van dat bestuur onder invloed van spanningsvelden tussen sectorale en algemene belangen.

\section{Autonome gemeente en decentralisatie in verband met governance}

\footnotetext{
10 Overeenkomstig de toen gangbare ambtelijke gebruiken werd de voornaam van de heer Eveleens niet onthuld. De meest intieme aanspreekvorm was tutoyeren met gebruik van enkel de achternaam.
} 
Op het eerste gezicht lijken de toonaangevende beleidsthema's van Binnenlandse Zaken, namelijk de autonomie van de gemeente en decentralisatie van beleidsverantwoordelijkheden, ook goed te passen in de governance-modus. ${ }^{11}$ Toch is dat maar schijn. De beleidsredenering achter gemeentelijke autonomie is de wenselijkheid om het bestuurscentrum voor een betekenisvolle lokale (representatieve) democratie in stand te houden (Willemse, 2001). Lokaal bestuurscentrisme is hier belangrijker dan de volstrekte vrijheid om naar eigen inzicht het bestuur in te richten. In dat geval zou immers ook de benoeming van de burgemeester, de inrichting van de gemeenteraad, de datum en het kiesstelsel van de raadsverkiezingen en nog veel meer aan de lokale discretie worden overgelaten. Ook zou bij een radicaal decentralisatiestreven de keuze van de taakoverhevelingen per gemeente de resultante moeten zijn van onderhandelingen tussen de afzonderlijke besturen en de hogere overheid. Dit denken viel echter absoluut buiten het beleidsvocabulaire van Binnenlandse Zaken.

\subsubsection{Directoraat-generaal Binnenlands Bestuur 1980-1987}

De dossiers van het bestuursbeleid zijn in deze periode ondergebracht in de directies die in de rechterkolom zijn genoemd.

- Bestuurlijke organisatie

- $\quad$ Financiële verhouding(en)

- Decentralisatie

- $\quad$ Achterstandsgebiedenbeleid

- Interbestuurlijke informatievoorziening

- Organisatie rijksdienst
Na 1984: directie Bestuurlijke en Financiële Organisatie (BFO)

Directie Coördinatie Bestuursbeleid (DCB)

Directie Coördinatie Minderhedenbeleid (DCM)

Directie Bestuurszaken en deels directie O\&A

Directie O\&A

\section{Grote projecten}

Het meteen afbreken van de oude directies BB en FBB werd in 1980 te cru geoordeeld. De oude directeuren mochten nog de weinige jaren die hen tot hun pensionering scheidden, blijven werken onder de jonge DG Brinkman. Deze plaatste echter naast hun directies een stafafdeling rechtstreeks onder zijn eigen leiding. In de geest van die tijd werd hier ook een relatief omvangrijke groep 'onderzoekers' geplaatst, die dichtbij het vuur moesten zorgen voor eigen wetenschappelijk gerichte beleidsonderbouwing. Ook zat hier de projectleiding van een van de belangrijkste beleidsoperaties naast de Reorganisatie binnenlands bestuur en de Nieuwe Gemeentewet, het Decentralisatieplan. Dit project maakte nog gebruik van de medewerkers van de directies BB en FBB, wat regelmatig tot fricties leidde. De aansturing van deze medewerkers was niet homogeen. Naar de smaak van de DG lieten zij te vaak de oren hangen naar de centralistische argumenten van de vakdepartementen en gaven de directeuren en afdelingshoofden hiertegen te weinig tegenwicht. In politieke zin waren er geen verschillen van mening op dit punt getuige de naadloze continuïteit tussen beleid (Decentralisatienota) en reorganisatie onder minister Wiegel (VVD) en minister Van Thijn (PvdA; Decentralisatieplan).

\section{Minderhedenbeleid}

Een belangrijke structuurverandering in 1980 was de komst van een nieuwe, derde directie, die van Coördinatie Minderhedenbeleid (DCM). De toevoeging van deze vreemde eend in de rustige vijver van het binnenlands bestuur was een gevolg van het ijveren van secretaris-generaal (SG) Van Dijke, zijn raadsadviseur Van Ruller en een aantal actoren van buiten het ministerie. De hoofdopgave van de minderhedenproblematiek lag bij de gemeenten en dit was de belangrijkste verklaring voor de toevoeging van de nieuwe directie onder leiding van Henk Molleman aan de toko

\footnotetext{
11 Op zichzelf zijn de met de bedoelde shift samenhangende inzichten voor Binnenlandse Zaken niet vreemd. Binnenlandse Zaken, dat altijd zo hamert op de 'integrale aanpak' tegen de 'verkokering' moet veel van de contextverbredende benadering herkennen. De relatie tussen verschillende actoren en factoren bepaalt dan de onvoorspelbare uitkomst van vaak grillige processen. Een ander kenmerk van bestuursbeleid is de nadruk op bottom-up redeneringen. De autonomie van de gemeente, de 'eerste bestuurslaag', staat hoog in het vaandel. Daarmee spoort toch zeker het besef dat ondergeschikten in verticale verhoudingen niet minder, wel anders zijn.
} 
van DG Brinkman, maar overigens moest altijd nog even worden nagedacht over de logica van deze combinatie (PIVOT 113, 2003). Het behoeft weinig toelichting dat de plotselinge instroom van een relatief groot aantal sociologen, veelal bovendien afkomstig uit de verschillende windstreken waar ook de doelgroep vandaan kwam, tot de nodige cultuurbotsingen binnen de ambtelijke organisatie leidden. We komen daar uitgebreider op terug. De directie DCM zou tot $2001 \mathrm{bij}$ Binnenlandse Zaken blijven en daarna de diaspora ingestuurd worden.

\section{Doorvoering nieuw organisatiecriterium}

Pas in 1984 kantelde ook de formele organisatiestructuur. Dit moment werd gemarkeerd door het aantreden van een nieuwe DG, Jos Staatsen, afkomstig van Milieuhygiëne. Elco Brinkman was tot het ministerschap geroepen. Staatsen was een pragmaticus, die strategisch dacht en minder politiek zoals zijn voorganger. De herschikking van de oude directies naar de nieuwe oriëntatie van het beleid zat al wel in de pen. Coördinatie Minderheden bleef ongemoeid onder leiding van Henk Molleman. Staatsen vond in het algemeen dat Binnenlandse Zaken te ver afstond van de realiteit van het bestuur. Daarom achtte hij het nodig een vierde directie toe te voegen, die speciaal de opdracht kreeg zich te oriënteren op een aantal uitvoeringsaspecten binnen de opdracht van Binnenlandse Zaken. Dat werd de Directie Bestuurszaken, waarin onder meer toezichttaken werden gebundeld. Han Kapsenberg, afkomstig van DCM, en Johan Hoff kregen de leiding. Hoewel deze directie bepaald niet zonder succes was (BBI, GBA), werd zij in 1987 alweer opgeheven. Deel van dit succes was juist dat uitvoeringsaspecten weer even voldoende impuls hadden gekregen, waardoor plaatsing in een eigen directie niet meer nodig, misschien zelfs schadelijk werd geacht.

Wat de overige beleidstaken betreft, werden de directies BB en FBB gehergroepeerd tot enerzijds een directie Bestuurlijke en Financiële Organisatie (BFO) voor Gemeentewet, Gemeentefonds en indeling van de bestuurlijke kaart van Nederland en anderzijds de Directie Coördinatie Bestuursbeleid (CB) voor decentralisatie en deregulering en het nodige interdepartementaal overleg. In deze directie onder leiding van Floris Plate en Hans de Waal was de meeste discussie over de uiteindelijke invulling van de missie ter verbetering van het openbaar bestuur. Het aanvankelijke elan waarmee Decentralisatieplannen waren voorbereid, was enigszins bekoeld door gebrek aan resultaten.

Van verschillende kanten kwam de kritiek dat Binnenlandse Zaken te drammerig was opgetreden tegen de vakdepartementen, als Don Quichotte tegen de windmolens. De directie koos nu de voor de hand liggende koers de departementen aan te vallen op de verschillende bestuursinstrumenten als specifieke uitkeringen, planprocedures, toezichtsfiguren en gedeconcentreerde diensten. Zo kon Binnenlandse Zaken meer op eigen terrein de strijd aanbinden dan wanneer de discussie ging over de inhoudelijke wenselijkheid van decentralisatie op een bepaald beleidsterrein. Het moederdepartement verwees dan naar een algemene voorkeur voor de Gemeentewet, de Financiële Verhoudingswet en de Provinciewet, die veelal alternatieve, generieke instrumenten bevatten, die uit oogpunt van gedecentraliseerd bestuur de voorkeur genoten. Denk aan de algemene uitkering uit het Gemeentefonds, de meerjarenbegroting of het bestemmingsplan, algemene taakverwaarlozingsregelingen en de inspectierol van het provinciebestuur. Deze aanpak was relatief succesvol blijkens de dalende aantallen specifieke bestuursinstrumenten die jaarlijks werden geteld.

Minstens zo belangrijk was de omstandigheid dat de jaren tachtig in het teken stonden van afslanking en ombuiging. Menige centralistische optuiging van beleid moest eigenlijk verdwijnen omdat er geen geld meer voor was. Maar overigens waren de oogsten van de afdeling vrij mager en, voor zover in beleidsontwikkeling van andere ministeries meegenomen, moeilijk aan te tonen. Ministers als Koos Rietkerk en Cees van Dijk konden er ook niet erg warm voor lopen. Nog de meest intensieve samenwerking was er met staatssecretaris Dieuwke de Graaf-Nauta, die zich 
tussen 1986 en 1994 erg inspande om van dit onderdeel iets te maken en met alle medewerkers intensief contact had over allerhande dossiers van rijksbeleid.

In de directie, later afdeling, CB werden ook de adviezen voorbereid voor de minister en de staatssecretaris op vrijwel alle ministerraadsstukken. Deze stukken stelden de medewerkers wekelijks op de proef door de vraag voor te leggen en te (laten) beantwoorden wat de effecten van allerlei beleidsvoornemens konden zijn voor de werking van het bestuur, wat het 'belang van Binnenlandse Zaken' voor het bevorderen van goed bestuur bij al die stukken kon zijn. Als stelregel werd de kwaliteit van bestuur afgemeten aan de doelmatigheid, doeltreffendheid en het democratisch gehalte ervan, maar wat is dat precies en hoe kun je die effecten ex ante bepalen? Geleidelijk werd hiervoor een reeks indicatoren ontwikkeld, maar dat bleven sjablonen, benaderingen van één hoofdidee, namelijk dat het bestuur het best is gediend met handelingsvrijheid van gemeenten, democratisch gekozen organen met de meeste kans op integraal, op de situatie aangepast bestuur en de kleinste kans op verspilling.

De directie Organisatie en Automatisering (O\&A) bleef bij deze reorganisatiebeweging nog buiten schot. Zij zag de regeringscommissaris voor de rijksdienst, Herman Tjeenk Willink, toegevoegd in haar gelederen.

\subsubsection{Directoraat-generaal Openbaar Bestuur 1987-1994}

Eerst wordt weer de nieuwe verdeling van de hoofdtaken in twee rijtjes gepresenteerd.

- Bestuurlijke organisatie

- $\quad$ Financiële verhouding(en)

(FV)

- Decentralisatie

- $\quad$ Achterstandsgebiedenbeleid

- Interbestuurlijke informatievoorziening

- Organisatie rijksdienst
Directie BFO / Afd. Bestuur en Wetgeving (B\&W)

Directie BFO / Afd. Financiële Verhouding(en)

Directie Interbestuurlijke Betrekkingen en Informatievoorziening, afdeling Coördinatie

Bestuursbeleid (IBI/CB)

IBI / CB en DCM

IBI / Afd. Overheidsinformatievoorziening en

Organisatie (OI\&O)

IBI / OI\&O

\section{Inhuizing O\&A}

De operationalisering van goed bestuur werd nog ingewikkelder toen in 1987 ook de directie Organisatie en Automatisering (O\&A), die vooral de rijksdienst betrof, aan Coördinatie Bestuursbeleid werd toegevoegd. Het directoraat-generaal ging Openbaar Bestuur heten in plaats van Binnenlands Bestuur. DG werd Jan Hendrikx, die Jos Staatsen opvolgde. Resultaat van deze fusie werd de directie Interbestuurlijke Betrekkingen en Informatievoorziening (IBI) onder leiding van Wim Kuyken en later Marjanne Sint en Marbeth Bierman. Hierbinnen treffen we de afdeling Coördinatie Bestuursbeleid (CB), en daarnaast de afdeling Overheidsinformatievoorziening en Organisatie, waarin we onderdelen van het oude O\&A herkennen. Op het terrein van informatievoorziening waren er nog wat kleinere afdelingen met specifieke taken, zoals persoonsinformatiebeleid, nieuwe informaticatoepassingen, onderzoek en ontwikkeling en algemeen overheidsinformatiebeleid. Hierdoor konden enkele leidinggevenden tijdelijk onderdak krijgen.

\section{Bestuursakkoord}

CB bleef een open, flexibele afdeling. Hier bleven de meeste ministerraadsstukken stromen. De medewerkers van deze afdeling werden ook steevast ingezet als boodschappers vanuit de andere directies (vooral BFO) naar de vakdepartementen. Daarnaast hadden de medewerkers veelal een bepaald bestuurlijk thema onder hun hoede, zoals toezicht of sociale vernieuwing. Het was dus een matrixorganisatie. Deze afdeling had relatief de minste eigen producten, maar ontleende zijn identiteit aan het bijdragen aan de bestuurlijke kwaliteit van de producten van anderen. Dit maakte de meerwaarde van de afdeling relatief onzichtbaar. Een van de weinige echt eigen producten van 
CB werd het Bestuursakkoord tussen Rijk, IPO en VNG, dat vanaf 1987 diende om het bestuursklimaat tussen de bestuurslagen te normaliseren, na een aantal jaren van kille bezuinigingen, die de gemeenten en provincies als onredelijke afwenteling hadden ervaren. Daarnaast werd het project D'gemeenten en D'provincies, de nationale ideeënbus voor deregulering en decentralisatie en voor experimenten met beleid, hier uitgevoerd.

\section{Sociale vernieuwing, Decentralisatie-impuls}

Omstreeks 1990, onder minister Dales, werd deze situatie anders. Aan de afdeling CB werd een aantal grote eigen projecten toevertrouwd, waarvan Sociale vernieuwing leidde tot een forse uitbreiding van de formatie. Een ander groot CB-project was de Decentralisatie-impuls (DI), waarbij rugwind werd gecreëerd door een bondgenootschap van minister-president Lubbers en minister van Financiën Kok en door koppeling aan een budgettaire taakstelling, die voor IPO en VNG het spel veranderde van klaagzangen en het indienen van verlanglijsten naar echt onderhandelen. Vooral het thema sociale vernieuwing bracht een verdere verbreding van de oriëntatie van de afdeling en van het hele DG tot stand. Door de pogingen burgers en maatschappelijke organisaties te mobiliseren voor wijk- en buurtprojecten werd de vanzelfsprekende identificatie met gemeenten weliswaar niet losgelaten, maar aangevuld met ervaringen op microniveau. Dit samenspel met andere partners relativeerde de eenzijdige heilsverwachting van overheidssturing, die binnen Binnenlandse Zaken tot dan toe dominant was. De afdeling ging zich meer en meer vereenzelvigen met het burgerperspectief, al stond de gemeente nog steeds wel op de eerste plaats in relatie met de burger.

Als opmerkelijk detail, tussenconclusie, kan genoemd worden dat de directie Bestuurszaken in deze periode alweer is opgeheven. Dat is hiervoor al vermeld, maar daar komt bij dat deze directie nooit meer is opgevolgd door een soortgelijk uitvoeringsgericht onderdeel. De redenering van DG Staatsen dat het nodig was voor Binnenlandse Zaken om meer gevoel te ontwikkelen voor de uitvoeringspraktijk, was kennelijk eenmalig en persoonsgebonden. Aannemelijk is dat de hoofdstroom aan opvattingen binnen het ministerie juist moeilijk te rijmen is met al te directe contacten (bemoeienis) met het grondvlak.

\subsubsection{Opsplitsing van Interbestuurlijke Betrekkingen en Informatievoorziening 1994-2002}

Gedurende deze, relatief lange reorganisatieloze periode waren de dossiers als volgt verdeeld.

- $\quad$ Bestuurlijke organisatie

- $\quad$ Financiële verhouding(en)

- Decentralisatie

- $\quad$ Achterstandsgebiedenbeleid

- Interbestuurlijke informatievoorziening

- Organisatie rijksdienst
Directie BFO / Afd. B\&W

Directie BFO / Afd. FOBB

Directie Grotestedenbeleid en Interbestuurlijke

Betrekkingen (GSIB) / Afd. Interbestuurlijke

Betrekkingen (GSIB/IB)

GSIB en DCM

Directie Informatievoorziening Openbare Sector (IOS)

Directie GSIB / Afd. Organisatie en Kwaliteit

Rijksdienst (OKR)

Grotestedenbeleid, Stadsprovincies

In 1994 kwam het experiment met sociale Vernieuwing ten einde. De opvolger was het grotestedenbeleid, dat in de afdeling zo mogelijk een nog groter deel van de aandacht opeiste (Van Putten, 2006).

Er was ook een aparte staatssecretaris, na 1998 zelfs een eigen minister voor grotestedenbeleid (met een intermezzo in 2002 onder het kortstondige kabinet-Balkenende I). Aanvankelijk bleef de hoofdzakelijk interdepartementaal coördinerende taak toegewezen aan de medewerkers van de afdeling Coördinatie Bestuursbeleid, die behalve contactpersoon voor een ministerie ook een grote stad kregen toegewezen. De afdeling CB werd voor een ander deel uitgeleend aan een ander groot project, de opbouw van Stadsprovincies, bij BFO. Er was ook aanleiding voor strategische 
bezinning. Alom was de overheid onder invloed gekomen van het uit Amerika overgewaaide New Public Management (De Vries en Van Dam, 1998: 16, 213). Bedrijfsmatig werken werd de norm. Klantgerichte prestaties moesten meetbaar en transparant worden aangeboden. De naam van de Directie Coördinatie Minderhedenbeleid werd veranderd in Directie Integratie Minderheden. Coördinatie was uit; dat werd meer geassocieerd met vergaderen dan met producten maken.

\section{Koninkrijksrelaties}

In 1999 werd het bestuur over de Nederlandse Antillen onderdeel van Binnenlandse Zaken. Tot dan toe had het Kabinet der Nederlandse Antillen (KABNA) een zwervend bestaan geleid, ondergebracht bij verschillende ministeries al naar gelang de coalitiebesprekingen nog wat wisselgeld nodig hadden om een van de partners te contenteren. Binnenlandse Zaken haalde deze trofee binnen als een parel aan de kroon. Voor de goede verhoudingen met een semi-zelfstandige natie werd de rode loper uitgerold en werd het woord Koninkrijksrelaties aan de naam van het ministerie toegevoegd. De directie Koninkrijksrelaties werd ondergebracht bij een nieuw directoraat-generaal Constitutionele Zaken en Koninkrijksrelaties, want deze paste niet meer bij het al zwaar opgetuigde directoraat-generaal Openbaar Bestuur. DG Jan-Willem Holtslag beleefde rond de eeuwwisseling een toppunt wat betreft de reikwijdte van zijn onderdeel, maar een neergaande lijn zou na de top niet ver meer verwijderd zijn.

\section{De Tweede Minister}

De afdeling grotestedenbeleid (GSB) werd in 1999 opgericht als aparte eenheid. De afdeling CB was ook wel onbestuurbaar groot geworden met circa 24 medewerkers. Zo ontstond bij een zoveelste reorganisatie binnen het directoraat-generaal Openbaar Bestuur de directie Grotestedenbeleid en Interbestuurlijke Betrekkingen GSIB en daarbinnen de afdelingen GSB, Interbestuurlijke Betrekkingen (IB) en Organisatie en Kwaliteit Rijksdienst (OKR). Naast GSIB was een aparte directie Informatievoorziening Openbare Sector ook beschikbaar voor de tweede minister van het departement (Van Boxtel), die ook de ontwikkeling van ICT binnen het openbaar bestuur (e-government) in zijn portefeuille had (PIVOT 92, 2003).

\section{Faciliterende rol}

Afdelingshoofd IB Berend van der Ploeg, afkomstig van VNO, voelde zich aangetrokken tot de gedachte dat Binnenlandse Zaken zich vooral dienstbaar moest opstellen om het probleemoplossend vermogen van het bestuur als geheel te verbeteren. Daarin paste niet het enge wij-zij-denken van Binnenlandse Zaken jegens de andere departementen, noch de strenge lagenstructuur tussen Rijk, provincies en gemeenten, zelfs misschien niet de scherpe grens tussen private en publieke sector. Toch konden de medewerkers van IB niet verhinderen dat na een periode van verbreding (interactief bestuur, ketenregie) de afdeling zich uiteindelijk weer ging toeleggen op zijn oorspronkelijke kerntaak, de adviezen bij ministerraadsstukken, de gedragsregels tussen de bestuurslagen, de sanering van bestuursinstrumenten en zelfs decentralisatie.

\section{Politiek primaat zet de toon}

Op het politieke front liet de geheel nieuwe ervaring van een paarse coalitie zijn sporen na (De Vries, 2001). Op verschillende departementen werden hevige discussies gevoerd over sturing. Bij LNV werd langzaam maar zeker de macht van het groene front gebroken. Binnenlandse Zaken leek de wind mee te hebben als het gaat om de strijd tegen sectorale deelbelangen. Het ondoorzichtige overleg- en adviesstelsel werd gesaneerd met de bedoeling de ijzeren driehoek van belangenorganisaties te weren uit de algemene beleidsvoorbereiding. Bij Verkeer en Waterstaat bezorgde de Betuweroute de ingenieurs een koude douche. Voortaan zou men eerst met onbekende betrokkenen en omwonenden om de tafel gaan om bezwaren en alternatieven te onderkennen in plaats van te varen op de koers van de georganiseerde belangen. In deze periode kwam de rijksoverheid onder invloed van het neo-liberale denken. Privatisering en verzelfstandiging kwamen in de mode, omdat deze zowel klantgerichte dienstverlening als de werking van de ministeriële verantwoordelijkheid ten goede zouden komen. De paarse ministersploeg toonde zich 
bijzonder gevoelig voor hun politiek primaat en ontwikkelde een stevig wantrouwen jegens de ambtenaren met een aantal onverkwikkelijke incidenten als symptoom. Docters van Leeuwen, Van Wijnbergen, Geelhoed werden zo bekende ambtenaren (meer in Bekker, 2012). Persoonlijkheden als Jan Pronk, Wim Kok en Tineke Netelenbos versterkten deze koele sfeer. Dat lag niet alleen aan paars, want het werd niet beter bij het kabinet-Balkenende I (affaire-Van Lieshout).

\subsubsection{Directoraat-generaal Koninkrijksrelaties en Bestuur 2002-2008}

In deze periode waren de zes hoofddossiers weer op andere wijze over directies verdeeld.

- $\quad$ Bestuurlijke organisatie

- $\quad$ Financiële verhouding(en)

- Decentralisatie

- $\quad$ Achterstandsgebiedenbeleid

- Interbestuurlijke informatievoorziening

- Organisatie rijksdienst
Directie BFO/B\&W

Directie BFO/FOBB

Directie GSIB/IB

Directie GSIB/Afd. GSB (tot 2007)

na 2004 DG Management Openbare Sector (MOS)

/ Directie Informatievoorziening Openbare Sector (IOS)

na 2004 DGMOS/Directie Personeel,

Organisatie en Informatie Rijk (POIR)

\section{Vertrek DCIM en O\&A}

Tijdens de coalitiebesprekingen van 2002 werd de eerste bres geslagen in het bastion van DGOB. De directie Integratie Minderheden werd overgedragen aan het ministerie van Justitie, waarmee een haat-liefdeverhouding bestond. De liefde kwam tot uiting in de gedeelde huisvesting en verwantschap in missie en algemene oriëntatie, maar animositeit was er ook door rivaliteit op het terrein van de veiligheidscompetenties en door de ervaren verschillen in organisatiecultuur. De overgang was voor de collega's van DCIM een hele cultuurschok, ook omdat zij moesten werken in een guurder politiek klimaat ten opzichte van hun doelgroepen onder Hilbrand Nawijn en Rita Verdonk.

Het directoraat-generaal Openbaar Bestuur werd na de kabinetsformatie van 2003 verder uitgehold door overdracht van Organisatie in de rijksdienst en Informatievoorziening naar het collegadirectoraat-generaal Management in de Openbare Sector (DG-MOS). Daar werd een nieuwe directie Personeel, Organisatie en Informatie Rijk (POIR) opgericht en de directie IOS werd integraal aan DG-MOS overgedragen.

De Koninkrijksrelaties kwamen echter weer terug. Het woord Koninkrijksrelaties stond zelfs voorop in de benaming van het nieuwe directoraat-generaal Koninkrijksrelaties en Bestuur (DGKB).

\section{Restauratie van vertrouwen, vertrek GSB}

Onder het kabinet-Balkenende II met minister Zalm op Financiën na 2003 was het klimaat tussen de bestuurslagen tot een dieptepunt gezakt, vergelijkbaar met de periode Rietkerk. Naast bezuinigingen was vooral de afschaffing van een groot deel van het eigen lokaal belastinggebied hier debet aan. Hierdoor moest vanaf 2006 weer geïnvesteerd worden in herstel van vertrouwen, de bestuursakkoorden-oude stijl werden weer opgepoetst en decentralisatie, die natuurlijk om meer redenen plaatsvond, kon als pleister op de wonde dienen.

In 2007 werd ook het grotestedenbeleid aan Binnenlandse Zaken onttrokken. De minderheden verhuisden mee van Justitie naar het ministerie van VROM, waar een aparte projectminister voor Wonen, Wijken en Integratie werd ingesteld.

Toch was niet alles kommer en kwel in deze periode. Onder leiding van SG Holtslag werd na lange tijd weer eens grootscheeps gereorganiseerd onder de naam De Leeuwensprong, waarbij nogal wat werd geïnvesteerd in een gemeenschappelijke organisatiecultuur (programma Leo). Een hoofdpunt was het versterken van de externe oriëntatie van de medewerkers (zie ook Rob-advies over ' Cultuur met een FORS postuur', Raad, 2004). Bovendien werd - voor dit onderzoek relevant - een stafeenheid Strategische Kennisontwikkeling (SKO) opgericht. Zou deze eenheid een nieuwe 
bestuurstheorie gaan ontwikkelen?

\subsubsection{Directoraat-generaal Bestuur en Koninkrijksrelaties, 2008 -}

Wederom voorafgegaan door een nieuwe directie-indeling voor de behartiging van de zes dossiers.

- Bestuurlijke organisatie

- $\quad$ Financiële verhouding(en)

- Decentralisatie

- $\quad$ Achterstandsgebiedenbeleid

- Interbestuurlijke informatievoorziening

- Organisatie rijksdienst
Directie Openbaar Bestuur en Democratie (OBD)/

Afd. Kaderstelling en Kwaliteit Bestuur (KKB) en

Programmadirectie Krachtig Bestuur

Directie OBD / Afd. Bestuurlijke en Financiële

Verhoudingen (BFV)

Directie OBD / Afd. BFV

(binnen DGBK de aparte programmadirectie $P K B$ rondom de problematiek van bevolkingsdaling)

Directie Dienstverlening, Regeldruk en Informatievoorziening (DRI) + OBD / Afd. Democratie en Burgerschap (D\&B)

$D G$ Organisatie en Bedrijfsvoering Rijk / Directie Organisatie en Informatie Rijk (POIR)

Hereniging 'IB' en 'BFO', terugkeer O\&A, samensmelting met DGMOS

Het kabinet-Balkenende IV bracht weer eens een grootscheepse reorganisatie mee. Het directoraat-generaal Bestuur mocht niet zo heten. Dat zou wel lekker kort zijn en mooi rijmen met het andere grote directoraat-generaal Veiligheid. Koninkrijksrelaties moest in de naam vermeld blijven om de gebiedsdelen overzee niet voor het hoofd te stoten. Dan maar DGBK.

Vooral de hereniging van Financiële verhouding(en), Bestuurlijke Organisatie en Wetgeving met Decentralisatiebeleid en Interbestuurlijke betrekkingen, die sinds 1984 waren gescheiden, was een opmerkelijke stap. ledere periode vraagt kennelijk weer andere accenten en verbindingen.

\section{Democratie en Burgerschap}

Daarnaast werd de nieuwe directie Openbaar Bestuur uitgebreid met een geheel nieuw onderwerp: Democratie. Sinds Thorbecke had het ministerie nooit een beleidsonderdeel voor dat thema gekend, al zou men na lezing van dit boek de stelling kunnen verdedigen dat een bepaalde democratie-opvatting in feite de raison d'être vormde voor bijna alle dossiers van het bestuursbeleid. Maar dat is nog iets anders dan reflectie op de democratie in al zijn facetten. Kennelijk was de tijd er rijp voor. De grootste ingreep was echter een gedeeltelijke samensmelting van Management Openbare Sector en Openbaar Bestuur. Informatievoorziening openbare sector kwam zo weer terug bij het openbaar bestuur, maar in de onderhandelingen tussen de bazen werd Organisatiebeleid voor de rijksdienst ondergebracht bij het onderdeel dat de bedrijfsvoering voor de hele rijksdienst ging verzorgen: DG Organisatie en Bedrijfsvoering Rijk. Binnen de afdeling Democratie en Burgerschap werden ook weer oude onderdelen opgenomen (GBA, reisdocumenten), die vroeger meer bij interbestuurlijke informatievoorziening pasten en die vooral vanwege de associatie tussen burgerzaken en burgerschap leken te zijn ingebracht.

Aparte aandacht voor kwaliteit van lokaal bestuur Inhoudelijk bleef de hoofdaandacht van de nieuwe directeur-generaal Andrée van Es onveranderd op de interbestuurlijke betrekkingen gericht: decentralisatie, bestuursakkoorden en dergelijke oude thema's. Grootscheepse bestuurlijke reorganisatie of herziening van de organieke wetgeving bleef uit. Aparte programmadirecties voor Dienstverlening, regeldruk en informatievoorziening en voor Krachtig Bestuur hadden, evenals onderdelen van de afdeling Democratie en Burgerschap, echter meer dan in de vorige periode de neiging om binnen de black box van gemeenten te gaan kijken hoe het bestuur werkelijk functioneerde en wat daaraan te verbeteren viel. In de volgende paragraaf komt deze probleemgerichte benadering terug als kenmerkend voor een bepaalde werkwijze binnen Binnenlandse Zaken, in contrast met het meer doctrinaire structuurdenken. 


\subsection{Organisatiecultuur}

\section{Toespitsing op IB en BFO}

Organisatiecultuur wordt hier opgevat als 'de manier waarop we hier met elkaar omgaan'. Een simplistische definitie voor een moeilijk grijpbaar begrip (Raad voor het openbaar bestuur, 2004). Want deze 'eigen wijze van werken' of 'eigen stijl' wordt bepaald door wat Schein (2006) noemt "aangeleerde, impliciete en gemeenschappelijke veronderstellingen waarop mensen hun dagelijks gedrag baseren".

Het beschrijven van de organisatiecultuur in alle onderdelen van Binnenlandse Zaken sinds 1969 zou onbegonnen werk zijn en bovendien een zeer onoverzichtelijk geheel opleveren.

Daarom beperkt deze paragraaf zich tot een typerende tegenstelling die een brug vormt naar onze zoektocht naar paradigmatische verschillen tussen verticaal government en horizontaal governance. De twee afdelingen Interbestuurlijke betrekkingen (daarvoor Coördinatie Bestuursbeleid geheten) en Bestuurlijke en Financiële organisatie hebben relatief lange tijd naast elkaar bestaan en vormden ieder de exponent van een bepaalde uitgesproken benaderingswijze van het bestuur binnen het ministerie.

\section{Voorbeeld Bestuurlijke Drukte}

De werkwijze van de afdeling IB onderscheidt zich op kenmerkende wijze van die bij de zusterdirectie BFO. IB zoekt veelal de analyse per onderwerp in de functionele verbanden tussen beleid en organisatie, waar historisch gegroeide verhoudingen, sturingscondities in het veld en politieke opportuniteit dominant zijn. Daarin worden de algemene bestuursopvattingen van Binnenlandse Zaken zo goed mogelijk ingepast. BFO begint doorgaans te redeneren vanuit de doctrine, vanuit de rechtsregel of de structuur en beveelt de bestuurspraktijk daarnaar toe te buigen. IB heeft van nature veel gevoel voor de grilligheid van de praktijk, voor de ambiguïteit van de werkelijkheid en voor het momentum van contingente factoren. IB'ers werken in verschillende, wisselende netwerken, al naargelang het onderwerp.

Een voorbeeld is te geven aan de hand van een recent onderwerp, dat bij beide onderdelen speelt, de zogeheten bestuurlijke drukte. De analyse vanuit BFO is in lijn met het advies van de commissie-De Grave (2005) en gaat ongeveer als volgt. Er is in Nederland een verrommeling ontstaan van verantwoordelijkheden. Die moet worden geredresseerd door verantwoordelijkheden duidelijker toe te delen. Door al die betrokkenheid van iedereen met alles wordt het land onbestuurbaar, ontstaan er patstellingen. Misschien moeten bestuurslagen worden afgeschaft of samengevoegd of hun bemoeienis met onderwerpen worden verboden. IB heeft hetzelfde onderwerp anders benaderd. In enkele woorden samengevat: bestuur zonder fricties is een fictie, er zijn veel factoren van structurele of culturele aard die het gevoel van bestuurlijke drukte veroorzaken, dus simpele oplossingen bestaan niet, goed procesmanagement vergt maatwerk en is vaak de sleutel, meervoudig gezamenlijk eigenaarschap is bij moeilijke vraagstukken juist goed. Zie hiervoor ook de verkenning van Jan Andries Wolthuis (2006), dat een aardig beeld geeft van het belang van organisatiecultuur.

\section{Voorbeeld Middenbestuur}

Een ander voorbeeld in dezelfde context betreft de aanpak van het project Middenbestuur. Tijdens het kabinet-Balkenende III werd het plan opgevat om nog eens grondig de positie van de provincies, de kaderwetgebieden en andere samenwerkingsverbanden tussen Rijk en gemeenten tegen het licht te houden. Op de achtergrond speelde dezelfde problematiek van bestuurlijke drukte als zojuist geschetst, maar ook dat in een regio als de Randstad ambities niet konden worden verwezenlijkt binnen de schaal van de bestaande instituties. Natuurlijk kon verwacht worden dat bij provincies en gemeenten reminiscenties aan stadsprovincies en gewesten ('landjepik') zouden 
opdoemen als Binnenlandse Zaken weer met een grootscheeps project over structuren en grenzen in het middenbestuur zou beginnen. Daarom opperde de afdeling IB om het proces vooral open in te gaan, met de bedoeling om echt te leren over de feitelijke betekenis van middenbestuur in deze tijd, dus niet uit te gaan van een vooropgezet model (zie ook Soeterbroek, 2004). Misschien is de werkelijkheid al veel dichter toegegroeid naar een complexe netwerkkluwen in plaats van een piramidale bestuurstoren, zeker als men daar de provincie aan de top moet projecteren. Ook zou het verkennen van deze werkelijkheid het meest leerzaam zijn als de medewerkers van verschillende afdelingen (het projectteam) zelf op onderzoek zouden uitgaan bij verschillende actoren in het middengebied; niet alleen de overheden, maar ook de semi-publieke organen als Kamers van Koophandel, maatschappelijke organisaties en bedrijven. Misschien zou een werkwijze als beleidsmediation (stakeholdergesprekken bij beleidsontwikkeling in controversiële domeinen, maar nog voordat een conflict is uitgebroken) gelet op de historische gevoeligheden goed toepasbaar zijn (zie ook Laws et al., 2012). Uiteindelijk werd door de trekkende organisatie BFO gekozen voor een meer klassieke aanpak: een bureau werd ingehuurd voor onderzoek over de stand van zaken, dat door het projectteam werd besproken. De eigen waarneming van de praktijk werd beperkt tot enkele werkbezoeken van de minister met zijn gevolg bij het bestuur van provincies en gemeenten en in plaats van het zorgvuldig opbouwen van commitment door coproductie werd verwezen naar de beleidsverantwoordelijkheid van de minister, die uiteindelijk zijn langverwachte rapport met opties voor een Randstadprovincie presenteerde. Hij had het geluk dat de meningsverschillen vanuit de provinciebesturen niet verder reikten dan de keuze tussen één ongedeelde Randstadprovincie en een twee-vleugelmodel. Maar door het beleid zo te simplificeren tot de gewenste schaal van de provincie was een kans gemist om dichter bij de werkelijke problemen van synergie en daadkracht in het middenbestuur te komen dan de analyse van de gewenste schaal van de provincie. Wellicht was dit de reden waarom het rapport en ook het advies van de commissie-Kok (2006) vrijwel onmiddellijk in een la belandden. ${ }^{12}$

'Daar gaat de gemeente over!'

Om te voorkomen dat er een karikatuur ontstaat van het contrast tussen IB en de directie BFO, past nog een voorbeeld van een project van deze directie, dat laat zien dat het ook anders kan. In 1997 startte staatssecretaris Van de Vondervoort met de directie BFO een project onder de titel 'Daar gaat de gemeente over!'. Ondanks de suggestie die van deze strenge, dirigistische naamgeving uitging, was het project een toonbeeld van een open zoektocht. In talloze debatten en werkbezoeken bij gemeenten probeerde de directie een beeld te krijgen van een nieuwe rol van gemeenten. Meer regisseur van processen en facilitator van plaatselijke netwerksamenwerking dan het bestuurscentrum dat alle publieke activiteit monopoliseert, was het toekomstbeeld dat hier voor de gemeenten uitkwam. Omgekeerd kunnen ook bij de afdeling IB projecten worden aangewezen die weinig ruimte laten voor verrassingen en leren in de organisatie, waar ook weinig emergentie optreedt. Denk bijvoorbeeld aan een reeks kabinetsstandpunten over bestuursinstrumenten als toezicht, specifieke uitkeringen en planverplichtingen uit 2006.

\section{Schematische tweedeling}

In feite wordt hier gepoogd twee benaderingswijzen voor beleidsontwikkeling te typeren die in Reinkultur weinig voorkomen, maar die in de praktijk duidelijk herkenbaar zijn. Deze zijn schematisch weergegeven in figuur 4.2.

Figuur 4.2 Twee denkpatronen naast elkaar

\section{'BFO’ (Bestuurlijke en Financiële Organisatie) 'IB' (Interbestuurlijke Betrekkingen)}

\footnotetext{
${ }^{12}$ Een volgende poging strandde in 2014 op de eis van de provincies bij structuurverandering ook extra taken te krijgen. Dat
} kan een andere factor zijn geweest, al was dit gelijk-oversteken in 2006 geen conditio sine qua non. 


\begin{tabular}{|c|c|}
\hline Uitgaand van bestuursmodel of doctrine & Uitgaand van pluriforme bestuurspraktijk \\
\hline $\begin{array}{l}\text { Coherentie tussen verschijnselen geattribueerd } \\
\text { door het model }\end{array}$ & $\begin{array}{l}\text { Coherentie tussen verschijnselen ervaren door } \\
\text { betrokkenen }\end{array}$ \\
\hline $\begin{array}{l}\text { Onzekerheids- en complexiteitsreductie als } \\
\text { hoofdactiviteit ter wille van beheersbaarheid } \\
\text { doelrealisatie }\end{array}$ & $\begin{array}{l}\text { Onzekerheid en complexiteit als weldadig } \\
\text { gegeven; beheersbaarheid alleen op niveau van } \\
\text { waarden en oogmerken }\end{array}$ \\
\hline $\begin{array}{l}\text { Planmatig voorbereiden van welomschreven } \\
\text { product; VBTB-proof }\end{array}$ & $\begin{array}{l}\text { Open zoektocht vanuit probleemdefinitie en } \\
\text { timeframe, laat je verrassen. VBTB moet worden } \\
\text { gecontenteerd door taaltrucs }\end{array}$ \\
\hline Laat je niet afleiden & $\begin{array}{l}\text { Side-effects zijn minstens zo leerzaam als } \\
\text { hoofdspoor }\end{array}$ \\
\hline Rationeel-causaal sturingsmodel & Constructivistische sturingsopvatting \\
\hline Voeding door uitbesteed onderzoek & Eigen onderzoek en waarneming voorop \\
\hline $\begin{array}{l}\text { Politiek primaat: instructie komt van de leiding, } \\
\text { ambtenaren werken uit en voeren uit }\end{array}$ & $\begin{array}{l}\text { Politiek ultimaat: ambtenaren verkennen } \\
\text { alternatieve oplossingen; politiek kiest uiteindelijk } \\
\text { de meest wenselijke optie }\end{array}$ \\
\hline $\begin{array}{l}\text { Individuele ambtenaar ondergeschikt en } \\
\text { uitwisselbaar }\end{array}$ & $\begin{array}{l}\text { Individuele ambtenaar en zijn/haar persoonlijke } \\
\text { motivatie, netwerk en beleving zijn bepalend voor } \\
\text { het resultaat }\end{array}$ \\
\hline $\begin{array}{l}\text { Organisatie spreekt met één mond, is als een } \\
\text { piramide }\end{array}$ & $\begin{array}{l}\text { Organisatie is meervoudig netwerk, werkt samen } \\
\text { naar binnen en naar buiten }\end{array}$ \\
\hline Aan de top van de organisatie 'gebeurt het' & Aan de grens van de organisatie 'gebeurt het' \\
\hline Structuren en regels zijn bepalend & Werkwijze en inhoud zijn bepalend \\
\hline
\end{tabular}

\section{Voorbeeld XPIN}

Als 'tweede man' van het Expertisebureau voor Innovatieve Beleidsvorming XPIN heeft de auteur bepaalde uitvergrote aspecten van het rechter model aan den lijve meegemaakt (2001-2005). Een korte chronologische beschrijving van de wederwaardigheden van XPIN aan de hand van langskomende mensen en ideeën illustreert nog beter de kwaliteit en ook de beperkingen van deze werkwijze (XPIN, 2005). De vrijheid om associërend te werk te gaan en synergie te zoeken op basis van de eigen professionaliteit van het team levert een hoge productie op. Er wordt geleerd door verknoping van verwante verschijnselen die langskomen. De omgeving, het toeval en de contingentie regeren. De kans op impact is afhankelijk van ontmoetingen van actoren die echt op zoek zijn naar antwoorden op vragen. Anderzijds is er weinig te merken van politieke of andere sturing, de relevante omgeving beperkt zich hoofdzakelijk tot de doelgroepen die men zelf interessant acht (de voorhoede), en het bureau is niet belast met een opgave om het gedrag van mensen of organisaties in of buiten de rijksdienst te veranderen of te verbeteren. Van institutionele doorwerking in termen van dit onderzoek is dan ook geen sprake. 'Zo kan ik het ook', zal een regulier beleidsonderdeel dat meer werkt overeenkomstig de 'linker kolom' zeggen. Dit is ook geen beleid meer, maar louter 'vloeibaarheid' (Frissen, 2013: 94). 


\subsection{De invloed van politieke bazen en kabinetsperioden}

\section{Een zoekend ministerie}

Wie alle bovengenoemde reorganisaties en wisselingen in de configuratie van dossiers over directies overziet, moet wel een beeld krijgen van een ministerie op drift. Voortdurend op zoek naar de steen der wijzen, de ultieme bestaansgrond en de meest succesvolle aanpak, werden alle opties uitgeprobeerd. Uiteindelijk spiegelde het ministerie zich steeds weer vergeefs aan de machtige collega-departementen van Financiën en Justitie. Vooral Financiën riep afgunst op. Waarom kon Binnenlandse Zaken als coördinerend middelendepartement (personeel, informatie, organisatie) niet net zo invloedrijk zijn als (de Inspectie der Rijks-)Financiën? De machtsbasis van Financiën als centrale belastinginner ontbrak. Maar als het gaat om beleidskennis en -competentie kon Binnenlandse Zaken ook niet bogen op een monopoliepositie. Immers, elk ministerie had een eigen bestuurstheorie, sommige meer dan één (In 't Veld, 2001). Elk ministerie deed aan taakverdeling en organisatieontwikkeling. Zou het natuurlijke beleidsoverwicht van de ministers van Binnenlandse Zaken daar een bovengeschikte positie in kunnen aanbrengen?

\section{Ministers en staatssecretarissen}

Wat was de rol van bewindslieden in deze ontwikkeling? In 1999 beleefde Nederland de affaire rond Bram Peper (Van Osch, 2010). Deze minister werd voordat hij veel had kunnen bereiken opgevolgd door Klaas de Vries, die te kennen gaf vooral op de winkel te willen passen. Wat bestuurlijk leiderschap betreft, heeft het ministerie in de hele beschreven periode veel pech gehad met ministers. Twee van hen overleden in het harnas (Koos Rietkerk en len Dales), waardoor interimmers als Jan de Koning en Korthals Altes moesten waarnemen. Een ambitieuze minister als Ed van Thijn moest twee keer vervroegd aftreden en kon zo niet veel bewerkstelligen (Van Thijn, 1994). Hans Dijkstal was zeer aimabel, maar zijn beleidsagenda was beperkt. Hetzelfde gold voor Johan Remkes, die als enige minister drie kabinetten overleefde en maar liefst een zittingsduur van vijf jaar volmaakte. Anderen, zoals Rudolf de Korte, waren juist een heel kort politiek leven beschoren. Hans Wiegel was een minister die door veel ambtenaren werd bewonderd als politieke alleskunner en fixer. Bij de staatssecretarissen werd ook Dieuwke de Graaff-Nauta op handen gedragen. Zij heeft stilletjes veel bereikt.

Of het aan de persoonlijke kwaliteiten of de korte politieke levensduur van de 21 (!) in deze veertig jaar passerende ministers heeft gelegen of aan de vrij abstracte en weinig controversiële aard van de onderwerpen, de geschiedenis van het bestuursbeleid is niet sterk getekend door de politieke sturing van de bewindslieden. Weinig bewindslieden hebben hun stempel op dit beleidsterrein gezet, met uitzondering van staatssecretaris Wim Polak aan de start van de coördinerende taak. Ien Dales heeft zich onsterfelijk gemaakt met haar persoonlijke interventie over integriteit in het bestuur. De belangrijkste sturende factoren waren toch vooral continu van aard: de Vierde Macht, de VNG en de voortdurende noodzaak te bezuinigen. Een eveneens permanent politiek gegeven waren de heersende opvattingen bij de bazen van het ministerie over democratie en het politiek primaat. Opvattingen over de verhouding tussen beleid en uitvoering, de wenselijkheid van decentralisatie, de dominantie van rationele en causale redeneringen en de hoofdrol van de overheid bij het ordenen van het maatschappelijk leven waren nauwelijks aan politieke partijaffiliatie of eigen ideeën van bewindspersonen gebonden. Van een geleerde als De Gaay Fortman is bekend dat hij zich in een vreemd vakgebied geplaatst voelde (Bak, 2004). Dat gold niet voor Peper en Van Thijn, maar die kregen te weinig kans om als minister hun inzichten te ontplooien. Tekenend is het lot van de discussienota 'Op zoek naar samenhang en richting' van Bram Peper (1999), die door minister-president Kok niet eens werd besproken in de ministerraad. Ook voor andere ministers, zoals Klaas de Vries en Hans Dijkstal, kon je bewondering hebben hoe zij zich in korte tijd als leiders positie wisten te verwerven. De auteur maakte Cees van Dijk later als lid van de adviescommissie Decentralisatie-impuls mee als een scherp waarnemer met een kritisch en origineel politiek oordeel. Als minister moesten ze allemaal manoeuvreren binnen zeer smalle 
marges en kwamen ze niet toe aan nieuwe plannen op basis van eigen reflecties over het openbaar bestuur of organisatievraagstukken.

lets anders is dat de positie van krachtig geachte bewindslieden van wezenlijk belang was voor de interdepartementale invloedspositie. Oneerbiedig gezegd: kon je de minister om een boodschap sturen. In dat opzicht maakte het wel veel uit welke persoon minister was, of hij/zij tevens vicepremier was, enzovoort. Hans Wiegel is in dit verband al genoemd. Er waren ook conjunctuurgolven in de plaats van Binnenlandse Zaken binnen de interdepartementale pikorde. Een dieptepunt in de interdepartementale positie van het ministerie kwam, ook volgens enquêtes met rijksambtenaren, onder de ministers Johan Remkes en Thom de Graaf. Het is moeilijk de vinger te leggen op een echte reden voor dergelijke dagkoersen.

\section{Secretarissen-generaal en directeuren-generaal}

Als het gaat om de inhoudelijke koersbepaling, lijkt het bewind van de secretarissen-generaal en directeuren-generaal van groter belang. Te beginnen met Pieter van Dijke, die de visionaire aanzet heeft gegeven voor de ombouw naar een moderne beleidsorganisatie. Vis was meer een tussenpaus, maar Van Aartsen, Kuijken en Holtslag hebben alle drie de toon gezet in hun tijd als het erom gaat wat kon en wat niet kon, wat belangrijk werd geacht en wat niet. Veel meer dan de ministers markeren zij dus tijdperken. Van Aartsen en Kuijken waren mannen van het grote gebaar, licht autoritair, Holtslag was aimabel en inhoudelijk sterk, maar o zo omzichtig. De directeurengeneraal werden in de loop van de tijd steeds meer van belang, en overvleugelden uiteindelijk de positie van de SG. Brinkman onder Van Dijke rauwdouwer met een haast politieke stijl, Jos Staatsen onder Vis, bedachtzame strateeg vanuit de topambtenarenstal van milieubeleid, Jan Hendrikx weer een echte gemeenteman en gewiekste bestuurder met een bourgondische stijl. Daarna kwamen Geert Jansen, die je om een boodschap kon sturen, en Holtslag voornoemd, die werd opgevolgd door Van Halder, een geliefd manager met een gezaghebbende uitstraling maar per saldo met meer vragen dan antwoorden. In de combinatie met SG Holtslag vormde hij niet de voorhoede voor spannende nieuwe ontwikkelingen.

\subsection{Hoogtepunten van beleid}

Waren er hoogtepunten op het vlak van beleid? Dat is natuurlijk een subjectieve vraag. Hieronder worden in chronologische volgorde de meest toonaangevende beleidsfeiten genoemd. Beleidsdaden kan men het niet allemaal noemen, want het meeste bleef toch papieren werkelijkheid. De lijst laat zien met welke officiële documenten (wetten, nota's) het bestuursbeleid binnen de gekozen dossiers zich in de loop van de tijd heeft gemanifesteerd.

Voor de goede orde: dit zijn niet de items die bouwstenen vormen voor het onderzoek, dat zijn namelijk de innovaties, het begin van nieuw beleid, terwijl hier doorgaans de eindpunten van lange beleidsprocessen zijn vermeld. Laten we het mijlpalen noemen, momenten waar iets werd afgerond.

1969 - Nota Bestuurlijke Organisatie

1970 - Financiële Verhoudingswet

1971 - Rapport van de commissie-Van Veen over departementale organisatie en coördinatie

1975 - Eerste coördinerende taak staatssecretaris voor financiële effecten lagere overheden

1976 - Wet Reorganisatie binnenlands bestuur, tweede coördinerende taak bestuurlijke effecten

1978 - Rapport van de Ministeriële commissie Taakverdeling en Coördinatie (Mitaco)

1980 - Eindrapport Commissie hoofdstructuur rijksdienst (Vonhoff)

1980 - Decentralisatienota

1981 - Besluit Informatievoorziening Rijksdienst, coördinerende taak informatievoorziening O.S.

1982 - Instelling Nationale Ombudsman

1983 - Minderhedennota

1983 - Decentralisatieplan 
1983 - Intrekken Wet Reorganisatie binnenlands bestuur

1984 - Wet gemeenschappelijke regelingen

1984 - Eerste Saneringsverslag Specifieke Uitkeringen

1984 - Rapport 'Een schuyt die tegen stroom wordt opgeroeyt' (grotestedenbeleid)

1986 - Oprichting 12e Provincie Flevoland

1987 - Eerste Bestuursakkoord Rijk-VNG

1989 - Wet D'gemeenten en D'provincies

1989 - Rapport commissie-Montijn (grotestedenbeleid)

1990 - Nota Sociale Voorziening

1991 - Wet Openbaarheid van Bestuur

1993 - Conclusies Rapporten commissie-Deetman Staatkundige Vernieuwing

1993 - Akkoord Decentralisatie-impuls

1994 - Wet Sociale vernieuwing

1994 - Contourennota Integratiebeleid Minderheden

1994 - Oprichting Gemeentelijke Basisadministratie GBA

1995 - 3e Beleidsnota 'Terug naar de Toekomst', Nationaal actieprogramma elektronische snelweg

1995 - Convenanten grotestedenbeleid I met respectievelijk de G4 en de G15

1995 - Rapport commissie-Sint over verzelfstandiging

1996 - Rapport Werkgroep Procesmanagement

1997 - Kabinetsreactie Besturen op de Tast

1997 - Publicatie Decentraliseren met beleid

1998 - Bestuursakkoord Nieuwe Stijl

1998 - Wet Inburgering Nieuwkomers

1999 - (Doorstart)Convenant Grotestedenbeleid II G4 en G21 1999-2004

2002 - Wet dualisering gemeentebestuur/provinciebestuur

2004 - Afschaffing Onroerende Zaak Belasting - gebruikersdeel

2005 - Convenanten Grotestedenbeleid III 2005-2009

2006 - Kaderwet zelfstandige bestuursorganen

\subsection{Conclusies}

Ook aan dit feitelijk organisatorisch overzicht houden we enige belangrijke conclusies over. In de eerste plaats dat het ministerie in de afgelopen decennia in organisatorisch opzicht behoorlijk door elkaar heen is gehusseld. Afhankelijk van beleidsaccenten bleken alle onderdelen met alle andere op enig moment combineerbaar onder eenzelfde directie. Dit indiceert paradoxaal de relatieve homogeniteit van het geheel. Hoewel dit op het eerste gezicht niet het meest in het oog springende kenmerk van Binnenlandse Zaken is, konden ICT-ontwikkelingen, bestuurlijke organisatie, burgerschap, de organisatie van de rijksdienst en grotestedenbeleid soms moeiteloos door dezelfde directie-ingang. Dan moesten ze toch uiteindelijk ook eenzelfde taal (discours) spreken. Een ambtelijke biotoop is volgens de wetten van de bureaupolitiek en bureaucratie van invloed op hoe de bewoners spreken en schrijven. Verderop verkennen we dit verder.

Een tweede conclusie direct in het verlengde hiervan is dat de organisatie kennelijk moeite had haar draai te vinden. Zoveel reorganisaties wekken de indruk van een geprangd gemoed bij de leiding en van een voortdurend zoeken naar het wezen van het bestuursbeleid. Dit is van belang voor onze poging een duurzame, maar aan de omgevingsdynamiek aangepaste bestuurstheorie te vinden.

Bestaan er ondanks de relatieve homogeniteit van de biotoop toch enige cultuurverschillen? De beschouwing over de organisatiecultuur onderstreept de verdeeldheid in percepties over het openbaar bestuur binnen twee eenheden die tot elkaar veroordeeld waren om aan de verbetering 
van het binnenlands bestuur bij te dragen. Deze gespletenheid zal ook in de projecten tot uiting komen, waarbij uiteindelijk één denklijn als dominant naar voren zal komen.

Wie de verschillende perioden vergelijkt uit oogpunt van de ontwikkeling van een funderende bestuurstheorie van Binnenlandse Zaken, zal nu al concluderen (voorspellen?) dat de eerste perioden, rond 1980, een stempel hebben gedrukt op het beleid. Alle grote thema's, zoals reorganisatie van het middenbestuur, reorganisatie van de rijksdienst en decentralisatie, zijn toen ontstaan en hebben het tot het einde van de periode uitgehouden zonder merkbare schokken. Alleen de reorganisatie van de rijksdienst is op de golven van privatisering en verzelfstandiging nogal heen en weer geslingerd. Daar komen we op terug in hoofdstuk 9.

Dat deze thema's op de agenda van Binnenlandse Zaken zijn gehandhaafd, betekent niet dat dit ook passende thema's waren die de bestuurlijke problemen van de tijd konden tackelen. We zullen zien of op deze hoofdthema's een consistente bestuurstheorie is ontwikkeld die bovendien in staat is gebleken aansluiting te vinden bij de noden van de tijd. Het bereiken van beleidssucces is daarvoor een aanwijzing, maar ook visie-ontwikkeling die voldoet aan de eisen van een strategische bestuurstheorie: gestaag lerend voortgaan in wisselwerking met de samenleving.

Een veelzeggend detail werd terloops al geconstateerd: de directie Bestuurszaken, die speciaal was opgericht om zich met uitvoeringsaspecten bezig te houden, is na drie jaar alweer opgeheven. Kennelijk werd de bemoeienis door het ministerie met het grondvlak, de gemeenten, als wezensvreemd ervaren (de Grondwet benoemt gemeenten als zelfstandige overheden met een eigen open huishouding), maar daarmee werd ook een waardevolle bron van informatie over het werkveld afgesneden.

Ten slotte is een uitkomst alleen al op statistische gronden dat de politieke leiding slechts beperkte kansen kreeg om een stempel op beleid en organisatie te drukken. Binnenlandse Zaken biedt bewindslieden geen reservoir voor politieke stemmentrekkerij, wat iets anders is dan dat het ministerie politiek onbelangrijk vond. Integendeel, het leek er eerder op dat het ministerie bestond om de politiek te dienen.

Dit korte historisch overzicht van de organisatie van het bestuursbeleid was nodig om de lezer enige samenhang te tonen in de materie waarmee hierna wordt verdergegaan, dan opgeknipt in de volgende dossiers:

- $\quad$ bestuurlijke organisatie;

- $\quad$ interbestuurlijke betrekkingen en decentralisatie (inclusief Financiële verhouding(en));

- $\quad$ achterstandsgebiedenbeleid (= PCG, sociale vernieuwing, grotestedenbeleid);

- $\quad$ interbestuurlijke informatievoorziening;

- $\quad$ organisatie rijksdienst. 


\section{Dossier bestuurlijke organisatie}

\subsection{Inleiding}

Dit hoofdstuk handelt over het dossier bestuurlijke organisatie. Het bevat de volgende inhoud:

- inleiding over het hele dossier (paragraaf 5.2); dan volgen de projecten;

- reorganisatie binnenlands bestuur, het wetgevingsproject om in het hele land doe-provincies in te voeren en daarmee 'het regionale gat' te dichten (paragraaf 5.3);

- complementair bestuur, een bijna wetenschappelijke beleidsverkenning naar de vraag of afspraken tussen bestuurslagen onder een algemeen wettelijk regiem geplaatst moesten worden (paragraaf 5.4);

- Bestuur op Niveau, Stadsprovincies: een hernieuwde poging om regionale superprovincies in te voeren, dit keer alleen rond een aantal grote steden (paragraaf 5.5);

- project Middenbestuur (paragraaf 5.6), streven gericht op het instellen van grote landsdeel dekkende provincies;

- dualisering gemeentebestuur: wetgeving om checks and balances binnen het lokaal bestuur te versterken door het losknippen van de verstrengeling tussen raad en bestuurscollege (paragraaf 5.7).

Het hoofdstuk sluit af met een concluderende paragraaf 5.8 over de bestuurstheorie bij het dossier bestuurlijke organisatie.

\subsection{Algemene ontwikkeling van dit dossier}

\subsubsection{Selectie van cases}

\section{Gemeentelijke herindeling}

Eerst focust de schijnwerper op de voorbeelden die samenhangen met de organisatie van het binnenlands bestuur. Vanuit Binnenlandse Zaken is permanent gesleuteld aan de structuur en begrenzing van onze gemeenten en provincies. De gemeentelijke herindeling, lees: schaalvergroting, is een onmisbaar onderdeel van het binnenlands bestuur geworden. leder jaar is het aantal gemeenten weer met een tiental, soms minder, teruggelopen. In de jaren zeventig waren er ongeveer 1000 gemeenten in ons land, begin 2014 nog ruim 400. Toch is het onderwerp gemeentelijke herindeling niet opgenomen bij de beschreven cases, juist omdat het een toonbeeld is van continuïteit. Er is nauwelijks een onderwerp van rijksbeleid te vinden waar de koers zo onverdroten en gestaag is aangehouden als gemeentelijke herindeling. Ongeacht de politieke samenstelling van de kabinetten is er een kennelijke stilzwijgende consensus dat gemeentelijke herindeling, lees schaalvergroting, noodzakelijk is, maar met mate. Er is bij de indeling van onze gemeenten nergens een voorbeeld te vinden van een nieuw inzicht of een bijzonder project dat kan wijzen op vernieuwing, ja een verschuiving, in het bestuursbeleid. Niet ontkend kan worden dat het verhaal achter herindeling, dus waarom herindeling nodig werd geacht, in de loop van de decennia iets veranderde (Denters, 1996; Korsten en Tops, 1998; Korsten, Abma en Schutgens, 2007; Schutgens, Maessen en Korsten, 2009). Vergroting van bestuurskracht kreeg als adagium steeds weer een nieuw jasje: dan eens op basis van getalsmatige eisen (bestuurskrachtig was die gemeente die een minimale gemeentegrootte kende van zus of zoveel inwoners), dan op grond van een knelpuntenbenadering, dan op basis van een zelfevaluatie of visitatie op bestuurskracht. Gemeentelijke herindeling is de ostinato achtergrondmuziek gedurende de hele periode die hier wordt beschreven. Wat er wel is gebeurd, zonder dat daar bij Binnenlandse Zaken een apart 
vernieuwingsproject voor nodig was, is de verlegging van het initiatief voor herindeling. De provincies kregen een sleutelrol en er werd meer gestuurd op draagvlak of zelfs initiatief bij de deelnemende gemeenten zelf. Rustig aan, dan breekt het lijntje niet. Herindelingsinitiatieven sloegen geleidelijk om van het doen van voorstellen van bovenaf (Rijk of provinciebestuur) naar een beweging van onderop. Dat blijkt uit een vergelijking van de kaders voor herindeling, die verschillende kabinetten erop nahielden.

Onvoldoende reden om hier een vernieuwend idee, een beleidsomslag te verwachten. Daarom ontbreekt dit 'project' hier in het rijtje.

\section{Regionaal middenbestuur}

Dat is bij de inrichting van het regionaal en middenbestuur anders. Daar zit aanmerkelijk meer dynamiek in de beleidsontwikkeling. Dit hoofdstuk beperkt zich tot pogingen het middenbestuur, in het bijzonder de provincies, te reorganiseren.

De beleidsontwikkeling in dit dossier vindt met horten en stoten plaats. Het idee dat ingrijpen in de bestuurlijke organisatie nodig is, kan worden beschouwd als de oervader van het bestuursbeleid, omdat de Nota Bestuurlijke Organisatie uit 1969 gebaseerd was op de constatering dat de historisch overgeleverde indeling in bestuurslagen niet meer paste bij de maatschappelijke ontwikkelingen. De Reorganisatie van het Binnenlands Bestuur uit de jaren zeventig was het antwoord op deze constatering. Deze poging tot hervorming zou als eerste inbreuk op de jaren (eeuwen)lange continuïteit in ons bestuurlijk stelsel beschouwd kunnen worden, ware het niet dat zij in 1983 stukliep op geharnast verzet van de kant van gemeentebesturen en hun politieke bondgenoten. De analyse zat echter diep, want in aangepaste vorm duikt hetzelfde streven weer op in de jaren negentig, weliswaar selectief gericht op grootstedelijke gebieden: de stadsprovincies. Dit keer waren het de burgers die in de vorm van referenda roet in het eten gooiden, maar waarschijnlijk waren er meer tegenkrachten werkzaam, want de Tweede Kamer had deze lokale kiezersuitspraak alleen wel kunnen trotseren of wat aanpassingen kunnen toewerpen, maar het hele project kwam tot stilstand. Wat overbleef, was een vorm van versterkte gemeentelijke samenwerking (Kaderwetgebieden), waaraan departementen rechtstreeks taken en geld konden toedelen. Voor de stroomlijning van het middenbestuur resteerden niet meer dan pogingen om de lappendeken van gemeentelijke samenwerkingsvormen (gemeenschappelijke regelingen) te ordenen. Stiekem zal men daarbij gehoopt hebben dat deze gebundelde en geïntegreerde gemeenschappelijke regelingen ooit kiemen zouden kunnen worden voor een bestuur op regionale schaal, zonder dat duidelijk werd gemaakt of deze de eerste (gemeentelijke) of de tweede (provinciale) bestuurslaag, of beide zou moeten vervangen. Op papier heeft dit beleid nog wel resultaat opgeleverd, maar inmiddels is de wettelijke verplichting tot bundeling en integratie van gemeenschappelijke regelingen alweer afgeschaft.

De meest recente (schijn)aanval op de traditionele indeling van ons land in de provincies die ons vanuit de middeleeuwen zijn overgeleverd, richtte zich eerder op schaalvergroting: dromen over mammoetgemeenten en landsdeelprovincies zoals de Randstadprovincie. De initiatieven hiervoor kwamen vooral uit stedelijke hoek (de 'Holland Acht' heette de kongsi van de bestuurders van de vier grote steden en van de vier Randstadprovincies inclusief Flevoland, die voor een echt Randstadbestuur pleitten; het VNG-bestuur, dat vanuit grootse visioenen over de rol van megagemeenten meeging op de golf van schaalvergroting naar uiteindelijk nog 60 gemeenten, werd in 2010 teruggefloten door de leden). Maar alle pogingen bleven voorlopig zonder noemenswaardig resultaat.

De enige structuuringreep die wel met succes is uitgevoerd (naast de sluipende voortgang in herindelingen, het meest recent van onderop door initiatieven van gemeenten zelf), is de dualisering van het lokaal en provinciaal bestuur aan het begin van de $21 \mathrm{e}$ eeuw. Het betreft hier een interne reorganisatie van de onderlinge verhouding tussen de organen van het decentraal bestuur. Daardoor gingen zij wat meer lijken op de nationale overheid, waar de volksvertegenwoordiging en het dagelijks bestuur sinds jaar en dag duidelijk onderscheiden taken en rollen vervullen. 


\subsubsection{Alternatieve benaderingen}

\section{Onderhandelend bestuur}

Intussen zien we ontwikkelingen voortschrijden die wellicht aanknopingspunt boden voor nieuwe benaderingen van de organisatie van het binnenlands bestuur. Daar is veel meer de fluïde samenwerking ten aanzien van afzonderlijke maatschappelijke vraagstukken dan de integrale indeling van taken en verantwoordelijkheden aan overkoepelende bestuurlijke eenheden aan de orde. Binnenlandse Zaken had daar op sommige momenten natuurlijk wel oog voor, maar duurzaam was die benaderingswijze niet. Twee voorbeelden daarvan worden hieronder uitgelicht. Gedoeld wordt eerst op het begrip complementair bestuur, dat gedurende korte tijd rond 1980 de gemoederen in bestuurlijk Nederland bezighield, tegelijkertijd met de discussies over de reorganisatie van het binnenlands bestuur en met de opkomst van het decentralisatiebeleid.

Hoewel complementair bestuur goed aansloot bij de algemene ontwikkelingen in de netwerksamenleving, moest dit begrip toch naast de beide andere het onderspit delven. We kunnen nu zelfs constateren dat het hele begrip complementair bestuur dertig jaar na dato in de vergetelheid is geraakt.

Een ander voorbeeld van een kortstondige escapade van Binnenlandse Zaken in een andere richting dan die van centraal verdeelcentrum voor ordelijke bestuurlijke organisatie vanuit de top betreft de gedachte dat het ministerie zich zou kunnen positioneren als neutrale bemiddelaar bij de talloze belangenconflicten die het bestuur teisteren. Dit idee heeft het in 1985 niet verder geschopt dan de bestuurskamer van de ambtelijke top, want hoewel de gedachte daar in woorden werd omarmd, is er nooit iets van terechtgekomen.

\section{Vorm boven inhoud}

Welke onderwerpen horen in dit dossier, de organisatie van het binnenlands bestuur, thuis en welke niet, omdat die meer de interbestuurlijke betrekkingen raken? Er ligt een dunne lijn tussen vorm en inhoud, tussen organisatorische huls en werkinhoud. Bij de discussies over een nieuwe indeling van provincies is de rangschikking van het onderwerp onder Bestuurlijke organisatie het meest duidelijk, al zijn hier ook nadrukkelijk aspecten van taakverdeling aan verbonden. Een onderwerp als Complementair bestuur past hier ook beter dan bij taakverdeling en decentralisatie, omdat interbestuurlijke samenwerking tussen bestuurslagen als alternatief voor reorganisatie en structuurwijziging kan worden beschouwd. Dat het voor sommigen ook kon fungeren als alternatief of bedreiging voor decentralisatie, is onloochenbaar. De reden voor de rangschikking onder organisatie is dat de behandeling van het onderwerp louter generiek is gebleven, een vormkwestie. Bij de uitwerking van het thema Interbestuurlijke betrekkingen/Decentralisatie staan steeds de inhoudelijke kleuring met bepaalde onderwerpen, met sectorale belangen en problematieken voorop.

Hierna komen drie voorbeelden voorbij op het terrein van de provinciale indeling en reorganisatie, de dualisering binnen het decentraal bestuur alsmede de casus Complementair bestuur tegen de achtergrond van de zoektocht naar paradigma's. Steeds wordt hierbij de persoon van de projectleider of gezichtsbepalende beleidsontwikkelaar opgevoerd als vertolker van het leidende idee en van veronderstellingen achter het beleid (de bestuurstheorie).

Als de genoemde onderwerpen als ijkpunten voor het denken bij Binnenlandse Zaken in dit dossier beschouwd mogen worden, valt op voorhand een grote continuïteit in het denken op. De grootste schokbeweging was wellicht de overgang van een streven naar opvulling van het regionale gat tussen gemeenten en provincies naar een opschaling van het middenbestuur in de richting van landsdelige provincies, maar zelfs dat is maar schijn. Want onder de landsdelige provincies passen weer 40 tot 60 mammoetgemeenten, die dus weer het regionale gat kunnen opvullen. De grootste vernieuwing in het denken over het binnenlands bestuur is het ontstaan van deze gedachte zelf 
begin jaren zeventig: er moet gestreefd worden naar integraal samenhangend en slagvaardig bestuur dat op eenduidige wijze de publieke taken onderling verdeelt.

\subsection{Reorganisatie van het binnenlands bestuur}

\subsubsection{Inleiding}

De Reorganisatie binnenlands bestuur betreft een ambitieus wetgevingsproces, waarvan de voorbereiding al startte in 1974, dat in 1978 het Staatsblad bereikte, maar daarna in 1983 bij de afzonderlijke Invoeringswet roemloos ten onder ging. Een project in formele zin was het niet. Een lijnafdeling bij de directie Binnenlands Bestuur had het voortouw.

Het is niet eenvoudig bij dit zeer ambitieuze project een duidelijke trekker te vinden. Stuwende (f)actoren waren buiten het ministerie in de planologie te vinden en ook had de politieke meerderheid hier duidelijke opvattingen over, maar binnen het ministerie hadden mannen als directeur Binnenlands Bestuur Charles de Menthon Bake, zijn afdelingshoofd Adriaansen en bij ontstentenis van een directeur-generaal SG Pieter van Dijke het voortouw. Geen van hen kon worden geïnterviewd, maar medewerker van het eerste en laatste uur van dit project Eduard de Wilde hielp deze case uit de brand. Behalve door zijn feedback kon de historische juistheid van de beschrijving verder worden versterkt door meelezer Arthur Ringeling, die de beleidsontwikkeling vanaf het prille begin onder meer als ingehuurd onderzoeker heeft meegemaakt. Veel van hetgeen hier volgt, is overigens in bestuurskundeland algemeen bekend, gezien de bestuurskundigen die verderop worden geciteerd (Tops, Toonen, In 't Veld).

Bronnen voor deze paragraaf vormen verder de Nota Bestuurlijke Organisatie (TK 10310, nr. 2) en de Kamerstukken over de reorganisatie binnenlands bestuur (onder nr. 14322). Over de reorganisatie binnenlands bestuur is overigens veel gepubliceerd, (Ringeling, 1975; Ruiter, 1975; Verkruisen, 1975; Ruiter, 1976; Breunese en Van der Heijden, 1979; Breunese, 1982; Breunese, 1983; Tops, 1985; De Pree, 1997), maar niet over het interne besluitvormingsproces. Het dichtst bij komt nog de destijds veelbelovende student Pieter Tops, die begin 1982 stage loopt bij Binnenlandse Zaken en deze ervaring mede gebruikt als een van de bronnen voor zijn bekroonde en door de VNG gepubliceerde doctoraalscriptie (Tops, 1985: 65-76).

\subsubsection{Projectbeschrijving en verhalen}

\section{Het regionale gat}

Sleutelen aan de bestuurlijke organisatie was een nieuwe opdracht van Binnenlandse Zaken. De push op de achtergrond was afkomstig van de ruimtelijke ordening, het ministerie van Volkshuisvesting en Ruimtelijke Ordening dus, met zijn Tweede Nota. Het idee dat het historisch gegroeide Nederlands middenbestuur niet paste op de maatschappelijke en bestuurlijke samenhangen van de twintigste eeuw, leidde tot het vermetele streven om de grenzen van de provincies opnieuw te tekenen. Op zichzelf was het natuurlijk een vernieuwing van de eerste orde sinds Thorbecke dat we de fundamenten van de bestuurlijke organisatie in Nederland (niet alleen de grenzen, maar ook 'wat is een provincie, een gemeente, eigenlijk?') niet meer als gegeven moesten beschouwen, maar daarentegen als object van beleid en sturing om de prestaties van het bestuur bij de tijd te laten blijven.

In 1974 was een afdeling Bestuurlijke Organisatie opgericht onder leiding van Hans Adriaansen en daarbinnen een bureau Gewesten binnen de directie Binnenlands Bestuur van Paul Gilissen, met de opdracht te komen tot constructief beleid: het maken van een zodanige bestuurlijke indeling die past op de hedendaagse sociale structuur. ${ }^{13}$ De motor achter dit denken was onder meer Charles de Menthon Bake, directeur Binnenlands Bestuur, in goede harmonie met de ruimtelijke ordenaars van de Rijksplanologische Dienst. Secretaris-generaal Pieter van Dijke was ook een sterke figuur,

\footnotetext{
13 Interview met Eduard de Wilde, 8 augustus 2007.
} 
die zich direct met dit onderwerp bemoeide, maar meer een manager dan de persoon die aan de ideeënontwikkeling van dit project gekoppeld kan worden.

Voorgeschiedenis: ruimtelijke ordening als motor

De 'Tweede nota ruimtelijke ordening' uit 1966 pleitte voor een bestuurlijke organisatie die aan de schaal van de ruimtelijke ordening was aangepast.

In 1969 was onder minister Beernink en staatssecretaris Van Veen een 'Nota Bestuurlijke

Organisatie' verschenen, waarin hoofdlijnen van een bestuur met gewesten werden voorgesteld.

Dit was de start van uitgebreid bestuurskundig onderzoek. Dat onderzoek werd destijds nog goeddeels in eigen huis verricht, met het eigen bureau Wetenschappelijk Onderzoek Binnenlands Bestuur in samenwerking met de Rijksplanologische Dienst. Maar het veldwerk was uitbesteed aan een consortium onder leiding van het Instituut voor Bestuurswetenschappen (1972-1975). Het was de start van werkelijk sturend bestuursbeleid, gericht op het opnieuw modelleren van het systeem van het huis van Thorbecke naar de eisen van de moderne tijd. Hier begon begin jaren zeventig een nieuw beleidsterrein, wat in termen van Hogwood en Peters beleidsinnovatie wordt genoemd. Het was de tijd van het maakbaarheidsdenken. Zoals elders het 'constructief onderwijsbeleid' opkwam, zou bij Binnenlandse Zaken gesproken kunnen worden van 'constructief bestuursbeleid'. Dat was echt nieuw! Alle vervolg hierop valt in de categorieën beleidsaanpassing of beleidsopvolging (policy succession).

\section{Kerngedachte}

Wat was de innovatie dan? Had die zelfs wellicht paradigmatische allure? Het idee was dat na de beleidsingrepen de schaal en taakopdracht van het bestuur weer bij elkaar zouden passen. De veronderstelling was namelijk dat $80 \%$ van de sociale betrekkingen en van de ruimtelijke bestuurstaken zich binnen een bepaalde straal rondom de steden afspeelt. De constatering was dat in de twintigste eeuw gemeentelijke taken steeds vaker de bedding van de gemeenten te buiten gingen en schaalvergroting behoefden. Arbeidsvoorziening, ruimtelijke ordening, mobiliteit, politie en brandweer en nog veel meer taken vergden een territoriaal bestuursniveau van gewestelijke schaal. Daarvoor kon intergemeentelijke samenwerking in gemeenschappelijke regelingen of soms de figuur van zelfstandige bestuursorganen een oplossing bieden. Daaraan kleefden echter de risico's dat deze organisatievorm macht kon ontplooien zonder directe democratische controle en dat ze zo afhankelijk zou worden gemaakt van de ruggespraak met de deelnemende gemeenten dat de slagvaardigheid hierdoor te veel te lijden zou krijgen. Ook ontwikkelden gemeenschappelijke regelingen en zelfstandige bestuursorganen zich per sector, naargelang de toevallige omstandigheden die zich daar voordeden. Dat werd al gauw een lappendeken, met als belangrijk nadeel de onderlinge samenhang en afstemming tussen de verschillende organisaties die elkaar toch op verschillende momenten nodig hadden. Daarom werd gezocht naar een nieuwe democratische bestuursvorm op dit schaalniveau. Daar bevond zich het "regionale gat", een term die gedurende de hele onderzoeksperiode al gangbaar was om de problematiek van gebrekkige coördinatie tussen bestuurseenheden aan te duiden.

Angst voor 'de vierde bestuurslaag'

Er was echter nog één uitkomst van een dergelijk proces die nog erger werd gevonden dan de democratische nadelen van de gemeenschappelijke regelingen, namelijk de Vierde Bestuurslaag. Het handhaven van gemeenten en provincies naast het creëren van een nieuw regionaal bestuur zou daartoe kunnen leiden, omdat er druk zou worden uitgeoefend voor deze nieuwe gewestelijke eenheden democratische verkiezingen in te voeren. Dit zou de toch al niet geringe bestuursdichtheid van ons land verder vergroten. Daarom werd in het eerstvolgende kabinet (Den Uyl, 1973-1977) de optie van 44 gewesten kort nadat dit aantal wetenschappelijk onderbouwd was gepresenteerd in de Structuurschets bestuurlijke organisatie snel weer verlaten. Later werd dit denkmodel met opgelegde eenheden van verlengd lokaal bestuur gebruikt bij een andere, bescheidener doelstelling, namelijk 'bundeling en integratie' van gemeentelijke samenwerkingsverbanden krachtens de Wet gemeenschappelijke regelingen uit 1984 (WGR). Deze mochten echter niet uitgroeien tot echte bestuurslaag met een gekozen volksvertegenwoordiging, open huishouding, eigen belastinggebied e tutti quanti. 
De doorbraak naar provincies-nieuwe-stijl

Er was maar één uitweg, het ineenschuiven van bovengemeentelijke bestuurstaken in (een groter aantal) provincies, de zogeheten Doe-provincies. Het ging om een gelijktijdige verschuiving van grenzen en van taken en bevoegdheden. Voor de oplossing van het schaalprobleem had iedereen zich tot dan toe blindgestaard op de gemeentelijke bestuurslaag, van oudsher inderdaad de belangrijkste vorm van decentraal bestuur. De 44 van hogerhand in te stellen gewesten zouden nog steeds het karakter houden van verlengd lokaal bestuur. Met die gedachte werd nu gebroken door de keuze voor de provinciebesturen, die van oudsher democratisch waren gekozen, maar na een rijke geschiedenis tijdens de Republiek, in het Koninkrijk qua bevoegdheden en middelen werden kort gehouden tot plannende en toezichthoudende organen met weinig doe-taken. De taakverschuiving naar de provincies zou zowel van bovenaf (decentralisatie van rijkstaken) als van onderen (negatieve lijst van gemeentelijke taken) moeten plaatsvinden. Door de combinatie van schaalverandering en taakverschuiving konden eindelijk ook passende eenheden worden gecreëerd om decentralisatie van rijkstaken mogelijk te maken, wat steeds maar niet wilde lukken bij gebrek aan krachtige regionale bestuurseenheden. Zo werd het grote wetgevingsproject 'Reorganisatie van het binnenlands bestuur' geboren. Dit was de vernieuwing die het eerst is gepresenteerd door de Voorlopige Wetenschappelijke Raad voor het Regeringsbeleid (1975). Binnenlandse Zaken greep deze vondst (let wel: geen beleidsinnovatie meer na wat sinds 1969 al vooraf was gegaan, maar een ingrijpende beleidsopvolging) aan met grote vanzelfsprekendheid alsof men niet al jaren via een andere boeg bezig was geweest.

Binnen Binnenlandse Zaken werd Charles de Menthon Bake profeet van deze gedachte. Zijn discipelen waren voornamelijk de medewerkers van de directie Binnenlands bestuur, in het bijzonder de afdeling Bestuurlijke Organisatie/Bureau Gewesten. Dit bureau was in de jaren na 1974 toen er nog maar drie mensen werkten belangrijk uitgebreid en telde in 1976 een tiental jonge, hoog gekwalificeerde ambtenaren. In verband met de ingrijpendheid van de operatie werden ook de directie Financiën Binnenlands Bestuur en vooral de zusterafdeling Bestuur en Wetgeving veelvuldig ingeschakeld. Hierbuiten was de Rijksplanologische Dienst een niet onbelangrijke bondgenoot. De toenmalige minister De Gaaij Fortman was spoedig bekeerd, niet gehinderd door het feit dat hij nog maar enkele maanden eerder de Structuurschets bestuurlijke organisatie met het model van de 44 gewesten had omarmd.

Geïnterviewd is Eduard de Wilde, die begint met een anekdote die hijzelf opdiept "om te illustreren hoe knullig het destijds toeging":

"Op 15 juli 1975 werd het concept-wetsvoorstel Reorganisatie Binnenlands bestuur aangeboden: er was niemand op het departement aanwezig! In een persconferentie zou de presentatie van het nieuwe ontwerp worden toegelicht. Ik was nog stagiair. In de Rolzaal zat De Gaaij Fortman, tegenover alle journalisten en ik, zonder enige ervaring, zat ernaast. Het wetsontwerp was tijdens de allerlaatste ministerraad voor de zomer behandeld en intussen waren alle ambtenaren met vakantie gegaan. Charles de Menthon Bake, Hans Adriaansen, Paul Gilissen, Louis Berger, Jan de Pree. En dat waren ze allemaal behalve ik, voor zover het beleid betrof.

(...)

Wie er ook wel veel van wisten. waren de opstellers van de Structuurschets gewesten van de afdeling wetenschappelijk onderzoek Binnenlands Bestuur, Jeroen Staatsen en Henk Bakkerode, die waren gekomen tot 44 samenhangende gebieden. Dat is het enige echt wetenschappelijke werk geweest in het hele traject. Die gebieden waren echt redelijk gefundeerd op bestaande maatschappelijke samenhangen, die goed waren onderzocht. De Nota Beernink-Van Veen, zo heette die, uit 1969, zat op twee lijnen: gemeentelijke herindeling en ordening in de samenwerking. Maar uitgangspunt was: er mag geen vierde bestuurslaag komen (NB Europa speelde in het geheel geen rol). Daarna ontstond het idee dat die provincies eigenlijk veel te weinig deden. Die konden wel worden opgetuigd met meer taken en zo worden ineengeschoven met die samenwerkingsgebieden. 'Doe-provincies' noemden we die. Er kwamen positieve lijsten van taken die alleen door de provincies gedaan mochten worden, negatieve lijsten die 
gemeenten niet meer mochten doen; allemaal juridische constructies op basis van twijfelachtige, kunstmatig geconstrueerde criteria; havens met meer dan zoveel schepen of zoveel ton vracht en dergelijke. Allemaal juridisch tekentafelwerk. De uitkomst raakte steeds verder verwijderd van het onderzoek van Jeroen Staatsen en Henk Bakkerode, dat was gebaseerd op verkeersstromen, sociografische patronen, zelfs religieuze verbanden. Later kwamen er meer monsterlijke juridische instrumenten waarmee de provincie moest worden groot gemaakt, zoals het Provinciaal Beleidsplan, een idee van Brinkman."14

\section{Hellend vlak}

De afbakening van die nieuwe eenheden was dus het resultaat van een typisch Haags technocratisch proces. Typerend is de anekdote over de indeling van de gemeenten Bleiswijk en Bleskensgraaf. Hoorden die nu bij de provincie Rotterdam of bij Den Haag? Nu was er bij de directie Financiën Binnenlands Bestuur een medewerker, Aat Tetteroo genaamd, die toevallig in Bleiswijk woonde. Die werd in de kamer van Hans Adriaansen ontboden, waar een aantal ambtenaren over de kaart van Zuid-Holland gebogen zat. Het antwoord op de vraag waar deze medewerker doorgaans zijn boodschappen placht te doen, Rotterdam of Den Haag, maakte dat in het wetsvoorstel deze gemeenten aan Rijnmond toevielen.

Bovendien bleek al spoedig het ingezette beleid niet houdbaar tegen de vele kritiek, in het bijzonder vanuit de bestaande besturen van gemeenten en provincies, onder aanvoering van de VNG. De Wet reorganisatie binnenlands bestuur begon met 26 provincies, toen werden het er 24 . Daarna bleek ook dat niet haalbaar en bij Nota van wijziging werd overgestapt op 17. Deze aanpassingen vergden een grote verbale acrobatiek om de redenering overeind te houden. Daarvoor was Hans Bevers binnen het Bureau Gewesten de juiste man. Deze 'tweedehandsautoverkoper', zoals hij zichzelf noemde, wist alles onder de uitroep "Tom Poes, verzin een list" met soepele teksten te verpakken. Maar uiteindelijk werd duidelijk dat het tij was gekeerd. De politieke steun begon te tanen. Politieke partijen ontdekten gevoelige nadelen, zoals de dreiging dat nieuwe bestuurseenheden rondom steden van kleur zouden verschieten. De PvdA bleef nog met Piet Stoffelen als woordvoerder en enige echte protagonist over. De VNG organiseerde een ondermijnende PR-actie en het keurige Binnenlandse Zaken stelde daar geen krachtige lobby tegenover. De ambtenaren volstonden ermee onderling vast te stellen dat de campagne van de VNG (onder leiding van tegenspeler Ebel Meijer) 'onder de gordel' was. Effectief was zij wel. Eduard de Wilde aan het woord in hetzelfde interview:

"De stukken van Hans Bevers zaten vol met doelredeneringen. Hij kon alles verkopen! Achteraf is het ongelofelijk dat dit het haalde in het kabinet en de Tweede Kamer passeerde met mensen als Hennekam en Piet Stoffelen. Als ik vanuit mijn latere ervaringen bij EZ en Buitenlandse Zaken terugkijk, valt op dat wij zo eenzijdig waren georiënteerd op IPO en VNG. En dat waren toch volstrekt conservatieve en weinig inspirerende clubs. Wij zaten maar voortdurend alleen in de Willemshof, terwijl de VNG ons beschouwde als de baarlijke vijand. We hadden nooit contact met de SER, met het bedrijfsleven of met allerlei organisaties die in de samenleving echt iets wilden. We wisten daar echt niets van! We waren er niet op uit om steun van anderen te mobiliseren, een tegenlobby te starten. Ministeries gaven ook heel weinig support. VRO was een uitzondering. Ik herinner me dat ik een mooi stuk had geschreven over natuurbeheer, Nationale parken en Landschappen; dat vond ik zelf tenminste en ook mijn bazen Adriaansen en De Menthon Bake vonden dat. Dat natuurbeheer kon het beste naar de provincies, had ik met kracht van argumenten beredeneerd. CRM zag daar wel iets in. Die hadden een probleem met dat onderwerp, maar toen kwam ik in interdepartementaal overleg. Moest je ambtenaren van EZ, van V\&W horen: 'Ach die provincies! Daar komt toch niets van terecht.' Dat terwijl dit officieel, ja wettelijk bekrachtigd kabinetsbeleid was."

\footnotetext{
14 Interview met Eduard de Wilde op 8 augustus 2007 in Den Haag.
} 
Minister De Gaaij Fortman, van huis uit hoogleraar privaatrecht, was misschien niet de meest aangewezen persoon om dit dossier tot een goed einde te brengen. Van hem is de profetische uitspraak: "Binnenlands Bestuur is zo taai als apenhaar." Maar ook zijn opvolgers Wiegel en Van Thijn kregen het niet voor elkaar.

"Waarom ging het mis? We stuitten op een opeenstapeling van weerstanden van allerlei groepen met verschillende motieven. De provincies waren tegen, de VNG was faliekant tegen, veel departementen zagen er niets in. Groot probleem was ook dat de politieke samenstelling van regionale eenheden dreigden te veranderen, daardoor werden CDA en VVD kopschuw, omdat de PvdA-stemmers uit de grote steden de politieke kleur van de nieuwe bestuurseenheden gingen bepalen. Daardoor waren Jan Franssen en Piet Hennekam uit de Tweede Kamer er ook nog eens niet blij mee. In plaats van dat je ergens klein begint en het een olievlekwerking laat worden, was de aanpak erg juridisch en weinig bestuurlijk. Een grand design vanaf de tekentafel". ${ }^{15}$

\section{De ontknoping: roemloze ondergang}

In 1978 was het door het aannemen van de Wet reorganisatie binnenlands bestuur al bijna zover gekomen dat de provincies, de pijlers van de zeventiende-eeuwse Republiek, aan mootjes waren gehakt om het legendarische "regionale gat" te dichten. Al tijdens de parlementaire behandeling was duidelijk geworden dat bij de sprong van 26 naar 17 provincies fundamentele zwakten in de redenering achter een zo ingrijpende reorganisatie door de vaardig opgeschreven teksten niet verhuld konden worden (zie Breunese en Van der Heijden, 1979). Pas in 1983 moest minister Van Thijn het wetsvoorstel tot invoering van de reorganisatie binnenlands bestuur intrekken. Zonder invoering geen reorganisatie. De elf provincies bleven ongemoeid, er kwam alleen een twaalfde provincie, Flevoland, bij. Ironisch genoeg vloekte deze nieuwe bestuurseenheid met alle inzichten over sociale samenhang als basis voor bestuurlijke structuur, waarop zo zwaar was getamboereerd. Immers, de samenhang tussen Almere en Amsterdam of het Gooi is aanmerkelijk sterker dan die met de rest van de polder.

\subsubsection{Aanwijzingen voor de in dit project gehanteerde bestuurstheorie}

De reflectie op de beschreven ontwikkelingen kan gevoed worden door andere waarnemers, die zich verbaasden over bureaucratische rationaliteit, uniformiteit, technocratie, een universalistische bestuurstheorie, uitgaan van de maakbaarheid van de bestuurlijke reorganisatie. Binnen zijn indeling in vertoogtradities typeert Hein-Anton van der Heijden (1990: 189) het beleid als neocorporatistisch. Zo was opvallend hoezeer de Concept-structuurschets uit 1974, waarin 44 gewesten naar voren kwamen, op wetenschappelijk onderzoek was gebaseerd. De start was dus veelbelovend: grondig onderzoek en ontwikkeling in een aparte afdeling Gewesten van een bestuurstheorie die dus niet alleen op Haagse werkelijkheid was gebaseerd. Echter, de beleidsontwikkeling begon al gauw na de fase van wetsontwerpen te schuiven los van de empirische grondslag. Het basisdocument van de Structuurschets bleef tot het einde in 1983 de grondslag voor de redeneringen toen de inhoud van het beleid allang was afgedreven van de wetenschappelijke conclusies. In ieder geval speelde het criterium dat de bestuurseenheden voor burgers aanspreekbaar moesten zijn volgens Van der Heijden (1990: 189) geen enkele rol.

Als tweede getuige kan Pieter Tops worden opgevoerd, die zijn doctoraalscriptie begint met een citaat van Joop den Uyl uit 1983, die in de Volkskrant de reorganisatie van het binnenlands bestuur nota bene beschrijft als een poging om "regionaal vorm te geven aan een participerende democratie". Terecht verbaast Tops zich over deze kwalificatie:

\footnotetext{
15 Interview met Eduard de Wilde, zie vorige voetnoot.
} 
"Als er één beleidsvoornemen is geweest dat werd gekenmerkt door een technocratische, apolitieke benadering en dat alleen onder bestuurders belangstelling wist te wekken, dan was het wel de reorganisatie van het binnenlands bestuur." (Tops, 1985: 9)

Voor zover er democratische motieven in het spel waren bij de reorganisatie van het binnenlands bestuur, waren deze erop gericht gekozen bestuursorganen (in casu vooral provinciale staten) meer greep te geven op de beleidsbepaling in de regio, zeker niet op het vergroten van invloed van burgers, bedrijven en instellingen.

En verderop vervolgt Tops over de bestuursideologie van Binnenlandse Zaken, waar hij de volgende kwalificaties aan toekent:

- Men beschouwt het openbaar bestuur als een beleidsmachine, waarvan het mechaniek aan revisie toe is.

- $\quad$ Een op institutionele vereenvoudiging gerichte benadering is noodzakelijkerwijs monocentrisch en centralistisch.

- De wenselijkheid van een reorganisatie van het binnenlands bestuur staat voorop en niet de mogelijkheid ervan.

- Doorvoering van de verandering op uniforme wijze van bovenaf wordt nodig geacht, op basis van een totaalvisie met samenhang tussen alle aspecten (Tops, 1985: 59-61).

\section{Doelstelling, beleidsredenering}

De probleemanalyse en de doelstelling van het beleid zijn duidelijk gericht op versterking van bestuurscentrisme, van het leggen van verantwoordelijkheden in één hand. Zelfs na het falen van het beleid in 1983 was niet het argument dat deze ambitie op een misplaatst centraliteitsdenken berustte, maar dat de beoogde doelen ook op incrementele wijze binnen de bestaande bestuurlijke organisatie bereikt konden worden.

De democratie-opvatting is voor Binnenlandse Zaken misschien wel de belangrijkste drijfveer om dit project aan te vatten. Het was misschien minder moeilijk geweest om bijvoorbeeld in gestroomlijnde gemeenschappelijke regelingen regionale taakbehartiging te organiseren, maar het was nadrukkelijk de bedoeling een bestuurslaag te creëren met democratisch gekozen organen die rechtstreeks de meest relevante maatschappelijke problemen op regionale schaal zou kunnen aansturen. Deze overweging geldt voor het hele dossier gelijkelijk.

Wat betreft de sturingsaanpak zien we louter hiërarchisch instrumentarium. Merk op dat de 'uitvinding' die ten grondslag ligt aan de Wet reorganisatie binnenlands bestuur, namelijk het omvormen van provincies tot de centrale spil van het binnenlands bestuur, pas na de jaarwisseling van 1975 ontwikkeld is en dat al voor het zomerreces van datzelfde jaar een compleet wetsvoorstel is ingediend. De centrale overheid liet er geen gras over groeien en heeft ook niet veel behoefte gevoeld via overleg en consultatie tot een breed gedragen modus te komen. De oplossing werd als intrinsiek elegant, logisch en doeltreffend beschouwd en behoefde alleen maar te worden ingevoerd, bij wet natuurlijk. Eduard de Wilde verzuchtte achteraf: "Had men maar gekozen voor voorzichtige experimenten en olievlekwerking."

\section{Informatieverwerving}

De manier waarop het beleid werd gevoed met informatie, was bij uitstek technocratisch. Denk aan het wetenschappelijk onderzoek bij de Structuurschets, dat een groot vertrouwen in het kennen van de werkelijkheid verraadt, en aan de technocratische tekentafeloplossingen, die rationele analyse toereikend achten voor het onderbouwen van besluiten. Er was geen spoor van twijfel door de confrontatie met verschillende percepties (de kritiek van de VNG werd als 'onder de gordel' beschouwd). Ook al was de uitvoering uiterst aanvechtbaar (zie de anekdote rond Aat Tetteroo), het beleid bleef vasthouden aan de sociografische benadering om werkelijk samenhangende gebieden aan te wijzen, een methode van rationele beleidsvorming die in het begin nog met wetenschappelijk onderzoek was omlijst. Tekenend voor de rationele maakbaarheidsverwachtingen 
van die tijd was het geloof in het Provinciaal Beleidsplan als fundament voor integraal regionaal bestuur (Van Kroonenburg et al., 1981). In de scherpte van dit project zal de bestuurscentrische benadering van Binnenlandse Zaken later niet meer terugkomen.

Wel blijkt uit de manier waarop het handwerk van Hans Bevers wordt beschreven ('doelredeneringen'), een zeker besef van het willekeurige karakter van de presentatie van het beleid. De ambtenaren waren zich zeker bewust van de weinig rationeel verdedigbare verkooptechnieken. Dit hoort nu eenmaal bij de politieke kant van het ambtelijk bedrijf. De ambtenaren hebben een weinig hoge dunk van de politici, die deze doelredeneringen zo laten passeren. Er wordt een duidelijk verschil gezien tussen het rationeel gefundeerde beleid en de vaak op wenselijkheden en belangen gefundeerde politiek.

Ten slotte zij herinnerd aan de opmerking dat het beleid zich louter op VNG en provincies oriënteerde, niet op de SER en andere maatschappelijk gewortelde adviesorganen, laat staan op de bedrijven, maatschappelijke organisaties en burgers. Dit is ook een belangrijke indicatie van de manier waarop men in dit dossier naar de eigen positie en naar die van het openbaar bestuur keek.

\subsubsection{Typering van dit project volgens overige onderzoekscriteria}

\section{Mate van beleidsvernieuwing}

Hieronder zullen door het resumeren van de feiten in de ontwikkeling van de reorganisatie van het binnenlands bestuur veranderingsmomenten worden gemarkeerd aan de hand van de begrippen van Hogwood \& Peters: beleidsaanpassing ('policy maintenance'), beleidsinnovatie, beleidsopvolging ('policy succession') en beleidsbeëindiging.

1969. Beleidsinnovatie: nieuw beleid wordt geïntroduceerd, waardoor ingrepen in het middenbestuur in het vizier komen. Begonnen wordt met gewesten, geconsolideerde vormen van verlengd lokaal bestuur.

1976. Beleidsopvolging: het kabinet-Den Uyl wendt de steven uit vrees voor het ontstaan van een vierde bestuurslaag. De oude provincies worden opeens gezien als voertuigen voor het beoogde streven om passende bestuurseenheden in het leven te roepen. Dat is de grote beleidsaanpassing: de provincies die na Napoleon bewust kort waren gehouden, worden nieuw leven ingeblazen als 'Doe-provincies'. Daarna volgen alleen nog kleine stapsgewijze beleidsaanpassinkjes door het aantal beoogde provincies in te perken: van 26 naar 24, naar 17. In feite wordt met deze terugtocht geleidelijk de geloofwaardigheid van de bestuurstheorie dat bovenlokale en regionale taken kunnen samenvloeien in één bestuurlijke bedding, die van de nieuwe provincies, steeds verder uitgehold. Andere aanpassingen vinden plaats op het terrein van de taaktoedeling en de instrumentatie van de nieuwe bestuurseenheden: het betreft de introducties van de positieve en negatieve lijsten in de wetgeving (taken die alleen door provincies en andere taken die in ieder geval niet meer door gemeenten mogen worden uitgevoerd) en van het provinciaal Beleidsplan.

1983. In het volgende kabinet wordt de knoop doorgehakt. Pas bij de invoeringswet volgt de intrekking van het hele pakket. Wat resteert, is de beslissing om één nieuwe provincie Flevoland - in het leven te roepen, die echter ironisch genoeg vloekt met alle uitgangspunten van sociale en bestuurlijke samenhangen.

Deze totale nederlaag lijkt erg op beleidsbeëindiging in strikte zin. Er gebeurde verder een hele tijd niets wat erop leek. Of moeten we de schaamlap bestaande uit de voortgezette pogingen om de gemeenschappelijke regelingen te bundelen en te harmoniseren nog opvatten als een vorm van beleidsopvolging? De stroomlijning van gemeenschappelijke regelingen kan toch nauwelijks als functioneel equivalent voor de democratische doeprovincies gelden, tenzij we uitgaan van de heimelijke verwachting bij sommige ambtenaren bij Binnenlandse Zaken dat dergelijke gebundelde administratieve eenheden zich op den duur 'vanzelf' zouden ontwikkelen tot echte bestuurslagen. 
Evaluatie van dit beeldbepalende beleidsproject heeft nimmer plaatsgevonden. Ongetwijfeld heeft het gebrek aan succes ertoe bijgedragen dat het ministerie hier weinig animo voor had, wat niettemin uit oogpunt van kansen op leereffecten een gemiste kans mag heten. Niettemin heeft de denklijn achter dit project een zwaar en langdurig stempel gedrukt op de bestuurstheorie van Binnenlandse Zaken. Het streven om het middenbestuur opnieuw te modelleren, zodat de vele vormen van regionale publieke dienstverlening en verlengd lokaal bestuur onder een democratisch dak samengebracht kunnen worden, is zeer hardnekkig gebleken. Dat er ook geleerd is uit de ervaring met cumulatie van weerstanden bij een landelijke aanpak op basis van een blauwdrukachtige beleidsredenering, mag blijken uit de volgende poging met provinciale herindeling: de stadsprovincies.

\section{Doorwerking, institutionalisering}

Over de doorwerking van het beleid behoeft niet lang uitgeweid te worden. Aan bekendheid en zelfs papieren acceptatie van het beleid was geen gebrek in deze periode. Het bereikte zelfs een zekere periode het Staatsblad. Maar uiteindelijk is het blijvende resultaat nihil, of zelfs negatief als we de inrichting van de provincie Flevoland bezien vanuit de oorspronkelijke overwegingen voor het maken van nieuwe provincies. Immers, de maatschappelijke samenhang van Almere met Amsterdam en het Gooi was vele malen groter dan met de Noordoostpolder en Dronten. Ook constructies als het Provinciaal Beleidsplan en de Negatieve lijst van gemeentelijke taken hebben de slag niet overleefd.

\subsubsection{Conclusies}

Kortom, zowel de doelstelling, de sturingsaanpak, de democratie-opvatting als het leerproces in dit overambitieuze project voor de reorganisatie van het binnenlands bestuur waren top-down en technocratisch, pur sang government-gericht. Score A kan zonder aarzeling worden toegekend. Al deze signalen wijzen dezelfde kant op van technocratisch top-down bestuur, terwijl eind jaren zeventig tegelijkertijd een hoogtepunt van de democratiseringsgolf gaande was. Politieke windows of opportunities voor een andere benadering werden niet gezien.

Dit project was voor de bestuurstheorie van Binnenlandse Zaken toonaangevend. Dat het niet lukte, werd louter geweten aan het politieke krachtenveld, maar niet aan de visie zelf, zoals zal blijken.

\subsection{Complementair bestuur}

\subsubsection{Inleiding}

Dit project betreft de opdracht aan een externe werkgroep met (vooral academische) experts om de regering te adviseren over het verschijnsel van interbestuurlijke beleidsafspraken. De opdracht werd verstrekt in 1976 en wel voor bepaalde tijd. De werkgroep kwam in 1980 met zijn eindrapport, na een tussenrapport in 1977 voor discussie aan het bestuurlijke veld te hebben voorgelegd. Het secretariaat van de werkgroep berustte bij het ministerie van Binnenlandse Zaken.

Als pas afgestudeerde student bestuurskunde had de auteur tot zijn schande nog nooit gehoord van het begrip Complementair bestuur, waar de bestuurspraktijk inmiddels druk mee bezig was. ${ }^{16}$

\footnotetext{
16 Ook minister De Gaay Fortman kende de term niet. Volgens de overlevering zou het begrip door Henk van Ruller in een nota aan de minister zijn voorgelegd, waarop De Gaay hem bij de bespreking ervan vroeg: "Wat is dat ook alweer, complementair bestuur?" De term dankt volgens de interimrapportage van de werkgroep zijn ontstaan aan het rapport 'Bestuurlijke Organisatie' van de VNG, anno 1969. Anno 2007 schaamt een ervaren afdelingshoofd van de directie Constitutionele Zaken en Wetgeving zich helemaal niet meer nooit van het begrip te hebben gehoord; zo diep is het onder het stof begraven, waar het door oudgediende Roel de Wit weer uit is opgediept. Tijdens een bijeenkomst van bestuurders over de Randstadproblematiek op 8 juni 2007 riep hij het bestaan van een rapport bij Binnenlandse Zaken over Complementair Bestuur in herinnering, dat zijns inziens een sleutel bevatte voor de oplossing van de problemen van daadkrachtige interbestuurlijke samenwerking.
} 
Binnen Binnenlandse Zaken was de oud-gemeentesecretaris van Leiden Johan van der Poel als plaatsvervangend directeur Binnenlands Bestuur belast met het formuleren van inzichten over dit thema, dat later onder de vlag van bestuursakkoorden en convenanten veel meer gemeengoed zou worden. Bij ministeriële beschikking werd hiertoe op 24 mei 1976 een gemengde werkgroep ingesteld om het verschijnsel te bestuderen. Secretaris was de jonge ambtenaar L.C. Brinkman, destijds hoofd van het bureau SG. Elco's eerste baan was geweest bij het overlegorgaan in de Noordvleugel van de Randstad, het Coördinatiebureau Noordelijk Deel Randstad. Daar had hij persoonlijk ervaren wat ervoor nodig is besturen en maatschappelijke organisaties in overleg tot gemeenschappelijk inzicht en afstemming van handelen te brengen. Als politicoloog/

bestuurskundige bracht hij ook de nodige visie mee over de moderne trends van schaalvergroting en losbreken uit afgebakende gemeenschappen die andere instrumenten dan verticale gezagsuitoefening noodzakelijk maakten.

Terugkijkend op die periode stelt hij in een interview ${ }^{17}$ over dit project:

"In de zestiger jaren bestond als het ging om de positionering en slagkracht van de overheid aan de kant van bestuurskundigen een vrij sterke stroming die zei: als je nou maar de procedures inzichtelijker en democratischer maakt en tegelijkertijd het beleidsvoorbereidend onderzoek, aspect voor aspect, beter inricht krijg je automatisch beter resultaat. Tegelijkertijd was er het besef dat er sprake was van schaalvergroting. De burger zag geleidelijker de horizon van zijn levenssfeer vergroten. Je deed niet meer alleen boodschappen in het dorp waar je woonde of bleef werken in de plaats waar je geboren was. Dezelfde notie die later veel sterker is geworden, speelde ook bij de structuuraanpassingen. Bij het begrip over complementair bestuur stond echter het inzicht voorop dat structurele benadering de problemen niet oplost. De zorg was gericht op de versnippering van besluiten en op het gebrek aan rationele onderbouwing van de besluiten. Daar waar de vakdepartementen allerhande belangen rationeel probeerden te verankeren, kwamen er steeds meer rechtsvormen, afwegingskaders en regelingen bij. De verschillende zaken werden aspect voor aspect geregeld. We ervoeren een groot gebrek aan afweging van het algemeen belang op één moment, op één plek. Die plek kon ook best een vergaderkamer met verschillende besturen zijn. Als het beslismoment maar weer kon worden gedefinieerd en de beslissing voor alle partijen eenduidig kon worden vastgelegd. Die zoektocht naar een gezaghebbend moment of plek, waaraan we allemaal gehouden zijn, lag ten grondslag aan complementair bestuur. Voor die coördinatie en integratie moesten competenties niet opnieuw worden toegewezen, maar deze moesten worden overstegen. Dat is vandaag nog steeds niet gelukt, met alle gevolgen voor het presterend vermogen van de overheid en voor het vertrouwen van de burgers van dien."

Het was in de Ministerstaf ook Elco Brinkman die de aanzet heeft gegeven voor de instelling van de werkgroep, al was het maar om eens te verkennen wat het fenomeen horizontaal of complementair bestuur betekende voor het Huis van Thorbecke.

Voor het sterk staatsrechtelijk georiënteerde Binnenlandse Zaken lag het niet in de rede om in termen van afhankelijkheden en machtsevenwichten te denken. Eind jaren zeventig beleefde Binnenlandse Zaken de overgang van de legalistische sfeer naar een periode van Sturm und Drang. Meer dan de flexibele, open en aimabele voorzitter Johan van de Poel is secretaris Elco Brinkman als de innovatiedrager te beschouwen van de werkgroep, opgevat als de drijvende kracht die het belang van deze ontwikkeling voor het openbaar bestuur inzag en dus ook de waarde ervan voor het bestuursbeleid goed wist in te schatten.

\section{Verantwoording}

Hoofdrolspelers waren Roel in 't Veld (lid van de commissie) en Elco Brinkman, die beiden in de gelegenheid waren commentaar te leveren op de weergave van de gedachtegang hieronder. In 't

17 Interview met Elco Brinkman op 7 september 2007. 
Veld heeft bovendien de voorstudie 'Wachten op het omslagpunt' gelezen ten behoeve van een coreferaat bij een lezing in het ministerie van Binnenlandse Zaken op 27 augustus 2013. Zijn reactie met betrekking tot de bevindingen over complementair bestuur was niet dat de weergave van de feiten niet klopt, maar dat bij de vraag over de doorwerking te weinig aandacht zou zijn besteed aan de invloed van het concept buiten het ministerie. Ook meende In 't Veld dat de kritiek op het ontbreken van netwerkrelaties met maatschappelijke partners anachronistisch zou zijn en miskent wat de opdracht van de werkgroep was. Op beide punten wordt hieronder ingegaan.

Bronnen voor de beschrijving van deze casus waren verder vooral de stukken van de Werkgroep Complementair Bestuur zelf $(1977,1980)$ en daarnaast interviews met Brinkman, In 't Veld en De Wilde.

\subsubsection{Projectbeschrijving en verhalen}

\section{Discussie binnen de werkgroep}

De opdracht van de werkgroep was open geformuleerd, maar mondde uit in de vraag of er aanleiding bestaat voor wettelijke regulering van dit nieuwe fenomeen. Het werd een eerste confrontatie tussen de juridische denktrant die binnen Binnenlandse Zaken gangbaar was en een meer bestuurskundige benadering. Deze discussie werd binnen de commissie het meest pregnant verwoord door de Twentse staatsrechthoogleraar Ruiter enerzijds en de moderne bestuurskundige Roel in 't Veld anderzijds. Hieronder volgt het relaas van laatstgenoemde. ${ }^{18}$ Willem Konijnenbelt, een wetenschappelijk vertegenwoordiger vanuit het bestuursrecht, nam een minder uitgesproken positie in.

Op enig moment, na vele vergaderingen langs elkaar heen argumenteren, kwam men binnen de commissie onder de beminnelijke leiding van Johan van de Poel zover dat men over en weer de verdiensten van de verschillende benaderingen begon te waarderen. Het lukte echter niet om meteen een ondubbelzinnig en gemeenschappelijk eindrapport op te stellen. De open taakopdracht en de samenstelling van de werkgroep boden een goede gelegenheid om een werkelijk open verkenning uit te voeren. Het werkproces werd na enige tijd, nadat de werkgroep hiertoe toestemming had verkregen van de minister, omgebogen naar een verkenningstocht, waarbij de spraakmakende omgeving werd uitgenodigd inbreng te leveren. Daartoe werd een tussenfase ingelast met het uitbrengen van een interim-rapport, dat nog vele vragen openliet. Niet werd, zoals aanvankelijk gevraagd, het eindrapport medio 1977 gepresenteerd, dat verscheen niet eerder dan september 1980. Eind 1977 werd een interim-rapport uitgebracht, dat aan een maatschappelijke commentaarronde werd onderworpen. Hiervan hebben overigens vooral wetenschappelijke auteurs gebruikgemaakt. In de eindfase was Johan van de Poel al om gezondheidsredenen afgetreden. De inmiddels tot DG benoemde secretaris Brinkman, die het interimrapport grotendeels had geschreven, werd waarnemend voorzitter en John Steegh volgde hem op als secretaris.

De sterk verschillende disciplinaire invalshoeken van Ruiter en In 't Veld ontmoetten elkaar in de tweede fase ergens bij de gemeenschappelijke vertrouwdheid met het begrip bestuursinstrumenten. Belangrijk was het voorwerk van de Delftse bestuursrechthoogleraar Wessel, die bestuursinstrumenten nauwkeuriger had geclassificeerd in termen van sturings- en temperingstechnieken, ex ante en ex post, et cetera, waardoor duidelijk werd dat er meer is dan louter de bevoegdheid van bestuursorganen (Wessel, 1979). In de praktijk kunnen allerlei bijkomende vormen van feitelijke beïnvloeding, zoals informatie en overleg, wel degelijk materieel effect hebben op de formeel geldende uitkomst, vergelijkbaar met een formele interventiebevoegdheid als nadere regeling of plantoetsing. Dit inzicht droeg ertoe bij procesmatige

18 Interview met Roel in 't Veld op 24 augustus 2007. 
factoren en omgangsvormen geleidelijk aan te waarderen als bestuurlijk relevante kenmerken naast de 'harde' structuurelementen als organisatie, regelgeving en bevoegdheden. ${ }^{19}$

\section{Maatschappelijke ontwikkelingen}

De werkgroep kreeg oog voor maatschappelijke ontwikkelingen die al sinds het begin van de jaren zestig merkbaar waren: schaalvergroting, fragmentatie van sectoraal beleid en het gebruik van wisselende samenwerkingsverbanden voor verschillende onderwerpen. De overheid zag deze ontwikkeling als een serieuze bedreiging voor de houdbaarheid van het Huis van Thorbecke. Zoals we zagen, was een van de reacties gericht op het creëren van grotere, regionale bestuurseenheden. Omgekeerd werden samenwerking en afstemming wel gezien als hulpmiddel dat de noodzaak voor grootscheepse structuurverandering in de bestuurlijke organisatie relativeerde.

Ook elders waren soortgelijke zoektochten als in de werkgroep Complementair Bestuur gaande, waarbij de rode draad was dat orde in de chaos moest worden geschapen. Voor zover de oplossing niet gevonden kon of mocht worden in centralisatie of het aanpassen van de bestuurlijke organisatie, was overleg en afstemming de voor de hand liggende remedie. Ook in verticale verhoudingen werd overleg tussen gelijkwaardige partners verondersteld, die de facto wederzijds van elkaar afhankelijk waren. Een prille ontdekking van horizontaal bestuur dus.

Dat riep echter meteen de vraag op of dat zonder nadere regulering wel goed kon gaan. Zonder geformaliseerd stelsel van rechten en plichten zouden overleg en informatie-uitwisseling tot vrijblijvendheid of machtsmisbruik kunnen leiden, die afbreuk doen aan de bedoelingen van de hoofdstructuur van de bestuurlijke organisatie. Bovendien zijn afspraken met rechtsgevolg onmisbaar voor het reduceren van onzekerheid, op basis waarvan de verschillende bestuursniveaus afgewogen besluiten kunnen nemen. Versnippering en teloorgang van samenhangende rationele afweging werden diep betreurd. Zo was prof. P. de Haan een niet aflatende ijveraar voor de zogeheten Operationele Gebiedsaanwijzing (OGA), waarbij ruimtelijk relevante beslissingen voor bepaalde ontwikkelingsgebieden zouden worden gebundeld in handen van één gebiedsautoriteit. Ergens zou een baken gevonden moeten worden om de ingewikkelde verwevenheid van besluiten aan te verankeren. Dat zocht men in de procedurele waarborgen van interbestuurlijk overleg: complementair bestuur.

\section{Reflecties op de gevoerde discussies}

Uiteindelijk leken beide redeneringen (samenwerking als bedreiging en samenwerking als uitlaatklep) elkaar te neutraliseren, waardoor per saldo niets veranderde, noch in de bestuurlijke organisatie, noch in de regulering van samenwerking.

De bevindingen en aanbevelingen van de werkgroep kunnen verder terzijde blijven. Geconstateerd mag worden dat de beraadslagingen ongetwijfeld boeiend en leerzaam zijn geweest, maar tot niets hebben geleid. Ook als dertig jaar na dato aan deelnemers van de werkgroep wordt gevraagd waar het in feite om te doen was, krijgt men nog vergelijkbare antwoorden. Elco Brinkman zelf legt tijdens zijn vraaggesprek nadruk op de verwachting in die periode (juist bij een belangrijke stroming in de bestuurskunde) dat rationalisering van beleidsprocessen en procedures zou kunnen leiden tot effectiever bestuur en meer slagkracht. Als uitkomst van bestuurskundig onderzoek zouden procedures van samenwerking, overleg en afspraken gestroomlijnd en aan spelregels gebonden moeten worden met het oog op het bereiken van operationele prestatieafspraken. In 't Veld benadrukt een soortgelijk inzicht uit de bestuurskunde, de destijds door hemzelf aangehangen Public Choice-benadering, waarin processen, incentives en informele omgangsvormen voorwaarden scheppen voor productieve samenwerking. Zolang men zich blijt fixeren op bestaande formele competenties, waarbij bestuursorganisaties overleg nodig hebben om te voorkomen dat men al te pijnlijk op de tenen van een ander gaat staan, is men nog niet bezig om de kwaliteiten van elke organisatie naast elkaar te leggen om maatschappelijke problemen beter aan te kunnen pakken.

19 De beschrijving van de interne gang van zaken is ontleend aan het interview met Roel in 't Veld op 24 augustus 2007. 
Anderen zagen de spelregels die werden geformuleerd in het leerstuk van het complementair bestuur juist als noodzakelijke voorwaarden om ondermijning van de bestaande competenties en van rechtstatelijke eisen te voorkomen. Coproductie, zoals in toenemende mate gebruikelijk in het bedrijfsleven en in de netwerkmaatschappij, is nog iets anders dan damage-control vanuit organisatiebelangen. Een begin in de richting van die denkomslag is gemaakt, maar men is er niet ver mee gekomen en, blijkens de terugblik van Brinkman anno 2007, is de overheid nog steeds zo ver niet.

"Uiteindelijk staat niemand te springen om competenties in te leveren. Macht of vermeende macht speelt ook in dit goede vaderland een bepalende rol. Ik maak dat vandaag de dag dagelijks mee in discussies tussen VROM en V\&W. Daarachter spelen natuurlijk honorabele belangen van groene ruimte of mobiliteit, maar de discussie gaat steeds over de vraag wie het laatste woord heeft, wie de vergunning al dan niet mag verlenen. Uiteindelijk is dan het eind van het liedje dat er helemaal niet over wordt beslist."

\section{Gebrek aan aantrekkingskracht}

Ondanks de prominente rol van DG Brinkman als innovatiedrager ontbrak een brede voorhoede van 'complementaristen' binnen het ministerie. Het discours speelde zich hoofdzakelijk af binnen de werkgroep en in de wetenschap. De verankering binnen het ministerie was, wellicht met uitzondering van enkele medewerkers binnen de directie Binnenlands Bestuur, nauwelijks aanwezig. Door de introductie van bestuurskundig denken lag er met dit dossier in beginsel een kans voor Binnenlandse Zaken om zijn missie te verbreden van structuuringrepen in het bestuur naar sturing op condities voor samenwerking en beïnvloeding door interactie, zo valt op te maken uit de reflectie van In 't Veld en ook uit die van Brinkman, hoewel de laatste zich meer met de gemaakte keuzen identificeert.

In de eerste plaats kan worden vastgesteld dat die kans om een nieuw terrein te verkennen ruimschoots is geboden, gelet op de extra tijd die is genomen en de vele conferenties en publicaties die aan het onderwerp zijn gewijd. De bal lag door de open opdracht ("nader onderzoek in te stellen naar de verschillende verschijningsvormen van complementair bestuur ...") voor open doel om het bestuur dichter bij de werkelijkheid van de werkvloer te brengen.

Tegelijkertijd valt op dat de verkenning erg theoretisch en abstract is gebleven. De werkelijkheid lijkt afschrikwekkend ingewikkeld wanneer die op een manier wordt gepresenteerd als bijvoorbeeld in het duizelingwekkende hoofdstuk 7 van het Eindrapport van de Werkgroep Complementair Bestuur, dat over planning gaat. Daar worden 153 mogelijke varianten van interbestuurlijke planningsrelaties onderscheiden die nog weer vermenigvuldigd kunnen worden met 20 verschillende financieringsvormen. Die planfiguren zijn een uiting van de toenmalige bestuurlijke werkelijkheid, waarin door Rijk en provincies voor alles en nog wat een planverplichting aan lagere overheden werd opgelegd (Adviescommissie sanering planprocedures, 1985). Ergens in deze reuzenmatrix met circa 4000 hokjes, elk een type besturingsnetwerk bevattend, treedt een kanteling op van verticaal, hiërarchisch naar horizontaal bestuur. De praktisch ingestelde bestuurder is bij dit etaleren van geleerdheid allang afgehaakt.

Bovendien kwam men niet echt los van het juridische structuurdenken. Immers, de werkgroep is er voortdurend op uit om binnen de baaierd van bestuursrelaties onderscheid te maken tussen geoorloofde en niet toelaatbare vormen van complementair bestuur. De zelfgekozen opgave van de werkgroep bleek al gauw een zoektocht naar de kwadratuur van de cirkel. Er is sprake van existentiële en toenemende wederzijdse afhankelijkheid van bestuursorganen in hun beleidsbepaling. Om de handelingscompetentie (autonomie) van de verschillende bestuursorganen te waarborgen, is overleg, voortdurend overleg, onvermijdelijk. Besturen die in samenwerking met andere besturen zich zouden willen vastleggen op beleidsafspraken, omdat de aard en schaal van de materie erom vraagt, doorkruisen hiermee het democratisch bestel. Immers, men geeft daarmee 
stukjes autonomie prijs, bindt democratisch gekozen volksvertegenwoordigingen aan arrangementen met de buren en bovenburen. lets wat enerzijds waarborg biedt, is tegelijkertijd bedreiging. Hoe kom je daaruit? Niet zo, blijkt uit deze casusbeschrijving.

$\mathrm{Er}$ is niet op kleine schaal geëxperimenteerd met nieuwe werkvormen, er zijn geen pogingen gedaan de opgedane inzichten in brede kring te verspreiden aan de hand van herkenbare en aansprekende casuïstiek. Ook nu nog leest het rapport als een academisch verhaal uit een andere wereld. Er zijn sindsdien duizenden spannender verhalen gepubliceerd over de horizontalisering van bestuursverhoudingen en over informele doorsteekjes tussen formele competenties om problemen op te lossen.

Wat als ...

Indien complementair bestuur, of netwerkbestuur werkelijk als de passende typering van de hedendaagse bestuurlijke werkelijkheid was geduid, indien de mening was ingedaald dat "openbaar bestuur complementair zal zijn of niet zal zijn", om Noordegraaf (1999: 310) te parafraseren, dan zou men logischerwijs naar de kenmerken van het klassieke bestuur zijn gaan kijken met de vraag wat daaraan aangepast moest worden. Bijvoorbeeld minder strakke regelgeving en planning om ruimte te laten voor overleg en afstemming. Zo ingrijpend was de notie van complementair bestuur in potentie.

Anders dan een nieuw perspectief op een toekomstige rol van Binnenlandse Zaken werd de hybride ontwikkeling die achter het vage begrip complementair bestuur (publiek, privaat?) schuilging, uiteindelijk gezien als een bedreiging voor een ordelijke gang van zaken binnen het Huis van Thorbecke.

De werkgroep kwam in zijn Eindrapport tot de conclusie dat complementair bestuur (gedeelde verantwoordelijkheid, samenwerking tussen gemeenten en rijk) in de gegeven omstandigheden zelfs gevaarlijk zou kunnen zijn. Immers, binnen de geconstateerde afhankelijkheidsrelaties en onevenwichtige machtsverhoudingen zou dit onwillekeurig leiden tot verdere kneveling van gemeenten door de vakministeries (vergelijk wurgcontracten uit de private sfeer). De werkgroep herhaalt deze waarschuwing ten overvloede nog eens:

"Het kan niet genoeg beklemtoond worden: complementair bestuur is geen alternatief voor decentralisatie, maar vergt decentralisatie en is zonder decentralisatie riskant." (Werkgroep, 1980: 9, cursiveringen van de werkgroep)

$\mathrm{Na}$ ontvangst van het rapport verdween het al gauw in een diepe la. Liever ging men door op de alternatieve sporen om het bestuur meer structureel aan de nodige voorwaarden te laten voldoen. Als beleidslijn prevaleerde dat eerst aanmerkelijke vordering van decentralisatie moest plaatsvinden alvorens met dit nieuwe instrument verder te gaan. Ongetwijfeld zullen er ook lieden zijn geweest die er de voorkeur aan gaven de verhoudingen te blijven bezien overeenkomstig formele competenties in plaats van deze te verbinden aan onvoorspelbare afspraken vanuit veronderstelde feitelijke afhankelijkheden.

Ontbreken van maatschappelijke werkelijkheid

Waarom is het nu niet gelukt? In 't Veld memoreert terecht dat zijn verwachting destijds hooggespannen was toen Brinkman halverwege het proces werd benoemd tot directeur-generaal. Daarmee kwam hij immers in een ideale positie om zijn ideeën te verwezenlijken. Brinkman zelf verontschuldigt zich echter door te stellen dat de denkwijzen die verbonden waren aan bestaande competenties te sterk waren, zelfs zo dat die 25 jaar later nog niet zijn doorbroken. Liever keerden de smaakmakende bestuurders terug in de andere denkgroef, die van de structuurmaatregelen en bestuurlijke reorganisatie, maar per saldo leverde hetzelfde competentiedenken daar ook blokkades op voor succes, al zagen we dat die minder aan de bestuurders dan aan politici waren toe te schrijven. Zo houdt het hele stelsel zichzelf in een verlammende greep. Is dat nu niet te doorbreken en heeft Binnenlandse Zaken daarbij geen sleutelrol te vervullen?, zo vraagt Brinkman 
zich af. Zoals ook al werd gesignaleerd bij het dossier van de bestuurlijke reorganisatie is communicatie en bewustwording een cruciale factor. Vastgesteld kan worden dat in het geval van complementair bestuur nauwelijks gewerkt is aan marketing. Het woord is aan De Wilde:20
"We hadden de vakdepartementen moeten uitdagen zich aan de ideeën achter complementair bestuur te verbinden."
"Complementair bestuur bleef gezien worden als een smoezelig begrip, nauwelijks oorbare vorm van handjeklap, in plaats van een normale praktijk die effectief en slagvaardig bestuur mogelijk maakte."
"Wat ontbrak, was het aan tafel uitnodigen van maatschappelijke organisaties om bewijsmateriaal aan te dragen dat het anders moest en kon. Maar voor Binnenlandse Zaken waren maatschappelijke organisaties non-existent, althans geen gesprekspartners."

\section{Eenzijdige overheidsoriëntatie}

Dit laatste citaat leidt tot een kanttekening die evenzeer samenhangt met de begrenzing van de missie van Binnenlandse Zaken als bestuursdepartement. Het bestuur houdt in de bestuurstheorie van Binnenlandse Zaken op bij de overheidsorganen.

Bij herlezing van de nota Complementair bestuur van 1980 valt ook op dat het alleen gaat over relaties tussen overheden. De definitie van complementair bestuur lijkt nadrukkelijk beperkt tot overleg tussen besturen van openbare lichamen van verschillende bestuursniveaus. Zowel Brinkman als In 't Veld wijten deze beperking aan de opdrachtformulering. In die opdracht is de beperking echter niet te vinden. Dat begint pas bij de interpretatie die de werkgroep zelf aan die opdracht verbindt: "De eerste vraag is: in hoeverre is er in de Nederlandse gedecentraliseerde eenheidsstaat op grond van in de bestuurspraktijk ervaren knelpunten aanleiding om nieuwe, zogenaamde 'complementaire' vormen van samenwerking tussen de bestuurslagen te introduceren." (cursivering JFS) Met geen woord wordt gerept over bestuursrelaties met andere organisaties, bedrijven, maatschappelijke organisaties, die in de jaren negentig volop in de schijnwerpers zouden komen met begrippen als netwerkbestuur, coproductie en publiek-private samenwerking. ${ }^{21}$ Zelfs al was die zelfbeperking te wijten aan de beperkte formele opdracht aan de commissie, dan nog geldt dat maar weinig commissies zich door dat soort beperkingen laten ringeloren. In deze tijd zou het ondenkbaar zijn dat een begrip als complementair bestuur zo beperkt zou worden uitgelegd binnen de bestuurskolom. Vergeet niet dat de werkgroep Complementair Bestuur breed was samengesteld met bestuurskundigen als S.O. van Poelje en R.J. in 't Veld, waarvan de laatstgenoemde als exponent mag worden beschouwd van het moderne denken over besturing in de maatschappelijke context en over hybride organisaties met vertakkingen in de publieke en private sfeer.

Is dit een te strenge beoordeling van de werkgroep vanuit begrippen die pas later zijn opgekomen? Toch is het niet zo dat de ontwikkeling van netwerkbestuur over de grenzen van publiek en privaat heen zo plotseling zou zijn opgekomen dat die nog niet echt relevant was aan het begin van de jaren tachtig. Denk alleen aan de rol van projectontwikkelaars, grote woningbouwcorporaties en aan een vereniging als de ANWB (die al in 1927 een hoofdrol speelde bij de totstandkoming van het eerste Rijkswegenplan), de adviserende hoofdrol van ingenieursbureaus in de ruimtelijke ordening. Vergelijk ook de invloedrijke rol van welzijnsorganisaties en milieuorganisaties in de jaren zestig en zeventig.

Aannemelijk lijkt dat de werkelijkheid van netwerkrelaties wel bestond, maar dat deze (semi)private actoren in het dominante overheidscentrisch denkmodel van het openbaar bestuur niet passen in de probleemstelling van wederzijdse afhankelijkheden en in de ordening van het stelsel van het

\footnotetext{
20 Desgevraagd bevestigd in het interview met Roel in 't Veld op 24 augustus en met Elco Brinkman op 7 september 2007.

21 De Raad voor territoriale decentralisatie vraagt in zijn Kanttekeningen bij het interimrapport 'Complementair Bestuur verkend', mei 1978, of de definitie van complementair bestuur wel de contracten tussen overheid en (pseudo)particulieren kan omvatten.
} 
openbaar bestuur. De rapporten van de Werkgroep Complementair Bestuur vormen hiervan een illustratie. (Het ging toen om planning over meer lagen. De RBB maakte een adviesboekje hierover. In 't Veld was bezig met planning en Kickert, Aquina en Korsten - werkzaam in de vakgroep van In 't Veld - schreven het boekje 'Planning binnen perken'. Het waren de jaren van Fritz Scharpf met zijn werk over Politikverflechtung, verstrengelingen tussen overheidsorganisaties van verschillende niveaus. Later zou de adviescommissie-Vonhoff de staf breken over planning.) Het woord netwerkmanagement was nog niet gemunt.

Kortom, de uitvinding en uitgebreide bestudering van horizontaal bestuur vormden geen handvat voor een nieuwe verbindende rol van Binnenlandse Zaken, zoals heel goed had gekund (vergelijk de veel latere ontwikkeling van het Kenniscentrum-PPS bij Financiën), noch ook van een moderne sturingsfilosofie, die later brede aanhang verwierf, in het bijzonder in de wetenschappelijke wereld. Hieronder zullen nog veel voorbeelden in dezelfde sfeer volgen die evenmin beklijfden. Bij wijze van intermezzo komt hieronder één typerend voorbeeld naar voren van de blinde vlek die Binnenlandse Zaken toch uiteindelijk toonde ten opzichte van andere, meer horizontale manieren van denken en werken, die werden geïntroduceerd door mensen als Henk van Ruller en Johan Hoff.

\section{Bemiddeling als bestuursinstrument}

De oudste optekening van de open stakeholderbenadering binnen BZK dateert van Johan Hoff, hoofd van het Bureau Bijzondere Adviezen. ${ }^{22}$ We schrijven omstreeks 1975. Het bureau was al omstreeks 1971 door minister Beernink opgericht om de problemen van de grote steden te tackelen, niet zo structureel als tegenwoordig, maar één voor één. De eerste opdracht die Hoff kreeg, betrof de sluis in het Amsterdam-Rijnkanaal, die op instorten stond. Het was een rijksmonument, maar vanwege de functie voor de scheepvaart was Rijkswaterstaat belanghebbende. De gemeente Utrecht was vanuit de stedelijke economie belanghebbende en had zich tot Binnenlandse Zaken gewend, maar de gemeente Nieuwegein en de provincie waren medeeigenaar, het object was gelegen in de gemeente Vreeswijk (thans Nieuwegein). Door een ingeving, geholpen door zijn eigen open natuur, besloot hij tot de ongebruikelijke actie om alle betrokkenen bij elkaar te brengen en zo in een open gedachtewisseling het probleem helder te maken. Dat waren meer dan twintig personen uit zeven instanties. Neveneffect was dat iedereen voor een stuk probleemeigenaar werd. Toen de druk hoger werd, kwam dit de snelle oplossing ten goede. ${ }^{23}$ Later werd dit de standaardaanpak van Johan Hoff.

Aan het begin van de jaren tachtig reisde de oervader van het bestuursbeleid en trouwe kompaan van Johan Hoff binnen het ministerie, Henk van Ruller, regelmatig naar de Verenigde Staten om zich te oriënteren op de nieuwste ontwikkelingen. Hij kwam daar onder meer in contact met de Kettering Foundation in Chicago en met het Brookings Institute in Washington. Dat was de tijd waarin ministeries nog meenden dat ze hun eigen research en development moesten onderhouden. In die instituten trof hem de werkwijze die in Amerika inmiddels gemeengoed was geworden onder de naam Negotiated Investment Strategy. Dat is wat we nu in Nederland aanduiden met de term beleidsbemiddeling (Laws et al., 2012). Al enige jaren is er een ontluikende beroepspraktijk van beleidsbemiddelaars in Nederland, maar het is nog allerminst wijdverbreid. Veel minder dan conflictbemiddeling buiten de rechtszaal (mediation), wat sterk in opkomst is. In de Verenigde Staten is conflictbemiddeling ook standaardpraktijk bij de ontwikkeling van nieuw beleid en nieuwe regels, overal waar tegengestelde belangen in het spel zijn. De meest belanghebbende partij, niet zelden grote bedrijven, doen er verstandig aan zich in een vroeg stadium te verstaan met stakeholders om gerechtelijke procedures of ingrijpen van de overheid te voorkomen. Overheden zijn dan niet zelden als een van de belanghebbenden van de partij, maar niet per se als regievoerende instantie zoals in Nederland doorgaans het geval is bij nieuw beleid in het publieke

\footnotetext{
${ }^{22}$ Welke ambtenaar wil niet in zo'n bureau werken?

${ }^{23}$ Interview met Johan Hoff, 24 juli 2007 te Den Haag
} 
domein. De mediators zijn meestal doorknede onderhandelaars of ex-rechters die als onafhankelijke bemiddelaars hun sporen hebben verdiend. Overheden en politici zullen zich zelden dat aureool van onafhankelijkheid kunnen aanmeten.

Naar aanleiding van deze bezoeken werd in de directieraad van het directoraat-generaal Binnenlands Bestuur besloten een verkenning uit te voeren naar de toepasbaarheid van het instrument Bemiddeling in het Nederlands openbaar bestuur. Johan Hoff en Mieke Teeuwen, een van de leerlingen van Henk van Ruller, en anderen vormden een taakgroep, die in 1986 als volgt rapporteerde: "Bemiddeling als probleemgerichte aanpak van bestuurlijke vraagstukken kan een zinvol (nieuw) instrument zijn in de gereedschapskist van het binnenlands bestuur. De introductie zal zeer zorgvuldig moeten geschieden, zeker als het DGBB daarbij het voortouw neemt." Daarna volgen nog een paar maningen tot grote voorzichtigheid en wordt de vreemdheid van het instrument beklemtoond, meer dan positieve kansen die ook elders uit het rapport spreken. Het hoogste ambtelijke orgaan van het directoraat-generaal nam deze aanbevelingen onverkort over. Maar dat ging niet van harte, want wat ermee gebeurde, is uiteindelijk niets. Een illustratief voorbeeld van waar het hart echt lag als het gaat om de keuze tussen plannen maken voor nieuwe structuren of probleemgerichte samenwerking.

\subsubsection{Aanwijzingen voor de gehanteerde bestuurstheorie}

\section{Doelstelling en beleidsredenering}

De doelstelling van het beleid is duidelijk gericht op versterking van bestuurscentrisme, maar niet door het leggen van verantwoordelijkheden in één hand. De integraliteit en de eenheid van bestuursbeslissingen moet aan de vergadertafel worden bereikt en alle betrokkenen moeten aan het resultaat worden gebonden. Het ontwerpen van een instrumentarium dat hiervoor geschikt zou zijn, was de opdracht van de werkgroep Complementair Bestuur zoals de leden die zelf zagen. Hoewel de vorm dus samenwerking behelsde, was de kern van de taakopvatting rationeeldeductief, niet de open resultante van vrije associatie van gelegenheidspartners in een netwerksituatie. De meest in het oog springende beperking is dat de focus louter overheden betreft. Het gaat dus hoogstens over multi-level governance en niet over netwerkbestuur in brede zin.

\section{Sturingsaanpak}

Wat betreft de sturingsaanpak zien we een commissie met louter deskundigen met een hoog profiel van wetenschappelijkheid en gezaghebbendheid via rapporten met de samenleving communiceren. Wel is na het verschijnen van het interimrapport ruim gelegenheid geboden voor debat en zijn de reacties zorgvuldig van commentaar voorzien in het eindrapport vermeld. Anders dan bij de reorganisatie van het binnenlands bestuur is ook ruim de tijd genomen voor deliberatie en overleg. Ook lijkt het erop dat de werkgroep werkelijk gaandeweg tot inzichten is gekomen die het ministerie vooraf niet al had. Anderzijds is niemand op het idee gekomen om hier en daar een experiment in te richten en af te dalen tot de dagelijkse bestuurspraktijk om daar de interactie met het veld te ondergaan. De actuele beleidsvormers waren geen partij in de beraadslagingen, zij lieten het academisch vertoog aan een deskundigencommissie over. Was er wel sprake van sturing of moeten we eerder spreken in termen van een vrij proces van beleidsontwikkeling, maar dan goeddeels buiten de ambtelijke omgeving?

\section{Democratieopvatting}

Hoewel de eindverantwoordelijkheid van de gekozen volksvertegenwoordiging bij bepaalde onderwerpen in het eindrapport van de werkgroep Complementair Bestuur ergens wordt geproblematiseerd (Werkgroep, 1980: 49), is de representatieve democratie in dit project relatief het meest afwezig van alle projecten die in dit hoofdstuk worden beschreven. Dat betekent echter geenszins dat de werkgroep blijk zou geven van een meer participatieve democratie-opvatting.

Informatieverwerving 
De informatieverzameling van de werkgroep was mede door de open en zoekende houding van de voorzitter in aanleg divers. In feite was de werkwijze door de aanwezigheid van een aantal andere leden overwegend deductief in plaats van inductief. Denk bijvoorbeeld aan het schema van bestuursinstrumenten (Wessel, 1979). De werkgroep bleef overwegend binnen de veilige muren van de vergaderkamer, wist veel van de theorie en daalde weinig af naar de dagelijkse praktijk van het openbaar bestuur. Ondanks de toelichting van In 't Veld over het belang van informele procesvoorwaarden is hierover in het rapport weinig terug te vinden. Het eindrapport is vrijwel geheel juridisch van aard (wettelijke regeling, toezicht en beroep, planvoorschriften, bestuursovereenkomsten). Het discours buiten de werkgroep bewoog zich overwegend in wetenschappelijke kringen (Werkgroep, 1980: bijlage I) en ging ver over de hoofden van bestuurders, beleidsmakers en politici heen. De belangrijkste beperking van de oriëntatie op de werkelijkheid schuilt in het gegeven dat de werkgroep zich louter richtte op afstemming tussen overheden. Geen moment was er de neiging om ook wederzijdse afhankelijkheden met maatschappelijke organisaties of met het bedrijfsleven in de beschouwing te betrekken, wat het realiteitsgehalte van de verkenning aanmerkelijk ten goede was gekomen.

Dezelfde beperking zien we ook bij de verkenning van beleidsbemiddeling als bestuursinstrument. Anders dan in de Verenigde Staten, waar men deze werkwijze vandaan haalde, werd een voorstel alleen uitgewerkt voor Binnenlandse Zaken als bemiddelaar in bestuursgeschillen tussen overheden.

\subsubsection{Typering van dit project volgens overige onderzoekscriteria}

\section{Mate van beleidsvernieuwing}

Als project was de werkgroep Complementair Bestuur in meer dan één opzicht vernieuwend: het onderwerp horizontaal bestuur, de samenstelling van de werkgroep overwegend met mensen van buiten de overheid, de werkwijze met een tussenrapport voor open maatschappelijke discussie en een eerste oefening met 'modern' bestuurskundig denken. Minder innovatief was de nadruk op interbestuurlijke samenwerking met voorbijgaan van partners in de samenleving en ook het feit dat de werkgroep zijn hoop vestigde op oplossingen door formele wetgeving. Hier laat zich de vraag stellen of je een project van ver voor de bestuurskundige shift langs de maatlat van government naar governance kunt leggen. Dat zou een anachronisme opleveren. Het thema zelf, en de samenwerkingsgedachte die erachter zat, was zeker een voorafschaduwing van de hier bedoelde tendens. De wijze waarop het werk van de werkgroep echter neersloeg in een supermatrix met plannings- en sturingsmodaliteiten, suggereert een maakbaarheidsdenken dat weer meer aan government doet denken. Hoewel horizontaal bestuur niet een bestaand beleidsthema was waarop de werkgroep voortbouwde, maar omdat de Wet gemeenschappelijke regelingen wel al sinds 1950 bestond voor bestuurlijke samenwerking tussen gemeenten onderling, is dit thema toch als beleidsopvolging te typeren.

\section{Bijdrage van dit project aan de bestuurstheorie}

Wel aannemelijk is, gelet op de fundamentele discussies tussen verschillende wetenschappelijke disciplines binnen de werkgroep, dat het onderwerp complementair bestuur kansrijk was voor het genereren van een omslag in het denken. Er werd tenminste geïnvesteerd in discussie, juist met bestuurskundigen. Echter, binnen Binnenlandse Zaken, waar in dezelfde periode met veelal dezelfde mensen aan de reorganisatie van binnenlands bestuur en aan de werkgroep Complementair Bestuur werd gewerkt, werden dit destijds nauwelijks als verenigbare grootheden beschouwd.

Toch heeft binnen de persoon van Elco Brinkman het gedachtegoed van complementair bestuur en het streven naar een nieuwe ordening van taken en structuur van het bestuur een spanningsveld aan het licht gebracht dat hijzelf wel degelijk als zodanig heeft ervaren. In het interview over dit dossier ${ }^{24}$ concludeerde Brinkman, dat toen het puntje bij het paaltje kwam de bestuurders kennelijk

${ }^{24}$ Interview met Elco Brinkman op 7 september 2007 te Zoetermeer. 
kozen voor de vertrouwde beelden over ieders machtsposities boven het avontuur van de samenwerking. De conversatie tussen frames kan ook binnen éénzelfde organisatie en zelfs binnen één enkele persoon plaatsvinden. Dat is een amendement op veel van de bekende literatuur over discoursanalyse, die veelal is gericht op de louter persoonlijke zingeving door middel van taaluitingen (Van der Arend, 2007: 42). Dit is een interessante bijvangst van dit onderzoek, dat bij de conclusies vermeld mag worden.

\section{Leerprocessen en evaluatie}

Evaluatie van dit project heeft niet plaatsgevonden. Evenmin is iets merkbaar van een duidelijk aanwijsbaar leereffect op organisatieniveau ten aanzien van de werkwijze of van de inhoud van de werkgroep. Ongetwijfeld zijn hiermee kansen op een vroegtijdige doorbraak in het governmentdenken verloren gegaan. Een grotere nadruk op samenwerking en de relatieve onmogelijkheid van structuuroplossingen bij de oplossing van afstemmingsproblemen had veel latere mislukkingen kunnen voorkomen. Een gunstiger uitleg beklemtoont dat het sterk instrumenteel-juridisch gerichte project ook latere ontwikkelingen, zoals convenanten of coproductie, niet in de weg heeft gestaan.

\section{Doorwerking en institutionalisering}

Over de doorwerking van de ideeën over complementair bestuur hoeft geen misverstand te bestaan: deze is geheel achterwege gebleven. Onbedoeld geeft de werkgroep in haar eindrapport zelf de reden hiervoor aan:

"Deze reacties [op het interimrapport van 1977, JFS] hebben de werkgroep gesterkt in haar indruk dat aan complementair bestuur een praktische bruikbaarheid moet worden toegeschreven. Wel moet gewaakt worden tegen een in zo ruime mate gezamenlijk optrekken en delen van verantwoordelijkheden door verschillende overheden dat een vaak principieel en praktische juistere oplossing n.l. het zoveel mogelijk in één hand brengen of laten van verantwoordelijkheden, buiten het zicht raakt."

Kortom, eigenlijk wilde men er liever niet aan. Dat geldt ook voor de intern omarmde gedachte van bestuursbemiddeling. Dat is een andere houding dan een die voortkomt uit het besef van een onontkoombare realiteit van wederzijdse afhankelijkheden, zoals het governance-denken veronderstelt.

De rapporten zijn in een diepe la verdwenen, zozeer dat in de 21e eeuw de term complementair bestuur zelfs uit het bestuurlijk jargon is geschrapt. De in de jaren negentig sterk opgekomen praktijk van convenanten en bestuursovereenkomsten is niet rechtstreeks verbonden met de vingeroefeningen van de werkgroep Complementair Bestuur. Dat zou ook het antwoord moeten zijn op de stelling van In 't Veld dat de werkgroep vooral buiten Binnenlandse Zaken veel effect heeft gesorteerd. Dat hij persoonlijk de inzichten uit de werkgroep meenam naar het ministerie van OCW, kan zijn waarneming wellicht vertekenen. Hoever tijdens de werkzaamheden van de werkgroep de bekendheid van het gedachtegoed van complementair bestuur ging, is moeilijk te zeggen. Hiernaar is geen onderzoek gedaan, maar de vraag is gewettigd of zelfs alle bestuurders het concept op hun netvlies hadden. De praktijk van convenanten en bestuursafspraken ontwikkelde zich wel zeer voortvarend vanaf de jaren tachtig, te beginnen met het milieubeleid onder minister Winsemius en in hoofdstuk 6 zullen we ook het fenomeen van de bestuursakkoorden tegenkomen. Dit verschijnsel is echter met geen mogelijkheid rechtstreeks toe te schrijven aan de aanbevelingen van de werkgroep Complementair Bestuur.

\subsubsection{Conclusies}

De werkgroep Complementair Bestuur was op zichzelf in procedureel en inhoudelijk opzicht een verfrissende poging tot vernieuwing binnen het bestuursbeleid. Het bevatte verschillende elementen van de governance-benadering avant la lettre. Multi-actor en multi-layer bestuur wel, relaties met maatschappelijke actoren kwamen in deze vroege periode nog helemaal niet in beeld, 
ook niet binnen de bestuurskunde trouwens. Een shift naar governance was deze exercitie dus nog niet. De aanpak van de materie was dus, ondanks het samenstellen van een gemengde werkgroep en in weerwil van de aanduiding van het onderwerp als complementair bestuur, de klassieke government-benadering. Zowel de inhoudelijke oriëntatie van de werkgroep als het gebrek aan doorwerking van die elementen die leken op netwerksamenwerking in het bestuursbeleid, bevestigt de dominantie van die bestuurstheorie in het ministerie van Binnenlandse Zaken. Erkend moet worden dat de eerste voorzichtige stappen ter verkenning van een andere benadering het hoogst haalbare was. De tijd was bij Binnenlandse Zaken en zijn politieke omgeving niet rijp voor echt netwerkbestuur. We kunnen de score A - toekennen.

Het interessante van deze casus is vooral de complete doofpot waar het onderwerp binnen Binnenlandse Zaken in terechtkwam. Zozeer dat omstreeks 2010 waarschijnlijk nog minder mensen de term kennen dan in 1980. Ook kan de invloed van dit rapport in het discours binnen het bestuursbeleid worden verwaarloosd. Het heeft, behalve onder de directe deelnemers van de werkgroep, geen invloed gehad op de ontwikkeling van de bestuurstheorie van Binnenlandse Zaken. En daar gaat het hier om.

\subsection{Bestuur op niveau, stadsprovincies}

\subsubsection{Inleiding}

Vernieuwing Bestuurlijke Organisatie, Bestuur op Niveau

$\mathrm{Bij}$ de reorganisatie van het binnenlands bestuur betrof het voorstel alle provincies. Bij het volgende offensief vanuit dezelfde gedachtegang in 1992 was de les geleerd dat dit te veel vijanden op een hoop dreef. Dat project heette 'Vernieuwing Bestuurlijke Organisatie' (VBO, ook wel met de subtitel 'Bestuur op Niveau' (BON) aangeduid) en dat ging om de vorming van stadsprovincies. Ditmaal was het ook een project in formele zin, omdat een aparte organisatie-eenheid werd ingericht met deelnemers van direct betrokkenen. Dit project eindigde in 1995 abrupt door de uitslag van het referendum over de Stadsprovincie in Rotterdam.

Projectorganisatie, projecttrekkers

Secretaris-generaal Jozias van Aartsen zag in dit project voor zijn departement een kans geschiedenis te schrijven. Hij stond erom bekend graag rechtstreeks te werken met een aantal jonge vertrouwelingen overal in het ministerie. Persoonlijke kwaliteiten wogen bij hem zwaarder dan sterren en strepen. Een van die ambtenaren was Pien Zaaijer, die al eerder met speciale opdrachten was belast, zoals lid van de Interdepartementale Werkgroep Privatisering (IWP, zie paragraaf 9.3) en co-secretaris van de commissie-Wiegel over departementale herindeling. Pien Zaaijer werd projectleider en innovatiedrager van VBO. Zij werd meteen in een directeursschaal aangesteld. Kort daarna werden aan haar VBO-team hoog betaalde deelprojectleiders toegevoegd. In de eerste plaats Wandi van Leeuwen, die van Financiën overkwam. Ruby Hoogerboord en Gerard Houterman bleven formeel medewerkers van hun afdeling (Coördinatie Bestuursbeleid), maar waren de facto volledig met VBO bezig.

Pien Zaaijer en Gerard Houterman zijn voor deze casus geïnterviewd. Bronnen voor deze casus zijn verder het rapport van de commissie-Montijn (1989), de Nota's Bestuur op Niveau 1, 2 en 3 (Tweede Kamer 21062) en de Kaderwet Bestuur in verandering (TK 23048). Daarnaast wordt verwezen naar een artikel van Koppenjan en Zaaijer (1997).

\subsubsection{Projectbeschrijving en verhalen}

Geboorte van een nieuw project

Aanleiding om weer te beginnen was de problematiek van de grote steden. De commissie-Montijn (1989) had deze in verband gebracht met de besluitvormingsstructuur in het ommeland. In 
bestuurlijk Nederland waren er veel aanhangers te vinden van de stelling dat een opschaling van de bestuurlijke organisatie aan het oplossingsvermogen voor talrijke maatschappelijke problemen zou bijdragen. Maatschappelijke problemen die vooral tot uiting kwamen in de grote steden. De grootste protagonisten van Bestuur op Niveau waren dan ook de burgemeesters van de grote steden, Peper en Patijn. In de politieke wereld was wederom de PvdA de grootste aanhanger van operatief ingrijpen. Van Heemst was in de Tweede Kamer de woordvoerder van deze fractie. Het rapport van de commissie-Montijn (zie ook paragraaf 7.3) verscheen aan het eind van de kabinetsperiode in 1989; tijdens de kabinetsformatie was er dus gelegenheid om grootse daden aan te kondigen. Daar kwamen weinig ambtenaren aan te pas.

Eind 1986 was de Rijksplanologische Dienst gevorderd tot de Vierde Nota Ruimtelijke Ordening met omvangrijke bouwopgaven in groeikernen buiten de grote steden. Vanuit de Vinex-nota (Vierde Nota Extra) is toen de roep om 'Bestuur op Niveau' ontstaan en al in 1988/1989 heeft Binnenlandse Zaken een projectgroep opgericht om een nota over bestuurlijke organisatie voor te bereiden. Voor de bij Vinex behorende verkeersvoorzieningen werden in korte tijd Vervoerregio's ingericht, wat volgens Gerard Houterman ${ }^{25}$ bij Binnenlandse Zaken de verzuchting deed slaken: "Zie je, het kan wél! ... Maar zó, sectorgewijs, moet het niet."

\section{Gedifferentieerde, stapsgewijze aanpak}

De verandering ten opzichte van de operatie in de jaren zeventig was dat niet meer openlijk gestreefd werd naar een landsdekkend model. Daarnaast was de aanpak eerder van onderop, opschaling van het grootstedelijk gemeentebestuur, dan aanpassing van de provincies, al waren de gevolgen voor de resterende provincies niet minder ingrijpend en pijnlijk. Maar in ieder geval kreeg Binnenlandse Zaken niet meer alle gemeenten tegen. Bovendien werd behoedzaam begonnen in die gebieden waar de problemen het ernstigst werden ervaren en de animo voor een alternatief bestuursorgaan relatief het grootst was (daarom naast de vier grote steden regio Eindhoven, Twente wel; West-Brabant, de Stedendriehoek en Zuid-Limburg niet). Maar het bleek nog lang niet behoedzaam genoeg. Bovendien was een gefaseerde aanpak op zichzelf niet echt nieuw. Al tijdens de neergaande spiraal van de Reorganisatie binnenlands bestuur omstreeks 1980 viel minister Wiegel terug op een geleidelijke invoeringsstrategie. "Met de provinciale herindeling zal worden begonnen in die gebieden waar zulks urgent is en de omstandigheden daartoe aanleiding geven" (Memorie van Antwoord, TK 1980-1981, 14322, nr. 28: 11).

Behoedzaam? Het project was toch vooral gebaseerd op een overrompelingstactiek om de weerstand te breken. Dat was de tweede uiting van het feit dat was geleerd uit de ervaringen van de Reorganisatie binnenlands bestuur, die in de modder was vastgelopen. Projectleider Pien Zaaijer omschrijft het zo:26
"Je moet met een dergelijke operatie die rammelt aan de machtsrelaties haast maken. Dit keer hadden we twee troeven: een krachtige kongsi van gemotiveerde bestuurders en de overval die werd gecreëerd tijdens de kabinetsformatie van 1989. Vooral de tegenmacht van de provincies, van het IPO moest hiermee worden doorbroken en dat is goeddeels gelukt."

De periode waarin de weerstand tegen bestuurlijke reorganisatie bij grote uitzondering leek te kunnen worden doorbroken (in het bijzonder Regio Rotterdam 1992-1994), was misschien toch nog te kort om een zo ingrijpende verandering inclusief wetswijziging te realiseren, hoe voortvarend de unieke combine van ambtenaren en bestuurders uit Rijk en regio ook werkte.

\section{Ambities}

\footnotetext{
25 Interview met Gerard Houterman, 2 augustus 2007 te Utrecht.

${ }^{26}$ Interview met Pien Zaaijer, 19 juli 2007 in het Paleis Noordeinde te Den Haag.
} 
Tijdens het project was iedereen ervan overtuigd dat het nu eindelijk zou lukken. Tegelijkertijd zuchtten de medewerkers onder de complexiteit van de aanpak. Alles moest worden gekoppeld, iedereen moest meepraten, ter wille van de heilige integraliteit en de samenhang. Achteraf zijn de inschattingen over de stuurbaarheid en wenselijkheid van een dergelijk ambitieus project verschillend. Zaaijer meent nog steeds dat men gewoon had moeten doorzetten:

"Het is doodzonde dat de politiek het hoofd heeft gebogen voor die voor de wetgever tot niets verplichtende referenda. Het had best gekund. De provincies bleven weliswaar ongelofelijk kritiek leveren vanuit eng positiedenken. Dat is me wel tegengevallen van het IPO, dat zij nooit in staat waren over hun schaduw heen te springen ter wille van de grote belangen die op het spel stonden, maar gelukkig deden zij dat nogal doorzichtig, zodat de politiek hen uiteindelijk wel had afgestraft."

Volgens sommige geïnterviewde projectmedewerkers was het misschien beter geweest om eerst alleen in de regio Rotterdam, en desnoods Amsterdam, voorzichtig te gaan experimenteren met veel specifiek plaatselijke elementen. Dan was de voortgang van het project zonder de ballast van andere gebieden misschien nog voortvarender geweest, en vooral hadden meer herkenbare elementen van elk gebied opgenomen kunnen worden. Deelprojectleider Gerard Houterman, van huis uit politicoloog, meent achteraf anders dan Pien Zaaijer dat het project vanaf het begin de hand overspeelde. De ingreep in de politieke machtsverhoudingen waren volgens hem gewoon te groot om die zonder revolutie of staatsgreep te laten gebeuren.

Hij mijmert nu tijdens het interview:

"Ik droomde wel eens, en nu nog wel, van een andere aanpak in het openbaar bestuur: houd het simpel. Probleem voor probleem, met maatwerk. Als een bepaald groot maatschappelijk probleem wordt gesignaleerd, waarom geef je het dan niet aan een tijdelijke projectorganisatie met de opdracht alle betrokkenen te verzamelen en dan net zo lang te werken tot het is opgelost. Nee, maar je moet nu alles en nog wat erbij slepen ter wille van gelijkheidsbeginselen, integraliteit, et cetera. Typisch is ook het grotestedenbeleid zo aangepakt. Ik heb bijvoorbeeld nooit begrepen waarom de provincies zo nodig bij het grotestedenbeleid aan tafel zaten, wat die ermee te maken hadden. Projecten worden bij Binnenlandse Zaken altijd onnodig groot opgeblazen en zijn dan niet meer beheersbaar. Ook in het VBO was het veel beter geweest als we op kleine schaal, in Amsterdam en in Rotterdam bijvoorbeeld, met uitzonderingsbepalingen hadden kunnen experimenteren op bepaalde terreinen, maar dat laten onze wetgeving en onze gelijkheidsdoctrine niet toe."

\section{Voortgang, denklijn met draagvlak}

Het proces van wetgeving verliep uiterst voortvarend. Dit was nu zo'n voorbeeld waar de ambtelijke machinerie gesmeerd liep. Er zat bepaald flow in het project, Binnenlandse Zaken haalde alles uit de kast en wist de bestuurlijke omgeving optimaal te mobiliseren en te regisseren. De beleidsredenering ${ }^{27}$ was samenvattend gebaseerd op drie pijlers:

- Door een toespitsing van de vorming van nieuw agglomeratiebestuur op die gebieden waar de problemen van stad en ommeland het sterkst werden ervaren en de animo voor reorganisatie ook het sterkst was, kwam de reorganisatie tegemoet aan reëel ervaren problemen van bestuurlijke stagnatie en drukte.

- De toekenning van provinciestatus aan stedelijke regio's voorkwam de vorming van een vierde bestuurslaag en ook de noodzaak om de Grondwet te wijzigen, die slechts voorziet in gemeenten en provincies. De attributie van de meeste ordenende taken aan de stadsprovincie zorgde voor slagvaardig en daadkrachtig bestuur op het juiste niveau, dat bovendien van democratische legitimatie was voorzien.

${ }^{27}$ Gebaseerd op Memorie van Toelichting bij de Kaderwet Bestuur in Verandering, TK 1992-1993, 23048, nr. 3. 
- De gelijktijdige vorming van (deel)gemeenten waarborgde de inrichting van stevige, levensvatbare en gelijkwaardige eenheden van lokaal bestuur voor de bestuurstaken dichtbij de burgers, waarbij de scheve machtsverhouding tussen het bestuur van de grootste gemeente en de randgemeenten in de regiobesturen werd doorbroken.

Binnen de grote steden was er echter ook weerstand, vooral tegen het onvermijdelijke laatste onderdeel van het pakket, namelijk dat de stadsprovincie gepaard moest gaan met opsplitsing van de grootstedelijke gemeente in deelgemeenten op de schaal van Amstelveen en Hoogvliet. In Rotterdam manifesteerde zich de tegenstand in een lokale Stadspartij van Manuel Kneepkens, die bij de gemeenteraadsverkiezingen van 1994 flink aanhang won.

\section{Stagnatie}

Er waren, het verdere verloop overziende, drie punten waar de beleidsredenering op strandde:

- de veronderstelling dat er territoriaal schaalniveau als een gemeenschappelijke noemer gevonden zou kunnen worden die de bovengemeentelijke problemen ongeveer zou dekken (een gebied met een bepaalde straal rondom de centrumstad); deze gedachte bleek uiteindelijk onvoldoende onaantastbaar om iedereen te overtuigen van de noodzaak van de ingreep; 28

- de veronderstelde centripetale kracht uit de grote steden die voldoende zou zijn om de centrifugale krachten vanuit de provincies en ook een aantal argwanende randgemeenten te overwinnen;

- $\quad$ de veronderstelde onverschilligheid van de burgers ten aanzien van de inrichting van bestuurlijke entiteiten.

Dat laatste gaf uiteindelijk de nekslag na het idee van de twijfelende nieuwgekozen Rotterdamse gemeenteraad om de stadsprovincie in een referendum aan de burgerij voor te leggen. Die beslissing weerspiegelt overigens op zichzelf ook weer scheuren in de hechte coalities achter de schermen, de Rotterdamse voorhoede van gelovigen met hun achterbannen in stad en regio. En tussen de Rotterdamse behoefte om een eigen weg te volgen met het landelijke project Bestuur op Niveau bestonden ook spanningen, die na de kabinetswisseling waarbij staatssecretaris De GraaffNauta werd opgevolgd door Tonny van de Vondervoort, duidelijker aan het licht traden (Koppenjan en Zaaijer, 1997: 218).

\section{Afhechting}

Een ander niet echt opgelost probleem, namelijk wat er moest gebeuren met de weinig samenhangende brokstukken van de resterende provincies Noord- en Zuid-Holland, is nooit bevredigend opgelost. Daar kwam het VBO-project gewoon niet meer aan toe. Op 17 mei (referendum Amsterdam) en na 7 juni 1995 (referendum Rotterdam) kwam de wagen met korte schokken tot stilstand.

$\mathrm{Na}$ de schok van het referendum is nog even geprobeerd de motor weer aan de gang te krijgen. $\mathrm{Er}$ werd in 1996 een zware commissie onder leiding van oud-Eurocommissaris Frans Andriessen ingesteld met de opdracht om de regio Rotterdam voor de tweede keer te proberen vlot te trekken. Gerard Houterman, die als secretaris mocht optreden, blikt met genoegen hierop terug:

"Ik dacht dat wordt een gebed zonder eind: vijf bedaagde mannen. Maar het ging als een mes door de boter. Ze wilden maar vijf of zes keer vergaderen, ze waren akkoord met mijn planning, ik vertelde wat er speelde, ze vroegen: zoek dat nog eens uit. Helemaal geen gezeur.

\footnotetext{
${ }^{28}$ De feiten maken deze constatering verklaarbaar. Het mobiliteitspatroon van de bevolking is grilliger en verder voortgeschreden dan de kaartjes van gewesten en stadsprovincies wilden doen geloven. Eigenlijk was dat al veel eerder gebeurd. Zo wordt bijvoorbeeld al sinds het begin van de twintigste eeuw de recreatiebehoefte van de Amsterdammers voldaan in de Loosdrechtse plassen en in Zandvoort. Verder halen zij hun werkgelegenheid in IJmuiden (Hoogovens en haven), gingen ze wonen het Gooi en later Almere; allemaal buiten het Regionaal samenwerkingsgebied Amsterdam gelegen. Aan het eind van de twintigste eeuw waren de netwerkrelaties nog veel verder uitgedijd, waardoor het vangen van de belangen van de burgers in bestuurlijke grenzen nauwelijks nog doenlijk was geworden.
} 
Die mensen hadden ook zoveel ervaring; ik vond dat schitterend. Wat ik niet verwacht had, is dat die stadsprovincie Rotterdam zo gauw weer in beeld kwam. Een hele hoop mensen die wij spraken, zeiden: het is toch zonde, we waren zo dichtbij en er is zoveel in geïnvesteerd. Toen zei Andriessen: wat zouden we toch moeilijk doen, laten we er één gemeente van maken. Toen hebben we hem ervan kunnen overtuigen: als je dat doet, is het einde oefening, dat wordt door niemand gepikt. Nou toen kwamen we met een nieuwe stadsprovincie boven op de bestaande gemeenten, met een groter gebied en wat andere bevoegdheden. De Eerste Kamer heeft daar een stokje voor gestoken en toen was het schluss."

\subsubsection{Aanwijzingen voor de gehanteerde bestuurstheorie}

\section{Doelstellingen}

Nu volgt een typering van de denkwijze binnen het project VBO/Stadsprovincies.

De doelstelling van het beleid is duidelijk gericht op versterking van bestuurscentrisme, door het leggen van verantwoordelijkheden in één hand. De integraliteit en de eenheid van bestuursbeslissingen staan voorop en de beslissingsbevoegdheid van een passend bestuurlijk gremium rond de grote steden zal dit resultaat bewerkstelligen. Er is een zekere concessie gedaan aan het uniformiteitsdenken door toe te laten dat een aantal stedelijke gebieden anders bestuurd zouden worden dan de rest van het land. Stilletjes hoopte men dat dit nodale bestuursmodel van lieverlee een olievlekwerking zou krijgen. In ieder geval ging de differentiatie niet zover dat elke regio naar eigen inzicht zijn bestuursverhoudingen kon regelen. Het waren in grote lijnen dezelfde taken en bestuursstructuren die in alle stadsprovincies werden vastgelegd.

\section{Sturingsaanpak}

Wat betreft de sturingsaanpak zien we een samenspel tussen politieke top-down sturing en het smeden van coalities met stedelijke partners. Gemeentelijke ambtenaren en bestuurders werken nauw samen met de projectleiders bij Binnenlandse Zaken. Ook met de vakdepartementen bestaan goede samenwerkingsrelaties, en niet alleen met VROM dit keer. Met stedelijke middenveldorganisaties, zoals de Kamers van Koophandel, de woningcorporaties en de arbeidsbureaus, bestaan contacten, maar veel verder dringt men niet door in de regionale samenleving. Het projectteam houdt nauw voeling met de minister en staatssecretaris en die informeren en consulteren op hun beurt de fracties in de Tweede Kamer intensief. Pien Zaaijer en Gerard Houterman typeren dit weliswaar als een andere wereld dan de contacten die ze hebben in het veld, maar die moet er ook zijn. Alleen één partij heeft iedereen over het hoofd gezien: de burgers van de grote steden.

De sturingsaanpak van het project was per saldo gemengd. De hoofdzaak was in aanvang pure top-down machtsstrategie ('overval'). Tijdens het project werkte men hiërarchisch met veel netwerktechnieken.

\section{Democratie-opvatting}

Als we de nadruk leggen op de verhouding overheid-samenleving, was er veel welwillendheid om achter de coulissen van het lokaal bestuur naar werkelijke samenlevingsprocessen te kijken, maar uiteindelijk ging men de verbinding met de plaatselijke gemeenschap niet diep genoeg aan. Als die zich bij referendum tegen de vorming van stadsprovincies, en vooral tegen het opheffen van de vertrouwde gemeenten, uitspreken, keert het tij. Uiteindelijk durft zelfs de Tweede Kamerfractie van de PvdA niet tegen de eigen achterban in te gaan die als kiezerspotentieel zo betekenisvol in aantal is, al betreft het slechts de inwoners van één van de gemeenten en een minderheid van de mensen die in de Stadsprovincie zouden opgaan. Evenmin als bij de overige projecten in dit dossier is participatieve democratie hier in beeld.

De informatieverwerving was weinig open voor zover het gaat om de beleidsvorming. De doelstelling lag vast; die kwam uit de partijpolitiek, op aangeven van het rapport van de commissieMontijn, waarna de PvdA-bestuurders hun wensen in de kabinetsformatie hadden ingebracht. De 
nodige wetgeving en de gebiedsindeling moesten zorgvuldig worden uitgewerkt. Daarbij werd veel overleg gepleegd en samengewerkt, maar dit proces bleef hoofdzakelijk ambtelijk en relatief verrassingsvrij. Er was dus sprake van uitwerking op basis van politieke instructie, die weer was gebaseerd op een strak rationele analyse. Dat staat tegenover open experimenten of toevallige ontwikkelingen op verschillende plaatsen waaruit zich een bepaald patroon aftekent of een variant wordt geselecteerd.

\subsubsection{Typering van dit project volgens overige onderzoekscriteria}

\section{Mate van beleidsvernieuwing}

Het proces van Bestuur op Niveau is met enige goede wil te beschouwen als een rechtstreekse beleidsopvolging van de Reorganisatie binnenlands bestuur, dat voorgoed leek te zijn afgeblazen. Maar in werkelijkheid is het ideaal van integraal regionaal bestuur nooit echt weggeweest en in feite was het dan ook meer continuering van oud beleid.

\section{Invloed op de bestuurstheorie}

De bestuurstheorie van Binnenlandse Zaken werd nauwelijks door dit project beïnvloed, hoogstens bevestigd. De massieve investeringen die erin werden gestoken, gingen niet naar fundamentele verkenningen over de verhouding tussen overheid en samenleving. De trein denderde in goede harmonie tussen de in aanmerking komende besturen onverdroten voort, totdat de burgers van Rotterdam en Amsterdam er een stokje voor staken.

\section{Leerprocessen en evaluatie}

Evaluatie van VBO heeft niet plaatsgevonden. Dat is toch wel opvallend tegen de achtergrond van de enorme inzet van middelen die Binnenlandse Zaken hiervoor heeft gebruikt. Veel medewerkers kwamen door het project in de positie om de praktijk van het regionaal bestuur uit eigen waarneming te leren kennen. Dat was een opening voor leervermogen, al ging men met een vooropgezette opdracht het land in. Natuurlijk is wel leergeld betaald, maar een schok in de werkwijze of in de ideologie van de mainstream, bijvoorbeeld in de geest van de droom van Gerard Houterman, heeft het zeker niet teweeggebracht. Gezien de aandacht die de leiding voor dit project heeft gehad, was de kans op zelfreflectie met behoorlijke impact aanwezig, maar de breed gedeelde waarneming dat het project toch "bijna geslaagd" was, dat het ook anders had kunnen aflopen, voorkwam al te diepgravende introspectie.

\section{Doorwerking, institutionalisering}

Over de doorwerking van het beleid is al duidelijk gemaakt dat de hoofdopzet niet is gelukt. Maar men is verder gekomen dan ooit. Het project kreeg grote actualiteit en bekendheid. Complete wetsvoorstellen waren ingediend bij de Tweede Kamer. Vooral het bestuurlijk momentum in de stedelijke gebieden is niet zonder gevolg gebleven. Weliswaar zijn er geen stadsprovincies gekomen, maar de gevoelde noodzaak van bestuurlijke ingrepen was in de gebieden reëel aanwezig. Gerard Houterman schrijft drie bestuurlijke 'verworvenheden' indirect toe aan het project VBO: de opschoning van de lappendeken van gemeenschappelijke regelingen, de betere intergemeentelijke verhoudingen tussen de centrumstad en de randgemeenten, onder meer in de samenwerkingsgebieden als Regionaal Orgaan Amsterdam ROA en Rijnmond en - tegen de draad in - het doorzetten van vrij grootschalige gemeentelijke herindelingen (of liever: annexaties) rond Utrecht (Vleuten-De Meern) en Den Haag (Nootdorp, et cetera). Zonder het gezaaide urgentiegevoel was dit volgens hem niet gelukt tegen alle weerstand in.

Uiteindelijk heeft ons land tot het begin van de 21e eeuw een product aan de Vernieuwing Bestuurlijke Organisatie overgehouden, namelijk Kaderwetregio's in dezelfde gebieden die waren voorbestemd stadsprovincie te worden. ${ }^{29}$ Dit zijn gemeenschappelijke regelingen met rechtstreeks

${ }^{29}$ De intrekkingswet WGR-plus maakt aan deze figuur per 1 januari 2013 een einde. 
bij wet toegekende bevoegdheden, bijvoorbeeld om infrastructuurmiddelen of woningbouwcontingenten te verdelen.

Evenals het product van de eerste Reorganisatie binnenlands bestuur (de provincie Flevoland) was dit een onbedoelde uitkomst. Het begon verdacht veel op een vierde bestuurslaag te lijken, maar dan zonder democratisch gekozen volksvertegenwoordiging. Bovendien voegde het nog een actor toe aan de veelheid van bestuursorganen in de dichtbevolkte Randstad, waardoor de bestuurskracht en efficiency volgens velen per saldo afnam in plaats van toenam.

\subsubsection{Conclusies}

De conclusie voor de hoofdvraag van dit onderzoek kan zijn dat op de as tussen government en governance alleen de sturingsaanpak (alles top-down) licht was opgeschoven ten opzichte van de Reorganisatie van het binnenlands bestuur, omdat althans binnen de bestuurskolom intensief werd samengewerkt. De doelstelling (verdelen van verantwoordelijkheden, niet delen: 'cockpitbestuur'), de democratieopvatting (in dienst van de representatieve democratie) en het leerproces (informatievergaring van achter de tekentafel of door wetenschappelijk onderzoek) wijzen onveranderd dezelfde kant op van de government-modus. $\mathrm{Er}$ is onvoldoende beweging in het denken om anders dan score A te concluderen. Door de brede inzet van medewerkers die zich ook met de praktijk van de nieuw in te voeren regelingen bezighielden, is enig leereffect door onderlinge discussie niet uit te sluiten. Er is echter niet geëvalueerd en niet officieel op de onverwachte stranding van het project gereflecteerd.

Met een nieuw regiobestuur zoals Binnenlandse Zaken steeds weer probeert te construeren, worden veel functies op één hoop gegooid: dienstverlening die een bepaalde schaal verlangt om doelmatig te zijn, het afwegen van conflicterende belangen tussen stad en platteland, doorzettingsmacht ten aanzien van grote projecten en democratische verantwoording en controle in gemeenschappelijke regelingen. Voor al deze functies is de oplossing Stadsprovincie te grof, zo stelden critici. Het werkt als een Zwitsers zakmes: dat kan álles, maar je zou toch liever een echte schroevendraaier, schaar of kurkentrekker hebben.

\subsection{Project middenbestuur}

\subsubsection{Inleiding}

Nog een derde poging, dit keer schaalvergroting van provincies Het project Middenbestuur liep van 2005 tot 2006, toen het als een nachtkaars uitging. De start borduurde voor het eerst voort op signalen uit de kring van provincies zelf, namelijk de wens om te komen tot krachtige vergrote bestuurlijke eenheden met de schaal van landsdelen.

Het geloof bij Binnenlandse Zaken in de inhoudelijke wenselijkheid en mogelijkheid van een bestuurlijke reorganisatie in het middenbestuur is anno 2007 nauwelijks aangetast, zo blijkt uit gesprekken met betrokken ambtenaren. ${ }^{30}$ Voor de meest betrokken ambtenaren ligt de dominante verklaring van het mislukken van structuurhervormingen niet bij hun analyse en toch ook niet bij de burgers. Zij zijn ervan overtuigd dat stiekem partijpolitieke belangen het opgeven van baantjes en posities in de bestaande bestuursorganen in de weg staan en ontlenen die mening onder meer aan de gang van zaken na het referendum. De eerdergenoemde commissie-Andriessen met gezaghebbende bestuurders was het al snel eens over de wenselijke doorstart van de Vernieuwing Bestuurlijke Organisatie. De stadsprovincies zouden in aangepaste vorm alsnog zo spoedig mogelijk gerealiseerd moeten worden. De Tweede Kamer wilde er echter niet aan. Men durfde de weerstand niet te trotseren. Als zoveel argumenten en gezaghebbende uitspraken de

\footnotetext{
30 Blijkens het interview met Pien Zaaijer, 19 juli, met Eduard de Wilde op 8 augustus 2007, dachten zij er toen nog steeds zo over. Maar dat geldt niet voor iedereen. Anderen zien het althans in retrospectief als overspannen blauwdrukdenken, zoals Gerard Houterman in een gesprek op 2 augustus en Frans van Bork op 21 augustus 2007.
} 
referendumuitslag niet konden overrulen, moesten er wel verborgen belangen uit de partijpolitieke sfeer meespelen, zo menen veel ambtelijke gesprekspartners. Zo sterk is de overtuiging bij Binnenlandse Zaken dat men werkte aan een goede zaak, maar die als gevolg van 'oneigenlijke' (politieke!) weerstanden niet kon winnen.

Als de analyse van Binnenlandse Zaken zo gedegen is, is het wel bevreemdend dat de oplossing niet steeds dezelfde kant op wijst. Dit keer was het IPO zo verstandig het initiatief in eigen hand te nemen. Weer een leerervaring van de vorige keer dus.

De provincies zagen kansen voor duurzaam en glorieus voortbestaan eerder in schaalvergroting dan in schaalverkleining. Op verzoek van het IPO werd een commissie onder leiding van voormalig topambtenaar Ad Geelhoed ingesteld, die in 2002 advies uitbracht onder de titel 'Op schaal gewogen'. Dit kwam uit op vier of vijf krachtige landsdelige provincies.

\section{Rol van Binnenlandse Zaken, projecttrekker}

Binnenlandse Zaken hield zich voorlopig koest in dit hernieuwde debat. Nieuwe pogingen moeten wederom van politieke interventies komen, en dan liefst gevoed door regionale initiatieven, zoals inderdaad gebeurde met de Holland Acht (2005). Deze combinatie van bestuurders van vier grote steden en vier Commissarissen van de Koningin (CdK) ging het om het creëren van een Randstadprovincie (of misschien twee, zoals CdK Borghouts van Noord-Holland bepleitte). De Haagse politiek was eerst zelf te zeer aangeslagen door de perikelen rond Pim Fortuyn (die overigens de provincies geheel wilde afschaffen). Pas in 2005 startte minister Remkes een nieuw project, maar voorzichtigheidshalve voorlopig zonder vooropgezette uitkomst als doel. Het heette Verkenning over de positie van het middenbestuur.

Dit keer was Helen Bader uitverkoren om de kar te trekken. Zij werd onder politieke verantwoordelijkheid van minister Remkes projectleider van een nieuw project, Middenbestuur, dat in feite vooral ging over de Randstad. Weer waren er een paar condities veranderd waardoor een gunstiger machtsbalans mogelijk leek. Ditmaal waren niet alleen de bestuurders van de grote steden, maar ook de vier provinciebesturen in het complot betrokken.

De analyse van dit project wint aan geloofwaardigheid door de kritische lezing van het manuscript door Jan Andries Wolthuis, die het proces van nabij heeft meegemaakt.

Bronnen zijn, naast eigen waarnemingen van de auteur, het rapport van de commissie-Geelhoed (2002), van de commissie-De Grave (2005) en de commissie-Kok (2008), het manifest van de Holland Acht (2005) en de interne nota van Wolthuis (2006).

\subsubsection{Projectbeschrijving en verhalen}

Eduard de Wilde, reorganisatieman van het eerste uur, bekent dat hij al eerder was bekeerd:

"Intussen zien we een andere omslag in het denken: vergroting in plaats van verkleining. Dat gebeurt onder invloed van denken in Europees verband ... Ikzelf kreeg steeds meer te maken met Europese zaken en de gevolgen van de EU voor het binnenlands bestuur ... Op een gegeven moment kreeg ik in verband met grensoverschrijdende samenwerking de opdracht om de taken van ons decentraal bestuur te vergelijken met die van onze Duitse buren. Toen pas kreeg ik in de gaten dat de deelstaten en zelfs de Bezirke onvergelijkelijk andere en meer uitgebreide taken hebben dan onze provinciebesturen. Ik heb contact gezocht met een professor in Munster en ben daarheen gereisd om een week lang bevoegdheden te vergelijken. We hebben toen een uitgebreide Bevoegdhedencatalogus gemaakt. Dat was voor het eerst dat zoiets gebeurde! Ik heb later ook nog een studie gemaakt van de Franse situatie en ook daar kwam ik tot de conclusie dat de schaal van het Nederlandse bestuur veel te benepen is als we om ons heen kijken." 
$\mathrm{Er}$ is natuurlijk ook een heel andere verklaring mogelijk voor deze plotselinge bekering van kleinere (stads)provincies naar grotere (landsdeel)provincies, namelijk als een andere poging om hetzelfde doel te bevorderen: krachtig (verlengd) lokaal bestuur. Als het einddoel geformuleerd kan worden als het verdelen van Nederland in enkele tientallen operationele bestuurlijke ('doe'-)eenheden of supergemeenten, zal het middenbestuur ook moeten opschikken, omdat dit anders veel te dicht op de lip van die eenheden komt. Dus alvast de provincies opschalen past in het zelfde denkpatroon als beginnen bij het reorganiseren van de eerste bestuurslaag en is zolang dat laatste nog niet lukt een logisch verdedigbare maatregel.

\section{Framing in termen van bestuurlijke drukte}

Het centrale concept waarmee bestuurlijk Nederland de eigen organisatie te lijf wilde, was in deze periode 'Bestuurlijke drukte'. De grote dichtheid van bestuurlijke verantwoordelijkheden zou de voortvarendheid van besluitvorming belemmeren, en voor de economische en ruimtelijke ontwikkeling van de Randstad uiteindelijk fatale gevolgen hebben.

Het project ging wederom voorzichtig van start, niet met een specifieke blauwdruk, maar met een open verkenning. Niettemin had die verkenning nog aanmerkelijk opener kunnen zijn als niet op voorhand van de probleemanalyse Bestuurlijke Drukte was uitgegaan, die werd aangedragen door de commissie-De Grave (2005): "Er zijn gewoon te veel besturen, er moet te veel overlegd worden. Daardoor stagneert de besluitvorming."

\section{Informatieverzameling, probleemdefiniëring}

Een voorstel dat in de zomer van 2005 intern aan Helen Bader is voorgelegd, ging uit van een open verkenning onder verschillende stakeholders over de beleving van de positie van het hele bestuur op het niveau tussen gemeenten en Rijk. Zeer inductief dus. De suggestie was hierbij zogeheten Beleidsmediators in te huren. Ook uit de afdeling IB kwamen voorstellen van soortgelijke strekking van de kant van Michel Visser in samenspraak met Jan Andries Wolthuis van de kennisafdeling SKO. Een dergelijke aanpak werd door de algemene leiding echter niet overgenomen. Frans Soeterbroek vond eveneens geen gehoor met zijn dodelijke commentaar op het rapport van de commissie-De Grave over bestuurlijke drukte:

"De commissie lijkt niet te beseffen dat het probleem van bestuurlijke drukte er iedere keer anders uitziet, afhankelijk van welk thema je centraal stelt. Als je, zoals de commissie doet, de wereld bekijkt door de ogen van de strijd tegen illegale arbeid kom je al snel tot de conclusie dat arbeidsinspectie en vreemdelingenpolitie nog intensiever moeten samenwerken. Er zijn echter ook thema's te benoemen (illegale vrouwenhandel?) die duidelijk maken dat die verantwoordelijkheden juist ontvlochten dienen te worden. En waar de commissie de bestuurlijke drukte bij de bedrijfsontwikkeling rond Schiphol wil oplossen door een bestuurlijke autoriteit voor dit gebied te creëren, lijkt dit een monstrum als je bijvoorbeeld de woningbouwopgaven in de Noordvleugel of de verzelfstandiging van Schiphol centraal zou stellen." 31

Even vlamt de oude geest weer op, maar dooft als een nachtkaars

${ }^{31}$ Gevonden in 2009 op www.bestuurskunde.nl/actueel/nieuws.php?nieuwsid=67. 
Helen Bader heeft toen wel nog Frans Soeterbroek uitgenodigd als adviseur, maar veel invloed heeft hij met zijn opvattingen over fluïde bestuursvormen ${ }^{32}$ niet gehad. In plaats van een echte verkenning in verschillende gebieden met ongetwijfeld verschillende uitkomsten werd een afstandelijke literatuurstudie uitbesteed en een aantal werkbezoeken georganiseerd met de minister, waarbij tevoren vaststaat dat de gelegenheid voor verrassende ontdekkingen minimaal zal zijn. De aap kwam al gauw uit de mouw. Het politiek bestuur was op reorganisatiepad. Waar dat goed uitkwam, werd het rapport 'Op schaal gewogen' van de commissie-Geelhoed (2002) van zijn stoflaag ontdaan. De uitkomst van het proces was in de loop van 2006 een nieuwe poging voor provinciale herindeling, maar ditmaal in de Randstad. De andere landsdelen zouden vanzelf wel volgen. Minister Remkes zag ervan af om zelf met wetsvoorstellen van die strekking te komen. Liever zette hij een nieuwe commissie aan het werk. Op de valreep, toen het kabinet-Balkenende III (CDA-VVD) al demissionair was, kwam de commissie-Kok vlak voor Kerst 2006 nog met een pleidooi voor de oprichting van een Randstadprovincie (Commissie-Kok, 2006).

Opvallend is dat de verkiezingsprogramma's voor de verkiezingen voor de Tweede Kamer op 22 november in datzelfde jaar die bestuurlijke wens nauwelijks weerspiegelden. Weer bleek het onderwerp reorganisatie binnenlands bestuur politiek nauwelijks te leven. Ook het coalitieakkoordBalkenende IV zweeg erover. Voor de Randstad werd een Urgentieprogramma aangekondigd, dat in handen werd gelegd van de minister van Verkeer en Waterstaat. Ach, en ook de term bestuurlijke drukte lijkt in 2008 alweer uit de mode in het wereldje van het binnenlands bestuur. Jan Andries Wolthuis van de afdeling IB maakte in 2006 nog een rondgang langs bestuurders in het land om zich te informeren over de werkelijke problemen achter dit begrip. Hij kwam tot de conclusie dat het idee voornamelijk tussen de oren zat. Interessante bevindingen zijn dat bestuurlijke drukte in de betekenis van het ervaren van complexe samenwerkingsrelaties belangrijke voordelen heeft en dat frictieloos bestuur op een bestuurlijke fictie berust. Daarnaast signaleert hij diepgewortelde cultuurkenmerken van het Nederlands openbaar bestuur die niet zomaar kunnen worden opgelost door een nieuwe structuur (Wolthuis, 2006). Deze studie illustreert mooi het verschil tussen de meer sociologische benadering van IB en de juridisch modificerende aanpak van BFO.

\subsubsection{Aanwijzingen voor de in dit project gehanteerde bestuurstheorie}

Het verhaal wordt eentonig: zowel qua inhoudelijke denkrichting, sturingsfilosofie, democratieopvatting als wijze van informatievergaring blijt een klassieke benadering van het openbaar bestuur dominant.

\section{Doelstelling}

\footnotetext{
$32 \mathrm{Er}$ is een veelheid van bestuurlijke arrangementen beschikbaar die geen van alle het optimale besturen zijn. Daarom zocht Soeterbroek bij zijn onderzoek niet naar een samenhangend systeem van sturingsmechanismen, maar naar bestuurlijke lichtheid. Een palet van in de praktijk naast elkaar voorkomende sturingsmechanisme presenteerde Soeterbroek aan de hand van een negental begrippen in de periferie van bestuurskundige theorieën. Is dit nieuwe taal van 'de ongekende overheid'? Deze negen begrippen zijn:

1. Multi-level governance; op welk niveau de besluitvorming te organiseren? Is er een samenhangend bestuurlijk systeem of is een orde een illusie?

2. Fragmegratie; oftewel hoe kom je tot een goede coördinatie en sturing van processen? Er is sprake van elkaar aanjagende en afwisselende processen van fragmentatie en integratie.

3. Dansen door de schalen; oftewel met lichtheid spelen met schaalniveaus. Denken en handelen op meerdere ruimtelijke, bestuurlijke en tijdsschalen.

4. Meta-governance; oftewel de overheid krijgt veel meer invloed door intelligenter om te gaan met sturing. Leidt dat tot een intelligente overheid of tot misplaatste maakbaarheid?

5. Creatieve destructie; oftewel modes in bestuurlijke agenda's. Opkomst, ondergang en herrijzenis van beleidsconcepten en denkmodellen.

6. Postmoderne betekenisgeving; oftewel sturen door discours. Sturen via verleidelijke beelden, verhalen en metaforen.

7. Multi-level games; oftewel op verschillende tafels spelen. Strategisch gedrag door instutionele logica of vervelende bestuurlijke spelletjes?

8. Coöpetitie; oftewel de dubbelcultuur van samenwerken en rivaliseren.

9. Paradoxaal sturen; oftewel hoe om te gaan met beleidsaccumulatie. Loslaten om greep te krijgen of de confrontatie aangaan om een brug te slaan?
} 
De doelstelling van het beleid lijkt aanvankelijk open en voorwerp van een zoektocht, die ook had kunnen uitkomen op een nadruk op netwerksamenwerking, maar dat is maar schijn. Zowel de Randstadbestuurders als de commissie-Geelhoed leggen de nadruk op de noodzaak verantwoordelijkheden in één hand te leggen. Nieuw is de schaal waarop men die verantwoordelijkheden projecteert, die vervaarlijk dichtbij de nationale staat oprukt. De argumentatie wordt dit keer niet ontleend aan de grootstedelijke problematiek, maar aan het verschijnsel bestuurlijke drukte. Overigens, hoewel bestuurlijke drukte als de kern van het probleem werd gezien, was het waarschijnlijk ook de verklaring van het mislukken van de oplossing. Al die organisaties die de drukte maken, hebben ook hun belangen bij de bestaande provincies.

\section{Sturingsaanpak}

Wat betreft de sturingsaanpak is even intern discussie geweest over een inductief zoekproces met vele, ook maatschappelijke partners, maar de uitkomst was klassiek. Binnen de bestuurskolom bestond dit keer relatief veel overeenstemming, zowel provincies als grote steden voelden wel voor landsdelige provincies; de departementen die allicht de meeste bedreiging zouden kunnen voelen van dit soort ideeën, waren minder betrokken in het overleg. Zij zullen gedacht hebben: het zal mijn tijd wel duren. En terecht. De discussie ging aan de samenleving wederom vrijwel geheel voorbij, laat staan aan burgers als citoyens in een participatieve democratie.

\section{Informatieverwerving}

De informatieverwerving was beperkt tot een uitbestede literatuurstudie, kennisnemen van de analyses van de commissies-Geelhoed en De Grave. Later kwam daar nog de commissie-Kok bij. Inhoudelijk zowel als procedureel was het allemaal gebaseerd op de ingenieursbenadering, die Tops heeft beschreven (zie ook paragraaf 5.2.2 en Tops, 1985: 58).

\subsubsection{Typering van dit project volgens overige onderzoekscriteria}

\section{Beleidsverandering}

De derde fase van beleidsopvolging na de Reorganisatie van het binnenlands bestuur en na Vernieuwing Bestuurlijke Organisatie kwam bepaald aarzelend op gang. Bovendien kan men zich afvragen of hier werkelijk sprake was van beleidsopvolging, of van geheel nieuw beleid. Immers, de insteek leek niet meer te zijn om het regionale gat op te vullen tussen gemeenten en provincies, maar veeleer om een daadkrachtiger en samenhangender bestuurseenheid in het leven te roepen op het niveau tussen de bestaande provincies en Rijk. De continuïteit zit wel degelijk in de behoefte om op het subnationale niveau wildgroei in bestuursstructuren op te ruimen (bestuurlijke drukte), hoezeer de verwachting dat dit mogelijk zou zijn door het creëren van nieuwe eenheden ook omstreden geacht moet worden. Beleidsaanpassing ontstond op het moment dat het open verkennend proces over de toekomst van het middenbestuur werd aangehaakt aan de locomotief van de Holland Acht, dat een probleemverkenning verving door een vooropgezette oplossing. Ook hier had dadendrang vanuit Haagse vergaderkamers de overhand boven verkenningen aan de bestuurstheoretische fundamenten.

\section{Leerprocessen en doorwerking}

Dit vrij weinig spectaculaire project heeft zo mogelijk nog minder doorwerking gehad dan zijn voorgangers. In de doodstille afronding van het proces was al helemaal geen plaats voor evaluatie en voor leereffecten is evenmin weinig aanwijzing te vinden. De rondgang van Wolthuis (2006), op eigen initiatief van de afdeling IB, heeft althans nog enig inzicht opgeleverd.

\subsubsection{Conclusies}

In het onderscheid tussen government en governance is bij het project Middenbestuur, dat direct afkoerste op het instellen van landsdelige provincies, weinig veranderd. Op het vlak van de 
doelstelling (verdelen van verantwoordelijkheden, niet delen), de sturingsaanpak (alles top-down), de democratieopvatting (in dienst van de representatieve democratie) en het leerproces (informatievergaring van achter de tekentafel, uit de commissiekamer of door wetenschappelijk onderzoek) bleef de government-modus dominant. Intern waren er enige aanvechtingen om het dit keer anders aan te pakken via een open verkenning, maar die suggesties kregen geen politieke en ambtelijke steun. Daarom weer score A. Het project was veel minder grootschalig opgezet dan de voorganger VBO. Contacten met het veld bleven beperkt tot enige werkbezoeken. Nergens blijkt reflectie op de bestuurstheorie als zodanig. Het project is door de val van het kabinet meegesleurd, maar onder het volgende kabinet bleek er geen animo om het weer op te pakken. Het project is ook niet geëvalueerd en heeft dus ook weinig bijgedragen aan de ontwikkeling van de bestuurstheorie binnen het subsysteem Binnenlandse Zaken.

\subsection{Dualisering van het gemeentebestuur}

\subsubsection{Inleiding}

Het idee dat het omgekeerd monisme binnen het decentraal bestuur moest worden doorbroken (het college is feitelijk de baas maar op papier de raad) werd politiek breed gedragen, maar de uitwerking was allerminst gesneden koek. Toch is deze gecompliceerde wetgevingsopgave binnen vier jaar gerealiseerd. Dit project had de vorm van een staatscommissie met de daaruit voortvloeiende wetgevingsarbeid die binnen het ministerie van Binnenlandse Zaken werd uitgevoerd. De implementatie vond plaats in een gezamenlijk opgezette organisatie-eenheid binnen de VNG. Dit alles speelde zich af binnen de kabinetsperiode van Paars II, tussen 1998 en 2002.

\section{Geboorte van een nieuw project}

In de jaren negentig groeide de onvrede over het functioneren van de gemeentelijke politiek. Gemeenteraadsvergaderingen waren zelden interessant. Tijdens verkiezingen werd het steeds moeilijker om lokale politiek over het voetlicht te krijgen. Bij het project Sociale vernieuwing zullen we het schokeffect nog tegenkomen dat de opkomstcijfers bij de gemeenteraadsverkiezingen van 1990 binnen de Haagse politiek teweegbracht. Dit werd vooral toegeschreven aan het monistisch stelsel van de Gemeentewet, waardoor wethouders en raadsleden vrijwel niet te onderscheiden rollen vervulden.

In 1998 zorgde een politieke impuls ervoor dat het streven naar dualisering in gemeenten op de beleidsagenda verscheen. Het onderwerp was in alle verkiezingsprogramma's van de grote politieke partijen geagendeerd. Het hoeft dus niet te verbazen dat dit thema in het regeerakkoord van het tweede paarse kabinet verscheen. Tijdens het eerste kabinet-Kok was al gewerkt aan voorstellen voor het mogelijk maken van de wethouder buiten de raad, maar nu moest de hele structuur van het gemeentebestuur op de schop. Een nieuw woord werd hiervoor uitgevonden: dualisering, wat neerkwam op ontvlechting. Ontvlechting betekent dat ieder orgaan, het college en de raad een eigen rol moest krijgen. De raad moest meer werk maken van controle op het handelen van het college en het college moest ruimte krijgen. Wethouders maakten niet langer deel uit van de raad. Een staatscommissie onder leiding van prof. Elzinga werd samengesteld om dit idee uit te werken.

\section{Politiek en ambtelijk ondernemerschap}

De secretaris van die commissie werd na een korte aanloopperiode Meine Henk Klijnsma. Deze heeft niet alleen het rapport van de commissie, maar ook de wetgeving en de latere implementatie ondersteund. 
Bronnen voor de beschrijving van dit project vormen interviews met Klijnsma en Van der Linde. Daarnaast de Kamerstukken betreffende de Wet dualisering gemeentebestuur (TK 28243) en de Wet dualisering provinciebestuur (28243), alsmede de evaluatierapporten van de commissieLeemhuis (2004) en van de commissie-Hermans (2005). Voorts is geput uit de congrespublicatie 'Staat van de dualisering' (Ministerie BZK, 2008) en uit het boek van Boogers (2010) over lokale politiek.

\subsubsection{Projectbeschrijving en verhalen}

\section{Als een mes door de boter}

De meeste verhalen over de dualiseringsoperatie spreken van verbazing over het proces. Dat het lukte om binnen één kabinetsperiode de hele cyclus van beleidsvoorbereiding, wetgeving en begin van implementatie voor elkaar te krijgen. Dit wijst op een sterk top-down gestuurd proces, maar er moet ook al voldoende draagvlak in het politiek en gemeentelijk veld gezaaid zijn.

De onverwacht royale realisatiescore van de aanbevelingen van de commissie is in belangrijke mate te danken aan de inzet en aan het politiek ondernemerschap van de voorzitter en secretarissen van de commissie. Het heeft co-secretaris Klijnsma verbaasd hoeveel ruimte een projectmedewerker als hij kon krijgen om een belangrijke kwestie als deze te sturen. ${ }^{33}$ Noch de Tweede Kamer, noch de politieke of ambtelijke leiding van het ministerie hebben veel tegenspraak of bijsturing geleverd. Een van de redenen kan ook zijn geweest dat de kwestie van de burgemeestersbenoeming, waaraan de commissie-Elzinga veel woorden heeft gewijd, als een bliksemafleider fungeerde. Die discussie werd uiteindelijk elders uitgevochten. Intussen werden vrijwel alle ingrijpende structuurveranderingen in de positie van de raad, de competenties van het college van burgemeester en wethouders, de nieuwe instrumenten van de lokale democratie zoals de rekenkamer en onderzoeksmogelijkheden van de raad, zonder slag of stoot aanvaard. Deze thema's geven al aan waar de bestuursdoelstellingen en de democratie-opvattingen van de dualisering op gericht waren.

\section{Doelbereiking en effecten}

De hoofdgedachte was versterking van de lokale democratie, ten koste van de dominantie van het bestuur. Zo moesten de raadsdebatten levendiger worden. Als we nu, na een aantal jaren, het geweeklaag horen van wethouders die op grote schaal naar huis worden gestuurd, lijkt de opzet geslaagd te zijn om de gemeenteraad meer tanden te geven. Aardema, et al. (2011: 81) stellen in hun onderzoek naar vallende wethouders vast:

"Sommige ex-wethouders zien verband met het in 2002 ingevoerde duale stelsel: 'De fractie was wel blij met het dualisme. Men voelde zich wat vrijer en niet bij voorbaat ingeperkt door de kennis van de wethouder. Men stelde zich ook wat 'macho' op ten opzichte van het college.' Deze ex-wethouders menen dat hun conflict tien jaar eerder niet zo snel zou zijn voorgekomen."

Indien het de bedoeling was om iets te doen aan de machtsbalans tussen raad en college, zou dit signaal wijzen op een zeker succes. Of dit ook de kwaliteit van het gemeentebestuur en in het bijzonder van de lokale politiek ten goede is gekomen, is een andere vraag. In de ogen van de ondervraagde wethouders is dat niet het geval. Sommigen zien een verslechtering van de kwaliteit van de raadsleden. Dat is natuurlijk een subjectief gegeven en mogelijk beïnvloed door de frustraties van een wethouder die in een conflict het onderspit heeft gedolven. Als het al waar zou zijn, is dit niet het gevolg van het dualisme. Wel voor zover de wethouders meer haantjesgedrag bij raadsleden signaleren (Aardema et al., 2011: 83). Maar in hetzelfde onderzoek komt ook kritiek van de kant van de raadsleden op de effecten van dualisering:

33 Interview met Meine Henk Klijnsma op 26 juli 2007 in Den Haag. 
"De bestuurlijke verantwoordelijkheid ligt bij het college. De raad ziet daarop toe. Een raadslid: 'Het is nu minder leuk om raadslid te zijn. Je gaat er niet meer over. Je stelt kaders en het college gaat aan de slag, terwijl je er vroeger zelf over ging. Je bent nog slechts kritisch volger."' (Aardema et al., 2011: 82)

Voor zover de verwachtingen waren gericht op levendige politieke debatten en vitale politieke partijen op gemeentelijk niveau, zijn die overwegend beschaamd.

Volgens Klijnsma kan ook worden vastgesteld dat interpretaties van de dualisering in belangrijke mate zijn bepaald door de push-factor van de bureaus die, nog voor inwerkingtreding van de wet, op grote schaal omzet roken met het aanbieden van cursussen en begeleidingstrajecten. Klijnsma leidde deze indruk af aan het gegeven dat opeens in de adviespraktijk op gemeenteniveau relatief nieuwe thema's naar voren kwamen die in de commissie helemaal niet zoveel nadruk hadden gekregen. Zoals het invulling geven aan de 'kaderstellende taak'.

Hoewel kritiek op de dualisering niet van de lucht was, is de invoering van het nieuwe systeem intussen even onomkeerbaar als het Qwerty-toetsenbord.

\section{Vernieuwingsimpuls}

Annex aan het wetgevingsproces is veel aandacht besteed aan de implementatie van de dualisering, dat is gepresenteerd als een cultuurverandering, de zogeheten Vernieuwingsimpuls. Samen met de VNG is een projectorganisatie ingericht, die de gemeenten inging om met raad en daad bijstand te verlenen bij de ingrijpende veranderingen in werkwijze. Aanvankelijk waren in dit Actieprogramma Lokaal Bestuur ook medewerkers van Binnenlandse Zaken gedetacheerd, die hiermee rechtstreeks toegang kregen tot de gemeentehuizen. Op deze manier kwam weer een directe informatiestroom over de werkelijkheid van het lokaal bestuur het ministerie binnen. Zoals we ook zullen zien in hoofdstuk 7 en 8 , was deze grensoverschrijdende activiteit echter van beperkte duur, omdat die zich moeilijk laat rijmen met de doctrine van het Huis van Thorbecke. Althans met de interpretatie van Binnenlandse Zaken van de autonomie der bestuurslagen.

Een interessant aspect is ook dat men begon te werken met een aantal pilotgemeenten om hier ervaring op te doen met de wijze waarop de in Den Haag bedachte plannen in de lokale praktijk werden ontvangen en verwerkt. Dit wijst op een erkenning binnen het ministerie van het belang van de lokale werkelijkheid, die niet per se congruent behoeft te zijn met de Haagse beelden daarvan.

De introductie van de dualiseringsoperatie als een cultuurverandering bracht vooral bij gemeenten hier en daar fundamentele discussies op gang over de positie van de gemeente, over de relatie met de samenleving en over de regierol van het lokaal bestuur. Binnen Binnenlandse Zaken was hiervan echter niet veel te merken, althans buiten het directe kringetje van de projectmedewerkers van de Vernieuwingsimpuls. Als handreiking voor de gemeenten produceerde de Vernieuwingsimpuls via de VNG een vijttiental boekjes over diverse aspecten van de dualisering, zoals de modelverordening voor de raad, de rekenkamer, et cetera. De VNG heeft in dit kader een handreiking gepubliceerd voor de samenloop tussen interactief bestuur en de dualistische verhoudingen tussen gemeenteraad en gemeentebestuur (Vernieuwingsimpuls, 2003). Bij Binnenlandse Zaken waren op dat moment alweer andere zaken actueel.

\subsubsection{Aanwijzingen voor de gehanteerde bestuurstheorie}

Op een aantal punten heeft dit project wel degelijk een bijdrage geleverd aan de bestuurstheorie van Binnenlandse Zaken en wel vooral in de fase van implementatie toen de organisatie werd geconfronteerd met de werkelijkheid van het lokaal bestuur. Ook de evaluaties waren in dat opzicht verfrissend. In de fase van beleidsontwikkeling was een relatief nadeel dat het denkwerk vooral plaatsvond in en rond de staatscommissie, dus grotendeels buiten de organisatie. 


\section{Doelstelling en beleidsredenering}

De hoofddoelstelling van het initiatief was gericht op het versterken van het politiek fundament van het lokaal en provinciaal bestuur. In dat opzicht is de focus dus voornamelijk gericht op het machtscentrum en op de representatieve democratie. Daarmee is het een exponent van de government-benadering. Daarnaast zitten er ook interessante hiermee contrasterende kanten aan het beleid, zoals zich dat gaandeweg in de praktijk heeft ontwikkeld. Er is niet eenzijdig gewerkt aan het versterken van de volksvertegenwoordiging, maar het arrangement heeft sterke trekken van een stelsel van checks en balances gekregen. De betrekkingen met de 'derde actor' naast de volksvertegenwoordiging en het dagelijks bestuur, de al dan niet georganiseerde civil society, zijn hierbij wel onderbelicht gebleven. ${ }^{34}$ De representatieve democratie was duidelijk primair. Verder is de implementatie van het model zorgvuldig betrokken bij de nieuwe wetgeving. Hierdoor kon Binnenlandse Zaken meer gevoel krijgen voor de moderne praktijk in het lokaal bestuur, maar dat ook veel governance-werkelijkheden hiermee verder het ministerie binnenstroomden, kan niet worden vastgesteld.

\section{Sturingsaanpak}

Qua sturingsaanpak kan wel worden gesproken van een overrompelende top-down benadering, maar wel moet daarbij worden aangetekend dat er een jarenlange discussie in gemeenteland aan vooraf is gegaan, en dat de uitkomsten zeker op draagvlak in het veld konden rekenen.

Vooral in de implementatie- en uitwerkingsfase is er werkelijk sprake geweest van een wisselwerking tussen beleidsniveau en het veld van de gemeentelijke praktijk. In dit opzicht toonde BiZa bij de informatieverwerving even zijn governance-gezicht. Maar deze aanpak was wel weer tijdelijk.

\subsubsection{Typering van het project volgens overige onderzoekscriteria}

\section{Typering als beleidsverandering}

Hoewel het als compleet nieuw oogt, dateert het streven naar een evenwichtige verhouding tussen de democratische organen in het lokaal bestuur al uit de tijd van Thorbecke zelf. Ook in de nieuwe Gemeentewet van 1983 is natuurlijk naar de tekortkomingen van het monisme gekeken, maar de tijd was pas rijp toen in 1998 de landelijke politiek het aandurfde dit aan te pakken. In termen van Hogwood en Peters is dit beleidsaanpassing.

\section{Leerprocessen en doorwerking}

De doorwerking is boven elke twijfel verheven. De ingrijpende verandering werd binnen één kabinetsperiode met wetgeving en al gerealiseerd. Het ministerie heeft ook voorbeeldige nazorg betracht door het veranderingsproces actief te ondersteunen.

Het beleid is meermalen geëvalueerd. Misschien heeft het succes van het project hiertoe bijgedragen. In ieder geval zijn er zelfs nieuwe commissies ingesteld om deze evaluatie te begeleiden. Het betreft de commissie-Leemhuis voor de gemeenten en de commissie-Hermans voor de provincies, die in 2004 en 2005 respectievelijk de rapporten 'Aangelegd om in vrijheid samen te werken' en 'Zonder wrijving geen glans' uitbrachten. In 2008 werd ook nog na uitgebreid onderzoek door Binnenlandse Zaken de 'Staat van de dualisering' aan de Tweede Kamer gezonden. Nog weer later, in 2012, zijn instrumenten die rechtstreeks voortvloeiden uit de dualiseringsoperatie, zoals de gemeentelijke rekenkamers, geëvalueerd. De stelling is hierdoor vol te houden dat het dualiseringsproject een zeker zo grote investering in de ontwikkeling van de bestuurstheorie van Binnenlandse Zaken heeft betekend als de pogingen tot reorganisatie van het middenbestuur, maar dan dichter op de praktijk van het lokaal bestuur. Voor het onderwerp van dit

\footnotetext{
34 Is het inmiddels geen tijd om de dualisering te laten volgen door een volgende 'Vernieuwingsimpuls', waarbij de samenleving wordt aangehaakt aan de rol van de gemeenteraad: trialisering dus?
} 
boek is vooral interessant in hoeverre dualisering ook tot een duurzame cultuurverandering binnen gemeentebesturen heeft geleid. Daarvoor kunnen we ook nog gebruikmaken van de jaarverslagen van de Begeleidingscommissie van de Vernieuwingsimpuls. Hoewel het in de loop van de tijd steeds moeilijker is om de ontwikkelingen in het decentraal bestuur causaal te verbinden aan de ingreep in het bestel van 2002, wordt de analyse breed gedeeld dat de operatie enerzijds heilzaam is geweest voor het verhelderen van de verhoudingen binnen het gemeentebestuur. Ook wijzen de meeste analyses niet in de richting van een uitholling van de positie van de gemeenteraad, zoals wel was gevreesd. Ook al kunnen niet alle voorbeelden van vallende wethouders zonder meer aan de dualisering worden toegeschreven, zij onderstrepen dat de raad zijn tanden kan laten zien. Wat uiteindelijk niet lijkt te zijn gelukt, is het vitaliseren van de lokale democratie, een van de hoofddoelstellingen van de dualisering. Het had bijvoorbeeld tot de mogelijkheden behoord dat raden of raadscommissies rond complexe issues meer hoorzittingen waren gaan houden ten behoeve van de eigen meningsvorming, zoals de Tweede Kamer wel deed en doet. Maar daar tegenin staat dat raadsleden hun raadsparticipatie erbij doen, naast betaald werk. Van het vaak houden van hoorzittingen kwam dan ook weinig tot niets terecht. Misschien was dat politiseringsstreven ook wel een onmogelijke opgave, als tenminste wordt verwacht dat gemeenteraden in publieke aandacht zouden kunnen wedijveren met de Tweede Kamer en op een soortgelijke wijze (partij)politiek zouden kunnen bedrijven. Volgens Boogers (2010: 15-19) miskent dit het sui generis karakter van lokale politiek (zie paragraaf 13.2).

\subsubsection{Conclusies}

Per saldo noteren we bij het project Dualisering van het decentraal bestuur een governmentbenadering met enkele governance-kantjes. De indicaties met betrekking tot het onderscheid tussen government en governance betreffen de doelstelling in dit geval annex de democratieopvatting (in dienst van de representatieve democratie), de sturingsaanpak (overrompelende top-down besluitvorming, echter nadat het veld hiervoor rijp bleek). Alleen voor het leerproces tijdens de implementatiefase koos het ministerie tijdelijk de andere route door daadwerkelijk te gaan meelopen in de gemeentelijke organisatie. De meeste signalen wijzen dus nog de government-kant op. Door niet alleen de verhouding tussen de bestuursorganen, maar ook die met de samenleving in de probleemstelling te betrekken had dat misschien ook anders gekund. In theorie althans, want dan had het proces ongetwijfeld meer tijd gekost dan beschikbaar was binnen de ene kabinetsperiode. Hiervoor waren de tijd en het veld namelijk zeker niet rijp. Per saldo kan score A - worden toegekend.

Door het vele denkwerk dat intern aan het wetgevingsproces, de implementatie en later aan de evaluatie is besteed, bood dit project een werkelijke impuls aan eigentijdse visievorming.

\subsection{Conclusies over de bestuurstheorie bij bestuurlijke organisatie}

\subsubsection{Resumé van dit dossier in de loop van de tijd}

Massieve aandacht voor majeur probleem

Een beleidsinnovatie was in ieder geval de agendering van de gedachte dat het regionale gat moet worden opgevuld door nieuwe bestuurseenheden te creëren tussen de historisch gegroeide gemeenten en provincies (gewesten, doe-provincies, stadsprovincies). De veronderstelling dat een nieuw te scheppen bestuurslaag het probleem van integratie en coördinatie op het subnationale niveau kan oplossen, is een nieuwe probleemstelling en doelstelling in het bestuursbeleid. De weerbarstigheid van dit beleidsprobleem maakt dat meermalen ingrijpende beleidsaanpassingen en zelfs beleidsopvolging door een geheel nieuw project nodig was.

\section{Schaalvergroting}


Inhoudelijk is ten aanzien van het middenbestuur de volgende reeks beleidsthema's te reconstrueren: Gewesten - Ineenschuiven naar provincies - Complementair bestuur als nieuw concept - Stadsprovincies - Landsdelige provincies.

De aanpak van de projecten was klassiek, hoofdzakelijk van achter het bureau, met een uitzondering voor het VBO-project, waarin de constructieve samenwerking met stadsbesturen veel energie losmaakte.

De beleidsontwikkeling was niet een antwoord op een roep uit de samenleving. We zien een louter deductieve benadering vanuit een bestuurlijke elite.

Was er sprake van cumulatief leren? Waren evaluaties aanleiding voor bijstelling van de koers? Nauwelijks. De overgang van de reorganisatie van het binnenlands bestuur met 26 of een ander aantal doe-provincies naar een beperkt aantal stadsprovincies is zeker een uiting van enig leereffect: pak het probleem alleen daar aan waar werkelijke knelpunten worden ervaren en waar steun kan worden gemobiliseerd, dus niet landsdekkend. Maar de invulling was ook in de stadsprovincies overwegend uniform en gestandaardiseerd. Na 2000 had men uit het voorafgaande de conclusie kunnen trekken: 'laat de probleemdefinitie en oplossing door alle betrokken partijen, inclusief de bevolking bepalen', maar die stap heeft het ministerie niet gemaakt. Ook later kon men vaak horen dat de bevolking van een minister visie en sturing verwacht. Ministers zijn er om meerwaarde te bieden, om te 'scoren'. Gevolg is op het terrein van de bestuurlijke organisatie een grote mate van hardnekkigheid, althans op het middenveld van het openbaar bestuur, dat wil zeggen een streven naar een blauwdrukachtige structuuringreep die eigenlijk niet meer past in onze gefragmenteerde samenleving. Dit vormt een contrast met de onderkant van het bestuursgebouw, bij de gemeentelijke herindeling, waar incrementalisme wel de overhand had en waar per saldo meer resultaten behaald zijn.

Toch was ook daar de richting van het beleid een constante: schaalvergroting is een vereiste ter wille van bestuurskracht. De motor van het beleid was hier lange tijd het decentralisatiestreven. De toeneming van bevoegdheden en verantwoordelijkheden van het lokaal bestuur zou volgens de geldende bestuurstheorie door kleinere gemeenten niet meer verwerkt kunnen worden. Dat is een omstreden stelling als die niet wordt gerelateerd aan de aard van de taken en aan empirisch onderzoek naar de relatie tussen schaal en bestuurskracht. Daar waar sterke gemeenschappen van belang zijn voor de inbedding van collectieve actie, zou een daadkrachtig maar afstandelijk gemeentebestuur wel eens averechts kunnen werken. Veel gemeentelijke herindelingen zijn in weerwil van groot maatschappelijk verzet van de burgerij, ook herhaaldelijk via referenda met grote cijfers bevestigd, doorgevoerd. Het contrast met het referendum van Rotterdam is treffend. De machtsverhouding geeft de doorslag, waarbij Tweede Kamer en Binnenlandse Zaken de opvatting van verspreide lokale plattelandsgemeenschappen nog wel willen en kunnen trotseren. Weliswaar vindt gemeentelijke herindeling sinds 2002 alleen nog op vrijwillige basis plaats, maar de trend in het aantal gemeenten is onverminderd dalend. De bestuurstheorie over de bestuurskracht is dominant ongeacht of men bestuurders van nationaal, provinciaal of lokaal niveau erover hoort. Overeenkomst tussen bestuursbeleid over de organisatie van het lokaal bestuur en van het middenbestuur is het technocratisch patroon: het ideaal van een duidelijke verdeling van machtscentra, waarbij de verantwoordelijkheden in maximaal drie lagen eenduidig verdeeld kunnen worden en waarbij samenwerking en afwijkende maatwerkpatronen tot een minimum beperkt zijn.

In de volgende paragraaf volgt een overkoepelende analyse van de bevindingen in dit dossier in het licht van de hoofdvraagstelling van dit onderzoek.

\subsubsection{Gemeenschappelijke bestuurstheorie}

\section{Uniforme staatsopvatting}


Tops (1985: 21), Van der Heijden (1990: 165 e.v.) en anderen schrijven de aanpak van dit vraagstuk toe aan een bepaalde staatstheorie. In tegenstelling tot de pluralistische idee waarin de staat fungeert als arena waar de strijd tussen conflicterende belangen en opvattingen kan worden uitgevochten, is volgens deze opvatting de monolithische staat belast met de opgave om boven de partijen het algemeen belang te formuleren. Dit impliceert een apolitieke, centralistische, rationalistische en technocratische benadering. Als die opvatting bij Binnenlandse Zaken op alle terreinen zou domineren, waren we gauw klaar met onze probleemstelling. Dat is niet zonder meer het geval, zoals nog zal blijken in hoofdstuk 7 en 8 .

\section{Technocratische neiging}

Hier passen de kwalificaties van Boogers en Hendriks (2005), die in de discussies over het middenbestuur de volgende vaste patronen en kenmerken ontdekken:

- bestuurscentrisme;

- legalisme;

- generalisme.

Vooral bij de inrichting van de bestuurlijke organisatie lijkt de ingenieursbenadering te floreren. Op zichzelf is het niet verwonderlijk dat juist dit onderwerp vraagt om een dichotome benadering (je gaat erover of niet) en een duidelijke schematische structuur, dus om concentratie van verantwoordelijkheden. Immers, het wezen van een bestuurlijke organisatie is dat ergens een punt is waar finale legitieme besluiten genomen kunnen worden: vastigheid te midden van een grillige en dynamische werkelijkheid. Dat dus de kaarten niet worden gezet op het omgaan met complexiteit, de kunst van ad hoc samenwerken en het inductief verzamelen van informatie en energie tot zich een oplossing uitkristalliseert, is op dit terrein niet zo verwonderlijk. De korte en snel vergeten escapade met complementair bestuur doet daar niets aan af.

\section{Eenzame positie}

De voortdurend terugkerende aandrift om het bouwwerk te slopen en opnieuw op te bouwen roept juist meer vraagtekens op. Hiermee wordt immers de vastigheid die er is in machtsverdeling en in organisatorische stevigheid op de proef gesteld. Er moeten wel heel dringende redenen zijn voor zittende machten en bestaande organisaties om hun positie prijs te geven. Daar komt toch een bepaald beeld van de eigen positie van Binnenlandse Zaken om de hoek kijken. Dat is het beeld dat dit ministerie, en daarbinnen de politieke leiding, als het ware boven de bestaande machten is verheven en op basis van een visie van het algemeen belang van bovenaf kan ingrijpen om de structuur en de werkwijze te veranderen.

In dit dossier heeft Binnenlandse Zaken geen concurrenten, maar ook weinig bondgenoten. Te weinig om het in zijn eentje tot een succes te brengen. Bij de reorganisatie van het binnenlands bestuur waren zelfs VNG en IPO in het kamp van de vijand te vinden. De enige gemotiveerde bondgenoot buiten het parlement in dit project was hier misschien het ministerie van VRO. De andere ministeries waren op zijn best onverschillig. Ze zagen ongetwijfeld op tegen een hoop gedoe dat herschikking van hun taken en relatiepatronen met zich meebracht.

\section{Rol van bestuurders}

Interessant is het in dit verband vast te stellen dat de meeste initiatieven voor de herinrichting van de bestuurlijke organisatie afkomstig lijken van bestuurders (minister, staatssecretaris, colleges van grote steden) en hun inspiratoren uit denktanks, partijbureaus, et cetera, dus niet zozeer van ambtenaren en ook niet van gekozen politici. Hoewel in alle gevallen projectleiders (De Menthon Bake, Zaaijer, Bader) kunnen worden aangewezen, die geloofden in hun zaak, waren zij toch niet degenen op wie de innovatie dreef. Zij hadden het idee niet bedacht, zij stuwden het voort, maar op de vleugels van de bestuurders, hun bazen.

Er is één politieke partij die de achtereenvolgende projecten steeds van harte steunt en dat is de PvdA. Maar of die houding voortvloeit uit het delen van een interventionistische bestuursopvatting 
of dat meer opportunistische calculaties over machtsvoordeel die opvatting verklaren, is moeilijk te zeggen (niet bekend).

De ordening van de bestuurlijke organisatie tot echt zelfsturende eenheden is als de kwadratuur van de cirkel, maar blijft generaties daadkrachtige bestuurders prikkelen tot hernieuwde pogingen. Het blijft maar steeds niet lukken. Uiteindelijk is, naast de vanuit het beleid beredeneerd ongerijmde twaalfde provincie en de eveneens met de doctrine vloekende kaderwetgebieden, alleen de bundeling van samenwerkingsverbanden uit de WGR tot stand gekomen, overigens na achttien jaar ook weer gestopt.

Al met al wordt de intrinsieke zwakte van de argumentatie steeds duidelijker. In een tijd van verplaatsing van politiek, van netwerkbestuur en van uiterst complexe problemen lijkt het een illusie dat het reorganiseren van regionale bestuurscentra hiervoor soelaas zou bieden. En zolang zullen de zittende machten (randgemeenten, politieke partijen die hun machtsverlies calculeren), zo nodig gesteund door de 'wisdom of crowds' in referenda, hun posities niet opgeven. Uiteraard speelt deze overweging ook bij de huiver om beleidsbemiddeling toe te passen en bij het schipbreuk lijden van complementair bestuur, zoals ook Brinkman bevestigt door de machtsfactor met zoveel woorden te noemen.

\subsubsection{Conclusies}

\section{De schaduw van Thorbecke}

Het model van Thorbecke (een vast patroon van democratische besluitvorming terugkerend in drie bestuurslagen met welomschreven wettelijke taken en verantwoordelijkheden) is voor

Binnenlandse Zaken een gegeven. Dit organisch ontworpen schema is vrijelijk geïnterpreteerd en getransponeerd om de sturingsbehoefte van laat twintigste-eeuwse doeners te accommoderen. Binnenlandse Zaken koesterde met 'Het Huis van Thorbecke' een karikaturaal beeld van het open en dynamische staatkundige ideaal van Thorbecke (Toonen, 1982).

Uiteindelijk is er één beleidsdoelstelling achter alle beschreven projecten te reconstrueren: het democratisch gekozen bestuur op decentraal niveau moest in een positie worden gebracht dat het werkelijk iets te zeggen, iets af te wegen had. Of aan dat ideaal in de tijd van Thorbecke wel was voldaan, valt overigens ernstig te betwijfelen. In de late twintigste eeuw werd dit de raison d'être van het ministerie, dat de meest radicale structuurwijzigingen rechtvaardigen kon.

Opmerkelijk is dat geen van deze prestigeprojecten achteraf wetenschappelijk is geëvalueerd met uitzondering van de succesvolle dualisering. Wat gemist wordt, is systematisch lerend vermogen waardoor ook andere inzichten of perspectieven op bestuur worden toegelaten. Het discours lijkt zo vast te lopen in een autopoietisch patroon van zelfbevestiging binnen wat sommigen kortweg de bestuurderskaste noemen.

De meeste projecten in dit hoofdstuk hebben een belangrijke bijdrage aan de bestuurstheorie van Binnenlandse Zaken geleverd. Het begon allemaal met echt wetenschappelijk onderzoek (Nota Bestuurlijke Organisatie, 1969; Structuurschets bestuurlijke organisatie, 1974), maar de beleidsprojecten voor een nieuw middenbestuur die eind jaren zeventig tot bloei kwamen en nadien door andere varianten werden opgevolgd, werden door verschillende auteurs als bijna reactionaire bestuursdoctrines getypeerd (Van der Heijden, 1990; Tops, 1985; Boogers en Hendriks, 2005): neo-corporatisme, ingenieursbenadering, bestuurscentrisme. Met deze inzet voor bestuurlijke organisatie en met de vrijwel gelijktijdige commissie-Vonhoff voor de organisatie van de rijksdienst werd omstreeks 1980 veel aan de bestuurstheorie van Binnenlandse Zaken geïnvesteerd, maar dan in een variant die in een voorbije tijd leek te passen. Wat dat betreft, was de bijdrage van het project Complementair Bestuur wel eigentijdser, maar niet succesvol. De meeste vooruitgang werd nog behaald door het project Dualisering, dat bovendien goed werd geëvalueerd. 
Dat in het dossier van de bestuurlijke organisatie de government-benadering de overhand heeft, hoeft niet te verrassen. Binnenlandse Zaken zoekt, gegeven zijn natuurlijke opdracht, ordening en taakverdeling in het bestuur. Is het constateren van de government-benadering in dit dossier een tautologie? Er is nauwelijks een andere actor die deze positie kan betrekken, maar ook Binnenlandse Zaken had wel degelijk alternatieve strategieën kunnen bedenken, die meer recht deden aan de contingente verhoudingen in de bestuurlijke omgeving. Als de autonomie van gemeenten zozeer als hoeksteen van beleid werd opgevat, had die wellicht ook meer tot uiting kunnen komen in de structuur- en inrichtingskeuzen van het lokaal bestuur. Daarvoor werd echter te veel waarde gehecht aan uniformiteit in de Nederlandse eenheidsstaat.

In dit opzicht is het zelfs opmerkelijk dat niettemin in dit dossier in twee projecten duidelijke governance-elementen hun intrede hebben gedaan. Bij complementair bestuur door de beleidsredenering die sterk uitging van interbestuurlijke samenwerking en multi-level-bestuur. Bij dualisering door een aantal proceskenmerken in de implementatiefase. Een shift is echter ver te zoeken.

Ten slotte: is het niet vreemd dat EEG of EU nergens een rol lijkt te spelen? Misschien impliciet als spiegel bij de ideeën over een landsdelingschaal voor provincies (vergelijk Breeman et al., 2012). 


\section{Dossier interbestuurlijke betrekkingen en decentralisatie}

\subsection{Inleiding}

De beschrijving van projecten wordt nu voortgezet met cases op een terrein waar Binnenlandse Zaken een coördinerende rol vervulde. Daarmee is dit dossier niet minder bepalend geweest voor de kleuring van het bestuursbeleid. Misschien wel in tegendeel: in het vorige hoofdstuk zijn we al verschillende beleidskeuzen tegengekomen die in feite waren gebaseerd op de prioritaire belangen van het decentralisatiestreven en van inzichten over goede interbestuurlijke betrekkingen. De volgende projecten zullen op een zelfde wijze als die in hoofdstuk 5 worden beschreven en geanalyseerd, waarbij de gezochte verhaallijn in het discours (de bestuurstheorie) wordt gedestilleerd uit doelstelling, sturingsaanpak en democratie-opvatting, leerprocessen in combinatie met het beklijven ervan in de tijd:

- De inrichting van de uitvoering van de nieuwe coördinerende taken van Binnenlandse Zaken voor het functioneren van het binnenlands bestuur vanaf 1973 (paragraaf 6.3);

- Het introduceren, na 1980, van offensief decentralisatiebeleid vanuit Binnenlandse Zaken in plaats van lijdelijk toezien dat de vakdepartementen zich steeds meer met de decentrale overheden bemoeien (paragraaf 6.4);

- In het verlengde daarvan het organiseren van de sanering van specifieke uitkeringen (paragraaf 6.5);

- De introductie sinds 1987 van Bestuursakkoorden tussen het Rijk en de decentrale overheden (paragraaf 6.6);

- $\quad$ Een project D'gemeenten en D'provincies, erop gericht om voorstellen voor decentralisatie en deregulering en experimenten van onderaf te laten komen (paragraaf 6.7);

- De nieuwe aanpak om decentralisatievoornemens te genereren door begrotingsonderhandelingen waarbij ook VNG en IPO aan tafel zitten: de Decentralisatieimpuls (paragraaf 6.8);

- $\quad$ Een verkenning en bezinning op de resultaten van al dat decentralisatiebeleid, leidend tot de vraag of voor meer maatwerk en integraal beleid behalve vermindering van rijksbemoeienis ook toerusting en veranderbereidheid bij de decentrale overheden nodig is: Decentraliseren met beleid (paragraaf 6.9);

- De korte inzet voor het realiseren van meer differentiatie tussen gemeenten als inbreuk op het diepgewortelde uniformiteitsdenken binnen Binnenlandse Zaken: Gedifferentieerde contracten met gemeenten (paragraaf 6.10).

De laatste twee projecten hebben het niet veel verder gebracht dan voorstellen op ambtelijk niveau, zij het steeds met medeweten en instemming van de ministers.

Eerst volgt in paragraaf 6.2 een inleiding over het hele dossier.

Het hoofdstuk sluit weer af met een concluderende paragraaf 6.11 over de bestuurstheorie bij het dossier Interbestuurlijke betrekkingen en Decentralisatie.

De beschrijving van de projecten is naast de genoemde openbare bronnen en interviews in belangrijke mate gebaseerd op de eigen waarneming van de onderzoeker, maar de juistheid ervan wordt geschraagd door de reacties van enkele meelezers, in het bijzonder Hans Wilmink (die tussen 1980 en 1994 in de beleidsontwikkeling participeerde), Arie-Jan Vos (van 1978-1984 en van 1994-1998 actief in dit veld) en Jan Andries Wolthuis (die zijn loopbaan begon bij interbestuurlijke betrekkingen, van 2002-2008). 


\subsection{De ontwikkeling van interbestuurlijke betrekkingen en het decentralisatiebeleid}

\subsubsection{Typering van de projecten}

\section{Dominant thema}

De algemene ontwikkeling van het dossier van de interbestuurlijke betrekkingen en het decentralisatiebeleid vormt de rode draad van het hele bestuursbeleid en is als zodanig al grotendeels verteld in hoofdstuk 4. Opmerkelijk is dat de afbakening van het decentralisatiebeleid ten opzichte van andere dossiers moeilijk te maken is, zozeer staat dit thema in het hart van het bestuursbeleid. Sociale vernieuwing en grotestedenbeleid werden van lieverlee in het teken geplaatst van decentralisatie, namelijk door het beleid te richten op een streven naar brede doeluitkeringen en meer beleidsvrijheid voor gemeenten als oplossing van de maatschappelijke problemen in achterstandsgebieden. Voorstellen voor de bestuurlijke organisatie werden onderbouwd aan de hand van hun bijdrage aan het decentralisatiestreven (gemeentelijke herindeling om taakuitbreiding mogelijk te maken, stadsprovincies idem, complementair bestuur werd afgeblazen uit vrees voor het omzeilen van decentralisatiebesluiten door vakdepartementen). Daarom is afzonderlijke geschiedschrijving van het decentralisatiebeleid vrij arbitrair. Hier richt het zoeklicht zich op het decentralisatiebeleid in enge zin: die operaties die zich rechtstreeks richten op de (neerwaartse) verschuiving in de taak- en verantwoordelijkhedenverdeling tussen de vakdepartementen en de decentrale overheden. Zozeer stond decentralisatie in het centrum van de verbetering van de interbestuurlijke betrekkingen dat beide begrippen voor velen vrijwel synoniemen waren. Dat dit toch niet helemaal het geval was, kwam tot uiting bij de bestuursakkoorden en het reguliere overhedenoverleg.

\section{Grondslag van decentralisatiebeleid}

Het decentralisatiestreven is misschien altijd wel latent aanwezig geweest bij Binnenlandse Zaken, maar expliciet beleid en geconcentreerde inspanningen laten op zich wachten tot ongeveer 1980. Formeel werd de positie van het ministerie hiervoor ingericht, beginnend met kabinetsbesluiten over de coördinatie van alles wat de gemeentefinanciën raakt, daarna ook met een passage in de Memorie van Toelichting van de Wet Reorganisatie binnenlands bestuur. ${ }^{35}$ Uiteindelijk werd de positie wettelijk beklonken met artikel 117 in de nieuwe Gemeentewet van 1991, luidende: "Onze Minister bevordert de decentralisatie ten behoeve van de gemeenten."

1980 was het jaar waarin Binnenlandse Zaken in de aanval ging met een eigen beleidsnota en een Decentralisatieplan. Kort na deze offensieve actie, die met veel aplomb en politiek tamtam werd uitgevoerd, maar die weinig concreet succes opleverde, raakte het schip van staat in guur weer, waar decentralisatie wel bij voer. De economische malaise van de jaren tachtig en de noodzakelijke budgettaire terugtred van de rijksoverheid schiep enerzijds mogelijkheden om decentralisatie onder andere gedaanten te presenteren en anderzijds een klimaat om vakdepartementen zelf te bewegen om decentralisatie als een van de opties in nood te overwegen. Verschillende heroverwegingsexercities vonden plaats onder de noemer 'sanering van bestuursinstrumenten' (specifieke uitkeringen, toezicht, planprocedures en gedeconcentreerde rijksdiensten), maar hadden per saldo steeds dezelfde strekking: zoek besparingen door het verminderen van bemoeienis van de vakdepartementen met de decentrale overheden. Deze aanpak op het snijvlak van heroverweging, deregulering en decentralisatie bleek aanzienlijk productiever dan de rechtstreekse aanval op taken en bevoegdheden van vakdepartementen. Eind jaren tachtig werd de strategie van de strijd met de vakdepartementen verbreed door in het project D'gemeenten en D'provincies de decentrale overheden zelf te laten meespreken via een soort ideeënbusprocedure en door als terugvaloptie in de discussie op te nemen dat eventueel eerst met

\footnotetext{
35 Een beschikking van de minister-president d.d. 23 juni 1973 bekleedt de staatssecretaris van Binnenlandse Zaken met coödinerende bevoegdheid voor alles wat de gemeentefinanciën in betekenende mate raakt; In de Memorie van Toelichting bij de Wet Reorganisatie binnenlands bestuur (1974) werd de minister van Binnenlandse Zaken aangewezen als coördinerend minister voor de bevordering van de goede verhouding tussen het Rijk en de lagere publiekrechtelijke lichamen in het algemeen en van een gedecentraliseerd bestuur in het bijzonder.
} 
de voorgestelde nieuwe verantwoordelijkhedenarrangementen geëxperimenteerd kon worden. Deze aanpak was niet zo succesvol als de daaropvolgende uitbreiding van het wapenarsenaal: de Decentralisatie-impuls. Nieuw hierin was dat het kabinet een taakstellende bezuiniging had ingeboekt, die ingevuld kon worden via onderhandelingen met VNG en IPO: macht in ruil voor geld. Belangrijk bij deze 'innovatie' was vooral dat de minister-president en de minister van Financiën zich als mede-belanghebbende bij decentralisatie beschouwden en aan de onderhandelingstafel naast de minister van Binnenlandse Zaken tegenover de VNG en IPO, maar soms ook tegenover de vakministers, plaatsnamen. Geen gelegenheid om decentralisatie aan de orde te stellen werd onbenut gelaten. Heroverweging en decentralisatie werden al genoemd, maar ook in de discussie over staatkundige vernieuwing (commissie-Deetman) verscheen een van de deelrapporten over dit thema. 'Over decentralisatie is nooit een vers geschreven' noemde de speciale Kamercommissie dit rapport (Commissie-Franssen, 1993). Die commissie kwam na flink wat heen en weer praten tot de ontdekking dat decentralisatie heus niet alleen moet worden bevochten in een ongelijke machtsstrijd met de vakdepartementen, maar dat niet zelden deze ministeries zelf tot het inzicht komen dat decentralisatie wenselijk is. Decentralisatie van het welzijnsbeleid is bijvoorbeeld ontwikkeld vanuit het vakdepartement (CRM, Knelpuntennota 1974), nog voordat Binnenlandse Zaken een eigen Decentralisatienota had geproduceerd.

\section{Andere initiatieven voor de verbetering van de interbestuurlijke betrekkingen}

Een grensgeval van decentralisatiebeleid, maar passend in het rijtje van bestuurlijke overleggen over interbestuurlijke betrekkingen was de introductie van bestuursakkoorden met VNG en IPO. Vooral de zogeheten Bestuursakkoorden Nieuwe Stijl (BANS) plaatsten de betrekkingen tussen de overheden in het licht van goede samenwerking, gericht op de aanpak van allerlei sectorale maatschappelijke vraagstukken, waar dus de vakdepartementen in het spel werden betrokken. Aan het eind van de jaren negentig werd de discussie van touwtrekken tussen overheidslagen en departementen verlegd naar effectieve probleemoplossing en bestuurskracht. Duidelijk werd dat na decentralisatie niet vanzelf alle voorgespiegelde heilzame effecten optraden. Beloofde effecten als maatwerk, integraal bestuur, grotere burgerbetrokkenheid, et cetera bleven vaak achterwege, omdat de technocratische nadelen van het centralistische beleid in handen van gemeenten en provincies niet meteen verdwenen. Verkokering, regelzucht en standaardisatie bleven na decentralisatie op een ander bestuursniveau vaak gewoon bestaan (Fleurke et al., 1997: 24-29). Het probleem van goed bestuur zat dus dieper dan de taakverdeling. Misschien zouden overheden elkaar moeten helpen om de beperkingen te overwinnen, 'decentraliseren met beleid' was meer dan taken en verantwoordelijkheden over de schutting te gooien. Later, omstreeks 2006, kwam zelfs kortstondig de opvatting bovendrijven dat gemeenten en provincies in dit opzicht een verschillende aanpak vergen. Differentiatie als beleidsthema heeft het overigens niet echt lang volgehouden binnen het bestuursbeleid dat toch vooral mikte op ordening van gelijksoortige eenheden. Al gauw was het beleid weer terug bij de oude decentralisatie-operaties, waarbij Binnenlandse Zaken zichzelf graag ziet als bewaker van de autonomie van de gemeenten en provincies tegenover 'de bemoeizuchtige vakdepartementen'. In het kabinet-Rutte was het enige nieuws op dit front de taalkundige vernieuwing dat voortaan gesproken werd over decentralisaties (meervoud). De meeste projecten die hieronder beschreven worden, betreffen procesmatig andere aanpakken om hetzelfde inhoudelijke doel, namelijk meer decentralisatie, te bereiken. Daarom zal bij de typering van de innovaties op hun governance-gehalte vooral gekeken worden naar de procesmatige dimensies van de bestuurstheorie.

\subsubsection{Coördineren ten behoeve van decentraal bestuur}

\section{Waartoe coördineren?}

In de loop der jaren zijn over de missie van het bestuursdepartement verschillende nieuwe invalshoeken de revue gepasseerd. Daarbij zijn ideeën te onderscheiden vanuit bepaalde vernieuwende bestuurlijke visies (bestuursbemiddeling, procesmanagement, scheiding tussen 
beleid en uitvoering en maatschappelijke democratie) of meer inhoudelijke rolopvattingen (minderhedenbeleid, duurzame ontwikkeling, troubleshooten in de wijken, burgerschapsvorming). Uiteindelijk heeft van al deze ideeën stand gehouden de coördinerende taak ter bewaking van de belangen van de autonome gemeenten en provincies ten opzichte van bemoeizuchtige ministeries. Anno 2005 gebeurt dit aan de hand van de Code Interbestuurlijke Verhoudingen nog immer in nauwe verbondenheid met de VNG en het IPO. Minderhedenbeleid en grotestedenbeleid, die Binnenlandse Zaken in nauw contact brachten met actuele maatschappelijke problematiek, zijn alweer afgestoten. Bestuurlijke betrokkenheid bij verzelfstandiging is wel erkend, maar niet echt voorzien van beleid en van groot inzicht in de werkelijke problemen van de uitvoering. Prille verworvenheid is de aandacht voor democratie en burgerschap, maar het is niet te zeggen waartoe die zal leiden.

\section{Coördinatie uit de gratie}

In de loop van de jaren raakte het begrip coördinatie als 'soft' uit de gratie. Minister Remkes spreekt liever over 'interventies'. Dat klinkt inderdaad stoerder.

Het lijkt op het eerste gezicht of Remkes met deze taal terugvalt op een gepasseerd station, het krachtige centrum van bestuursmacht dat aan de knoppen draait waarna de samenleving zich in de gewenste richting beweegt. Een alternatieve veronderstelling is dat hij bewust of onbewust blijk geeft van een modern bestuursinzicht over gefragmenteerde sturingsrelaties die tot ver in de samenleving doorlopen. Navraag bij medewerkers die er dichter bovenop zaten, leert dat het begrip coördinatie door een bepaalde bureaucratische praktijk in diskrediet was geraakt. Het werd te veel geassocieerd met een ambtelijke routine die niet veel meer behelsde dan het benoemen van een onderwerp, het samenstellen van een interdepartementale werkgroep en het eindeloos hierover vergaderen. Binnenlandse Zaken levert dan de procedureel secretaris, het eerstverantwoordelijke vakdepartement meestal de voorzitter (als dit geen onafhankelijke derde is) en de inhoudelijk secretaris en andere stakeholders zijn leden. Van Ruller noemde dit ietwat misprijzend de Notarisrol (Van Ruller en Schrijver, 1986). Als dit het beeld is dat past bij 'coördinatie', zijn inderdaad 'trefzekere interventies' niet het eerste waar je aan denkt. De 'stadsmarinier' (zie paragraaf 7.4.2) is meer het type aanpak dat past bij een coördinerende rol van troubleshooter à la Van Ruller.

\section{Binnenlandse Zaken als verandermanager}

Hieronder volgen zes verschillende beleidsvernieuwende projecten die in de periode 1976-2009 achtereenvolgens gericht waren op de effectieve realisering van veranderingen in de verantwoordelijkhedenverdeling in de verhouding tussen de bestuurslagen. Dit streven naar decentralisatie was in de genoemde periode een centraal thema in het beleid van de rijksdienst. Binnenlandse Zaken stond aan de lat om decentralisatie te bevorderen. Dit werd alom een zeer zware opgave geacht: Binnenlandse Zaken als verandermanager. Terugkijkend op deze periode onderscheiden we verschillende veranderstrategieën. Bij elk hiervan kunnen weer ambtenaren als 'held' worden genoemd.

\subsection{Coördinerende taak}

\subsubsection{Inleiding}

De coördinerende taak is eigenlijk geen project, maar het was in de jaren zeventig toch een belangrijke bestuurlijke vernieuwing. Op deze manier werd de ene na de andere coördinerende taak in het leven geroepen, waarbij Binnenlandse Zaken vooropliep. Na de specifieke uitkeringen (1973) kwamen de verhoudingen met de lagere publiekrechtelijke lichamen in het algemeen (1974), decentralisatie (1980), minderhedenbeleid (1980), sociale vernieuwing (1989), integrale veiligheid (1994) en grotestedenbeleid $(1975,1994)$. Het gaat hier verder over de opdracht van Binnenlandse Zaken om de andere ministeries (en eigen vakdepartementale onderdelen zoals 
Openbare Orde en Veiligheid) op de vingers te kijken bij hun bemoeienis met gemeenten en provincies. Hoe deze opdracht bij Binnenlandse Zaken als een noviteit invulling kreeg sinds 1976, is onderwerp van deze casus, die gedurende de gehele onderzoeksperiode (en daarna) doorloopt. Tussen 1984 en 2008 is er ook een herkenbare organisatorische eenheid mee belast. De opgave deze taak vorm te geven ('project') loopt tussen 1973 en 1984.

Bronnen voor deze beschrijving vormen interviews met Elco Brinkman, Jan Krapels, Johan Hoff, Floris Plate, Frans van Bork en Lodewijk van Vliet. Daarnaast zij verwezen naar het rapport van de Centrale Werkgroep Veranderingsorganisatie ter voorbereiding van de reorganisatie van 1980, de Memorie van Toelichting bij de begroting van Binnenlandse Zaken over de Coördinerende taak (TK 1979-1980, 15800 VII, nr. 2) en het artikel van Krapels (1978).

\section{Aanleiding voor de coördinerende taak}

In 1976 was dr. Henk van Ruller bij het ministerie van Binnenlandse Zaken benoemd als Raadsadviseur voor Coördinatievraagstukken. Het was de tijd van het kabinet-Den Uyl (1973-1977): veel moest en kon anders. Staatssecretaris Wim Polak, die onder meer gemeentefinanciën in zijn portefeuille had, kende Van Ruller uit de gemeenteraad van Amsterdam en had hem in het ministerie geparachuteerd met een aantal bijzondere opdrachten.

Alle besluiten over middelen op de rijksbegroting die de positie van gemeenten en provincies in belangrijke mate raken, konden voortaan alleen in overleg met de staatssecretaris van Binnenlandse zaken tot stand komen. Om deze afspraak kracht bij te zetten werd de staatssecretaris permanente toegang verleend tot alle Ministerraadsvergaderingen. Andere staatssecretarissen zijn daar alleen welkom als een onderwerp uit hun portefeuille op de agenda staat, maar die van Binnenlandse Zaken was er altijd om te bewaken dat geen onderwerp dat tot zijn coördinerende competentie behoort aan zijn aandacht ontsnapte Door deze permanente aanwezigheid kreeg deze functionaris de facto bijna de status van vijftiende minister.

\subsubsection{Projectbeschrijving en verhalen}

\section{Aard van de innovatie}

De behoefte om het rijksbeleid te coördineren (lees: bij te sturen) was zo dringend dat de staatssecretaris hiervoor bekleed werd met een aantal gloednieuwe bevoegdheden en attributen. Voor het eerst kreeg het ministerie van Binnenlandse Zaken in 1973 coördinerende bevoegdheden ten aanzien van de specifieke uitkeringen van alle ministeries.

De bestuurlijke redenering die ten grondslag lag aan deze bevoegdheid, was overwegend financieel van aard. In de jaren zestig en zeventig van de vorige eeuw waren de taken van de gemeenten door de rap groeiende verzorgingsstaat snel in omvang toegenomen. Het tempo waarin de omvang van de rijksbegroting toenam, was hoger dan dat van de stijgende welvaart, en de bijbehorende uitvoeringslast werd in veel gevallen bij de gemeenten gelegd. Dit gebeurde meestal door middel van wetgeving, het zogeheten medebewind. Maar even belangrijk was de praktijk om gemeenten een financiële bijdrage in het vooruitzicht te stellen, mits zij zich aan de voorwaarden van rijksbeleid conformeerden. Uiteraard werden de resterende kosten voor rekening van de gemeente gelaten. Door dit lokmiddel, waaraan gemeenten binnen hun eigen huishouding geen weerstand konden bieden, werd de gemeentelijke begroting in toenemende mate geregeerd door de aanbiedingen en bijbehorende voorwaarden van rijksdepartementen. Behalve een centraliserend effect bracht dit verschijnsel ook grote financiële tekorten met zich mee. Vooral bij de vier grote steden was dit merkbaar, bijvoorbeeld op terreinen als stadsvernieuwing en welzijnsbeleid, waar de rijksoverheid grote ambities ten toon spreidde. Grote steden raakten in financiële problemen en werden klanten van 'Artikel 12'.

Het was dan ook geen toeval dat als vertegenwoordigers vanuit Binnenlandse Zaken in interdepartementale overleggremia vooral twee ambtenaren optraden uit de hoek van de 
gemeentefinanciën. Het waren de heer A. Eveleens, hoofd van de Inspectie Gemeentefinanciën, die verantwoordelijk was voor de toepassing van artikel-12-maatregelen, en Johan Hoff van Bureau Bijzondere Adviezen, waar de (financiële) problemen van de grote steden werden behandeld. Daarnaast was binnen de directie Binnenlands Bestuur één medewerker, jhr. Alexander van Sonsbeeck, aangewezen die contacten met de vakdepartementen onderhield. De directeuren Jan Mulder (FBB) en Charles de Menthon Bake (BB) beperkten hun interdepartementale contacten tot enkele voorportalen, zoals de Rijksplanologische commissie en de eigen Interdepartementale Commissie Binnenlands Bestuur (ICBB).

De ambtelijke kijk op de interbestuurlijke betrekkingen maakte in deze periode een fundamentele omslag door. Frans van Bork, die destijds als student bij Binnenlandse Zaken begon, brengt dit door een treffende waarneming onder woorden:

"Voor de oude garde, die de verzorgingsstaat en de bijbehorende Financiële Verhouding(en) had opgebouwd, was de beleving dat het systeem in wezen goed in elkaar zat. De nieuwe generatie ambtenaren die zijn intree deed, keek er vooral kritisch tegenaan. Het systeem produceerde te veel perverse effecten en er moest dus worden ingegrepen. Dat was de missie van de coördinerende taak op het terrein van (financiën) binnenlands bestuur, welke moest worden uitgevoerd zonder veel machtsmiddelen tegen massieve weerstand, van alle vakdepartementen en intern van de oude garde, in." 36

\section{De innovatiedrager}

Naast deze algemene coördinerende bevoegdheid richtte staatssecretaris Polak een specifiek instrument in voor de grote vier gemeenten, namelijk gestructureerd overleg met het Rijk. In dit zogeheten Agenda-overleg trad hij zelf als voorzitter op en andere bewindslieden werden afhankelijk van de agenda aan tafel uitgenodigd om de meest knellende onderwerpen te bespreken en om hierover afspraken te maken. Henk van Ruller werd secretaris van het Agenda-overleg. Hier lag het accent veel minder op het veranderen van structuren en systemen dan op het oplossen van concrete problemen.

De bij coördinatie passende werkwijze behelsde een mengeling van netwerken, praten en overtuigen enerzijds en dreigen, machtsstrategie en via de politieke band spelen anderzijds.

De innovatiedrager was op de achtergrond staatssecretaris Polak zelf, die visie paarde aan gedrevenheid. Zijn apostel in de ambtelijke organisatie was zonder twijfel Henk van Ruller. Diens werkwijze was even onorthodox als effectief. In de eerste plaats nestelde hij zich dichtbij het vuur, rechtstreeks onder de SG. Hij schermde zich echter niet af achter de eikenhouten lambrisering van Binnenhof 19 (of later de derde verdieping van de Laagbouw aan de Schedeldoekshaven met zijn pantryservice). Zijn stijl was 'eropaf gaan'. Het aanpakken van het probleem stond bij hem boven alles en schotten, sterren en strepen werden daar aan ondergeschikt gemaakt. In dat opzicht was Van Ruller een vroege exponent van netwerkbestuur/governance. Dat moest ook wel voor onderwerpen als drugsproblematiek, stadsvernieuwing, de bodemvervuiling van Lekkerkerk, muitende Molukkers, schade van een sneeuwstorm in het Noorden ('de Blizzard' van 1981), de aanlanding van LPG, enzovoort, waarvoor veelal onwillige partijen met beslissingsmacht samengebracht moesten worden. Door uitgebreid overleg met de betrokkenen vond hij de gezochte overeenstemming, veelal met hulp van zijn pragmatisch ingestelde collega uit de lijnorganisatie, Johan Hoff. Als een nieuw probleem zijn bureau bereikte, klom hij niet zelden met een medewerker of met Johan Hoff in zijn $2 \mathrm{CV}$ en reed naar de plaats des onheils om zich een oordeel te vormen. Van Ruller omringde zich bij voorkeur met jonge veelbelovende werkstudenten of net afgestudeerde academici die nog niet waren gevormd door ambtelijke mores. Zijn werkkamer in Binnenhof 19 was een kantoortuin waar een aantal jonge medewerkers een bureau hadden. Als hij een vertrouwelijk telefoongesprek moest voeren dat niet voor hun oren bestemd was, ging hij

36 Interview met Frans van Bork in Den Haag op 21 augustus 2007. 
even uit het raam hangen, want mobiele telefoons bestonden toen nog niet. Hij belde ook rustig met ministers en staatssecretarissen als dat voor zijn troubleshooten nodig was.

Van Ruller liet door 'coördinatie' gewoon te doen zien dat Binnenlandse Zaken een nuttige verbindende rol kon vervullen. De verkokering tussen de ministeries was eind jaren zeventig op een hoogtepunt beland. Dus daar was heel wat te bereiken als je de moeite nam je bureau te verlaten.

\section{Het team eromheen}

Uiteindelijk was de missie van Van Ruller (en Polak) om een permanente functie bij Binnenlandse Zaken in te richten voor de stroomlijning van regelingen in het binnenlands bestuur. De contouren van een dergelijke functie lagen in de kern al besloten in verschillende bestaande onderdelen van het toenmalige Binnenlandse Zaken: bij het Bureau Bijzondere Adviezen van Johan Hoff en het Bureau Algemene Zaken (Lex Elias) van de Directie Financiën Binnenlands Bestuur. Deze bureaus kregen brieven van gemeenten binnen die zich beklaagden over de effecten van rijksbeleid. Soms werd omgekeerd ongewenst gedrag bij gemeenten aangekaart, wat kon leiden tot schorsing en vernietiging door de Kroon. Dat kon niet buiten Binnenlandse Zaken om. Over die ad hoc zaken en zaakjes (héél veel zondagsrust, want de seculiere aspecten van de Zondagswet, zoals het verbod om zwembaden op zondag gesloten te houden, werden te vuur en te zwaard gehandhaafd) werden dan ambtsberichten gewisseld. Maar in toenemende mate gingen medewerkers eind jaren zeventig zich proactief bezighouden met de ontwikkeling van nieuw beleid van vakdepartementen, vanuit het gezichtspunt van integraal bestuur op gemeentelijk niveau. Dat was de nieuwe taak die Polak voor ogen had, uitmondend in geregisseerde decentralisatie van rijkstaken en sanering van bestuursinstrumenten.

De bemensing van die functie had Henk van Ruller georganiseerd door middel van een stageproject voor jonge academici, een model dat 25 jaar later is gekopieerd in het Rijkstraineeproject. De werving en selectie alsmede de coaching van de nieuwe ambtenaren nam Henk van Ruller persoonlijk ter hand. Jonge academici (juristen, economen, sociale wetenschappers en historici) werden aangesteld en in een traject van praktijkstages van drie halve jaren getraind bij achtereenvolgens een gemeente of provincie (de doelgroep van Binnenlands Bestuur), bij een vakdepartement (de werkpartners voor bestuursbeleid) en binnen het eigen ministerie (collega's waar de beleidskaders werden gevormd). Aan het eind van deze stageperiode werd een vaste functie binnen het departement aangeboden, bij voorkeur in de sfeer van de nieuwe coördinerende taken.

\section{Opbouw van een nieuwe organisatie}

Een formeel erkende coördinerende bevoegdheid betekende nog niet meteen de institutionalisering van een apparaat dat hieraan daadwerkelijk uitvoering kon geven in interdepartementaal overleg. Die zogeheten externe coördinatiestructuur (buiten het ministerie) kwam op het terrein van de interbestuurlijke betrekkingen na 1980 tot stand en bestaat nu nog steeds. Hiervoor was eerst een machtige man nodig op de nieuwe positie van directeur-generaal Binnenlands Bestuur. Elco Brinkman werd de stuwende kracht. De reorganisatie werd echter in twee fasen voltrokken. Eerst werd een aantal jaren gewerkt met een interne coördinatiestructuur om de externe coördinatieactiviteiten van medewerkers van verschillende directies tot een eenheid te smeden onder regie van een zware Stafafdeling van de DG onder leiding van de genoemde Johan Hoff. Van Ruller en Krapels hadden eerder hiervoor interne overleggen ontworpen van medewerkers die zich bemoeiden met verschillende ministeries overeenkomstig de hoofdbeleidsgebieden van de commissie-Vonhoff: fysieke, sociaaleconomische en sociaal-culturele aangelegenheden. Pas in 1984, toen Elco Brinkman alweer was vertrokken, werd de missie van Van Ruller bekroond met de oprichting van een Directie Coördinatie Bestuursbeleid. Het plan van Van Ruller met Binnenlandse Zaken is neergelegd in een artikel van een van zijn leerlingen, Jan Krapels, in Bestuurswetenschappen 1978. Hierin beschrijft hij de rijksdienst als een versplinterde eenheid, waar Binnenlandse Zaken op het kruispunt iets van de verloren gegane horizontale (departementen) en verticale (Rijk, gemeenten en provincies) integratie moet zien terug te brengen. 
Daarvoor worden binnen BiZa centrale werkgroepen gevormd, OFA (overleg fysieke aangelegenheden), OSEA (sociaaleconomische) en OSCA (sociaal-culturele aangelegenheden), die de departementen niet zozeer op hun beleidsinhoud in de gaten houden als wel op de mogelijkheid om op decentraal niveau geïntegreerde uitvoering te kunnen realiseren. De in 1977 afgekondigde reorganisatie moest Binnenlandse Zaken een naar buiten gerichte organisatiestructuur verschaffen. Tezamen met de reorganisatie van het binnenlands bestuur, waar tien jaar voor werd uitgetrokken, zou de desintegratie van het binnenlands bestuur in de loop van de jaren tachtig tot staan zijn gebracht, aldus Krapels en Van Ruller.

Een bindende factor vormde het nieuwe decentralisatiebeleid met de gezamenlijke opdracht om een decentralisatieplan te maken, waarover hieronder meer.

\subsubsection{Aanwijzingen voor de gehanteerde bestuurstheorie}

\section{Doelstelling}

De inhoudelijke doelstelling van het project verraadt een bestuurscentrische opvatting, omdat veel heil wordt verwacht van nieuwe structuren en taakverdelingen binnen het openbaar bestuur. De filosofie van de commissie-Vonhoff klinkt duidelijk door in de gedachten van de ontwerpers van het idee waarbij Binnenlandse Zaken zou zorgen voor samenhang en taakordening.

\section{Sturingsaanpak}

Qua sturingsaanpak is de benadering noodgedwongen samenwerkingsgericht. Het gaat om horizontale coördinatie, niet om verticale machtsuitoefening, Althans in hoofdzaak. Omdat het achterliggende probleem wel degelijk wordt gezien als een machtsvraagstuk (de zwakke gemeenten tegenover de boze sectorale krachten), is soms een beroep op verticale methoden verleidelijk: wetgeving en kabinetsuitspraken over normen van goed bestuur, taakstellingen over vermindering van bestuursbemoeienis en bestuursinstrumenten, bondgenoten inschakelen om veranderingen door te drukken. Deze machtsstrategie zal in de volgende paragraaf terugkomen.

\section{Democratieopvatting}

Over de democratie-opvatting als zodanig is in de beginperiode weinig discussie. Die is vanzelfsprekend traditioneel. Het is zelfs niet overdreven te stellen dat het behoud van de lokale representatieve democratie bijna synoniem was met het beleden belang van de autonome gemeente. Gedurende een bepaalde periode in de jaren negentig sloeg de twijfel toe, zoals we zullen zien in paragraaf 6.9, maar daarna is de bestuurstheorie van de Gideonsbende weer onverdroten voortgezet. In die kortstondige periode van bestuurlijke vernieuwing rond de eeuwwisseling werd ook niet toevallig vanuit de afdeling Interbestuurlijke betrekkingen een excursie naar participatieve democratie en procesmanagement ondernomen (zie verder in hoofdstuk 9).

\section{Informatieverwerving}

De innovatiedragers waren ook kind van hun tijd in de zin dat zij de rationele besluitvorming, het rationele actormodel van de Commissie voor de bevordering van Beleidsanalyse en de RAND Corporation omarmden. Dat de coördinerende taak voor goed binnenlands bestuur tot stand kwam op het hoogtepunt van het rationele bestuurscentrisme, tweede helft jaren zeventig, leidde ertoe dat coördinatie een Vonhoffiaanse (neo-corporatistische) invulling heeft gekregen die het bestuursbeleid jarenlang heeft gekleurd.

Dat planningsdenken is later overigens helemaal verdwenen en vervangen door de even modieuze opvattingen van de procesplanners, en vooral ook wat betreft de wijze van informatievergaring zijn ook kenmerken van governance te herkennen. De oriëntatie op de werkelijkheid is weer bottom-up. Niet alleen omdat decentralisatie de belangrijkste doelstelling is, maar ook omdat men zijn inspiratie ontleent aan concrete praktische problemen (die inderdaad veelvuldig voortvloeien uit bureaucratisch centralisme en verkokering). De ondernemende ambtenaar, die door persoonlijke verkenning van ontwikkelingen in het veld zich in staat acht om verkokering te doorbreken en niet op elkaar aansluitende arrangementen te verbinden, is typerend voor dit veld. Van Ruller en Hoff 
waren hier prototypen van. Hun latere opvolgers lieten zich meer disciplineren door de politieke cultuur van het New Public Management, maar altijd is er een belangrijke vrijbuiterscomponent van de frontlijnwerker in het werkveld van de coördinerende taak overeind gebleven.

\subsubsection{Typering van dit project volgens overige onderzoekscriteria}

\section{Mate van beleidsvernieuwing}

Ten dele voortbouwend op rudimentaire voorlopers van de coördinerende taak, bijvoorbeeld in de Inspectie voor de Gemeentefinanciën, was dit project van Polak en Van Ruller in termen van beleidsvernieuwing toch vooral een (organisatorische) innovatie in het bestuursbeleid. En zij zagen dat zelf ook zo, een systeemsprong ten opzichte van het oude legalistische Binnenlandse Zaken. Gemeenschappelijke achtergrondfactoren die verklaren waarom deze coördinerende taken op een bijzondere manier werden aangepakt, waren de volgende:

- $\quad$ De onderwerpen die te maken hadden met de beheersbaarheid van de verzorgingsstaat stonden hoog op de politieke en maatschappelijke agenda, maar de ambtelijke organisatie was hierop nog niet toegesneden. De grootste slag moest intern worden gestreden. De zittende generatie ambtenaren, die het naoorlogse bestuurssysteem had opgebouwd, zag de rol van Binnenlandse Zaken vooral als behoud en beheer, fundamenteel anders dan de aanstormende critici. De generatie ambtenaren die de verzorgingsstaat, het binnenlands bestuur en de bijbehorende Financiële Verhoudingswet hadden opgebouwd waardeerden dit stelsel in wezen positief. Hier bovenop trad een nieuwe kritische generatie aan, die meende dat het stelsel de grenzen van zijn sturingsmogelijkheden had bereikt en dat het tijd werd voor een omkering.

- Een voor de behartiging van deze taken ingestelde Gideonsbende koesterde een gevoel van vernieuwing en verovering ten opzichte van de rest van de ambtenarij en politiek. Deze voorhoede koesterde de verwachting dat de weerspannige meerderheid door politieke machtsvorming kon worden overruled; altijd kan een beroep worden gedaan op het politieke machtscentrum, eerst om de opdracht en de legitimatie van de Gideonsbende vast te leggen en daarna om alle te verwachten conflicten met de achterhoede te beslechten. De feitelijke werking van het binnenlands bestuur met zijn 583 specifieke uitkeringen en departementale verkokering, onder meer ondubbelzinnig beschreven door de Commissie hoofdstructuur rijksdienst, leek hen gelijk te geven.

- Behalve redeneren en overleggen hebben de coördinatoren zelf geen machtsmiddelen en instrumenten (regels, geld) tot hun beschikking; zij moeten het hebben van de overtuigingskracht dat zij eigenlijk hogere belangen dienen en van hun steun door politiek en abstracties als de burger, de samenleving. Eigenlijk was de ambtelijke steun van bondgenoten onontbeerlijk. Het meest in aanmerking hiervoor kwam Financiën, in het bijzonder de Inspectie der Rijksbegroting, maar deze werd door velen eerder als concurrent en tegenspeler gezien dan als bondgenoot.

- $\quad$ Ideeën en maatschappelijke noodzaak zijn volgens deze gedreven bestuurlijke vernieuwers uiteindelijk sterker dan enghartige deelbelangen die alleen uit bureaupolitieke motieven de status quo tegen het hogere, bredere algemeen belang bewaken.

Het succes van de inspanningen om een extern coördinerende taak op te tuigen betreft niet alleen een interne reorganisatie, het verschuiven van poppetjes en het anders tekenen van harkjes. Het gaat om veranderen van werkwijze en oriëntatie, externe gerichtheid op de daadwerkelijke gang van zaken binnen departementen en binnen gemeenten. Over deze aanpak en over de impact van die werkwijze gaat een flink deel van de hiernavolgende voorbeelden.

Hoe men ook verder over de effecten van deze beleidsvernieuwing mag oordelen, deze is beklijfd. Het was in twee opzichten een systeemsprong:

1. In de organisatiecultuur werd de externe oriëntatie bij de beoordeling van maatregelen in het binnenlands bestuur ingebakken. Zij werd gematerialiseerd door de aanstelling van 'accountmanagers' die permanente contacten onderhielden met de bronnen van de 
beleidsontwikkeling in het binnenlands bestuur, de vakdepartementen en allang niet meer het moederdepartement Binnenlandse zaken.

2. De inhoudelijke beoordeling van de beleidswerkelijkheid werd in plaats van drager van het bestaande bestel fundamenteel kritisch. De generatie beleidsambtenaren van de wederopbouw na de oorlog werd opgevolgd door een aanstormende, vernieuwingsgezinde generatie met hoge ambities (en maakbaarheidspretenties).

Evaluatie van de coördinerende taak als zodanig is niet vinden, al zou men elke reorganisatie die na 1980 is gevolgd als zodanig kunnen beschouwen. Deze hebben tot de dag van vandaag niet wezenlijk tot verandering geleid van de gedachten die door Polak en Van Ruller zijn gezaaid, ook al gaf de introductie tot dit dossier in paragraaf 6.2 aan dat het woord coördinatie tot misverstanden leidde en daardoor uit de gratie raakte.

\section{Bijdrage aan de bestuurstheorie}

Van Ruller cum suis hebben veel invloed gehad op de bestuurstheorie van Binnenlandse Zaken. Deze invloed was ook langdurig en hardnekkig, maar of hij ook een empirisch gefundeerde visie op de verhouding tussen overheid en samenleving bevatte, is de vraag. Gaandeweg leidden de daadwerkelijke pogingen tot coördinatie met de vakdepartementen natuurlijk tot een leerzame confrontatie met de wereld van de sectoren. In dat opzicht is indirect een bijdrage geleverd aan het geleidelijk binnenbrengen van andere ideeën dan louter vanuit de eigen doctrine. Deze invloeden zullen in de volgende paragrafen herkenbaar zijn, maar leidden ook tot verschansing in de eigen beelden van goed bestuur.

\subsubsection{Conclusies}

Hoewel bij de uitwerking van de coördinerende taak ook elementen te vinden zijn die passen bij de governance-modus, kan de meerderheid van de kenmerken als government georiënteerd worden beschouwd. Door de aanvankelijke gerichtheid op concrete problemen en oplossingen valt, zelfs ten opzichte van veel latere projecten, vóór 1980 een verfrissende open benadering op. Deze aanpak is herkenbaar overgenomen vanuit het Agenda-overleg met de grote steden. Overigens vormt de mainstream bestuurstheorie, gericht op een heldere verdeling van taken en verantwoordelijkheden, de belangrijkste opgave van de coördinerende taak, die meestal vrijwel is gelijk te stellen met het behartigen van de belangen van de autonome gemeenten in het binnenlands bestuur tegenover de verkokerde vakdepartementen. Een aantal keren is bij de uitwerking van goed bestuur, waarop het beleid van de vakdepartementen werd getoetst, ook gedacht aan vormen van interactieve beleidsvorming en burgerparticipatie, wat duidt op het doordringen van participatieve democratieopvattingen, maar dat bleef niet de mainstream.

Overall signaleren we bij dit initiatief een zoekende houding, maar als fundament de klassieke bestuursinzichten. Een duidelijke mengvorm met eindscore A -

De zoektocht naar 'goed bestuur' als toetssteen voor deze opdracht vormde een van de potentiële bijdragen aan het ontwikkelen van een beleidstheorie binnen Binnenlandse Zaken. Het bleef echter vooral aan de eenzame frontlijnambtenaren om eigen verbanden te smeden tussen het vele dat zij meemaakten. Een gedeelde bestuursvisie die de afdeling oversteeg, werd niet bereikt met de matrixachtige dwarsverbanden die door het bestuursbeleid in de relatie met andere sectoren van overheidsbeleid werden gelegd. De invloed van deze opgave op de bestuurstheorie was dus groot en ook wel beweeglijk, maar de aan de bestuurspraktijk opgedane leerervaringen bleven eilandjes.

\subsection{Offensief decentralisatiebeleid}

\subsubsection{Inleiding}

Nieuw machtsspel voor ambtenaren 
Deze casus betreft vooral een ommekeer in het denken binnen het bestuursbeleid en minder een afgebakend project. De periodisering is te plaatsen vanaf 1980 tot heden. Vóór 1980 was de dominante denklijn dat Binnenlandse Zaken geen eigen rol had om te interveniëren in de organisch groeiende verhoudingen en arrangementen in het binnenlands bestuur. De heersende opvatting was dat regelingen 'nu eenmaal' democratisch tot stand komen door gemeen overleg van het Kabinet met de Staten-Generaal, en dat binnen het kabinet Binnenlandse Zaken slechts één van de twaalf stemmen had, dus altijd het onderspit moest delven tegen een overmacht van vakdepartementen. De meest vergaande interventie was het doen van een adviesaanvraag aan de Raad voor het binnenlands bestuur, waarvan men tevoren de uitkomst kon raden, zowel inhoudelijk als wat betreft bestuurlijk effect.

$\mathrm{Na} 1980$ lag dat anders. Binnenlandse Zaken had een aantal ambitieuze ambtenaren aangetrokken, waarvan politicoloog Elco Brinkman de meest vooraanstaande exponent was. In tegenstelling tot het zittende personeelsbestand in het onderdeel Binnenlands Bestuur, overwegend juridisch opgeleiden (bij de directie Financiën Binnenlands Bestuur was gemeenteambtenaar met GA $\|^{37}$ de gangbare achtergrond), waren deze ambtenaren sociaalwetenschappelijk geschoold en dachten over macht niet als gegeven, maar als iets wat te veroveren was.

De introductie van beleid waarbij Binnenlandse Zaken en niet alleen het vakministerie de toon aangaf als het ging om verantwoordelijkheden tussen bestuurslagen, was dus de innovatie. De moderne beleidsambtenaren van Binnenlandse Zaken prikten de uitkomsten van besluitvormingsprocessen (wetgeving) door als resultanten van strijd en handig communiceren. Daar konden zij zelf ook aan gaan meedoen. Het tij was gunstig door een politiek klimaat dat steeds meer rijp werd voor een terugtredende en deregulerende overheid. De verzorgingsstaat had zijn eigen grenzen bereikt. Niet lang daarna kwam er ook een economische conjunctuur bij die dwong tot budgettair ingrijpen. De tactiek van Brinkman, die omstreeks zijn 30ste jaar werd aangesteld als DG Binnenlands Bestuur, was ongeveer de volgende: zorg (bij voorkeur tijdens een kabinetsformatie) dat er een programmatische kabinetsuitspraak ligt die als Archimedisch punt kan dienen. Het mooiste is als het regeerakkoord een kwantitatieve taakstelling bevat waar andere ministeries op kunnen worden vastgepind. Een soortgelijk effect zou uitgaan van kamerbreed aangenomen moties, ingediend door de Vaste Kamercommissie van Binnenlandse Zaken, waarin de regering voor het laatst werd gemaand decentralisatieresultaten te laten zien. Gekscherend werd door de 'politiek ondernemende' ambtenaren geopperd om enkele interne vingeroefeningen over taken die wel zouden kunnen worden gedecentraliseerd 'achter een boom te laten liggen', waar een toevallig passerend Kamerlid zijn voordeel ermee zou kunnen doen. Binnenlandse Zaken hoefde dan alleen nog maar bij de departementen langs te gaan om te oogsten.

\section{De innovatiedrager}

Brinkmans overrompelende aanpak lag ten grondslag aan de succesvolle opmars als jonge, knappe en hardwerkende ambtenaar, die vooral goed was in netwerken. Hij was de protegé van SG Van Dijke en van minister Wiegel. Ongehoord vonden de collega's de berichten dat deze jonge vlegel met zijn aimabele vrouw Janneke in hun doorzonwoning in de Leidse Merenwijk de minister en de hele ambtelijke top op party's bij hen thuis ontvingen. Dan moest je wel lef hebben! Na een korte periode als hoofd van het Bureau Secretaris-generaal, waar je het hele departement door en door leert kennen, kon hij de gooi naar de nieuwe post van directeur-generaal maken. Hier werd hij meteen de meerdere van de twee oude zittende directeuren van BB en FBB en kon hij beginnen met reorganiseren, waarbij hij een grote eigen stafafdeling inrichtte met voldoende capaciteit voor eigen onderzoek en ontwikkeling.

\footnotetext{
37 GemeenteAmbtenaar II. Deze vakopleiding van de Bestuursacademies, die doorgaans in de avonduren werd gedaan,
} gold als springplank voor hogere gemeenteambtenaren. 
Bronnen voor deze casus zijn behalve die welke in de vorige paragraaf werden genoemd de Decentralisatienota en het Decentralisatieplan (TK 16492, nrs. 2 resp. 8) en de adviezen van de Raad voor het binnenlands bestuur (1984, 1987 en 1989).

\subsubsection{Projectbeschrijving en verhalen}

\section{Taakstellende decentralisatie, toch geen resultaat}

Zo ging het dus bij de decentralisatie, waar de Decentralisatienota zelf als Archimedisch punt moest fungeren voor het Decentralisatieplan, zo ging het bij de sanering van specifieke uitkeringen, waar taakstellingen van $-25 \%$ werden genoemd, en bij de vermindering van het aantal rijksambtenaren, waarbij aan een target van $-2 \%$ per jaar werd vastgehouden. Minister Van Thijn had al eens een bezuinigingstaakstelling van 50 miljoen gulden in het regeerakkoord weten te krijgen, louter en alleen te effectueren door het beperken van rijksambtenaren die duurzame betrekkingen met gemeenten en provincies onderhouden. Deze methode was een begin, maar hij was wel erg grof en uiteindelijk ook niet erg effectief. Van Thijn bleek zich te hebben verrekend. De rondgang langs de ministeries, die meer ongenoegen dan geld opleverde, leidde in ieder geval tot het inzicht dat bij de hele rijksoverheid niet meer dan 2000 tot maximaal 4000 rijksambtenaren waren die potentieel 'duurzame betrekkingen met decentrale overheden' onderhielden.

\section{Decentralisatie als contingent proces}

De Decentralisatienota van 1980, de ideologische basis voor het beleid, was in feite een apologie voor het stelselmatig uitkammen van alle rijksbeleid en regelingen op zoek naar maximale decentralisatie. Immers, de voordelen van decentralisatie (maatwerk, integraal bestuur, betrokken burgers) waren zo groot en de krachten die tegengesteld uitwerkten zo sterk dat omkering van de bewijslast gewettigd was: decentraal, tenzij. Let wel, nergens werd de indruk gewekt dat er een ideale of logische taakverdeling zou kunnen worden ontworpen op basis van overwegingen van aard of schaal. Dat soort argumentatie werd wel voortdurend naar voren gehaald bij de reorganisatie van het binnenlands bestuur. Decentralisatie van taken was vanaf het begin een politiek spel, waarbij contingente factoren een grote rol spelen. De taakverdeling en bestuurlijke traditie (functioneel bestuur in het onderwijs, zorg en sociale zekerheid, centralisme bij landbouw, lokale aanhechting in de veiligheidsketen, provinciale aanhechting bij het economisch beleid) misten elke logica en samenhang. De versterking van de lokale en provinciale autonomie zou stapsgewijs en organisch moeten groeien, uitgaande van bestaande arrangementen en verhoudingen. De ambtenaren van Binnenlandse Zaken die naar de departementen werden gestuurd, kregen daar te maken met weerstand vanuit gegroeide verbanden en werden al gauw gezien als 'vandalen' die de geldende verhoudingen 'sloopten' en die tegen elke prijs en overal decentralisatie moesten bepleiten. Deze discussies dreigden snel weg te lopen van de echte opgave: maatschappelijke problemen oplossen. In dat opzicht was de materie typisch governmentdenken.

\subsubsection{Aanwijzingen voor de gehanteerde bestuurstheorie}

Inhoudelijk leverde de politisering van het bestuursbeleid onmiskenbaar een verbreding van het speelveld op, omdat de politieke besluitvorming die aan bestuurlijke arrangementen ten grondslag ligt in het beleid van Binnenlandse Zaken werd betrokken. Het offensieve decentralisatiestreven bleef gedurende de lange periode die het omspant een ingreep met inhoudelijk een nogal eenkennige gouvernementele argumentatie: als het maar decentralisatie opleverde binnen de bestuurskolom. Aanvankelijk naar provincies-nieuwe stijl, later bij voorkeur naar gemeenten.

Doelstelling, sturingsaanpak en democratieopvatting

Zoals we hebben gezien, is deze decentralisatiefilosofie meer gericht op het verdelen dan delen van verantwoordelijkheden. Over sturingsaanpak en democratieopvatting kunnen we het gestelde in de vorige paragraaf herhalen. 


\section{Informatieverwerving}

Indirect was de bijdrage van bestuurskundigen en politicologen aan de bestuurstheorie van Binnenlandse Zaken misschien dat zij in principe open zouden moeten staan voor maatschappelijke analyse, maar in de eerste jaren was hier nog weinig van te merken. Ze konden vooral goed redeneren en machtsspelletjes leveren vanuit een bepaalde Haagse beleidsvisie. De vooruitgeschoven ambtenaren kregen uiteraard veel invloeden te verwerken vanuit de sectoren waarin ze opereerden, maar in de meeste gevallen vond eerder een loopgravenstrijd plaats dan een intelligente dialoog.

\subsubsection{Typering van dit project volgens overige onderzoekscriteria}

\section{Mate van beleidsvernieuwing}

De opmars der politicologen en bestuurskundigen was binnen Binnenlandse Zaken een novum, al kwam deze later op gang dan bij veel vakdepartementen. Zij dachten over macht niet als gegeven (zero sum) maar als iets wat te veroveren was. Ze prikten de uitkomsten van besluitvormingsprocessen (wetgeving) door: niet de wil van hogerhand (de wetgever) zagen zij hierin, maar zij beschouwden het als resultanten van zware strijd en handig communiceren. Daar konden zij zelf ook aan gaan meedoen. Helemaal nieuw was het idee zeker niet, maar in het verleden ontbraken de tanden aan dit beleid. Het zou dus beleidsaanpassing genoemd kunnen worden.

\section{Doorwerking, institutionalisering}

Het politieke steekspel van de 'interventies' is in het bestuursbeleid ook niet meer weggegaan en is in dat opzicht een duurzaam succes.

De innovatie van Brinkman had weinig resultaten in termen van concrete decentralisatie. En waar die plaatsvonden, kon Binnenlandse Zaken zich zelden beroemen op de verovering ervan. ${ }^{38} \mathrm{De}$ zichtbare winst was vooral van bureaupolitieke aard: Binnenlandse Zaken had zich als lastige, maar onvermijdbare tegenspeler een geïnstitutionaliseerde plaats verworven aan de vergadertafels van interdepartementaal overleg.

\section{Leerprocessen}

De evaluatie van deze aanpak laat voorlopig op zich wachten, al heeft de Raad voor het binnenlands bestuur al vroeg in de jaren tachtig de vloer aangeveegd met de machtsstrategie in het decentralisatiebeleid (Raad voor het binnenlands bestuur, 1984, 1987, 1988). Het decentralisatiestreven was het meest bepalende element van de bestuurstheorie van Binnenlandse Zaken in de onderzoeksperiode. Ook andere projecten werden voor dit streven ingezet (onder meer sociale vernieuwing, grotestedenbeleid, Bestuursakkoorden en Beleids- en bestuursinstrumentarium).

\subsubsection{Conclusies}

Omdat de vernieuwing duidelijk van de top uitging, met de nieuwe DG als spil, is het vreemd om dit proces te beschrijven als een resultaat van een vrije verkenning in een chaotische fase van onzekerheid en creatieve externe oriëntatie binnen de organisatie. En toch is dat element er wel. Niet zozeer de ideeën als wel de mensen die ze belichaamden, kwamen van buiten: Brinkman, maar eerder al Henk van Ruller, die we hierboven al zijn tegengekomen, en een reeks jonge

\footnotetext{
${ }^{38} \mathrm{Er}$ is zegge en schrijve één voorbeeld waarbij de overdracht van een specifieke uitkering, die technisch gezien zonder meer mogelijk was (omdat de grote steden een aparte toedeling kennen in het Gemeentefonds), politiek werd afgedwongen na een patstelling tussen staatssecretaris De Graaff-Nauta en minister Van Aardenne en de arbitrage van minister-president Lubbers werd ingeroepen, die Binnenlandse Zaken in het gelijk stelde. Van het zogeheten voorwaardenscheppend beleid om bedrijfsterreinen te herstructureren vond ook hij dat grote steden dat zelf moesten kunnen. De wethouders en ambtenaren van deze steden waren allerminst dankbaar voor deze gewonnen vrijheid. Ze raakten als prijs hiervoor echter wel een handige entree binnen het ministerie van Economische Zaken kwijt.
} 
academici, waaronder de auteur. De belangrijkste uitdaging van de ambitieuze en hardwerkende jonge held Brinkman lag intern. Hij moest de traditionele inzichten en belangen van de nog zittende directeuren BB en FBB overwinnen. Als de oude orde als legalistisch kan worden beschreven, werd de nieuwe gedreven door een idealisme voor maatschappelijke vernieuwing, dat hierboven al als ambtelijk ondernemerschap is getypeerd. Hiermee werd een basis voor netwerkbestuur/ governance gelegd, maar daar bleef het bij. Voor de bestuurstheorie van Binnenlandse Zaken werd in deze periode inhoudelijk een belangrijker basis gelegd, die louter government-oriëntatie vertoonde. Bij de hoofdmissie van de Gideonsbende, een evenwichtiger verantwoordelijkhedenverdeling in het binnenlands bestuur was de government-benadering in denk- en werkwijze niettemin overheersend. Zowel de doelstelling, de sturingsaanpak, de democratie-opvatting als het leerproces in dit project waren top-down en technocratisch, government-gericht. Alle criteria voor het onderscheid tussen government en governance betreffende doelstelling (verdelen van verantwoordelijkheden, niet delen), de sturingsaanpak (alles top-down), de democratieopvatting (in dienst van de representatieve democratie) en het leerproces (informatievergaring van achter de tekentafel) wijzen dezelfde kant op. Daarom geen twijfel over score A. Dit had met name op het onderdeel leerproces ook anders gekund, zoals bijvoorbeeld de Raad voor het binnenlands bestuur in diverse adviezen bepleitte (Raad, onder meer 1984, 1987, 1989).

De invloed op de bestuurstheorie van Binnenlandse Zaken was zeer groot, maar weinig reflexief. De inhoud van het discours bleef door de decennia heen statisch (met uitzondering van de episode die in paragraaf 6.9 aan de orde komt).

\subsection{Sanering van specifieke uitkeringen}

\subsubsection{Inleiding}

Dit project vloeide in 1982 voort uit de Heroverweging van Rijksuitgaven (TK 1981-1982, 16625, nr. 41), waarin de basis werd gelegd voor een jaarlijkse sanering van alle specifieke uitkeringen. Als een project van Binnenlandse Zaken, met aanvankelijk een eigen projectleider en jaarlijkse rapportages, heeft dit systeem van 1983 tot $2003^{39}$ geduurd, maar even later vlamde de drang tot saneren weer op en deze is tot heden nog niet gedoofd. Dit was een succesvolle beleidsinnovatie, zowel institutioneel, afgaand op de lange adem ervan, alsook inhoudelijk. Men kon er geen genoeg van krijgen, ook toen het aantal specifieke uitkeringen al geringer was geworden dan men in 1982 had kunnen dromen.

Bronnen voor deze paragraaf zijn de interne notitie 'Het Pottenverhaal' van Van Ruller cum suis, het deelrapport van de Heroverweging Financiële Verhouding (TK 1981-1982,16625, nr. 41), het artikel van Van Bork en Schrijver (1981) en het rapport van de Stuurgroep Brinkman (2004), alsmede interviews met F. van Bork en $\mathrm{H}$. Boerboom.

Sanering van bestuursinstrumenten, een kolfje naar de hand van het bestuursbeleid Van verschillende kanten kwam de kritiek dat Binnenlandse Zaken te drammerig was opgetreden tegen de vakdepartementen, als Don Quichotte tegen de windmolens. De directie Coördinatie Bestuursbeleid koos nu de koers de departementen aan te vallen op de verschillende bestuursinstrumenten zoals specifieke uitkeringen, planprocedures, toezichtsfiguren en gedeconcentreerde diensten. Zo kon Binnenlandse Zaken meer op eigen terrein de strijd aanbinden dan wanneer de discussie ging over de inhoudelijke wenselijkheid van decentralisatie op een bepaald beleidsterrein. Ook kon worden meegelift op grote operaties van andere ministeries, zoals de Heroverweging van Financiën of de Deregulering van Justitie. Het

\footnotetext{
39 In 2003 verscheen het laatste Overzicht Specifieke Uitkeringen, maar sinds 2007 is op basis artikel 20 van de Financiële
} Verhoudingswet een nieuwe reeks jaarlijkse overzichten ('Onderhoudsrapporten') begonnen. 
moederdepartement verwees dan naar een algemene voorkeur voor de Gemeentewet, de Financiële Verhoudingswet en de Provinciewet, die veelal alternatieve, generieke instrumenten aanbieden, die uit oogpunt van gedecentraliseerd bestuur de voorkeur genoten. Denk aan de algemene uitkering uit het Gemeentefonds, de meerjarenbegroting of het bestemmingsplan in plaats van planprocedures, algemene taakverwaarlozingsregelingen voor het toezicht, en de inspectierol van de provincie in plaats van gedeconcentreerde rijksdiensten. Deze aanpak was relatief succesvol blijkens de dalende aantallen specifieke bestuursinstrumenten die jaarlijks werden geteld.

\subsubsection{Projectbeschrijving en verhalen}

\section{Toespitsing op specifieke uitkeringen}

Zoals hierboven is uiteengezet, begon de coördinerende taak van Binnenlandse zaken voor de interbestuurlijke betrekkingen met de beteugeling van specifieke uitkeringen als meest indringende en bezwaarlijke vorm van centralisatie. In 1978 produceerde de eerdergenoemde Henk van Ruller samen met 'trainee' Frans van Bork en ondergetekende een interne nota met de frivole titel 'Het Pottenverhaal'. Hierin werd als probleemstelling geformuleerd dat specifieke uitkeringen sluipenderwijs een ondermijnende werking uitoefenden op de Financiële Verhouding(en) en daarmee op de gemeentelijke autonomie. De Financiële Verhouding was en is gebaseerd op drie pijlers:

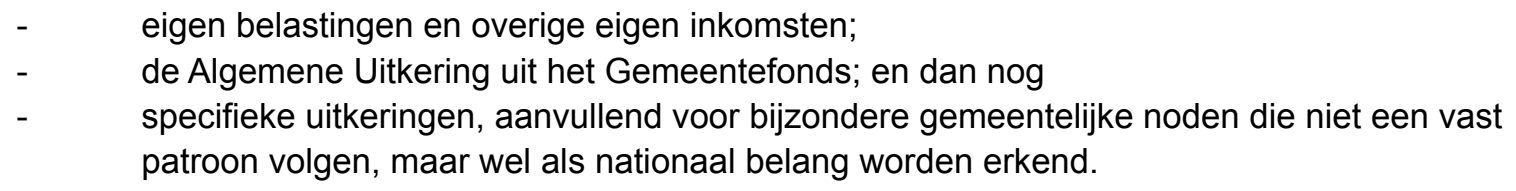

In de jaren zestig en zeventig van de twintigste eeuw waren specifieke uitkeringen ontdekt als effectief sturingsmiddel voor vakdepartementen om specifieke doelstellingen te effectueren via de geldkraan. Daarmee werd de neutraliteit van de Financiële Verhouding(en) ondermijnd. Door een bepaalde categorie uitkeringen, de lokkertjes, werd ook de gezondheid van de gemeentelijke financiële huishouding op de proef gesteld. De gemeenten werden namelijk verleid tot het doen van uitgaven waarin het Rijk slechts een partiële of een tijdelijke bijdrage verstrekte; de resterende uitgaven bleven voor eigen rekening. Vooral die categorie specifieke uitkeringen, de bijdragen, was Binnenlandse Zaken een doorn in het oog. Het verschijnsel werd vooral als probleem op de agenda gezet, omdat het aantal specifieke uitkeringen in de jaren zeventig gestaag was gegroeid en naar schatting $70 \%$ van de gemeentelijke inkomsten uitmaakte. Ook werd als problematisch ervaren dat een overzicht ontbrak. Het verschijnsel ging alle kenmerken van wildgroei vertonen. Gemeenten gingen subsidiologen inhuren om op de hoogte te blijven van alle mogelijkheden, experimenten werden opgezet en bij gebleken succes beëindigd, omdat de gemeenten ze wel moesten voortzetten onder druk van de lokale belanghebbenden; regelingen van het ene ministerie reden die van een andere in de wielen.

Kortom, het werd een wild spel, en dat kon voor een ministerie dat als een van zijn hoofddoelstellingen een ordelijk binnenlands bestuur had genoteerd, niet door de beugel. Het ministerie zou hiertegen actief moeten optreden. Dat was een uitspraak die nogal wat weerstand opriep binnen het legalistische denken van die tijd. Was immers niet de eenheid van kabinetsbeleid heilig en gold dat niet a fortiori als het kabinetsbeleid in de Staten-Generaal was gefiatteerd, zelfs in de vorm van wet- en regelgeving was voorzien van de handtekening van het Staatshoofd? Zo liep het namelijk meestal wel: ministeries zetten hun specifieke uitkeringen netjes in de begroting en bij de meer belangrijke regelingen werd een wettelijke regeling gemaakt. Ook kwam het regelmatig voor dat een regeling er kwam op aandringen van moties uit de Tweede Kamer. In het algemeen was begin jaren zeventig de situatie zo dat de hoofdambtenaren van Binnenlandse Zaken de toevloed van specifieke uitkeringen wel betreurden, maar het niet op hun weg vonden liggen om het formeel juiste proces van besluitvorming over inhoudelijk rijksbeleid te blokkeren. 
De ambtelijke populatie van overwegend juristen die zich met het binnenlands bestuur bezighielden, werd in de tweede helft van de jaren zeventig in snel tempo uitgebreid met economen, sociologen en politicologen die daar een slag anders over dachten. Zij zagen de toename van regelingen als een uitkomst van een machtsstrijd of van calculerend gedrag en vonden het niet meer dan logisch om in die machtsstrijd een tegenwicht te organiseren als daar goede argumenten voor waren en als die politiek gelegitimeerd konden worden. Van Bork en Schrijver (1980) illustreerden deze zienswijze met een artikel in Bestuurswetenschappen, waarin zij niet alleen het verschijnsel specifieke uitkeringen beschreven, maar ook voor een bepaalde categorie, de bijdragen, het mechanisme dat volgens hen daarachter zat. 'De Bijdragespiraal' was niet alleen de uitkomst van centralistische bemoeizucht door vakdepartementen die met de 'gouden koorden' wilden regeren, maar werd evenzeer in stand gehouden door subsidieverslaafde wethouders die hun lokale ambities konden realiseren met de financiële steun van het Rijk. Op systeemniveau was echter uiteindelijk het gevolg dat de gemeenten steeds verder afhankelijk werden van rijksbijdragen, omdat de aanvullende kosten een steeds groter deel van de algemene middelen opsoupeerden. Daarom konden gemeenten niet anders dan voor steeds onbeduidender lokale belangen de hand ophouden bij de vakdepartementen, die daarin weer een kans zagen om met bijbehorende voorwaarden de gemeentelijke praktijk te sturen.

\section{Sanering van specifieke uitkeringen}

In de slipstream van het decentralisatiestreven kwam er beleid voor specifieke uitkeringen dat niet alleen defensief was ingesteld, zoals staatssecretaris Polak al had geregeld met zijn waakhondfunctie in de Ministerraad, maar ook sanering van het bestaande behelsde. Daartoe moest eerst inzicht worden verschaft in de omvang van het verschijnsel. De operatie Sanering Specifieke Uitkeringen behelsde allereerst het maken van een jaarlijks Overzicht en daarvoor werden nieuwe comptabiliteitsregels uitgevaardigd die ministeries verplichtten al hun specifieke uitkeringen afzonderlijk te presenteren. Het eerste Overzicht kwam in 1983 en telde maar liefst 583 regelingen. Hieraan ging een groot aantal definitiegevechten vooraf. ${ }^{40}$ De 583 regelingen werden gecanoniseerd en vervolgens werden hieraan taakstellingen gekoppeld om het aantal binnen één kabinetsperiode met $25 \%$ terug te brengen. Ruw, maar doeltreffend in de handen van terriërs als Peter Welling en Hein Glerum. Eind jaren negentig, na nog drie gelijksoortige saneringsoperaties, was het aantal specifieke uitkeringen geslonken tot 116. In 2003 werd zelfs het jaarlijkse corvee om een afzonderlijk Overzicht Specifieke Uitkeringen uit te brengen afgeschaft. De praktijk om specifieke uitkeringen in de afzonderlijke begrotingshoofdstukken te verantwoorden werd voldoende ingesleten geacht.

Maar nog waren de politici niet verzadigd. Een van de pijlers in het Programma Andere Overheid van minister Thom de Graaf was gewijd aan de vernieuwing van de verhoudingen tussen de bestuurslagen en het belangrijkste onderdeel daarvan behelsde, jawel, een sanering van specifieke uitkeringen. Alsof dat afgekloven thema een 'andere overheid' werkelijk profiel zou geven. Een commissie onder leiding van Elco Brinkman (!) wist met voorstellen te komen om het aantal specifieke uitkeringen nog terug te brengen tot 22 op termijn (op korte termijn 34) (Stuurgroep Brinkman, 2004). Het jaarlijkse Overzicht Specifieke Uitkeringen kwam in 2007 via een omweg terug, omdat de Financiële Verhoudingswet in artikel 20 een verplichting hiertoe bevat. In de recentste overzichten staat ook een meerjarig rijtje aantallen regelingen, hoewel dit niet meer taakstellend is.

Overigens hebben al die saneringen meer geresulteerd in bundeling van kleine regelingen tot brede doeluitkeringen dan in grootscheepse verschuiving van het financieel aandeel van specifieke

\footnotetext{
40 Het ging dan bijvoorbeeld om zogeheten pendantregelingen, die zowel gemeenten als particulieren (bijvoorbeeld openbare en bijzondere scholen) tot doelgroep hadden of om regelingen waarvan gemeenten konden profiteren, niet als beleidsmaker, maar in hun hoedanigheid van eigenaar van grond of gebouwen. Die grenskwesties blijven hier verder terzijde. Interessant is wel het leerstuk van de verhouding tussen publiek- en privaatrecht, waarbij het eerste voorgaat. Een gemeente die eigenaar of huurder, koper of anderszins privaatrechtelijk rechtssubject is, doet dat nimmer vanuit particuliere motieven, maar altijd vanuit publiekrechtelijk belang. Gemeentelijk boseigendom kan dus nooit worden losgezien van een beleidsmatig oogmerk ten bate van de gemeenschap, aldus de doctrine.
} 
uitkeringen ten opzichte van de Algemene uitkering van het Gemeentefonds. In 2005 bedroeg die verhouding nog steeds $3: 2$ en na effectueren van alle voorstellen van de stuurgroep-Brinkman kan de verhouding ongeveer fiftyfifty worden.

\section{Perverse effecten van taakstellingen}

Is het spreekwoord nu 'Wie bepaalt, betaalt' of omgekeerd: 'Wie betaalt, bepaalt'? Allebei zijn in de praktijk herkenbaar, maar Binnenlandse Zaken voerde de laatste redenering aan om specifieke uitkeringen als machtsmisbruik te brandmerken in het streven naar decentralisatie in de verhoudingen tussen Rijk en andere overheden. Soms werden tegenstrijdige argumenten aangevoerd om toch maar bekostiging via het Gemeentefonds te bepleiten. Bijvoorbeeld het argument van de relatief geringe bedragen die een voorziening vergt, ook al is de spreiding over het land zeer ongelijk. Dan valt de verdeelproblematiek weg in de wet van de grote getallen. De beheerders van dat fonds waren daar niet altijd blij mee en ook de gemeenten niet altijd. Gert-Jan Uhl, de vroeg gestorven directeur BFO, die als architect van de moderne financiële verhouding(en) mag gelden, was juist dol op de wet van de grote getallen.

Behalve dat het ministerie - nodig of niet - veertig jaar lang hardnekkig bleef vasthouden aan het eenmaal gekozen streven om specifieke uitkeringen af te schaffen, bracht dit beleid ook ongerijmdheden voort. Zware gevechten werden geleverd over de definitie van specifieke uitkeringen om maar buiten de saneringsdrift te vallen of om toch maar de taakstellingen te kunnen halen. Dit is achteraf op te vatten als uitingen van symbolisch bestuursbeleid dat weinig meer te maken heeft met de maatschappelijke werkelijkheid. In het streven om zoveel mogelijk specifieke uitkeringen naar het Gemeentefonds over te hevelen worden concessies gedaan, bijvoorbeeld ten aanzien van de toepasbare verdeelsystematiek, maar ook ten aanzien van het axioma dat over de besteding van middelen uit het Gemeentefonds geen verantwoording hoeft te worden afgelegd. Om maar zoveel mogelijk regelingen binnen te halen worden in 2006 binnen de algemene uitkering zogeheten Integratie-uitkeringen en Decentralisatie-uitkeringen in het leven geroepen, waarvan de verdeling nog een tijdlang per gemeente precies wordt uitgerekend. Deze middelen worden dus niet volgens de algemene, globale verdeelmaatstaven uitgekeerd. Verder kunnen hierbij ook nog afzonderlijke informatie-eisen worden gesteld. Zie verder in paragraaf 8.2 onder Single information, single audit.

\subsubsection{Aanwijzingen voor de gehanteerde bestuurstheorie}

In de balans tussen government- en governance-denken slaat het denken door in de richting van het eerste. Als species van het decentralisatiebeleid behoeven niet alle kenmerken hier te worden herhaald. Inhoudelijk zou men met een maatschappelijke probleembenadering pragmatischer redeneren; ook al zou het verdeeltechnisch niet onvermijdelijk zijn, dan kun je een wethouder, gedeputeerde of bewindsman de credits gunnen om een subsidie te regelen en daarmee voor specifieke projecten de onderlinge samenwerking te onderlijnen. Maar wil dat echt een verdienste blijven, dan moet het met mate worden toegepast. Verder geldt alles wat hiervoor al over het decentralisatiebeleid is gezegd, een uiting van een offensieve ambtelijke aanpak, maar overwegend top-down ingericht, misschien nog wel technocratischer dan het streven naar decentralisatie van taken, omdat daar noodzakelijkerwijs meer elementen van contingent overleg insluipen.

\subsubsection{Typering van dit project volgens overige onderzoekscriteria}

Mate van beleidsvernieuwing

Henk van Ruller maakte de eerste interne nota over het fenomeen specifieke uitkeringen, onder de naam 'Het Pottenverhaal'. Later werkte de chef Financiële Verhouding(en), Gerrit-Jan Uhl, de criteria uit die een specifieke uitkering nog rechtvaardigen en wanneer de algemene uitkering voorkeur geniet. De beleidsinnovatie ligt aan het begin van het decentraliseringsbeleid omstreeks 
1980. De 'uitvinding' om decentralisatiebeleid te pakken via beleidsinstrumenten die geteld en gemaximeerd kunnen worden, kan een beleidsaanpassing worden genoemd.

\section{Doorwerking en institutionalisering}

Inderdaad heeft de sanering de eerste twintig jaar heilzaam gewerkt in het herstellen van het machtsevenwicht tussen het Rijk en de decentrale overheden. Het aantal specifieke uitkeringen liep terug van 583 tot iets boven de 100. Daarna kon het ministerie er geen genoeg van krijgen. Beleidsbeëindiging of beleidsopvolging bleef gedurende de hele onderzoeksperiode uit. Tijdens het Programma Andere Overheid in 2003 was sanering van specifieke uitkeringen nog steeds een speerpunt.

\section{Evaluatie en leerproces}

Het saneringsproces is voortdurend geëvalueerd, in de zin van monitoring van de bereikte aantallen. Minder werd op project-niveau nagegaan wat er te leren viel over de aanpak. De reden dat hier wat uitgebreider is stilgestaan bij de lange, steeds weer herhaalde beleidsgeschiedenis van dit saneringsstreven, zelfs nadat het echte probleem eigenlijk al was bestreden, is om te laten zien hoe hardnekkig bepaalde ideeën over 'goed en kwaad' in het openbaar bestuur in het discours van het bestuursbeleid zaten verankerd.

\subsubsection{Conclusies}

Het beleid was zeker doeltreffend, zozeer dat het ministerie er geen genoeg van kon krijgen. Omdat het nauwelijks elementen van netwerkbestuur/governance vertoonde, draagt het bij aan het beeld dat de hoofdstroom van het bestuursbeleid government-georiënteerd was. Score A, onversneden.

Zeker kan worden erkend dat de financiële verhouding relatief veel heeft bijgedragen aan de bestuurstheorie van Binnenlandse Zaken. Er is veel over nagedacht hoe financiën zo konden worden toegedeeld dat zij de beoogde bestuurlijke inrichting zo min mogelijk zouden verstoren. Maar die bestuurlijke inrichting was altijd leidend.

\subsection{Bestuursakkoorden}

\subsubsection{Inleiding}

Een nieuw idee leidde tot een nieuw project, dat regelmatig werd ververst, maar niet echt vernieuwd. Bijna elke kabinetsperiode na 1987 begint met de formulering van de gewenste spelregels in de interbestuurlijke verhoudingen. In 1999 werd dit aangevuld met inhoudelijke probleemgebieden waar Rijk en decentrale overheden gezamenlijk oplossingen voor moesten vinden. Sinds dit Bestuursakkoord-nieuwe stijl vindt een periodiek overhedenoverleg plaats, waar de minister-president en de voorzitters van IPO en VNG elkaar ontmoeten om over gezamenlijke vraagstukken te spreken. Ook de noviteit van Bestuursakkoorden heeft zich aan het eind van onze onderzoeksperiode eigenlijk overleefd. Het overhedenoverleg, dat al was begonnen tijdens de Decentralisatie-impuls (zie paragraaf 6.8), blijt over.

Bronnen: interviews met Jan Hendrikx, projectleider Marie-Louise van Muijen en Ciska Scheidel. Relevante documenten zijn de Bestuursakkoorden zelf (TK 1986-1987, 19843; TK 1990-1991, 21631), het Bestuursakkoord Nieuwe Stijl 'Overheden over toekomst' en de Code Interbestuurlijke Verhoudingen (Ministerie BZK, IPO en VNG, 2005).

\section{On speaking terms}

Bestuursakkoorden werden in de jaren negentig plotseling enorm populair. Op één punt onttrokken deze zich aan de definitie van complementair bestuur, omdat het zelden ging om de binding tussen besturen van afzonderlijke openbare lichamen; eigenlijk waren dit toch vooral herenafspraken 
tussen Binnenlandse Zaken en de VNG over algemene spelregels in de interbestuurlijke verhoudingen, meer in het bijzonder op financieel terrein. Dat was nodig voor het herstel van geschonden vertrouwen nadat het kabinet-Lubbers-I communicatief onhandig en naar het oordeel van de VNG onredelijk was begonnen met bezuinigingen, ook ten laste van het Gemeentefonds. Het idee voor het eerste bestuursakkoord is toegeschreven aan Ed Nijpels, toenmalig fractievoorzitter van de VVD en onderhandelaar voor de kabinetsformatie van het kabinet-Lubbers I in 1986. Dit was een idee dat uitstekend paste in de poldertraditie. Jan Hendrikx was directeurgeneraal Binnenlands Bestuur en een enthousiast adept van dit idee. Zijn voorganger Jos Staatsen had bestuursakkoorden al in het milieubeleid helpen introduceren, maar daar was het vooral bedoeld als sturingsinstrument in plaats van dwingende gedragsregels. De functie om de interne waarborgen voor goed bestuur vast te leggen in een gezamenlijk goodwill-document met de vertegenwoordigers van gemeenten en provincies, was een vondst en iets geheel nieuws in het binnenlands bestuur (vrij kort na de sceptische werkgroep Complementair Bestuur). Het werd ontvangen als het ei van Columbus en de ambtenaren vroegen zich af waarom zij dit niet zelf hadden bedacht. Maar natuurlijk kwam dit idee uiteindelijk toch ook uit een ambtelijke koker. Al na de eerste kabinetsperiode van Lubbers was de relatie tussen Rijk en gemeenten danig bekoeld door de gepercipieerde afwenteling van bezuinigingen op de decentrale overheden. Toen DG Staatsen voortijdig vertrok om burgemeester van Groningen te worden, was men het er bij de leiding van het ministerie over eens dat zijn opvolger uit de gemeentelijke kring zou moeten komen om het geschonden vertrouwen te verbeteren.

\section{De innovatie}

Jan Hendrikx had zich als burgemeester van Wijchen onder meer onderscheiden door een creatief idee in de sfeer van financieel beheer bij overheden met een kapitaaldienst. Dit lucratieve idee (hoogrentende leningen converteren voor laagrentende) trok ruim de aandacht en vond breed navolging. Zijn bestuurlijk-politieke kwaliteiten bleken daarnaast uit een succesvolle campagne om de zogeheten Stopwet te stoppen, waardoor zijn gemeente Wijchen met terugwerkende kracht zou worden beroofd van een eigen gemeentepolitiekorps. Zijn beminnelijke persoonlijkheid was echter minstens zo belangrijk voor een geslaagde sollicitatie naar deze begerenswaardige post in het binnenlands bestuur. ${ }^{41} \mathrm{Na}$ zijn aanstelling in 1985 wist hij inderdaad een zeer hartelijke relatie te ontwikkelen met de toenmalige hoofddirecteur van de VNG, Ed Berg. Zij hielden elkaar goed vast. Samen kwamen zij tot de conclusie dat het ontwikkelen van spelregels in het binnenlands bestuur en in het bijzonder in de Financiële Verhouding(en) van de allerhoogste urgentie was. Gevoeligheid voor de stijl van bejegening van 'lagere' overheden door het Rijk werd een belangrijk aandachtspunt bij Binnenlandse Zaken. Empathisch gedrag was dringend geboden, zeker ook vanuit rijksbelang geredeneerd, om de feitelijke afhankelijkheid van de medewerking van decentrale overheden aan het aanpakken van maatschappelijke vraagstukken als milieuvervuiling, integratie van minderheden of criminaliteitsbestrijding te materialiseren.

Een bestuursovereenkomst tussen de VNG namens alle gemeenten en het Rijk zou een belangrijke symbolische meerwaarde hebben. Gelijkwaardigheid tussen de partners in het Huis van Thorbecke was een gedachte die na de oorlog was weggezakt en die door de contractvorm uitstekend tot uiting kon worden gebracht. Dat was de waarde en ook het nieuwe van dit idee naast de zelfbinding van het Rijk, die wellicht ook wel met eenzijdige politieke oekazes bereikt kon worden. Met andere woorden zegt Jan Hendrikx over zijn idee:

"Het was een uitstekende manier om te bewerkstelligen dat de niet aanwezige partijen in de Ministerraad toch invloed konden uitoefenen op de besluitvorming." 42

\footnotetext{
${ }^{41}$ Van de zes directeuren-generaal Binnenlands Bestuur (of Openbaar Bestuur) die tussen 1980 en 2006 optraden, zijn er vier meteen daarna terechtgekomen in bestuurlijke functies (minister, CdK of burgemeester van een grote stad) en twee zijn SG geworden.

42 Interview met Jan Hendrikx, op 2 augustus 2007 in Zwolle.
} 
Daarbij was Hendrikx ervan overtuigd dat de kabinetsformatie de enige gelegenheid was om een dergelijk idee werkelijkheid te laten worden. In 1987 was er zo'n zeldzame kans. Er is weinig fantasie voor nodig om te weten dat de heren de partijleiders hebben aangesproken voor de verkiezingscampagne. Toevallig was het Ed Nijpels (VVD), die als eerste hapte en in een publicatie of interview in Elsevier het idee lanceerde.

\subsubsection{Projectbeschrijving en verhalen}

\section{Betekenisvolle gedragsnormen of mantra?}

Inderdaad heeft het Bestuursakkoord, dat mede dankzij de inzet van staatssecretaris Dieuwke de Graaff-Nauta tot stand is gekomen, een belangrijke rol gespeeld bij de verdere ontwikkeling van de samenwerking tussen de bestuurslagen en daarmee bij het organiserend vermogen van de Nederlandse overheid als geheel.

De indirecte effecten van het Bestuursakkoord door het openen van communicatiekanalen die anders waarschijnlijk met wantrouwen verstopt zouden zijn gebleven, waren minstens zo belangrijk als de gemaakte, nogal defensieve, afspraken zelf. Nu was het nog zaak elkaar op te zoeken bij de aanpak van complexe vraagstukken. Dat gebeurde nog erg schoorvoetend. Nog verder weg stond de verbinding met maatschappelijke partners die evenzeer nodig zijn bij de constructieve aanpak van problemen. Maar de eerste voorwaarde voor normale volwassen relaties tussen departementen, gemeenten en provincies was geschapen met het Bestuursakkoord. Het Bestuursakkoord was zo succesvol dat het na enkele herhalingen niet meer was weg te krijgen, ook al is de oorspronkelijke functie om normen voor goede interbestuurlijke betrekkingen vast te leggen allang overbodig geworden. Die waren intussen wel bekend of zouden door een enkele verwijzing naar bestaande documenten in herinnering gebracht kunnen worden. De belangrijkste spelregel was het zogeheten evenredigheidsbeginsel in de Financiële Verhouding(en). De accressen van het Gemeentefonds werden mathematisch bepaald door het percentage waarmee de Rijksbegroting jaar op jaar werd verhoogd of verlaagd. Daarmee werd voorkomen dat gemeenten zwaarder zouden worden 'gepakt' dan het Rijk. Daarnaast profiteerden gemeenten automatisch van meevallers bij het Rijk. En er waren nog meer gedragsregels, die vooral voor het Rijk zelfbinding impliceerden aan de norm dat lokale autonomie een groot goed is in een democratie. Dezelfde regels golden voor de provincies. Met het Interprovinciaal Overleg (IPO) werden soortgelijke afspraken gemaakt in een afzonderlijk bestuursakkoord.

Het klimaat waarin het nodig was om steeds weer de goede verhoudingen te beklemtonen binnen het bestuursbeleid, valt goed af te lezen uit het enige jaarverslag dat de afdeling Interbestuurlijke Betrekkingen ooit heeft uitgebracht, in 2006. De titel hiervan luidt: 'Werken aan vertrouwen: Een jaar van terugblikken en vooruitkijken'. Het jaarverslag begint met een hoofdstuk over interessante werkbezoeken die werden afgelegd in het veld, uiteenlopend van een zorgkantoor, daklozenopvang van het Leger des Heils tot jeugdpreventieprogramma's. In de rest van het stuk komt niets terug dat wijst op benutting van de inzichten over deze inhoudelijke problemen voor bestuursbeleid, maar richt alle aandacht zich op toezichtrelaties, decentralisatie en de naleving van de Code Interbestuurlijke Verhoudingen.

Symbolische of echte samenwerking? Bestuursakkoord Nieuwe Stijl Toen jaren later (1999) werd besloten tot de introductie van een ander type akkoord, een Bestuursakkoord Nieuwe Stijl (BANS), het eerste gezamenlijke bestuursakkoord met VNG en IPO samen, met een veel meer inhoudelijk karakter, durfde men toch de algemene bepalingen met dezelfde normen niet los te laten. In november 2004 werden de gedragsregels 'gecodificeerd' in een Code Interbestuurlijke Verhoudingen (Ministerie van BZK, IPO en VNG, 2005), die nog lang daarna werden aangehaald (Van Muijen en Wolthuis, 2008). Het kabinet-Balkenende III sloot in 2008 wederom een bestuursakkoord met VNG en IPO over algemene bestuurlijke principes en intenties.

Het Bestuursakkoord Nieuwe Stijl van 1999 had echter de ambitie om een probleemgerichte benadering te kiezen. 


\subsubsection{Aanwijzingen voor de gehanteerde bestuurstheorie}

Sturingsaanpak en democratie-opvatting worden hier niet apart behandeld. Bestuursakkoorden voegden weinig toe aan een gefundeerde bestuurstheorie. Het bleven vooral instrumenten voor het verbeteren van Haagse verhoudingen. In termen van governance-denken zou de samenwerkingsgedachte positief gewaardeerd kunnen worden, maar omdat het instrument zich zo duidelijk beperkte tot de Haagse wereld van Rijk, IPO en VNG was dat maar schijn. Het heeft niet geleid tot het samen met betrokkenen ter plaatse oplossen van maatschappelijke vraagstukken, ondanks intenties in die richting. De poging om af te dalen tot maatschappelijke problemen in het BANS is nauwelijks geslaagd, omdat met uitzondering van plattelandsbeleid in Noord-Limburg echte stakeholders niet betrokken waren. Dus alle uitgesproken intenties ten spijt bevestigt ook de geschiedenis van het Bestuursakkoord de dominantie van het government-denken binnen het bestuursbeleid.

\subsubsection{Typering van dit project volgens overige onderzoekscriteria}

\section{Mate van beleidsvernieuwing}

Zoals hierboven al is gesteld, was het bestuursakkoord in 1987 een beleidsinnovatie, maar daarna is tot het eind van de onderzoeksperiode sprake van voortzetting van het, vooral in communicatief opzicht, succesvolle instrument. Beleidsaanpassing was de eenmalige poging om de bestuursakkoorden in het veld tot leven te brengen (BANS).

\section{Leerproces, evaluatie}

Evaluaties werden na elk akkoord tussen de drie convenantpartners opgesteld (bijvoorbeeld TK 1993-1994, 19967, nr. 25), maar die hadden vooral betrekking op de naleving van de afspraken, niet op de impact op de bestuurstheorie. BANS is uitgebreid geëvalueerd, maar tot een vervolg heeft de 'nieuwe stijl'-aanpak niet geleid.

\section{Doorwerking, institutionalisering}

Dit staat in contrast met de landelijke afspraken op koepel-niveau over goede omgangsvormen tussen bestuurslagen. Ook nadat deze gedragsnormen allang gemeengoed waren geworden, konden nieuwe kabinetten en besturen van VNG en IPO er maar geen genoeg van krijgen steeds nieuwe handtekeningenceremonies te organiseren over ongeveer dezelfde bestuursafspraken.

\subsubsection{Conclusies}

In de vorm was de sturingsaanpak van een convenant naar zijn aard tweezijdig, maar de facto ging het gesprek alleen tussen Haagse koepels. Juist op het punt waar governance-benadering tot uiting zou kunnen komen, namelijk waar verschillende stakeholders concrete problemen gezamenlijk zouden kunnen aanpakken, is er sprake van een gemiste kans (met een enkele uitzondering binnen BANS, waar wel afzonderlijke gemeenten en provincies om de tafel werden gezet).

Door deze kortstondige poging van BANS is niet meer dan een magere A- aan dit project toe te kennen.

Dit had zeker ook anders gekund, zij het dat noch VNG en IPO, noch Binnenlandse Zaken zich konden losmaken van het dominante dichotome denken over de verhouding tussen Het rijk (de boze vakdepartementen) en dé decentrale overheden. Ook dit project begon na zoveel jaren sleets te raken en het illustreert het bestaan van een bestuurlijk papegaaiencircuit, waarin men het moeilijk vond om eenmaal ingesleten routines los te laten. Voor de ontwikkeling van een gezamenlijke bestuurstheorie is het periodiek formuleren van gedragscodes wel belangrijk, maar als een werkelijke relatie met het grondvlak en met de samenleving ontbreekt, kan hier niet al te veel van worden verwacht. 


\subsection{D'project}

\subsubsection{Inleiding}

De opzet van D'gemeenten en D'provincies duurde van 1987 tot 1993, inclusief een nogal moeizaam wetgevingstraject, dat diende om experimenten met dereguleringsvoorstellen wettelijk mogelijk te maken. Dat experimentele karakter was in Nederland slechts een deel van het project. Het leeuwendeel leek meer op een georganiseerde ideeënbus voor gemeenten en provincies om zelf voorstellen te doen voor decentralisatie en deregulering. De organisatie werd vormgegeven door de inrichting van een gezamenlijke overleggroep van Binnenlandse Zaken, Justitie, IPO en VNG. Een echt project dat rechtstreeks rapporteerde aan de minister, was het niet.

De jaren tachtig stonden in het teken van de grote operaties. Toch was aanvankelijk de oogst aan feitelijke decentralisatie mager. De medewerkers van de afdeling Coördinatie Bestuursbeleid keken reikhalzend uit naar nieuwe mogelijkheden om de vakdepartementen in beweging te krijgen. Heroverwegingsoperaties op de bagagedrager van Financiën waren een voorbeeld, zoals de sanering van specifieke uitkeringen, de sanering van planprocedures met een werkgroep onder leiding van Vonhoff, die het rapport 'Carnavalstocht van planprocedures' opleverde, maar nog niet direct veel resultaten. In 1987 kreeg de afdeling, onder directeur Floris Plate, afdelingshoofd Lodewijk van Vliet en projectleider Jan de Winter, opeens een nieuwe aanpak in de schoot geworpen: het project D'gemeenten (/D'provincies).

Bronnen: bovenstaande personen zijn geïnterviewd voor de beschrijving van deze casus. De feitelijke gang van zaken van dit project, die hier zeer kort wordt weergegeven, is meer uitgebreid te vinden in de stukken van de Tweede Kamer 1988-1989 bij het wetsvoorstel D'gemeenten en D'provincies, TK 21081, nr. 3 (Memorie van Toelichting). Verder zij verwezen naar het artikel van Schrijver (1992) en het evaluatierapport in bezit van de auteur.

\subsubsection{Projectbeschrijving en verhalen}

\section{Nederlandse vertaling van Frikommuner}

Het begin was mooi. Serendipiteit met een Scandinavisch voorbeeld, dat werd ontdekt tijdens een OESO-conferentie in Istanbul en dat perfect paste in een Nederlandse window of opportunities (Kingdon, 1995). Directeur Floris Plate kwam de beschrijving van het Zweeds/Deense voorbeeld tegen op een OESO-conferentie begin 1987 over Turkse bestuursontwikkeling. Na zijn terugkeer werd dit idee opgepikt door Jan de Winter, die destijds projectleider was in een slappe tijd voor decentralisatie. Flink aangepast aan onze egalitaire poldersamenleving kwam er inderdaad een project D'gemeenten en D'provincies. De VNG en het IPO werden in het complot betrokken en zorgden er meteen al voor dat het project niet op voorhand beperkt zou worden tot een te beperkt aantal (in Zweden negen) bevoorrechte gemeenten of gebieden. Alle gemeenten en provincies mochten voorstellen indienen. Vooral de VNG, voor wie alle leden even lief zijn, droeg bij aan deze keuze.

Bovendien zou in Nederland niet alleen lokale differentiatie naar plaatselijke behoefte vooropstaan, maar ook de landelijke invoering van nieuwe voorstellen, desnoods na een fase van experimenteren in een aantal gemeenten. Het was een soort ideeënbus (bottom-up in het kwadraat) en timing was een belangrijke factor voor de uitkomst. Er werden uiteindelijk 500 verschillende voorstellen ingediend, de meeste nogal administratief, maar ook een paar maatschappelijk interessante. Dat winkels na 18 uur open zijn, is inmiddels allang gemeengoed, maar in 1988 was dat nog zeer omstreden. De middenstand lag er dwars voor. Omdat EZ er wel wat voor voelde, werd een voorstel tot verruiming van de winkelopeningstijden verheven tot het eerste experiment op dat terrein in Nederland en voorloper voor de huidige Winkelsluitingswet. Uiteindelijk zou je kunnen zeggen dat de discussie over de winkelsluiting in Nederland is 
opengebroken door het avontuur in te gaan met de ideeënbuis en het experiment. Voor dat voorstel was op dat moment de tijd rijp en deze aanpak bracht dat naar boven.

\section{Nederlands uniformiteitsdenken}

Vooral de VNG en het IPO zorgden er meteen al voor dat het project niet op voorhand beperkt zou worden tot een te beperkt aantal (in Zweden negen) bevoorrechte gemeenten of gebieden. Hier komt duidelijk naar voren hoezeer in het Nederlandse denken over het openbaar bestuur de uniformiteit van de gemeenten en provincies is ingebakken. De trauma's uit onze vaderlandse geschiedenis van de Republiek zijn hier misschien debet aan, maar het is hier niet nodig om erover te psychologiseren. Het gaat erom hoezeer het discours hierdoor wordt getypeerd.

\section{Organische ontwikkeling op basis van toevallige factoren}

Het procesmatig bijzondere van het D'project was dus dat het zelf de uitkomst was van een vrije verkenning, van Floris Plate via Istanbul en Scandinavië naar een typisch Nederlandse vertaling van een nieuwe aanpak van onderop. Tegelijkertijd leidde deze aanpak inhoudelijk tot een open en onzeker resultaat, omdat dit afhankelijk was van de inbreng van de gemeenten en provincies. Het grote aantal voorstellen die zonder onderlinge afstemming waren ingediend, stond garant voor variëteit. De confrontatie met de ministeries leidde tot een selectieproces waarin de contingente factoren bepalend waren voor succes of falen. Naast het voorstel voor de verruiming van de winkelopeningstijden, dat werd gesteund door het ministerie van $E Z$, was er een voorstel waar het verantwoordelijke ministerie WVC op dat moment niets van wilde weten, namelijk het mogelijk maken van reclame in lokale radio en televisie. Dat was door de gevreesde concurrentie met de publieke omroep en met andere media onbespreekbaar, zelfs in de vorm van een experiment op bescheiden schaal. Reeds in de volgende kabinetsperiode bleken deze bezwaren als sneeuw voor de zon verdwenen en nu is reclame in de lokale en regionale omroep een doodnormaal verschijnsel.

\subsubsection{Aanwijzingen voor de gehanteerde bestuurstheorie}

\section{Doelstelling}

De vernieuwing van het project D'gemeenten zit weer vooral aan de proceskant. Inhoudelijk is er niet veel nieuws onder de zon. De doelstellingen zijn onveranderlijk gericht op decentralisatie en deregulering in de interbestuurlijke betrekkingen. Dus stroomlijning van de verantwoordelijkheden in de bestuurlijke kolom, ongeacht de resultaten in het maatschappelijke veld en ook vrijwel zonder druk van maatschappelijke partners die vonden dat dit een goed idee zou zijn (eerder integendeel). Wel was de inzet gericht op vergroting van de vrijheid onder in het bestuursgebouw, waardoor in theorie meer differentiatie en interactie met actoren (burgers) konden plaatsvinden, maar deze uitkomst werd niet gecheckt. Dus inhoudelijk zitten we nog steeds overwegend aan de governmentkant.

\section{Sturing en informatieverwerving}

Qua proces werd na de introductie van ondernemende ambtenaren weer een stukje meer onzekerheid toegevoegd, lef getoond. Vooral op het vlak van de gezamenlijke probleemverkenning is dit project anders en leidt het tot minder verticale sturingsaanpak. De inbreng van informatie kwam ongecalculeerd van onderaf. Dit ambtelijk geïmporteerde idee lijkt een schoolvoorbeeld van 'complex adaptieve dynamiek'. Uit Zweden, via Istanbul, op Nederlandse leest aangepast: 'assemblages' (Delanda, 2006). Dit zijn typische begrippen uit de complexiteitstheorie (Teisman, 2005). Inhoudelijk werd de uitkomst aan de regie van het toeval overgelaten (Schrijver, 1992).

\subsubsection{Typering van dit project volgens overige onderzoekscriteria}




\section{Mate van beleidsvernieuwing}

Door zijn aanpak was dit project een voorbeeld van beleidsaanpassing van het decentralisatiebeleid, dat op andere wijze werd voortgezet. Eigenlijk was ook de uitkomst best bevredigend, al was het maar omdat voor het eerst bleek dat gemeenten en provincies zelf zaten te springen om meer beleidsvrijheid. Misschien had het project ook een bijdrage aan de bestuurstheorie kunnen leveren als het een vervolg had gekregen en als de werkwijze van interactie met het veld beter was ingebed in de organisatie. Procesmatig bezien was deze aanpak namelijk wel opener dan het traditionele overleg in Haagse vergaderkamers, met echte gemeenten of provincies aan tafel en met een onberekenbare uitkomst.

\section{Doorwerking, institutionalisering}

Misschien wel daarom heeft de vernieuwing van het D'project zich niet doorgezet. Nadien is er nimmer meer iets dergelijks ondernomen. De ingewikkeldheid van de implementatie zal een van de factoren zijn geweest waarom men ervan terugschrikt. Elk experiment verlangt immers weer een aparte wettelijke regeling om de ontheffing van het geldende regiem mogelijk te maken. De experimentenwet D'gemeenten en D'provincies werd ongelukkigerwijs ook nog doorkruist door een kabinetswisseling (1989), waardoor nog extra vertraging werd opgelopen voor de winkelopeningstijdenregeling, die tijdens de demissionaire periode van het kabinet-Lubbers II controversieel werd verklaard. Naast de juridische ingewikkeldheid zal ook meegespeeld hebben dat vooral de gemeenten niet erg fantasierijk waren gebleken bij het doen van voorstellen die hun eigen takenpakket ingrijpend zouden kunnen vergroten. De circa 400 te onderscheiden voorstellen uit gemeentelijke kokers waren vrijwel zonder uitzondering gericht op de verlichting van bureaucratische voorschriften; de provincies hadden daarentegen wel claims voor nieuwe taken ingediend. Ten slotte heeft de (centrale) overheid zich weinig enthousiast betoond voor experimenten met alle onzekerheid en ongelijkheid die deze kunnen meebrengen. Dat zou in later jaren alleen maar meer worden. Behalve het gedoe dat een experiment en bijbehorende evaluatie meebrengt, is de kans te groot dat het experiment mislukt (beleidsschade) en als het zou slagen moet men zijn verlies toegeven (prestige) en is het beleidsinstrument kwijt. Ook in dat opzicht bracht het D'project niet wat op basis van de bestuurstheorie, mede op basis van Scandinavische ervaringen, verwacht mocht worden. Wel degelijk waren er resultaten, ook zeker door de steun van VNG en IPO, die versterking opleverden voor de positie van Binnenlandse Zaken, die tot dusver in zijn eentje had geopereerd. Misschien toch te veel een eenmalige window of opportunities; hoe dan ook, ondanks een goede respons van gemeenten en provincies is de experimentele aanpak-vanonderaf nimmer herhaald.

\section{Evaluatie, leerproces}

Wel is dit een van de weinige projecten die achteraf zijn geëvalueerd, zij het intern. De conclusie van die evaluatie was niet: 'dit nooit weer', maar de animo was danig bekoeld door het lange tijdsverloop tussen de start in 1987 en de afronding van de experimenten in 1993. Omdat er verder nooit meer iets met de aanpak is gedaan, zelfs niet met sommige elementen, kan toch worden gezegd dat hier weinig geleerd is. ${ }^{43}$

\subsubsection{Conclusies}

De hierboven beschreven kenmerken, de gezochte samenwerking met VNG en IPO en vooral afhankelijkheid van de inbreng van de D'gemeenten en van het daarop volgend overleg met de vakdepartementen, passen door hun onvoorzienbare karakter wel meer dan de eerder beschreven decentralisatieoperaties bij een governance-benadering, maar door nadruk op de uniforme toepassing van regels in het hele land werd aan deze benadering weer afbreuk gedaan. Het risico

\footnotetext{
43 Een soortgelijk idee, 'Right to Challenge', is in 2011 opnieuw toegepast bij het streven naar regeldrukvermindering, en 'toevallig' weer geïmporteerd uit Scandinavië, zonder dat iemand (behalve de schrijver dezes) het verband met dit eerdere project kon leggen.
} 
op al te gekke uitzonderingen op het takenpakket van de Nederlandse standaardgemeente werd door de gekozen opzet van het project onder invloed van de VNG de kop in gedrukt. Die gecontroleerde invulling gericht op landelijke implementatie van de voorstellen maakt het project meer government-achtig dan de Scandinavische variant. Het Nederlandse uniformiteitsdenken komt in vergelijking met de Scandinavische landen duidelijk tot uiting. Per saldo kan door het bottom-up karakter van het project de score A - worden toegekend. Het is de vraag of het bestaan van het Scandinavische voorbeeld voldoende is om te stellen dat het ook anders had gekund. De context van een bepaald bestuursklimaat dat daar is gegroeid, ontbrak hier waarschijnlijk. Er is ook nooit een herhaling gevolgd. In de Nederlandse wetgeving zijn er te weinig experimenteer- en ontheffingsbepalingen om flexibele toepassing van experimenten en maatwerk mogelijk te maken.

\subsection{Decentralisatie-impuls}

\subsubsection{Inleiding}

Begin jaren negentig werd er weer een window of opportunities aangegrepen om decentralisatie een slinger te geven. Dit keer was het een grootscheepse bezuinigingsoperatie van kabinetLubbers II, de Tussenbalans. De ondernemende ambtenaar heette Harry van Zon, destijds directeur Financieel-Economische Zaken en kort daarna plv. directeur-generaal Openbaar Bestuur. Zijn idee was in één zin samengevat: de kabinetsleiding onderhandelt over decentralisatie in ruil voor geld. De feiten met betrekking tot dit project zijn onder meer beschreven in TK 1991-1992, 22236, nrs. 1 en 5 en Aanhangsel TK 1991-1992, nr. 516. Het project liep alleen gedurende het kabinet-Lubbers III, na de zogeheten tussenbalans, dus van 1992-1994. Bronnen voor deze casus vormen de desbetreffende Kamerstukken onder nummer 22236, het artikel van Schrijver en Heij (1991) en interviews met Harry van Zon en Jeroen den Uyl.

\section{Aanleiding en uitvinding van innovatie}

Een volgende poging om decentralisatie te bevorderen was qua effectiviteit een grote stap voorwaarts. Het was de periode van de sociale vernieuwing (kabinet-Lubbers-Kok). Daar zaten de VNG en IPO aan de andere kant van de tafel en had Binnenlandse Zaken de steun verworven van Algemene Zaken en Financiën. Dat was belangrijk, althans binnen het machtsdenken. Tijdens het kabinet-Lubbers III moest er weer eens bezuinigd worden en een slimme ambtenaar had een winwin-formule opgesteld. Als de rijksoverheid bepaalde taken zou overhevelen, zouden de gemeenten/provincies die 'mogen' overnemen met een budget dat vooraf met $10 \%$ gekort zou worden. Zo konden ministeries met decentralisatie 'verdienen'. Gemeenten zouden de taken waarschijnlijk op ongeveer gelijk niveau voortzetten, maar hetzij in de sfeer van efficiency, hetzij met een meer precieze afweging van lokale behoeften voordeel kunnen bereiken. Deze financiële prikkel was een kolfje naar de hand van Harry van Zon, die na directeur Financieel-Economische Zaken te zijn geweest in 1990 werd benoemd tot plv. DG Openbaar Bestuur en projectleider van de zogeheten Decentralisatie-impuls.

\subsubsection{Projectbeschrijving en verhalen}

\section{Meerwaarde van dit project}

De grootste winst van dit project was de hartelijke steun van Lubbers en Kok als bondgenoten in het streven naar decentralisatie. Zij hadden gezag binnen het kabinet en hun warme pleidooien voor decentralisatie, al dan niet gedreven door geldelijk gewin, werkten aanstekelijk op hun collega's. Die begonnen echt creatief te worden, zoals minister Ritzen met de overdracht van de eigendom en het beheer van alle schoolgebouwen aan gemeenten. Aldus is de Decentralisatieimpuls van 1990-1993 verreweg de meest succesvolle van alle decentralisatie-operaties geweest, overwegend op de toer van de machtsstrategie, maar dan uitgebreid met meer argumenten dan alleen de bestuurlijke wenselijkheid van decentralisatie. De vernieuwing was tweeërlei: verbreding 
van de decentralisatiecoalitie met $A Z$ en Financiën en het scheppen van een onderhandelingsarena met als ruilobjecten taken en verantwoordelijkheden enerzijds en geld anderzijds. Het was een typisch vanaf de top neergedaalde vernieuwing die echter tot sommiger verbazing niet is beklijfd, althans niet in de vorm van een taakstellende bezuiniging op tafel lag als onderhandelingsmiddel in ruil voor positieversterking van decentrale overheden. De combine tussen Algemene Zaken, Binnenlandse Zaken en Financiën is later wel voortgezet in het zogeheten Overhedenoverleg, maar daar werd vooral onderhandeld over inhoudelijke geschilpunten (zie paragraaf 6.6). Het middel van financiële onderhandelingen veronderstelt de aanwezigheid van verschillende budgetten, wat zich bij gemeenten en provincies voordoet, maar ook in de zorg en bij het onderwijs of bij andere verzelfstandigde sectoren zou een soortgelijke onderhandelingssituatie niet ondenkbaar zijn. Zoiets kan natuurlijk nog komen, maar dan is dat niet te beschouwen als de rechtstreekse doorwerking van het idee van Harry van Zon in de organisatie. Dan zal het een tweede keer 'uitgevonden' moeten worden.

De winst van dit project zal binnen Binnenlandse Zaken mede worden afgemeten naar de mate waarin de onderhandelingspositie van het ministerie erdoor werd versterkt. Er waren per potentieel decentralisatie-onderwerp gemengde werkgroepen gevormd, waar de argumenten werden gewisseld en geslepen. Gemotiveerd door het politieke gewicht van de opdracht zochten ambtenaren over en weer naar bruikbare arrangementen en naar oplossingen voor de aangedragen bezwaren. Hier volgen drie voorbeelden van ideeën die aldus ontstonden.

\section{Voorbeelden van creatieve oplossingen in dit project}

\section{a. WSW}

De Sociale Werkvoorziening zou eigenlijk een louter lokale taak moeten zijn. Het grootste belang dat van de kant van het ministerie van Sociale Zaken en Werkgelegenheid naar voren werd gebracht, was het behoud van het zeer grote aantal plaatsen voor gehandicapten (circa 90.000) dat in deze sociale werkplaatsen werd gerealiseerd. Daarbij kwam dat om historische redenen de verdeling van WSW-plaatsen zeer ongelijk was gegroeid. Het zou dus zeer moeilijk worden om middelen vooraf structureel en dus min of meer gelijkmatig over gemeenten te verdelen, waarbij zij in de toekomst zelfstandig de WSW in de gegroeide omvang in stand zouden houden. Het ging ook om veel geld (3,2 miljard gulden!). Eigenlijk moest een oplossing worden gevonden voor het streven om een landelijke taakstelling overeind te houden door de inzet van lokale middelen. Voor Binnenlandse Zaken werd de werkgroep getrokken door Jeroen den Uyl. Hij bedacht een oplossing die gebruikmaakte van het Coase-theorema. Nobelprijswinnaar Coase had aangetoond dat de introductie van ruilhandel, ook bij publieke middelen, tot optimalisering van allocatie leidt. Den Uyl wilde alle gemeenten een taakstelling meegeven om een vooraf meegegeven aantal WSWplaatsen in stand te houden, maar die hoefden ze niet binnen de eigen gemeente te realiseren. Als dat beter uitkwam, zouden zij ook plaatsen bij andere gemeenten mogen inkopen. Dit ei van Columbus heeft het dankzij geharnaste weerstand van de verantwoordelijk staatssecretaris (Elske ter Veld) niet gehaald, maar is later op heel andere terreinen, onder meer bij de emissiehandel wel toegepast. 44

b. De grootste debatten vonden plaats bij het ministerie van LNV, waar opviel dat iedereen buiten dat ministerie ervan overtuigd was dat belangrijke gebiedsgerichte taken op het gebied van natuurbehoud, recreatie, landinrichting en bosbeheer het beste in handen van de provincies gelegd zouden kunnen worden. De laatste 'echte Landbouwminister', Gerrit Braks, verzette zich met hand en tand. Dit was doorgaans voldoende reden voor de politieke Regiegroep o.I.v. minister-president Lubbers om niet door te bijten, want het vermijden van een ministerscrisis stond nog hoger op de prioriteitenlijst dan het bereiken van decentralisatieresultaat en budgettaire winst. Toch bleek de veranderingsnoodzaak in het afbrokkelende Landbouwbastion aan de Bezuidenhoutseweg al zover voortgeschreden dat een compromis onafwendbaar bleek. Uiteindelijk werd de Dienst landelijk gebied geboren, een zelfstandig bestuursorgaan dat zowel door het Rijk als door de provincies

\footnotetext{
${ }^{44}$ Interview met Jeroen den Uyl op 6 augustus 2007 te Amsterdam
} 
werd aangestuurd. Deze unieke organisatie hield de uitvoeringsmacht centraal, terwijl middelen en beleidsvorming werden gedecentraliseerd. Men hoeft niet te beweren dat dit een fraaie oplossing was, maar uitvoerbaar was zij wel en het was de enige manier om LNV in beweging te krijgen.

c. De decentralisatie van de onderwijshuisvesting is al genoemd. In tegenstelling tot bovengenoemde onderwerpen was hier van weerstand van het ministerie geen sprake; integendeel, Onderwijs en Wetenschappen kwam zelf met dit idee naar voren, omdat dit ministerie realisatie en het beheer van gebouwen in alle gemeenten van Nederland als wezensvreemde taak beschouwde. De grootste weerstand kwam hier van de kant van de VNG, die vooral aanhikte tegen de voorgestelde korting van bijna $10 \%$ op het jaarlijkse bouwbudget (circa 1,5 miljard gulden). De creatieve oplossing die hier in overleg met de mensen van O\&W werd gevonden, was dat niet alleen de bouwopgave, maar ook het eigendom van alle bestaande onderwijsgebouwen werd overgedragen aan de gemeente. Het ging dus in feite om een majeure kapitaalsoverdracht, terwijl de gemeenten zich blindstaarden op de jaarlijkse investeringslasten. De bestaande gronden en gebouwen konden op langere termijn door de gemeenten vrijelijk worden herschikt om efficiënter en meer passend bij de plaatselijke situatie te worden benut dan alleen vanuit het gezichtspunt van één sector, namelijk onderwijs, en vanuit een centraal punt ('Zoetermeer') mogelijk was. Dit is een van de hoofdredenen voor decentralisatie; daar konden de gemeenten weinig bezwaar tegen hebben. Dat de financiële baten van de eigendomsoverdracht op termijn ruimschoots zouden opwegen tegen de verminderde jaarlijkse toevoeging aan het Gemeentefonds voor bouwuitgaven, kon moeilijk worden bewezen, maar waarschijnlijk kwam het de gemeenten beter uit zich van de domme te houden en te klagen over de onredelijke $10 \%$ korting, dan dit toe te geven.

\section{Adviescommissie}

De creativiteit van de eigen ambtenaren werd nog vergroot door de inbreng van een externe adviescommissie van drie door de wol geverfde oud-politici Cees van Dijk, Gijs van Aardenne en Walter Etty, die als 'buitenboordmotor' aan het project waren toegevoegd. Zij bleken van grote waarde, door hun creativiteit, hun inhoudelijke bestuurlijke kennis en ervaring en door de vergaandheid van hun voorstellen die ook de ambtenaren motiveerden om meer te durven. Zo kwam de kracht van politiek bestuurders naar voren. Eigenlijk waren zij ook ingehuurd om deuren te openen die voor anderen gesloten bleven. Zij zouden gemakkelijker toegang hebben tot ministers en door bestuurlijk massagewerk wellicht weerstand kunnen wegnemen. Die kwaliteit heeft nauwelijks merkbaar effect gehad. Een interessante kanttekening is nog te plaatsen bij het advies van Walter Etty, die vergaande decentralisatie van de Algemene bijstandswet en aanverwante onderdelen naar de gemeenten bepleitte in de vorm van een budgetuitkering. De medewerkers van SZW, maar ook van de afdeling Financiële Organisatie Binnenlands Bestuur bij Binnenlandse Zaken waren hier nog allerminst aan toe, omdat men het uitgavenpatroon van de bijstandsuitkeringen in combinatie met de omvang van de ermee gemoeide bedragen niet geschikt achtte voor toepassing van een vooraf genormeerde verdeling. Later is het er toch van gekomen bij de invoering van de Wet werk en inkomen.

\subsubsection{Aanwijzingen voor de gehanteerde bestuurstheorie}

Uit oogpunt van beleidseffectiviteit en relevantie is het een winstpunt dat de vakministeries geprikkeld werden om mee te denken. Sommige voorstellen hebben hierdoor wel iets aan maatschappelijke relevantie gewonnen, zoals de voorbeelden laten zien, maar op het niveau van een duurzame visie werd Binnenlandse Zaken vooral in zijn oorspronkelijke bestuurstheorie bevestigd. Onderhandelingen en samenwerking met stakeholders versterken het governanceelement enigermate in procesmatige zin (horizontale sturingsverhoudingen, informatievergaring van buitenaf).

\section{Sturingsaanpak}


Wat betreft de kenmerken die voor dit onderzoek van belang zijn, hoeven we niet in herhaling te treden. De onderscheidende variabele in dit project is niet de doelstelling of de informatievergaring en ook de democratie-opvatting is een constante, maar de sturingsaanpak: gezamenlijk optrekken binnen de rijksdienst en onderhandelen met gemeenten en provincies.

\title{
6.8.4. Typering van het project volgens overige onderzoekscriteria
}

\author{
Mate van beleidsvernieuwing \\ Wederom een beleidsaanpassing naar aanleiding van omgevingsfactoren: een \\ bezuinigingsoperatie ('Tussenbalans 1991') te benutten om decentralisatie tot \\ onderhandelingsobject te maken (macht voor geld), waarmee tevens voor het eerst de machtige \\ bondgenoten Algemene Zaken en Financiën geïnteresseerd raakten in het onderwerp, ook op \\ ministerieel niveau.
}

Doorwerking en institutionalisering

Opmerkelijk is dat, ondanks relatief succes van deze aanpak, het bij deze ene keer is gebleven. Het project is niet geëvalueerd en er is dus ook institutioneel weinig van geleerd, met uitzondering van één verworvenheid, het betrekken van de genoemde ministers in het Overhedenoverleg, dat in het kader van de Bestuursakkoorden met VNG en IPO nog steeds bestaat. De bijdrage aan de bestuurstheorie van Binnenlandse Zaken op langere termijn is minimaal.

\subsubsection{Conclusies}

De overwegende inhoudelijke oriëntatie blijft een government-karakter dragen, zoals alle decentralisatie-operaties van Binnenlandse Zaken. De doelstelling (verdelen van verantwoordelijkheden, niet delen), de sturingsaanpak (alles top-down), de democratieopvatting (in dienst van de representatieve democratie) en het leerproces (informatievergaring van achter de tekentafel) wijzen overwegend op een government-modus, maar die kenmerken van het decentralisatiebeleid zijn al in de andere projecten van dit hoofdstuk naar voren gekomen. Een kanttekening is dat in dit project meer gelijkwaardig overleg mogelijk leek, met respect voor contingente beleidsfactoren. Twijfel tussen A en A- zal niet veel discussie oproepen. We houden het op A, omdat er in vergelijking tot het D'project nauwelijks signalen van het grondvlak doordrongen. Van de opzet is alleen het Overhedenoverleg tot op heden geïnstitutionaliseerd. Meer leek niet haalbaar.

\subsection{Decentraliseren met beleid}

\subsubsection{Inleiding}

In deze paragraaf wordt een korte periode van bezinning beschreven na de evaluatie van het Decentralisatiebeleid (1997), die in 1999 uitmondde in een intern project, dat moest leiden tot een nota aan de Tweede Kamer. Uiteindelijk heeft in 2001 het resultaat zijn neerslag gevonden in een kabinetsreactie op een Rob-advies, maar daarin waren de scherpe kantjes al nauwelijks meer herkenbaar. Belangrijk is deze fase voor de eventuele ontwikkeling van een eigentijdse bestuurstheorie, maar helaas heeft het die status voor het hele bestuursbeleid niet weten te bereiken.

\section{Denken vanuit maatschappelijke problemen}

De nieuwe directie Coördinatie Bestuursbeleid en haar opvolgers (afdeling Interbestuurlijke Betrekkingen) verkeerden in permanente discussie over de formulering van hun missie en 
doelstellingen bij het verbeteren van het bestuur. ${ }^{45} \mathrm{Het}$ is weinig bevredigend om dit ongeveer gelijk te stellen met 'binnen voorgenomen rijksbeleid het bewaken van belangen van de gemeenten'; dat kan toch geen doel op zichzelf zijn, vonden veel medewerkers. Doelmatig, doeltreffend en democratisch bestuur zou aan andere maatstaven moeten worden afgemeten. Dit besef zou geduid kunnen worden als een ontluikend governance-denken, gericht op maatschappelijke probleemoplossing. Er zijn verschillende pogingen aanwijsbaar om Binnenlandse Zaken meer in een adviserende en verkennende rol te plaatsen om de kwaliteit van het bestuur op een hoger plan te brengen, niet vanuit vooropgezette doctrines, maar uitgaande van wat in de praktijk werkt. Producten uit die periode waren onderzoek naar de effecten van decentralisatie 'Decentraliseren met Beleid' (Fleurke et al., 1997), de kabinetsreactie op het slotadvies van de Raad voor het binnenlands bestuur 'Besturen op de Tast', een aantal leerbijeenkomsten met gemeenten en andere betrokkenen over complexe vraagstukken als integrale veiligheid, jeugdzorg en gebiedsontwikkeling, en de escapades van Binnenlandse Zaken op het terrein van procesmanagement en ketenregie (zie verderop in hoofdstuk 8 en 9).

Een volgende poging om de missie van Binnenlandse Zaken opnieuw in te vullen redeneert consequent vanuit maatschappelijke problemen. Bij een doeltreffende aanpak hiervan worden alle bestuurlijke grenzen permeabel verklaard of zelfs ontkend. De rol van Binnenlandse Zaken zou dan zijn deze bottom-up benadering bestuurlijk te propageren en te faciliteren. Zoals ook is te zien in de werkwijze van het Agenda-overleg en later in het grotestedenbeleid (paragraaf 7.4) kan in het bestuursbeleid steeds een onderstroom worden herkend die niet bij structuren en systemen, maar bij concrete problemen en verbindingen aangrijpt.

Bij deze alternatieve denkwijze kunnen verschillende personen worden genoemd, die echter weinig gehoor vonden. In 2008, wanneer dit relaas ophoudt, beschouwt de directeur Informatiebeleid Openbare Sector (IOS) Harry van Zon (die we in de vorige paragraaf al in twee andere functies tegenkwamen ${ }^{46}$ ) zich als een van de weinige exponenten van deze richting, redenerend vanuit de burger en vanuit megatrends, waaronder informatisering. Met bepaalde tussenpozen werd ook voor deze aanpak binnen Binnenlandse Zaken enige ruimte gecreëerd om de benodigde inzichten te ontwikkelen.

\section{Bronnen bij evaluatie van Decentralisatiebeleid}

De eerste kans om deze aanpak tot hoofdstroom te verklaren ontstond wederom binnen de afdeling Interbestuurlijke betrekkingen (IB), zoals Coördinatie Bestuursbeleid na 1999 (na de afsplitsing van Grotestedenbeleid) was gaan heten. De afdeling had in 1995 het decentralisatiebeleid laten evalueren door prof. Fleurke cum suis (VU). Hun eindrapport 'Decentraliseren met beleid' had de werkelijke effecten van het beleid dichterbij gebracht. Dat gaf te denken over de werkelijkheidswaarde van decentralisatiebeleid, al jaren in het hart van de afdeling (Fleurke et al., 1997). Daarbij kwamen indrukken uit de sociale vernieuwingsperiode, uit de escapade met procesmanagement en interactieve beleidsvorming en de beleidsverkenning naar aanleiding van het RBB-advies 'Besturen op de Tast' (RBB, 1995). Ambtelijke trekkers uit deze periode Arie Jan Vos, Berend van der Ploeg, Jeroen den Uyl en Gerard Houterman zijn allen geïnterviewd en in de gelegenheid gesteld feedback te leveren. Kamerstukken die de

\footnotetext{
45 In september 1986 schreven beleidsmedewerkers Van Bork en Schrijver een notitie aan de toenmalige DG Openbaar Bestuur Jan Hendrikx met een voorstel om de missie van de coördinerende taak in het bestuursbeleid te interpreteren als 'voorkomen van afwenteling'. Frans van Bork, die bij de Raad voor de gemeentefinanciën had gewerkt, was vertrouwd met het begrip afwenteling vanuit de invalshoek van de bestuursinstrumenten. Dit begrip paste ook binnen het idee dat Binnenlandse Zaken de finale hoeder zou moeten zijn van het algemeen belang te midden van een oceaan van deelbelangen. Inderdaad zou dit een nieuwe inhoudelijke invulling zijn van de gezochte kwaliteit van overheidsbeleid, waarbij het resultaat van het najagen van deelbelangen wordt vertaald als afwenteling op andere belangen, op andere gebieden of toekomstige generaties. Op het bestuurlijke terrein beperkte de missie zich tot de specifieke programma's die toevallig op de politieke agenda waren doorgedrongen, zoals de sanering van specifieke uitkeringen en planprocedures, grotestedenbeleid, de totstandkoming van stadsprovincies e.d. Alles wat deze strevingen belemmerde, moest worden gesignaleerd. Dit is het niet geworden. De medewerkers zochten vaak naar meer uitdagende invullingen van goed bestuur.

${ }^{46}$ Of dit met zijn opvattingen samenhangt, vermeldt de historie niet, maar na zijn afscheid als directeur IOS vertoonde zijn loopbaan, anders dan alle andere (plv.) directeuren-generaal Openbaar Bestuur geen opgaande lijn meer.
} 
onderstaande verhalen ondersteunen zijn: TK 1997-1998, 25665, nr. 1 (Positie openbaar bestuur) en TK 2000-2001, 22236, nrs. 45 en 57 (Decentralisatie).

\subsubsection{Projectbeschrijving en verhalen}

Tussen 1995 en 1999 was Arie Jan Vos hoofd van de afdeling Interbestuurlijke betrekkingen. Onder zijn leiding was de afdeling al tot de slotsom gekomen dat standaardrecepten (decentraliseren!) niet werken. De meerwaarde van de afdeling zou zijn bij de departementen te makelen in bestuurlijke oplossingen met een ruim gevulde gereedschapskist aan arrangementen en voorbeelden van anderen onder de arm. Hij besloot een opdracht te geven aan Adviesbureau De Beuk teneinde te verkennen wat de beste strategie van de afdeling ten aanzien van decentralisatie verder zou zijn. In 1999 was Berend van der Ploeg zijn opvolger. Berends eigen idee was dat Binnenlandse Zaken en de andere ministeries samen op moesten trekken. Ook meer faciliteren dan bestrijden dus. Om met de beperkte capaciteit die zijn afdeling ter beschikking stond toch zinvol te kunnen bijdragen naast de grote inzet van de vakdepartementen, zouden we selectief investeren in enkele grote projecten: Nota Ruimte, Wet maatschappelijke ondersteuning, Integraal veiligheidsbeleid en dergelijke..$^{47}$

\section{Missie van coördinatie}

Tijdens een strategiebijeenkomst 'op de hei' in 1999 kwam de afdeling tot de formulering dat hun taak was anderen te helpen het bestuur bij de tijd te houden. Anders dan gebruikelijk bij een dergelijke externe opdracht was het idee van het bureau De Beuk om samen met de hele afdeling te oefenen in bijeenkomsten over concrete casussen met 'stakeholders' uit verschillende complexe beleidsvelden van gemeenten, instellingen, maatschappelijke organisaties, et cetera. Hier kwam onder meer de ketenbenadering (zie paragraaf 8.5) als dominante aanpak naar voren. $\mathrm{Na}$ afloop werd Frans Soeterbroek van De Beuk gevraagd in samenwerking met Mieke Pistorius van de afdeling IB een afsluitend rapport op te stellen, om te bouwen tot een beleidsnota voor de minister. $\mathrm{Na}$ enige tijd stoeien werd Gerard Houterman, een van de werkloos geworden projectleiders uit het project Stadsprovincies, gevraagd dit project tot een goed einde te brengen. Met hem waren we het er gauw over eens dat een vruchtbaar uitgangspunt zou zijn om de overheid principieel als één en ondeelbaar te beschouwen. De gewone burger maakt immers ook het onderscheid niet tussen de verschillende segmenten, lagen en onderdelen van de overheid. Het zou eigenlijk niet mogen uitmaken op welk niveau zich een maatschappelijk probleem aandient. Als het onderwerp een beetje complex is, zullen in praktijk toch alle lagen betrokken moeten zijn; de praktische ambtenaar moet die besturen in de backoffice aan elkaar verbinden zonder dat de samenleving daar last van heeft. Frans Soeterbroek bedacht de toepasselijke titel "Dansen tussen de schalen", maar dat was voor de toenmalige minister Klaas de Vries een tikkeltje te frivool. Het verhaal werd uiteindelijk ondergebracht in de kabinetsreactie op een advies van de Rob over decentralisatie in 2001 (TK $2001,22236, \mathrm{nr} .57$ ) en de genoemde gedachtegang kwam lang zo prominent niet naar voren. In feite werd het einde van het algemene decentralisatiestreven ingeluid en vervangen door een meer incidenteel inspelen op contingentie. Dit zou echter niet lang worden volgehouden. Dat Binnenlandse Zaken deze benadering niet echt wist te waarderen, illustreert het hierna volgende voorbeeld in paragraaf 6.10. Het kabinet-Balkenende IV kondigde al weer een volgende decentralisatieoperatie aan. De strijdbijl in het gevecht met de boze vakdepartementen werd weer opgegraven. Dit discours laat zich, behalve uit bovenstaande projecten, goed herkennen in het Jaarverslag van de afdeling IB van 2006:

"De inzet van het in twee teams ('sociaal' en 'fysiek') georganiseerde accountwerk is interdepartementale, en steeds meer ook interbestuurlijke, beleidsontwikkelingen te signaleren en zorg te dragen voor coördinatie en actief bijdragen in de beleidsvorming van andere departementen op het onderdeel bestuurlijke arrangementen (kerndossiers). Vanuit de

47 Interview met Berend van der Ploeg, 11 september 2007 te Den Haag. 
bijzondere verantwoordelijkheid van BZK ten aanzien van de interbestuurlijke verhoudingen bewaken en bevorderen we de consistentie in het interbestuurlijk handelen en plegen interventies naar andere ministeries en naar de decentrale overheden op basis van de Code Interbestuurlijke Verhoudingen.

We denken mee over de beste bestuurlijke arrangementen, meestal in zeer nauwe samenwerking met FO, die verantwoordelijk is voor de financiële arrangementen. De handhaving van die Code vraagt een aanzienlijke inhoudelijke maar ook coördinerende inspanning. Zo bekeken is de Code een van de 'hardere instrumenten' in ons werk. We hebben het zo georganiseerd dat anderen in principe niet 'om ons heen kunnen' door een 'interbestuurlijke verhoudingenvakje' op het aanbiedingsformulier van de ministerraad."

\subsubsection{Aanwijzingen voor de gehanteerde bestuurstheorie}

\section{Typering van het interne discours}

Wat betreft doel-oriëntatie is vooral de afdeling Interbestuurlijke Betrekkingen in de jaren vlak voor de eeuwwisseling pragmatischer en probleemgevoeliger geworden. Dit past in een trend naar vermaatschappelijking (governance). Op verschillende aspecten lijkt een ware omslag op til. De doelstelling was niet langer gericht op het verdelen van verantwoordelijkheden, maar op totaalarrangementen gegeven de inhoud van de problematiek. De sturingsaanpak werd consensueel.

Binnen de democratie-opvatting slopen elementen van participatieve democratie en interactieve beleidsvorming in. Vooral het proces van informatievergaring werd verkennend en experimenteel. Al deze signalen wijzen dezelfde kant op, namelijk richting governance. Dat was een teken dat het in deze typische fin-de-siècle-periode ook anders kon. De bestuurstheorie van een deel van de organisatie werd wel degelijk geraakt, maar duurzame indaling in het dominante discours vond niet plaats.

\subsubsection{Typering van dit project volgens overige onderzoekscriteria}

\section{Mate van beleidsvernieuwing, doorwerking}

Even leek het decentralisatiebeleid en de Thorbeckiaanse bestuurstheorie van Binnenlandse Zaken van zijn voetstuk te vallen. In een fin-de-siècle-atmosfeer werden nieuwe ideeën verkend, 'Besturen op de tast' (Rbb, 1996), 'Dansen tussen de schalen', 'Decentraliseren met beleid' en procesmatig de les: verbind gelijkgestemde vernieuwers en je zult een transitie teweegbrengen. Organisatieadviseur Anne Alons leerde de medewerkers van IB wat een echte veranderstrategie inhoudt: netwerken bij de departementen, vernieuwingsgezinde krachten opsporen en deze met elkaar verbinden. Deze intensieve persoonsgerichte aanpak van binnenuit was een eyeopener en voor Binnenlandse Zaken destijds twee bruggen te ver. De algemene leiding liet het allemaal begaan, maar werd niet echt geraakt door al deze inzichten. Grada Lautenbach merkt op dat de term coördinatie na 2000 is vervangen door 'interventiekracht'. ${ }^{48}$

"Steeds stuiten we vanuit het streven naar doelrealisatie op bepaalde belemmeringen.

Bijvoorbeeld: de gemeenten zijn te klein, of het Gemeentefonds past niet, of de bestuurskracht van het lokaal bestuur schiet tekort, provincies zijn te groot."

Volgens haar komen deze thema's als gevolg van het pleidooi voor decentralisatie op de agenda. Zij ziet de discussies over het bestuur juist als middel, niet als doel op zich.

"Die kwesties komen juist door inhoudelijke beleidsproblemen op de agenda. Voorbeeld is verkeer en waterstaat. De inhoudelijke behoeften van het openbaar vervoer, dat zich op regionaal niveau afspeelt, daar moest in worden voorzien. Vanuit die inhoud gingen we

48 Vraaggesprek met Grada Lautenbach, gehouden op 16 augustus 2007 te Den Haag. 
meedenken en kwamen uiteindelijk uit op zoiets als vervoersregio's. Daarna kwamen we weer onze collega's bij Binnenlandse Zaken tegen, die behoefte hadden aan overzichtelijkheid en stroomlijning en al gauw vonden dat er wildgroei ontstond."

Kortom, als aanvechting had de ingeslagen koers van dit deel van het directoraat-generaal Openbaar bestuur potentie van beleidsvernieuwing, maar omdat hij niet echt doorzette, zou deze in termen van Hogwood en Peters nooit zo genoemd mogen worden.

\subsubsection{Conclusies}

Voor het eerst zien we tekenen van volledig governance-denken in een deel van het bestuursbeleid. Dit gebeurde heus niet clandestien, maar met welgemeende steun van de ambtelijke top. Dit bleek echter niet voldoende voor een echte shift.

Hier tegenover staat namelijk dat de kabinetten na 2000 weer taakstellingen bleven formuleren over het aantal specifieke uitkeringen, waardoor de weinig productieve loopgravenstrijd tussen Binnenlandse Zaken en vakdepartementen weer oplaaide. De tekenen waren dus maar tijdelijk. De oester klapte kort na de eeuwwisseling dicht en het Haagse decentralisatiebeleid (Binnenlandse Zaken tegen de rest) hernam zijn loop, inclusief de sanering van bestuursinstrumenten. Deze duidelijke oprisping van governance-denken (score B) beklijfde niet. Het bleef bij een vriendelijke aanvechting, waaronder de dominante government-benadering niet van zijn plaats kwam. Verderop zullen nog andere soortgelijke voorbeelden voorbijkomen die eenzelfde lot ten deel zouden vallen, zoals die in de volgende paragraaf.

\subsection{Gedifferentieerde contracten met gemeenten}

\subsubsection{Inleiding}

Onderstaand voorbeeld mag misschien nauwelijks de naam project dragen, het was meer een idee. Het stelde het uniformiteitsdenken van Binnenlandse Zaken aan de orde. De periode waarin dit speelt, loopt van 1998 tot 2006. In het laatste jaar werd een zeer kortstondig project rond het thema differentiatie opgetuigd.

Reden dat het hier wordt opgevoerd, is dat het zeer illustratief is voor het intern gevoerde discours en dat de initiatiefnemer niet zomaar een medewerker, maar een directeur van het ministerie was, Marbeth Bierman. Later is hetzelfde thema ook op het bureau van de minister beland en is er wel degelijk een tijdelijk project opgetuigd, dat echter met een zekere onwennigheid en zonder enig resultaat anders dan een dik rapport over scenario's in bestuurlijke en Financiële Verhouding(en) heeft geopereerd en als een nachtkaars uitging.

Bronnen: behalve enkele interne notities, in bezit van de auteur, en de aantekeningen uit het interview met de betrokken directeur zijn er over de eerste manifestatie van het idee over differentiatie weinig bewijsstukken voorhanden. Het tweede initiatief op het terrein van differentiatie in het binnenlands bestuur heeft zijn neerslag gevonden in TK 2006-2007, 30096, nr. 26. Naast dit kamerstuk, een ander rapport van het ministerie van Binnenlandse Zaken (2004), de Code Interbestuurlijke Verhoudingen (2005) en het rapport van de commissie-Bovens (2006), een interne nota ter uitwerking van de differentiatiegedachte over deals met afzonderlijke gemeenten (in bezit van de auteur) en andere inside-information is het interview met mevrouw Bierman als bron voor deze casus gebruikt.

\subsubsection{Projectbeschrijving en verhalen}

Ontstaan van het idee 
Een van de laatste directeuren voor Interbestuurlijke Betrekkingen, Marbeth Bierman, die vol zat met creatieve invallen en praktische inzichten, kwam in 1998 tijdens een lange autorit met de vraag of het niet eens mogelijk was om gemeenten veel meer zakelijk en afzonderlijk te benaderen. Zij vroeg zich af waarom het binnenlands bestuur alleen met twee modellen kan werken: hetzij medebewind of autonomie, uniforme wettelijke regiems voor alle gemeenten of helemaal niets. En zeker niet 'afrekenen' op geleverde prestaties. Waarom niet eens een Derde Weg verkennen, uitgaande van de wederkerige verhouding. Vergelijk deze gedachtegang met het latere boek 'De Transactiestaat' van Wolfson (2005). Dan zou het Rijk met een gemeente een bedrag kunnen afspreken om dit en dit te bereiken in lijn met de rijksdoelstellingen om zo op basis van afrekenen achteraf een beter resultaat te kunnen boeken dan de gemiddelde gemeenten. Binnenlandse Zaken verzette zich instinctief tegen deze haast commerciële gedachte, hoewel de consensuele contractrelatie al vaker voorkomt en de traditionele medebewindsrelatie steeds minder. Gemeenten tekenen al in op een vrijblijvend aanbod van het Rijk dat bedoeld is om te verleiden (experimentregelingen) of zij staan aan de wieg van nieuwe arrangementen die passen in het rijksbeleid, maar niet zijn voorgeschreven (HALT-regeling, kinderopvang, school-adviesdiensten, volwasseneneducatie) totdat het landsdekkend wordt gemaakt. Mevrouw Bierman liep al lang rond met dezelfde gedachte in verschillende varianten, dat er behoefte bestaat aan flexibiliteit en vergaande mate van differentiatie. Vooral bij Binnenlandse Zaken, dat gewend is aan een uniforme ambtenaren-cao en aan uniforme gemeenten. Pas toen het echt niet anders kon, kwamen alleen enkele regio's als kaderwetgebieden in aanmerking, maar verschillende regiems golden daar niet en toen Friesland met een eigen variant aankwam, kon daar niet over worden gesproken.

\section{Standaardisatie als huismerk van Binnenlandse Zaken}

Tijdens een interview jaren later zet mevrouw Bierman haar ervaringen nog eens uiteen. Het concrete idee van takenpakketten en afspraken had Bierman in de Verenigde Staten opgedaan, waar bepaalde federale taken, zoals drinkwatervoorziening, door bepaalde staten die daarvoor belangstelling en capaciteiten hebben, kunnen worden overgenomen inclusief de middelen. In de rest van het land blijft de centrale overheid die taak gewoon zelf uitvoeren. Ook zag zij overal in de samenleving maximale flexibiliteit en differentiatie om zich heen. Bijvoorbeeld in de Bijenkorf, waar op elke vierkante meter een ander regiem, met andere arbeidsvoorwaarden en franchise-afspraken gelden. En dan blijft Binnenlandse Zaken maar vasthouden aan zijn uniforme gemeenten met uniforme wettelijk geregelde takenpakketten. Dat dit idee toen niet is omgezet in een serieuze verkenning, een project, wijt Marbeth Bierman vooral aan haar eigen tekort aan drammerigheid. Ze heeft wel talloze discussies gevoerd met onder meer de toenmalige DG Holtslag, die uiteindelijk zeker gevoel kreeg voor de bezwaren tegen blauwdrukdenken, maar een concreet initiatief heeft geen van beiden toen ondernomen. Ook is een verkennend gesprek met de VNG gevoerd om eens te polsen over flexibiliteit en differentiatie, maar tot een doorbraak heeft het toen niet geleid. Of de politiek hier nu de grootste dwarsligger is, is volgens Marbeth Bierman niet aannemelijk. Het zit dieper, in onze ambtelijke cultuur, het bureaucratisch denken.

"Wij kunnen slecht omgaan met transacties en met ongelijkheid", stelt zij vast en concluderend:

"In de maatschappelijke realiteit van de $21 \mathrm{e}$ eeuw wordt dat steeds idioter. Een signaal van een wereldvreemde overheid." 49

\section{Interne aanvechtingen van het gelijkheidsdenken}

In het Bestuursakkoord Nieuwe Stijl (BANS) is, zoals we zagen, wel een poging gedaan om meer probleemgericht op maat afspraken te maken tussen individuele bestuursorganen en ministeries, maar eigenlijk is dat steeds stukgelopen op de behoefte om vooral voor alle gemeenten gelijkelijk oplossingen aan te bieden, te voorkomen dat er een 'lappendeken' zou ontstaan. "We gaan toch niet het cafetaria-systeem invoeren?", sprak directeur-generaal Van Halder dreigend over

49 Interview met Marbeth Bierman op 17 juli 2007 in Heemstede. 
suggesties om gemeenten die ergens speciaal mee zaten, of die juist ergens voorop liepen, een Sonderbehandlung aan te bieden. Een schaars voorbeeld van probleemgericht maatwerk was het deelakkoord met LNV om met alle betrokkenen te komen tot plattelandsbeleid in Noord-Limburg. Ook binnen het grotestedenbeleid heeft het lang geduurd voordat men er anders dan met mooie woorden toe overging verschillende gemeenten te stimuleren hun eigen specifieke situatie en kwaliteiten te beklemtonen in de verplichte meerjarige ontwikkelingsplannen (MOP's). En toch is het in de Nederlandse bestuurscultuur een heel grote stap om differentiatie daadwerkelijk een groter accent te geven dan gelijkheid. Het enkele feit dat er 32 gemeenten als grote stad werden aangemerkt, spreekt al boekdelen. Met inachtneming van het diep gewortelde gelijkheidsbeginsel kon Binnenlandse Zaken geen weerstand bieden aan de aanspraak van steeds meer gemeenten om ook bij de 'groten' te horen, uit oogpunt van status en verdienste (bedoeld is: financieel voordeel).

Aan de vooravond van een nieuwe kabinetsformatie, toen er binnen de ministeries weer druk nagedacht werd over strategische opties, is dit denken nog wel in een directielijstje ideeën voor regeerakkoord 2002-2006 terechtgekomen. Het Rijk zou een programmabureau Ondernemend Bestuur kunnen inrichten, waarin goede, creatieve ideeën van gemeenten die bereid zouden zijn samenwerkingsafspraken aan te gaan, beloond zouden worden met regelvrijheid en reallocatieruimte. Later is hier nooit meer iets van gehoord. Wel bleek de uiteindelijke nota 'leder zijn rol' (!) (Ministerie van BZK, 2004) op papier veel ruimte te vragen voor differentiatie en uitvoeringsruimte, tussen gemeenten en provincies en zelfs op het niveau van professionals in onderwijs, zorg en veiligheid. Anderzijds stond de vraag centraal hoe iedere bestuurslaag 'zijn rol' kan krijgen binnen een ordelijke, eenduidige verdeling van verantwoordelijkheden. Verschillende sturingsfilosofieën lijken hier te botsen. Er is misschien niet eens goed uit te komen. De Code Interbestuurlijke Verhoudingen geeft dit goed weer (Ministerie van BZK, IPO en VNG, 2005: 17). Let vooral op de spanning tussen b en $\mathrm{c}$ :

"De visie op de interbestuurlijke verhoudingen uit de Code bestaat uit drie elementen: a. de Gemeente- en Provinciewet fungeren als basis voor de interbestuurlijke afspraken; b. de bestuurlijke ordening moet voorzien in de mogelijkheid om op een adequate manier de maatschappelijke opgaven aan te pakken. We werken dan ook probleemgericht;

c. daaruit volgt de noodzaak tot een heldere verdeling van verantwoordelijkheden, bevoegdheden en taken."

Vergeefse poging vanuit de VNG

In 2006 is Binnenlandse Zaken opeens driftig bezig differentiatiemogelijkheden te verkennen als reactie op de verkenning van de VNG (Commissie-Bovens, 2006) en op de kritiek naar aanleiding van het schrappen van het gebruikersdeel van de onroerend zaakbelasting. Zou het vergroten van differentiatie en verscheidenheid niet pleiten voor een herstel van het eigen lokaal belastinggebied? Uit een interne verkenning en ledenraadpleging over de toekomst van het lokaal bestuur kan worden geconcludeerd dat de maatschappelijke ontwikkelingen een kanteling van het lokaal bestuur naar de samenwerking met de lokale omgeving meebrengen. Door deze horizontale oriëntatie zal meer ruimte nodig zijn voor verschillen tussen gemeenten, omdat de lokale context nu eenmaal verschilt (Commissie-Bovens, 2006). In het kielzog van deze VNG-discussie werd binnen Binnenlandse Zaken een projectgroep opgezet om differentiatiemogelijkheden te verkennen. Daar wist men niet goed raad mee. De suggestie van Marbeth Bierman over zakelijke afspraken over de creatieve aanpak van problemen per gebied of gemeente (centres of excellence) zou waarschijnlijk te veel de kat op het spek binden; de ministeries zouden het kunnen opvatten als uitnodiging om zich met de details te bemoeien en eisen te stellen op kosten van de gemeenten, iets waar Binnenlandse Zaken net een kwart eeuw tegen gevochten had. Een uitgebreid rapport over scenario's in bestuurlijke en financiële verhoudingen biedt op zichzelf nog aardige inkijkjes in het denken binnen het bestuursbeleid van Binnenlandse Zaken (Ministerie van BZK, 2006). Enerzijds geeft het rapport uitgebreid blijk van erkenning aan contingente factoren die de verdeling van 
verantwoordelijkheden bepalen. Dat is al een hele stap, al wordt de contingentie vooral aan rijkszijde belicht, de ontwikkeling per onderwerp landelijk. Anderzijds worden vooral bezwaren aangevoerd op het terrein van uitvoerbaarheid en afhankelijkheid. Het volgende citaat is illustratief:

"Nadeel is onder andere dat differentiatie kan leiden tot een ingewikkelder verhouding rijk gemeenten als er meerdere modellen met de bijbehorende financiële arrangementen naast elkaar bestaan. Differentiatie kan ook ten koste van het 'integrale bestuur' van gemeenten gaan. Differentiatie van taken kan leiden tot een grotere afhankelijkheid van andere partijen, met name van de gemeente die de taken uitvoert voor andere gemeenten. Bovendien is de vraag in hoeverre gemeenten die taken uitvoeren voor andere gemeenten democratisch gelegitimeerd zijn." (Ministerie BZK, 2006: 46)

Overwegend wordt geredeneerd vanuit het gezichtspunt van het Rijk. Afgezien van de vraag betreffende technische mogelijkheden voor het verwerken van complexiteit in een ICT-tijdperk, wordt nergens gesproken over uiteenlopende wensen en behoeften van gemeenten als leidraad voor taaktoedeling. Bij gemeentelijke autonomie zou die invalshoek beter passen. Differentiatie werkt niet echt als die verscheidenheid van bovenaf planmatig wordt aangeboden. Hoe dan ook, na de kabinetswisseling van 2007 is het genoemde project geruisloos verdwenen.

\subsubsection{Aanwijzingen voor de gehanteerde bestuurstheorie}

Het initiatief zelf (een project is het niet te noemen) had alle kenmerken van een governancebenadering. De doelstelling was gericht op samenspraak en verschil maken, met een top-down sturingsaanpak is dan niet te volstaan; informatie en leren zal van onderop moeten ontstaan en de representatieve democratie kan minder uit de voeten met het accommoderen van verschillen dan met standaardbesluiten.

Het instrument maatwerkcontracten zou volgens een ambtelijke brainwave van de directeur IBI de gemeenterechtelijke doctrine van autonomie en medebewind kunnen aanvullen, maar realisatie daarvan was voor Binnenlandse Zaken een brug te ver. Zoals de commissie-Bovens van de VNG (Commissie Toekomst Lokaal Bestuur, 2006) beargumenteerde, zijn een sterkere maatschappelijke oriëntatie van het bestuur (governance) en differentiatie keerzijden van dezelfde medaille. Mevrouw Bierman probeerde in verschillende gesprekken het aloude uniformiteitsdenken bij Binnenlandse Zaken om te buigen. In 2006 was er zowaar - om eer te bewijzen aan de VNG-commissie - een korte aanzet tot een project bij BFO om differentiatiemogelijkheden te verkennen, maar toen het kabinet- Balkenende II viel, verdween dit project geruisloos. Net als complementair bestuur, en het Scandinavische Frikommuner-model, paste dit idee (nog) niet in het bestuursbeleid.

\subsubsection{Typering van dit project volgens overige onderzoekscriteria}

\section{Mate van beleidsvernieuwing}

Voor Binnenlandse Zaken was het zoeken naar differentiatie die verder ging dan de klassenindeling van het Gemeentefonds radicaal nieuw. De kortstondige verkenningen in deze richting waren op zichzelf wel innovatief, maar omdat ze niet tot beleidsbeslissingen hebben geleid, verdienen ze nauwelijks die naam in de hier gebruikte terminologie van Hogwood en Peters.

\section{Bijdrage aan de bestuurstheorie}

Dit stukje interne gedachtewisseling stelde vooral het belangrijke onderdeel van de bestuurstheorie, de standaardisatie van het Nederlandse model, ter discussie. Zonder succes overigens, want het idee werd ook weer snel afgestoten. Ook binnen de VNG zette de aanvechting door de commissie-Bovens niet door toen het binnenlands bestuur na een kabinetswisseling weer overging tot de orde van de dag. 


\subsubsection{Conclusies}

Het loslaten van het uniformiteitsdenken past zonder meer in de governance-modus. Daarom score B. Dat deze poging zo duidelijk niet aansloeg, is echter een zoveelste aanwijzing dat de government-benadering binnen Binnenlandse Zaken onverminderd stevig in het zadel zat.

\subsection{Conclusies over de bestuurstheorie bij interbestuurlijke betrekkingen en decentralisatiebeleid}

Hieronder volgt een resumé van de bevindingen op het gehele dossier decentralisatiebeleid en interbestuurlijke betrekkingen. Daarna kunnen conclusies worden geformuleerd over de hoofdlijn van het discours in dit voor het bestuursbeleid zo koersbepalende beleidsthema en over de vraag of hier tekenen van een omwenteling (shift) zichtbaar werden.

\section{Veranderstrategie en contingentie}

Decentralisatiebeleid begon met de meest voor de hand liggende methode, niet bepaald contraintuïtief. Kortweg kan deze methode worden gekarakteriseerd als ramkoers. 'De machtsstrategie' werd hij door de Raad voor het binnenlands bestuur (RBB) genoemd, maar dan vooral in verband te brengen met het strijdperk van Don Quichotte (Raad voor het binnenlands bestuur, 1984 en 1987). Al gauw kregen de vakministeries door dat er machten waren die nog sterker bleken dan regeerakkoorden en de kamerbrede dreigende moties, namelijk die welke zich in de arena van de vakdepartementen bevonden: belangengroepen, instellingen met hun werknemers, Kamercommissies en andere beleidsbepalende factoren en actoren. De politieke opdrachten en taakstellingen die Binnenlandse Zaken wist mee te krijgen, waren nooit specifiek genoeg om te voorkomen dat de ministeries die men hiermee confronteerde, met succes konden doorverwijzen naar de buren, waar decentralisatie misschien wel mogelijk was, maar hier niet.

De echte innovatie was vooral dát Binnenlandse Zaken met een offensief decentralisatiebeleid begon. Alle andere potentiële innovaties liepen spoedig spaak. Het bleven aanvechtingen. Latere varianten op de machtsstrategie (Decentralisatie-impuls) waren al iets meer sophisticated in die zin dat ze door coalitievorming meer macht wisten te mobiliseren en de VNG en IPO aan de andere kant van de tafel lieten plaatsnemen. Binnen het toetsingskader voor het typeren van bestuurstheorie als meer government- of governance-gericht (doelstellingen, proces, democratieopvatting, informatievergaring) zijn de projecten in dit dossier overwegend vernieuwingen op het vlak van procesaanpak geweest. Hierbij werd geleidelijk en mondjesmaat meer vrijheid van onderop, meer invloed van contingente factoren toegelaten. Een toepasselijke metafoor voor het ontstaan van een vernieuwing op dit terrein die van onderaf ontstond, het D'project, is de chaostheorie, waar wonderlijk spel van het toeval plus de aanwezigheid van 'attractoren' tot een zodanige klontering van energie leiden dat er opeens een besluit wordt genomen dat ook nog tot iets leidt. Ook het denkmodel van March en Olsen (1995) met hun garbagecan-model van beleidsvorming komt hier dicht bij in de buurt.

Er zaten nog andere kleine veranderpunten en innovaties in de aanpak van het decentralisatiebeleid, waarvan de sanering van bestuursinstrumenten over de volle breedte van de rijksoverheid de meest krachtige en succesvolle is geweest. Preventief toezicht en kroonberoep zijn met wortel en tak uitgeroeid, verplichte planprocedures verdwenen geleidelijk, omdat ze niet aan de maakbaarheidsverwachtingen konden voldoen. Alleen specifieke uitkeringen staan tot op de dag van vandaag op de agenda. Een uniek staaltje van beleidscontinuïteit voor Binnenlandse Zaken, alleen overtroffen door gemeentelijke herindeling.

Een fundamentele omslag naar een andere benadering leek zich aan het eind van de jaren negentig voor te doen nadat de evaluatie van Fleurke cum suis (1997) was verschenen. De afdeling Interbestuurlijke Betrekkingen ging hierdoor haar werk in een bredere context zien. Als je 
missie in plaats van streven naar decentralisatie wordt verstaan als het verbeteren van bestuurlijke arrangementen in het licht van de noden van de tijd, is de stap naar oplossingsgericht maatwerk nabij. En zo leek de afdeling met aandacht voor contingentie en verbetering van het oplossend vermogen de draai in de richting van governance te gaan maken. Deze omgevingsverkenning was echter van korte duur. Al snel werden weer streefcijfers gesteld en vertoonde de agenda weer de oorspronkelijke lijn: Gemeentefonds versterken, Bestuursakkoorden sluiten om de belangen van gemeenten te bewaken en loopgraven betrekken tegen de boze vakdepartementen.

Qua veranderstrategie om het beleid van de ministeries te beïnvloeden kwamen de decentralisatieoperaties van Binnenlandse Zaken niet echt over de brug. Daarvoor moet zo dicht mogelijk worden aangesloten bij de handelingsperspectieven van de betrokkenen en de daar al aanwezige veranderbereidheid. Dat vergt van de sturende actor een sterk inlevingsvermogen en bereidheid al naar gelang de specifieke situatie de bestuurlijke behoeften op maat te faciliteren. Daarvoor moet de prijs worden betaald van een sterk verbrokkeld patroon van veranderingen en aanpakken, maar het komt wel ten goede aan de effectiviteit en het enthousiasme van de partners. Verandering moet van binnenuit komen. Dat Binnenlandse Zaken van de ervaringen met de D' gemeenten en de Decentralisatie-impuls niet veel heeft opgestoken blijkt uit het feit dat het Programma Andere Overheid weer op de oude manier is opgezet, als een voor de hele rijksdienst uniforme top-down instructie die voorbijging aan de probleembeleving bij de afzonderlijke ministeries (zie paragraaf 9.4). Omdat dit boek geen beleidsanalyse beoogt, wordt hier afgezien van een uitspraak over de effecten van het decentralisatiebeleid. Het is zonneklaar dat er flink is gedecentraliseerd sinds 1980. Minder duidelijk is in hoeverre dit is toe te schrijven aan de inspanningen van Binnenlandse Zaken. Een mogelijke stellingname is dat het beleid hier en daar zijn eigen doelstellingen heeft overleefd. Immers, van de oorspronkelijk reële vaststelling in de Decentralisatienota dat het machtsevenwicht tussen Rijk en decentrale overheden was verstoord en dat de lokale autonomie dreigde te worden uitgehold, is niet veel meer over. Bovendien komt het initiatief voor decentralisatie allang niet meer van Binnenlandse Zaken. Toch blijft het decentralisatiestreven onverkort hoog op de agenda van het ministerie staan.

\section{Gemeenschappelijke bestuurstheorie}

Bij het dossier bestuurlijke organisatie stond Binnenlandse Zaken alleen, met uitzondering van een enkel vakdepartement en Kamerleden uit de Vaste Commissie. Bij het decentralisatievraagstuk was het subsysteem van het bestuursbeleid anders samengesteld. Binnenlandse Zaken stond hier tegenover de meeste vakdepartementen, ging vaak wel samen met Financiën (lang niet altijd), maar zeker waren VNG en IPO vaste bondgenoten op dit dossier.

Wat betreft de inhoudelijke doelstellingen van het beleid voor interbestuurlijke verhoudingen heeft het decentralisatiestreven gedurende de hele periode op het bestuursbeleid een zwaar stempel gedrukt. Of het gaat om de bestuurlijke organisatie, de financiële verhouding(en) of het achterstandsgebiedenbeleid, steeds werd de vergroting van de vooral gemeentelijke autonomie als de maatstaf voor de bestuurlijke beleidskeuzen gedefinieerd. "De heldere (gescheiden) verdeling van verantwoordelijkheden vloeit voort uit een probleemgerichte benadering", stelt de visie op de interbestuurlijke verhoudingen (Ministerie BZK, IPO en VNG, 2005). De probleemgerichte benadering mondt dus niet uit in een samenwerkingsmodel of in wisselende coalities en zeker de maatschappelijke partners (en de burgers) blijven buiten de boot. Binnenlandse Zaken zorgt dat het bestuur door middel van decentralisatie 'dichter bij de burger' komt en daar moeten dezen het mee doen. Dat er uiteindelijk vorderingen zijn gemaakt vanuit het gezichtspunt van de burger, is zeker. Alles beter dan het topzware bestuursmodel van de jaren zeventig. De bestuurstheorie over de interbestuurlijke betrekkingen concentreert zich op een antagonisme tussen de algemene decentralisatie-vriendelijke lijn van Binnenlandse Zaken en het sectoralisme van de vakdepartementen. Dit idee heeft zoals dit boek laat zien, het discours in het hele bestuursbeleid beïnvloed, niet alleen bij het decentralisatiestreven. Het genoemde antagonisme vormt ook een belangrijk onderdeel van de bestuurstheorie van Binnenlandse Zaken, als bindende factor voor de 
organisatie en beeldvormend kenmerk voor de taak en positie van het ministerie. Als hoeder van de democratische gedecentraliseerde eenheidsstaat tegenover desintegrerende deelbelangen van de sectoren. Het is echter de vraag of deze preoccupatie van het bestuursbeleid heeft bijgedragen aan de ontwikkeling van een robuuste bestuurstheorie die uiteindelijk ten dienste staat aan het oplossen van maatschappelijke problemen.

$\mathrm{Er}$ is veel op de veronderstelde tegenstelling met de vakdepartementen af te dingen. Toch is het bestuursbeleid grotendeels blijven steken in de strijd tegen dit fantoom, en hebben andere aspecten van de maatschappelijke ontwikkelingen daardoor relatief minder gewicht gekregen. 


\section{Dossier Achterstandsproblemenbeleid}

\subsection{Inleiding}

Binnenlandse Zaken is van oudsher belast met het scheppen van voorwaarden voor een vitaal en krachtig lokaal bestuur. Dat betekent onder meer de zorg voor het bestuurlijk geraamte, dat in hoofdstuk 5 is behandeld, en streven naar de bescherming van een autonome bestuurssfeer voor het decentraal bestuur, waardoor de oorspronkelijke gelaagde structuur van Thorbecke in stand kan blijven.

In de komende twee hoofdstukken wordt het zoeklicht gericht op het type van interventie vanuit Binnenlandse Zaken dat is gericht op het daadwerkelijk functioneren van gemeenten. Het gaat dan niet om de structuur, maar om de inhoud en de kwaliteit van het bestuur. Zo nu en dan signaleert het ministerie tekortkomingen of uitdagingen in het lokaal bestuur, waarvoor gemeenten niet lijken te zijn toegerust. In verband met de hooggeschatte autonomie van het lokaal bestuur zal bemoeienis hier terughoudend zijn, maar soms niet te vermijden. De onderwerpen en de manier waarop Binnenlandse Zaken in de gang van zaken bij de gemeenten intervenieert, zijn soms het gevolg van een plotseling nieuw inzicht of wending in de omstandigheden. Een aantal van die nieuwe ideeën die de bestuurskracht, het organiserend vermogen, van het lokaal bestuur tot onderwerp hebben, worden in deze paragrafen behandeld.

Het betreft nogal een verscheidenheid van onderwerpen. Drie ervan hebben te maken met inhoudelijke opgaven om oude en nieuwe achterstandsproblemen en vooral de cumulatie ervan, het hoofd te bieden: minderhedenbeleid, sociale vernieuwing, grotestedenbeleid. Deze komen in dit hoofdstuk aan de orde. Andere voorbeelden, in hoofdstuk 8, betreffen meer relatieve 'achterstanden' van de gemeenten en provincies, namelijk ten opzichte van nieuwe technologische ontwikkelingen of organisatiekundige inzichten, waar de decentrale overheden het been moesten bijtrekken. Naar de toenmalige inzichten van Binnenlandse Zaken zou dat niet vanzelf lukken zonder een extra impuls vanuit het moederdepartement. Twee voorbeelden zijn gericht op de interne informatiehouding van de gemeente, die zijn uitstralingseffecten heeft op de gehele publieke sector. Het derde voorbeeld betreft de dienstverlening die mede dankzij de informatie en communicatietechnologie op andere leest kan worden geschoeid: klantgericht. Het laatste voorbeeld, ketenregie, betreft de introductie van een nieuw concept dat de samenhangende probleemaanpak over de grenzen van organisaties en instellingen versterkt.

Voor de ontwikkeling van de bestuurstheorie voor Binnenlandse Zaken zijn deze onderwerpen van belang, omdat ze de potentie hebben in wisselwerking met eigentijdse maatschappelijke problematiek nieuwe aspecten in te brengen in het interne discours binnen de bestuurlijke wereld.

Hierna volgen twee hoofdstukken, waarbij het bestuursbeleid dus primair gemotiveerd wordt vanuit inhoudelijke problematiek. Met een dergelijke aanleiding mag men verwachten dat het ministerie en zijn satellieten zich primair rekenschap zullen geven van de behoeften en omstandigheden die ter plaatse gelden. Daarbij passen dus top-down inzichten over bestuursstructuren en systemen minder dan in de voorafgaande hoofdstukken. Hoewel beide hoofdstukken 7 en 8 dus interventies binnen de gemeentelijke beleidsvorming met zich meebrengen, zijn de onderwerpen zo verschillend dat zij behandeling in een apart hoofdstuk rechtvaardigen. Niettemin zullen de eindconclusies over de invloed van government- of governance-denkwijzen gezamenlijk aan het eind van hoofdstuk 8 worden geformuleerd. Aan het eind van hoofdstuk 8 zullen de bevindingen over de bestuurstheorie in de dossiers van hoofdstuk 7 en 8 worden samengevat. 
In hoofdstuk 7 worden de projecten beschreven die te maken hebben met geconstateerde achterstanden in het sociale domein, die cumulerend met andere problemen, voor de gemeentelijke bestuurskracht onoverkomelijk geacht worden.

Het betreft achtereenvolgens:

- minderhedenbeleid als bestuurlijke opgave voor gemeenten: de opvang van een hele categorie nieuwe burgers als gewone inwoners, uitmondend in een gebiedsgerichte aanpak in achterstandswijken (paragraaf 7.2);

- $\quad$ sociale vernieuwing, een poging om burgers in wijken die dreigden af te haken, bij de samenleving en de publieke zaak te betrekken, uitmondend in de vorming van een brede doeluitkering voor achterstandsproblemen van gemeenten (paragraaf 7.3);

- grotestedenbeleid als impuls voor het bestrijden van gecumuleerde achterstanden in steden en tevens voor de versterking van de potenties van de stad als economische motor (paragraaf 7.4);

- bedrijfsbetrokkenheid: het zoeken van samenwerking met bedrijven die zich verbinden met de oplossing van stedelijke problematiek (paragraaf 7.5).

Deze voorbeelden worden weer op de bekende manier geanalyseerd op de bijdrage aan een vitale bestuurstheorie, hun vernieuwingsgehalte, plaatsing op de as tussen government en governance en op hun institutionele doorwerking in het bestuursbeleid.

\subsection{Minderhedenbeleid}

\subsubsection{Inleiding}

Dit was geen 'project' in formele zin, maar een geheel nieuw beleidsterrein, dat in 1980 bij Binnenlandse Zaken begon en in 2001 vertrok naar een ander ministerie.

Als het gaat over nieuwe inzichten die een doorbraak betekenden voor de ontwikkeling van de missie van Binnenlandse Zaken, is de komst van het minderhedenbeleid zeker memorabel. Sinds de periode rond de Eerste Wereldoorlog, toen allerlei sectorale taken zich afsplitsten van het moederdepartement en de vakdepartementen werden gecreëerd, was het weinig aannemelijk om de zorg voor een inhoudelijk beleidsterrein bij Binnenlandse Zaken te plaatsen. Bij de verhalen over het minderhedenbeleid is de framing van de totstandkoming ervan memorabel. Daarmee begint het relaas over dit project dan ook in paragraaf 7.2.2. Daarna volgt de beschrijving van de werkwijze van deze directie in paragraaf 7.2.3. De schijnwerper wordt ten slotte gericht op het thema dat dit hele hoofdstuk de rode draad vormt: initiatieven om integrale (wijk)aanpak van achterstandsproblemen te ondersteunen, in dit geval het probleemcumulatiegebiedenbeleid. De paragraaf wordt afgesloten met enkele conclusies.

Hoofdpersonen van het minderhedenbeleid zullen weer als 'helden' worden gepresenteerd. Aan de wieg van de coördinerende taak voor het minderhedenbeleid stonden de eerdergenoemde Henk van Ruller, het Kamerlid Henk Molleman en CRM-ambtenaar Ger Ebbeling. Laatstgenoemde heeft de moeite genomen dit onderdeel zorgvuldig te lezen en berichtte dat hij het geheel met de analyse eens was. Hun rechterhanden Frank van Kuik en Jan de Winter deden het voorbereidende werk. Maar zonder vice-premier en minister van Binnenlandse Zaken Hans Wiegel was het misschien heel anders gelopen. Verder zijn Han Kapsenberg en Hugo Fernandes Mendez architecten van het probleemcumulatiegebiedenbeleid geweest.

Als bronnen voor deze casus dienen Kamerstukken, waaronder begrotingen van Binnenlandse Zaken uit 1981 en volgende jaren, de Minderhedennota uit 1983 (TK 1982-1983, 16102, nr. 21), de Nota Integratie Minderheden van 1999 (TK 26426, nr. 2), het rapport van de commissie-Blok (2004), het rapport van de WRR ter zake uit 1979, de institutionele beschrijving van het Rijksarchief (PIVOT 113, 2003), een lezing van oud-minister Van Thijn, een artikel van Scholten en Timmermans (2004), alsmede interviews met drie oud-plv. directeuren van de Directie Coördinatie 
Minderhedenbeleid, L. van der Linde, F. van Kuik, J. Kapsenberg, en de medewerkers H. Wilmink en J. de Winter.

\subsubsection{De verhalen: geboorte van een nieuwe taak}

Henk Molleman was voor de PvdA woordvoerder voor etnische minderheden. Bij motie vroeg hij op 23 juni 1977 ter gelegenheid van de bespreking van twee gijzelingsdrama's door Molukkers aan de regering om coördinerend beleid te ontwikkelen ten behoeve van alle minderheden. Zijn wens werd niet onmiddellijk verhoord. In januari 1978 volgde eerst een beleidsnota van de regering, wederom uitsluitend over Molukkersproblematiek. Wel opvallend was dat deze nota werd aangeboden door de minister van Binnenlandse Zaken, Hans Wiegel. Hierdoor werd de belangrijkste aanbeveling gesymboliseerd, namelijk om de zorg voor Molukkers niet alleen meer aan CRM, maar aan alle relevante ministeries toe te vertrouwen (SZW voor werk, VRO voor wonen, O\&W voor onderwijs enzovoort). Waarom kwam het onderwerp de integratie van etnische minderheden bij Binnenlandse Zaken terecht? In het onderzoek is een viertal verschillende interpretaties van deze historische vraag opgetekend, die hier achtereenvolgens worden gepresenteerd.

\section{Interpretatie duwers en trekkers}

Ger Ebbeling, directeur Culturele Minderheden bij CRM, was de meest uitgesproken push-(f)actor om het onderwerp van zijn ministerie over te hevelen naar Binnenlandse Zaken. Niet omdat het een zware, ondankbare en zeer complexe taak betrof, want dat is voor ambtenaren een uitdaging. Door jarenlange ervaring met het coördineren van de vele betrokkenen vanuit CRM was hij tot de slotsom gekomen dat positionering in dit ministerie het welslagen van dit werk in de weg stond. De belangrijkste reden was het zwakke prestige van het 'agogenministerie' in de Haagse pikorde.

Hierdoor miste hij het gezag om van VRO woningen los te praten, O\&W tot onderwijsinspanningen te bewegen, enzovoort. Ook de steden, die intern tot een samenhangende aanpak verleid moesten worden, zouden volgens Ebbeling zich meer gelegen laten liggen aan de sturing van Binnenlandse Zaken dan van CRM, zoals hij had ervaren in zijn pogingen om daar meer dan een nietje door bestaande stukken te laten slaan. Ten slotte zouden SZW en Buitenlandse Zaken naar zijn inschatting nimmer bereid gevonden worden om hun respectieve coördinatietaken samen te voegen en dan bij CRM onder te brengen, wat niet alleen de Tweede Kamer, maar ook Ebbeling hoogst wenselijk achtte. Een ministerie met een meer erkende algemene coördinatiepositie als Binnenlandse Zaken zou dan meer kans maken.

Omstreeks dezelfde tijd, begin 1978, nam de SG van Binnenlandse Zaken, Pieter van Dijke, het initiatief voor het inrichten van een kleine interdepartementale commissie (o.m. BiZa, CRM, Justitie) om na te denken over de uitwerking en organisatie van het beleid ten aanzien van de Molukkersproblematiek. Van Dijkes vertrouweling Henk van Ruller werd voorzitter. Het secretariaat werd gevormd door Ad Geelhoed van Justitie en Jan de Winter, afdelingshoofd bij CRM. Zij werden het er snel over eens dat de Molukkers pars pro toto vormden van een bredere problematiek, die destijds verspreid was georganiseerd (vluchtelingen bij Buitenlandse Zaken, buitenlandse werknemers bij Sociale Zaken, Surinamers, Antillianen en Molukkers bij CRM). Bij de behandeling van de nota 'De problematiek van de Molukse minderheid in Nederland' diende Molleman opnieuw een motie in van soortgelijke strekking. Ambtenaren bij Binnenlandse Zaken namen dus ook initiatieven, en creëerden daarmee ook een pull-factor om het naar zich toe te halen.

\section{Interpretatie restpost}

Binnenlandse Zaken vervulde wel vaker een stoffer-en-blikfunctie voor onderwerpen die nergens (of op verschillende plaatsen tegelijkertijd) in de rijksdienst thuishoorden, maar meestal zorgenkind waren voor de gemeenten (te beginnen bij de grote steden) of op een of andere manier een veiligheidsrisico veroorzaakten. Eind jaren zeventig kwam zoiets meestal op het bureau van Henk van Ruller, wiens functie Adviseur Coördinatievraagstukken heette. Zo ook de Molukkersproblematiek. Twee gijzelingsacties en de bezetting van de Indonesische ambassade 
waren voldoende om de politieke besluitvormers te alarmeren. Het ministerie van Cultuur, Recreatie en Maatschappelijk werk, dat verantwoordelijk was voor de maatschappelijke integratie van Molukkers, woonwagenbewoners en andere culturele minderheidsgroepen, kon deze problematiek niet langer aan. Openbare orde was een taak van Binnenlandse Zaken, maar om het alleen als zaak van openbare orde te beschouwen ging ook te ver. De gastarbeiders werden tot het domein van Sociale Zaken en Werkgelegenheid gerekend, terwijl Justitie zich belastte met de toelating en opvang van vluchtelingen.

\section{Interpretatie democratische grondrechten}

Voor de activisten van het eerste uur, zoals Han Kapsenberg, Ben Koolen en Lute van de Linde, lagen de drijfveren voor het beleid in de begindagen dichter bij de thema's burgerrechten en grondrechten, die ook al bij Binnenlandse Zaken thuishoorden. ${ }^{50} \mathrm{Zij}$ beschouwden het zonder discriminatie opnemen van minderheden in de gemeenschap als een voortvloeisel van de constitutionele waarden uit onze Grondwet. In geen departement werden deze algemene mensenrechten destijds meer doorleefd dan bij Binnenlandse Zaken. Dit komt ook in de buurt van de interpretatie achteraf van Ed van Thijn, die zich in 1979 als oppositieleider op enige afstand tot de besluitvorming bevond, tijdens een lezing in 2006:

"Het ontstaan van het minderhedenbeleid kan niet worden losgezien van de Molukse gijzelingsacties in de jaren zeventig. Dat was een vorm van extreem geweld (treinkaping, gijzeling van een school, bezetting van provinciehuis, enz.). Natuurlijk uiteindelijk met geweld beëindigd, maar de vraag rees: waar komt die extreme woede vandaan? De onvervulde droom van een onafhankelijke Molukse Republiek was één factor. Maar vooral ook het probleem van miskenning, achterstelling, uitsluiting, werkeloosheid en discriminatie, van generatie op generatie. En de woede die dat veroorzaakte. Voor mijn generatie politici was dat een wake-up call. Het kabinet-Den Uyl, later overgenomen door Van Agt-Wiegel, ontwikkelde een 1000banenplan. En vroeg zich af hoe het eigenlijk met andere minderheidsgroepen was gesteld. In die tijd ontstond het inmiddels klassieke, multiculturele concept van 'integratie met behoud van identiteit'. Na de Molukse gijzelingsacties is er voor het eerst, nota bene onder leiding van minister Wiegel, die PvdA-woordvoerder Molleman tot directeur van een nieuwe afdeling benoemde, een nationaal minderhedenbeleid ontwikkeld dat - dwars door de polarisatie van die dagen heen - algemene instemming verwierf. Het ging in die jaren om, wat genoemd werd, de doelgroepen van het minderhedenbeleid, hun gelijkberechtiging, hun emancipatie, het wegwerken van achterstanden en het tegengaan van discriminatie." ${ }^{.1}$

\section{Interpretatie integratie in gemeenten en gemeentelijk beleid}

De meest gehoorde redenering was dat gemeenten erop moesten worden aangesproken deze inwoners niet langer als een soort gewezen rijksonderdanen, maar als gewone burgers te beschouwen. Dit laatste punt, de verhouding met de gemeenten, was volgens velen de belangrijkste reden om Binnenlandse Zaken met de coördinatie te belasten, omdat dit ministerie immers de directe relaties met de gemeenten onderhield.

Achteraf reconstruerend uit verschillende gesprekken is de volgende argumentatie, verwoord door ooggetuige Jan de Winter, de meest aannemelijke:

"De fatale fout is geweest dat (etnische) minderheidsgroepen waaronder Molukkers zolang als doelgroep van het rijks welzijnsbeleid apart zijn gezet. De eerste zorg is dat deze mensen als gewone Nederlanders worden bejegend, met hun huisvesting, onderwijs, werk enzovoort en dan moeten ze net als alle burgers door de gemeente worden opgevangen en niet rechtstreeks

\footnotetext{
50 Uit een interview met Lute van der Linde op 23 juli 2007.

51 Lezing van Ed van Thijn op 29 april 2006 te Amsterdam, geboekstaafd in de weblog van Anja Meulenbelt: www.anjameulenbelt.nl/weblog/2006/04/29/van-thijn-over-minderhedenbeleid.
} 
door het Rijk. Wel is er eerst nog in coördinerende zin aandacht nodig, maar eigenlijk alleen als overgang naar zo snel mogelijke 'normalisatie'. Dat was de hoofdgedachte en via de ingangen 'gemeenten' en 'coördinatie' kwam men bij Binnenlandse Zaken terecht."52

Rol minister, politieke besluitvorming

Dit zijn al vier verschillende, tamelijk plausibele verhalen over deze keuze, en er zijn er meer. Belangrijk in ambtelijke kringen is natuurlijk ook het precedent. Door de behartiging van Molukkersvraagstukken, meer voor de vice-premier misschien dan voor Binnenlandse Zaken, had het ministerie in de persoon van Van Ruller al een voet tussen de deur. Toen zich de politieke vraag naar verbreding tot het minderhedenbeleid aandiende, was minister Wiegel nog niet voetstoots voor het idee gewonnen dit erbij te nemen. Hij had zijn handen vol aan de openbare- ordeaspecten. Hij meende terecht dat de capaciteit op zijn ministerie hiervoor ten enen male ontbrak. Niettemin gaf minister Wiegel zich in de loop van 1978 geleidelijk gewonnen voor een bescheiden directie minderhedenbeleid op zijn ministerie. De minister gaf aan zijn directie Organisatie en Automatisering opdracht hiervoor een opzet te ontwerpen. Dat advies pleitte voor een lichte coördinatiestructuur.

\section{Advies WRR}

Op 2 februari 1979 nam de ministerraad het principebesluit. In maart 1978 had de Wetenschappelijke Raad voor het Regeringsbeleid (WRR) het onderwerp Etnische minderheden nog op de eigen werkagenda geplaatst. Meestal loopt de WRR ver voor de troepen uit, maar op dit terrein kon hij de ontwikkelingen ternauwernood bijhouden. Toen het WRR-rapport 'Etnische Minderheden' in mei 1979 uitkwam, was er intussen veel veranderd. De WRR bepleitte een kentering in het denken over etnische minderheden: we moesten rekening houden met hun blijvende aanwezigheid en met structurele maatregelen om hun integratie, wederkerige aanpassing en gelijke kansen te bevorderen. Nog voordat het advies goed en wel verscheen, had het kabinet al besloten tot de aanwijzing van een coördinerend minister voor het minderhedenbeleid. Het rapport van de WRR, geschreven door Rinus Penninx (1979: XXV), vermeldt hierover:

"De beslissing om deze functie toe te kennen aan de Minister van Binnenlandse Zaken waardeert de Raad positief, omdat daarmee tot uiting wordt gebracht dat het hier niet alleen sociaal-culturele problemen betreft, maar ook andere beleidskwesties. De overweging dat de Minister van Binnenlandse Zaken primair verantwoordelijk is voor de onderlinge relatie tussen het Rijk, de provincies en de gemeenten, acht de Raad dan ook niet meer dan één van de relevante overwegingen bij de aanwijzing van hem als coördinerend minister."

Als we terugkijken, is de introductie van de nieuwe directie als in een stroomversnelling tot stand gekomen, grotendeels door de eendrachtige en energieke samenwerking van verschillende ambtenaren van verschillende ministeries. Het ongevraagde advies van de WRR kwam in feite als mosterd na de maaltijd.

Het politieke tij was er ook rijp voor, waarbij Kamerlid Molleman een belangrijke stuwende rol speelde. Minister Wiegel was, zoals vaker, op het juiste moment ter plaatse om de politieke winst te incasseren. In de ministerraad was een minister als Pais (Onderwijs) een groot pleitbezorger op de achtergrond.

\subsubsection{Inrichting van de Directie Coördinatie Minderhedenbeleid (DCM)}

De formule voor de directie was aanvankelijk analoog aan de kleine, hoogwaardige staf van de minister-president. Pas later nam de directie onder leiding van Molleman, onder druk van de zorg voor autochtone kansarmen, een wending naar meer algemeen achterstandenbeleid (probleemcumulatiegebiedenbeleid), waardoor men nauwer moest samenwerken met gemeenten.

52 Interview met Jan de Winter op 31 augustus 2007 te Den Haag. 
Hierdoor werd de directie groter, technocratischer en werd de samenhang met de andere onderdelen van DG Binnenlands Bestuur zichtbaarder, zeker toen deze ook thema's als sociale vernieuwing en grotestedenbeleid gingen behartigen.

Aanvankelijk was de directie in verschillende opzichten een vreemde eend in de bijt. Door gebrek aan een scherpe koers kon het beleid nog alle kanten op. Lute van der Linde verbaasde zich erover dat hij zijn activisme vanuit het Nederlands Centrum voor Buitenlanders als ambtenaar bij Binnenlandse Zaken vrijwel op dezelfde voet kon voortzetten. Hij vertelt over zijn entree in 1980:

"Verschillende mensen zoals Gert Jan Veerman en ik waren in de jaren zestig en zeventig sterk aangeraakt door mensenrechtenkwesties, Vietnam en de burgerrechtenbeweging in de Verenigde Staten. Ik was net dertig. Onze babyboomgeneratie stroomde de rijksdienst binnen. Een collega als Rein-Jan Hoekstra, die een aantal jaren ouder was, zag echt de revolutie aankomen en maakte zich als antirevolutionair zorgen. Minderhedenbeleid ging voor ons over gelijke rechten. Ik had eerder al bemiddeld tussen Justitie en Sociale Zaken en de Vakbeweging en kon als ambtenaar gewoon activist blijven. Ik was secretaris geweest van de Commissie voor Rechtsbijstand in Vreemdelingenzaken, een advocatenclub, die destijds nog de wet Arbeid Buitenlandse Werknemers heeft kapot geamendeerd (22 amendementen, 18 daarvan aanvaard). Dat kon ik gewoon blijven doen! In het redelijke hè, want ik was volgens mij vrij redelijk. De eerste jaren was er echt veel ruimte, maar toen het karakter van de Gideonsbende werd ingeperkt, ben ik in 1983 naar CZW overgestapt ... Aanvankelijk was het ook voor Ger Ebbeling de bedoeling om de directie te spiegelen aan de interdepartementaal optredende club voor Surinamers bij CRM. Een klein clubje naar het model van het kabinet van de ministerpresident bij AZ. Hoogwaardige staffunctionarissen die als troubleshooters dwars door de rijksdienst schoten. Maar helaas kreeg al gauw de ambtelijke reflex de overhand. Onder leiding van Henk Molleman, die de verleiding om te groeien niet kon weerstaan, werd een hele bureaucratie opgebouwd. Minder leuk was ook dat dezelfde Henk Molleman wispelturig en niet consequent opereerde. Dan had je maandenlang onderhandeld met verschillende ministeries en dan werd het resultaat in een overleg van Henk met DG's zo prijsgegeven.

De directie Minderheden stond erg los van de rest van Binnenlandse Zaken. We hadden nauwelijks contact met iemand als De Menthon Bake. Ik was wel verbaasd over het departement in die dagen. Ik had me als activist al voorbereid en twee grijze pakken aangeschaft, maar het halve departement bleek in spijkerpak te lopen. Ik verbaasde me ook over Elco Brinkman. Een DG die jonger was dan ik en razendsnel werkte. Ging je 's ochtends bij hem langs, had-ie 's middags al iets bij de minister gedropt. Elan was er in die tijd: BiZa verzet de bakens.

$(\ldots)$

De band met de gemeenten kwam pas eigenlijk goed op gang toen Molleman met het PCGbeleid begon. Mijn werk was vooral rijksbeleid, kiesrecht van minderheden, en dergelijke kwesties. De relatie met Justitie en Sociale Zaken was belangrijk. We werden het erover eens dat de tweede generatie moest worden gedefinieerd als Nederlands probleem, niet als vreemdelingenprobleem. Dat was een majeure beslissing. De Minderhedennota was het belangrijkste wapenfeit." 53

Er speelden ook toevalsfactoren, zoals een teveel aan geld. Dat kwam zo: in 1980 ging het kennelijk nog goed met de overheidsfinanciën. Minister Pais van Onderwijs claimde voor zijn CUMI-Nota (culturele minderheden) een fors bedrag voor extra lessen in Nederlandse en nietNederlandse taal en cultuur. Toen stak minister Wiegel zijn vinger op en vroeg voor 'zijn' minderheden ook een rond bedrag. Dat werd afgemaakt op 125 miljoen Henk van Ruller kreeg de opdracht een verdelingsplannetje te maken. In diens ruwe begroting paste ook een post voor personeelskosten. Rekening houdend met wisselgeld stelde hij $25 \mathrm{fte}$ voor, wat hij eigenlijk veel te

53 interview met Lute van der Linde op 23 juli 2007. 
veel vond gezien zijn eigen ideeën over een ideale slanke coördinatiestructuur. Het 'probleem' was echter dat Wiegel met zijn statuur gemakkelijk Financiën in de houding wist te zetten. De jonge ambtenaar Frank van Kuik, werkstudent bij Henk van Ruller, die naar Financiën werd gestuurd om eens voorzichtig te gaan praten over het lijstje, merkte tot zijn grote verbazing dat alle posten voetstoots werden aanvaard. Zijn minister had het pad voor hem geëffend. Zo begon de directie met een te ruime jas en dat is alleen maar erger geworden. Aan het eind van de rit had Henk Molleman 80 medewerkers tot zijn beschikking. ${ }^{54}$

Het is hier niet de plaats om de effectiviteit en kwaliteit van het minderhedenbeleid en later het integratiebeleid te bepalen. Daarvoor is heel ander soort onderzoek nodig, dat in 2004 nogal uitgebreid is verricht door de Tweede Kamer (Commissie-Blok, 2004). Hier gaat het om de bijdrage van het minderhedenbeleid aan de aanpak en inhoud van het bestuursbeleid. Nu is het wel opmerkelijk dat het rapport van de commissie-Blok, dat meer dan 600 bladzijden omvat (en dat zijn geen bijlagen), met geen woord rept over het probleemcumulatiegebiedenbeleid, wat een majeure bijdrage was aan het (bestuurs)beleid van Binnenlandse Zaken. Ook de kleuring van het minderhedenbeleid door de organisatorische plaatsing in de context van decentralisatiestreven krijgt daar geen aandacht. Wel wordt ten aanzien van de coördinatie geconcludeerd:

"In de jaren tachtig wordt een minderhedenbeleid geformuleerd met de volgende doelstellingen: voorwaarden scheppen voor emancipatie en participatie, het verminderen van sociale en economische achterstand, het voorkomen en bestrijden van discriminatie en het verbeteren van de rechtspositie. Met de WRR constateert de Commissie dat die doelstellingen in deze periode onvoldoende gerealiseerd zijn. Er is een discrepantie tussen beleid en uitvoering."

\section{Werkwijze van de Directie Coördinatie Minderhedenbeleid.}

Binnen de directie werden op papier voorwaarden gecreëerd om leerzame verbindingen met de werkelijkheid te leggen. Een afdeling Verticale en Groepencoördinatie (VGC) had tot taak om rechtstreeks contacten te leggen met het veld. Omdat hierin veel ambtenaren met een goed netwerk werden aangetrokken die zelf uit minderheidsgroepen afkomstig waren, was al een idee aanwezig over wat er in de verschillende gemeenschappen omging en hoefde men dat niet van koepelorganisaties te horen. Aan de andere kant leidde de ambtelijke aanpak van het overleg tot vervreemding van de werkelijkheid, of liever de veelvormige werkelijkheden die zich binnen de gemeenschappen van minderheden voordeden. Er ontstond op den duur een vorm van ijzeren ring rondom het minderhedenbeleid doordat vaste woordvoerders van de minderheden zich opwierpen als intermediair. In de praktijk ontwikkelden deze woordvoerders eigen belangen, die niet altijd parallel liepen met die van hun veronderstelde achterbannen.

Jan de Winter, die ook bij CRM had gewerkt, lichtte dit in een interview als volgt toe:

"Bij Binnenlandse Zaken werkten we volgens het model van het grotestedenbeleid zoals dat bij Van Ruller was opgebouwd met interdepartementale werkgroepen per onderwerp. Het probleem was alleen dat de meeste medewerkers van DCM niet wisten waar ze het over hadden, omdat ze grotendeels achter hun bureau werkten ... Ja, er waren wel contacten via de afdeling VGC, maar niet rechtstreeks met gewone mensen uit de minderhedengroepen, maar dat liep via hun woordvoerders en die hadden vaak hun eigen agenda. Bij CRM voerden wij zelf alle regelingen uit; dat was ook niet goed, want daarmee behandelden we de vreemdelingen anders dan Nederlanders, maar daardoor kwamen we wel in contact met gewone mensen. Ook de medewerkers van DCM die bewust werden geselecteerd, die zelf uit migrantengemeenschappen kwamen en daarom geacht werden te weten wat daar leefde, hadden een eigen agenda. Het jammere is dat er van lieverlee een soort tussenlaag is ontstaan

54 Informatie ontleend aan de gesprekken met Frank van Kuik, op 1 augustus en 10 september 2007. 
van mensen die er alle belang bij hadden hun achterban achterlijk te houden, ik zeg nu maar hard hoe het zat."55

\section{Opzetten lokaal minderhedenbeleid}

Deze afdeling werd ook geacht de bestuurlijke infrastructuur binnen de gemeenten op te bouwen. Over de vraag of gemeenten zelf al ver genoeg waren om eigener beweging gecoördineerd lokaal minderhedenbeleid op te zetten of dat ze hiervoor nog sturing van hogerhand behoefden, werd verschillend gedacht. Zo werd er een bestuurskosten-subsidie ontworpen die voor de decentralisten binnen het directoraat-generaal een doorn in het oog was, maar toch enige tijd stand hield, omdat het in de opbouwfase verstandig beleid was. Hier doorheen speelden verschillende opvattingen over de wenselijkheid van categoriale voorzieningen voor specifieke groepen. Minderhedenorganisaties zagen vaak meer heil in nationale veiligstelling van aparte voorzieningen dan in het alternatief te worden overgeleverd aan de lokale afweging tussen algemene en categorale voorzieningen. Voor gemeenten was de keuze voor generieke voorzieningen niet altijd de meest voor de hand liggende, omdat dat impliceert dat van elke instelling voor welzijn, huisvesting, educatie, arbeidstoeleiding, et cetera gevergd mag worden dat zij openstaat voor alle minderheidsgroepen, met alle taal- en cultuurproblemen van dien. Dit illustreert dat de perceptie van minderheidsbeleid als bestuursbeleid, in het bijzonder voorwaardenscheppend voor gemeentelijk organiserend vermogen, nog niet zo gek is.

\section{Interdepartementale coördinatie}

Daarnaast was er een afdeling die de horizontale relaties tussen de sectoren (ministeries) moest verzorgen. Het belangrijkste instrument was de Interdepartementale Commissie Minderhedenbeleid, vooral omdat hier ambtenaren van hoog niveau zaten die persoonlijke betrokkenheid voelden met het onderwerp, zoals Bas van Eindhoven van Onderwijs en Wetenschappen.

Volgens Lute van der Linde en anderen is het ideaal om beide benaderingen met elkaar te verbinden niet gelukt:

"Die integrale aanpak, daar kwam niet zoveel van terecht. Ik vond toch dat de directie heel erg verkokerd werkte. Er was een afdeling met vakspecialisten, daar zat de staatsrechtelijke kennis, iemand anders deed werkgelegenheidskwesties en iemand deed de subcommissie VROM. En daarnaast had je de contacten met de gemeenten en met de doelgroepen. En het lukte maar niet om die twee takken van sport met elkaar te verbinden. Dat is later wel gelukt in het probleemcumulatiegebiedenbeleid. De departementen in de $\mathrm{ICM}^{56}$ zorgden er wel voor dat Binnenlandse Zaken niet al te veel te vertellen kreeg. Dat was ook weer niet de bedoeling." 57

\subsubsection{Beleid voor probleemcumulatiegebieden}

Een echte innovatie vanuit DCM was de gebiedsgerichte aanpak in achterstandswijken. Immers, het gebiedsgerichte probleemcumulatie-gebiedenbeleid (PCG) was hier ontwikkeld, al in 1985. Midden in de barre jaren tachtig werd een budget vrijgemaakt, een relatief bescheiden bedrag van 10 miljoen gulden per jaar, dat in geselecteerde wijken werd uitgedeeld aan veelbelovende projecten. De analyse was dat minderheidsgroepen (én kansarme autochtonen) geconcentreerd woonden in slechte wijken en dat alleen een geïntegreerde aanpak daar van leefbaarheids-, welzijns- en sociaaleconomische problemen uitzicht op verbetering kon brengen. De stadsvernieuwing was in deze wijken voorgegaan, maar die richtte zich toch vooral op de

\footnotetext{
55 Interview met Jan de Winter op 31 augustus 2007 te Den Haag.

56 Interdepartementale Coördinatiecommissie Minderhedenbeleid.

57 Gesprek met Lute van der Linde op 23 juli 2007.
} 
gebouwde omgeving. Het innovatiedividend van DCM was onder meer de uitvinding van het probleemcumulatiegebiedenbeleid. Het is een aantrekkelijke hypothese dat deze 'uitvinding' bespoedigd zou kunnen zijn door de plaatsing van DCM in een omgeving (DG Binnenlands Bestuur) die sterk geneigd was in termen van integraal beleid en van decentrale (territoriale) samenhang te redeneren. De uit de aanpak van het PCG-beleid voortvloeiende omstandigheid dat rijksambtenaren zich intensief persoonlijk op de hoogte gingen stellen van

achterstandenproblematiek op wijkniveau, was voor Binnenlandse Zaken nieuw. Of het inhoudelijk veel zoden aan de dijk heeft gezet, valt te betwijfelen, maar als aanpak was het PCG-beleid invloedrijk. Het is alweer stopgezet in 1989, maar vooral om in krachtiger varianten terug te komen. We zullen die aanpak straks nog herhaald zien worden bij sociale vernieuwing en grotestedenbeleid.

Ter onderbouwing van de analyse volgen twee citaten uit de stenografische verslagen van de verhoren van de commissie-Blok (TK 2004, 28689, nr. 10: 59). Henk Molleman vertelt daar:

"We konden vanaf het begin al zien dat de wijken die er het slechtst aan toe waren en met de laagste huren, de instroomwijken zouden worden. Daar vindt dan de multiculturele samenleving plaats als een botsing tussen culturen en als een botsing van sociale belangen. $\mathrm{Nu}$, dat is niet gelukt.

Later hebben wij het geprobeerd in het kader van het zogenaamde probleemcumulatiegebiedenbeleid, een moeilijke naam die echter wel aangaf waar het om ging. Ik noem ook het oudewijkenbeleid. Wij hebben geprobeerd om dat op te pakken door terug te grijpen op het oude stadsvernieuwingsbeleid in de brede zin van het woord, dat niet alleen een bouwbeleid is maar ook een beleid van cultuur en een beleid van wijkhervorming. Dan zie je dat je alle departementen nodig hebt, want het idee erachter is dat je onverkokerd - dat is ook wat onder Van Boxtel geprobeerd is - je geld sluist naar de gemeenten voor die wijken. Daarbij moet dan niet worden gekeken of de centen van Onderwijs allemaal bij onderwijs komen en die van Sociale Zaken allemaal bij werkgelegenheid. Het gaat erom dat men de gemeente de opdracht, de bevoegdheden en de financiële mogelijkheden geeft om via een mobilisatiemodel - in een korte tijd, vier jaar - een soort totaalplan voor een wijk op te stellen. Dat behelst dan een verbetering van de bouw - daar zijn wij wel goed in - maar ook verbetering van het onderwijs, beter functioneren van de politie in de wijk, via wijkbureaus, verbetering van de vuilophaal enz. Zo'n plan zou de wijken vooruithelpen maar daar heb je enorme bevoegdheden voor nodig, in die zin dat ook de departementen ermee instemmen dat het geld naar de gemeente gaat en afzien van de eigen controle erop via bijvoorbeeld de methodiek van Onderwijs of de systematiek van de arbeidsbureaus. Nu, daar kom je niet doorheen. Dat hebben wij wel afgesproken maar dat wordt dan slecht gehaald. Bovendien zie je dat als je er op rijksniveau doorheen komt, er op gemeentelijk niveau net zo goed coördinatieproblemen zijn. Daar komt de hele problematiek dan weer terug. Op dat terrein zou ik gewenst hebben dat de minister, als hij het had gewild, zijn wil had kunnen doordrijven."

Zijn opvolger, Hugo Fernandes Mendez, komt verderop aan het woord (TK 2004, 28689, nr. 10: 197):

"Het sociale vernieuwingsbeleid was namelijk mijns inziens in wezen de in een ander jasje gestoken voortzetting van het probleemcumulatiegebiedenbeleid dat in het integratiebeleid is ontstaan. Dat is gebiedsgericht beleid. Dat is geen nieuwe uitvinding, want er stond al in de Minderhedennota van 1983 dat dit erg belangrijk was. Daarnaast ging het er nu toch ook om, heel toegespitst te kijken naar de ontwikkeling van de positie van de doelgroepen op essentiële terreinen zoals onderwijs, werkloosheid, discriminatie, rechtspositie, et cetera. Dat kreeg je echt niet in beeld op basis van de constitutionele gedachte rondom sociale vernieuwing. Dit was gewoon gebiedsgericht beleid op lokaal niveau, waarbij het Rijk slechts een faciliterende rol speelde." 
In de eerste plaats toont het citaat van Molleman aan hoezeer het minderhedenbeleid de algemene denklijn van Binnenlandse Zaken had opgezogen en ook dat de vervolgstap naar de weerbarstige praktijk van de (evenzeer verkokerde) gemeenten in feite niet is gezet (omdat de minister dat niet wilde). Het tweede citaat geeft het resterende verschil aan dat er bleef bestaan tussen het algemene bestuursbeleid van Binnenlandse Zaken en de kop die het minderhedenbeleid daarop zette.

\section{Specifiek minderhedenbeleid: emancipatie van nieuwkomers}

In de praktijk lag veel nadruk op de gedachte dat minderheidsgroepen weliswaar op den duur 'gewone' burgers moesten worden, maar dat voorlopig bescherming van eigen cultuur en instituties nodig bleven om die emancipatie mogelijk te maken en te begeleiden. Daarnaast was specifieke aandacht noodzakelijk om discriminatie tegen te gaan. Ebbeling noemt minderhedenbeleid verkapt antidiscriminatiebeleid, dat in het land van de kool en de geit niet zo mocht heten. De coördinerende rol van Binnenlandse Zaken kreeg in veel gevallen inhoud door tegenover de andere departementen toevoegingen in hun rijksnota's te verlangen van specifieke maatregelen voor minderheden en categoriaal beleid. De andere onderdelen van Binnenlands Bestuur, in het bijzonder Coördinatie Bestuursbeleid, hadden het er bepaald moeilijk mee, deze boodschap namens hun collega's over te brengen. Jan de Winter, die als kwartiermaker eerder bij Binnenlandse Zaken was gaan werken dan Molleman, zegt:

"Ik botste nogal met Molleman, want ik vond dat je de minderheden niet te veel in de watten moest leggen, niet te veel specifieke eigen voorzieningen moest creëren. Hij vond dat misschien ook in zijn hart nog wel, maar hij vond de tijd daar nog niet rijp voor. Dus er werden overal 'eigen cultuur-dingen in het leven geroepen' en specifieke minderhedenbelangen gediend, waar ik vond dat men aan de algemene regelingen moest deelnemen." 58

Elk immigrantenbeleid balanceert tussen deze polen: etnisch assimilationisme of multiculturalisme. Scholten en Timmermans beschrijven in hun artikel een aantal wendingen die het minderhedenbeleid in Nederland heeft doorgemaakt (Scholten en Timmermans, 2004). Na de fase van ontkenning (voorbereiding van terugkeer, opvang in gesegregeerde kampen) volgde in de eerste fase van het minderhedenbeleid integratie met behoud van identiteit als motto. Al in 1991 gooide Frits Bolkestein de knuppel in het hoenderhok door te waarschuwen voor de botsing tussen verschillende waardepatronen en te pleiten voor meer nadruk op integratie (assimilatie). Het kabinet koos voor de gemakkelijke weg en plaatste de culturele dimensie liever buiten beeld. Alle aandacht werd na 1994 verschoven naar de sociaaleconomische integratie. 'Werk, werk, werk' was het motto van het eerste paarse kabinet-Kok, en in het minderhedenbeleid werd dit accent nog verrijkt met 'taal, taal, taal'. Niet groepen, maar individuen werden begeleid naar een betere positie op de arbeidsmarkt. Die arbeidsmarkt zelf werd overigens ongemoeid gelaten, voor zover deze de competitie voor minderheden bemoeilijkte. ${ }^{59}$ De Wet Inburgering Nieuwkomers van 1998 was de bekroning van dit beleid. In deze periode werd ook voor het eerst erkend dat Nederland een immigratieland is.

Directie Coördinatie en Integratie Minderheden, afscheid van Binnenlandse Zaken Gaandeweg werd de directie geconfronteerd met nieuwe inzichten, die aanvankelijk geen enkele rol speelden. Een daarvan was de gedachte van inburgeringsbeleid, te beginnen met de

\footnotetext{
58 Interview met Jan de Winter op 31 augustus 2007 te Den Haag.

59 De directie beschikte ook over een ruim onderzoeksbudget van 2 miljoen gulden per jaar, verzameld uit verschillende departementale bronnen, en zette interessante onderzoeken uit met een stevige begeleidingsstructuur (de ACOM) onder leiding van prof. Köbben, met Rinus Penninx als secretaris. Een voorbeeld is het rapport 'Een eerlijke kans' van Frank Bovenkerk over discriminatie op de arbeidsmarkt en de ervaringen met positieve actie. De Minderhedennota van $1983 \mathrm{had}$ het middel van gedwongen quotering expliciet afgewezen en dat bleef zo.
} 
nieuwkomers en met het accent op de jeugd, waarbij het leren van de Nederlandse taal vooropstond. In deze periode bleven de dominante structuren vanuit het beleid 'integratie met behoud van culturele identiteit' nog overeind. Toch zat achter de verlegging van het accent naar economische integratie via de arbeidsmarkt al de stilzwijgende verwachting dat uiteindelijk de culturele verschillen wel zouden oplossen. Nog later, na de eeuwwisseling, werd het politiek correcte denken afgestraft en zag men de problemen van hoge criminaliteitscijfers en de totaal onverwachte (negatieve) invloed van religie als maatschappelijke factor. Zó integraal kon ook Binnenlandse Zaken niet denken. De omstandigheid dat de massa van ongeschoolde nieuwkomers in dezelfde wijken geconcentreerd woonden waar uitgerekend de Nederlandse burgers woonden die in hun bestaan het meest bedreigd werden en die de minste waardering konden opbrengen voor culturele afwijkingen, bemoeilijkten de kwestie aanzienlijk. Zeker voor een ministerie als Binnenlandse Zaken, dat overwegend dacht in termen van dé burger. De opkomst van Pim Fortuyn, die de dominante visie danig op de schop nam en de nasleep van '9/11' kwamen voor Binnenlandse Zaken als een overval. De ambtenaren van de Directie Coördinatie en Integratie Minderheden (DCIM), zoals DCM intussen heette, werden aan een tweeledige cultuurschok blootgesteld: verkassen naar Justitie en verplicht worden de kille beleidslijn van Nawijn en Verdonk te absorberen. Het is de vraag wat traumatischer was. Terugkijkend op hun bijdrage aan het bestuursbeleid is de aanwezigheid van concrete maatschappelijke problematiek belangrijk geweest voor de kijk van het ministerie van Binnenlandse Zaken op de wereld en voor de ontwikkeling van praktisch probleemoplossend vermogen. Daartoe droeg minderhedenbeleid bij en later het grotestedenbeleid. Het zette een andere, meer realistische, spiegel voor de effecten van het rijksbeleid dan door de vrij abstracte decentralisatieredeneringen werd aangereikt. Dat deze maatschappelijke oriëntatie gaandeweg in alle drie dossiers werd overschaduwd door bureaucratische plantoetserij, zette wel een domper op de feestvreugde, maar de noodzaak om zich met 'echte problemen' bezig te houden was voor het bestuursbeleid van Binnenlandse Zaken verfrissend.

Het is uiteindelijk anders gelopen met de maatschappelijke beleidsopdrachten van Binnenlandse Zaken. Het minderhedenbeleid en het grotestedenbeleid zijn beide in 2007 bij VROM terechtgekomen. ${ }^{60}$

\subsubsection{Aanwijzingen voor de gehanteerde bestuurstheorie}

Interpretatie tegen de achtergrond van de begrippen government en governance

Bij de inhoudelijke oriëntatie van het onderdeel bestuurskrachtontwikkeling van gemeenten kunnen de twee bestuursbenaderingen van dit boek als volgt worden geoperationaliseerd.

1. government: versterken integraal bestuur overheid (organiserend vermogen gemeente);

2. governance: versterken verbindingen tussen netwerken in wijken en met het middenveld (organiserend vermogen gemeenschap). Dat kon gebeuren door te investeren in het proces.

Zo beschouwd leek het vernieuwende idee van de inrichting van een coördinerende eenheid bij Binnenlandse Zaken met alle elan en voortvarendheid van die tijd op zichzelf een uiting van governance-denken. Voor het eerst werd serieus geprobeerd de problemen van migratie, de werkgelegenheid, onderwijs en huisvesting in samenhang te bezien op het passende lokale niveau. Maar in de weerbarstige praktijk was het minderhedenbeleid toch vooral gericht op de eerste benadering. Uit de interviews blijkt de gebrekkige verbinding tussen het horizontale en het verticale deel van de directie. Zelfs de aanpak van het probleemcumulatiegebiedenbeleid was maar ten dele geslaagd als poging om de problemen centraal te stellen, de actoren daarbij te zoeken en tot een vruchtbare coproductie aan te zetten. $\mathrm{Na}$ enige tijd werd dit een planprocedure in plaats van een proces.

\footnotetext{
60 Tot ieders verrassing kwamen ze in 2010 met DG-Wijken, Wonen en Integratie weer terug, maar zowel het grotestedenbeleid als het specifieke minderhedenbeleid liep toen al op zijn laatste benen. In 2012 werd voor de vijfde maal van departement gewisseld. Dit keer naar SZW.
} 


\section{Doelstelling en beleidsredenering}

De doelstelling van het beleid is gedurende de hele periode voorwerp van een zoektocht, want aan welke knoppen kun je draaien als emancipatie de uitkomst moet zijn? Gedurende de hele periode werd het beleid achtervolgd door de slogan 'integratie met behoud van eigen cultuur'. In de Minderhedennota van 1983 werd deze uitspraak weliswaar gerelativeerd, maar in feite was er permanent spanning tussen de druk in de richting van 'integreren' en van 'eigen cultuur', specifieke voorzieningen, culminerend in de discussie over het nut of onnut van Onderwijs in Eigen Taal en Cultuur. De simpele behartiging van de belangen van de doelgroepen is lange tijd de inzet geweest totdat het inzicht terrein won dat de doelgroepen hiermee uiteindelijk werden geïsoleerd van de rest van de samenleving. Het definiëren van minderhedenproblemen als Nederlands achterstandenbeleid en als inburgeringsvraagstuk was een interessante koerswending, maar daarmee werden de problemen wel weer erg groot gemaakt. De maatschappelijke denklijn gericht op integratie zou governance genoemd kunnen worden, de isolerende lijn 'eigen cultuur' lijkt meer op government.

\section{Sturingsaanpak}

Wat betreft de sturingsaanpak is er eveneens verschil tussen oorspronkelijke ideeën van de initiatiefnemers over een kleine club wendbare verbindingsofficieren en de uiteindelijke invulling van een directie met een klassieke bureaucratische aanpak. Natuurlijk kon de directie als coördinerende eenheid naar haar aard geen louter hiërarchische lijn hanteren, maar de opzet 'coördinatie' had nog veel meer verbindend en bemiddelend kunnen zijn dan directeur Molleman ervan heeft gemaakt. De directie wilde onwillekeurig 'ergens over gaan' (subsidies, regelingen en ambtenaren). Een regeling als de Bestuurskostenregeling heeft daarnaast ook weer de aanzet gegeven tot de ontwikkeling van gemeentelijke stakeholders, nieuwe actoren met een eigen dynamiek, het tegendeel van alles in één hand houden. Ook het probleemcumulatiegebiedenbeleid leidde tot verbreding van het netwerk en tot kansen voor inductief sturen totdat het werd gesmoord in bureaucratie.

\section{Democratie-opvatting}

Men zou kunnen verwachten dat bij een zo mensgericht vraagstuk als de integratie van minderheden de rechtstreekse betrokkenheid van de leden van de etnische gemeenschappen zowel als de groepen die met hen moesten samenleven een centrale rol zou spelen. Dit was echter niet het geval. Bij de etnische doelgroepen werd alleen overlegd met zelfbenoemde vertegenwoordigers van minderhedenorganisaties en met autochtone wijkbewoners werd helemaal niet gesproken. Verder week de democratieopvatting van DCM niet af van de rest van het ministerie.

\section{Informatievergaring}

De informatieverwerving was in opzet vrij breed. Ook hier zien we een gemengd beeld. Er werd veel wetenschappelijk onderzoek geëntameerd, de contacten waren interdepartementaal georganiseerd, veel meer dan ooit bij CRM het geval was geweest, en gingen ook in de richting van het veld en van de specifieke doelgroepen. Maar in geen van de gevallen werden de haarvaten bereikt, de werkelijke behoeften gepeild. Experimenteren of spelen met nieuwe varianten op bestaand beleid hoorde nauwelijks tot het vocabulaire van de directie in de interdepartementale sectorale werkgroepen, die klassieke schijngevechten leverden over regelingen en beleidsnota's.

\subsubsection{Typering van dit project volgens overige onderzoekscriteria}

\section{Mate van beleidsvernieuwing}

Uit de interviews en andere bronnen komt naar voren dat het minderhedenbeleid (evenals de sociale vernieuwing en het grotestedenbeleid) bij Binnenlandse Zaken terechtkwam, omdat de vakdepartementen het elkaar niet gunden en dan liever een inhoudelijk 'neutrale' derde als 
coördinator aanwezen. Nog belangrijker was echter dat deze onderwerpen werden geframed als opgaven voor het lokaal bestuur. Binnenlandse Zaken was het best geëquipeerd om gemeenten toe te rusten voor nieuwe bestuurlijke opgaven, zoals het opvangen en integreren van etnische minderheden als volwaardige burgers en het tegengaan van de sociale onttakeling in oude stadswijken. Het was een geheel nieuwe taak, een beleidsinnovatie dus, althans voor Binnenlandse Zaken. Er was een langere voorgeschiedenis vooraf gegaan bij CRM. Voor de rijksoverheid was het op zijn hoogst beleidsopvolging. Dat laatste zou in mindere mate ook gesteld kunnen worden van het probleemcumulatiegebiedenbeleid, zij het dat bij het ministerie van VRO met de stadsvernieuwing in de zin van fysieke wijkverbetering al was voorgegaan.

\section{Bijdrage aan de bestuurstheorie}

Ongetwijfeld heeft de toevoeging van een actueel maatschappelijk vraagstuk aan de taakopdracht van Binnenlandse Zaken meer begrip gekweekt voor de specifiek sectorale krachten die inwerken op politieke besluitvorming. Anderzijds is minderhedenbeleid altijd een buitenbeentje in het bestuursbeleid gebleven en zijn er veel pogingen ondernomen om deze directie te disciplineren in de dominante denklijn van de andere. Dat impliceerde dus zo snel mogelijk specifieke uitkeringen naar het Gemeentefonds overhevelen. Omgekeerd was de sociale vernieuwing schatplichtig aan het probleemcumulatiegebiedenbeleid.

\section{Evaluatie}

Evaluatie heeft grootscheeps plaatsgevonden tijdens het parlementair onderzoek van de commissie-Blok, maar juist de betekenis van inhuizing binnen Binnenlandse Zaken en de meerwaarde van de verbinding met een heel nieuwe wereld voor leereffecten binnen het bestuursbeleid is in het geheel niet belicht. Het lijkt er niet op dat veel leden van de commissieBlok, noch van hun informanten het minderhedenvraagstuk anno 2004 percipieerden als een bestuurlijk vraagstuk, zoals dat in navolging van anderen hier wel is gedaan. Het woord probleemcumulatiegebiedenbeleid komt in het hele rapport van de commissie-Blok niet voor. Bovendien is nooit geëvalueerd met het oog gericht op de positionering binnen BZK, en de werkwijze van de directie. Het heeft er overigens de schijn van dat de leereffecten op het bestuursbeleid beperkt zijn gebleven tot de persoonlijke ervaringen van medewerkers als Jan de Winter, Han Kapsenberg, Hans Wilmink, Budh Khargi, Maria Gonzalez, Bert van Vliet, Nico van Putten en Frank van Kuik, die gaandeweg van DCM overgingen naar plekken meer in het hart van het bestuursbeleid.

\section{Doorwerking en institutionalisering}

De doorwerking van het minderhedenbeleid als vorm van bestuursbeleid is groot geweest, wat niet hetzelfde is als doelbereiking. Het is door de almaar voortgaande instroom van nieuwkomers een hoofdthema van rijksbeleid geworden. De meeste onderdelen van het beleid zijn naar de gemeenten gedecentraliseerd. Alle grote steden hebben eigen afdelingen en voorzieningen gecreëerd. Alleen binnen Binnenlandse Zaken is de directie altijd vrij geïsoleerd gebleven. Uiteindelijk is de band met Binnenlandse Zaken geheel doorgesneden. In dat opzicht is beklijven niet het juiste woord. Het oorspronkelijke doel, het toerusten van de gemeenten voor een grote sectoroverstijgende opgave, was ook wel voltooid. Van een echte wisselwerking met de rest van het bestuursbeleid is maar beperkt sprake geweest. Ja, de ambtelijke invulling van coördinatiewerk is geleend van het decentralisatiebeleid en omgekeerd heeft het probleemcumulatiegebiedenbeleid invloed gehad op de aanpak van sociale vernieuwing en grotestedenbeleid.

\subsubsection{Conclusies}

De indicaties met betrekking tot het onderscheid tussen government en governance komen erop neer dat de intenties met het binnenhalen van de directie om binnen Binnenlandse Zaken een puur maatschappelijk vraagstuk aan te pakken vastliepen in een Haagse en bureaucratische benadering, zodat bijvoorbeeld de verbindingen met de doelgroep bleven hangen bij hun 
intermediaire woordvoerders. Governance in de betekenis van dit onderzoek kwam dus niet van de grond. Daarom komt de eindscore niet verder dan A -. En de bijdrage aan een eigentijdse bestuurstheorie van het directoraat-generaal was beperkt; deze kwam misschien nog het meest tot zijn recht door de gebiedsgerichte inzet van het PCG-beleid. Door veel breder de samenleving in de probleemstelling te betrekken had het beleid misschien anders gekund. Na de eeuwwisseling kwam dit manco onverbloemd tot uiting, maar voor een ander communicatiever beleid waren de omstandigheden eerder niet aanwezig.

\subsection{Sociale vernieuwing}

\subsubsection{Inleiding}

Het sociale vernieuwingsbeleid (1990-1993) was de kers op de taart van het kabinet-Lubbers-Kok en betrof een zuiver politiek ideaal om burgers in de wijken te mobiliseren, dat echter onder de hoede van Binnenlandse Zaken na enige tijd verkeerde in een bureaucratische mallemolen met 500 convenanten, interdepartementale strijd over de vulling van de brede doeluitkering, het Sociale Vernieuwingsfonds, en de verantwoording van de gemeenten over de besteding daarvan door de Uitvoeringsorganisatie Sociale Vernieuwing. Het was op papier een project, maar toch was er behalve de externe Commissie Sociale Vernieuwing onder leiding van Jan Schaefer, geen aparte organisatie-eenheid buiten de lijn, geen afgebakende doelstelling vooraf en geen einddatum gegeven. In feite was het project al beëindigd voordat het kabinet in 1994 ten val kwam.

De beschrijving van dit project vertoont gelijkenis met het vorige. Eerst wordt stilgestaan bij de redenen waarom sociale vernieuwing bij Binnenlandse Zaken terechtkwam en de wijze waarop het hier in het bestuursbeleid werd ingepast. Dan volgen de verhalen over de ontwikkeling van het project en de paragraaf wordt weer afgesloten op de bekende manier met een analyse van de elementen die voor dit onderzoek van belang zijn.

Bronnen zijn wederom de relevante Kamerstukken, zoals de Nota Sociale Vernieuwing van 1991, de Memorie van Toelichting op de begroting van Binnenlandse Zaken 1993, maar liefst drie evaluatiestudies van het Sociaal en Cultureel Planbureau (Van der Wouden, 1993 en 1994; Van der Pennen et al., 1996 en 1998) en de interviews met de projectleider L. van Vliet en zijn rechterhanden W. Bringmann en $\mathrm{H}$. Wilmink.

\subsubsection{Verhalen: geboorte van een nieuwe taak}

Sociale vernieuwing was het vlaggenschip van het kabinet-Lubbers-Kok, vooral voor het PvdAsmaldeel daarin. Het idee was geboren in Rotterdam, waar Philip Idenburg aan de wieg stond van een bottom-up benadering in de oude wijken. De aanleiding om deze aanpak op kabinetsniveau over te nemen was tweeërlei:

1. de profileringsbehoefte van het nieuw aangetreden kabinet. Na de zure bezuinigingsjaren tachtig was voor deze centrum-linkse combinatie het moment aangebroken om wat meer het sociale gezicht te laten zien en te gaan investeren in de steeds nijpender problemen van achterstandswijken.

2. de gepercipieerde bestuurlijke malaise waarin het land verkeerde ('de Kloof'), onder meer tot uiting komend in de gemeenteraadsverkiezingen van 1990. De lage opkomstcijfers schokten bestuurlijk Nederland. Hieruit sprak een vertrouwensprobleem, waaraan op alle manieren gewerkt moest worden onder meer door de burgers weer bij de publieke zaak te betrekken.

Gaandeweg werd sociale vernieuwing als een vervolgstap ook in andere dossiers gezien, maar dan zowel een variant van decentralisatiebeleid als een verdergaande stap ten opzichte van stadsvernieuwing en probleemcumulatiegebiedenbeleid, dieper de gemeente in.

Een wezenlijk nieuw onderdeel van het project Sociale vernieuwing was echter het inzicht dat de overheid de samenleving moet mobiliseren om echt grote problemen, zoals die van achterstandswijken, aan te pakken. 


\section{Positionering binnen Binnenlandse Zaken}

De geschiedenis vertoont opmerkelijke parallellen met het binnenbrengen van het minderhedenvraagstuk bij Binnenlandse Zaken. Weer werd CRM - inmiddels WVC - gepasseerd, weer speelde de vice-minister-president - ditmaal Wim Kok - een hoofdrol.

Alle tekenen wezen erop dat de minister van WVC, Hedy d'Ancona, was voorbestemd om het Rotterdamse idee van de sociale vernieuwing op rijksniveau te introduceren. Het was echter Wim Kok, leider van het PvdA-smaldeel in het kabinet, die daar een stokje voor stak. Hij beoordeelde sociale vernieuwing primair als een bestuurlijk vraagstuk ('ruimte voor de basis') en schoof de minister van Binnenlandse Zaken, Hedy's vriendin len Dales, naar voren. Zo werd deze kans Binnenlandse Zaken zomaar in de schoot geworpen. Zoveel politieke steun en zoveel elan voor een nieuwe aanpak zouden zich niet gauw meer voordoen. Als het niet primair een bestuurlijk vraagstuk was, zorgde Binnenlandse Zaken wel dat het op een bestuurlijke manier werd aangepakt en dat er bestuurlijke vruchten zouden worden geplukt.

In een grootscheepse actie van het hele kabinet, die overigens traag op gang was gekomen, werd de Wijkaanpak, via buurtprojecten in heel Nederland, actief gestimuleerd.

\section{Een golf van nieuw elan}

De moeizame en trage start is achteraf niet verwonderlijk als we zien wat voor revolutionaire reuzenzwaai het kabinet maakte. Denk aan het gehaspel van minister Dales in de Tweede Kamer, waar ze een definitie van sociale vernieuwing van 104 woorden voorlas. Ze had ook gewoon kunnen zeggen "we weten het nog niet zo", maar dat zegt een minister niet gauw. Uiteindelijk was het toch een swingende periode, waarin een aantal vanzelfsprekendheden overboord gingen. $\mathrm{Na}$ het passeren van de Nota Sociale Vernieuwing, een opgave, ging het crescendo. Zo was het een unicum dat bewindslieden van andere ministeries zo werden betrokken bij een beleidsproces als bij sociale vernieuwing. Minister Dales haalde mensen als Jacques Wallage en Elske ter Veld binnen om in het gebouw van Binnenlandse Zaken zelf naast de ambtenaren mee te schrijven aan het programma, voornamelijk wegens het persoonlijk vertrouwen dat ze in hen stelde. Dat was cultuurdoorbrekend. Ook het optreden van de commissie-Schaefer IPSV, die als een groep evangelisten het land doorreisden om mensen te bemoedigen en te enthousiasmeren, was onorthodox. Ongehoord was de formule van deze Interbestuurlijke Projectgroep waarin een aantal ervaren oud-wethouders zaten naast departementale vertegenwoordigers, die werkten met een zeker mandaat om namens hun ministerie te mogen beslissen. Jan Schaefer had dit als eis gesteld om slagvaardig te kunnen werken. Zeker in de eerste jaren van de commissie heeft dit ook goed gewerkt en gaven de ministeriële vertegenwoordigers soms scharrelruimte prijs tegen de wens van hun achterbannen in. Ook op kabinetsniveau heerste de koorts. Er werd een aparte ministeriële commissie Sociale Vernieuwing opgericht met Lodewijk van Vliet als secretaris. De ministerpresident en vice-premier Kok leidden deze vergaderingen met strakke hand. Van Vliet vertelt dat hij met dozen kopieën rechtstreeks uit de repro in de ministeriële commissie verscheen, maar hij hoefde ze niet eens open te maken, want de besluiten waren al gevallen. De dozen voelden nog warm. ${ }^{61}$

Maar het belangrijkste was de erkenning van het gegeven dat complexe problemen als sociale achterstand niet door de overheid kunnen worden opgelost. Er werd met hart en ziel gewerkt, onder indruk van ervaringen uit de vele werkbezoeken op locatie. De decentralisatiefilosofie werd van een andere argumentatie voorzien. Het ging er nu vooral om de mensen vrij baan te geven voor het aanpakken van hun problemen. Gemeenten konden hen daarbij begeleiden en mochten daarbij niet worden beperkt door de regeltjes en subsidievoorwaarden van departementen. Zo werd het toch in belangrijke mate een decentralisatieoperatie. Ambtelijk projectleider werd Lodewijk van Vliet, het hoofd van de afdeling Coördinatie Bestuursbeleid, een afdeling die in deze periode bijna verdubbelde in aantal medewerkers. Co-secretaris was Frank van Kuik van de directie Coördinatie Minderhedenbeleid (DCM), nadrukkelijk mede-eigenaar van het project.

61 Uit het interview met Lodewijk van Vliet, 30 juli 2007. 
Framing van sociale vernieuwing als bestuursbeleid

Het Probleemcumulatiegebiedenbeleid (PCG-beleid) kan worden beschouwd als rechtstreekse voorloper van de sociale vernieuwing, maar werd niet gezien als instrument in het decentralisatiestreven. Integendeel, bij DCIM zou men liever nog een tijdje extra sturingsmiddelen inzetten bij gemeenten om het kwetsbare minderhedenbeleid van de grond te krijgen. Men voelde het daar als een last dat een onderdeel van het directoraat-generaal openbaar bestuur nu eenmaal het goede voorbeeld moest geven, waardoor zij hun speelgoed het eerst moesten afgeven. In de interne competentiestrijd met de bestuurlijke directie IBI kon DCM het echter niet winnen. Secretaris-generaal Jozias van Aartsen zag aanvankelijk in het Fonds Sociale Vernieuwing een kans om voorwaarden te creëren voor een meer inhoudelijke grondslag voor het Gemeentefonds. Het Fonds Sociale Vernieuwing werkte met beweeglijke, beleidsgevoelige indicatoren zoals het aantal bijstandstrekkers, het aantal achterstandsleerlingen en dergelijke. De Algemene Uitkering van het Gemeentefonds is gebouwd op abstracte statistische gegevens als inwonertal, oppervlakte en dergelijke. De SG hoopte met meer voor de vakdepartementen herkenbare variabelen de stap kleiner te maken om gelden aan de Algemene Uitkering toe te vertrouwen.

\subsubsection{Ontwikkeling van het project}

\section{Episode met veel dynamiek, van korte duur}

Naast een voortzetting van bureaucratische loopgravenoorlogen was dit een periode met veel elan en vrolijke en verrassende contacten tussen ambtenaren en wijkbewoners, opbouwwerkers en initiatiefnemers voor projecten die hun kans schoonzagen voor subsidies. Ook gemeentebestuurders en -ambtenaren werden geïnspireerd door de zogeheten integrale aanpak. Zozeer sloeg dit begrip aan dat in de kortste keren de 'integrale aanpakken' over elkaar heen buitelden. Integrale veiligheid, integraal jeugdbeleid, integraal werkgelegenheidsbeleid en arbeidsmarktbeleid werden naast elkaar in de gemeenten geïntroduceerd ten dele als species van sociale vernieuwing (het integraal achterstandsgebiedenbeleid) en ten dele als eigensoortige opdrachten voor planvorming, die rekening houdt met context en met belendende beleidsterreinen. Paradoxaal was dat integrale aanpak de aanleiding was voor een nieuwe verkokering op een hoger niveau. ledereen zijn eigen integrale aanpak maakte de bestuurlijke drukte wel groter (Van der Wouden et al., 1994).

\section{Ambtelijke top heeft er gauw genoeg van}

Overigens was voor politiek denkenden het nieuwe er gauw vanaf. Al in het derde jaar werd vooral door de ambtelijke top alweer uitgekeken naar een volgend label voor beleid, terwijl de gemeenten en de wijken net een beetje op stoom kwamen. De verkiezingen wierpen hun schaduw al vooruit. Sociale vernieuwing kwam in zwaar weer, het mandaat van de vertegenwoordigers in de IPSV werd aangescherpt, voorzitter Schaefer werd chagrijniger over de bureaucratie, maar ook werden lasten van de uitvoeringsfase waarin de sociale vernieuwing terechtkwam zwaarder gevoeld. Vooral zat Binnenlandse Zaken zichzelf in de weg door het kennelijk onvermijdelijke planningsfetisjisme, waarover men de andere departementen vaak verwijten maakte. De gemeenten moesten plannen maken om in aanmerking te komen voor extra middelen. Hierdoor ontstond een papierberg, die nauwelijks nog in relatie stond met de werkelijkheid. De functie van die plannen was immers vooral om geld los te krijgen, minder om de eigen activiteiten te sturen of te representeren. Aan de inhoud van al die plannen kon het Rijk met geen mogelijkheid reëel aandacht besteden. De uitvoering van het Fonds Sociale Vernieuwing, waarvan de besteding toch netjes verantwoord moest worden, vergde een vaste bezetting van vijf medewerkers. Sociale vernieuwing was ook in zekere zin te populair geworden bij gemeenten. Let wel, het was begonnen in Rotterdam en overgenomen door de andere drie grote steden. Toen het Rijk het beleid ging inrichten, werden op gronden van gelijksoortige problematiek netjes 37 sociale vernieuwingsgemeenten geselecteerd. Binnenlandse Zaken had echter in de loop van de tijd niet kunnen tegenhouden dat, naast de 37 proefgemeenten, waar de problemen herkenbaar het 
zwaarst wogen, de deur werd opengezet voor alle gemeenten om convenanten te ondertekenen over sociale vernieuwing. Dit tegen de aanvankelijke voorkeur van minister Dales om zich te beperken tot een klein aantal gemeenten in.

Projectleider Lodewijk van Vliet hierover:

"Zo zuchtte minister Dales onder een grote stapel van 500 convenanten, die ze allemaal persoonlijk van haar handtekening moest voorzien. Dat deed ze "tussendoor", die stapel heeft haar nog een tijdlang begeleid. De minister ging ook naarmate de tijd verstreek meer druk ondervinden om resultaten van de inspanningen te laten zien. Enthousiasme en inspiratie waren daarvoor niet voldoende." 62

\section{Vastlopende ambities}

Hoewel de ministers Dales en Van Thijn nog steeds veel warmte voelden voor de in gang gezette beweging, leek het of de 'kleilaag' onder hen zich sloot. Nota's met nieuwe initiatieven, speechkansen, plannetjes voor vervolg kwamen er gewoon niet door tot grote ergernis van Lodewijk van Vliet. Qua bestuursstijl herstelde het Rijk zijn gouvernementele ongenaakbaarheid, de knieval voor het niveau van de buurt, de projectjes van de opbouwwerkers en de buurtcentra was gedaan; er was weer behoefte aan grote lijnen en zwaarwegende nationale belangen; grotestedenbeleid zou daar beter aan voldoen dan sociale vernieuwing. Het speelkwartier was over! En de eerlijkheid gebiedt te zeggen dat het zo ook niet verder kon doorgaan. Dan had Binnenlandse Zaken veel selectiever moeten zijn, alleen hier en daar de diepte in moeten gaan, maar het gelijkheidsdenken liet dat niet toe. Het is kennelijk alles of niets. Toen het speelde, konden de sterk meelevende ambtenaren niet de professionele distantie opbrengen om een duurzamer aanpak op rijksniveau neer te zetten. Voor het eerst zocht Binnenlandse Zaken de burgers op, maar ze probeerden wel meteen de allermoeilijkste groepen te bereiken, die Gabriël van den Brink later in zijn WRR-studie 'Mondiger of moeilijker' de bedreigde burgers noemde (Van den Brink, 2002).

\section{Lokale doorwerking}

Na een eerste evaluatieonderzoek in 1994 heeft het Sociaal en Cultureel Planbureau (SCP) enige tijd later in opdracht van Binnenlandse Zaken een vervolgonderzoek gehouden. Hierin werd vastgesteld dat veel gemeenten zich weinig hebben aangetrokken van het gegeven dat het Rijk opeens de stekker eruit heeft getrokken. Ze hebben jaren na dato nog sociale vernieuwingsbeleid gevoerd met dito wethouders. De constatering was dat sociale vernieuwing voldeed aan de behoefte om een integratiekader te creëren ten opzichte van de sterk verkokerde sociale sector. Uit verschillende onderzoeken komt naar voren dat de sociale vernieuwing heeft geleid tot de totstandkoming van allerlei nieuwe initiatieven op lokaal niveau en een impuls heeft gegeven aan sectoroverstijgende samenwerking. De verruiming van beleidsvrijheid en bestedingsvrijheid in de brede doeluitkering Sociale Vernieuwing - een zoveelste ingang voor decentralisatiebeleid - en de goedbedoelde pogingen om samenwerking tussen lokale instanties op uitvoeringsniveau ten behoeve van achterstandsbestrijding te versterken waren nog niet zo indrukwekkend. Wel baanbrekend was de nieuwe werkwijze waarbij het lokaal bestuur in samenspraak met bewoners en organisaties beleid ontwikkelde dat voor een deel was geïnspireerd door ideeën van direct betrokkenen. Vooral bij leefbaarheidsprojecten op wijk- en buurtniveau zijn hier interessante resultaten geboekt, ook al kan men afdingen op de mate van participatie van bewoners.

De aanpak was een kiem van wat in potentie een Copernicaanse revolutie moest worden in gemeentehuizen. Werkwijzen als Frontlijnsturing die pas aan het begin van de volgende eeuw werden benoemd, werden toen al op vrij grote schaal toegepast. Op rijksniveau is dit denken nauwelijks aangeslagen, omdat men voor de consequenties terugdeinsde. Wel zijn volgens de onderzoekers daar de onderlinge verhoudingen binnen de bestuurskolom veranderd, waarbij toerusting, facilitering en regie meer toepasselijke termen zijn geworden dan instructie,

62 Zie vorige noot 
implementatie en uitvoering (Van der Pennen et al., 1998: 166). Dit was typisch rooskleurig fin-desiècle-denken. Te rooskleurig, zoals we zullen zien.

\subsubsection{Aanwijzingen voor de gehanteerde bestuurstheorie}

Interpretatie tegen de achtergrond van de begrippen government en governance Meer dan het minderhedenbeleid, en zelfs dan het PCG-beleid, vertoonde sociale vernieuwing aanvankelijk trekken van de governance-benadering. Sociale vernieuwing was qua doelstelling breed, achterstandsbestrijding op elke mogelijke manier.

De ambtenaren die werden geïnspireerd door de commissie onder leiding van Jan Schaefer, richtten zich vooral op het mobiliseren van processen binnen de gemeenten. Op het grondvlak in buurten en wijken wordt alles vloeibaar, ook de schotten tussen publiek en privaat. Later is ook dit beleid van karakter verschoten door de klemtoon op decentralisatie en regelingen, waardoor de aandacht naar de Haagse loopgraven verplaatste en door de dwang van het gelijkheidsdenken waardoor alle gemeenten tot doelgroep werden verklaard en het beleid verbureaucratiseerde. Hoe dicht de governance-inzet aanzit tegen een alomvattend bestuurscentrisme, komt naar voren door de koppeling van een probleemgerichte bottom-up aanpak met steeds verder gaande ambities van preventief overheidsingrijpen. Lodewijk van Vliet wees tijdens het interview ten behoeve van dit onderzoek op het ontstaan van het integraal veiligheidsbeleid. Dat vloeide voort uit het inzicht dat een geconcentreerde buurtgerichte inzet gericht op de kwaliteit van de woonomgeving rechtstreeks doorwerkt op de veiligheidsbeleving en werkelijke veiligheidsresultaten. Zo werd de overheid steeds verder het domein van de samenleving ingezogen.

\section{Sturingsaanpak}

Wat betreft de sturingsaanpak zien we een interessant verschijnsel, dat onbedoeld ontstond. Naast de min of meer planmatige opzet van ministeriële en ambtelijke interdepartementale en interbestuurlijke commissies kreeg het idee sociale vernieuwing een andere, meer symbolische betekenis. Pieter Tops heeft dat in een lezing over de rol van taal in het bestuur aangeduid als de werking van een initiatief, een project, als ijsbreker met een hele reeks bootjes in zijn kielzog. Zo kreeg een vrij open ongedefinieerd begrip als sociale vernieuwing behalve alle regelingen, fondsen en wat dies meer zij onder die noemer, een functie als mobiliserende, zingevende attractor voor allerhande activiteiten binnen gemeenten of gemeenschappen waar Binnenlandse Zaken geen rechtstreekse betrokkenheid bij had.

Wat Binnenlandse Zaken zelf tot stand bracht, was onnoemelijk veel overleg en afstemming, wat geen verticale instructie mocht heten, maar ook niet echt samenwerking was. Met uitzondering van de allereerste fase, toen de departementale vertegenwoordigers zich nog relatief vrij voelden om naar bevind van zaken praktische oplossingen overeen te komen, die soms in strijd waren met de opvattingen thuis.

De fase waarin convenanten getekend moesten worden, had voor de gemeenten meer het karakter van een dictaat, hoezeer het woord convenant consensueel aandoet.

\section{Democratie-opvatting}

Voor het eerst werd in dit project geëxperimenteerd met participatieve vormen van democratie. In het bijzonder in de meest vergaande vorm, namelijk het bevorderen van zelforganisatie en maatschappelijk initiatief (vergelijk thans 'Doe-democratie'). In veel mindere mate kwam inspraak in de beleidsvorming, als complement van de representatieve democratie aan de orde.

\section{Informatievergaring}

De informatieverwerving was aanvankelijk bottom-up en experimenteel. Dat wil zeggen dat initiatieven bijna overal projectmatig en op maat werden ingericht, waarna geprobeerd werd de regels in Den Haag hierbij passend te maken. Al gauw werden de rollen omgekeerd en bepaalden de rek in de Haagse regels de mogelijkheden voor lokale speelruimte. Niettemin bleven de meeste 
activiteiten op lokaal niveau een incidenteel en projectmatig karakter houden, waardoor van echte doorstroming van veldinformatie naar duurzaam beleid nauwelijks sprake was.

\subsubsection{Typering van dit project volgens overige onderzoekscriteria}

Mate van beleidsvernieuwing

Voor Binnenlandse Zaken was sociale vernieuwing een nieuwe uitdaging, maar tegen de achtergrond van het al lopende Probleemcumulatiegebiedenbeleid was de beleidsinnovatie betrekkelijk. Wel echt nieuw was de manier waarop in het begin van het project contact werd gezocht met maatschappelijke initiatieven in de wijken. De inbedding in het streven naar decentralisatie en het saneren van specifieke uitkeringen maakte het project tot meer van hetzelfde binnen het bestuursbeleid. Uiteindelijk typeren we dit project als beleidsopvolging.

\section{Bijdrage aan de bestuurstheorie}

Sociale vernieuwing bood veel kansen voor Binnenlandse Zaken om de brug te slaan tussen bestuursbeleid en maatschappelijke problematiek in achterstandsgebieden. De blijvende bijdrage aan de bestuurstheorie lijkt beperkt, enerzijds omdat sociale vernieuwing spoedig in de groef van het decentralisatiebeleid belandde (brede doeluitkering), anderzijds omdat de wijkaanpak en het stimuleren van zelforganisatie van bewoners al na enkele jaren vaarwel werden gezegd.

\section{Evaluatie}

Dit project is voor de verandering wel uitgebreid geëvalueerd. Het SCP heeft twee opdrachten gekregen voor evaluatieonderzoek.

Eerst is antwoord gegeven op de vraag, in hoeverre het beleid van de rijksoverheid heeft geleid tot een verruiming van de mogelijkheden van gemeenten om lokale achterstandssituaties effectiever aan te pakken. Wat was nu op lokaal niveau daadwerkelijk te merken van de vergrote beleidsruimte? Vanuit het gezichtspunt van het gemeentelijk beleid en de bestuurlijke organisatie van sociale vernieuwing is gezocht naar de effecten van de beleidsinstrumenten van de rijksoverheid op de bestedingsvrijheid van de gemeenten. Gereconstrueerd worden de uitgangssituaties van de tien onderzochte gemeenten bij de start van de sociale vernieuwing. Bij vergelijking van de uitvoering van sociale vernieuwing op vier beleidsterreinen (individuele trajectbegeleiding, integraal wijkbeheer, onderwijs en ouderenzorg) bleek dat gemeenten hier verschillend mee omgingen. Hieruit kon Binnenlandse Zaken leren dat het belang van landelijke regelaanpassing niet onbetekenend, maar betrekkelijk is. Bij de analyse van projecten die in het kader van sociale vernieuwing zijn opgezet, krijgt de politieke context van de sociale vernieuwing veel aandacht (Van der Wouden et al., 1993 en 1994).

Enkele jaren later is onderzocht wat na verloop van tijd op lokaal niveau het blijvend effect is van deze impulsen en hoe er meer structureel vorm wordt gegeven aan achterstandenbeleid. Welke modellen van lokaal achterstandenbeleid zijn te onderscheiden, al dan niet onder de overkoepelende vlag van sociale vernieuwing? Zijn er verschillen in effectiviteit toe te schrijven aan de gekozen aanpak? Duidelijk wordt dat decentralisatie misschien een noodzakelijke, maar geen voldoende voorwaarde is voor eraan toegeschreven waarden als integraliteit, maatwerk en burgerparticipatie (Van der Pennen et al., 1996 en 1998). Deze bevindingen komen ongeveer tegelijk met de evaluatie van Fleurke et al. (1997).

Hoewel het van belang lijkt dat Binnenlandse Zaken de eigen vooronderstellingen van het bestuursbeleid tegen het licht houdt, ligt bij deze evaluaties niet zozeer de nadruk op de eigen werkwijze en aanpak van het ministerie. Is de gerichtheid op de opvoeding van de vakdepartementen zinvol en effectief? Hoe reëel is de wijkgerichtheid van het beleid? Het zoeklicht wordt daarentegen gericht op de gemeenten. De SCP-onderzoekers concluderen dat in feite belangrijke factoren van achterstanden anders aangetakt zijn dan op dat sub-lokale territoriale niveau of eigenlijk vooral beleidsresistent. Zij schrijven onder meer: "Lokale bestuurskracht is van 
meer factoren afhankelijk dan vergroting van het takenpakket en van de financiële middelen. Met name het vormgeven aan de samenwerking met belangrijke groeperingen en organisaties in de lokale samenleving is van groot gewicht, net zoals de strategie-ontwikkeling van betekenis is" (Van der Pennen et al., 1998: 166). Hier was achteraf het woord governance toepasselijk geweest. Misschien mede omdat de bevindingen vooral op de gemeenten werden geprojecteerd en niet op Binnenlandse Zaken, is deze uitspraak voor dovemansoren gedaan. Zelfs de hoopvolle verwachtingen die de onderzoekers uitspreken, zijn tien jaar later nog niet echt in vervulling gegaan. Zij stellen namelijk dat het 'principal-agent model' op terugtocht is en dat ministeries, vakdepartementen zowel als Binnenlandse Zaken, meer heil verwachten van een gezamenlijke aanpak, erop gericht om gemeenten toe te rusten en te ondersteunen bij de lokale beleidsvoering (Van der Pennen et al., 1998: 163; vergelijk Fleurke et al., 1997).

\section{Doorwerking en institutionalisering}

De doorwerking van sociale vernieuwing als inspirerend begrip is in gemeenteland groter geweest dan de impact binnen de Haagse beleidswereld. De decentralisatiewinst van het Fonds Sociale Vernieuwing zou uiteindelijk ook wel zijn binnengehaald op grond van de trend in het beleid, ofwel zij werd weer teruggedraaid kort nadat de aandacht van de politieke buitenwereld voor het beleid verslapte. Zo bleven de middelen voor Basiseducatie (Volwasseneducatie) toch uiteindelijk op de begroting van het ministerie van Onderwijs en kwamen ze niet over naar het Fonds Sociale Vernieuwing. De territoriale benadering van achterstandenbeleid als integraal, samenhangend probleem was eerder beproefd in het probleemcumulatiegebiedenbeleid vanuit de invalshoek van minderhedenbeleid. Het kreeg nu een stevig vervolg als algemene beleidsbenadering. Dit element is sindsdien niet meer uit het beleidsarsenaal van de rijksoverheid weg te denken, tot en met de latere 'Krachtwijken' toe.

De contacten van Binnenlandse Zaken met echte burgers waren van korte duur. Al die projecten op wijkniveau hadden gefloreerd door de kortstondige aandacht in de landelijke schijnwerpers, maar dat kon natuurlijk niet zo blijven. De meerwaarde van rechtstreekse informatielijnen werd gaandeweg minder ervaren en de bezwaren van het binnendringen in het gemeentelijke domein wogen steeds zwaarder voor de ambtelijke top van Binnenlandse Zaken. Een volgend kabinet diende zich aan en de voordelen die het zijn van vlaggenschip van een bepaald kabinet meebracht verkeren in hun tegendeel als de komst van een nieuw kabinet zijn schaduwen vooruitwerpt. Daarvoor moeten weer nieuwe beeldbepalende projecten en beleidsaccenten worden bedacht. Binnen de gemeente golden die bezwaren niet en was de betovering van het gedachtegoed van de sociale vernieuwing nog lang niet uitgewerkt.

Doorwerking was dus aanwezig in de betekenis van tijdelijke grote bekendheid met een vooral symbolische waarde. Voor de eigen ontwikkeling van het bestuursbeleid is sociale vernieuwing ook van groot belang geweest, omdat voor het eerst de ambtenaren van Binnenlandse Zaken uit eigen waarneming kennismaakten met de realiteit in de wijken en de weerbarstigheid van het achterstandenbeleid.

\subsubsection{Conclusies}

De opzet bij het experiment met sociale vernieuwing was voor Binnenlandse Zaken, zowel qua doelstelling, sturingsaanpak, participatieve invloedstoekenning en bottom-up informatievergaring, nooit eerder zo dicht bij governance geweest. Door de bureaucratisering in de loop van het proces wordt de score B -. Vooral het gegeven dat het allemaal zo van korte duur is geweest en zeker niet gecontinueerd is voor dit onderzoek bepalend om vast te stellen dat de governance-modus geen vaste grond onder de voeten had. Dat bleek ook al door de verwording van de oorspronkelijke opzet tot een 'ordinair' decentralisatie-offensief, gericht op vulling van het Fonds Sociale Vernieuwing. 
Leereffecten van het sociale vernieuwingsbeleid kwamen ten dele wel tot uiting in het grotestedenbeleid, dat hierna volgde. Binnenlandse Zaken trapte niet meer in de valkuil achterstandenbeleid te voeren met bijna alle gemeenten en het grotestedenbeleid probeerde ook het label (stigma) achterstandenbeleid te vermijden door de positieve functie van steden als motor van de economie ook in het beleid te betrekken. We vervolgen dat thema van het gebiedsgericht aanpakken van complexe vraagstukken in de komende paragrafen, die zijn verbonden met het grotestedenbeleid.

\subsection{Grotestedenbeleid}

\subsubsection{Inleiding}

Het grotestedenbeleid was méér dan een project, bijna een Deltaplan. Het kenmerkte zich ook door een zeer lange looptijd. Binnen BZK liep het van 1994 tot 2007, daarbuiten had het nog een uitloop tot 2009. De opzet was selectief: uitsluitend steden met een gecumuleerde problematiek met vereende krachten versterken op hun zwakke én sterke punten.

De ontwikkeling van bestuurskracht bij het lokaal bestuur werd niet alleen noodzakelijk geacht bij kleine gemeenten die over te weinig kwaliteit en capaciteit zouden beschikken om de problemen van deze tijd het hoofd te bieden. Zoals we al zagen bij minderhedenbeleid en bij sociale vernieuwing zijn de hardnekkigste problemen juist grootstedelijk en de indruk bestaat dat grote steden weliswaar beschikken over veel bestuurscapaciteit, maar dit waarborgt niet altijd slagkracht en samenhang. Het grotestedenbeleid was wellicht in belangrijke mate een schreeuw om meer aandacht en middelen, zoals zoveel beleid ertoe dient om prioritering te beïnvloeden.

Voor zover het een element was van bestuursbeleid, ging het erom het organiserend vermogen van de steden te vergroten, en voor zover nodig de voorwaarden hiervoor vanuit het rijksbeleid te creëren. Dat laatste impliceerde decentralisatie van bevoegdheden, het samenbundelen van regelingen in brede doeluitkeringen, wat in de volgende paragraaf aan de orde komt. Hier ligt de nadruk op de organisatorische prikkels om integrale beleidsaanpak te bevorderen. Zit daarin dan ook het governance-denken besloten?

Voor deze casus is vooral geput uit het overzicht van de geschiedenis van het grotestedenbeleid, geboekstaafd door Nico van Putten (Van Putten, 2006). Andere bronnen zijn de Memories van Toelichting van de begroting van BZK tussen 1994 en 2007, de Memorie van Toelichting op de 'Rotterdam-wet' (TK 2003-2004, 21062, nr. 117) en interviews met L. van Halder, H. Schartman, T. Leeuwestein, W. Bringmann, S. Bakker en G. Houterman, en beschouwingen van Tops (2007) en Hartman en Tops (2005), Het commentaar van Van Putten op het concept van deze paragraaf draagt op zijn beurt bij aan de betrouwbaarheid van de beschrijving. In het grotestedenbeleid zijn vele projecttrekkers aan te wijzen. Binnen Binnenlandse Zaken is vooral Bert van Vliet als eerste projectleider te vermelden.

Hieronder volgen de verhalen in de vorm van een historisch overzicht.

\subsubsection{Projectbeschrijving en verhalen}

Geboorte van een 'nieuwe' taak

Zoals we al zagen onder het project Coördinerende taak in hoofdstuk 6, bestond een aanspreekpunt voor de vier grote steden bij het Rijk al heel lang: het zogeheten Agenda-overleg, waar incidentele knelpunten van vooral financiële aard werden aangekaart en stuk voor stuk zo goed mogelijk opgelost. Naast zijn algemene coördinerende bevoegdheid richtte staatssecretaris Polak een specifiek instrument in voor de grote vier gemeenten, namelijk gestructureerd overleg met het Rijk. In dit zogeheten Agenda-overleg lag het accent op het oplossen van concrete problemen. Problemen die zich veelal in de grote steden het eerst manifesteerden, zoals de huisvesting van etnische minderheden, drugsproblematiek en tekorten van openbaar 
vervoersexploitatie, werden 'op de agenda geplaatst' en periodiek besproken met de desbetreffende bewindspersonen om aan oplossingen te werken. Polaks spreekbuis in de ambtelijke organisatie was de al veel genoemde Henk van Ruller, de secretaris van het Agendaoverleg.

Vanaf 1982 werd een begin gemaakt met een structurele aanpak. In het rapport 'Een schuyt die tegen stroom wordt opgeroeyt' van een gemengde werkgroep kregen de grote vier een programmatisch integraal beleid en zelfs een apart statuut in het vooruitzicht gesteld. De hoofdboodschap paste naadloos in het decentralisatiestreven van die tijd: geef de grote gemeenten, eerder nog dan de rest, beleidsvrijheid en de problemen kunnen worden opgelost. Dit rapport werd het begin van het grotestedenbeleid als onderdeel van bestuursbeleid.

Pas aan het begin van de jaren negentig ontstond met de commissie-Montijn aandacht voor de bestuurlijke structuuraanpassing als oplossingsrichting voor de problemen van de stad. De oplossing te zoeken in de bestuurlijke organisatie (stadsprovincie) werkte niet, zoals we zagen in dossier Bestuurlijke organisatie. In 1993 liep deze weg dood, hoewel op dat moment de hoop nog niet was opgegeven. In het kabinet-Kok I was zelfs nog een staatssecretaris, Tonny van de Vondervoort, met deze ondankbare taak belast. In een goed geregisseerd publiciteitsoffensief pleitten eerst burgemeester Peper van Rotterdam en later burgemeester Van Thijn van Amsterdam in 1994 voor een onorthodox Deltaplan, waarin overheden samen met ondernemers en sociale partners de problemen zouden aanpakken: werkloosheid, inburgering van migranten, onveiligheid op straat, leefbaarheid. Verruiming van het bestuurlijk kader door regiovorming werd nodig geacht.

Bij de aanvang van het paarse kabinet-Kok I in 1994 werd besloten een permanent partnerschap tussen Rijk en grote gemeenten te sluiten, waarbij beiden elkaar konden aanspreken op organisatorische voorwaarden voor een samenhangend beleid. Minister Dijkstal en staatssecretaris Kohnstamm kregen de opdracht als projectbewindsman, wat in naam meer inhield dan de coördinerende taak. De secretaris van de commissie-Montijn, Bert van Vliet, werd de eerste projectleider. Vanuit het Rijk werd gedacht aan decentralisatie ven regelingen; aan de kant van de steden werd de hoop gevestigd op integrale beleidsprogramma's en een versterkte regiefunctie ten aanzien van complexe problemen als ouderenzorg, volkshuisvesting, onderwijs, veiligheidsbeleid en verslaafdenzorg. Deze onderwerpen waren al goeddeels gedecentraliseerd, maar de steden konden er intern geen grip op krijgen.

In de eerste periode kostte de selectie van de deelnemende steden veel energie. De druk om het aantal te vergroten was sterker dan de behoefte om het aantal beperkt te houden. Beperken tot de grote vier werd niet haalbaar geacht. Men kon het odium niet riskeren een Randstadkabinet te zijn. Maar welke steden dan ook nog? Verschillende criteria buitelden over elkaar heen. Met enige bestuurlijke acrobatiek kwam de staatssecretaris tot 15 steden naast de grote vier. Wetenschappelijk niet te verantwoorden, maar sinds wanneer moet politiek consistent en rationeel zijn? Hij kwam ermee weg in de Tweede Kamer (Van Putten 2006: 33-34). Dit aantal is in de loop der jaren opgelopen tot 32, met inbegrip van 'grote steden' als Ede, Venlo, Sittard en Emmen.

Grotestedenbeleid in de eerste periode (GSB I): de opbouwfase (1994-1999) Hoe bevorder je een integrale aanpak van problemen binnen grote steden met complexe problemen? Door convenanten tussen het Rijk en de gemeenten (allemaal op hetzelfde feestelijke moment getekend met de minister-president). Ambitieuze streefpercentages werden daarin opgenomen met een hoog symbolisch gehalte, over onderwerpen die de gemeenten niet rechtstreeks in hun greep hebben (zoals gemiddelde leerprestaties in het onderwijs, die met 10\% zouden toenemen). In het eerste convenant met de vijftien middelgrote steden stonden ook andere, minder kwantitatieve indicatoren voor succes: "De mate van trots en zelfrespect is uiteindelijk de belangrijkste graadmeter voor het succes van het grotestedenbeleid." Je moest het resultaat kunnen zien "aan de (pret)ogen van de bewoners" (Van Putten, 2006: 38). In datzelfde convenant 
uit oktober 1995 stonden ook de volgende mooie woorden: "Het is een klus voor minstens tien jaar", waarna "de stad weer een eigen identiteit heeft, tot uiting komend in betrokkenheid van de stadsbevolking bij het stedelijk leven" (Van Putten, 2006: 41).

Gaandeweg werd de inhoud van het aanbod van rijkszijde gevuld. Bijvoorbeeld de nieuwe Melkertbanen werden exclusief aan de 19 grote steden toegekend, extra middelen kwamen uit de begroting van Binnenlandse Zaken. De overige ministeries hielden hun uitkeringen op de eigen begroting, zij het dat staatssecretaris Kohnstamm nauwlettend in de gaten hield welke bedragen uit de desbetreffende regelingen daadwerkelijk ten goede kwamen aan de grote steden.

Dit was het kader voor de eerste periode van vier jaar GSB-beleid: algemene afspraken die golden voor de hele groep gemeenten, geleidelijk wat voorwaarden van rijkszijde in de vorm van extra middelen, banen en deregulering. En veel aandacht, van een ministeriële commissie onder leiding van de minister-president, een eigen projectstaatssecretaris en een visitatiecommissie onder leiding van Elco Brinkman, die alle steden bezocht. Binnenlandse Zaken wees een vaste groep contactambtenaren (accountmanagers) aan die de entree vormden tot de rijksoverheid en zij spraken met vaste counterparts in de steden en bij de vakdepartementen.

Nauwelijks wist de rijksoverheid verder door te dringen tot de kern van de problematiek per stad, nauwelijks was er contact met de stakeholders in de stedelijke samenlevingen.

Dan mag het een wonder heten dat al in het eerste oogstjaar 1998 van staatssecretaris Kohnstamm al enige vooruitgang valt te meten op terreinen als werkloosheid en veiligheid. Zouden al die politieke aandacht en goede voornemens dit kunnen bewerkstelligen? De doelstelling dat een merkbare trendbreuk moest worden ingezet, is op deze terreinen gehaald. Bij andere terreinen (ouderenzorg, onderwijs, jeugdbeleid) vallen de resultaten tegen.

GSB II en III: pp stoom met een echte minister en meerjarenontwikkelingsplannen In de volgende kabinetsperioden werd, ongeacht de politieke kleur, het grotestedenbeleid met meer kracht voortgezet (GSB II: 1999-2004, GSB III: 2004-2007 en verder tot 2009). Deze continuïteit was dus een groot verschil met PCG-beleid en sociale vernieuwing, waarvan de spanningsboog minder dan één kabinetsperiode kon worden vastgehouden.

Hoewel beide beleidsperioden worden gepresenteerd als nieuwe impulsen, bekrachtigd met afzonderlijke convenanten tussen het Rijk en de steden, staan ze hier bij elkaar, omdat de aanpak niet wezenlijk verschilde.

De maatschappelijke problemen (werkloosheid, scheef samengestelde woningmarkt en bevolkingssamenstelling, integratie van intussen gestaag toestromende migranten) bleven groot. Daarbij hoorde een bijpassende bestuurlijke benadering. Het antwoord op de bestuurlijke opgave werd gezocht in een nog meer samenhangende, programmatische en resultaatgerichte werkwijze. De taken werden verdeeld. Het Rijk werd geacht de voorwaarden te creëren door het wegnemen van knelpunten in de regelgeving en in de verkokering van rijksbudgetten.

Van de gemeentebesturen werd verwacht dat zij de eigen regiefunctie versterkten, waarbij "de stad door een goed ingericht proces burgers, bedrijven en instellingen - met inachtneming van ieders eigen verantwoordelijkheid - weet te betrekken bij het ontwikkelen van een strategische visie op de stad en het daarvan afgeleide programma" (Van Putten, 2006: 54).

Slagkracht, integrale aanpak en krachtige coördinatie zijn de kernwoorden. Een projectminister (achtereenvolgens Van Boxtel, Remkes, De Graaf, Pechtold en Nicolaï, later nog Vogelaar en Van der Laan) werd als trekker aangesteld. De 'resultaatgerichte en programmatische aanpak' moest vorm krijgen in meerjarige ontwikkelingsplannen (MOP's). Doelstellingen zijn nog meer in streefgetallen geformuleerd dan tijdens de eerste fase al was gebeurd. Verder viel op hoe gelijkvormig de opgestelde MOP's waren die deze beoogde outcomes per stad moesten genereren. Het Centraal Planbureau (CPB), dat in 2000 een ex ante evaluatie op de binnengekomen plannen losliet, maakte melding van de gelijkvormigheid ervan. Het CPB stelde 
vast dat de opdracht om outcome-doelstellingen te realiseren veel te hoog was gegrepen als sturingsambitie voor het grotestedenbeleid.

Het SCP analyseerde vervolgens 'het raadsel van de stedelijke beleidsuniformiteit'. Hoe is die te verklaren? Bestuurskundige Denters veronderstelde de conformerende werking van de vele departementale regels. Het SCP ontkende deze factor niet, maar niet als enige verklaring. Immers, ook bij onderwerpen die traditioneel zijn vrijgelaten, schreven de gemeenten elkaars plannen over. Dit planbureau gaf de beperkte keuzemogelijkheid voor stedelijke ontwikkeling de schuld. In een onzekere markt was het geen wonder dat alle steden uiteindelijk kozen voor toerisme, ICTbedrijvigheid en historische binnensteden als pijlers voor de toekomst. De ambtenaren in de backoffice' veronderstelden dat de stedelijke plannenmakers waren gelijkgeschakeld door de instructies van de accountmanagers van Binnenlandse Zaken om de kans op rijksinstemming te maximaliseren (Van Putten, 2006: 58). Bij de instelling van een aparte afdeling grotestedenbeleid, wat ongeveer samenviel met de overgang van GSB I naar GSB II, werden vaste contactpersonen per stad aangesteld, de zogeheten accountmanagers. Zo herinnert Simon Bakker zich:

"Ik had de zorg voor de vijf Brabantse steden. Je kreeg zo meer feeling voor de bijzondere problemen in die steden, rapporteerde daarover aan Van Boxtel. Die wilde zelf ook de steden in, legde ook veel werkbezoeken af. Al die signalen pikte hij dan op en hij sprak daar dan collegaministers op aan als dingen niet goed gingen, ook buiten het eigen bestuurlijk-financiële arrangement van GSB om, want er waren nog tal van andere regelingen. Parallel aan dit proces was VROM bezig met de wijkenaanpak. Dat was het werk van Annet Bertram, wat al was begonnen onder staatssecretaris Remkes met zijn 56 wijken. De ambtenaren van VROM, de directie Stad en Regio, zaten veel dichter op de praktijk in de wijken. Wethouder Stadig had daar zijn bedenkingen over: 'Daar komen die accountmanagers van VROM weer langs. Dan moet ik er weer met de fiets achteraan, want die mensen weten meer van onze wijken dan wij zelf.' Binnenlandse Zaken bleef toch wat meer op afstand."63

De weinig creatieve reactie van de steden op de uitdagingen van het grotestedenbeleid fungeerde als demasqué en droeg ertoe bij om het probleem meer als probleem van bestuurskracht en bestuurskwaliteit te definiëren. Toch was er in het grotestedenbeleid ook ruimte voor innovatie.

\section{Stimulering van bewonersinitiatieven}

Minister van Boxtel reageerde op het kuddegedrag van de steden door prikkels in te voeren voor maatwerk in de stedelijke voorstellen. Ook voegde hij de doelstelling 'het bevorderen van burgerparticipatie' toe. In dat verband introduceerde hij ook in juli 2001 een nieuw programma onder de titel 'Onze buurt aan zet', waarin burgers werden geprikkeld om voorstellen voor leefbaarheid, veiligheid en integratie voor te stellen. Hoewel het extra geld welkom was, klonk duidelijk gemor uit de steden, omdat de minister dit geld niet gewoon in de grote pot had gestopt, maar apart had gehouden als sturingsmiddel in de richting van de wijken en buurten over de hoofden van de gemeentebesturen heen. Het instrument miste zijn uitwerking niet als stimulans voor bewonersinitiatieven. Niettemin werd het na 2005 weer afgeschaft, wellicht toch om de verhoudingen weer te herstellen: Binnenlandse Zaken voelt zich steeds ongemakkelijk met rechtstreekse sturingsrelaties in het veld, werkt van oudsher liefst getrapt via de bestuurskolom, of eventueel via een koepelorganisatie als het Landelijk Samenwerkingsverband Aandachtswijken (LSA), waarin bewoners en vrijwilligers van de 31 steden vertegenwoordigd zijn. Het LSA stimuleert het wijkopbouwwerk via de erkenning van de talenten van de bewoners. Belangrijker dan het stimuleren van burgerparticipatie was volgens directeur Herman Schartman de aanpassing van het diep geworteld beleidsdenken binnen de overheid, zowel bij de gemeenten, in de uitvoering als op het stadhuis, bij de vakdepartementen en zeker bij Binnenlandse Zaken. Dit komt later terug, maar

63 Interview met Simon Bakker op 30 augustus 2007 in Den Haag. 
eerst volgt een andere slag die Binnenlandse Zaken kon maken dankzij de aanwezigheid van het grotestedenbeleid: de wending richting Europa.

\section{Europees stedenbeleid}

De verkenningen om de verankering van sociale vernieuwing en later van het grotestedenbeleid te versterken leidden ook tot verkenningen op Europees niveau. De motieven hiervoor waren vooral plat financieel. De primaire reflex van veel ambtenaren was toch: Europa, daar zit geld. Zo was ook de gedachte bij mensen als oud-FEZ-medewerker Tom Leeuwestein, die met vasthoudendheid het idee lanceerde om het avontuur in Brussel te gaan ondernemen. Daarnaast waren deelprojectleider sociale vernieuwing Wouter Bringmann, medewerker minderhedenbeleid Budh Khargi en anderen actief voor dit lokkende perspectief. Zij gingen dus op pad om te kijken of er in Brussel wat te halen viel. Hierbij werden zij geholpen door oud-collega Huib Riethof, die na zijn afscheid goed thuis was geraakt in het Europese doolhof. Frank van Kuik, van vele markten thuis, werd door staatssecretaris Kohnstamm gevraagd als projectleider voor de voorbereiding van een Europese conferentie. ${ }^{64}$

Het is niet zo interessant dat de avontuurlijke heren een zoektocht naar bestaande subsidiemogelijkheden ondernamen, waarvan ze waarschijnlijk na enige tijd teleurgesteld en onverrichter zake zouden terugkeren. Memorabel is veeleer de vasthoudendheid waarmee zij uit zichzelf begonnen iets nieuws te creëren waar er nog niets was.

Hun redenering was hierbij even simpel als overtuigend: het kan toch niet zo zijn dat Europa een werkelijke politieke eenheid moet worden en dan zijn geld in de ogen van de Europese burgers zo onevenwichtig besteedt. Alles gaat naar de landbouw, het platteland of naar arme regio's, terwijl de meeste mensen wonen in de steden en terwijl daar ook minstens zulke schrijnende achterstanden heersen als in de ontvolkte plattelandsgebieden, zo betoogden zij.

Hier werd door de Nederlandse ambtenaren veel geïnvesteerd om een beleidswijziging te realiseren. Dat was niet eenvoudig, want zoals bekend wordt Europees beleid gedomineerd door het subsidiariteitsbeginsel. De tegenreactie van collega's in Brussel en in vele nationale hoofdsteden was dat steden meestal ook krachtige economische centra zijn en dat het de taak van nationaal beleid is om middelen zodanig te (her)verdelen dat achterstanden voorkomen of gecompenseerd kunnen worden. Alleen als gebieden ter grote van bijna een hele natie afglijden in armoede, is herverdeling en steun vanuit het Europese centrum gerechtvaardigd. Deze krachtige doctrine kon alleen worden overruled door verwijzing naar het grote aantal Europeanen (en Europese kiezers) dat in de grote steden woont en die niet erg gevoelig zullen zijn voor de subsidiariteitsdoctrine.

Het Nederlands voorzitterschap van 1997 werd benut om een interministeriële conferentie aan dit onderwerp te wijden, voorafgegaan door twee ambtelijke bijeenkomsten elders in Europa. Dit vergde veel voorbereiding, het opbouwen van contacten met bondgenoten in andere landen, met de Europese Commissie, het leggen van verbinding met Europese stedennetwerken als Eurocities en Quartiers en Crise.

Dit was een initiatief dat uiteindelijk wel de nodige vruchten afwierp. Nederlandse ambtenaren hebben hier zeker een werkzaam, zo niet baanbrekend aandeel in gehad. In 2004 is wederom het Nederlands voorzitterschap van de EU benut om dit onderwerp verder te verankeren in de structuurfondsen (URBACT). Daarnaast is een European Urban Knowledge Network opgericht, dat in Den Haag is gevestigd annex aan het Kenniscentrum grotestedenbeleid KCGS (later Nicis). Sinds 2003 is er binnen Binnenlandse Zaken een aparte afdeling Europese Aangelegenheden, geleid door Tom Leeuwestein, om de belangen van het binnenlands bestuur in de Brusselse machinerie meer proactief te behartigen dan alleen via de nationale overlegcircuits gebeuren kan.

Interbestuurlijke probleemgerichte teams

64 Interview met Tom Leeuwestein op 31 juli 2007 en met Wouter Bringmann op 6 september 2007. 
Aan de kant van de rijksoverheid waren de verschillende ministeries betrokken bij de beoordeling van de plannen en bij het verdergaande streven om regelingen te bundelen. De opgave van de afdeling Grotestedenbeleid (GSB) was om 25, later 31 steden te begeleiden en daarnaast de sturing van zes of zeven ministeries te combineren. Tot nu toe is de nadruk gelegd op de vrij traditionele benadering van het grotestedenbeleid: bundeling van geldstromen in een brede doeluitkering, het formuleren van onrealistische beleidsambities, het laten opstellen van obligate integrale plannen per stad, het gedrang om toegang te krijgen tot geldpotten (steeds meer steden mogen meedoen, lospeuteren van Europees geld). Dit was het officiële beleid gedurende de hele looptijd van het grotestedenbeleid. Wat er vervolgens gebeurde volgens Simon Bakker, was toch dat gemeenten de gebundelde middelen dankbaar in ontvangst namen en vervolgens vrolijk versnipperden over diensten en stadsdelen, zodat de burgers en organisaties weer moesten collecteren om de middelen voor een grensoverschrijdend probleem bijeen te krijgen. Er bleef dus een behoefte om binnen de steden te werken aan de interne organisatorische samenhang. Op verschillende momenten konden vreemde ogen die zich nu met de grootstedelijke problematiek gingen bezighouden, hier wel een heilzaam duwtje geven.

Geleidelijk ontwikkelde zich hiernaast een andere praktijk, waarbij de aandacht uitging naar specifieke gevallen en op uitvoeringsniveau gevoelde problemen. Herman Schartman zegt hierover:

"Het samen met de vakdepartementen optrekken om concrete en complexe problemen aan te pakken had de dragende gedachte van het Programma Andere Overheid moeten zijn. Helaas is het dat niet geworden. Wij hebben hiermee bij het grotestedenbeleid wel kunnen oefenen, al is het nog niet echt tot dominante werkwijze gemaakt. De meest kenmerkende ervaring is geweest het werken aan 'Rotterdam zet door'. Daarnaast hebben we in de laatste fase met VROM die adoptiewijken gehad, dat ook sterk die insteek gehad. Grotestedenbeleid is daarvoor een ideale proeftuin, want er zijn evidente problemen, die het doorvoeren van deze aanpak niet makkelijk maken. Je hebt er ontzettend veel mensen en veel departementen bij nodig. Daar liggen kansen om een paradigmawisseling in de overheid te introduceren en bestaande routines te doorbreken. Bijvoorbeeld de simpele routine dat je eerst beleid moet maken en pas daarna iets kunt doen. Terwijl er ook gevallen zijn waarbij het erop aankomt om de evidente dingen gewoon te doen. Ik vind zelf altijd een mooi voorbeeld een smalle straat in een oude Rotterdamse wijk, met veel allochtonen, waar de mensen elkaar ongeveer met messen te lijf gingen. In het buurthuis werd een mooie bijeenkomst georganiseerd met de wijkagent en de maatschappelijk werker, waar de problemen eindelijk grondig werden doorgepraat. De mensen communiceerden niet met elkaar. Een van de dingen was het feit dat de kinderen heel laat op straat speelden, wat veel overlast en herrie veroorzaakte. Goed gesprek, een aantal gedragsregels afgesproken. ledereen wilde zich eraan houden. Een van de dingen was dat de kinderen na negenen niet meer buiten kwamen, want dat vinden wij hier normaal. Toen zei de man van de gemeente: 'Eigenlijk moeten we deze afspraak bezegelen door aan het begin van de straat een klok te plaatsen. Wij zullen daarvoor zorgen.' Nou, dat heeft dus drie jaar geduurd voordat die klok daar kwam. Want hoe gaat dat? Zoiets komt op het gemeentehuis en daar vraagt men zich af: Een klok, hoezo? Is dat beleid? Krijgt voortaan iedere straat die erom vraagt een klok? In plaats dat iemand gewoon een klok aanschaft. Altijd wordt gevraagd naar het bestaande beleid. En niet wordt gevraagd wat dan de betekenis is van dat beleid! Dat is toch een luie manier van denken. Als je het maar hebt opgeschreven, dan handel je daar voortaan naar. Dit vraagt bij iedereen in de overheid een omwenteling in het denken, bij de uitvoerders op straat, bij het stadhuis en zeker bij het Rijk."65

\section{De Rotterdam-wet}

${ }^{65}$ Vraagggesprek met Herman Schartman op 15 augustus 2007. 
Een voorbeeld van een onorthodoxe werkwijze komt uit 'Rotterdam zet door', een deel van het collegeprogramma van het Rotterdamse gemeentebestuur 2002-2006, waarbij ernstige grootstedelijke problematiek wordt aangepakt. Inderdaad heeft het Rijk, door tussenkomst van het ministerie van BZK, hierbij een actief faciliterende rol gespeeld. Hierbij is duidelijk verder gegaan dan reageren vanuit de bestaande doctrine (zie hierover ook TK 2003-2004, 21062, nr. 117). Er moest in dit geval gewoon een onorthodoxe oplossing worden gevonden en daarbij helpt de departementale stammenstrijd niet. Zo konden opeens onbespreekbare opties als Woningtoewijzing en Kansenzones realiteit worden. Ivo Veenkamp en Tom Leeuwestein zijn diep in de materie gedoken en kwamen onder meer uit op de sleutelrol van huisjesmelkers, die vervolgens is aangepakt. Tempo houden, steun verwerven en als die er komt, blijken mensen opeens wel te kunnen meedenken in plaats van nee-zeggen. Het heeft iets weg van het andere Rotterdamse voorbeeld uit dezelfde collegeperiode, de functie van de Stadsmarinier, de informele maar doortastende troubleshooter.

\section{Interdepartementaal en interbestuurlijk teamwerk}

De verdienste van een aantal mensen in het GSB, en niet in de laatste plaats minister Van Boxtel, was uiteindelijk om de ministeries uit de loopgraven te krijgen en te laten functioneren als werkelijk probleemgerichte gesprekspartner van de steden, die over hun bureaupolitieke belangen konden heen springen. De ministeries kregen ieder ook een deel van de coördinerende taken toegewezen. Zo werden Hengelo, Leiden, Emmen en Eindhoven bijvoorbeeld aan SZW toegewezen, Heerlen, Deventer, Dordrecht en Groningen aan VROM, et cetera.

De meest sprekende toepassing van de probleemgerichte aanpak kwam niet van Binnenlandse Zaken, maar van VROM. DG Annet Bertram zette zich persoonlijk in voor het inrichten van wijkadoptieteams. Hier volgt het relaas van 'accountmanager' Simon Bakker:

"Omstreeks 2005 kwam Binnenlandse Zaken met een wijkgericht programma 'Sociale herovering' om uitdrukking te geven aan de betrokkenheid bij de stad op wijkniveau en dat is samengegaan met VROM in 'Nieuwe coalities voor de wijk'. Die combinatie ontstond vlak voor de kabinetswisseling. En nu hebben we dan die 40 wijken. Alles wijst erop dat meer een wijkenbenadering wordt gekozen voor de ergste problemen. Hele teams van ambtenaren, bestuurders, experts gaan gericht de buurten in om steeds meer feeling te krijgen voor de problemen. In het laatste jaar van Balkenende III ontstond nervositeit. De minister-president wilde zijn sociale gezicht laten zien, loskomen van de Haagse wereld en meer zichtbaar worden in het land. Daarnaast wilde hij voorkomen dat een optocht van ministers en staatssecretarissen achter elkaar dezelfde wijken zouden bezoeken en daarom vroeg hij aan Pechtold 'de wijkaanpak' van het kabinet te coördineren. $A Z$ had daarom een initierrende rol en entameerde een samenwerkingsverband tussen VROM, AZ, BZK en VWS. Dat bestuurlijke idee is door Bertram opgepikt en concreet gemaakt. Puur troubleshooting, en coachend ten opzichte van de gemeenten die het ook niet allemaal konden. Het idee bestond dat de steden, die gebukt gingen onder steeds meer gedecentraliseerde taken, behoefte hadden aan ondersteuning. Deze werkwijze gaat een beetje ten koste van de aanvankelijke BZK-lijnen, die vooral via de centrale gemeentelijke organisatie liepen, de GSB-coördinator. Het is ook maar zeer de vraag of onze ambtelijke leiding zo gecharmeerd was van een zo diepgaande bemoeienis met de gemeenten. Mevrouw Bertram was daar echt dag en nacht mee bezig. Gemengde teams van de gemeente en van verschillende hoge departementsambtenaren ontfermden zich over een wijk en beijverden zich om zoveel mogelijk concrete problemen direct op te lossen. Zo kon het gebeuren dat een DG van SZW aan de bel hing bij een collega van OC\&W, omdat hij in 'zijn' adoptiewijk een concreet probleem was tegengekomen dat vastzat op de rigide toepassing van arbeidsmarktregelingen." 66

66 Interview met Simon Bakker op 30 augustus 2007 in Den Haag. 
Uiteindelijk gaat het niet om de structuren, de regels of om competenties, maar om het presteren van de overheid als geheel, benadrukt directeur Herman Schartman. Hiermee was de minister voor grotestedenbeleid de facto wellicht een van de eerste 'programmaministers' geworden met ambtenaren die, ofschoon afkomstig van verschillende ministeries, zich medewerkers van het GSB-team voelden. Deze innovatie kostte overigens bijna tien jaar. Dat was ook de tijd die het grotestedenbeleid gegund was.

De 27 middengrote steden gingen nog verder. Bakker hierover:

"Daar wordt met 'Aanval op de Uitval' afgedaald tot op individueel caseniveau, van een jongere, een langdurig werkloze of een veelpleger. Men komt daarbij achter de voordeur. Alle instellingen die met zo'n geval te maken hebben, worden bij elkaar getrommeld, de aanwezigen moesten vaak kennismaken omdat ze elkaar zelfs in een stad als Dordrecht niet eerder hadden ontmoet. Daar is mevrouw Vogelaar een groot voorstander van. De bijdrage van BZK was al voor 2006 financieel mogelijk te maken om de methodiek te verspreiden en te verbeteren. De uitvoering organiseren, de hoe-vraag."

Een derde voorbeeld in dezelfde sfeer, het Expertteam grotestedenbeleid, is minder succesvol geweest. De opzet was gericht op de mogelijkheid om een team van ervaren en creatieve adviseurs, onder leiding van Wolter Lemstra, in te zetten voor het steunen van het gemeentebestuur bij complexe problemen. Zij konden bemiddelen, adviseren, bijsturen, met vreemde ogen een suggestie doen. Dat was wel een goede en nuttige rol, maar toch bleken de grote steden er niet toe bereid om hier op grote schaal van gebruik te maken. Was een dergelijke interventiewijze wel welkom bij de gemeenten binnen het bestaande bestuursbestel? Soms werkt het echt niet, soms een korte tijd. De 27 steden waren grotere supporters dan de vier grote steden. De grote vier hadden weinig op met de aanpak van het Expertteam. Of dat nu terecht is, kan worden betwijfeld, maar deze steden meenden dat ze zelf wel voldoende deskundigheid hadden. Gerard Houterman maakte deel uit van het Expertteam. Hij meent dat het zo zat:

"We hadden een convenant over grotestedenbeleid, maar de uitvoering daarvan verliep moeizaam. Ik denk dat het van Leon van Halder vandaan kwam, die zei: 'Kunnen we niet een clubje mensen oprichten dat die uitvoering gaat aanzwengelen'. De steden hadden meer de houding 'geef het geld maar aan ons, liefst zonder regels, dan komt het wel goed'."67

\section{Gaten dichten}

Het dieper induiken op concrete problemen en het leggen van noodverbanden, waar deze paragraaf voorbeelden van geeft, is volgens Schartman en Houterman een manier om gaten te dichten. Zij illustreren dat met een tekeningetje van blokken naast elkaar met voegen daartussen. Het structurele patroon blijft de bestuurlijke toekenning van vaste taken aan diensten; deze structuur is volgens hen doorgaans heel adequaat, maar soms vallen onderwerpen tussen wal en schip. Daar heb je dan even frontlijnsturing en uitvoeringsgerichtheid nodig om even verbindingen te leggen. Het volstrekt opengooien van de structuren ten gunste van volstrekt praktijkgestuurde incidentele probleem-oplossingscombinaties is in die visie geen systeemalternatief om complexe vraagstukken te benaderen. In de schets die de werking van het systeem moet verbeelden wordt dus ook geen metafoor gebruikt die over de blokken heen gaat en die voortdurend nieuwe actoren van buiten de overheid incorporeert.

Zonder dat het is gekomen tot een revolutionaire kanteling in het bestuursbeleid, kwam er voor Binnenlandse Zaken in 2007 een verrassend einde aan het grotestedenbeleid, omdat het kabinetBalkenende IV besloot dit beleid te incorporeren met wonen en integratie van minderheden. Misschien wel mede omdat was gebleken dat de grenzen tussen de departementen eigenlijk geen rol meer speelden voor de organisatie van grotestedenbeleid, raakte Binnenlandse Zaken het kwijt.

67 Interview met Gerard Houterman, 2 augustus 2007 te Utrecht. 
Eigenlijk wijst dit verlies dus op een succes voor zover de doelstelling gericht was op samenwerking op rijksniveau. Dit was dus gelukt, zodat Binnenlandse Zaken als 'neutraal' coördinerend ministerie kennelijk niet meer nodig was om de belangen van de vakdepartementen te overkoepelen. Het feit dat deze taak voor het grotestedenbeleid nu kon worden toebedeeld aan een van de vakdepartementen, kan worden beschouwd als teken van onderling vertrouwen binnen het Rijk. Eerder zagen we iets soortgelijks al gebeuren bij het minderheden-/integratiebeleid.

\subsubsection{Aanwijzingen voor de gehanteerde bestuurstheorie}

Interpretatie tegen de achtergrond van de begrippen government en governance Bij het typeren van het grotestedenbeleid heeft per saldo een technocratisch en bureaucentrische benadering de overhand boven de eveneens nu en dan herkenbare governance-benadering. De kwalitatieve beïnvloeding van het lokaal stedelijk bestuur verliep overwegend via integrale planvorming, deregulering en programmatische offensieven. Enerzijds zijn complexiteit en integrale aanpak de trefwoorden van het grotestedenbeleid. Anderzijds worden bijna alle kaarten gezet op de sturende prestaties van het openbaar bestuur en op de kracht van planning en beleid. Weliswaar wordt participatie vanuit de lokale samenleving als formele voorwaarde voor de stedelijke beleidsvorming gesteld, maar vanuit het bestuursbeleid zijn er nauwelijks bewegingen om juist de verbreding naar maatschappelijke partners als de verantwoordelijke actoren voor het bereiken van de gestelde doelen te adresseren.

\section{Doelstelling}

In bestuurlijk opzicht was de doelstelling van het grotestedenbeleid een combinatie van decentralisatie en deregulering om ruimte te creëren voor onorthodoxe oplossingen van moeilijke problemen, maar tegelijkertijd vooral een massieve rijksinterventie om de ontoereikende bestuurskracht van de gemeenten aan te vullen. Daarom staat grotestedenbeleid in deze paragraaf over bestuurskrachtontwikkeling van het lokaal bestuur. Over een passende manier om hier vanuit het Rijk een effectieve rol te vervullen bestond grote onzekerheid: geld, kennis, steun en advies, beleidsvrijheid en minder regels, meer sturing, alles is geprobeerd.

In de laatste periode, na 2002, zien we wat daarbij steeds meer specifieke interventies ('maatwerk') gericht op de maatschappelijke samenhang van concrete problemen, in het bijzonder in de grootste vier steden, die zich weinig ontvankelijk tonen voor aanmaningen om iets te doen aan de kwaliteit van hun bestuurlijk functioneren (Tops, 2007: 113). Of zij hiervoor door hun omvang en verkokerde bestuurscultuur resistent zijn of juist zelf al voorlopers in vernieuwing en probleemgerichtheid, blijft hier in het midden. Uit het interview met Herman Schartman blijkt dat elementen van de governance-benadering zeker niet aan het bestuursbeleid zijn voorbijgegaan, juist in de context van het GSB. Hierbij moet vooral gedacht worden aan het samenwerkingsmodel en informatievergaring in de praktijk met behulp van gemengde teams. Het is echter niet gekomen tot een blijvende omslag in het denken, die Schartman typeert als meer gevoel voor de uitvoering.

\section{Sturingsaanpak}

Wat betreft de sturingsaanpak zien we wederom een mengeling tussen verticale en horizontale instrumenten. De verhouding van Binnenlandse Zaken ten opzichte van de ministeries en die ten opzichte van de grote steden rechtvaardigt eigenlijk geen hiërarchische benadering, maar tegelijkertijd nodigen verschillende overwegingen ertoe uit hiervan veelvuldig gebruik te maken. De ernst van de problematiek en de gepercipieerde tekortkomingen in het beleid en de politieke aandacht ervoor door afzonderlijke bewindspersonen (overigens bijna allen van D66) verleidden het ministerie tot het formuleren van grote prestaties die binnen relatief korte tijd bereikt zouden moeten worden bij de steden en bij de andere ministeries. Een crisisachtige situatie nodigt doorgaans uit tot krachtige top-down maatregelen en dat was hier ook het geval. Tegelijkertijd kan worden vastgesteld dat ambtenaren en bestuurders ook werden uitgedaagd onorthodoxe wegen te 
bewandelen en daar de ruimte voor kregen. Visitaties, frontlijnsturing en teamvorming brachten het bestuur dichter bij de complexe werkelijkheid, waarbij hokjes en competenties werden overstegen.

\section{Informatieverwerving}

De informatieverwerving verliep meestal via veel schijven in de gemeentelijke organisatie. Speciaal aangewezen contactpersonen voor grotestedenbeleid gaven de instructies en de wensen in verband met de planontwikkeling door naar boven en naar beneden. De nadruk lag meer op beleids- en planvorming (programmatische integrale aanpak), dan op inzicht in processen op microniveau. Maar ook hier waren uitzonderingen, zoals Onze Buurt Aan Zet (met voorbijgaan van de bestuurlijke lijnen) en Wijkadoptieteams (zelfs zonder aanzien van de eigen functie en competentie duiken ambtenaren op gesignaleerde knelpunten). Bestuurders en ambtenaren kregen hierdoor een verfrissend inzicht in de werkelijke mechanismen achter het eigen beleid. In Rotterdam heeft Binnenlandse Zaken echt gepionierd met de 'Rotterdam-wet', troubleshooting op hoog niveau. Een doorbraak naar een geheel nieuwe, probleemgeoriënteerde werkwijze bleef echter uit. Het is volgens de betrokkenen ook te weinig gelukt de innovaties in de werkwijzen over het voetlicht te krijgen. De sfeer van chagrijn tussen steden en Rijk is zo lang op de voorgrond getreden dat het label GSB te weinig is geassocieerd met de mooie dingen die onderhands zijn opgebloeid.

\subsubsection{Typering van dit project volgens overige onderzoekscriteria}

\section{Mate van beleidsvernieuwing}

De ontwikkeling van bestuurskracht bij het lokaal bestuur werd niet alleen noodzakelijk geacht bij kleine gemeenten die over te weinig kwaliteit en capaciteit zouden beschikken om de problemen van deze tijd het hoofd te bieden. Zoals we al zagen bij minderhedenbeleid en bij sociale vernieuwing, zijn de hardnekkigste problemen juist grootstedelijk en de indruk bestaat dat grote steden weliswaar beschikken over veel bestuurscapaciteit, maar dit waarborgt niet altijd slagkracht en samenhang.

Met zijn focus op verloederde wijken was het grotestedenbeleid zonder meer beleidsaanpassing ten opzichte van de hiervoor genoemde voorgangers. De vernieuwingen zaten in de kleine onorthodoxe experimenten die werden ingezet (Europees stedenbeleid, expertteam, gemengde wijkadoptieteams, Onze Buurt Aan Zet, de Rotterdam-wet en de hierna nog te behandelen bedrijfsbetrokkenheid).

Het grotestedenbeleid had een aantal sterke punten ten opzichte van zijn voorgangers. Het strekte zich uit over meerdere kabinetsperioden en de inspanning heeft, als een waar Deltaplan, bijna vijftien jaar geduurd. Verder ging het niet alleen over het aanpakken van achterstanden en zwakheden, maar ook over het versterken van compenserende economische en culturele motorfuncties van de stad.

\section{Bijdrage aan de bestuurstheorie}

Door deze kenmerken en door geleidelijk toenemende rechtstreekse contacten van ambtenaren van Binnenlandse Zaken met de maatschappelijke problematiek in de steden, heeft grotestedenbeleid wel degelijk bijgedragen aan de concretisering van de bestuurstheorie van Binnenlandse Zaken. Anderzijds is hier ook omgekeerd framing van grotestedenbeleid onder invloed van de bestuurlijke hoofdstroom van Binnenlandse Zaken merkbaar: decentralisatie en regionale bundeling en integratie. De technocratische planbenadering versterkte het 'Haags' bureaucratische karakter van het beleid ten nadele van de ontwikkeling van een pragmatische lokale bestuursvisie.

\section{Evaluatie en leereffecten}

Het grotestedenbeleid is wel regelmatig geëvalueerd, maar het betreft vooral evaluatie ten aanzien van de beleidseffecten en nauwelijks als beleidsproces binnen Binnenlandse Zaken. Op zichzelf 
waren zelfanalyse en visitatie bij het Rijk en bij de steden verdienstelijke innovaties als het gaat om het bereikte resultaat. Het boek van Van Putten (2006) is een eerste aanzet voor organisatorische reflectie van het GSB, maar komt nog nauwelijks aan zelfbeoordeling toe. Nu het GSB bij BZK is vertrokken - en nog later geheel is opgeheven - zal het hier wel niet meer van komen.

Leereffecten van het grotestedenbeleid zijn onderweg wel opgedaan en in een volgende fase verwerkt. Zo is na GSB I geconstateerd dat er nog te veel nadruk lag op losse projecten en dat er behoefte bestond aan een programmatische, planmatige aanpak. Na de tweede periode werd vastgesteld dat de sociale pijler te ver achterbleef in ontkokering en bestuurlijke vernieuwing en dus werd hier extra energie in gestoken tijdens GSB III. De partners hebben de leerpunten van GSB II ter harte genomen. Regionale afstemming was een probleem, dat is aangepakt tijdens GSB III. Er is na de evaluatie van GSB II afgestapt van outcome als streefdoelen, de volgende periode is men naar output gegaan, met SMART-indicatoren. De langdurige bemoeienis met de concrete problematiek in de steden heeft bij Binnenlandse Zaken bijgedragen aan een meer realistische kijk op de vraag wat (grote) gemeenten vermogen.

Ook ten aanzien van uitvoeringsprocessen zijn voor sommige medewerkers van Binnenlandse Zaken incidenteel eyeopener-effecten opgetreden (Hartman \& Tops, 2005). Grote inzichten zoals de contraproductieve werking van het primaat van beleid, die konden worden vastgesteld bij het grotestedenbeleid, zijn echter nog niet merkbaar doorgebroken.

\section{Doorwerking en institutionalisering}

De doorwerking van het grotestedenbeleid is relatief groot geweest. Niet ontkend kan worden dat de politieke aandacht ongewoon lang is vastgehouden en dat met grote inspanningen een deel van de beoogde doelstellingen daadwerkelijk zijn gehaald. De neergaande spiraal van verloedering is tot staan gebracht en de steden kropen geleidelijk uit het dal. Tegelijkertijd is de weerbarstigheid van het achterstandenbeleid groot, vooral op sociaal terrein is de voortgang in bestuurlijke zin te gering geweest. Voor het bestuursbeleid van Binnenlandse Zaken werd de werking van het GSB onderbroken door de beslissing het beleid over te brengen naar VROM, maar dit kan op zichzelf als succes van de samenwerking op rijksniveau worden uitgelegd. Kennelijk werd het minder van belang geacht dat de beleidscoördinatie over verschillende sectoren in handen van een 'neutraal' generalistisch ministerie zou komen.

Het beleid van minister Vogelaar met de veertig wijken en de inzet van bewonersbudgetten valt buiten het bereik van dit boek.

\subsubsection{Conclusies}

Het grotestedenbeleid was een project van lange adem. Gedurende langere tijd waren ambtenaren van Binnenlandse Zaken (en hun collega's van andere ministeries) direct bij lokale problematiek betrokken. Het project was ook zeer ambitieus. Maakbaarheid is een van de begrippen die zich hierbij opdringen. Er zijn onderweg ook pogingen geweest om onorthodoxe werkwijzen te hanteren (gemengde adoptieteams), die geheel in het governance-stramien passen, maar de hoofdlijn was plannen maken en plannen beoordelen, veel geld uitkeren volgens landelijke criteria die de inspanningen een standaardiserend effect gaven. Een shift tekent zich in deze lange projectperiode niet af. De score komt per saldo uit op A -, slaat dus door naar de government-kant. Er is gepionierd en door de lange looptijd kon ook geleerd worden, maar tot een duurzame invloed op de bestuurstheorie van Binnenlandse Zaken is het niet gekomen. Daarvoor waren de talloze aanzetten en impulsen nog te incidenteel en te veel geïsoleerd van een samenhangend bestuursbeleid. Wel is de mentale kaart van veel ambtenaren gekleurd door waargenomen praktijkvoorbeelden uit de grote steden.

\subsection{Project bedrijfsbetrokkenheid}


Nu volgt een deelproject binnen het grotestedenbeleid, dat wel geheel aan de kenmerken van netwerkgovernance voldoet. Het is, tekenend voor de positie binnen het bestuursbeleid, geheel aan één man opgehangen: Theo Hagendoorn. Dus in de verste verte geen project in formele zin, meer een initiatief en een klus, dat echter wel door de verantwoordelijke staatssecretaris van harte werd gesteund. Bij gebrek aan documenten en Kamerstukken (evenzeer illustratief) is de beschrijving voornamelijk afkomstig uit het interview met Hagendoorn. Het was een korte vreugde tussen 1995-1997.

\section{Projectbeschrijving en verhalen}

De energie van welwillende bedrijven zou ten nutte van het grotestedenbeleid kunnen worden aangewend. Dit idee, onder de noemer Bedrijfsbetrokkenheid, past bij uitstek bij de governancebenadering. Hoewel het overigens direct aansluit bij het grotestedenbeleid, komt het hier daarom naar voren als een afzonderlijke casus naast de paragraaf grotestedenbeleid. De hoofdgedachte is dat de kring van beleidspartners naast de gemeenten en andere bestuursorganen kon worden uitgebreid tot in aanmerking komende bedrijven.

\section{Scharrelruimte voor coördinerende ambtenaren}

In het grotestedenbeleid waren vanaf 1999 aan de ambtenaren van de gelijknamige afdeling een of meer steden toegewezen waarmee zij zich specifiek gingen bezighouden. Tegelijkertijd hadden de medewerkers een vast beleidsterrein onder hun hoede. Dat laatste was al de gebruikelijke taakverdeling voor de medewerkers van de afdeling Coördinatie Bestuursbeleid, die meestal een bepaald ministerie kregen toegewezen om permanent op de bestuurlijke effecten van hun handelen te volgen. Het begrip 'accountmanager' kon dus betrekking hebben op vaste contacten met ministeries of op contacten met bepaalde grote steden. Tevens waren aan dezelfde medewerkers algemene thema's en specialismen toebedeeld. Dat gebeurde meestal vanuit persoonlijke interesse of deskundigheid of omdat zo'n thema logisch paste bij een bepaald beleidsterrein. Zo was iemand specialist op het terrein van toezicht, of de ambtenaar die zich met milieubeleid bezighield wist ook alles van convenanten. Er was als uitvloeisel van de brede missie en doelzoekende instelling van de afdeling CB ook ruimte voor eigen initiatief en beleidsontwikkeling, wat vaak nieuwe specialiteiten opleverde.

Aldus ontdekte Theo Hagendoorn omstreeks 1995 dat bedrijven in achterstandswijken als samenwerkingspartners van de overheid een constructieve bijdrage kunnen en willen leveren aan de ontwikkeling van de leefomgeving. De energie van welwillende bedrijven zou ten nutte van het grotestedenbeleid kunnen worden aangewend. Dit idee, onder de noemer Bedrijfsbetrokkenheid, past bij uitstek bij de governance-benadering. De hoofdgedachte is dat de kring van beleidspartners naast de gemeenten en andere bestuursorganen kon worden uitgebreid tot in aanmerking komende bedrijven. Omdat bedrijven belang hebben bij het welzijn van hun klanten, is hier een vanzelfsprekende win-win aanwezig, maar er leek meer aan de hand. In dezelfde tijd speelde de Brent Spar-affaire bij Shell, waar overduidelijk bleek dat bedrijven grote gevolgen ondervinden van beeldvorming, van goodwill en reputatie bij de bevolking als geheel.

\section{Onverwachte wending in loopbaan}

De ambtenaar bij Binnenlandse Zaken die zich in zijn werk op die ontwikkeling ging toeleggen, was Theo Hagendoorn. Een van de redenen dat hij extra ruimte kreeg voor verkenningen, was dat de leiding van de directie niet veel in hem zag, wat waarschijnlijk ten onrechte was, maar dat terzijde. Door hem op pad te sturen naar nieuwe, nogal aan de marge gelegen terreinen, kon hij niet veel kwaad en bovendien hoopte men stiekem dat Theo aldus zijn kansen zou vergroten door buiten het 
ministerie een andere functie te vinden. Hier volgt het verhaal aan de hand van het interview met Hagendoorn. 68

Vraag: Hoe is het idee van Bedrijfsbetrokkenheid ontstaan?

Theo: "Ik was contactpersoon bij een werkgroep van de OESO over stedelijk beleid. Vanaf het begin van de jaren tachtig was de OESO tot het besef gekomen dat men verder moest kijken dan het economisch beleid van de lidstaten, maar ook moest kijken naar de condities voor de economische prestaties, onder meer de kwaliteit van het openbaar bestuur. In bet bijzonder het bestuur van de steden had aandacht, omdat steden als de motor voor de economie werden beschouwd. In dat kader vond in 1995 in Schotland een OESO-conferentie plaats over wat wij sociale vernieuwing noemden. Lodewijk (van Vliet) en ik gingen daarheen. Daar in Schotland ontmoetten wij de Amerikaan Mike Brinda, die directeur was van een netwerkorganisatie van ondernemers in Minneapolis. Bedrijven in Minneapolis zetten zich in voor het terugdringen van langdurige werkloosheid. Via projecten voor het creëren van kansen voor moeilijke groepen vooral door het starten van nieuwe bedrijfjes. Het initiatief hiervoor lag dus helemaal bij de particuliere sector. Lodewijk en ik waren onder de indruk van het verhaal van Mike Brinda en na terugkeer ging ik shoppen bij de gemeente Rotterdam, waar een soortgelijke situatie bestond. Ook in Rotterdam bestond een groep grote ondernemingen die wel iets wilden doen voor kansarmen. Samen met Conrad Bons van de Erasmus Universiteit hebben we een startdocument opgesteld en dit besproken met wethouder Hans Simons. Simons was wel bereid wat budget hiervoor uit te trekken, mits wij een aantal partners wisten te mobiliseren, zoals het Arbeidsbureau en de Kamer van Koophandel. Samen met de gemeente hebben we een uitwisselingsprogramma opgezet tussen twaalf ondernemers uit Rotterdam en ongeveer een even groot aantal uit Minneapolis. Daarover heb ik een rapportage gemaakt, waarmee de groep in Rotterdam verder kon. Een conferentie is georganiseerd, en een eigen netwerk opgebouwd. Ze hebben presentaties gehouden voor de Kamer van Koophandel. In 1999 was het zover dat we konden zeggen: we zijn klaar. Het proces liep verder vanzelf door.

Ikzelf kreeg van Hans de Waal tijd en middelen van ongeveer 1994 tot 1997, onder meer voor een reis naar Amerika, voor de rapportage en dergelijke.

Bij VWS liep aansluitend daarop een project Samenleving \& Bedrijf om het bedrijfsleven bij het welzijnsbeleid te betrekken. De motorfunctie lag daar bij de Rabobank, die zich zo maatschappelijk wilde profileren. Toen heb ik een tweede reis naar de Verenigde Staten gemaakt, dit keer samen met een collega van VWS (Ronnie Lemmens). Bij die gelegenheid bezochten we bedrijven in Minneapolis die vestigingen in Nederland hadden. We vroegen aan hen of we deze dochterbedrijven konden aanspreken op hetzelfde gedrag. In principe wel, hoewel het zelfstandige resultaatverantwoordelijke vestigingen betrof. We hebben Mike Brinda naar Nederland gehaald en zijn met hem de ondernemers langsgegaan. Dit heeft weer tot nieuwe initiatieven geleid en tot een publicatie van Mike Brinda, Ronnie Lemmens en mijzelf."

Ontvangst bij Binnenlandse Zaken

Vraag: Was dit alles, uitkomst van de inspanningen van één medewerker, nu ook van harte beleid van Binnenlandse Zaken?

Theo: "Natuurlijk moesten ze eerst ervaring opdoen, de kat uit de boom kijken. Maar opvallend is wel dat de bewindslieden en de werkvloer er meer in zagen dan de ambtelijke top. Staatssecretaris Kohnstamm wilde graag. Hij nam contact op met bedrijven als Blokker en Veenman. Toen werd het Ondernemings Platform Stedelijke vernieuwing (OPS) opgericht. Later heeft Van Boxtel banken en verzekeringsmaatschappijen, zoals Rabo, ING en ABN-AMRO, hiervoor weten te interesseren. Dit was dus een product van de inspanningen van Binnenlandse Zaken, eerder dan EZ of VWS. Later werd dat anders. Omstreeks 1999 gingen VNO-NCW en MKB-Nederland en ook VWS en EZ zich ermee bemoeien. Zo werden negen regionale bijeenkomsten onder de naam 'De Ondernemende

68 Interview met Theo Hagendoorn op 11 september 2007. 
Stad'georganiseerd met lokale bestuurders en bedrijven over de vraag wat zij aan elkaar konden hebben.

Het thema is nu nog steeds in zwang, maar Binnenlandse Zaken is al lang gestopt. Leon van Halder was van mening dat de verantwoordelijkheden zo veel mogelijk bovenover moesten lopen. Via afspraken met de gemeentebesturen en zo. Bij VROM (directie Stad en Regio) zeiden ze: 'Afspraken bovenover zijn geen garantie voor resultaat. Wij lopen zelf in de stad en nemen waar wat er gebeurt.' Accountmanagers die probleemgericht werken, geven zo nu en dan een duwtje om processen van verbetering op gang te brengen. Zo'n impuls kan ook gericht zijn op bedrijven. Daar is niks geformaliseerd. Beleid? Het gebeurt incidenteel. 'De Ondernemende Stad' was gericht op bewustwording. In die periode kwamen er twee adviezen van de SER, met als strekking: ga dit nu niet regelen of in beleid omzetten, maar maak gebruik van het particulier initiatief. Aanvankelijk lag er veel nadruk op milieu, maar GSB zorgde ervoor dat maatschappelijk verantwoord ondernemen ook doorwerkte in de sociale sfeer. Investeren in de opleiding van vaklieden en zo. Het stokje werd met de opening van het kenniscentrum MVO in 2002 overgenomen door EZ. Wij hadden de handen vol aan GSB II en wij hadden ons eigen Kenniscentrum Grotestedenbeleid.

Bovendien gold bij Binnenlandse Zaken in die periode de taakopvatting dat het niet goed was lang aan een onderwerp te blijven plakken. ABP: Aanjagen, laten Beklijven en Pleite was het adagium: hit and run. We moesten zoveel mogelijk van ons af organiseren."

Vraag: Ja, maar die filosofie heerst toch ook bij EZ? Werd het bedrijfsleven als deel van de bestuurlijke infrastructuur gezien?

Theo: "Inderdaad is er een onderstroom gegroeid waarin bedrijven zich meer van hun sociale kant willen laten zien. Aan de kant van het bestuur is nog minder geagendeerd dat je daarop kunt bouwen. Zelfs bij EZ is dat nog nauwelijks het geval. Daarbij komt dat Binnenlandse Zaken huiverig is voor de associatie met corporatisme. Ten slotte is het een kwestie van lef. Mijn relatie met Binnenlandse Zaken was heel los. Ik vind wel jammer dat men kansen heeft laten lopen. Zelf is me als goede herinnering bijgebleven dat ik als een soort opbouwwerker met de Stichting

Maatschappelijk Ondernemerschap aan de gang ging in wijken als De Hatert in Nijmegen, met het schoolhoofd en de wijkagent. Later is dat ook in Enschede gedaan, waar de vuurwerkramp als katalysator fungeerde. OPS was daar heel actief en Enschede was toen mijn account. Een veel geziene partij in deze kringen was ook een bedrijf als Albert Heijn. Binnen Binnenlandse Zaken heb $i k$ verschillende momenten de kans gezocht om de dienstleiding te wijzen op de energie bij het bedriffsleven die benut zou kunnen worden voor maatschappelijke vraagstukken, ook in mijn hoedanigheid als lid van de Ondernemingsraad. Uiteindelijk bleef men vasthouden aan de vaste relatie met het gemeentebestuur als enige verbinding met het veld. Thom de Graaf had als persoon een vrij eenzijdige gerichtheid op de bestuurlijke wereld. Onder Pechtold kreeg ik signalen dat VNO wel weer eens wilde praten over betrokkenheid bij het grotestedenbeleid. Ik heb toen een gesprek gearrangeerd met Bernard Wientjes. Alleen dat bleek drie dagen voor het aftreden van minister Pechtold plaats te vinden. Daarna heb ik informeel nog geprobeerd bij VNO duidelijk te maken dat de aandacht voor het bedrijfsleven bij Binnenlandse Zaken niet van binnenuit kwam. Daarvoor moest druk van buitenaf georganiseerd worden. Maar dat heeft men uiteindelijk toch niet opgepikt."

Tien jaar later blijkt de belangstelling bij Binnenlandse Zaken voor dit thema bedrijfsbetrokkenheid geheel te zijn verdampt. Ten dele is dit te verklaren door de natuurlijke geneigdheid van Binnenlandse Zaken om afstand te houden tot het werkveld van de steden; principieel liet men contacten met de lokale samenleving liever aan de gemeenten over, hiermee ook tegemoetkomend aan gemeentelijke kritiek van te gedetailleerde bemoeienis. Maar dat verklaart nog niet dat men de maatschappelijke actoren ook op landelijk niveau de rug toekeert. Dat is een kwestie van oriëntatie.

\subsubsection{Aanwijzing voor de gehanteerde bestuurstheorie}

Interpretatie tegen de achtergrond van de begrippen government en governance 
De relatie met de governance-benadering spreekt voor zichzelf uit de opgetekende ervaringen van Theo Hagendoorn. Weer is duidelijk dat binnen het bestuursbeleid ruimte werd gecreëerd om deze benadering te verkennen, maar het blijft in de marge en verdampt na verloop van tijd helemaal. Ook dit is een voorbeeld waarbij Binnenlandse Zaken penetreert in de lokale bestuurspraktijk om de (stedelijke) gemeenten beter toe te rusten voor probleemoplossend vermogen. Overduidelijk is dat het ministerie zich hier om begrijpelijke redenen ongemakkelijk bij voelt. Politieke bestuurders en accountmanagers in het veld hebben er nog de minste moeite mee. Theo was vrijwel als eenling op dit terrein bezig. Het geheel maakt de indruk van getolereerd hobbyisme, waarbij de bewonderenswaardige invloed die deze eenling kon hebben, binnen het ministerie nauwelijks op waarde werd geschat.

\section{Sturingsaanpak}

Wat betreft de sturingsaanpak is louter gewerkt met horizontale instrumenten, samenwerken en communiceren. De interventies bleven voor de buitenwereld vrij onzichtbaar. Ook de bewindslieden Kohnstamm en Van Boxtel volstonden met netwerksturing.

\section{Informatievergaring}

De informatieverwerving verliep op een bijzondere manier. Merk op dat de aanleiding voor de bemoeienis van Theo met bedrijfsbetrokkenheid op een grillige manier tot stand kwam: via een toevallige ontmoeting met een Amerikaan in Schotland. Zo gaat het met complexe onderwerpen vaker (vergelijk het ontstaan van het project D'gemeenten). De verdere ontwikkeling van het thema verliep ook via trial and error. Toevallige combinaties van personen uit kringen van universiteit, ondernemers, andere ministeries en gemeenten wisten elkaar te vinden en ontdekten door voorbeelden uit verre landen of door een entree via het moederbedrijf de mogelijkheden van de toepassing van nieuwe praktijken in de eigen omgeving. Nergens wordt gerept over een planmatige aanpak of over diepgaande analyse voorafgaand aan formele besluiten. Weer begint in Rotterdam de victorie, zoals bij de Stadsprovincie en de sociale vernieuwing.

\subsubsection{Typering van dit project volgens overige onderzoekscriteria}

\section{Mate van beleidsvernieuwing}

De gedachte om vanuit Binnenlandse Zaken private ondernemingen te betrekken bij het versterken van de bestuurskracht van de grote steden was totaal nieuw. Evenals bij het eerdere voorbeeld Differentiatie tussen gemeenten (paragraaf 6.10) is echter te weinig van dit beleid beklijfd om van beleidsinnovatie volgens Hogwood en Peters te kunnen spreken.

\section{Bijdrage aan de bestuurstheorie}

De kans om bedrijven als maatschappelijk relevante partners en stakeholders in de bestuurstheorie te incorporeren, is niet duurzaam opgepakt. Dit project toont aan dat een andere kijk op de actoren in de bestuurlijke werkelijkheid wel mogelijk is, maar dat er meer nodig is om deze ook op te nemen in duurzaam doorwerkend discours binnen het subsysteem van Binnenlandse Zaken.

\section{Doorwerking, institutionalisering}

De doorwerking van het onderwerp bedrijfsbetrokkenheid in de samenleving en binnen het lokaal bestuur is relatief groot geweest. Alleen heeft Binnenlandse Zaken hier zelf geen betrokkenheid meer mee gehad. Het onderwerp is geleidelijk als wezensvreemd voor de klassieke rol en doelgroep van het ministerie van de agenda verdwenen. Om dezelfde reden heeft geen evaluatie plaatsgevonden van de geïsoleerde inspanningen van de enkele geïnteresseerde medewerkers op dit terrein. Zij zijn er niet in geslaagd de beleidsagenda van het ministerie te bereiken. Opvallend is bijvoorbeeld dat in het boek van Van Putten (2006) over het GSB elke verwijzing naar het onderwerp beleidsbetrokkenheid ontbreekt. 
We kunnen ook veilig stellen dat leereffecten ten aanzien van de ervaringen met het ontginnen een geheel nieuwe netwerk voor het versterken van het organiserend vermogen van het stedelijk lokaal bestuur, het plaatselijke bedrijfsleven, bij Binnenlandse Zaken niet te traceren zijn.

Sociale Zaken en EZ zijn in 2008 nog wel actief op het domein van maatschappelijk verantwoord ondernemen, maar Binnenlandse Zaken doet er helemaal niets meer aan. Dat is ook een kwestie van capaciteit. De terugtrekkende beweging van het ministerie tot op het kerndomein, de verhouding met de decentrale overheden, liet dergelijke escapades als met bedrijfsbetrokkenheid niet meer toe. $\mathrm{Na}$ het vertrek van het grotestedenbeleid naar VROM is ook de inhoudelijke drijfveer om medestanders te zoeken voor het lenigen van maatschappelijke nood verdwenen. Wellicht is de herontdekking van het onderwerp Lokale bestuurskwaliteit binnen Binnenlandse Zaken met het oprichten van de Projectdirectie Krachtig Bestuur (2008) aanleiding om ook het onderwerp bedrijfsbetrokkenheid en coproductie opnieuw uit te vinden. Hagendoorn en anderen zijn dan echter niet meer aanwezig om ervaringen over te dragen.

\subsubsection{Conclusies}

Het is bij het initiatief Bedrijfsbetrokkenheid net als met sociale vernieuwing, decentraliseren met beleid en met differentiatie. Daar waar netwerkgovernance onmiskenbaar aanwezig is, lijkt het geen lang leven beschoren in het bestuursbeleid van Binnenlandse Zaken en zijn onderzaten. Bij dit 100\% governance-initiatief (score B) is voor Binnenlandse Zaken uitzonderlijk dat de verbinding met het bedrijfsleven is aangegaan, maar blijkens het voortijdig einde ervan en de afhankelijkheid van één enthousiaste ambtenaar was dit klaarblijkelijk ook een brug te ver.

De conclusies over de volle breedte van het dossier Achterstandenbeleid volgen aan het eind van hoofdstuk 8 , zoals in de inleiding van dit hoofdstuk al is aangekondigd. 


\section{Dossier Interbestuurlijke informatievoorziening}

\subsection{Inleiding}

Als het gaat om de versterking van de gemeentelijke organisatie als basis voor integrale beleidsvorming en organiserend vermogen, kunnen we behalve naar de aanpak van nieuwe complexe vraagstukken ook kijken naar de administratieve organisatie en de interne processen binnen het decentrale bestuur ('onder de motorkap'). Vooral tijdens de periode van directeurgeneraal Staatsen (1984-1987) is relatief veel aandacht besteed aan het verbeteren van tekortschietende beheerskwaliteit bij gemeenten. In hoofdstuk 1 is al gememoreerd dat in deze periode een aparte directie Bestuurszaken werd opgericht om zich bezig te houden met uitvoeringsaspecten in het binnenlands bestuur. Deze directie heeft impulsen gegeven voor de verbetering van de uitvoeringskwaliteit bij gemeenten. In dit hoofdstuk worden hiervan twee innovatieve voorbeelden belicht: BBI en GBA. Deze afkortingen worden aanstonds verduidelijkt. De (eerste) modernisering van de GBA is een goed voorbeeld van de mogelijkheden die worden geboden door de ontwikkeling van de informatie- en communicatietechnologie. Dit is een belangrijke drijfveer voor het wegvallen van hiërarchie en voor de versterking van netwerkbenaderingen. Vandaar dat ICT in deze zoektocht naar nieuwe verhoudingen tussen overheid en samenleving zeker op zijn plaats is. Dat geldt ook voor ontwikkelingen in de dienstverlening die 'de klant' centraal stellen met behulp van kwaliteitsinstrumenten en via de ketenbenadering. Beide innovaties uit het eind van de twintigste eeuw zijn in staat de klassieke hiërarchische relaties te ondermijnen en probleemoplossing op maat daarvoor in de plaats te stellen. We zullen zien of daarmee de bestuurstheorie van Binnenlandse Zaken omver is gekegeld. Hieronder volgt de beschrijving van vier casussen:

- $\quad$ Beleids- en beheersinstrumentarium (BBI) annex single audit, single information, een interventie bij de inrichting van de gemeentelijke jaarstukken (paragraaf 8.2);

- $\quad$ ICT-beleid en GBA: de opzet van een gemoderniseerde en geautomatiseerde gemeentelijke basisadministratie, voorheen Bevolkingsregister (paragraaf 8.3);

- Kwaliteitsinstrumenten, stimulerende activiteiten in de geest van New Public Management om klantgericht werken binnen gemeenten te introduceren (paragraaf 8.4);

- Ketenregie, initiatief om Binnenlandse Zaken als nationaal kenniscentrum te laten fungeren voor de ontwikkeling van een radicaal case-gerichte aanpak van sociale problematiek (paragraaf 8.5).

\section{2. $\mathrm{BBI}$, single information, single audit}

\subsubsection{Inleiding}

Een project dat in gemeenteland in de jaren tussen 1987 en 1989 veel aandacht heeft getrokken, heette Beleids- en Beheersinstrumentarium, kortweg BBI, met verve geleid door Johan Hoff. Het werd als een afgebakend project opgezet, met vanuit Binnenlandse Zaken medewerkers van verschillende directies. Er werd samenwerking gezocht met VNG en IPO en met de verenigingen van gemeentelijke directeuren Financiën en met de accountantswereld. Het beoogde de gemeenteraad weer grip te geven op de beleidskeuzen achter de voor velen tot dan toe onbegrijpelijke gemeentebegroting. Een uitvloeisel van het BBI-project, dat in de jaren 2005-2007 hierop voortborduurde, betrof de informatieverplichtingen bij de verantwoording van specifieke uitkeringen. Trekker en initiator van dit Single Audit-project was Jiska Nijenhuis. Het verhaal volgt hieronder weer op analoge wijze als bij de andere voorbeelden. 
Bronnen voor de beschrijving van deze casus zijn onder meer de dissertatie van Aardema over dit project en zijn doorwerking (2002a), een brochure over single information en single audit uit 2005, eigen waarnemingen van de schrijver en interviews met J. Hoff, A.J. Vos en J. Nijenhuis.

\subsubsection{Projectbeschrijving en verhalen}

\section{Geboorte van een nieuw project}

In 1985 was bij de op uitvoeringsaangelegenheden gerichte Directie Bestuurszaken het idee voor een programma geboren vanuit een specifiek punt van zorg. Aanleiding was bezorgdheid over het functioneren van de gemeentelijke administratie en van de gemeentelijke democratie. Aan de Universiteit van Twente (Bestuurskunde) werd opdracht gegeven onderzoek te doen naar de omgang van raadsleden met de gemeentelijke begrotingsstukken. Dit onderzoek wees uit dat de meeste raadsleden niet in staat waren de gemeentelijke begroting te doorgronden. Dat was nogal een schokkende uitkomst voor een ministerie dat het functioneren van de gemeentelijke democratie tot hoeksteen van zijn beleid heeft gemaakt. Maar evenzo werd hier de stelling bevestigd dat gemeenten organisatorisch eigenlijk te zwak zijn om zware verantwoordelijkheden te dragen, zoals de tegenstanders van decentralisatie veronderstelden. Ook hiermee werd het hart van het bestuursbeleid geraakt.

De schuld werd gegeven aan de onbegrijpelijke telefoonboeken die door jarenlange bureaucratische ontwikkelingen een eigen leven waren gaan leiden. De makers van de Comptabiliteitsvoorschriften die de uniforme inrichting van de gemeentebegrotingen mede bepaalden, realiseerden zich dat de stukken waren losgezongen van hun primaire functie. De informatie zou namelijk primair transparante informatie voor raadsleden moeten bieden ten behoeve van het afwegen van prioriteiten om nog maar te zwijgen van burgers die zouden willen weten wat er met hun goede geld gebeurt. Een ander motief was dus de geloofwaardigheid van de stelling die naar de andere ministeries werd hooggehouden, namelijk de wenselijkheid van decentralisatie. De plaatsvervangend directeur van de Directie Bestuurszaken en voorzitter van de Commissie voor de Gemeentelijke Comptabiliteitsvoorschriften Johan Hoff was ervan overtuigd dat Binnenlandse Zaken dan ook de verplichting had ervoor te zorgen dat de gemeenten hun zaken op orde hadden.

Een ochtendje brainstormen tussen Hoff en zijn toenmalige directiesecretaris Arie Jan Vos leverde de hoofdlijnen op van een nieuw project onder de titel Beleids- en beheersinformatie (BBI). De gemeentelijke beleidsinformatie moest op orde worden gebracht als basis voor alle vitale processen die op dat fundament rusten. Gemeenten moesten worden verleid om best practices te ontwikkelen op het terrein van begrotings- en beleidspresentatie: wat willen we bereiken, wat moet daarvoor gedaan worden en wat mag dat kosten? Dat was een ware revolutie ten opzichte van de geheel vanuit de organisatie opgebouwde systematiek van begrotingsposten voor activiteiten van afzonderlijke afdelingen. In 1987 is het project officieel van start gegaan met massale bijeenkomsten. In 1989 werd de evangelisatie bij afzonderlijke gemeenten door Binnenlandse Zaken stopgezet. Een groep gemeenten en de VNG zetten het werk voort in de Stichting BBI.

De opzet van het BBI-project was drieledig:

- Door transparante presentatie van de plannen en realisatiegegevens zou de positie van de gemeenteraad worden versterkt.

- De interne beheersing van de organisatie zou worden verbeterd.

- De klantgerichtheid zou toenemen.

Uiteindelijk is het perspectief van de samenleving, 'welk probleem willen we oplossen en met welke middelen', leidend bij de beantwoording van beleids- en beheersvragen. Dit waren simpele gedachten die theoretisch goed werden doordacht, maar praktisch niet altijd bleken te werken. 


\section{De BBI-beweging}

Het BBI-project van Johan Hoff was dus primair opgezet om de bestuurskwaliteit binnen gemeenten te verhogen. Johan Hoff was begiftigd met bijzondere communicatieve gaven. Hij wist mensen voor zich te winnen door een open, ontwapenende houding, wat nog werd versterkt door zijn Haags accent en apart stemgeluid, waarmee hij niettemin knap lastige ambtelijke taal produceerde. De manier waarop hij de inzichten en ideeën die hij samen met Cees Schouten en Arie Jan Vos binnen de directie Bestuurszaken had ontwikkeld, uitdroeg bij de doelgroep van chefs Financiën binnen de gemeenten, bracht daar groot enthousiasme teweeg. Eindelijk werd hun metier in Den Haag serieus genomen en werd hun werk in de gemeentelijke organisatie ook naar behoren gewaardeerd, namelijk als het hart van de voorwaarden voor het functioneren van de lokale democratie en voor de afweging van publieke belangen.

Ongeveer vijftig proefgemeenten sloten zich aan bij een voorhoede die wilde experimenteren met nieuwe presentatievormen van de jaarstukken. Veel andere gemeenten volgden de ontwikkeling met belangstelling. Talrijke bijeenkomsten werden georganiseerd om van elkaars vorderingen te leren. Het is niet overdreven om in het land van gemeentefinanciën te spreken van een ware BBIbeweging. In dat opzicht had Johan Hoff buitengewoon veel succes met zijn project. Op het hoogtepunt in 1989 was er een feestelijke bijeenkomst met circa 2000 deelnemers in het grote congrescentrum Orpheus in Apeldoorn. Het swingde.

Johan Hoff vertelt hierover:

"We hadden een heleboel partijen bij elkaar. Ik had vijftig proefgemeenten, een project in NoordBrabant met een hele groep over de 'Begroting In Een Oogopslag', contact met de Vereniging van gemeentesecretarissen, de chefs Gemeentefinanciën, en andere. Het verificatiebureau van de VNG deed mee. Het is erg aangeslagen, het leeft nog. Ook in de wetenschap. Prof. Van Helden uit Groningen heeft er veel publicaties aan gewijd, ook internationaal. Ik ontdekte, ook bij de gemeenten, dat er iets mis was. Dan kwam ik voorlichting geven. Ik pakte de begroting en vroeg hen wat vinden jullie van die begroting? Ja, we hebben geld beschikbaar gesteld, voor dit en voor dat. Maar dan vroeg ik: weten jullie ook wat ermee gebeurd is? Hoe meet je die dingen? $\mathrm{lk}$ vond het schitterend. Je zag iets gebeuren. Je zag resultaten. Niet dat vage gedoe zoals met die coördinatie. Het heeft toch een impuls gegeven, lk wist wel dat het een langdurig proces was. Het meest is me bijgebleven dat het een beweging was. Ik deed dat met allerlei onconventionele middelen. Ik had de steun van de DG, vooral Jan Hendrikx en later Jansen. Hendrikx wilde eigenlijk nog veel verder gaan. Die geloofde helemaal in kengetallen. Mij is altijd de vraag bijgebleven: hoe is het mogelijk dat het gelukt is er een beweging van te maken? We zijn een dag wezen fietsen in de Achterhoek met burgemeesters, gedeputeerden, et cetera. Ik wist van tevoren dat Binnenlandse Zaken het nooit alleen kon doen. Maar er is wel wat gebeurd, want vroeger was Binnenlandse Zaken toch wel een stofnest geweest. Die aanpak met al die actoren was nieuw. Mensen laten samenwerken. Als je het niet kan verkopen dat het belangrijk is, red je het niet. De adviezen van de Commissie voor de Comptabiliteitsvoorschriften werkten niet. Dus ik zei: we moeten de boer op!"

Resultaten in de praktijk

Voor de verdere typering van dit project laten we Harry Aardema aan het woord, die in 2002 op het onderwerp promoveerde, overigens vooral op basis van waarnemingen uit de periode 1996-2000, toen Binnenlandse Zaken zich allang uit het project had teruggetrokken. Zoals we vaker zullen zien, is het vrij kenmerkend voor de impulsen van een beleidsministerie als Binnenlandse Zaken om zich niet langer dan strikt nodig zelf op te houden met de realisatie en implementatie van een project, zeker als dit de medewerkers voert tot binnen de grenzen van het gemeentelijk domein. Te constateren is echter dat de essentie van de BBI-gedachte ook in de implementatiefase nadat Binnenlandse Zaken zijn handen ervan aftrok, niet wezenlijk is veranderd. 
De conclusie uit het onderzoek van Aardema is dat BBI weliswaar veel bekendheid, overweging en instemming heeft geoogst in gemeenteland (hij schat circa 90\%), maar dat de doorwerking daarmee ongeveer ophoudt. Aardema stelt dat de theorie sterk afwijkt van het feitelijk gedrag van de mensen die ermee werkten. In de eerste plaats zijn lang niet alle instrumenten die horen bij een consequente toepassing van het BBI-gedachtegoed overal daadwerkelijk ingevoerd (bijvoorbeeld jaarverslagen en effectmetingen op een manier dat het beleid er echt feedbackinput aan kan ontlenen), maar die formele conformiteit (die Aardema schat op circa 50\%) blijft hier verder rusten.

Belangrijker zijn in de tweede plaats de tekortkomingen ten opzichte van de bestuurlijke essenties van de ideeën voor een betere gemeentelijke organisatie. De gemeenteraad zou voortaan sturen op hoofdlijnen en niet op details, de leidinggevenden zouden sturen op basis van integraal management, zij zouden verantwoordelijkheden verder doordelegeren op basis van resultaatafspraken (contractmanagement) met een heldere afbakening van bevoegdheden, en resultaten zouden periodiek worden getoetst en verantwoord. Hier ging het al mis volgens Aardema, omdat de theorie van BBI te weinig rekening hield met het menselijk tekort dat het gedrag van ambtenaren en politiek bleef bepalen. Hierdoor zijn uiteindelijk de beoogde heilzame effecten voor de kwaliteit van het gemeentebestuur nagenoeg geheel achterwege gebleven: betere afwegingen in de gemeenteraad, betere beheersing van de organisatie en betere klantgerichtheid. Aardema schrijft dit toe aan de onverminderde kracht van individueel gerichte belangenoriëntatie van alle betrokkenen. Als die individuele rationaliteit niet wordt vervangen door een collectieve, eindigt het model in een leugenachtige schijnvertoning. BBI ging eigenlijk uit van een veronderstelde oriëntatie op het algemeen belang (probleemgericht resultaten bereiken en onderweg leren om volgend jaar nog beter te presteren voor de burgers).

Wat Aardema in de praktijk zag gebeuren met stukken en plannen volgens een mooi schema, was een papieren exercitie die echter ver verwijderd bleef van de werkelijkheid. In de administratie en binnen de organisatie klopten de cijfers allemaal, maar de medewerkers, de managers en de bestuurders bleven elkaar voor de gek houden en vroegen niet door om elkaars belangen niet te veel te bedreigen.

Het wordt nog erger als ook de neveneffecten van BBI in de beschouwing worden betrokken. Volgens Aardema zijn er namelijk naast enkele positieve neveneffecten (commercieel succes voor het bedrijf BMC, dat uit het project voortkwam) niet onaanzienlijke negatieve neveneffecten (Aardema, 2002b) te verbinden aan BBI en zijn opvolgers zoals VBTB in de rijksdienst.

De verticale werking van $B B I$, single information, single audit Een verwant project, dat een uitvloeisel was van $\mathrm{BBI}$, leeft in tegenstelling tot $\mathrm{BBI}$, tot de dag van vandaag binnen Binnenlandse Zaken voort als een van de prioritaire activiteiten van het DG Bestuur voor het stroomlijnen van de interbestuurlijke betrekkingen. Interbestuurlijke betrekkingen zijn al besproken onder het dossier Decentralisatie, maar de analyse van single information, single audit kan beter aansluiten bij BBI.

Een van de nevenproducten van het BBI-project betrof de afstemming van informatie tussen Rijk en gemeenten. Het ging in het bijzonder om verantwoordingsinformatie. De redenering was ongeveer als volgt: gemeenten beschikken over een eigen democratisch gelegitimeerd systeem van verantwoording. Daarbij wordt als het goed is door de gemeentelijke accountant een (steekproefsgewijze) controle toegepast op alle uitgaven, dus ook op de ontvangen specifieke uitkeringen van het Rijk. Hierbij worden in het vak van publieke accountant algemeen gangbare toetsingscriteria en beoordelingsmethoden toegepast betreffende rechtmatigheid (en doelmatigheid) van de besteding. Althans zo zou het moeten zijn. Daarnaast wordt op rijksniveau eveneens verantwoording afgelegd in de rijksrekening, waarbij per ministerie een uitspraak wordt gedaan over de besteding van onder meer de specifieke uitkeringen die op de begroting voorkomen. ledereen is het erover eens, dat het ongewenst en overdreven zou zijn om de gemeentelijke accountant en de rijksaccountant allebei onafhankelijk van elkaar de dossiers ten stadhuize te laten napluizen. 
Het was de vinding van Johan Hoff om een informatiepiramide te tekenen, met het Rijk aan de top. Zijn retorische vraag was steeds: hoe is het te verdedigen dat de rijksoverheid over (de rechtmatigheid en doelmatigheid van) gemeentelijke uitgaven meer zou willen weten dan de gemeenteraden? En overigens: als dat het geval is, moet die informatie wel aan de maat zijn. Johan Hoff stelt:

"Als de gemeente hun plannen op orde hadden, zou niet alleen het democratisch functioneren van de gemeente zelf hiervan profiteren, maar alleen dan zal ook de gemeente een betrouwbare informatiebasis voor het Rijk kunnen leveren. Het was dus ook een voorwaarde voor decentralisatie dat het binnen de gemeente geen rotzooitje was."

\section{Weerstand vanuit de accountantswereld}

De stelling uit het BBI-project was dus dat de gemeenteraad het laagste, meest gedetailleerde niveau van informatie is en dat het dus niet aangaat om daarbinnen nog weer nadere eisen te stellen ten behoeve van de verantwoording op het hoogste, rijksniveau. Voor gemeenteraden is het doorgaans niet interessant (beleid op hoofdlijnen) om te specificeren wat de herkomst van de begrotingsmiddelen is geweest: eigen inkomsten, algemene uitkering of specifieke uitkering van een vakdepartement. De vakministeries en een groot deel van de accountantswereld stellen daartegenover dat een algemene verantwoording op gemeentelijk niveau nog geen garantie biedt dat die ene specifieke uitkering van een bepaald ministerie in alle gemeenten daadwerkelijk is bekeken, dus deel heeft uitgemaakt van de steekproef van de accountant. De toedeling van de middelen en de bijbehorende verantwoording gebeurt nu eenmaal, ingevolge het budgetrecht van het parlement, ten dele via specifieke uitkeringen met de bijbehorende voorwaarden en dat rechtvaardigt een aparte verantwoording, anders dan bij de algemene uitkering.

Een redeneerlijn die herkenbaar terugkeert uit een eerder project van de begintijd over middellange termijnplanning (1978), is dat de gemeentelijke administratie per definitie de basis vormt van de informatiepiramide, dus via aggregatie ook bruikbaar is voor alle mogelijke informatiebehoeften op rijksniveau.

Een andere redeneerlijn is die van de Financiële Verhouding: wie A (specifieke uitkering) zegt, moet op de blaren zitten en ook B zeggen (specifieke controle).

Beide redeneringen zijn in hun ongenuanceerdheid onbruikbaar, maar zijn binnen Binnenlandse Zaken hardnekkig. Verschillend wordt gedacht over de mate waarin gemeenten geacht mogen worden adequaat te besturen en een betrouwbaar fundament te vormen voor de piramide. Of moet Binnenlandse Zaken de gemeenten eerst toerusten (opvoeden) voordat het zover is (en zolang is controle onvermijdelijk)? Voor velen binnen Binnenlandse Zaken is de autonomie heilig of althans staat of valt het systeem met lokale democratische zelforganisatie.

De discussie is een tijdje blijven steken. De bovengenoemde heroverweging uit 2000 leverde als resultaat op een uitgebreide doorlichting van alle specifieke uitkeringen, maar die leidde niet tot enige aanpassing van de bestaande toezichtsverhoudingen.

Nieuwe impuls door Jiska Nijenhuis na 2005

De situatie was na veel onderhandelen weinig opgeschoten. Aan de gemeenten werd namelijk toegestaan de verantwoording van specifieke uitkeringen te verwerken in een bijlage van hun algemene jaarstukken. Voordeel was dat ze de accountant niet apart hoefden te laten komen voor de verificatie van afzonderlijke verantwoordingsstukken per uitkering, of later per departement. Nadeel bleef dat de gemeentelijke jaarrekeningen het formaat houden van telefoonboeken met informatie die de gemeenteraad niet interesseert. Uiteindelijk is het streven naar single audit en single information op een andere manier voortgezet.

In 2005 solliciteerde Jiska Nijenhuis naar een functie bij de afdeling Financiële Organisatie. Zij was in Deventer accountant geweest en kende het klappen van de zweep. In die tijd was er weer eens discussie rondom de specifieke uitkeringen, naar aanleiding van het rapport van een stuurgroep 
onder leiding van Elco Brinkman. Een van de kwesties betrof de administratieve lasten. Nijenhuis wist de juiste snaar te treffen om de gedachtevorming rond single information en single audit vlot te trekken.

De nieuwe benadering werd nu het zoveel mogelijk beperken van die informatie. De ministeries vroegen namelijk tot dan toe van alles over de besteding. Jiska Nijenhuis en haar nieuwe project Single information, Single audit (SiSa) verlangde voortaan beperking tot het strikt noodzakelijke dat functioneel is om drie redenen:

- $\quad$ de vaststelling van het definitieve bedrag op de rijksbegroting;

- $\quad$ idem voor Europese bijdragen;

- $\quad$ en wat voor het jaarverslag van de gemeente zelf van belang is.

Als tegenprestatie wierp het ministerie van Binnenlandse Zaken zich op als ontvanger van alle gegevens: zorgt ervoor dat die uiterlijk 15 juli van het jaar $t+1$ ontvangen zijn, toetst de volledigheid ervan en stuurt ze door naar de desbetreffende departementen. Dit plaatst Binnenlandse Zaken in een sleutelpositie, maar ook als boeman in de richting van de gemeenten. Het SiSa-project is tevens een groot en lastig administratief proces geworden. Men is begonnen met 29 regelingen en voor het begrotingsjaar 2007 is men zover dat 79 specifieke uitkeringen op deze manier verwerkt kunnen worden. Tot opluchting van alle betrokkenen bleek het systeem dit tweede jaar te draaien. 93\% van de gemeenten leverde op tijd zijn huiswerk in. De oorspronkelijke gedachte om de informatiebehoefte van het Rijk ondergeschikt te maken aan die van de gemeente, is opgegeven en vervangen door kritische zelfbeperking bij het vragen van informatie door het Rijk. Die beleidskeuze blijkt wel realiseerbaar en vruchten af te werpen.

Als meest opvallende voorbeeld noemt Jiska Nijenhuis de Wet werk en bijstand, die voorheen vier pagina's informatie van alle gemeenten vergde en waar nu met zes regels kan worden volstaan.

Daar staat tegenover dat zich intussen een tegendraadse beweging aftekent. In het streven om zoveel mogelijk specifieke uitkeringen naar het Gemeentefonds over te hevelen worden concessies gedaan, bijvoorbeeld ten aanzien van de toepasbare verdeelsystematiek, maar ook ten aanzien van het axioma dat over de besteding van middelen uit het Gemeentefonds geen verantwoording hoeft te worden afgelegd. Om maar zoveel mogelijk regelingen binnen te halen worden binnen de Algemene Uitkering zogeheten Integratie-uitkeringen en Decentralisatie-uitkeringen in het leven geroepen, waarvan de verdeling nog een tijdlang per gemeente precies wordt uitgerekend. Deze middelen worden dus niet volgens de algemene, globale verdeelmaatstaven uitgekeerd. Verder kunnen hierbij ook nog afzonderlijke informatie-eisen worden gesteld. Ten slotte gaat sinds 2005 het Besluit Begroting en Verantwoording van de Financiële Verhoudingswet (de vroegere gemeentelijke Comptabiliteitsvoorschriften) uit van het adagium 'iedere doelgroep zijn eigen documenten'. Dan blijft er weinig winst over.

\subsubsection{Aanwijzingen voor de gehanteerde bestuurstheorie}

\section{Doelstelling}

Bij de inhoudelijke positionering van deze casus past een onderscheid tussen het kortstondige project om de gemeenten beter toe te rusten enerzijds en de toepassing van BBI op de informatierelaties met het Rijk anderzijds. Het eerste onderdeel past binnen het thema bestuurskrachtontwikkeling. Zoals al is vastgesteld, spoort deze activiteit volledig met de government-traditie: het versterken van het integraal bestuur binnen de lokale overheid (organiserend vermogen gemeente).

Het tweede onderdeel past meer binnen het thema interbestuurlijke betrekkingen en decentralisatie. Daar is de mainstream uiteindelijk herkenbaar als het streven naar een uniform stelsel van financiële verhouding(en) met scherpe dichotomie van algemene en specifieke uitkeringen. 
De doelstelling van het beleid is door Aardema (2004) beschreven in een oplopende reeks van finaliteiten. Voor dit onderzoek is de meest relevante constatering dat de praktijk van het openbaar bestuur onevenredig nadruk legde op de organisatiegerichte dimensie van de bestuurskunde. Dat gold zeker in het decennium van het bedrijfsmatig denken dat in Nederland het bestuur in de jaren negentig kenmerkt (en dat nog steeds belangrijke sporen nalaat, het New Public Management). Deze dimensie plaatst Aardema tegenover de mensgerichte dimensie en het resultaatgerichte en omgevingsgerichte denken. In figuur 8.1 is dit in schema gezet.

Figuur 8.1 Vier werelden van besturing volgens Aardema

\begin{tabular}{|c|c|c|c|}
\hline \multirow{4}{*}{ intern } & \multicolumn{2}{|l|}{ zacht } & \multirow{4}{*}{ extern } \\
\hline & $\begin{array}{l}\text { Culturele sturing } \\
\text { Stimuleren } \\
\text { MENSGERICHT } \\
\text { informeel, waarden, bottom-up } \\
\text { Samenbrengen Aanvaardbaar }\end{array}$ & $\begin{array}{l}\text { Innovatieve sturing } \\
\text { Vernieuwen } \\
\text { OMGEVINGSGERICHT } \\
\text { informatie, vraag, dienend } \\
\text { Doeltreffend Verkennen }\end{array}$ & \\
\hline & $\begin{array}{l}\text { Beheersen Rechtmatig } \\
\text { ORGANISATIEGERICHT } \\
\text { formeel, normen, top-down } \\
\text { Regelen } \\
\text { Bedrijsmatige sturing }\end{array}$ & $\begin{array}{l}\text { Doelmatig Koers bepalen } \\
\text { OUTPUTGERICHT } \\
\text { doelen, aanbod, markt } \\
\text { Presteren } \\
\text { Resultaatgerichte sturing }\end{array}$ & \\
\hline & \multicolumn{2}{|l|}{ hard } & \\
\hline
\end{tabular}

Naar: Aardema, 2004

Is hiermee het BBI-project van Binnenlandse Zaken afdoende getypeerd als bijdrage aan het 'harde' government-denken? Die conclusie lijkt voorbarig. De inzet was wel degelijk de gemeentelijke beleidsstukken te richten op probleemoplossingscombinaties, op maatschappelijk relevante resultaten en op ontkokerde verhoudingen. Voor de typering van het bestuursbeleid van Binnenlandse Zaken is er voor beide benaderingen iets te zeggen. Toch prevaleert hier de eerste, omdat het de bedoeling is de vraag te toetsen of nieuwe ideeën (zoals $\mathrm{BBI}$ ) wellicht de weerspiegeling zijn van een verschuiving van government naar governance. Dat is niet waar te maken.

Inderdaad was het streven zonder meer gericht op het versterken van het integraal bestuur en daarmee past BBI inhoudelijk in de government-traditie van Binnenlandse Zaken. Maar tegelijkertijd was de opzet erop gericht de administratieve praktijk van het bestuur dichter bij de werkelijkheid te brengen. Alleen werd de werkelijkheid van de gemeentelijke praktijk niet in de kern getroffen.

\section{Sturingsaanpak}

De sturingsaanpak was meer dan enig ander voorbeeld dat we tot nu toe hebben gezien, gebaseerd op samenwerking aan de basis. De nationale politiek bleef ver weg van het BBI, de initiatiefnemers waren zich vanaf het begin bewust van de noodzaak het veld te mobiliseren. De verschillende netwerken die werden benut of opgebouwd (Vereniging Gemeentesecretarissen, FAMO, Nivra), speelden een hoofdrol en bleven niet beperkt tot publieke of ambtelijke organisaties. $\mathrm{Na}$ enige tijd werd zelfs ook de creativiteit van de markt ingeschakeld op basis van de commerciële kansen van het project. De aanpak van de informatierelaties in het deelproject Single information, Single audit was wel veel klassieker. Hier was de invloed van de markt merkbaar remmend, omdat de accountantswereld omzetverlies vreesde door het saneren van afzonderlijke controles of 
controleprotocollen voor specifieke uitkeringen. In de laatste episode ging het politieke deel van de overheid zich bemoeien met de sturing door taakstellingen te formuleren en de administratieve lastenverlichting bij de gemeentelijke verantwoordingsinformatie als een van de speerpunten van beleid aan te merken.

\section{Democratieopvatting}

Overduidelijk was de aanleiding tot het project vooral zorg voor het functioneren van de representatieve democratie. De democratieopvatting was niet gericht op coproductie met burgers. De samenleving is nog lang geen partner in het beleids- en beheersinstrumentarium en in de Financiële Verhouding(en).

\section{Informatievergaring}

De informatieverwerving verliep in belangrijke mate via de netwerkcontacten met het veld, maar waarschijnlijk werd hiermee nog niet de rank and file in de gemeentelijke organisatie bereikt, laat staan een accuraat beeld van de maatschappelijke werkelijkheid opgebouwd, zoals Aardema laat zien. Experimenten van onderop zijn in de vijftig voorhoedegemeenten veelvuldig ondernomen. Bij de sanering van de informatierelaties was dat nauwelijks het geval. De toevallige ontdekking van Jiska Nijenhuis leidde wel tot een incrementele ontwikkeling van een nieuwe aanpak van het SiSa, die uiteindelijk ook meer een harmonieuze verhouding met vakdepartementen en gemeenten toeliet.

\subsubsection{Typering van dit project volgens overige onderzoekscriteria}

\section{Mate van beleidsvernieuwing}

Het bestuurs- en beleidsinstrumentarium (BBI) van gemeenten betreft de jaarstukken (begroting, rekening, accountantsverklaring), waarmee het gemeentebestuur aan de volksvertegenwoordiging inzicht verschaft in de beleidsplannen, waarna deze worden gefiatteerd. Het was dus een schok toen in 1985 uit onderzoek bleek dat deze stukken in het geheel niet aan hun functie beantwoordden. Raadsleden konden deze bureaucratische monsters eenvoudig niet lezen. In de hoedanigheid van plaatsvervangend directeur van die directie Bestuurszaken was Johan Hoff voorzitter van de Commissie voor de Gemeentelijke Comptabiliteitsvoorschriften en dat was de hoedanigheid die hem in de wereld van de boekhouders bracht, dicht bij de gemeentelijke BBIpraktijk. Het project was dus een uitvloeisel of voortzetting van bestaande inspanningen van Binnenlandse Zaken als regulator van de gemeentelijke informatiepraktijk. Alleen de procesaanpak van $\mathrm{BBI}$ was radicaal nieuw. In dat opzicht spreken we van beleidsopvolging.

De opzet was drieërlei:

- door transparante presentatie van de plannen en realisatiegegevens zou de positie van de gemeenteraad worden versterkt;

- $\quad$ de interne beheersing van de organisatie zou worden verbeterd; en

- de klantgerichtheid zou toenemen.

Bijdrage aan de bestuurstheorie

Een brug slaan tussen de gortdroge achterkant van het bestuur (comptabiliteit) en de mainstreambestuurstheorie, met praktijkbijdragen uit het hele land, dat was een uitdaging. Als de politieke hamvraag 'wat-waarom-hoe' vertaling kon krijgen in financiële beleidsstukken van gemeenten, zouden daarmee belangrijke kwesties als transparantie, integrale beleidsafweging, prestaties en participatie in het lokaal bestuur aangepakt kunnen worden en zou en passant het verticaal toezicht worden gemoderniseerd. Toch is BBI er uiteindelijk niet echt in geslaagd de brug te slaan. De aanpak, passend bij New Public Managementdenken, bleef net te technocratisch en tijdgebonden om een slinger aan de bestuurstheorie te kunnen geven. Bovendien werd ook dit project na verloop van tijd aan de VNG en aan de markt 'teruggegeven', met als gevolg dat de directe contacten met de bestuurspraktijk en de bijbehorende dilemma's tussen eerlijk, transparant presenteren en de politieke wenselijkheid verslapten. Het loslaten van taken die niet strikt genomen bij een 
beleidsministerie thuishoren is begrijpelijk, maar uit oogpunt van de ontwikkeling van een passende bestuurstheorie ook riskant. Juist de directe kennisneming van dit soort spanningsvelden had verdere doordenking van de bestuurstheorie op het niveau van publieke waarden mogelijk kunnen maken, iets wat nu buiten het ministerie om plaatsvond in de dissertatie van Aardema over het BBIproject, waarover hierna meer.

\section{Evaluatie}

Interne evaluatie van het BBI-project van Binnenlandse Zaken heeft niet plaatsgevonden. Pas na vijftien jaar volgde Aardema's boek 'Doorwerking van BBI: evaluatie van een veranderingsbeweging bij de Nederlandse gemeenten'.

Leereffecten voor het bestuursbeleid in de trant van Aardema's betoog zijn niet waar te nemen. Zelfs de geleidelijke omschakeling van het streven tot afschaffing van specifieke verantwoordingsvoorschriften naar het vereenvoudigen daarvan kan niet worden gezien als een leereffect. De komst van een nieuwe medewerker van buiten, Jiska Nijenhuis, was hiervoor nodig.

\section{Doorwerking en institutionalisering}

De externe doorwerking van het $\mathrm{BBI}$ als vorm van bestuursbeleid is relatief groot geweest. Het voldeed ook aan een maatschappelijke behoefte. Aardema laat zien dat de doorwerking op een bepaald punt blijft steken in bureaucratisch gedrag. Weliswaar past BBI onmiskenbaar in een bredere ontwikkeling van bedrijfsmatig werken en verzakelijking van het openbaar bestuur die in de jaren negentig grote bloei beleefde, maar het project blijft toch nog vrij geïsoleerd binnen het bestuursbeleid. Hoewel de chefs gemeentefinanciën en controllers hun finest hour beleven, worden ze daarmee nog niet tot publieke figuren met wie ook de politieke spraakmakers warme relaties onderhouden. Daarvoor is de vermaatschappelijking van het beleids- en beheersinstrumentarium nog onvoldoende ver voortgeschreden. Intern leeft het project alleen nog door in de vorm van SiSa en door blijvende aandacht voor de interbestuurlijke informatierelaties. De oorspronkelijke inzet voor de toerusting van de lokale democratie en voor de informatiekwaliteit binnen de gemeenten is niet overeind gebleven.

\subsubsection{Conclusies}

De inzet van BBI was versterking van het klassieke government binnen het lokaal bestuur en vooral versterking van de kwaliteit van de representatieve democratie daarbinnen. De aanpak van het BBI-project was vrij onorthodox, zeker binnen de wereld van chefs financiën en accountants. Een shift van government naar governance is hier niet te ontdekken, wel een frisse wind. Daarom score A -

\subsection{ICT doorbreekt bestuurslagen: de gemeentelijke basisadministratie (GBA)}

\subsubsection{Inleiding}

De opkomst van informatietechnologie was voor het bestuursbeleid een bepalend element in de relatie tussen overheid en burger en tussen overheden onderling.

Daarom zijn maatregelen van Binnenlandse Zaken op dit terrein die zijn gericht op de modernisering van het lokaal bestuur, interessant om te bezien of daar zich een beweging in de richting van de burgers aftekent.

Hieronder passeert als saillant voorbeeld de Gemeentelijke Basisadministratie de revue die potentieel een dergelijke kanteling zou kunnen illustreren met de vraag wat dit betekende voor de bestuurstheorie van Binnenlandse Zaken. We positioneren dit project tussen 1986 en 2002.

De trekkers zijn Han Kapsenberg en Harry van Zon. Beide heren kwamen we eerder tegen, bij respectievelijk minderhedenbeleid en de Decentralisatie-impuls. Zij zijn beiden ook geïnterviewd. 
Andere bronnen zijn de institutionele beschrijving van het Rijksarchief (PIVOT 92, 2003), documenten vanuit de VNG (Aarts, 1967) en de TU Delft (Van den Hoven en Van de Bogaard, 2002), alsmede het Tweede Kamerstuk over Modernisering Gemeentelijke Basisadministratie persoonsgegevens (GBA), TK 2000-2002, 27859, nr. 1.

\subsubsection{Projectbeschrijving en verhalen}

Gemeentelijke Bevolkingsadministratie, Gemeentelijke Basisadministratie

De hierboven genoemde directie Bestuurszaken, die zich moest bezighouden met

uitvoeringskwesties, kwam al gauw in aanraking met kwesties op het terrein van automatisering en informatietechnologie binnen de gemeenten. Directeur Han Kapsenberg ging zich hier persoonlijk mee bezighouden. Aanjager was DG Jos Staatsen zelf, die zich ergerde aan alles wat niet bij de tijd was. Binnen zijn onderdeel was dat de bevolkingsadministratie. Een stofnest, zo noemde Staatsen het. Hij zag ook met lede ogen dat allerlei gemeenten aan de gang gingen met modernisering en automatisering, maar daarvoor eigen stukjes software ontwierpen, waardoor een lappendeken dreigde te ontstaan. Han Kapsenberg vertelt dat hij zich met de volle steun van Jos Staatsen omringde met de beste krachten die maar te vinden waren: Peter Tas (oud directeur O\&A, later zelfstandig adviseur), Rien Hekman (hoofd van de Inspectie Bevolkingsadministratie en docent aan verschillende bestuursscholen) en John Loose als projectleider. Samen trokken ze twee jaar uit voor nadenken, en voorbereiding.

Binnen BZK was een andere directie speciaal aangewezen voor deze aangelegenheden in de hele openbare sector, de Directie Overheidsorganisatie en Automatisering (O\&A), en in het bijzonder de afdeling Automatisering onder leiding van prof. Bas Brussaard. Deze zeer geleerde man had een duidelijk adagium voor de wijze waarop informatievoorziening georganiseerd dient te worden: systeemontwikkeling centraal (gestandaardiseerd), informatievergaring decentraal. Qua habitus was de uitstraling van Brussaard bij uitstek technocratisch. Een raison d'être van zijn directie was te verhinderen dat het wiel twee keer zou worden uitgevonden. Natuurlijk had Brussaard als informaticus gelijk met zijn adagium, maar op één moment ging het mis.

\section{Voorgeschiedenis van GBA}

Begin jaren tachtig ontstond er discussie over de inrichting van een nieuw

persoonsinformatiesysteem. Informatietechnologie zou hierbij uiteraard een sleutelrol vervullen. $\mathrm{Er}$ waren in grote lijnen drie modellen:

- centrale opslag van gegevens in een Centrale Persoonsadministratie (CPA);

- decentrale opslag met mogelijkheid tot uitwisseling (de latere gemeentelijke

bevolkingsadministratie, GBA); en

- gemeenschappelijke opslag door samenwerkende gemeenten (Samenwerkingsverband voor de Overkoepeling van de Automatisering bij de Gemeenten (SOAG), tien regionale rekencentra die gemeenteapplicaties ontwikkelden en centraal verbonden waren via de VNG).

Om verschillende redenen, die hier te ver voeren, koos Brussaard voor CPA en het directoraatgeneraal Binnenlands Bestuur voor GBA.

Toen automatisering in de jaren zestig doorbrak in Nederland, zag de afdeling van Brussaard bij Binnenlandse Zaken de bevolkingsregistratie meteen als geschikt object om te automatiseren. Het betrof enorme hoeveelheden informatie met kwalitatief overzichtelijke bewerkingen. De ontwikkeling van een Centrale Persoonsregistratie (CPA) werd vanaf dat moment ter hand genomen. Een belangrijke overweging hierbij was de 'wildgroei' aan registraties - elke gemeente registreerde haar inwoners op zijn eigen wijze, met ponskaarten, formulieren, handarbeid en eigen gebouwde computersystemen. De afloop van de CPA is bekend: om redenen van gemeentelijke autonomie en om redenen van privacy strandde deze geautomatiseerde centrale basisregistratie in 1984 op de Tweede Kamer. Privacy was opeens een politiek issue geworden, en dat was door de 
ontwikkelaars bij Binnenlandse Zaken onvoldoende voorzien. De SOAG was geen reëel alternatief. Dit project had tot een omvangrijk financieel debacle geleid, waardoor de gemeenten en de VNG hun bekomst hadden van dit model, dat bovendien moeilijk te rijmen was met democratische controle.

Het is interessant om te constateren dat de keuze voor de optie GBA in eerste instantie niet gevolgd werd, maar na 1984 wel. Vanuit de wijdverspreide gedachte in de jaren zestig dat centralisatie bij automatisering het meest efficiënt was, werkte O\&A vanaf het begin aan een Centrale Persoonsadministratie. In Nederland zou uiteindelijk na 1984 definitief gekozen worden voor de gemeente: de autonome gemeente onderhield het contact met de burger, en dus moest de gemeente de spil vormen in de GBA.

Al in 1967 stelde dr. H.J.B. Aarts, werkzaam bij de VNG, een compromis voor van een decentrale registratie met een centrale voorziening. De gemeentelijke computers werden gekoppeld via een real time, on line coupling net (Aarts, 1967: 283).

Twee systemen naast elkaar binnen één ministerie

Het klinkt ongelofelijk, maar Kapsenberg, die dus van zijn DG opdracht kreeg om de bevolkingsadministratie op lokaal niveau te moderniseren, had pas geruime tijd na de beslissing in de Tweede Kamer in de gaten dat O\&A elders in het ministerie met CPA in feite ook een model had ontwikkeld dat tot geautomatiseerde persoonsadministratie zou leiden.

Kapsenberg en zijn mensen kwamen hierop uit via een intensief proces van samenwerken en innovatie met alle betrokken partijen in het veld, niet in de laatste plaats met het bedrijfsleven. Terugblikkend vertelt hij:

"Cor van Tilburg van de VNG had het inzicht dat je de gemeenten alleen met wetgeving in het gelid kon krijgen. Dat was een novum, wetgeving over automatisering. We hebben uiteindelijk zelfs het hele logisch ontwerp opgenomen in de Wet GBA, wat nog steeds een unicum is. Het GBA-project is inderdaad heel groot geworden. Op het hoogtepunt hadden we 150 man. Die activist uit Amsterdam die zo hamerde op de privacy, kom hoe heet hij, hebben we gewoon uitgenodigd om te komen praten en in het projectteam opgenomen. We werkten vooral veel samen met het bedrijfsleven, al die grote softwarebedrijven die de gemeenten bedienden, zoals $\mathrm{L}+\mathrm{T}$, Centric en zo. Daar zat de knowhow en de creativiteit. Een grootheid in die tijd als Max Copijn werd een ambassadeur voor het GBA. Geleidelijk raakten ook de afnemers geïnteresseerd. Zij vormden een eigen club die als pressiegroep ging fungeren. De Belastingdienst, de IBG, Roel Bekker zat er voor de Huursubsidie."69

\section{Resultaat}

Het GBA werd ingevoerd in 1994, tien jaar na het eerste idee. Het project GBA werd in 1999 opgenomen in een Agentschap Basisadministratie, Persoonsgegevens, Reisdocumenten (BPR) onder Binnenlandse Zaken.

Het GBA kan volgens het ministerie uiteindelijk wel een succes genoemd worden. In 2000 schreef het ministerie in een stuk over de GBA: "Inmiddels worden per jaar zo'n 60 miljoen berichten over het GBA-netwerk verzonden, terwijl destijds nog van 18 miljoen berichten werd uitgegaan. Zonder GBA zouden tal van essentiële vormen van dienstverlening in het publiek domein niet meer goed denkbaar zijn" (TK 2000-2001, 27859, nr. 1). Verder wordt opgemerkt dat de kwaliteit van de gegevens heel hoog is, en dat veel meer afnemers op het netwerk zijn aangesloten dan verwacht. Vergeet niet dat de afdelingen bevolking het achtergebleven stofnest van de gemeenten waren en opeens de trotse voorhoede in automatisering werden. Dat was een cultuurschok in die wereld.

\section{Drie alternatieve modellen}

69 Interview met Han Kapsenberg, 9 juni 2008. 
In een rapport van de TU Delft wordt de systeemarchitectuur voor de bevolkingsadministratie uit verschillende perioden naast elkaar geplaatst (Van den Hoven \& Van de Bogaard, 2002).

De CPA vertoont uiteraard een strakke hiërarchische lijn van gemeenten naar een centraal bureau buiten de overheid, dat weer lijntjes heeft met allerlei landelijke instanties, zoals de Belastingdienst, de Sociale Verzekeringsbank, Defensie, et cetera.

De architectuur die H.J.B. Aarts presenteerde op een conferentie over automatisering van de bevolkingsadministratie, noemde hij zelf een 'composite structure'.

Gegevens zouden lokaal moeten worden ingevoerd en beheerd. Een nationaal centrum zou (in samenwerking met de gemeenten) daarnaast voor uniformiteit moeten zorgen in procedures, formulieren, en techniek. In zijn architectuur stond de autonomie van gemeenten voorop, maar samenwerking op intergemeentelijk niveau was van groot belang. Alle gemeenten zijn door een geïntegreerd systeem met elkaar verbonden.

In de opzet van de GBA gold het elektronisch berichtenverkeer als de kern van het systeem. De architectuur van het GBA heeft in de loop van de tijd een interessante evolutie doorgemaakt. In het begin werd nog gedacht over een decentrale registratie met een centrale voorziening, waarbij de gemeentelijke computers werden gekoppeld. In de uiteindelijk gerealiseerde opzet zijn gemeenten niet meer met elkaar verbonden en is er ook geen enkele centrale voorziening meer. Daarmee drukt het systeem een vergaande autonomie van de gemeenten uit. De uitwisseling van berichten loopt via elektronische brievenbussen, waar gemachtigden van anderen worden gescheiden. Opvallend is dat de gemeenten tegenover de afnemers geplaatst zijn (Tas \& Luitjens, 1993: 41).

De laatste ontwikkeling betreft de 'service architectuur' in de modernisering van het GBA uit 2002. In dit model staat iedereen op hetzelfde niveau: gemeenten en afnemers, en een nieuwe actor 'burgers'. Burgers zijn blijkbaar een aparte categorie afnemers. De 'dienstenbus' bereikt iedereen die een eigen abonnement heeft op de bus. In die zin zijn gemeenten niet meer alleen leveranciers van informatie, maar ook afnemers - zij kunnen ook informatie krijgen van de bus. In de begeleidende tekst wordt de metafoor van de ruggengraat genoemd: "Binnen een organisatie ontkoppelt de dienstenbus op deze wijze niet alleen de backoffice systemen van de frontoffice systemen, het ontkoppelt ook de backoffice systemen onderling. Het vormt daarmee de ruggengraat van de ICT-infrastructuur binnen organisaties." Elke ruimtelijkheid lijkt opgelost.

In het bijzonder de laatste stap zou een verschuiving van government naar governance kunnen indiceren. De samenleving komt dan niet alleen meer via leveranciers en afnemers in beeld. Ook komt de volkomen gelijkwaardigheid tussen alle actoren die zijn betrokken bij de bevolkingsregistratie, hier tot uitdrukking. De latere ontwikkeling in de richting van een Burgerservicenummer trekt die lijn door. Er wordt een transactieveld gecreëerd. De burgers krijgen zelf het beheer over hun gegevens, maar de overheid kan deze raadplegen als voorwaarde voor het toekennen van rechten. Dit vergezicht is echter niet gerealiseerd.

\subsubsection{Aanwijzingen voor de gehanteerde bestuurstheorie}

Samenvatting van de kenmerken op de as government-governance

In essentie is GBA toch een echt government-project. Zowel de doelstelling, de sturingsaanpak, de democratie-opvatting als het leerproces in dit project waren top-down en technocratisch. De criteria voor het onderscheid tussen government en governance betreffen immers de doelstelling (verdelen van verantwoordelijkheden, niet delen), de sturingsaanpak (alles top-down), de democratieopvatting (in dienst van de representatieve democratie) en het leerproces (informatievergaring van achter de tekentafel, in dit geval zeer uitgesproken en langdurig, of door wetenschappelijk onderzoek). In het GBA is met behulp van het instrument wetgeving uiteindelijk sterk top-down gestuurd. De informatieverwerving was bij het GBA in extreme mate gebaseerd op Analyse en Instructie. Kapsenberg legt in zijn interview veel nadruk op de planmatige en rationele aanpak ("twee jaar nadenken"). Weliswaar is veel gewerkt met experimenten en pilots, maar dit waren 
steeds 'gecontroleerde' experimenten. Wellicht kunnen deze beter simulaties worden genoemd dan experimenten met een onzekere uitkomst met de bedoeling om uit verschillende ervaringen de beste aanpak te leren. Interne evaluatie van het GBA als proces heeft niet plaatsgevonden. Al deze signalen wijzen dezelfde kant op. Alleen is in dit geval moeilijker dan bij andere projecten aan te geven dat het ook op productieve wijze anders had gekund. De belofte van ICT voor geheel nieuwe verhoudingen tussen overheid en samenleving kwam geleidelijk aan het licht, maar nog niet in het project GBA.

\subsubsection{Typering van dit project volgens overige onderzoekscriteria}

\section{Mate van beleidsvernieuwing}

De ontwikkeling van een wettelijk systeem voor bevolkingsadministratie bestond al sinds Napoleon, maar het geautomatiseerd landelijk systeem was beleidsopvolging van het oude handmatige systeem, omdat ICT het mogelijk maakte de verhoudingen met leveranciers en afnemers van basisinformatie horizontaal in te richten.

\section{Invloed op de bestuurstheorie van Binnenlandse Zaken}

Door de relatief zeer intensieve voorbereidings- en onderzoeksfase (op zichzelf kenmerkend voor de government-aanpak: van Analyse naar Instructie) had het GBA potentie voor beïnvloeding van de bestuurstheorie van Binnenlandse Zaken. De betekenis van ICT voor de omkering van de piramide en voor horizontale informatierelaties werd in dit project gaandeweg duidelijk. Toch kwam het verband tussen een technisch systeem en maatschappelijke ontwikkelingen bij de rest van de organisatie niet over, waardoor deze bijdrage niet tot stand kwam.

De verbazingwekkende ontdekking dat er twee tegengestelde systemen voor persoonsadministratie binnen hetzelfde ministerie naast elkaar ontwikkeld konden worden, is een aanwijzing voor de zwakke betrokkenheid van de algemene leiding bij dit onderwerp.

\subsubsection{Conclusies}

Het GBA kan uiteindelijk wel een succes genoemd worden. Het systeem (decentrale dataverzameling en opslag, selectieve berichtenuitwisseling) heeft in het hele land uitstekend gewerkt binnen verwaarloosbare foutenmarge en dat kan niet van veel BZK-projecten gezegd worden. Ondanks alle bovengenoemde government-kenmerken in doelstelling, top-down sturingsaanpak en bij leerontwikkeling steunen op rationele planning valt niet te ontkennen dat ICT een breekijzer vormt voor horizontalisering van de verhoudingen in het openbaar bestuur. Later is die beweging organisatorisch neergeslagen in de aparte directie DIOS (Directie Informatievoorziening voor de Openbare Sector). De volgende paragraaf gaat hier dieper op in en geeft ook een typering van het ICT-beleid van Binnenlandse Zaken.

\subsection{Kwaliteitsinstrumentarium en bestuurlijke vernieuwing}

\subsubsection{Inleiding}

In het begin van de jaren negentig begon Binnenlandse Zaken zich te bemoeien met de condities voor gemeentelijke dienstverlening, die met behulp van ICT aan kwaliteit kon winnen en vooral efficiënter kon worden. Het ministerie ging de ontwikkeling van zogeheten Servicecentra voor de overheid (SCO) actief stimuleren met behulp van experimenten. Dit initiatief (later overgegaan in Overheidsloket 2000), dat zich ontwikkelde tussen 1991 en 2004, vormt de kern van deze casus. Servicecentra zouden de verhouding tussen overheid en burger/klant doen kantelen. Eerst door een frontoffice in te richten waar de burger bij de hand werd genomen in het doolhof van de gemeentelijke organisatie, later door de backoffice rechtstreeks te richten op klantgroepen met 
bepaalde overeenkomstige vraagpatronen. In 1995 werd dit concept opgevolgd door Overheidsloket 2000. Pioniers waren Louis Berger, Jan Post en Matt Poelmans.

In dezelfde fin-de-siècle-periode kwamen onder invloed van het New Public Management instrumenten in zwang die de positie van de burger als klant moesten versterken, zoals kwaliteitshandvesten. Initiatieven die gemeenten en andere overheidsorganisaties moesten prikkelen om innovaties in front- en backoffice te introduceren, buitelden over elkaar heen: benchmarking, dienstverleningsexperimenten van het innovatiecentrum InAxis, het programma Andere Overheid, allemaal impulsen voor korte tijd in dezelfde stroom, geïnitieerd door Binnenlandse Zaken. Na SCO en Kwaliteitshandvesten worden nog twee andere initiatieven behandeld, die een korter bestaan beschoren waren: Centrum voor Good Governance (2006-2008) en InAxis (2002-2009). In deze geest was ook een groot deel van het Programma Andere Overheid gericht op ICT-toepassingen bij gemeenten, maar dit project komt grotendeels pas in hoofdstuk 9 aan de orde. Zij kunnen in de tijd worden geplaatst tussen 2002 en 2009. Deze projecten en projectjes worden in deze paragraaf belicht en afgesloten met een analyse van hun betekenis voor de bestuurstheorie van het bestuursbeleid.

Interviews met Harry van Zon, Marbeth Bierman en Tom Keek vormen bronnen van informatie voor deze paragraaf, evenals - toepasselijk voor dit onderwerp - de website van het ministerie. Daarnaast is gebruikgemaakt van de Beleidsnota's Informatisering in de Openbare Sector (BIOS 2 'De computer gestuurd' en BIOS 3 'Terug naar de toekomst', TK 1990-1991, 20644, nr. 15 respectievelijk TK 1995-1996, 20644, nr. 24) en een evaluatierapport over InAxis (Kruiter et al., 2008). Informatief voor deze sector is ten slotte het adviesrapport over burger en overheid in de informatiesamenleving (Commissie-Docters van Leeuwen, 2001).

\subsubsection{Projectbeschrijving en verhalen}

Vooral het voorbeeld van de servicecentra laat zien dat de ontwikkeling van ICT de motor vormde voor governance-denken binnen Binnenlandse Zaken in diens functie om het lokaal bestuur bij de tijd te houden. De ontwikkeling van ICT dwong Binnenlandse Zaken te interveniëren in het functioneren van gemeenten. ledere gemeente dreigde zelf het wiel uit te vinden en eigen systemen te ontwikkelen. Dit was dus een duidelijk top-down government-motief. Tegelijkertijd bood die technologie alleen kansen om de bestuurskracht van gemeenten te versterken door schotten af te breken. Er werden mogelijkheden gezien om de responsiviteit van het openbaar bestuur te vergroten, door de vraag van de burger meer gewicht te geven ten opzichte van de verkokerde organisatie van de gemeenten. Bestuurlijke vernieuwing, in dezelfde tijdgeest als de sociale vernieuwing, was de trigger, maar de grensverleggende informatietechnologie maakte het mogelijk. Bij bestuurlijke vernieuwing lag binnen Binnenlandse Zaken het accent vooral op dienstverlening, minder op democratische vernieuwing, wat in politieke debatten in deze periode meer aandacht kreeg.

\section{Servicecentra}

De directie Interbestuurlijke Betrekkingen en Informatievoorziening (IBI) was de broedplaats van zowel de sociale vernieuwing als de interventies in de dienstverlening van gemeenten. In de beginperiode had de directie een kleine vernieuwingsgerichte afdeling met de naam BIBIT (rijstplantje) onder leiding van Louis Berger om nieuwe concepten en ontwikkelingsmogelijkheden te verkennen. Louis is later met bonje vertrokken, maar zijn pionierswerk gaf een ondernemende aanzet tot latere ontwikkelingen.

Klantgerichtheid en kwaliteitszorg worden in de jaren negentig speerpunten van beleid. Dit is de periode waarin het New Public Management ook in Nederland in opkomst is. De relatie overheidburger komt in deze periode hoog op de agenda, ook van het bestuursbeleid van Binnenlandse Zaken. Vooral de kwaliteit van dienstverlening krijgt aandacht, vanuit de bedrijfsmatige visie dat de 
burger als klant moet worden beschouwd. De opkomende informatica vormde een welkome aanleiding om deze kwaliteit te moderniseren en te verbeteren, omdat overheidswerk voor $90 \%$ uit informatievoorziening bestaat. Het ministerie ging in 1991 na de Beleidsnota Informatisering in de Openbare Sector (BIOS-2) de ontwikkeling van zogeheten Servicecentra voor de overheid (SCO) actief stimuleren met behulp van experimenten (TK 1990-1991, 20644, nr. 15). Servicecentra zouden de verhouding tussen overheid en burger/klant kantelen. Eerst door een frontoffice in te richten waar de burger bij de hand werd genomen in het doolhof van de gemeentelijke organisatie, later door de backoffice rechtstreeks te richten op klantgroepen met bepaalde overeenkomstige vraagpatronen. In 1995 werd dit concept opgevolgd door Overheidsloket 2000 (TK 1995-1996, 20644, nr. 24).

Vooral dit voorbeeld laat zien dat de ontwikkeling van ICT de motor vormde voor governancedenken binnen Binnenlandse Zaken in diens functie om het lokaal bestuur bij de tijd te houden. De ontwikkeling van ICT dwong Binnenlandse Zaken te interveniëren in het functioneren van gemeenten. ledere gemeente dreigde zelf het wiel uit te vinden en eigen systemen te ontwikkelen. Dit was dus een duidelijk top-down government-motief. Tegelijkertijd bood die technologie alleen kansen om de bestuurskracht van gemeenten te versterken door schotten af te breken. Er werden mogelijkheden gezien om de responsiviteit van het openbaar bestuur te vergroten, door de vraag van de burger meer gewicht te geven ten opzichte van de verkokerde organisatie van de gemeenten.

\section{ICT-loket}

In 1995 introduceert het ministerie van Binnenlandse Zaken in navolging van de Servicecentra het project 'Overheidsloket 2000'. Jan Post was de onvermoeibare eerste trekker van dit project. Hij werd opgevolgd door Matt Poelmans. Het project bouwt voort op de SCO-experimenten die Binnenlandse Zaken in een aantal gemeenten had laten uitvoeren. Dit Overheidsloket 2000 beloofde, naast de aandacht voor verbetering van de dienstverlening naar burgers toe, ook doelmatigheidswinst door gericht gebruik van informatietechnologie. Onder leiding van Binnenlandse Zaken en de Vereniging van Nederlandse Gemeenten werden vijftien experimenten met elektronische loketten gestart. In deze experimenten worden drie typen van vraagpatronen van burgers/klanten onderscheiden. Het gaat om drie vormen:

1. loket voor ouderen en gehandicapten;

2. loket vastgoedinformatie;

3. ken-uw-rechtenzuil.

Om de kwaliteit van de dienstverlening daadwerkelijk te kunnen meten heeft Binnenlandse Zaken in samenwerking met de VNG een standaardinstrument voor kwaliteitsmetingen bij gemeenten ontwikkeld. De zogeheten kwaliteitsmonitor meet de waardering van de burgers van een gemeente voor de dienstverlening. Steekproefsgewijs wordt aan burgers gevraagd hoe zij de dienstverlening van hun gemeente ervaren. Dit levert een score op die werd gebruikt voor longitudinale vergelijking in de tijd. De toepassing hiervan is niet doorgezet.

\section{Kwaliteitshandvest}

Een volgend instrument dat Binnenlandse Zaken een tijdje actief heeft gestimuleerd, is het Kwaliteitshandvest. Dit is een instrument waarin helder is vastgelegd wat de burger kan verwachten en wat er gebeurt als die verwachting niet uitkomt. Het kwaliteitshandvest biedt de cliënt het recht om een overheid direct aan te spreken op een mogelijke gebrekkige dienstverlening. Uit de ervaringen in Engeland (citizen's charters) blijkt dat kwaliteitshandvesten een bijdrage kunnen leveren aan een betere publieke dienstverlening. Het instrument is actueel geworden toen een groot aantal overheidsinstellingen verzelfstandigd werd. Het is een schriftelijke verklaring van een overheidsorganisatie waarin de normen van haar dienstverlening en service- en leveringsvoorwaarden worden vastgelegd. Burgers kunnen aanspraak maken op de gestelde normen en als er niet aan kan worden voldaan, wordt men gecompenseerd door de 
dienstverlenende organisatie. Door deze beloften geprikkeld zullen gemeenten en andere instellingen die kwaliteitshandvesten hanteren, gaan nadenken over de opzet van een totaal kwaliteitszorgsysteem.

Het Programma Andere Overheid (2003-2007) stelt hoge ambities met betrekking tot de invoering van kwaliteitshandvesten in alle overheidsorganisaties. Het kabinet wilde dat alle overheidsorganisaties, die frequent contacten met burgers hebben, aan het eind van de kabinetsperiode een kwaliteitscontract met normen voor dienstverlening hebben afgesloten met de mensen die haar diensten afnemen.

Deze doelstelling is in de voortgangsrapportage van december 2004 als volgt toegespitst:

- Begin 2007 zijn de overheidsorganisaties die verantwoordelijk zijn voor $80 \%$ van de burgercontacten, begonnen met de invoering van een kwaliteitshandvest.

- Het betreft de volgende organisaties: rijksorganisaties (o.a. zbo's en agentschappen) en alle gemeenten (burgerzaken, gemeentelijke heffingen en vergunningen, belastingen, sociale zaken, bouw- en woningtoezicht en ruimtelijke ordening).

- Eind 2008 gebruiken alle genoemde organisaties een kwaliteitshandvest (TK 2004/05, 29362, nr. 25).

Tijdens het volgende kabinet waren er weer andere prioriteiten. Deze streefgetallen zijn in ieder geval niet gehaald.

Organisatorische invalshoeken van burgergeoriënteerd bestuursbeleid

Aan kwaliteitsinstrumenten wordt na de eeuwwisseling bij Binnenlandse Zaken vanuit verschillende invalshoeken en organisatie-eenheden gewerkt:

- $\quad$ ICT in de publieke sector, zoals dit onderdeel vanaf het begin al was gericht op mogelijkheden van technologietoepassing voor de relatie overheid-burger.

- management en personeelsontwikkeling in de publieke sector, als voorwaarde voor een goed functionerende responsieve overheid;

- $\quad$ vernieuwing in het openbaar bestuur, de efficiency en de modernisering van de rijksdienst en de andere overheden (Programma Andere Overheid, InAxis, Expertisebureau Innovatieve Beleidsvorming XPIN, Administratieve Lastenvermindering).

Vermeldenswaard is de opvolger van het programma Overheidsloket 2000 (OL2000), dat ondergebracht werd bij de Stichting ICTU, een op afstand geplaatste ontwikkelorganisatie voor egovernment. Hier zagen stimuleringsprojecten als Burger@overheid en later Burgerlink het levenslicht. Hier werd door Matt Poelmans de BurgerServiceCode ontwikkeld, een instrument dat ook internationaal succesvol was, omdat het een prestigieuze prijs in de wacht sleepte. Organisatorisch worden trouwens alle onderdelen die zich bezighouden met ICT-ontwikkeling, managementontwikkeling en overheidspersoneelsbeleid samengebracht binnen het DG Management en Personeelsbeleid. Het andere DG, voor de relaties met de gemeenten, hield zich sinds de reorganisatie 'Leeuwensprong' van 2004 nauwelijks meer bezig met de relaties tussen overheid en burgers en met klantgerichtheid van de dienstverlening. Overigens werd deze reshuffling van onderdelen binnen het ministerie bij de volgende reorganisatie in 2008 alweer ongedaan gemaakt, toen beide DG's fuseerden.

\section{Good governance in publiek management}

Binnen het DG Management en Personeelsbeleid voor de openbare sector zagen we aandacht voor benchmarking, visitaties en coaching opkomen en weer verdwijnen. In 2006 werd een Centrum voor Good Governance opgericht als aanjager voor kwaliteitsbeleid in de openbare sector, maar bij de volgende reorganisatie in 2008 werd het alweer opgeheven. De hier gebruikte betekenis van het begrip governance wijkt af van die in de context van dit onderzoek. Weliswaar is de gerichtheid op burgers en klanten van belang (toezicht, verantwoording, responsiviteit), maar de overheidsorganisatie is de centrale, verantwoordelijke actor die ter wille van de publieke zaak aan 
haar kwaliteit moet werken. De overheden vormen dan ook de enige doelgroep van het CGG. Horizontale samenwerkingsrelaties met maatschappelijke partners zijn niet aan de orde in dit begrip governance. Een citaat uit de presentatie op de website van het ministerie illustreert dat het niet ging om netwerkbestuur/governance in de zin van dit onderzoek: ${ }^{70}$

"Voor Good Governance voor de Nederlandse openbare sector legt het Ministerie van BZK de nadruk op de kwaliteit van het product of dienst die wordt geleverd. Het gaat hierbij om de legitimiteit van het optreden in de ogen van burgers en bedrijven. Om dit te kunnen beoordelen is verantwoordingsinformatie noodzakelijk. Ook gaat het om publieke prestaties. Om de vraag of de kwaliteit van de diensten en producten die worden geleverd voldoende is en of deze producten op een kostenefficiënte wijze tot stand komen. Op dit punt is het belang van stuurinformatie voor het management evident.

In de visie van het ministerie van BZK op Good Governance zijn drie elementen van belang: 1. Het belang van de factor arbeid: de nadruk ligt op het 'human capital': de manier waarop professionals en managers het vertrouwen van burgers moeten winnen en behouden. Uiteindelijk is alles mensenwerk.

2. Het geven van ruimte: deugdelijk management veronderstelt dat organisaties en professionals de ruimte krijgen om hun werk te doen.

3. De openbare sector moet niet groter en duurder zijn dan strikt noodzakelijk is voor de uitvoering van de aan haar toebedeelde taken. Een moderne organisatie wordt geacht zoveel mogelijk kostenbewust en efficiënt te opereren, bijvoorbeeld door de inzet van ICT, maar ook door kostenbesparingen, herontwerp van processen en slimmer werken."

Eind 2006 vormden gesprekken met gemeentesecretarissen de aanleiding om het programma Good Governance uit te breiden en daarbij autonomie van gemeenten geen beletsel te laten zijn voor een stimuleringsprogramma waarin zo veel mogelijk vraaggestuurde instrumenten worden ontwikkeld en aangeboden die overheidsorganisaties in staat stellen om te meten, te leren en te verbeteren. Voorbeelden hiervan zijn medewerkersonderzoek, (intern) klanttevredenheidsonderzoek, integriteitsanalyses en -trainingen, kwaliteitshandvesten en prestatievergelijking (benchmarking).

Ook zou worden geïnvesteerd in de ontwikkeling van horizontale verantwoordingsinstrumenten waartegenover de afschaffing van verticale arrangementen van toezicht in het vooruitzicht wordt gesteld. Dit programma is in 2008 bij opheffing van het CGG overgedragen aan de Programmadirectie Krachtig Bestuur en daarna opgelost in het Kwaliteitsinstituut Nederlandse Gemeenten, het agentschap KING van de VNG.

\section{Directie IIOS en InAxis}

Tussen 2002 en 2009 investeerde Binnenlandse Zaken in innovatie in de openbare sector. Aanleiding was een alarmerend rapport van de commissie-Van Rijn, die waarschuwde voor de noodzaak de aantrekkingskracht van het openbaar bestuur voor de arbeidsmarkt op peil te houden met het oog op de komende vergrijzing. Innovatie zou die wervende kracht van het openbaar bestuur vergroten. De Commissie voor Innovatie in het Openbaar Bestuur InAxis onder leiding van Wolter Lemstra loofde subsidies uit voor vernieuwende experimenten. Gaandeweg bleken deze voor ongeveer $80 \%$ neer te slaan in het domein ICT-toepassingen in gemeenten. Het behoeft dan ook niet te bevreemden dat InAxis in 2004 werd ondergebracht bij de directie Innovatie en Informatievoorziening Openbare Sector (IIOS). InAxis was de broedplaats voor veel vernieuwing op het terrein van burgerparticipatie (e-democracy), en e-government.

Ook dit onderdeel, dat voeling hield met de nieuwste ontwikkelingen in het veld, wordt in 2008 alweer afgeschaft. Bij die gelegenheid worden de effecten van InAxis geëvalueerd. Kruiter cum suis concluderen ten aanzien van de bijdrage van de InAxis-medewerkers dat zij tijdens de

${ }^{70}$ Zie www.minbzk.nl, geraadpleegd op 9 augustus 2008. 
experimenten de rol van facilitator of collaborator op zich namen. Door een flexibele opstelling waarin het publieke organisaties werd toegestaan om van de planning af te wijken en doelstellingen, normen en prioriteiten opnieuw te bepalen, heeft InAxis aan een belangrijke noodzakelijke voorwaarde voor leren voldaan (Kruiter et al., 2008: 42). De commissie Innovatie Openbare Sector heeft onder leiding van Wolter Lemstra een waardevolle impuls gegeven voor vernieuwende experimenten en voor het uitdragen van best practice, totdat de verantwoordelijke minister het niet langer een taak van Binnenlandse Zaken oordeelde om innovatie in het openbaar bestuur te bevorderen.

De directie IOS ontpopte zich binnen Binnenlandse Zaken een tijd lang als ongeveer de enige navelstreng die Binnenlandse Zaken aan het prille begin van de $21 \mathrm{e}$ eeuw met de burger onderhield. Dienstverlening, burgerparticipatie en klantgerichtheid waren overal elders uit het beleidsvocabularium verbannen behalve in samenhang met ICT. Ook het meldpunt Administratieve Lastenvermindering werd van de weeromstuit hier ondergebracht, omdat hier toch ook de dienstverlening en de relatie met de burger vooropstaan. De laatste directeur van IIOS, Harry van Zon, zegt hierover spontaan, terwijl de onderzoeker hem over een ander onderwerp kwam interviewen (zie dossier Decentralisatie):

"Ik ben in dit huis ongeveer de enige die de Burger centraal stelt. Dat is namelijk in deze tijd ook mogelijk nu we leven in de e-overheid. De overheid is één geheel vanuit het gezichtspunt van burgers, en we kunnen alle verbindingen leggen die we willen om een bepaald vraagstuk aan te pakken. Het organiseren in hokjes, verschillende overheden die elkaar "in medebewind" opdrachten geven, mensen die van het kastje naar de muur worden gestuurd, het is allemaal niet meer nodig. En de mensen pikken het ook niet meer, want ze zijn veel mondiger geworden. Ze wensen goede service. De bureaucratische logica kan daar nog niet goed mee omgaan, omdat die niet uitgaat van de problemen of van de klanten, maar van competenties en structuren. De moderne oplossing die door de gemeente Ten Boer werd gekozen mocht niet van DG Bestuur omdat dat niet paste in het Huis van Thorbecke. Wij moeten hier de processen van verandering een beetje helpen. Politici doen dat niet, want zij zijn part of the problem geworden."71

\section{Commissie-Docters van Leeuwen}

In 2001 volgde de commissie-Docters van Leeuwen, die als opdracht had gekregen na te gaan wat de invloed van ICT zou kunnen zijn op de bestuurlijke organisatie. Vanuit Binnenlandse Zaken was Nicole Kroon (directie IIOS) als secretaris toegevoegd en Berend van der Ploeg (IB) als adjunctsecretaris. Deze commissie, waarin vice-voorzitter Paul Frissen een belangrijke penvoerende rol vervulde, kwam met de opzienbarende aanbeveling voortaan het medebewind af te schaffen. Deze hiërarchische verhouding past volgens de commissie niet meer in een ICT-tijdperk waarin iedere overheid in principe kan beschikken over dezelfde informatie, tot op het meest specifieke detailniveau. In de netwerksamenleving ziet de commissie eilandjes van autonomie ontstaan die verbonden zouden moeten worden door een Proceswet Interbestuurlijke Samenwerking. Nadat die wet in werking is getreden, moet het medebewind geheel worden afgeschaft, aldus de commissie (Eenmalige Adviescommissie, 2001). Juist deze aanbeveling, die door Docters van Leeuwen en Frissen tijdens de laatste vergadering werd gelanceerd, is binnen het ministerie bepaald slecht gevallen. Zozeer dat de hele boodschap van het rapport van de commissie hieronder heeft geleden. Tom Keek mocht de kabinetsreactie redigeren. Dit voorbeeld figureert hier vooral als extreme uiting van een denkwijze: redeneer vanuit de problemen, niet vanuit de structuren. Nadeel van die denkwijze was dat volgens Binnenlandse Zaken wel degelijk glashelder moest zijn wie waarvoor kon worden aangesproken om de problemen te kunnen aanpakken. Dat was even uit het oog verloren.

\footnotetext{
${ }^{71}$ Interview met Harry van Zon op 21 augustus 2007.
} 


\subsubsection{Aanwijzingen voor de gehanteerde bestuurstheorie}

\section{Doelstelling}

De doelstelling van het beleid sluit evenals bij BBI direct aan bij het bedrijfsmatig denken van het New Public Management. Nieuw is dat de focus voor het eerst niet ligt op de interne bestuursinrichting en de interbestuurlijke verhoudingen, maar op de relaties met burgers, zij het als afnemers en gebruikers. Dienstverlening krijgt buitensporig veel aandacht ten opzichte van beleidsvorming en politiek-bestuurlijke innovatie. De overheid als bedrijf en de burger als klant. Dat betekent wel een verschuiving, maar nog niet naar een gelijkwaardige positie van maatschappelijke partners als coproducent van publieke waarden. Het is overigens ook een tijdelijke preoccupatie, want het bevorderen van de kwaliteit van dienstverlening vond Binnenlandse Zaken na verloop van tijd geen kerntaak meer, omdat de markt dat ook kon leveren. Alleen de vermindering van administratieve lasten hield het langer dan een of twee kabinetsperioden vol.

\section{Sturingsaanpak}

De sturingsaanpak was sterk gebaseerd op samenwerking. De positie van Binnenlandse Zaken als 'baas' van de gemeenten was echter wel degelijk ook bepalend voor de kans om invloed uit te oefenen op de introductie van nieuwe werkwijzen binnen de gemeenten. Anders dan bij het GBA, waar wetgeving beschikbaar was, is bij de hier beschreven instrumenten vooral met het instrument subsidie gewerkt.

\section{Informatievergaring en leerprocessen}

De ontwikkeling van kwaliteitsinstrumenten en de innovaties bij InAxis waren anders dan het GBA, dat met 'gecontroleerde' pilots werkte, meer op trial and error gebaseerd. Binnen InAxis is het meedenken met de projectleiders in het veld en aanpassing aan gewijzigde verwachtingen zelfs tot huisstijl verheven (Kruiter et al., 2008; Sonnenschein, 2010).

\subsubsection{Typering van dit project volgens overige onderzoekscriteria}

\section{Mate van beleidsvernieuwing}

Dit beleid was door de sterke invloed van technologische ontwikkelingen relatief vernieuwend. Het kwam echter niet uit het niets naar boven. De voorgeschiedenis is te vinden in de directie O\&A, een combinatie van de gedachten over datasystemen en over een effectievere overheidsorganisatie zoals in de commissie-Vonhoff was behandeld. Het is een nieuwe variant van bestaande oriëntaties, onder invloed van de nieuwe bestuurskundige opvattingen uit het New Public Management: beleidsopvolging dus in termen van Hogwood en Peters.

\section{Bijdrage aan de bestuurstheorie}

Uiteindelijk lijkt de invloed van ICT op het bestuur nog de meest substantiële te zijn geweest. De interactiemogelijkheden, de mate waarin informatie gedeeld kan worden, de vergroting van de autonomie van het individu zetten de wereld op zijn kop. De burger als klant en als citoyen komt in de schijnwerper. Maar ook zijn de sturings- en controlemogelijkheden van het bestuur als gevolg van de toepassing van ICT nooit zo groot geweest. Het zou dus vreemd zijn als de bestuurstheorie van Binnenlandse Zaken hierdoor onaangedaan zou blijven. Tegelijkertijd is die invloed ook ambivalent en allesbehalve uitgekristalliseerd. Heel lang kon de stelling worden betrokken: 'ICT is maar een middel', met andere woorden ondergeschikt aan de echte inhoudelijke politieke en bestuurlijke keuzen. De uitdaging ICT te benutten voor beter bestuur is wel opgepakt door Binnenlandse Zaken, maar zou toch de hele onderzoeksperiode in een aparte niche gehouden worden. De kernopvattingen over de taak van Binnenlandse Zaken, de positie ten opzichte van de vakdepartementen, de democratie en de rol van rationele kennis en causaliteit werden er niet door aangetast. Geleidelijk zou het besef gaan doordringen dat de overheid zijn greep op de aanpak van maatschappelijke ontwikkelingen moet delen met de zelforganiserende samenleving en wat betreft technologische innovaties het primaat moet laten aan de markt. Opvallend is dat de 
beleidsrelevantie van ICT vooral is gezocht in administratieve systemen en basisregistraties, maar nauwelijks in de invloed van internet en sociale media op de samenleving.

\section{Evaluatie}

Net als bij het GBA heeft er geen procesevaluatie plaatsgevonden van de pogingen om nieuwe (kwaliteits)instrumenten bij gemeenten te introduceren. InAxis is vooral in de buitenwereld voorwerp van evaluatie en onderzoek geweest. Hoewel InAxis als facilitator van leerprocessen wordt getypeerd, slaat dit vooral op de leereffecten van derden. De eigen organisatie is niet geheel overtuigd van de kracht die de aanpak van InAxis toevoegt aan het adaptief vermogen van het ministerie, want om onduidelijke redenen wordt dit project in 2008 plotseling beëindigd.

\section{Doorwerking en institutionalisering}

De doorwerking van het GBA als blijvend fundament voor bestuursbeleid is groot geweest. Voor de kwaliteitsinstrumenten is dat maar zeer ten dele het geval. De bekendheid van de éénloketgedachte was in gemeenteland zeer groot door de sterke communicatie van OL2000; ook de verbreiding van geïntegreerde frontoffices in gemeenten is royaal geweest. Andere kwaliteitsinstrumenten zijn na 2000 sporadisch toegepast of nu en dan weer eens in de belangstelling gekomen. Het is opvallend hoe kortstondig alle initiatieven hebben bestaan. Alleen de sanering van administratieve lasten is een blijvertje gebleken. Intern is wel degelijk een blijvende onderstroom gecreëerd, die de bottom-up oriëntatie vooropstelt om de manier waarop overheidsmaatregelen bij burgers en bedrijven uitwerken terug te leggen naar het achterliggende beleid. Dit effect loopt door tot na het afsluiten van de onderzoeksperiode van dit boek.

\subsubsection{Conclusies}

Bovenstaande initiatieven op het terrein van ICT in het openbaar bestuur hebben allemaal hun grondslag in dezelfde beweging, namelijk de omkering van aanbodgestuurde overheidsorganisatie naar een vraaggerichte benadering. Tegelijkertijd speelt een moderne sturingsopvatting mee, waarbij erkend wordt dat toezicht en kwaliteitsbewaking vanuit de top erg moeilijk is en beter (en goedkoper) georganiseerd kan worden door interne feedback- en correctiemechanismen. De Nieuw Public Management-benadering heeft dus zeker overeenkomsten met governance-denken, maar de nadruk op samenwerking en horizontale communicatie tussen vele gelijkwaardige autonome partners ontbreekt. Hoewel een fundamentele onzekerheid over de werkelijkheid zou kunnen worden herkend in de keuze voor korte feedbacklijnen, is er ook duidelijke voorkeur voor streefcijfers en meetbare prestaties. ICT is natuurlijk ook een echte ingenieurswereld. Ondanks veel stelligheid in de teksten van alle plannen zien we in deze periode, anders dan bij de ontwikkeling van het GBA, veel trial and error en samenspel met gemeenten bij de vorming van nieuwe ideeën.

Via de invalshoek administratieve lastenvermindering komt Binnenlandse Zaken nog dichter bij een probleemgestuurde interpretatie van de bestuursopdracht dan vanuit ICT of managementkwaliteit. Het streven om de lasten en regeldruk voor burgers (en bedrijven) te verminderen leidt tot een probleemgerichte benaderingswijze van klachten en ideeën die binnenkomen op de website www.lastvandeoverheid.nl. De individuele symptomen van vaak onmatig en tegenstrijdig overheidsingrijpen worden benut als spiegel voor het beleid. Hiervan kan een opvoedende werking uitgaan. Projecten als 'de Kafkabrigade' en 'Casusadoptie', die (mede) door Binnenlandse Zaken worden gesteund, pakken een concrete casus bij de kop en brengen alle partijen die ermee te maken hebben, binnen en buiten de overheid, bijeen om de cumulatieve effecten van ieders inbreng te laten zien. De oplossing van het probleem van de individuele burger kan zo in zicht komen, maar belangrijker is het leereffect voor de voorkoming van soortgelijke problemen in de toekomst. 
Opvallend is dat de verbreding van de horizon binnen Binnenlandse Zaken tot de ervaringen van burgers en bedrijven voor de verbetering van het functioneren van het openbaar bestuur hoofdzakelijk plaatsvindt bij onderdelen die zich bezighouden met de effecten van de nieuwe technologie: ICT-beleid.

Een volgend opmerkelijk fenomeen is het gebrek aan continuïteit bij de initiatieven op dit terrein. Servicecentra van de overheid, één loket OL2000, kwaliteitsmonitors, kwaliteitshandvesten, XPIN, InAxis en Good Governance zijn stuk voor stuk initiatieven die voorbijtrekken en weer worden opgeheven. Een enkele keer wordt het project onder een ander label nog een tijdje voortgezet, zoals de BurgerServiceCode, Burgerlink, en Burger@overheid, maar de indruk van incidentalisme en hobbyisme ${ }^{72}$ overheerst.

\subsection{Ketenregie}

\subsubsection{Inleiding}

Ketenregie was binnen Binnenlandse Zaken weer zo'n typerend 'project'. Het komt in 1999 bij toeval en haast terloops tot stand en heeft een soortgelijk einde in 2001. Project in de zin van beleidsimpuls met een begin en een eind was het dus wel, maar planmatig en gestuurd door een vooraf gestelde doelstelling zeker niet. Binnenlandse Zaken heeft op basis van persoonlijke interesse en contacten van ambtenaren en passend binnen de bestuurlijke agenda van die tijd omstreeks 2000 een substantiële bijdrage kunnen leveren aan de ontwikkeling van praktijkkennis in het veld voor probleemgericht bestuur. Denk aan frontlijnsturing, casusadoptie, procesmanagement, et cetera. De vorming van leerkringen, uitwisseling van best practice, het uitbrengen van handreikingen en andere publicaties, bieden uiteraard een heel andere werkwijze dan het maken van wetten, het bouwen van systemen en het toedelen van taken en verantwoordelijkheden. Niettemin kan een ministerie een waardevolle rol vervullen als aanjager van innovatie en als kenniscentrum (vergelijk Financiën ten aanzien van Publiek-Private Samenwerking). Echter, Binnenlandse Zaken heeft na een kortstondige aanzet voor dergelijke vormen van metasturing er meestal gauw weer de brui aan gegeven. Dat was ook het geval bij een thema waar Binnenlandse Zaken ver is gekomen met het ontwikkelen van een toonaangevend centrum van vernieuwing: ketenregie. Dit is, verwant aan netwerksturing, gericht op de verbinding van de vele hulpverleners en publieke instellingen die allemaal bezig zijn met een individueel probleemgeval. Management vanuit het probleem, de casus en dus niet, zoals gebruikelijk vanuit het aanbod, de hulporganisaties. Initiatiefnemer en trekker was IB-medewerker Marjolein Vermeeren, externe motor was consultant Anja van der Aa.

Bronnen van deze beschrijving vormen de eigen waarneming van de auteur en interviews met $L$. van Halder, M. Vermeeren en B. van der Ploeg. Daarnaast zijn met steun van Binnenlandse Zaken uit dit project handreikingen voortgekomen, die veel achtergrondinformatie verschaffen (Van der Aa en Konijn, 2001; Poorthuis, 2003).

\subsubsection{Projectbeschrijving en verhalen}

Ontstaan van een nieuw project

Binnen het realistische bestuursdenken van de afdeling Interbestuurlijke Betrekkingen (IB) rondom de eeuwwisseling pasten ideeën over horizontalisering en samenwerking goed. Eerder zagen we dat in die periode de samenwerkingsgedachte bij de directie GSIB floreerde, onder meer in het project Bestuursakkoord Nieuwe Stijl (BANS). Marjolein Vermeeren, Mieke Pistorius en Francien

\footnotetext{
$72 \mathrm{Nu}$ en dan weerklinkt in de gangen van Binnenlandse Zaken dit woord als misprijzende aanduiding voor de activiteiten van ondernemende ambtenaren. Reden om 'hobbyisten' als geuzennaam aan te nemen voor publieke pioniers die hun nek uitsteken uit persoonlijke gedrevenheid voor vernieuwing in het openbaar bestuur.
} 
l'Ortye kwamen toevallig ketenregie tegen en gingen in dit concept verder investeren. Zij ontwikkelden samen met de pioniers van Ketens en Netwerken, Anja van der Aa en Theo Konijn, een handreiking voor de bestuurspraktijk ('Ruimte voor regie'), een conferentie, pilotprojecten in een aantal gemeenten en kleinere ontmoetingen voor experts.

Vermeeren, die als BANS-contactpersoon van Verkeer en Waterstaat overkwam naar de afdeling IB, kende Anja van der Aa nog van een opdracht bij Verkeer en Waterstaat. Tijdens een lunchgesprek bespraken zij het idee om Binnenlandse Zaken in te schakelen bij de uitwerking van het concept ketenregie. Afdelingshoofd Berend van der Ploeg werd gewonnen voor een kleine studieopdracht en daarop volgde weer een vervolg.

Marjolein Vermeeren hierover:

"Na een kwartiertje sparren met Berend kwamen we tot de conclusie 'laten ze maar een klein verkennend onderzoekje doen, dan zien we wel wat er van komt'. Zo hebben Anja en Theo een heel beperkte opdracht gekregen, voor 30.000 gulden of zo: 'Kunnen we hier wel of niet wat mee, een beetje snuffelen.' Het resultaat was dat wij zeiden: 'Dit is echt interessant.' Toen hebben we een aantal cases onderzocht in het domein jeugd, veiligheid en sociale zaken. Het meest bijgebleven zijn mij de gesprekken met de mensen uit de hele jeugdketen in Lelystad, en later in Haarlem hebben we alle mensen uit de sociale keten gesproken. Dat vond ik toch wel de mooiste ervaring. En toen hebben we bedacht: het zou toch wel heel aardig zijn om vanuit een afdeling als Interbestuurlijke Betrekkingen ook iets bij te dragen aan de theorievorming op dit terrein. Op dat moment was de hype nog in opgaande lijn. ledereen had het over ketenregie, maar niemand wist eigenlijk wat het was. Toen zijn we begonnen (met Berenschot, Anja en Theo) aan het ontwikkelen van een methodisch kader en een handreiking. Dat is echt een bestseller geworden. Die is enorm veel opgevraagd door mensen uit het veld, gemeenten en departementen. Daarna (toen was ik grotendeels met zwangerschapsverlof) hebben we nog heel kritisch gekeken naar de vraag: wat is nou de rol van het Rijk en hoe kan het Rijk de werking van ketenregie op lokaal en regionaal niveau faciliteren? Dat hebben andere mensen toen overgenomen. Is dat nou een project? Het is eigenlijk meer een initiatief, zou ik zeggen." ${ }^{73}$

\section{Kenniscentrum}

Zo werd Binnenlandse Zaken een erkend kenniscentrum voor dit denken en omgekeerd werd de ketenbenadering een vast aandachtspunt in het toetsingsrepertoire van de medewerkers die de ministeries bijstonden in het verbeteren van hun bestuurlijke arrangementen. Anja van der $\mathrm{Aa}$ fungeerde als trait-d'union tussen wetenschap (weer het duo Roel in 't Veld en Mark van Twist, maar ook Geert Teisman) en de praktijk. Uitgangspunt was de verbetering van publieke dienstverlening en dan in het bijzonder in het sociale domein. De reden daarvoor was vooral dat burgers hier het meest direct van merken en dat de organisatie op dit domein het meest verbrokkeld is. De kwaliteit van de dienstverlening is afhankelijk van de verbindingen tussen vaste instellingen die zich per geval flexibel moeten groeperen rond een hulpvraag. Die flexibele samenwerking tussen instellingen met vaste organisatiebelangen is de setting voor ketenregie en die vind je vooral in de sociale sector. Bij fysieke aangelegenheden gaat het meestal om de ad hoc verbinding tussen instanties die niet zozeer hun eigen dienstverleningsproduct, maar hun lokaal te articuleren belangen inbrengen: in netwerksamenwerking.

Voor het eerst was de afdeling IB direct geïnteresseerd in uitvoerende dienstverleners in het veld, niet alleen in dienst van gemeenten, maar ook in maatschappelijke instellingen dicht bij cliënten. In de arbeidsvoorziening werd de ketengedachte zelfs opgenomen in de wetgeving (SUWI), maar niet overal sloeg deze gedachte aan.

Het concept heeft volgens Marjolein Vermeeren in ieder geval in haar tijd doorgewerkt als een basisfilosofie van IB in alle advisering:

\footnotetext{
${ }^{73}$ Vraaggesprek met Marjolein Vermeeren op 25 juli 2007.
} 
"Leon [van Halder, toen directeur GSIB, JFS] was ook al gauw gewonnen voor het concept en heeft toen nog gezorgd dat het werd ingebracht in de Sociale Verkenning die het kabinet-Paars II ging opstellen toen hun visieloosheid werd verweten. Daaruit is later Operatie Jong! voortgekomen die herkenbaar met de ketenregie verderging.

(...)

Ikzelf heb ervan geleerd toch op een andere manier naar organisaties te kijken. Je bent namelijk bezig te kantelen naar een oriëntatie vanuit het resultaat, of vanuit het probleem. Als ik er kritisch naar kijk, dan is het in het publieke domein heel lastig te vertalen, omdat je geen incentives hebt om de keten echt te beïnvloeden zoals Albert Heijn dat wel doet. Als een stuk van de keten daar niet functioneert, dan kunnen zij die eruit gooien. Zover zijn we bij de overheid niet gekomen. Het is dus een nuttige aanvulling op de benaderingswijze, maar niet op het sturingsinstrumentarium."

\section{Wat is ervan terechtgekomen?}

De activiteiten van Binnenlandse Zaken en de groep rond Anja van der Aa werden sterk gestuurd door gebleken kansen en de beschikbaarheid van energie. Toen Marjolein en andere van haar enthousiaste collega's vertrokken naar DG Veiligheid en elders was het spoedig gedaan met de voortrekkersrol van Binnenlandse Zaken.

De follow-up van de bevindingen uit de verkenning van de tekortkomingen van ketenverbindingen binnen het openbaar bestuur liet volgens Marjolein ook te wensen over:

"Toen het ging om randvoorwaarden vanuit het Rijk is daar niet veel meer mee gebeurd. Toen bleek dat er in Rotterdam honderden projecten gaande waren, hoorden we vanuit de keten steeds weer dat er bijna altijd werd gewerkt met projectsubsidies, wat een ramp is in de praktijk. Daar doet het Rijk volop aan mee. We zijn alleen kritisch op specifieke uitkeringen, maar de politiek wil graag scoren en werkt dus dolgraag met die projectsubsidies. Het is typisch een voorbeeld van systeemaanpak. Minister Van Boxtel zag dat wel, maar de politiek is eigenlijk niet bezig met dergelijke hoe-vragen. Er was wel steun van mijn directe bazen, al zal het aan DG Holtslag en hoger grotendeels zijn voorbijgegaan. Het was ook echt een product van zijn tijd."

In de volgende periode ging er spoedig weer een andere wind waaien in het ministerie. In plaats van coördineren of faciliteren spreekt men liever over interveniëren. In 2006 lijkt de bestuurlijke agenda vooral beheerst te worden door het thema 'bestuurlijke drukte', dat mede in verband wordt gebracht met de overmatige toepassing van begrippen als ketenaanpak en netwerkbestuur, die daarom op een lager pitje worden gezet. Tijdens een bijeenkomst bij de overgang van het kabinetBalkenende III zei de eerdergenoemde Leon van Halder (inmiddels DGKB) dat deze begrippen nu niet meer actueel zijn. In de Tweede Kamer is er kort gewerkt met themacommissies, die op dezelfde manier vanuit een samenhangend domein naar de werkelijkheid keken, maar deze zijn snel aan een roemloos einde gekomen.

De verruiming van het relatienetwerk naar uitvoeringsorganisaties en middenveld is niet duurzaam gebleken. De afdeling IB ging nog wel nu en dan met werkbezoek, maar dat waren meer incidentele excursies die niet verder doorwerkten in het beleid.

Zoals in alle andere voorbeelden in dit dossier biedt werkelijke verdieping in uitvoeringsproblemen een goede ingang tot het vergroten van responsiviteit en probleemgerichtheid van het bestuur. Het helpt om oude beleidsambities te temperen, maar creëert op zijn beurt nieuwe verwachtingen voor het vinden van het ei van Columbus.

Het besef dat de burger centraal staat in de publieke dienstverlening, impliceert dat afzonderlijke diensten en instellingen zich als het ware binnenstebuiten moeten keren en zich moeten afvragen welke andere dienstverleners van belang zijn voor een optimale aanpak voor deze specifieke cliënt. Dat is case-management, waarbij de achterliggende organisaties elkaar blindelings weten te vinden voor afstemming. Daarvoor zijn samenwerking tussen verschillende instellingen, ad hoc afstemming, korte lijnen en ketenregie nodig. Ook gedeelde informatie en systemen zijn 
behulpzaam voor deze effectieve manier van werken. Frontlijnsturing is een begrip dat toepasbaar is op uitvoerende ambtenaren met een goed overzicht en een ruim mandaat die in een stedelijke omgeving met veel actoren probaat kunnen optreden om problemen op te lossen (Hartman en Tops, 2005).

Binnenlandse Zaken heeft op basis van persoonlijke interesse en contacten van ambtenaren en passend binnen de bestuurlijke agenda van die tijd omstreeks 2000 een substantiële bijdrage kunnen leveren aan het denken over ketenregie. Intussen is ook dit onderwerp als onderwerp van bestuurlijke metasturing alweer afgedaan.

\subsubsection{Aanwijzing voor de gehanteerde bestuurstheorie}

\section{Doelstelling, beleidsredenering}

De relatie met de governance-benadering is evident. De essentie van de ketenbenadering is het verbinden van alle relevante actoren die kunnen bijdragen aan de oplossing van een concreet probleem, of deze zich nu in de overheid, semi-overheid of in de particuliere sector bevinden. Weer is duidelijk dat binnen het bestuursbeleid meteen ruimte werd gecreëerd om deze benadering te verkennen. Zeker ook met een open mind als we kijken naar de opdracht om eerst maar een onderzoekje te laten doen. Dit keer is Binnenlandse Zaken zelfs vrij ver gegaan door in het vervolg op dit onderzoekje te besluiten de voorhoede te gaan versterken met het uitbouwen van het theoretisch fundament van het concept. Daarmee zijn de betrokken medewerkers bovendien ver gekomen, omdat hun boekje als 'bestseller' werd getypeerd. Dit alles stond niet in de weg dat het thema na een jaar of twee weer achter de horizon was verdwenen. Dit keer werd het 'getolereerd hobbyisme' niet door een eenling, maar door een vijftal enthousiaste vrouwelijke (!) medewerkers gedragen. DG Leon van Halder zorgde persoonlijk voor introductie van het begrip in kabinetsverkenningen, waarna het later een leidmotief werd voor het project Jong! van het kabinetBalkenende II. Toen de discussie zich verplaatste naar de rol van het Rijk, verslapte de belangstelling van dezelfde departementsleiding spoedig, misschien omdat ketenregie heel dicht in de buurt komt van de behandeling van individuele gevallen, wat Binnenlandse Zaken liefst aan de gemeenten overlaat. Een andere factor is dat de trekker, Marjolein Vermeeren, vertrok naar DG Veiligheid.

\section{Sturingsaanpak}

Wat betreft de sturingsaanpak is nauwelijks van hiërarchische sturingsinstrumenten gebruikgemaakt, al zou men publicatie van een handreiking als een lichte vorm van sturing kunnen opvatten. In de praktijk is veel gedaan aan informele netwerkvorming en het deelnemen aan bijeenkomsten van praktijkmensen die van ketenregie wilden leren.

\section{Informatievergaring}

De informatieverwerving was typisch experimenterend en via trial and error. De nadruk lag wel relatief veel op analyse, omdat Binnenlandse Zaken vooral investeerde in een consistent conceptueel kader rond ketenregie. De inbreng voor dit conceptueel kader ontleende men echter aan toevallige cases die men was tegengekomen in het netwerk van belangstellende pioniers. De analyse leidde echter niet tot 'instructie' in de betekenis van eenzijdige beleidsmaatregelen.

\subsubsection{Typering van dit project volgens overige onderzoekscriteria}

Mate van beleidsvernieuwing

Dit beleid is een species van de beweging in de vorige paragraaf, met dien verstande dat het niet is gericht op de dienstverlening maar vooral op de beleidsontwikkeling. Door op een andere manier (back-casting) te kijken naar de effecten van beleid op het grondvlak, zouden beleidskokers doorbroken kunnen worden. Afhankelijk van de nadruk die men wil leggen op de overeenkomst of het verschil met de andere behandelde initiatieven, is het beleidsaanpassing of beleidsopvolging. 
Het is echter weer zo'n tijdelijke bevlieging geweest, die niet heeft kunnen rijpen tot een fundamentele bouwsteen in de bestuurstheorie van Binnenlandse Zaken. Er zijn twee verklaringen voor het plotseling stoppen van dit werk: het ministerie kwam tot de conclusie dat je dit soort leerprocessen ook aan de markt of aan de wetenschap kon overlaten en het concept paste niet in het typische aanbodsdenken van de overheid.

\section{Bijdrage aan de bestuurstheorie van Binnenlandse Zaken}

Het wordt eentonig: wederom heeft geen evaluatie plaatsgevonden van de gepleegde inspanningen op dit terrein. Het 'project', of liever initiatief, is gewoon als een nachtkaars uitgegaan. Eventuele leereffecten zijn bij Binnenlandse Zaken niet specifiek toe te schrijven aan dit initiatief. Hoogstens heeft het indirect en impliciet zijn uitwerking gehad op de manier waarop ook toekomstige medewerkers tegen de aanpak van complexe problemen aankijken. De uitingen van deze korte episode zijn al besproken bij het dossier Interbestuurlijke betrekkingen (paragraaf 6.9). Buiten Binnenlandse Zaken hebben andere ministeries het stokje overgenomen. Zoals gezegd heeft het programma Jeugd! veel gedaan met het gedachtegoed van ketenregie en ook bij Veiligheidsbeleid, Sociale Zaken en Grotestedenbeleid (later VROM) is ermee verder gewerkt om de verkokerde verhoudingen in het veld transparant te maken. Dat betekent dat als het gaat om instrumentarium van bestuursbeleid Binnenlandse Zaken door anderen rechts is ingehaald en (weer) heeft volstaan met een beetje zaaien, maar aan oogsten en implementeren is niet toegekomen.

\section{Doorwerking en institutionalisering}

De doorwerking van het onderwerp ketenregie binnen het lokaal bestuur is zeker niet onbevredigend te noemen. Niet alleen door de geproduceerde 'bestseller', maar ook omdat het begrip ketenaanpak inmiddels alom ingang heeft gevonden in de desbetreffende (vooral sociale) beleidssectoren. De opbrengst kwam vooral de lopende praktijk van het grotestedenbeleid, het jeugdbeleid en veiligheidsbeleid ten goede. Het keten-denken werd toegevoegd aan de gereedschapskist van de afdeling Interbestuurlijke Betrekkingen, maar allengs minder onder de uitdrukkelijke benaming van Ketenregie. Daarmee leek de investering juist in het theoretisch en conceptueel fundament voor een belangrijk deel aan het eigen ministerie voorbij te zijn gegaan. Het stelselmatig uitbouwen van het ketenconcept als centrale gedachte voor de versterking van de effectiviteit en probleemgerichtheid van het (lokaal) bestuur heeft geen doorwerking gekregen in de agenda van het ministerie voor het bijdragen aan de bestuurskracht van gemeenten.

\subsubsection{Conclusies}

De escapade met ketenregie is weer een duidelijke illustratie van de eerdere constatering dat Binnenlandse Zaken wel experimenten onderneemt met governance, maar dat dit niet wordt voortgezet in een consistente lijn die vervolg krijgt in instituties en verdere beleidsontwikkeling. Op zichzelf scoort dit project als pur sang governance een B. Het concept heeft aanwijsbare externe doorwerking gehad, onder meer in het jeugdbeleid, maar minder duurzaam invloed op de bestuurstheorie van Binnenlandse Zaken.

\subsection{Conclusies over de bestuurstheorie bij de versterking van bestuurskracht}

\section{Contrast met de hoofdstukken 5 en 6}

In meerdere opzichten waren de achterliggende twee hoofdstukken 7 en 8 spiegelbeeldig ten opzichte van de eerdere thema's bestuurlijke organisatie en decentralisatiebeleid. Kwamen de initiatieven daar hoofdzakelijk uit de modus government, bij de versterking van het lokaal bestuur is bijna zonder uitzondering toepassing van het governance-denken dominant. Te noemen zijn de probleemgerichte thema's als de integratie van minderheden, de verloedering van stadswijken in vergelijking met de meer bestuurlijke kwesties als de structuur en de rol van het middenbestuur of 
decentralisatie van rijkstaken. Op het eerste gezicht is dat verschil wel verklaarbaar, omdat de opdracht tot versterking van de werkwijze van het lokaal bestuur impliceert dat Binnenlandse Zaken dicht bij de bestuurspraktijk in het veld opereert, waar schematische en technocratische benaderingen nu eenmaal minder voor de hand liggen. Dat is bij de aanpak van structuur en verantwoordelijkhedenverdeling anders. De configuraties van partnerschappen zijn hier wisselend, dus weer anders dan bij de bestuurlijke organisatie (VNG en IPO zijn vaak tegenstanders) en dan bij de interbestuurlijke betrekkingen (vakministeries zijn vaak de tegenpartij). Binnenlandse Zaken is in de ontwikkeling van het discours in het bestuursbeleid eigenlijk de enige constante factor.

Het valt op dat Binnenlandse Zaken bij dit soort inhoudelijke opdrachten al gauw in de knoop komt met de eigen positiebepaling. Als het ministerie bij een bepaald aspect of onderwerp eenmaal goed op dreef is en diep is doorgedrongen in de mechanismen van de lokale praktijk om die vervolgens te gaan uitwerken tot beleid, wordt Binnenlandse Zaken teruggefloten door de eigen hoofdoriëntatie: de onaantastbaarheid van de lokale autonomie. Het beleid mag niet ontaarden in interventies op het niveau waar de gemeenten zelf bevoegd zijn, in het relatienetwerk dat nodig is om concrete problemen op te lossen. Alleen nu en dan lijken aanvechtingen om toch wel iets bij te dragen aan de bestuurskwaliteit van de gemeenten nu en dan voet aan de grond te krijgen. In hoofdstuk 10 wordt hierover een stelling opgeworpen.

Ook contrasterend met de thema's uit de eerdere hoofdstukken is dat de meeste initiatieven niet afkomstig lijken van bestuurders, maar van ambtenaren (Ebbeling/Van Dijke/Van Ruller, Hoff, Staatsen/Kapsenberg, Hagendoorn, Vermeeren). Uitzonderingen op deze regel zijn sociale vernieuwing en grotestedenbeleid.

\section{Impact van deze dossiers}

Van alle pogingen is eigenlijk alleen het GBA een blijvend succes voor Binnenlandse Zaken gebleken. De andere initiatieven zijn hetzij doodgebloed, hetzij door andere ministeries of organisaties overgenomen. Van minderhedenbeleid, BBI, grotestedenbeleid en sociale vernieuwing is het materieel resultaat moeilijk vast te stellen. Ze zijn zeker niet (geheel) mislukt, maar niet binnen het ministerie beklijfd als geïnstitutionaliseerde loten aan de bestuurstheorie van het bestuursbeleid.

De laatstgenoemde twee projecten zijn wel grondig geëvalueerd, al heeft juist de eigen rol van Binnenlandse Zaken hierin een zeer bescheiden plaats gekregen. Weliswaar kan niet ontkend worden dat deze drie megaprogramma's binnen het ministerie zeer veel stof hebben geleverd voor interne conversatie en het referentiekader van individuele ambtenaren zeker hebben verrijkt met een keur aan praktijkervaringen en stukken bestuurstheorie. Rechtstreekse vernieuwing van de bestuurstheorie in de richting van een omslag naar netwerkbestuur/governance is ondanks alle nieuwe verbindingen met maatschappelijke problematiek op lokaal niveau niet te constateren. Deze conclusie wordt vooral ontleend aan het gegeven dat stelselmatig aanvechtingen van de heersende bestuurstheorie die onmiskenbaar in deze richting gingen (sociale vernieuwing, Bedrijfsbetrokkenheid, Procesmanagement, Ketenregie), voortijdig zijn getermineerd.

De genoemde projecten voldeden wel in belangrijke mate aan de criteria van netwerkbestuur/ governance (doelstelling samenwerking, sturing horizontaal, democratieopvatting participatief, leerproces inductief), maar ze mochten niet worden gecontinueerd. Dit blijkt uit de lotgevallen van deze projecten die in de voorgaande paragrafen zijn beschreven. Hun invloed is van korte duur geweest en zij zijn bij Binnenlandse Zaken vrijwel vergeten. Datzelfde zagen we al bij het onderwerp Complementair bestuur en bij de pogingen om de contingentie en differentiatie in het decentralisatiebeleid te vergroten. Tekenend is de hier herhaalde signalering uit paragraaf 4.2.3 en 4.2.4 dat de directie Bestuurszaken na drie jaar alweer is opgeheven en ook nooit meer is opgevolgd door een soortgelijk onderdeel. De redenering van DG Staatsen dat het nodig was voor Binnenlandse Zaken om meer gevoel te ontwikkelen voor de uitvoeringspraktijk, was dus eenmalig 
en persoonsgebonden. De tentatieve conclusie was dat de mainstream opvatting binnen het ministerie juist moeilijk te rijmen is met al te directe contacten (bemoeienis) met het grondvlak. Dit kan zelfs nog meer bevreemden nu het relatieve succes van de projecten van deze uitvoeringsdirectie, $\mathrm{BBI}$ en GBA, is beschreven. Het past echter in het patroon dat Binnenlandse Zaken niet te dicht op de huid van de gemeenten wil zitten. Dat maakt het echter moeilijk om volgens de governance-modus bottom-up en op maat beleidsinformatie te vergaren (Variëteit -> Selectie).

Dat er steeds weer aanvechtingen komen die horizontale bestuursverhoudingen beklemtonen, geeft aan dat de aandrang richting governance ook binnen het ministerie hardnekkig was, maar de kracht van de klassieke bestuurstheorie blijkt keer op keer sterker. De stelling die al eerder in het decentralisatiebeleid is onderzocht, wordt dus ook bij de andere beleidsdossiers in het binnenlands bestuur bevestigd: bij Binnenlandse Zaken heeft de zogenoemde shift van government naar governance geen wortel geschoten. 


\section{Dossier organisatie en werkwijze van de rijksdienst}

\subsection{Inleiding}

In hoofdstuk 4 van deze studie bleek al dat de organisatie van de rijksdienst een van de eerste en belangrijkste drijfveren was voor de ontwikkeling van bestuursbeleid. Naast de organisatie van het binnenlands bestuur als gevolg van de modernisering van de samenleving was ook de rijksdienst door de ontwikkeling van de verzorgingsstaat niet meer op zijn taak berekend. In paragraaf 4.2.1 is al een korte beschrijving van de voorgeschiedenis opgenomen, die uitmondde in gericht organisatiebeleid voor de rijksdienst sinds minister Beernink. Het organisatiebeleid voor de rijksdienst vertoont een duidelijke rode draad. Verkokering was in dit verhaal de grote draak die verslagen moest worden. Vanzelfsprekend zou dat nooit lukken. In de jaren tachtig en negentig van de twintigste eeuw stonden de Grote Operaties centraal, die aanzienlijk succesvoller waren, omdat de financiële omstandigheden daartoe noodzaakten: snijden en afstoten. Daarna kwam er weer even aandacht voor de relaties tussen de rijksoverheid en de samenleving, maar het Programma Andere Overheid wist de juiste snaar niet te raken. In dit hoofdstuk worden drie voorbeelden beschreven:

- Reorganisatie rijksdienst; dit project is zeer kort beschreven, omdat het al zo vaak is gedaan en omdat uit die beschrijvingen wel blijkt dat hier echt geen shift is te verwachten (paragraaf 9.2);

- Scheiding van beleid en uitvoering, verzelfstandigingen (paragraaf 9.3).

- Procesmanagement en interactief bestuur (paragraaf 9.4).

Het Programma Andere Overheid komt onder het laatste voorbeeld ter sprake, maar zal daar alleen kort getypeerd worden voor zover dat van belang is voor de centrale vraagstelling van dit boek. Het hoofdstuk wordt weer afgesloten met een concluderende analyse van de bestuurstheorie in het hele dossier (paragraaf 9.5). Dit is het kortste van de vijf empirische hoofdstukken; het verhaal dreigt eentonig te worden.

\subsection{Reorganisatie van de rijksdienst en de grote efficiency-operatie}

\subsubsection{Inleiding}

Pogingen de rijksdienst grondig te reorganiseren passen in een lange geschiedenis (zie paragraaf 9.5). Deze paragraaf focust kort op het werk van de commissie-Vonhoff, die exemplarisch is voor het denken binnen Binnenlandse Zaken over de wenselijke veranderingen in de rijksorganisatie tussen 1978 en 1985, maar ook nog daarna.

Behalve uit de rapporten van de Commissie hoofdstructuur rijksdienst en de Jaarberichten van de Rijkscommissaris voor de reorganisatie van rijksdienst is geput uit de institutionele beschrijving van het Rijksarchief (PIVOT 143, 2003), de dissertatie van Van der Heijden (1990) en een publicatie van Noordegraaf et al. (2005).

\subsubsection{De ontwikkeling van het project}

\section{De Commissie}

Zoals hoofdstuk 5 over de organisatie van het binnenlands bestuur begon met de reorganisatie van het binnenlands bestuur, kan deze paragraaf het best worden aangevangen met een toonaangevend project uit dezelfde periode: de reorganisatie van de rijksdienst. Het voordeel is dat de bestuurstheorie tenminste lekker duidelijk was. Coördinatie, taakverdeling en integraal bestuur waren codewoorden. Planning, bij voorkeur integraal, was het meest typerende instrument in die 
tijd. Planningsprofeten als De Wolff en De Haan hadden veel invloed in deze hoogtijperiode van de maakbare samenleving. De commissie-Van Veen, de Ministeriële Commissie Taakverdeling en Coördinatie Mitaco en de commissie-Vonhoff hebben hun analyse duidelijk gebaseerd op een klassiek centraal rationeel sturingsmodel, dat in hun tijd, eind van de jaren zeventig eigenlijk al overleefd was (Van der Heijden, 1990: 207). Het nieuwe van de commissie-Vonhoff was de samenstelling van de commissie, bestaande uit mensen van buiten en de benadering van de rijksorganisatie als open systeem dat met zijn omgeving communiceert. De rijksoverheid wordt volgens Vonhoff uit elkaar getrokken door belangengroepen, decentrale overheden, adviesorganen, het parlement, et cetera. De commissie pleit op allerlei manieren voor versterking van integratie en sturend vermogen. De wereld van de sectoren leidt tot verkokering en de wereld van de integratie is te zwak geëquipeerd om hier tegenwicht tegen te bieden.

De Commissie hoofdstructuur rijksdienst (Vonhoff, CHR) heeft behalve lijvige rapporten met mooie poëtische titels ('Elk kent de laan die derwaart gaat' en 'Voordat de lade klikt') niet veel concreets opgeleverd. Om de implementatie te ondersteunen werd een Regeringscommissaris voor de reorganisatie van de rijksdienst aangesteld in de persoon van Herman Tjeenk Willink, die nog een aantal jaren met kritische Jaarberichten is gekomen tot hij zichzelf als vruchteloos roepende in de woestijn ging beschouwen en tot hoger posten (lid en later voorzitter van de Eerste Kamer, vicepresident van de Raad van State) werd geroepen. In plaats van implementeren van de aanbevelingen van de commissie-Vonhoff ging Tjeenk Willink vooral door met analyseren. De aanbevelingen van de CHR zijn te rubriceren in drie clusters:

- $\quad$ versterken van het sturend vermogen van de rijksoverheid via wetgeving, planning, financiële instrumenten, informatiesystemen, evaluatie en dergelijke beleidsinstrumenten;

- $\quad$ organisatie en coördinatie van ministeriële taken door het stelselmatig bundelen van thema's in vijf hoofdbeleidsgebieden;

- $\quad$ toepassing van de open systeembenadering, door het participatie- en behoeftepatroon van de betrokken maatschappelijke velden te incorporeren in samenhangende beleidsvorming.

\section{De organisatorische resultaten}

De inspanningen van de directie Organisatie en Automatisering, afdeling Organisatie, die alle genoemde hoge commissies ondersteunde, hebben bescheiden resultaten opgeleverd blijkens de brief van de minister van Binnenlandse Zaken die het project Reorganisatie rijksdienst afsloot (TK 1985-1986, 17353, nr. 27). De ambtelijke stukken die beogen papieren samenhang in het rijksbeleid te presenteren, zoals een jaarlijks Actieprogramma van het kabinetsbeleid, de Begrotingstoelichting voor het Interdepartementaal Welzijnsbeleid en de Financiële Nota Sociale Zekerheid, hebben het niet lang volgehouden. Het samenballen van coördinatie van het rijksbeleid in vijf hoofdbeleidsgebieden, zoals de CHR bepleitte, heeft het niet gehaald; de sanering van 70 coördinerende ministersfuncties tot 16 was al een heksentoer. Het aantal externe adviesorganen is in deze periode teruggebracht van 348 tot 184 . Een proces dat nog altijd voortgaat, tot er niet een meer over is. Ook de organisatie van beheersverantwoordelijkheden is in deze periode aangepakt, maar dan in tegengestelde richting van de uiteindelijke concernvorming met grote shared services. In de jaren tachtig streefde men juist naar decentralisatie van beheerstaken naar het management, gekoppeld aan contractmanagement. Beheer en beleid in één hand. Ook zelfbeheer en verzelfstandiging van diensten wordt al genoemd, maar nog niet in erg warme bewoordingen. Pas later zien we Binnenlandse Zaken optreden als supporter van de scheiding tussen beleid en uitvoering.

\subsubsection{Aanwijzingen voor de gehanteerde bestuurstheorie}

Interpretatie tegen de achtergrond van de begrippen government en governance De CHR was eigenlijk eerder de afsluiting van een tijdvak dan het begin van een nieuwe visie. Tjeenk Willink bleek in zijn aanbevelingen en Jaarberichten zijn tijd daarentegen vooruit te zijn. Hij hamerde voortdurend op verbindingen op de grensvlakken tussen politiek, ambtelijke dienst en samenleving. 
Hiermee lijkt hij een exponent van netwerkbestuur/governance avant la lettre (Noordegraaf et al., 2005). Omdat het niet passend zou zijn Tjeenk Willink bij het ministerie van Binnenlandse Zaken in te lijven, hoewel hij een kamer had op de derde verdieping in de Schedeldoekshaven, staan zijn hartenkreten niet in de lijst van vernieuwende initiatieven van het bestuursbeleid.

Samenvattend was de benadering van de CHR bij uitstek government-gericht, zo bureaucentrisch dat het kabinet er niet aan wilde. De adviezen van de Regeringscommissaris hadden veel governance-elementen, waar de heersende bestuurscultuur evenmin weg mee wist.

\subsubsection{Typering van dit project volgens overige onderzoekscriteria}

\section{Mate van beleidsvernieuwing}

De commissie-Vonhoff was een volgende in een reeks van ministeriële commissies die eenzelfde doel beoogden. Alleen het nieuwe was dat de commissie was samengesteld uit louter externen. Een vorm van beleidsaanpassing zouden Hogwood en Peters dit noemen.

\section{Bijdrage aan de bestuurstheorie}

De bijdrage van de grote denktank die de commissie-Vonhoff was aan de bestuurstheorie van Binnenlandse Zaken moet niet onderschat worden. Theorievorming was een belangrijker resultaat van de reorganisatie van de rijksdienst dan praktische verbeteringen. Het project paste in de reeks commissie-Van Veen en MITACO (Ministeriële commissie Taakverdeling en Coördinatie).

Concentratie van de centrale afwegingsfunctie tegenover de centrifugale krachten van de sectordepartementen is de hoofdboodschap die het beleid van Binnenlandse Zaken voor jaren typeert. Samen met de ideeën over de bestuurlijke organisatie en over decentralisatie en Financiële Verhouding(en) vormt dit de ruggengraat van het bestuursbeleid. Volgens sommigen een atavisme, maar kenmerkend en toonaangevend voor de taakopvatting van het ministerie.

\subsubsection{Conclusies}

Van der Heijden noemt het werk van de commissie-Vonhoff de afsluiting van een tijdvak, waarin sterk volgens rationele stramienen over de overheidsorganisatie werd gedacht. In bijna alle opzichten passen de criteria voor government (score A). De impact op de bestuurstheorie van Binnenlandse Zaken vanuit deze beginperiode van het bestuursbeleid is minstens zo groot als die van de reorganisatie binnenlands bestuur, waardoor een shift van government naar governance mogelijk lang is tegengehouden.

\subsection{Scheiding beleid en uitvoering}

\subsubsection{Inleiding}

De grote verzelfstandigingsgolf werd niet ontwikkeld bij Binnenlandse Zaken. Voortrekker was Financiën in de Interbestuurlijke Begeleidingscommissie Privatisering (IBP), waar meerwaarde werd gezien van de scheiding tussen beleid en uitvoering in het verlengde van het bedrijfsmatige denken. Dit kwam als New Public Management uit de Verenigde Staten overwaaien. Binnenlandse Zaken kwam pas vrij laat aan boord. Eerst gedreven door dezelfde efficiencymotieven, later met staatsrechtelijke overwegingen in verband met de ministeriële verantwoordelijkheid. Bij Financiën zijn vooral Ad van de Ven en Hein Hamer te noemen. Trekkers binnen Binnenlandse Zaken waren Pien Zaaijer, Marianne Sint, Hans Wilmink en Govert van Wesel. Deze personen zijn ook allen geïnterviewd voor dit onderzoek.

Bronnen voor de beschrijving zijn verder de Kamerstukken over de Kaderwet zbo's (TK 27426), het proefschrift van Van Twist (1995), het rapport van de commissie-Sint (1994) en van de commissieKohnstamm (2004).

\subsubsection{Ontwikkeling van dit project, verhalen}




\section{Ontstaan van een nieuw project}

Het rapport van de commissie-Vonhoff over de reorganisatie van de rijksdienst (1980) en het optreden van de regeringscommissaris Tjeenk Willink in de jaren daarna, hadden niet veel concreets opgeleverd. Binnenlandse Zaken verkeerde begin jaren negentig eigenlijk in een overgangsperiode en had nog geen nieuwe draai gevonden. Intussen was het ministerie van Financiën met zijn van nature economische rationaliteit vooral enthousiast over de mogelijkheden van privatisering van delen van de overheid die tot dusver als onlosmakelijke publieke entiteiten waren gezien. Financiën was de trekker van de Interbestuurlijke Begeleidingscommissie Privatisering (IBP), die begon met het propageren van echte marktwerking, maar later werd dit genuanceerd. Bij Binnenlandse Zaken was (plaatsvervangend) SG Van Aartsen de grote protagonist van bedrijfsmatig werken.

Onder het kabinet-Lubbers werd op de golven van het Amerikaanse gedachtegoed van 'Reinventing government' meer de nadruk gelegd op de zegeningen van bedrijfsmatig werken. Pien Zaaijer was samen met Mark van Twist secretaris van de commissie-Wiegel over departementale herindeling en later projectleider van de Grote Efficiency-operatie. Sinds de taakstellende afslankingsoperaties van begin jaren negentig heeft verzelfstandiging van uitvoerende diensten een grote vlucht genomen. Het is interessant na te gaan hoe dit idee is ontstaan. In de jaren tachtig was er al veel werk verzet om bedrijfsmatig werken in de overheid te introduceren. De eerste privatiseringen van SDU, RCC en Loodswezen dateren uit die periode. Pien Zaaijer was als jong ambtenaar van de directie Organisatie en Automatisering van Binnenlandse Zaken daarbij door SG Jozias van Aartsen ingezet, die graag werkte met mensen waar hij veel in zag. We zijn haar al tegengekomen in haar rol bij de Stadsprovincies, verderop in haar loopbaan (paragraaf 5.5).

Pien Zaaijer herinnert zich nog uit de jaren tachtig lange en moeizame discussies met talloze ambtenaren die het drukken van de Staatscourant bij uitstek als een overheidstaak zagen en zich niet konden voorstellen dat een zo verheven en voor de democratische rechtsstaat vitaal product door een bedrijf gemaakt zou worden. Velen konden niet aanvaarden dat overheidsproducten van een bedrijf afkomstig zouden zijn. De discussies gingen steeds over de vraag wat een overheidstaak is. Anderen vonden dat juist efficiënt en modern, zolang de beleidsbepaling maar democratisch zou worden vastgesteld en zolang de markt niet wordt gecontamineerd door concurrentievervalsing en monopolisme. Een onderscheid tussen beleidsvoorbereiding en uitvoering zou het management van de dienst ten goede komen. Wat begon als optie voor bedrijfsmatiger werken in de rijksdienst ontwikkelde zich vervolgens tot organisatieprincipe voor een kleinere beter beheersbare overheid.

\section{Kerndepartement en verzelfstandiging}

De rapporten van het college van SG's en van de commissie-Wiegel in 1993, hebben aan 'verzelfstandiging' expliciet het onderwerp 'kerndepartement' gekoppeld.

Geleidelijk dringt het besef door dat de bestuurlijke verhouding tussen departement en dienst steeds meer de crux lijkt te worden van processen van verzelfstandiging. De commissie-Wiegel adviseerde uiteindelijk tot een verregaande scheiding van beleid en uitvoering, waarbij de daaruit voortvloeiende veel kleinere departementen als hoogwaardige en flexibele kerndepartementen konden worden beschouwd. De commissie wees er in dat verband op dat kerndepartementen die zich concentreren op de hoofdlijnen van beleid, politiek beter aanstuurbaar zijn. Door deze concentratie op de hoofdlijnen van beleid wordt de volle werking van de ministeriële verantwoordelijkheid ook primair afgebakend tot deze hoofdlijnen en de bewaking van de uitvoering.

\section{Staatsrechtelijke draai}

Het loskoppelen van beleid en uitvoering was niet zomaar voor het constitutioneel denkende ministerie van Binnenlandse Zaken aanvaardbaar. Ministeriële verantwoordelijkheid was heilig. Een 
hoeksteen van de democratie. Dat ging je niet zomaar prijsgeven. Een voorbeeld is een studie over het fenomeen inspectie. Daar was de ministeriële verantwoordelijkheid het leidende thema. Omdat Inspecties werden gezien als onafhankelijke toets op de uitvoering, als instrument voor de democratische verantwoording aan het parlement, zou eigenlijk de veelvoorkomende figuur dat Inspecties onder de directeur-generaal ressorteren, uit den boze moeten zijn. Inspecties zouden rechtstreeks aan de SG moeten rapporteren. Pas dan zou de minister rechtstreeks uit het veld negatieve feedback over de werking van het beleid kunnen ontvangen en daarmee zijn verantwoordelijkheid over het systeem kunnen waarmaken. Dus niet het inrichten van checks en balances voor de principaal-agent-relatie, maar de kwaliteit van de parlementaire controle stond in deze redenering voorop.

De boodschap waarmee Pien Zaaijer op gezag van Hans Wiegel, zijn secretaris Mark van Twist en anderen zoals Roel in 't Veld, de staatsrechtdenkers in het ministerie overtuigde, ging als volgt. De doctrine was dat de rechtstreekse hiërarchische aansturing van uitvoerende diensten een waarborg vormde voor kwaliteit en ministeriële verantwoordelijkheid. Dit was volgens de commissie-Wiegel een misvatting. Het losmaken van die diensten zou juist de ministeriële verantwoordelijkheid ten goede komen, omdat dit namelijk voor het eerst ertoe zou dwingen verhoudingen en hoofdinstructies expliciet te maken die bij interne diensten altijd impliciet bleven. Op de achtergrond was Michiel Scheltema de wetenschappelijke stuwende kracht voor het agenderen van dit onderwerp geweest (zijn oratie ging al in 1977 hierover). In navolging van het Zweedse model zag hij grote voordelen van het onttrekken van taken aan de ministeriële bolwerken. Diensten als Studiefinanciering en Kadaster met zijn enorme werkachterstand leverden telkens weer problemen op voor de verantwoordelijke ministers. Scheltema meende dat willekeur kon worden voorkomen. Als staatssecretaris meende hij dat een dienst als de Immigratie- en Naturalisatie Dienst (IND) politieke invloed op individuele gevallen moest uitsluiten. Politieke bemoeienis met allerlei beleidsarme onderwerpen kon alleen ongewenst zijn. Hij was enthousiast over maatschappelijke spreiding van verantwoordelijkheid, wat tegelijkertijd bij Binnenlandse Zaken bedenkingen opriep zolang het ging om publieke verantwoordelijkheid.

\section{Kleiner maken van departementen}

De kwestie van de ministeriële verantwoordelijkheid was voor het veld in de jaren negentig echter niet de grootste drijfveer. Naast de slogan 'bedrijfsmatig werken' die goed in de tijdgeest paste, was voor de SG's de verleiding groot om de uitvoering te gebruiken bij het invullen van de taakstelling voor het verkleinen van het ambtenarenapparaat. Dat was de grote efficiencyoperatie, die wederom in nauwe samenwerking tussen Financiën en Binnenlandse Zaken (wederom met Pien Zaaijer als projectleider) werd uitgevoerd. Met de invoering van verzelfstandigingen kon je snel aan je taakstellingen voldoen door gebruikmaking van een soort verdwijntruc. In zijn dissertatie 'Verbale vernieuwing' laat Mark van Twist (1995) mooi zien hoe de werkelijkheid gedragen wordt op de vleugels van een verhaal dat past in de omstandigheden van de tijd, in dit geval het verhaal van de kerndepartementen. "Je kunt cynisch concluderen dat vernieuwing alleen een papieren exercitie is, maar dat was niet mijn intentie. Bestuurlijke vernieuwing is ook verbale vernieuwing, zoeken naar nieuwe taal. De regels worden voor een deel steeds opnieuw geformuleerd. Begin jaren negentig gebeurde dat door na te denken over kerndepartementen. Taal beschrijt niet alleen, taal creëert ook. Je schept door de taal een beweging, op weg naar een nieuwe werkelijkheid" (Kooistra, 2009).

\section{Emancipatie van de uitvoering}

Naast de push-factor van de inkrimping van de overheid was er ook een pull-factor. Dat was de emancipatie van de uitvoering, de behoefte van uitvoeringsorganisaties om los van het departement eigen trots en professionaliteit te ontwikkelen. De verwachting van betere dienstverlening en de behoefte aan vermindering van het aantal ambtenaren dreef een aantal rijksorganisaties naar buiten.

De leiding van deze uitvoerende organisaties kreeg de smaak te pakken. Het was best interessant om zelfstandig te zijn, geen last te hebben van ambtelijke rechtspositieregelingen en ook niet van 
beleidsbemoeienis uit het centrale departement, dat toch geen benul had van de uitvoeringspraktijk.

Intussen zijn veel overheidsdiensten verzelfstandigd. De veronderstelling dat de grip van het beleid hierdoor zou toenemen, is niet uitgekomen. Integendeel, de uitvoeringsorganisaties hebben niet zelden het ministerie in macht overvleugeld. Zij doen het ook niet slecht, getuige de initiatieven van zeven grote uitvoeringsdiensten (De Manifestgroep) om het voortouw te nemen op het terrein van ICT-samenwerking en horizontale verantwoording. Wel wordt de minister nog steeds lastig gevallen met vragen over de uitvoeringspraktijk.

\section{Rol van Binnenlandse Zaken}

De motie-Lauxterman over de spanning tussen functionele en territoriale decentralisatie had al in 1988 een impuls gegeven aan het denken binnen Binnenlandse Zaken en had daar geleid tot de nota 'Functioneel bestuur, waarom en hoe'. Daar leefde men nog geheel in de sfeer van het streven naar decentralisatie naar gemeenten en provincies en beschouwde aandacht voor functionele decentralisatie als potentiële concurrent. Maar nadat de kansen voor territoriale decentralisatie enigszins uitgeput leken, ontstond meer aandacht voor de andere bestuurlijke aspecten van verzelfstandiging: de ambtelijke rechtspositie en de ministeriële verantwoordelijkheid. Omstreeks 1990 was Binnenlandse Zaken nog alleen bij het onderwerp betrokken als het zijn eigen diensten betrof, zoals de Geneeskundige zorg voor de politie. In 1991 verlangde de Tweede Kamer dat werd ingegrepen. Er zou een wet op de zbo's moeten komen, ze zouden allemaal moeten worden doorgelicht. Minister Dales had er niet veel trek in. Zij kon de klus eerst nog afschuiven naar de Algemene Rekenkamer. Die kwam in 1994 met een negatief rapport over het thema van de ministeriële verantwoordelijkheid bij zelfstandige bestuursorganen. Een commissie onder leiding van de Drentse CdK Oele werd in 1992 ingesteld om bij elke verzelfstandiging te adviseren. Dit was een subcommissie van de Adviescommissie Rijksdienst (SG's). Ad van de Ven (Financiën) en Govert van Wesel (Binnenlandse Zaken) werden co-secretarissen. Deze commissie was enige jaren invloedrijk, maar ging daarna uit als een nachtkaars. Het heeft enige tijd gekost, maar daarna ging Binnenlandse Zaken ook voluit meedraaien in de toetsing van verzelfstandigingsoperaties, als bestuurlijk geweten.

Omstreeks 1994 ontstond binnen Binnenlandse Zaken het besef dat de vraag of en hoe de scheiding tussen bestuur en uitvoering gestalte kon krijgen via verzelfstandiging primair een bestuurlijke vraag betrof, eerder dan dat het een vanzelfsprekende bijdrage vormde aan bedrijfsmatig en dus efficiënter werken. Tot dan toe had het primaat bij Financiën gelegen in het bijzonder bij de Interdepartementale beraadgroep Privatisering onder leiding van Hein Hamer met secretaris Ad van de Ven. Privatiseringen raakten ook minder in zwang nadat de SG's in 1995 een nota 'Verantwoord verzelfstandigen' aanboden (de commissie-Sint). De redenering kantelde nu in de richting van een voorzichtig 'nee, tenzij'. De praktijk bleek echter vaak sterker dan de leer. Het vormen van een zelfstandig bestuursorgaan was voor veel departementale managers aantrekkelijk om van een aantal beheersmatige problemen af te komen. Bestuurlijk was de minder vergaande Agentschapsvorm, uitgerust met een aantal nieuwe bevoegdheden eigenlijk toereikend, vond de commissie-Sint. Dit was het moment waarop Binnenlandse Zaken zich intensiever met het onderwerp ging bemoeien. Rijkelijk laat op dit bestuurlijk cruciale thema, dat dus door Financiën en niet door Binnenlandse Zaken tot ontwikkeling is gebracht.

De verworvenheid van die commissie is geweest dat in ieder geval in de bestuurstheorie bedrijfsmatige overwegingen voor een goed georganiseerde uitvoering werden losgekoppeld van bestuurlijke overwegingen om ook echt een eigen bestuurlijk orgaan daarvoor in te richten. Dat laatste doe je alleen als bijvoorbeeld verbindingen met wortels in de samenleving of professionele codes worden gehinderd door onderbrengen in een departementale organisatie. De drie verzelfstandigingsgronden die de commissie-Sint noemde, zijn door de wetenschap (prof. Scheltema) uit de gegroeide praktijk gedestilleerd. Het zijn:

- $\quad$ behoefte aan een onafhankelijk oordeel van deskundigen (Raad voor de Kunst, Kiesraad); 
- $\quad$ directe betrokkenheid van maatschappelijke geledingen die maakt dat niet alleen de minister verantwoordelijkheid moet dragen;

- $\quad$ uitvoering van taken in grote aantallen gelijksoortige individuele gevallen die beschermd moeten worden tegen politieke beïnvloeding.

In de praktijk werden de normen die de commissie-Sint had opgesteld, echter steeds opgerekt om toch maar te kunnen verzelfstandigen (bijvoorbeeld bij Staatsbosbeheer, waar de betrokkenheid van maatschappelijke partners werd geconstrueerd). Het kwam erop neer dat de minimale voorwaarden in de praktijk werden beschouwd als dwingende redenen voor verzelfstandiging. Het streven dat de departementen klein moesten worden gemaakt, bleef de drijfveer.

\section{Het stempel van Binnenlandse Zaken}

In 1996 werd in Aanwijzingen voor de rijksdienst vastgelegd dat Binnenlandse Zaken en Financiën verplicht moesten worden geconsulteerd. Vice-premier Dijkstal zat als een bok op de haverkist.

Geleidelijk werd het voortouw van Financiën overgenomen, en in 1998 werden er gemengde teams gevormd (BiFi-teams) die verzelfstandigingen bij de vakministeries zouden begeleiden en toetsen. Vanuit Binnenlandse Zaken werd Govert van Wesel deelnemer en het staatsrechtelijk geweten. De vraag is of Binnenlandse Zaken deze kans te baat nam om de kwaliteit van het bestuur (uitvoeringskwaliteit, interactie met 'klanten', principaal-agentverhouding, dienstverlening, vertrouwen) te vergroten of zich beperkte tot de kwaliteit van het statuut. Wilmink was penvoerder geweest van het rapport-Sint en trekker van de Doorlichting van Zelfstandige Bestuursorganen. Organisatiekundigen zoals hij vonden het interessant om in vraagstukken te duiken zoals hoe interfaces tussen kerndepartement en uitvoerende dienst in te richten.

Voor nu is vooral interessant hoe diep het bestuursdepartement zich in deze begeleidingstaak zou laten betrekken bij de operationele problemen van specifieke diensten of dat het zich zou beperken tot het toepassen van algemene sjablonen op de structuurkeuzen die gemaakt moeten worden.

Omdat zij alle diensten onder ogen kregen met hun bijzondere problemen en reorganisatieopgaven, waren Wilmink en Van Wesel in de gelegenheid om dieper in de verschillende organisaties te duiken. Preciezer betrokkenheid zou kunnen leiden tot meer gevoel voor contingente ontwikkeling en vooral voor uitvoeringsproblemen aan het loket. Wilmink geloofde niet zo in algemene regels, wilde liever de diepte in, kijken naar het functioneren van de diensten en bepaalde typen erin. De doorlichting gaf een aanzet tot deze benadering. Govert van Wesel wilde zich juist beperken tot het juridische kader. Hij oriënteerde zich op Constitutionele Zaken en Wetgeving voor steun. Toevallig wist hij door jarenlange betrokkenheid heel veel van de materie en kon hij ook voorbeelden uit de achterzak halen waar nieuwe diensten weer hun voordeel mee konden doen. Zo was men door praktijkervaring tot inzichten gekomen hoe het niet moest. Bijvoorbeeld een Raad van Toezicht optuigen volgens modellen van het vennootschapsrecht, als club die tot opdracht heeft het belang van het voortbestaan van de Dienst te bewaken, past niet in het publiekrecht, waar alleen het algemeen belang maatstaf mag zijn. Een interface-orgaan zoals een Raad van Toezicht mag ook niet in de weg staan dat de minister zo nodig kan ingrijpen in de directie. Dit zijn wel juridische inzichten die gaandeweg hebben bijgedragen aan een redelijke set voorwaarden voor het inrichten van zelfstandige diensten, maar eigenlijk had Binnenlandse Zaken na de juichperiode tussen 1990 en 1995 geen beleid over voor- en nadelen van verzelfstandiging, laat staan over organisatorische verbetermogelijkheden voor de uitvoering van overheidsbeleid. De minister moest voldoende middelen hebben om op de rem te trappen. Binnenlandse Zaken had niet de positie om buiten de vakministeries om in gesprek te gaan met de diensten zelf, net zo als Binnenlandse Zaken ervoor terugdeinsde binnen de gemeenten te interveniëren in wijkproblemen. ${ }^{74}$

\section{Praktische uitvoerbaarheid of staatsrechtelijke zuiverheid}

\footnotetext{
${ }^{74}$ Interview met Govert van Wesel, 6 september 2007.
} 
Dat Binnenlandse Zaken zelfs geen consistente visie had op de hoofdvraag of scheiding van beleid en uitvoering nu uiteindelijk heilzaam was, bleek enkele keren. Er zijn twee benaderingen mogelijk: een bestuurskundige die kijkt naar de uiteindelijke effecten op de dienstverlening en een staatsrechtelijke: waak tegen inperking van de reikwijdte van de ministeriële verantwoordelijkheid. De laatstgenoemde benadering had meestal de overhand, al voelde Binnenlandse Zaken zich meestal te zwak ten opzichte van de vakdepartementen om hier veel ruzie over te maken. Anders dan bij de decentralisatie was Binnenlandse Zaken ook weifelmoedig over de voordelen van verzelfstandiging. Aan het eind van de jaren negentig kwam Binnenlandse Zaken voor het dilemma om wel of geen toestemming te geven voor enkele vanuit inhoudelijke samenhang voor de hand liggende fusies tussen diensten van verschillende departementen, zoals de Keuringsdienst van Waren en de Vleeskeuringsdienst, tussen inspecties voor de Jeugdzorg van Justitie en een soortgelijke dienst bij VWS of tussen de Economische Controle Dienst en de Algemene Inspectie Dienst van Landbouw. Dit type voorstellen werd uiteindelijk door Binnenlandse Zaken afgewezen omdat twee ministers dan verantwoordelijk zouden worden voor één dienst en dit paste niet in de opvattingen over een zuivere ministeriële verantwoordelijkheid.

Toen het proces van verzelfstandiging tot zelfstandige bestuursorganen (zbo's) goed en wel onomkeerbaar was geworden kwam in 2004 het advies 'Een herkenbare staat' van de commissieKohnstamm dat concludeert dat de meeste zelfstandige bestuursorganen beter terug kunnen keren in de boezem van de ministeriële verantwoordelijkheid. Opeens kreeg de onduidelijkheid in de parlementaire controle weer meer aandacht, zelfs zozeer dat het ontbreken van die controle als bewijs werd aangevoerd dat die diensten niet konden deugen.

Gesteld wordt dat andere vormen van controle en verantwoording (horizontaal, bestuurlijk, ambtelijk) belangrijk zijn, maar ondergeschikt aan politieke controle door het parlement. Er zou volgens het voorstel scherper toezicht moeten komen op de verdeling van verantwoordelijkheden en bevoegdheden tussen ministers en zbo's. Ministers moeten over voldoende bevoegdheden beschikken om zbo's hun taken goed te laten uitvoeren. Zo moeten zij aanwijzingen kunnen geven, besluiten kunnen vernietigen en inlichtingen kunnen inwinnen. Daartoe moeten zij begrotingen en eventuele tarieven kunnen goedkeuren, bestuurders kunnen aanstellen en ontslaan en zelfs over de hoogte van hun bezoldiging kunnen beslissen.

In termen van machtsverhoudingen was trouwens de geest allang uit de fles: het is niet goed voorstelbaar dat veel raden van bestuur weer terugkeren in schoot van de departementale bestuursraden. Met een generiek bestuurlijk rapport als dat van Kohnstamm lijkt het alsof er niets is gebeurd bij de desbetreffende diensten. Dus dit rapport heeft verder nauwelijks materieel effect gehad. Het illustreert alleen hoezeer Binnenlandse Zaken aan de buitenkant van de problematiek van de scheiding beleid en uitvoering is gebleven. Juist in deze periode was deze, in de gegroeide machtsverhoudingen wereldvreemde, gedachte extra merkwaardig, omdat inmiddels eindelijk vrij strakke regels waren neergelegd in een Kaderwet zbo's, die bijna het Staatsblad had bereikt. De Vaste Commissie voor Binnenlandse Zaken van de Tweede Kamer had lange tijd geijverd voor deze wet. Met behulp van deze machtige bondgenoot konden alle voorschriften die Binnenlandse Zaken in onderhandelingen met de vakdepartementen niet overeind had weten te houden, alsnog per amendement wettelijk worden vastgelegd. Het wetsvoorstel dat met 27 artikelen was begonnen, kwam met 45 artikelen uit de parlementaire behandeling! Deze wet, die als geste naar het afscheid nemende Kamerlid Olga Scheltema (en haar echtgenoot prof. Michiel Scheltema) de Lex-Scheltema werd genoemd, zou beter de Lex-Van Wesel kunnen heten, want tussen de indiening van het wetsvoorstel in 2000 en de plaatsing in het Staatsblad in 2007 was hij de continue factor. ${ }^{75} \mathrm{Het}$ advies van de commissie-Kohnstamm (waarvoor Binnenlandse Zaken de secretarissen had geleverd in de personen van Han van de Broek en Willem Pedroli) leidde tot

\footnotetext{
75 In 2007 moest Van Wesel de SG Holtslag herinneren aan het feit dat de Kaderwet in de Eerste Kamer lag te wachten en dat voortgang van het wetgevingsproces het ministerie goed uit zou komen bij de reactie op kritiek vanuit de Tweede Kamer op nieuwe verzelfstandigingen.
} 
ongemakkelijke momenten in de Kamer. Wat moest Binnenlandse Zaken nou: het verschijnsel netjes regelen (en legitimeren) of het te vuur en te zwaard bestrijden, zoals Kamerlid Te Veldhuis (VVD) wilde? Een reeks verantwoordelijke ministers voor Bestuurlijke Vernieuwing (Thom de Graaf, Alexander Pechtold, Johan Remkes) hield de boot van de Kaderwet zbo's af en uiteindelijk was het (onbedoeld) Atzo Nicolai die het voorstel in de Eerste Kamer verdedigde. ${ }^{76}$ Eindelijk was er een stevige juridische basis om rechtstreeks contacten met de uitvoerende diensten te onderhouden, maar nog steeds deinsde het ministerie hiervoor terug. De eigen doctrine over ministeriële verantwoordelijkheid stond in de weg om zich met operationele zaken op het terrein van andere ministeries te bemoeien! Daarmee maakt Binnenlandse Zaken het zichzelf ook onmogelijk om daadwerkelijk de rol van bestuursdepartement, hoeder van bestuurskwaliteit binnen het Rijk, ten uitvoer te brengen. Dit wordt bevestigd in het interview met Hans Wilmink:

"Het formalistische sleutelen aan de bestuurlijke voorwaarden is een zielloze manier van werken aan het openbaar bestuur, omdat je niet doordringt tot de vraag wat in het uiteindelijke resultaat van de dienstverlening beter werkt. (...) We hadden als Binnenlandse Zaken niet voldoende een probleemgerichte houding om te proberen de prikkels voor goede uitvoeringspraktijk te optimaliseren. Dat is via het project Good Governance van DGMP en de kwaliteitsinstrumenten wel geprobeerd, maar zij hadden weer weinig verbinding met de mensen van Organisatie Rijksdienst van DGKB."77

\subsubsection{Aanwijzingen voor de gehanteerde bestuurstheorie}

Interpretatie tegen de achtergrond van de begrippen government en governance Het dossier van de organisatie van de rijksdienst, waar materieel de meeste verandering plaatsvond door een nieuwe kijk op uitvoering, illustreert op een heldere manier de voorkeursbenadering van Binnenlandse Zaken. In de eerste plaats de voorkeur voor een algemeen formele benadering van bestuurlijke voorwaarden boven een poging om werkelijke mechanismen over het functioneren van uitvoeringsdiensten en over de interactie met beleid boven tafel te krijgen en te beïnvloeden. In het verlengde hiervan de diep verankerde weerstand om zich, met voorbijgaan van de primair verantwoordelijken (de vakdepartementen) te bemoeien met de kwaliteit van het bestuur. En ten slotte de uiteindelijke inhoudelijke voorkeur voor controle en binnen de overheid houden van uitvoeringstaken boven loslaten en organiseren van horizontale prikkels en controlemechanismen, op basis van een strikte toepassing van het leerstuk van de ministeriële verantwoordelijkheid. Wat de minister niet zelf rechtstreeks kan beïnvloeden, kan niet worden beheerst door het democratisch gekozen machtscentrum, dus kan het niet deugen (zie het rapport van de commissie-Kohnstamm). Dat Binnenlandse Zaken vaak niet echt kon of durfde doorbijten, doet niets af aan de primair gevoelde voorkeurshouding die zich in dit dossier openbaarde. De criteria die indicaties moeten opleveren voor government of governance recapitulerend: de doelstelling is gericht op een samenhangend integraal takenpakket per helder afgebakend bestuurscentrum. De sturingsbenadering is navenant top-down. De democratie-opvatting laat weinig ruimte voor participatie en andere afrekening dan via het verkiezingsproces (let hierbij op de dissidente inbreng van Tjeenk Willink) en informatie en leren is sterk rationeel-wetenschappelijk ingericht.

\subsubsection{Typering van dit project volgens overige onderzoekscriteria}

Mate ven beleidsvernieuwing

\footnotetext{
76 Deze had instructie gegeven deze klus aan zijn opdrachtgever over te laten, maar in een onbewaakt ogenblik had hij het stuk, dat door de postkamer per ongeluk in het tekenboek was gestopt toch uitgestuurd. Zo is nogal halfhartig een Kaderwet zbo's aan het staatsrecht toegevoegd, waarin Binnenlandse Zaken een centrale positie kreeg toegewezen.

77 Vraaggesprek met Hans Wilmink op 7 augustus 2007.
} 
Het idee dat het losknippen van de band tussen beleid en uitvoering de ministeriële verantwoordelijkheid juist zou kunnen versterken, was een radicaal nieuwe gedachte, maar beleid over de ministeriële verantwoordelijkheid voor uitvoerende diensten bestond al veel langer. Hoewel schoorvoetend, begon Binnenlandse Zaken rond 1993 verzelfstandiging onder bepaalde voorwaarden te bevorderen tot de diensten het idee al te enthousiast gingen omarmen en de minimumvoorwaarden waarbij verzelfstandiging aanvaardbaar kon zijn als dwingende argumenten voor verzelfstandiging gingen aanvoeren.

\section{Bijdrage aan de bestuurstheorie}

$\mathrm{Na}$ de bestuurscentrische visie van de Reorganisatie rijksdienst was het voor Binnenlandse Zaken niet vanzelfsprekend de draai te maken naar primaat voor marktpartijen en naar verzelfstandiging van uitvoeringsorganisaties. Uit bovenstaande verhalen kan worden opgemaakt dat de twijfel zich meermalen van het ministerie heeft meester gemaakt. De mooiste illustratie hiervan is het optreden van de commissie-Kohnstamm (2004). Ook was de infiltratie van het ministerie in de afzonderlijke diensten niet zo diepgaand dat hiervan een krachtige invloed van de uitvoeringspraktijk op het denken van Binnenlandse Zaken kon uitgaan. In praktijk blijkt de doctrine van de ministeriële verantwoordelijkheid een doeltreffende uitvoering door bemoeienis met operationele zaken van een ander ministerie in de weg te staan. Dus om de ministeriële verantwoordelijkheid te beschermen moet deze eerst worden geschonden. De bestuurstheorie van het ministerie is minder aan het wankelen gebracht dan het doorslaand succes van het verzelfstandigingsbeleid zou doen verwachten. De bemoeienis van Binnenlandse Zaken met verzelfstandiging was gericht op beheersbaarheid van het systeem, niet op kwaliteitsverbetering van de dienstverlening in de diensten. Dat is te verklaren uit de gescheiden verantwoordelijkheden, maar roept vragen op over de doelstellingen van bestuursbeleid.

\subsubsection{Conclusies}

De keuze voor restrictief formalistisch beleid op het gebied van uitvoeringsorganisaties, met een korte uitzondering van de euforie voor de kerndepartementen in de periode 1990-1995, verraadt wederom de dominantie van het government-denken. Daarom score A. Binnenlandse Zaken heeft bovendien de kans voorbij laten gaan de bestuurstheorie te voeden met ervaringsgegevens van 'street-level bureaucrats' in de nieuwe verhoudingen van diensten die de overgang naar verzelfstandiging moesten doormaken.

\subsection{Procesmanagement en interactief bestuur}

\subsubsection{Inleiding}

In deze paragraaf wordt de in het licht van dit boek relevante escapade van Binnenlandse Zaken op het terrein van horizontale besturingsprocessen op rijksniveau beschreven. Aan de kortstondige verkenning over procesmanagement (1997-1998) ten behoeve van de ontwikkeling van grote infrastructurele projecten voor de ICES kleefden nog verschillende vervolgactiviteiten, bijvoorbeeld in het kader van de commissie-Wallage en de commissie-Docters van Leeuwen en van het Programma Andere Overheid. Deze worden hierna kort beschreven en afgesloten met een typering in het licht van dit onderzoek.

Als trekkers worden vooral Marbeth Bierman en Tom Keek opgevoerd, die ook zijn geïnterviewd. Schrijver heeft ook veel informatie uit eigen waarneming opgedaan. Deze paragraaf bevat nogal wat inside-information. Daarbij zijn het afdelingsdocument 'Maat en Ritme' (1998), de ongepubliceerde discussienota 'Koersbepaling voor maatschappelijke democratie', de publicaties van de Directie IBI (1998) en het onderzoeksrapport ten behoeve van de informele hoorzitting in de 
Tweede Kamer '10 jaar motie-Willems' uit $2003^{78}$ geraadpleegd. Daarnaast zij verwezen naar de volgende algemeen toegankelijke documenten: het deelrapport van de Interdepartementale Commissie Economische Structuurversterking over procesmanagement, de rapporten van de commissie-Wallage (2001) en de commissie-Docters van Leeuwen (2001), hoofdstuk 10 uit het boek 'Brave burgers gezocht' (Schrijver en Van Zuylen, 2010), de dissertatie van Sonja van der Arend (2007), de Beleidsdoorlichting Burgerparticipatie (TK 2011-2012, 30985, nr. 7) en de Handelingen van de Vaste Commissie Binnenlandse Zaken uit de periode tussen 1998 en 2009.

\subsubsection{Projectbeschrijving en verhalen}

\section{Geboorte van een nieuw project}

$\mathrm{Na}$ een aantal kostbare ervaringen met massale bestuurlijke en maatschappelijke weerstand tegen grote investeringsprojecten, zoals de Betuwelijn, de HSL, de nationale luchthaven en de Tweede Maasvlakte werd een nieuw bestuurlijk inzicht geboren: procesmanagement.

Dit behelsde in feite de verwachting dat een verhevener vorm van sturing in plaats van beleidsanalyse vanuit de studeerkamer uitkomst zou bieden: metasturing. Procesmanagement in plaats van gewoon management. Het was 1997. De toenmalige directeur IBI, Marbeth Bierman, fluisterde minister Dijkstal in dat hij zijn vinger kon opsteken toen in het kabinet aan de orde kwam dat er nagedacht moest worden over bestuurlijke methoden om de besluitvorming over grote projecten beter te laten verlopen. Er was veel aardgasgeld beschikbaar om te investeren, maar dan moest het niet stagneren door stroperige procedures. Waarom zou Binnenlandse Zaken zich met investeringsprocessen bemoeien? Dat was immers een bestuurlijke kwestie, al hadden vooral ministeries als V\&W en VROM inhoudelijk met deze materie te maken. De Interdepartementale Commissie Economische Structuurversterking had de opdracht zinnige investeringsprojecten te inventariseren voor de besteding van de aardgasbaten van de Nederlandse staat. Dat was al een lastige opgave, maar in toenemende mate rezen er zorgen over de mogelijkheden om grote investeringsprojecten ook daadwerkelijk binnen redelijke tijd te effectueren tegen de weerstand van allerhande belanghebbenden in. Minister Zalm van Financiën voorzag zoveel praktische problemen om het geld op te krijgen dat hij de gedachte opperde om apart aandacht te besteden aan de planologische besluitvormingsprocedure. De meeste beleidsmakers kregen hierbij associaties over stroomlijning van planologische beslissingsprocedures, versoberen van inspraak en doorzettingsmacht. Maar sommigen zochten de oplossing in de kwaliteit van de interactie in het voortraject. Deze stroming kreeg naast een aparte werkgroep voor een versnelde 'Rijksprojectprocedure' ruimte om een studie uit te voeren naar de kwaliteit van de besluitvormingsprocessen.

\section{Aantrekkingskracht van de hoofdgedachte}

Zo kreeg Binnenlandse Zaken het voorzitterschap en secretariaat van een interdepartementale werkgroep Procesmanagement en dit gaf een impuls aan het denken over interactief werken en publiek-private samenwerking binnen Binnenlandse Zaken. Een unicum? Wel voor Binnenlandse Zaken. Ooit (jaren zeventig) was Binnenlandse Zaken al gepasseerd door het ministerie van Financiën, dat zich het onderwerp Beleidsanalyse toe-eigende; daarna werd het stil op het gebied van de kwaliteit van beleidsvoorbereiding. Het onderwerp was op zichzelf geenszins nieuw noch uniek. Op 1 december 1993 had het Kamerlid Wilbert Willems al een motie ingediend waarin hij de regering uitnodigde te gaan experimenteren met vormen van interactieve beleidsvorming (TK 1993-1994, 21427, nr. 100). Verkeer en Waterstaat pakte dat op, maar Binnenlandse Zaken bleef toen buiten beeld. Staatssecretaris Van de Vondervoort lanceerde in 1997 het al eerder vermelde project 'Daar gaat de gemeente over', waarmee ze het land in trok om indrukken te verzamelen over de nieuwe regierol van gemeentebesturen, meer te midden van hun inwoners dan erboven staand. Het thema had de potentie om het object van bestuursbeleid te verbreden van interbestuurlijke machtsverhoudingen naar besluitvormingsprocedures. Intern was er behoefte aan

${ }^{78}$ TK 2003-2004, 29362, nr. 2. 
verbreding van de instrumentenkoffer van bestuursbeleid. Arie Jan Vos probeerde dit na een van de missiebijeenkomsten van zijn afdeling Coördinatie Bestuursbeleid duidelijk te maken in het document 'Maat en Ritme'. Hierin werd de rol van Binnenlandse Zaken beschreven als makelaar in passende bestuursarrangementen, die op allerlei terreinen kunnen liggen: regelingen, sturingsinstrumenten, processen, samenwerkingsvormen, et cetera. In dit klimaat werden sommigen binnen de afdeling $\mathrm{CB} / \mathrm{IB}$ gelovigen. De opvattingen over professionelere besluitvorming bleven echter steken in onbewezen (onbewijsbare?) stellingen over de winstverwachtingen in tijd en geld van goed overleg met belanghebbenden. Een interessante ervaring was de nauwe interdepartementale samenwerking tussen ambtenaren van verschillende departementen onder leiding van Binnenlandse Zaken, die elkaar konden vinden op deze hoofdgedachte.

\section{Weerstand}

Tegelijkertijd ondervonden we de spanning met de hoofdstroom van het denken, die al dat gepolder maar zinloze, ja gevaarlijke, tijdverspilling vond. De ontvangst van het rapport van de werkgroep in de ICES was dan ook een koude douche, herinnert Marbeth Bierman zich. In de politieke arena werd er lippendienst aan bewezen, onder meer door een alinea in het regeerakkoord van 1998 over goed procesmanagement (TK 1998-1999, 26024, nr. 10: 55). Maar niet meer dan dat. Ook binnen Binnenlandse Zaken stuitte procesmanagement en interactieve beleidsvorming op de doctrine van de representatieve democratie die uitging van politieke sturing die van bovenaf behoort neer te dalen na een onderhandelingsproces via partijprogramma's. Die denkwijze leek moeilijk te verenigen met participatie en inspraak nog voordat doelstellingen en plannen waren uitgekristalliseerd, wat de veronderstelling is achter procesmanagement. Deze onderwerpen werden ook uiterst omzichtig benaderd, omdat de leiding haarfijn aanvoelde dat hiermee het hart van politiek en macht in het geding kwam. Hier ging bureaupolitiek omgekeerd werken, namelijk om in plaats van erom te vechten ervoor te zorgen dat deze onderwerpen ver van je bureau bleven. Minstens zo belangrijk als argumentaties over doorkruising van ons democratisch systeem lijkt echter het gebrek aan politieke belangstelling voor processen en voor 'hoe-vragen'. Desgevraagd zullen veel politici nog wel het nut van interactief bestuur beamen, maar hun aandacht gaat primair uit naar output en resultaten. Dat wordt door veel ambtenaren al gauw verward met de voorkeur voor een rechte weg naar het doel, maar veel politici laten kwesties over de aanpak liever over aan de technocraten.

\section{Debat tussen doven}

Het was intussen interessant hoe in het vooronder een tweedeling tussen twee groepen gelovigen zich aftekende: degenen die geloofden in een alternatief sturingsmodel, getooid met het lelijke jargonwoord interactieve beleidsvorming en de rest die daar weinig van moest hebben.

Waarschijnlijk was het vooral het ongeloof in het traditionele sturingsmodel, dat in de Betuwelijn zijn failliet had bewezen, veeleer dan de bewezen kwaliteiten van het alternatief dat de aanhang van de interactieve beleidsvorming verklaarde. Maar de ambities en de impliciete verwachtingen waren niet mis. Door het bijeenbrengen van betrokkenen en (tegengestelde) belangen zouden nog ongedachte oplossingen oprijzen die de tegenstellingen konden overstijgen (win-win). Door de betrokkenen te laten meedenken in het beleidsproces, zou de weerstand als sneeuw voor de zon wegsmelten, omdat die voor een groot deel verklaard kan worden uit 'not invented here'-gevoelens. Tot op de dag van vandaag verketteren beide groepen elkaar: mislukte interactieve processen worden door de ene partij aangevoerd als bewijs van hun onbruikbaarheid en door de andere als bewijs van de onwil om het concept goed toe te passen. Het echte bewijs is moeilijk te leveren, maar er is ook meer retoriek dan empirisch onderzoek voorhanden. De werkgroep Procesmanagement hield een aantal verkennende gesprekken met wetenschappers en experts uit het veld, maar verzuimde de deelnemers te vragen over de gedane aanbevelingen tijdens deze 'diners pensants' te publiceren.

Inspraakpunt 
Ondanks alle weerstanden hebben in plaats van Binnenlandse Zaken vooral ministeries in de ruimtelijke hoek het instrument voor eigen gebruik verder ontwikkeld. In 2006 heeft het kabinet op voorstel van een interdepartementale werkgroep onder leiding van prof. Pieter Tops het oude woord inspraak in ere hersteld (Nota Inspraak Nieuwe Stijl: maatwerk, TK 2005-2006, 29385, nr. 7). Dat goed Hollandse woord was sinds de jaren zestig misbruikt voor een rechtsbeschermingsvoorziening aan het eind van de planvorming, maar werd nu weer de betekenis toegekend van meedenken met beleidsvoornemens door belanghebbenden in een vroeg stadium: Inspraak nieuwe stijl. Niet Binnenlandse Zaken, maar Verkeer en Waterstaat vormde met het Inspraakpunt de kern van kennisontwikkeling op dit terrein.

Het idee van veel ambtenaren dat een echt alternatief voor top-down sturing te vinden zou zijn in interactieve beleidsvorming, is nooit de status van geloof ontstegen. Binnenlandse Zaken heeft er even brood in gezien, maar is daarna overgegaan tot de orde van de dag. Andere ministeries zijn ermee aan de haal gegaan. Bij de 'Grote nota's' over ruimte, milieu, verkeer en vervoer, natuur en ruimtelijke economie rond de eeuwwisseling werd namelijk ruim gebruikgemaakt van interactieve beleidsprocessen.

\section{Na interactief bestuur volgt 'maatschappelijke democratie'}

In de verhouding tussen overheid en samenleving hebben we niet te maken met een tweepolige verhouding, bestuur versus politiek, maar ten minste met een driehoek of vierhoek die evenwichtig moet zijn ingericht.

De tegenpool van de overheid, gerepresenteerd door bestuur en politiek, is de samenleving, bestaande uit burgers en bedrijven. Dit zijn niet alleen onderdanen, maar in toenemende mate mondige en zelfbewuste deelgenoten in de publieke zaak.

Een andere tegenspeler van bestuur en politiek zijn de uitvoerende instellingen, de ambtenaren en van subsidie afhankelijke professionals. Binnen een hiërarchische zienswijze zijn zij

ondergeschikten, in een bestuurskundige realiteit zijn het belangrijke actoren die autonome schakels vormen in de lange keten tussen de wereld van beleid en de leefwereld van de burgers. Tom Keek, die binnen de afdeling IB belast was met het voorbereiden van kabinetsreacties op de rapporten van de commissie-Wallage (2001) en de commissie-Docters van Leeuwen (2001), heeft op verschillende momenten aan de orde gesteld dat democratie verder gaat dan 'staatsdemocratie', de verhouding tussen staatsinstellingen zoals regering en parlement. Tom was persoonlijk bevlogen en geloofde in de toekomst van burgerparticipatie. Hij zag hier ook een taak voor Binnenlandse Zaken. Zijn gedrevenheid werd aangemoedigd door support van de minister. Klaas de Vries bemoeide zich persoonlijk met de voorbereiding van de stukken voor het overigens tam verlopende Algemeen Overleg met de Tweede Kamer. Ook minister Van Boxtel was geïnteresseerd. De laatstgenoemde organiseerde in het grotestedenbeleid een project 'Onze Buurt Aan Zet', waarbij wijkbudgetten werden uitgedeeld aan burgers met goede plannen. Deze ministeriële steun contrasteerde met de weerstand van de ambtelijke bazen. Directeur Herman Schartman en DG Leon van Halder verwoordden een andere benadering. Zij zaten ook klem. Het paste niet in de heersende rolopvatting om abstracte ideeën over relaties met burgers uit te dragen zonder dat de geadresseerden, de gemeenten, op een of andere manier gehouden konden worden aan normen of voorschriften op het terrein van burgerparticipatie. Binnenlandse Zaken is er volgens deze benadering niet om beschouwingen en paradigma's uit te dragen. Dat vond Tom Keek nu juist de uitdaging. Hij kreeg van zijn bazen de ruimte als het maar minimale capaciteit zou kosten. De oplossing die Tom daarvoor vond, was het lanceren van een nieuw begrip in de hoop dat dit vanzelf discussie zou genereren: maatschappelijke democratie. Daarnaast voelde Schartman zich ook wel geprikkeld door de bijgeleverde kritische benadering van het verkokerde en in zichzelf gekeerde parlement. ${ }^{79}$

\section{De positie van de Tweede Kamer}

${ }^{79}$ Interview met Herman Schartman op 15 augustus en met Tom Keek op 16 augustus 2007. 
Ook die Tweede Kamer had een ambivalente houding. Eigenlijk vindt de Tweede Kamer burgerparticipatie een beetje eng: het concurreert in de ogen van volksvertegenwoordigers met de representatieve democratie, maar dat kunnen ze zeker niet hardop zeggen. Hun houding blijkt echter voldoende uit het gegeven dat ze nooit meer gevraagd hebben waar het toegezegde Beleidskader Interactieve Beleidsvorming bleef. Na de paarse kabinetten kwam Balkenende. In plaats van het afzweren van de 'oude politiek' na de 'opstand van Fortuyn' leek deze alleen maar te worden gestut. Minister Thom de Graaf was de juiste man daarvoor. Toch wist Tom Keek in het nieuwe kabinet kansen te vinden om zijn ideeën van een bedding te voorzien. In het vorige kabinet had hij de kabinetsreactie op het rapport van de commissie-Docters van Leeuwen als zodanig aangegrepen, nu was het Programma Andere Overheid een welkome aanleiding. Het visiedocument dat dit programma begeleidde, legde veel nadruk op de eigen verantwoordelijkheid van burgers en organisaties in de samenleving en wees leunen op de verzorgingsstaat van de hand. Minister Thom de Graaf had minder affiniteit met burgerparticipatie dan zijn voorganger Van Boxtel, maar initiatieven van burgers om zelf publieke verantwoordelijkheid te nemen leken beter in zijn straatje te passen. Daarmee was een nieuwe tegenstelling geïntroduceerd: niet meer participatieve (inspraak) versus representatieve democratie, maar 'maatschappelijke' versus 'staatsdemocratie'.

\section{Rijksambtenaren tegen de stroom in, rol van politici}

Een derde categorie actoren waar Tom steun zocht en vond, waren de andere ministeries. Hier ontmoette hij een vrij uitgebreid gezelschap enthousiaste ambtenaren, die zelf ervaringen hadden met burgerparticipatie en stakeholdersoverleg of het gemis daarvan betreurden. Zij kwamen bijeen in ontmoetingen, onder meer van het Expertisebureau Innovatieve Beleidsvorming XPIN.

Aanmerkelijk meer enthousiasme ervoer Tom bij deze collega's dan in zijn eigen ministerie. Dat stimuleerde hem alleen maar om door te gaan, naast de intrinsieke vreugde om een nieuw inzicht te ontwikkelen en te lanceren. Het lukte echter niet dit inzicht in een gezaghebbend en ook daadwerkelijk gedragen visiedocument naar buiten te brengen.

Het leek echter wel alsof bij de nadering van de schokgolf in 2002 de beduchtheid voor dit soort onderwerpen steeds verder toenam. En zeker daarna zat de schrik er goed in. Vooral DG Van Halder voelde zich ongemakkelijk met het onderwerp te midden van de merkbare politieke onzekerheid. En als er dan een stuk langskomt waarin prikkelende stellingen worden betrokken over de rol van de Tweede Kamer gaan rode lampjes knipperen. Eerst werd een conceptdiscussiestuk teruggestuurd met het verzoek de kabinetsreacties op een advies van de Raad voor het Openbaar Bestuur erin te verwerken, maar toen dat was gebeurd, was er alweer een ander advies dat de ontwikkelingen leek in te halen: 'Vertrouwen in de buurt' van de WRR (2005). Ook daarmee ging Tom Keek voortvarend aan de slag. Maar toen kwam er een kabinetscrisis en een nieuwe minister, Alexander Pechtold, die weer van een heel ander hout was gesneden dan zijn voorganger. Hij was allerminst bang aangelegd, maar had weer minder gevoel voor abstracte betogen over fundamentele paradigma-wisselingen, waar Tom juist zijn hoop op had gevestigd. De poging strandde uiteindelijk in 2006 bij minister Pechtold, in die fase om overigens heel begrijpelijke redenen. Het tij was verlopen, er kwamen alweer nieuwe verkiezingen in zicht. De politieke urgentie om iets te ondernemen was bovendien totaal afwezig.

Daarmee kwam een voorlopig einde aan kortstondige oriëntatie van bestuursbeleid op andere thema's dan de inrichting en werking van het bestuur zelf. Binnenlandse Zaken leek daar genoeg aan te hebben en het parlement was blij toe. Er is nooit meer gevraagd om levering van toegezegde kabinetsstukken op dit thema. De volgende ervaringen zijn illustratief:

- In 1998 kwam minister Peper bij de behandeling van de begroting van Binnenlandse Zaken in de Tweede Kamer terug met een toezegging aan het Kamerlid Schutte. Die had opgemerkt dat het bestuur in een onderhandelingsproces met private partijen het risico loopt met faits accomplis bij het parlement aan te komen. Kortom, hoe kunnen die twee arena's worden gecombineerd? Over die interessante vraag wilde minister Peper wel een notitie aanleveren. De 
ambtenaren hadden binnen enkele dagen al een kladversie op schrift. Daar was de DG echter helemaal niet blij mee. Dit ging over democratie en over de delicate verhouding tussen regering en parlement en zou meer op de weg liggen van de directie Constitutionele Zaken en Wetgeving. Om een lang verhaal kort te maken: de toegezegde notitie is er nooit gekomen. De Tweede Kamer heeft er nooit meer om gevraagd, zeker niet nadat minister Peper was afgetreden.

- In deze periode had de Raad voor het Openbaar Bestuur twee adviezen uitgebracht ('Primaat in de Polder' in 1999 en 'Burgers Betrokken, Betrokken Burgers' in 2005) die in strijd met de wet geen van beide werden voorzien van een kabinetsreactie. Dat kan toch geen toeval zijn, want daar zit doorgaans een strakke voortgangscontrole op. In beide gevallen is overigens opvallend dat ook niet vanuit de Tweede Kamer is gepiept.

- In 2001 verscheen via de Rijksvoorlichtingsdienst van AZ het rapport van de commissie-Wallage 'In dienst van de Democratie'. Kort daarna kwam het rapport van de commissie-Docters van Leeuwen over ICT en overheid met als ondertitel 'De noodzaak van institutionele innovatie' (2001). De kabinetsreactie op beide stukken is er nog gekomen en zelfs besproken in de Tweede Kamer. Daar werd toegezegd een Beleidskader te gaan maken voor interactieve beleidsvorming, maar dat is er nooit gekomen. De lijdensweg van Tom Keek die dit dossier mocht beheren is met geen pen te beschrijven. De poging strandde uiteindelijk in 2006 bij minister Pechtold, in die fase om overigens heel begrijpelijke redenen, toen dit Beleidskader alweer was omgedoopt in een Koersbepaling voor maatschappelijke democratie. De ontwikkelingen en de politieke inzichten hadden namelijk niet stilgestaan, maar politieke urgentie om iets te ondernemen was totaal afwezig.

- Bij het Programma Andere Overheid stond op de lange lijst van actiepunten een nota aan de Tweede Kamer over Burgerschap. Hiervoor is een verkenning georganiseerd naar ervaringen van burgers die zich hebben ingezet voor de publieke zaak, maar de praktische aanbevelingen die daaruit kwamen konden geen genade vinden in de ogen van de minister, Thom de Graaf. Met hangen en wurgen is er toen een algemeen verhaal opgesteld met een aantal normen voor goed gedrag wanneer burgers zich met publieke aangelegenheden bezighouden. De (Vaste Commissie uit de) Tweede Kamer heeft dit stuk met vernietigende kritiek overladen, omdat het veel te betuttelend zou zijn en de nieuw aangetreden D'66 minister Pechtold concludeerde bij die beraadslaging dat hij het stuk beter kon intrekken, wat hij prompt deed. ledereen tevreden, maar dat roept wel de vraag op waar de noodzaak voor zo'n nota echt leefde.

- De directeuren van Binnenlandse Zaken hadden tijdens een strategische conferentie vastgesteld dat het hoog tijd werd dat het ministerie aandacht zou besteden aan het onderwerp 'Empowerment van burgers'. Dat thema zou begin 2006 worden uitgewerkt, maar in de loop van 2006 leek de aandrang alweer verdampt. Niemand van de directeuren maakte zich er warm voor en informeel kon men horen dat dit een onmogelijk onderwerp werd gevonden. Wat zou Binnenlandse Zaken ermee kunnen? Dit voorbeeld wordt verderop in deze paragraaf uitgewerkt.

Zie voor de worsteling van Binnenlandse Zaken met de burger ook Schrijver en Van Zuylen (2010).

\section{Andere Overheid?}

Begrijpelijk is dat de politici het gevoel kregen dat een opstand der burgers niet gedempt zou kunnen worden met abstracte en geleerde vertogen over dilemma's en ambiguïteit.

De gedachte dat er een wending moest plaatsvinden in de verhouding tussen burgers en overheid, was politiek wel degelijk zeer prominent op de agenda na jarenlang leungedrag van klanten die verwachtten dat de overheid alle maatschappelijke kwalen zou oplossen. In het kabinetBalkenende II wordt speciaal een minister voor bestuurlijke vernieuwing aangesteld: eerst, van 2003 tot 2005, Thom de Graaf, van 2005 tot 2006 opgevolgd door Alexander Pechtold. Hun project heet Andere Overheid (PAO). De bestuurlijke vernieuwing heeft onder het kabinet-Balkenende II de status van een 'groot project' (Programma), met veel evenementen, acties en bijeenkomsten. Het blijkt uiteindelijk niet echt te gaan over bestuurlijke vernieuwing. Het programma Andere Overheid 
ging met dat credo van start, maar gaandeweg werd steeds minder gehoord over de voorwaarden voor het overnemen van verantwoordelijkheden door een actieve samenleving. Interessant is bijvoorbeeld dat PAO de buitenwereld als referentiepunt kiest: de overheid wordt van binnenuit veranderd, maar daarbij probeert men voortdurend van buiten naar binnen te kijken: de 'toetsvraag' is: 'Wat zou Martijn hiervan vinden?', waarbij Martijn staat voor de burger (zoals die later in een andere politieke context Henk en Ingrid werd genoemd). Naast deze lijn is er ook een meer conceptuele lijn, die politiek veel herhaald wordt: PAO gaat uit van eigen verantwoordelijkheid voor de burger (en bedrijven). De overheid gaat minder doen en legt meer bij maatschappelijke partijen neer. Dit was vooral communicatie rond het project. Het programma Andere Overheid ging zelf steeds meer de kant op van het verbeteren van de dienstverlening door middel van elektronische snufjes (Programma Elektronische Overheid). Daarnaast kreeg de zogeheten Takenanalyse en de Vernieuwing van de Rijksdienst de meeste aandacht, waarbij de nadruk lag op het verminderen van het aantal rijksambtenaren.

Bij de start van het Programma Andere Overheid in 2002 vroeg minister Thom de Graaf her en der suggesties voor de opzet van het project. Een van die adviezen (van de stuurgroepvoorzitter van XPIN, Jacques Wallage), stelde voor om bij de ministeries te verkennen wat daar leefde en vervolgens op de golf van de aanwezige veranderbehoefte verder te werken. ${ }^{80}$ Ook wat betreft de inhoud werd in dit advies, en waarschijnlijk ook in andere, een aanpak bepleit die dichter bij concrete vraagstukken lag dan de abstract-bestuurlijke aanpak in het voorstel van het ministerie. Al gauw werd duidelijk dat Binnenlandse Zaken deze ruimte niet kreeg van de verantwoordelijke minister. Deze had waarschijnlijk weinig fiducie in de medewerking van de departementen. Het oude vijanddenken tegenover de perfide vakdepartementen vierde hoogtij. Na een radiostilte van bijna een halfjaar presenteerde Thom de Graaf zijn project aan de managers van de rijksdienst, die in de Beurs van Berlage waren opgetrommeld. Het gevolg was dat PAO weer een zoveelste topdown gestuurd project werd, met maar liefst 64 actiepunten opgetuigd. Het project is geen moment gaan leven bij de onderdelen van de rijksdienst, die toch die Andere Overheid moesten gaan vormgeven.

De verhouding tussen het moederdepartement en de andere ministeries was eenrichtingverkeer, maar dat gold ook voor de verhouding tussen de overheid en de samenleving. Aan het eind van de rit, toen Thom de Graaf al het veld had moeten ruimen, waren er nog drie hoofdprioriteiten overgebleven: kwaliteit van de dienstverlening (voornamelijk Elektronische Overheid), terugdringen van bureaucratie en regelzucht, en slagkracht van de rijksdienst. Het laatste onderwerp werd onder druk van een omvangrijke taakstelling na 2007 voortgezet in de Vernieuwing Rijksdienst onder leiding van SG Roel Bekker.

Op één onderdeel werkte het programmateam Andere Overheid aan het thema maatschappelijke democratie, maar wederom liet het programma zich leiden door de minister bij het formuleren van een nota 'Burgerschap'. Deze nota bevatte uiteindelijk minder lessen uit best practices in de samenleving, maar vooral een set normen voor het gedrag van burgers die zich inlaten met

80 Citaat uit het advies: "De meeste lezers zullen het stuk opvatten als een typisch BZK-product. Hiermee riskeert het al gauw 'not invented here' reacties. Wij herkennen nauwelijks co-eigenaarschap van de acties van de kant van partners in het openbaar bestuur die zelf ambitie hebben voor verandering of al actie in hun eigen domein hebben ingezet. Erger dan zo'n psychologische afweerreactie is het risico dat we straks weer het bekende duw- en trekmechanisme gaan beleven van departementen die achteroverleunen of zich actief of passief gaan verzetten bij de implementatie van de maatregelen en dat vooral de minister van BVK de kastanjes uit het vuur mag halen.

Een hiermee samenhangende reactie die het huidige stuk ongetwijfeld oproept is dat men overwegend acties op generiek instrumenteel niveau aantreft (regels, organisatie, uitkeringen). De relatie met de inhoudelijke doelstellingen en voor burgers herkenbare verbeteringen wordt niet gelegd en is ook allerminst gewaarborgd.

Ook hier willen we waarschuwen voor bekende sturingsmechanismen, zoals de targets van zoveel procent minder regels, uitkeringen, adviesorganen, etc., die al gauw een eigen leven gaan leiden. Daar schiet niemand wat mee op, zelfs niet als dit soort targets worden gehaald, maar nog niet vanzelf een voor burgers merkbare verbetering in handelingspraktijk opleveren. Ook bekend is het verschijnsel dat targets alsnog worden gehaald door met definities en cijfers te goochelen. Vooral de bestuurlijke partners en burgers in de samenleving zullen veel meer worden geïnspireerd door het idee dat een moderne overheid bijdraagt aan inhoudelijke doelstellingen zoals een sterke kenniseconomie, burgerschap, duurzame ontwikkeling, veiligheid en sociale cohesie." 
publieke aangelegenheden. De Tweede Kamer noemde dit stuk 'truttig' en de kersvers aangetreden minister Pechtold reageerde spontaan door het onderwerp terug te nemen, zoals we hierboven al zagen.

Het Programma Andere Overheid is een kenmerkend voorbeeld van hoe het beleid met een governance-benadering ook anders had gekund.

\section{Interactieve beleidsvorming}

Op 1 december 1993 had het Kamerlid Wilbert Willems al een motie ingediend waarin hij de regering uitnodigde te gaan experimenteren met vormen van interactieve beleidsvorming. Verkeer en Waterstaat pakte dat op met Infralab en de opvolgers daarvan, maar Binnenlandse Zaken bleef toen buiten beeld. De kans om zich te verdiepen in horizontaal bestuur en procesmanagement deed zich voor toen de realisatie van grote infrastructurele projecten stuitte op veel weerstand uit de samenleving. De oude inspraak nadat al over de plannen was besloten, voldeed niet meer. De nieuwe organisatie van besluitvormingsprocessen met betrekken van de samenleving kon worden beschouwd als een puur bestuurlijk vraagstuk. Mede daarom (en omdat VROM en V\&W het elkaar niet gunden) mocht Binnenlandse Zaken een werkgroep Procesmanagement voorzitten, die moest adviseren aan de Ministeriële Commissie Economische Structuurversterking. Deze ervaring is hiervoor beschreven.

Toen het Expertisebureau Innovatieve Beleidsvorming XPIN samen met anderen in de Tweede Kamer het tienjarig jubileum van de motie-Willems herdacht, was er nog weinig fundamenteel in de rijksoverheid veranderd op dit punt. Er was veel weerstand vanuit de doctrine van de representatieve democratie, hoewel de Tweede Kamer dat zelden hardop durfde te zeggen. $\mathrm{Er}$ ontstonden twee kampen van 'gelovigen' en 'ongelovigen' tegenover elkaar. Het Programma Andere Overheid had het onderwerp burgerparticipatie ook op zijn werklijst staan, maar strandde met een nogal ongelukkige nota in de Tweede Kamer. Tom Keek deed een poging om naar aanleiding van rapporten van de commissie-Wallage (2001) en van de commissie-Docters van Leeuwen (2001) een draai te geven aan het discours: in plaats van burgerparticipatie zou 'maatschappelijke democratie' beter in deze tijd passen. Maar zijn discussienota kwam in 2005 niet verder dan de werkkamer van minister Pechtold, die aan het eind van zijn ministerschap terecht weinig trek had in dit debat met de Tweede Kamer. Uit diezelfde Tweede Kamer kwam overigens in 2007 wel steun voor nieuwe experimenten (proeftuinen) in de vorm van motie-Anker en amendement-Schinkelshoek, die het project In Actie met Burgers! opleverden. Het vervolg is uitgebreid beschreven in de Beleidsdoorlichting burgerparticipatie 2007-2011 (TK 2011-2012, bijlage bij 30985, nr. 7).

\section{Empowerment van burgers als nieuwe beleidsopgave}

Typerend voor verschillende kenmerken van de beleidsvorming binnen Binnenlandse Zaken was de uitkomst van de directeurenconferentie in 2006. De directeuren van het hele ministerie plachten een of twee keer per jaar bijeen te komen om gezamenlijke thema's te bespreken. Zo ook aan de vooravond van het kabinet-Balkenende IV in 2006. De directeuren keerden van de hei terug met een prioriteitenlijstje voor de komende periode, waar het ministerie aan zou moeten gaan werken. Bovenaan de top-3 stond de opgave van het ministerie om iets bij te dragen aan de empowerment van burgers die een steeds belangrijker rol in het politieke domein zouden krijgen. Wat later de 'doe-democratie' of de participatiemaatschappij zou gaan heten. Het vervolg kan hier niet diepgaand worden beschreven; volstaan wordt met de typerende elementen:

- het bottom-up karakter van de beleidsontwikkeling bij Binnenlandse Zaken wordt geïllustreerd door het volgende. Een van de directeuren had het op zich genomen dit thema uit te werken, maar hij had geen idee hoe en al spoedig kreeg de druk van zijn werkagenda hem in de greep. Tot een paar enthousiaste medewerkers van een andere directie lucht kregen van de uitkomst van het directeurenberaad en aanboden om de voorbereiding ter hand te nemen. Zij namen de 
kar op sleeptouw. Typerend is dat aan de top wel iets besloten kan worden, maar dat deze zelden het apparaat in het gelid zet.

- het heersende idee over beleid en de rol van Binnenlandse Zaken. Na een aantal concepten werd een kleine expertmeeting gehouden. Steeds was de vraag: maar wat kan Binnenlandse Zaken in hemelsnaam aan beleid toevoegen als het gaat om de toerusting van burgers? Aan het eind van de bijeenkomst leek het kwartje bij de desbetreffende beleidsdirecteur te vallen: "O, dus Binnenlandse Zaken zou een actieplan moeten opstellen waarbij alles wat bijdraagt aan actief burgerschap gesteund moet worden en alles wat daar afbreuk aan doet, wordt bestreden?" Inderdaad, dat was ongeveer de uitkomst, maar voor deze directeur het teken dat hij er niets mee kon. Veel te open voor planning en controle. Dus niet passend in zijn beeld van beleid (bijna synoniem aan regelgeving).

- het gebrek aan cement binnen het departement. Als de collectiviteit van directeuren besluit tot een bepaalde prioriteitstelling, zou men verwachten dat zij hier vervolg aan geven, hun

belangstelling op het onderwerp richten, over de uitwerking informeren en elkaar aanspreken op relevante ontwikkelingen op dit terrein. Niets van deze verwachtingen werd gerealiseerd. Het klusje is toegedeeld en daarmee is de kous af. Toen er weinig uitkwam, is er ook nooit meer op aangedrongen vanuit de organisatie. In lijn met het bovenstaande, zou deze merkwaardige gang van zaken betrekking kunnen hebben op de gevoeligheid van het onderwerp. Maar het is ook een deel van de organisatiecultuur: ieder voor zich.

\subsubsection{Aanwijzingen voor de gehanteerde bestuurstheorie}

Interpretatie tegen de achtergrond van de begrippen government en governance Het was een duidelijk geluid uit de sfeer van netwerkbestuur/governance, maar de lotgevallen van dit thema binnen het ministerie en de bijbehorende parlementaire vakcommissie, bevestigen het beeld dat deze benadering niet dominant is. In tegendeel, hoe verder in de tijd en hoe harder de roep om verandering, hoe strakker lijkt te worden vastgehouden aan politiek primaat (Van Twist et al., 2009: 108). Het binnendringen van governance-elementen binnen Binnenlandse Zaken was een ambtelijke aangelegenheid, maar betrof vooral de democratie-opvatting en de sturingsaanpak. Ook de informatie- en leerprocessen die de innovators in dit project hanteerden, kenmerken zich door verkennen en verbinden van best practices uit het grondvlak. De informatievergaring was zoekend en sloot aan bij incidentele best practice. Bottom-up dus. Alleen de doelstelling van de inspanningen is moeilijk te plaatsen als meer of minder bestuurscentrisch. Procesmanagement kan zeer wel worden geïnterpreteerd als verplaatsing van de scope van het bestuur ter wille van meer effectieve beheersing. Anderzijds was de doelstelling gericht op het versterken van samenwerking en probleemoplossing, niet op het versterken van het bestuurscentrum door scherpere taakafbakening.

In alle vier kenmerken zien we dus de governance-aanpak bovenkomen, alleen het thema kan niet mainstream worden zolang de (politieke) leiding er niet aan wil. Hoe het zij, zolang met deze benadering het hart van de democratie, de politieke partijen en de media niet wordt geraakt, kan het niet echt beklijven.

\subsubsection{Typering van dit project volgens overige onderzoekscriteria}

Mate van beleidsvernieuwing

Dit onderwerp was voor Binnenlandse Zaken fonkelnieuw. Het ministerie ging er dan ook nogal onwennig mee om. Besluitvormingsprocessen kwamen wel eens ter sprake bij de interne advisering over ministerraadstukken, maar een eigen positiebepaling over de proceskwaliteit in wisselwerking met de samenleving was niet eerder voorgekomen. Een beleidsinnovatie dus, en dit keer wellicht een die met horten en stoten wel doorzet vooral in de periode die volgt op het afsluiten van dit onderzoek, maar immer in de marge van het beleid. 
De gedachte om 'Binnenlandse Zaken bestuursdepartement' nieuwe inhoud te geven op basis van maatschappelijke ontwikkelingen van mondige burgers, medebetrokkenheid van maatschappelijke partners en zelforganisatie kwam uit ambtelijke hoek. Deze benadering werd even door de zittende ministers geduld, maar de afstand tussen representatieve en participatieve democratie bleek voor de politieke arena (minister, volksvertegenwoordiging, partijen) niet overbrugbaar. De gebrekkige naleving van toezeggingen aan de Tweede Kamer om beleidsstukken te leveren over het thema burgerparticipatie (en stilzwijgen van het parlement daarover) geeft aan hoe gevoelig de spanning tussen representatieve en participatieve democratie in het bestuursbeleid wordt beleefd.

De ambtenaren wisten ook niet de juiste toon te treffen en operationele middelen aan te reiken om de omslag in de samenleving te faciliteren. De impact op de bestuurstheorie van Binnenlandse Zaken was, althans in de onderzochte periode, niet significant. Het idee om onderhandelend bestuur, burgerparticipatie en zelforganisatie een plaats te geven in het bestuursbeleid was een ambtelijk initiatief dat door de politieke leiding werd gedoogd, maar kon niet doorbreken als een structureel alternatief. Het bleef steken in het verbinden van individuele voorbeelden en praktijken.

\subsubsection{Conclusies}

Ondanks enige twijfel ten aanzien van de doelstelling kan dit initiatief als governance-project worden voorzien van score $B$. De korte geschiedenis van de wijze waarop wordt gereageerd op de opkomst sinds de jaren negentig van burgerparticipatie en interactieve beleidsvorming leert dat deze breed in de vakdepartementen en gemeenten opgepakte ontwikkeling niet organisch wordt geabsorbeerd in de bestuurstheorie van Binnenlandse Zaken, maar veeleer wordt afgestoten.

Vooral de interactie met het parlement over dit onderwerp is tekenend voor de ambivalentie die de politieke elite hierbij ten toon spreidt. Enerzijds kan men zich natuurlijk niet permitteren burgerinvloed en -betrokkenheid af te wijzen, maar het gebrek aan follow-up na verbale aansporingen wijst op dieper liggende onverschilligheid en zelfs weerzin tegenover participatieve vormen van democratie. Dit vormt een van de vier lakmoesproeven voor de shift naar governance. In dat opzicht is de hier geschetste ontwikkeling exemplarisch voor het hele domein: er waren wel initiatieven binnen Binnenlandse Zaken om te pionieren met vernieuwing, maar uiteindelijk wordt die niet omarmd in een vernieuwde bestuurstheorie.

\subsection{Resumé en conclusies}

\section{Samenvattend overzicht}

Over de talrijke projecten die gericht waren op een vrij fundamentele organisatieverandering in de rijksdienst hebben de mensen van NSOB een overzichtsstudie gemaakt (Van Twist et al., 2009). Zij stellen vast dat er veel is gebeurd. Figuur 9.1 geeft een opsomming van de resultaten zoals deze in verschillende studies worden genoemd. 81

Figuur 9.1 Overzicht van pogingen tot reorganisatie van de rijksdienst

81 Dit overzicht, uit Van Twist et al. 2009, is gebaseerd op de inventarisaties in het rapport van de Rob 'Cultuur met een FORS postuur' uit 2004, het boek van D.M.E. Hovestadt 'Concern over het Rijk of het Concern Rijk?' uit 2007 en de Tweede tussenrapportage project Vernieuwing Rijksdienst uit 2009. Daarbij moet worden opgemerkt dat niet alle veranderingen direct een gevolg zijn van de respectievelijke veranderpogingen.

Sommige zijn in een bepaald rapport al genoemd, maar hadden een bepaalde 'incubatieperiode' nodig, voordat ze ook daadwerkelijk zijn ingevoerd. Het jaartal tussen haakjes geeft aan wanneer vervolgens de uiteindelijke implementatie van de desbetreffende aanbeveling plaats heeft gehad. Veranderpogingen die niet genoemd zijn, hebben, in ieder geval naar de mening van de bestudeerde bronnen, geen echte doorwerking gehad. 


\begin{tabular}{|c|c|}
\hline Veranderpoging & Concrete opbrengsten \\
\hline Van Veen (1971) & $\begin{array}{l}\text { - Verbetering van de (inter)departementale coördinatie door aanwijzing } \\
\text { coördinerende bewindsman voor belangrijke beleidsterreinen. } \\
\text { - Wetenschappelijke Raad voor het Regeringsbeleid wordt opgericht. } \\
\text { - Sociaal en Cultureel Planbureau wordt opgericht. }\end{array}$ \\
\hline WRR (1975) & $\begin{array}{l}\text { - Snoeien in 'wildgroei' adviesorganen, uiteindelijk bereikt door } \\
\text { Aanwijzingen Inzake adviesorganen (1978) }\end{array}$ \\
\hline MITACO (1977) & $\begin{array}{l}\text { - Introductie coördinatiestelsel (met als ingrediënten een uiteindelijke } \\
\text { beslissingsbevoegdheid bij de ministerraad, de introductie van onderraden } \\
\text { voor bredere beleidsgebieden en de daadwerkelijke introductie van } \\
\text { coördinerende bewindspersonen voor bepaalde beleidsgebieden) }\end{array}$ \\
\hline Vonhoff (1979) & $\begin{array}{l}\text { - Grootschalige hervormingsoperatie (Projectorganisatie Rijksdienst, } \\
\text { Herman Tjeenk Willink als speciale Regeringscommissaris Reorganisatie } \\
\text { Rijksdienst en oprichting Adviescommissie Reorganisatie Rijksdienst (ARD). } \\
\text { - Integrale aanpak personeelsontwikkeling door 'civil service' (later ABD, 1995) } \\
\text { en ontwikkeling Rijksdienstbreed personeelsbeleid (2003) } \\
\text { - Toename van projectmatig werken binnen en tussen departementen }\end{array}$ \\
\hline Reorganis. rijksdienst & $\begin{array}{l}\text { - Sanering aantal coördinerende bewindslieden en } \\
\text { projectbewindspersonen (1983-1986) } \\
\text { - Herziening stelsel externe adviesorganen en interdepartementale } \\
\text { commissies }\end{array}$ \\
\hline $\begin{array}{l}\text { Verbaan }(1983,1985) \\
\text { Wiegel }(1993)\end{array}$ & $\begin{array}{l}\text { - Zelfbeheer (decentralisatie van beheersbevoegdheden) } \\
\text { - Oprichting ABD (1995) en stimulering projectmatig werken in kader van } \\
\text { ABD-interimpool } \\
\text { - Fundamentele herbezinning op betere (onder)scheiding van beleid, } \\
\text { uitvoering en toezicht } \\
\text { - Introductie programmaministers ('ministers voor brandende kwesties') }\end{array}$ \\
\hline SG's (1993) & $\begin{array}{l}\text { - Interne verzelfstandiging komt nadrukkelijk op de agenda te staan (forse } \\
\text { groei aantal agentschappen) } \\
\text { - Denken in resultaten van beleid komt terug in VBTB-operatie (1999) }\end{array}$ \\
\hline & $\begin{array}{l}\text { - Herijking ministeriële verantwoordelijkheid (nu bepaald door de reikwijdte } \\
\text { van zijn/haar formele bevoegdheden) }\end{array}$ \\
\hline PAO (2003) & $\begin{array}{l}\text { - Minister voor Bestuurlijke Vernieuwing wordt aangewezen om } \\
\text { Vernieuwing Rijksdienst groots aan te pakken } \\
\text { - Resultaten op actielijnen }\end{array}$ \\
\hline $\begin{array}{l}\text { Vernieuwing Rijksdienst } \\
\text { (2007-2009) }\end{array}$ & $\begin{array}{l}\text { - DG Organisatie en Bedrijfsvoering rijk wordt opgericht om bedrijfsvoering } \\
\text { op hoger niveau te tillen } \\
\text { - Introductie nieuwe Rijkshuisstijl, één logo voor de gehele rijksdienst om } \\
\text { enkelvoudige en duidelijke identiteit van het Rijk te creëren } \\
\text { - Vorming van Rijksbrede ondersteunende diensten (Werkmaatschappij etc.) }\end{array}$ \\
\hline
\end{tabular}

Conclusies in het kader van dit onderzoek

Het ontwikkelde beleid sinds de commissie-Van Veen uit 1971 was een doelgerichte beleidsopvolging van langere traditie die is begonnen binnen het ministerie van Financiën. Sindsdien is het beleid een lange keten van aanpassingen geweest binnen dezelfde denklijn. Oriëntatie van de rijksdienst op de burger kan als relatieve beleidsinnovatie worden beschouwd.

Dit dossier is heel vaak geëvalueerd, maar dat betekent niet dat er daadwerkelijk is geleerd. Het beleid maakt nogal een wispelturige indruk. Denk aan de regressieve actie van de commissieKohnstamm die opeens terugdraaien van de verzelfstandigingen ging bepleiten of aan het weinig doelgerichte samenspel met de Tweede Kamer over beleidskader voor interactieve beleidsvorming. 
Kenmerkend voor de vernieuwing van de rijksdienst is de managementbenadering. Alles draait om beheersing en beheersbaarheid. Veelal worden veranderingen via zogenaamd ondergeschikte bedrijfs- en beheersprocessen aangezwengeld. Zo werd de invoering van 'VBTB' van grote invloed op het reilen en zeilen van het systeem van het openbaar bestuur: gepresenteerd als een aanpassing in het beheer van de rijksdienst. Niettemin was dit van grote betekenis voor het primaire proces van de organisatie. In soortgelijke beweringen bespreken ook Van Twist cum suis (2009) de vernieuwing van de rijksdienst.

Uit de lijst van activiteiten in figuur 9.1 zijn relatief weinig kenmerken van een governancebenadering te halen of die moet gezocht worden in de jaarberichten van de Regeringscommissaris Tjeenk Willink of in retorische uitingen rond het Programma Andere Overheid.

Hierboven zijn uit de enorme veelheid van projecten en initiatieven ter verbetering van de rijksdienst twee voorbeelden naar voren gehaald, die een potentiële wending naar netwerkbestuur inhielden.

De verzelfstandiging van de uitvoering zou de aanzet kunnen leveren tot een proliferatie van bestuurspraktijken en institutionele kernen van professionele specialisatie, waar samenwerking rond praktische problemen met veel partners onvermijdelijk zou kunnen worden. Binnenlandse Zaken pikte deze ontwikkeling duidelijk op met als hoofdinzet om de verzelfstandiging te breidelen en ondergeschikt te maken aan een uniform kader. Volstrekt begrijpelijk, maar vooral vanuit de behoefte om de beheersbaarheid vanuit een machtscentrum mogelijk te maken en minder om het probleemoplossend vermogen en de kwaliteit van de dienstverlening in 'het veld' te verbeteren.

De kortstondige bemoeienis van Binnenlandse Zaken met het onderwerp interactieve beleidsvorming en maatschappelijke democratie illustreert dat de aanvechtende benadering van netwerkbestuur/governance nu en dan wel degelijk gehoor vond, maar het gebrek aan follow-up en doorwerking ${ }^{82}$ van dit onderwerp maakt duidelijk dat de government-benadering en het bijbehorende politiek primaat uiteindelijk dominant is.

\footnotetext{
82 De hernieuwde opleving van het onderwerp in een afdeling Democratie en Burgerschap blijt buiten het bestek van dit boek. In de beschreven periode tot 2008 was er voor dit onderwerp weinig interesse binnen de top van Binnenlandse Zaken. Opvallend is dat bij een aantal lagere ambtenaren van verschillende onderdelen zonder functionele band met het onderwerp zoals Brandweer en Bureau SG uit persoonlijke belangstelling een eigen netwerk rond dit thema werd gestart, wat in 2006 leidde tot een publicatie van een handreiking voor het betrekken van burgers bij beleid voor intern gebruik binnen Binnenlandse Zaken. Dat mocht toch maar allemaal. Na 2008 kwam het onderwerp steeds meer in de belangstelling, vooral toen de thematiek zich verlegde naar de doe-democratie en de participatiemaatschappij.
} 


\section{Constateringen over het totale bestuursbeleid in de periode 1969-2009}

\subsection{Inleiding}

Nu de casussen zijn behandeld, wordt het tijd om de oogst te verzamelen. In dit verzamelhoofdstuk worden achtereenvolgens de volgende onderdelen gepresenteerd:

- $\quad$ bijeenbrengen van de resultaten met betrekking tot de hoofdvraag van dit onderzoek (paragraaf 10.2);

- $\quad$ bijvangst, overige constateringen die gaandeweg zijn opgevangen (paragraaf 10.3);

- $\quad$ mogelijke verklaringen van de uitkomsten, die concurreren met de conclusie dat zij wijzen op het uitblijven van een shift van government naar governance (paragraaf 10.4);

- $\quad$ reflectie om van de vele verhalen te komen naar een groot verhaal van het bestuursbeleid als toegift (paragraaf 10.5).

Het verzamelen van bevindingen is nog niet hetzelfde als het trekken van conclusies over het geheel. Dat volgt in hoofdstuk 14.

\subsection{Verzamelde resultaten met betrekking tot de hoofdvraag}

\subsubsection{Inleiding}

De gestelde verwachtingen

In hoofdstuk 1 is op basis van bestaande wetenschappelijke literatuur een aantal verwachte uitkomsten geformuleerd. Een belangrijke, vaak terugkerende verhaallijn in de bestuurskunde is in hoofdstuk 2 herkend als: we maken een shift mee van government naar governance. De vraag die werd gesteld is of deze shift ook bij het beleid met betrekking tot dat openbaar bestuur terugkeert: maakt de focus van dat beleid een kanteling naar het samenspel tussen vele actoren in de samenleving rond concrete issues en problemen? Hogwood en Peters ontdekten dat het meeste beleid voortbouwt op al bestaand beleid en dus incrementele verandering vertoont.

Beleidsorganisaties zijn hardnekkig. Van der Heijden, Peters en Schrijver analyseerden de vertooggemeenschap rond een traditioneel departement als Binnenlandse Zaken en op basis daarvan werd de verwachting geformuleerd dat het bestuursbeleid deze draai niet (of nog niet) meemaakt. De onderlinge verwevenheid (hiërarchie) tussen de verschillende dossiers zou wel herkenbaar moeten zijn, zozeer dat eigenlijk sprake is van een duidelijke continue hoofdlijn en dominant streven dat in andere dossiers doordringt. Dat zou het decentralisatiestreven kunnen zijn of nog breder het streven naar versterking van de integrale afweging van beleidsafwegingen op passend bestuursniveau door de representatief gekozen politieke democratie. Deze hoofdlijn valt niet te rijmen met een veronderstelde shift van government naar governance, zoals die hier is gedefinieerd.

Het relevante subsysteem voor het onderzoeken van het discours in het bestuursbeleid Een van de conclusies die gaandeweg zijn opgetekend, is dat Binnenlandse Zaken geen duidelijk partnerschap ontwikkelde met andere organisaties dat een consistent blok vormde in het bestuursbeleid. VNG en IPO waren lang niet altijd vaste bondgenoten. Denk aan de discussies over het middenbestuur en over verschillende onderwerpen waar Binnenlandse Zaken zich als hogere overheid opstelde om het landsbestuur te ordenen. Ook financieel liepen de belangen vaak uiteen. Vakdepartementen wisselden ook frequent van affiniteit op het terrein van bestuursbeleid. Hoewel ze niet principieel gekant waren tegen decentralisatie, hadden ze grote moeite met het 
tempo en de voorwaarden van Binnenlandse Zaken. Eigenlijk waren alleen Kamerleden in de Vaste Commissie van Binnenlandse Zaken van nature geneigd het ministerie te volgen, al speelden daar natuurlijk ook politieke overwegingen van coalitie en oppositie. Maar het politieke discours liep meestal parallel of was nog uitgesprokener, zoals we in hoofdstuk 11 zullen zien. Daarom is het verantwoord om in dit onderzoek het algemene discours over bestuursbeleid vooral te ijken aan de uitspraken en het gedrag van het ministerie zelf.

\subsubsection{Ontwikkeling en onderhoud van de bestuurstheorie}

Op verschillende momenten in de beschreven beleidsgeschiedenis is fundamenteel nagedacht over de kernopgave van het openbaar bestuur of over de rol van het bestuursdepartement daarin. Daarbij valt te denken aan de discussies in de vele commissies over de organisatie en het functioneren van de rijksdienst, de organisatie van het binnenlands bestuur en de coördinerende taak van Binnenlandse Zaken. Deze uitgangspunten van beleid waren onmiskenbare stellingnamen voor een krachtig, uniform en integraal bestuur met rationele besluitvormingsmethoden onder een democratisch gekozen volksvertegenwoordiging. Sommigen verklaren dat deze positiekeuze al onhoudbaar was op het moment dat zij werden ontwikkeld in de jaren zeventig (Van der Heijden, 1990: 207). Hoe dan ook, latere soortgelijke ijkmomenten van deze bestuurstheorie waarbij een antwoord werd geformuleerd op de onmiskenbare maatschappelijke ontwikkelingen van individualisering, belangenemancipatie en fragmentatie zijn uitgebleven. Of liever: ze waren er wel, maar ze leverden niet veel meer op dan vragen en mistigheid in de beantwoording. In ieder geval kwamen er geen ondubbelzinnige aanvullingen op het Grote Verhaal van Binnenlandse Zaken uit voort. Te noemen zijn bijvoorbeeld: de niet echt opgepakte discussies over complementair bestuur, het slotadvies van de RBB en de kabinetsreactie op dit 'Besturen op de tast', en de essays van minister Peper 'Op zoek naar samenhang en richting'. Er was inderdaad vooral een opmerkelijk tekort aan samenhang en richting in een consequente gecumuleerde beleidsontwikkeling om antwoord te geven op de vele analyses dat er een kloof moest worden gedicht, effectiviteit moest worden verbeterd, vertrouwen gezaaid en innovatie moest worden beproefd. Alle innovatieinstrumenten werden na korte tijd weer aan de kant gezet. Het laatst overkwam dat InAxis, het project Governance, de programmadirectie Krachtig Bestuur. Eerder zijn al genoemd sociale vernieuwing, Ketenregie, Bedrijfsbetrokkenheid en het project Differentiatie. Op deze manier, voortwerkend op een toen al overleefde bestuurstheorie uit de jaren zeventig kon er geen sprake zijn van een vitaal groeiende en tegen de tijdsomstandigheden bestand zijnde bestuurstheorie. Binnenlandse Zaken kon zo ook niet met gezag leidinggeven aan de bestuurlijke ontwikkelingen in de hele overheid. Het gegeven dat Binnenlandse Zaken zich eclectisch met steeds slechts enkele onderwerpen uit het bestuursbeleid bezighield, is een mogelijke verklaring voor de beperkte inzet voor de ontwikkeling van een robuuste bestuurstheorie. Zoals geconstateerd noemde het ministerie zich wel graag het Bestuursdepartement, maar kon het deze titel niet echt waarmaken voor alle voor de ontwikkeling van het openbaar bestuur relevante onderwerpen. Ook het leerinstrument evaluatie blijkt niet systematisch te zijn ingezet om bij te dragen aan het ontwikkelen van een solide bestuurstheorie of een beweging daar naartoe.

De oprichting van een centrale kenniseenheid SKO binnen DGKB sinds 2004, later verder uitgebreid tot een ministeriebrede centrale kenniseenheid voor onderzoek en strategische kennisontwikkeling was een verdienstelijke poging van SG Holtslag om in die richting te investeren. Dit boek biedt geen evaluatie van deze inspanningen, maar door zijn positionering vlak onder de SG stond deze centrale stafeenheid te ver van de beleidseenheden in het vooronder af om cement aan te brengen tussen de diverse onderdelen en leiding te kunnen geven aan de strategische visievorming. De evaluatie wordt impliciet door het ministerie zelf onderstreept door opheffing van de centrale strategische kenniseenheid in 2013.

Na deze samenvattende beschouwing over de eerste hoofdvraag betreffende de bestuurstheorie van Binnenlandse Zaken, komt nu de hoofdvraag met betrekking tot de verwachte omwenteling in de inhoud van die theorie aan de orde. 


\subsubsection{Gevonden patronen: shift of geen shift?}

Herkenbaarheid van de denktegenstelling in de dossiers van het bestuursbeleid

Met behulp van de hier gehanteerde variant van discoursanalyse is aan de discussies over fundamentele ontwikkelingen in het bestuursbeleid een aantal vrij scherpe tegenstellingen (verhaallijnen) te ontlenen die overeenkomen met het onderscheid zoals dat hiervoor is gepresenteerd tussen government en governance. Per domein zijn de volgende dichotomieën te noemen:

- Bestuurlijke organisatie is een kwestie van verdelen van verantwoordelijkheden versus Bestuur is een kwestie van delen van verantwoordelijkheden (samenwerken).

- Financiële Verhouding(en) is beter naarmate de middelen meer op basis van objectieve criteria worden verdeeld versus - Financiële Verhouding(en) is beter naarmate de middelen daar terecht komen waar de besteding de meeste maatschappelijke meerwaarde oplevert.

- Decentralisatie is herstel van machtsverdeling en beklemtonen van autonomie van gemeenten en provincies versus - Decentralisatie is voorwaarde voor optimale (gezamenlijke) oplossing van maatschappelijke problemen.

- Achterstandsproblematiek vergt hoge beleidsinzet en integrale planning vanuit het gemeentelijk beleidscentrum versus - Achterstandsproblematiek vergt gezamenlijke inzet van alle betrokkenen, niet in de laatste plaats die van de bewoners en hun organisaties.

- Informatiesystemen maken de bestuurlijke werkelijkheid kenbaar en beheersbaar door objectieve en koppelbare bestanden op het laagste niveau versus - Moderne informatie (internet) is zelforganiserend.

- De rijksorganisatie dient te worden ingericht met het oog op optimale werking van de ministeriële verantwoordelijkheid (politiek primaat) versus - De rijksorganisatie dient te draaien om effectiviteit van taakuitoefening te realiseren, waarbij democratische controle kan worden vervuld door checks and balances of door horizontale verantwoording.

Samenvatting van bevindingen uit de casussen De empirische beschrijvingen van het bestuursbeleid in vijf dossiers zijn in de hoofdstukken 5 tot en met 9 te vinden. De uitkomsten zijn daar ook uitvoerig onderbouwd. Hier volgen de scores in een samenvattend overzicht. De laatste kolom geeft antwoord op de gestelde vraag.

Figuur 10.1 Analyse van de 24 casussen in tabelvorm

\begin{tabular}{|l|l|l|l|l|l|l|}
\hline & $\begin{array}{l}\text { I } \\
\text { Mate van } \\
\text { Beleids- } \\
\text { veranderin } \\
g\end{array}$ & Evaluatie & $\begin{array}{l}\text { III } \\
\text { Typering van } \\
\text { Bestuurstheorie }\end{array}$ & $\begin{array}{l}\text { IV } \\
\text { Doorwer- } \\
\text { king }\end{array}$ & $\begin{array}{l}\text { V } \\
\text { Indicatie } \\
\text { voor } \\
\text { shift }\end{array}$ & $\begin{array}{l}\text { VI } \\
\text { Invloed op } \\
\text { Bestuurs- } \\
\text { theorie }\end{array}$ \\
& $\begin{array}{l}\text { Typering } \\
\text { Hogwood/ } \\
\text { Peters } \\
\text { t.b.v. } \\
\text { bestuurs- } \\
\text { theorie }\end{array}$ & $\begin{array}{l}\text { Government of } \\
\text { governance 1) }\end{array}$ & $\begin{array}{l}\text { Institutio- } \\
\text { nalisering }\end{array}$ & $\begin{array}{l}\text { (combinatie } \\
\text { van } \\
\text { kolommen } \\
\text { I, II en III) }\end{array}$ & $\begin{array}{l}\text { veel of weinig, } \\
\text { statisch of } \\
\text { dynamisch 2) }\end{array}$ \\
\hline Dossier bestuurlijke organisatie & & & & & \\
\hline
\end{tabular}




\begin{tabular}{|c|c|c|c|c|c|c|}
\hline $\begin{array}{l}\text { 1. Reorgan. Binn. } \\
\text { Bestuur } \\
\text { 2. Complementair } \\
\text { Bestuur } \\
\text { 3. VBO/Stadsprovincies } \\
\text { 4. Middenbestuur } \\
\text { 5. Dualisering }\end{array}$ & $\begin{array}{l}\text { opvolging } \\
\text { innovatie } \\
\text { aanpassing } \\
\text { opvolging } \\
\text { aanpassing }\end{array}$ & $\begin{array}{l}- \\
- \\
- \\
- \\
\pm\end{array}$ & $\begin{array}{l}A \\
A-\text { (multi-level) } \\
A \\
A \\
A-\text { (implementatie) }\end{array}$ & $\begin{array}{l}- \\
- \\
- \\
- \\
+\end{array}$ & $\begin{array}{l}\text { Nee } \\
\text { Nee } \\
\text { Nee } \\
\text { Nee } \\
\text { Niet echt }\end{array}$ & $\begin{array}{l}2 \\
4 \\
4 \\
4 \\
3\end{array}$ \\
\hline \multicolumn{7}{|c|}{ Dossier interbestuurlijke betrekkingen en decentralisatie } \\
\hline $\begin{array}{l}\text { 6. Coördinerende Taak } \\
\text { 7. Offensief Dec. beleid } \\
\text { 8. Specif. Uitkeringen } \\
\text { 9. Bestuursakkoorden } \\
\text { 10. D'gemeenten } \\
\text { 11.Decentralisatie- } \\
\text { impuls } \\
\text { 12.Decentr. met beleid } \\
\text { 13.Differentiatie }\end{array}$ & $\begin{array}{l}\text { innovatie } \\
\text { aanpassing } \\
\text { aanpassing } \\
\text { opvolging } \\
\text { aanpassing } \\
\text { aanpassing } \\
\text { opvolging } \\
?\end{array}$ & $\begin{array}{l} \pm \\
+ \\
- \\
\pm \\
- \\
- \\
- \\
-\end{array}$ & $\begin{array}{l}\text { A- (zoektocht) } \\
\text { A } \\
\text { A } \\
\text { A- (opzet BANS) } \\
\text { A- (bottom-up) } \\
\text { A } \\
\text { B } \\
\text { B }\end{array}$ & $\begin{array}{l}+ \\
+ \\
+ \\
+ \\
- \\
- \\
- \\
-\end{array}$ & $\begin{array}{l}\text { Nee } \\
\text { Nee } \\
\text { Nee } \\
\text { Niet echt } \\
\text { Nee } \\
\text { Nee } \\
\text { Nee } \\
\text { Nee }\end{array}$ & $\begin{array}{l}1 \\
2 \\
2 \\
2 \\
4 \\
4 \\
3 \\
4\end{array}$ \\
\hline \multicolumn{7}{|c|}{ Dossier kwaliteitsimpuls lokaal bestuur (achterstandsproblemenbeleid en informatievoorziening) } \\
\hline $\begin{array}{l}\text { 14. Minderhedenbeleid } \\
\text { 15. Sociale vernieuwing } \\
\text { 16. Grotestedenbeleid } \\
\text { 17. } \\
\text { Bedrijfsbetrokkenheid } \\
\text { 18. BBI/Single Audit } \\
\text { 19. ICT-beleid/GBA } \\
\text { 20. } \\
\text { Kwaliteitsinstrumenten } \\
\text { 21. Ketenregie }\end{array}$ & $\begin{array}{l}\text { ? } \\
\text { opvolging } \\
\text { aanpassing } \\
\text { innovatie } \\
\text { aanpassing } \\
\text { aanpassing } \\
\text { opvolging } \\
\text { innovatie? }\end{array}$ & $\begin{array}{l} \pm \\
\pm \\
+ \\
- \\
- \\
- \\
- \\
-\end{array}$ & $\begin{array}{l}A- \\
B-(\text { wijkaanpak }) \\
A-(\text { experimenten }) \\
B \\
A-(\text { het land in) } \\
A-(\text { multi-level) } \\
B-\text { (vraaggericht) } \\
B\end{array}$ & $\begin{array}{l} \pm /- \\
- \\
+ \\
- \\
+ \\
+ \\
- \\
-\end{array}$ & $\begin{array}{l}\text { Nee } \\
\text { Nee } \\
\text { Niet echt } \\
\text { Nee } \\
\text { Nee } \\
\text { Niet echt } \\
\text { Nee } \\
\text { Nee }\end{array}$ & $\begin{array}{l}4 \\
3 \\
3 \\
4 \\
4 \\
2 \\
3 \\
4\end{array}$ \\
\hline \multicolumn{7}{|c|}{ Dossier organisatie en werkwijze rijksdienst } \\
\hline $\begin{array}{l}\text { 22. Reorganisatie } \\
\text { Rijksd. } \\
\text { 23. Verzelfstandiging } \\
\text { 24. Interactief bestuur }\end{array}$ & $\begin{array}{l}\text { innovatie } \\
\text { opvolging } \\
\text { innovatie? }\end{array}$ & $\begin{array}{l}+ \\
- \\
-\end{array}$ & $\begin{array}{l}A \\
A \\
B\end{array}$ & $\begin{array}{l} \pm /- \\
+ \\
-\end{array}$ & $\begin{array}{l}\text { Nee } \\
\text { Nee } \\
\text { Nee }\end{array}$ & $\begin{array}{l}2 \\
4 \\
3\end{array}$ \\
\hline $\begin{array}{l}\text { 1) Government of gove } \\
\text { A = government } \\
B=\text { governance } \\
\text { A - = overwegend govern } \\
B \text { - = overwegend goverr } \\
\text { 2) Invloed op bestuurs } \\
1=\text { veel/dynamisch } \\
2=\text { veel/statisch } \\
3=\text { gering/dynamisch } \\
4=\text { gering/statisch }\end{array}$ & $\begin{array}{l}\text { nance } \\
\text { nent-modus m } \\
\text { ince-modus m } \\
\text { leorie }\end{array}$ & t enk & $\begin{array}{l}\text { ernance-elementen } \\
\text { ernment-elementen }\end{array}$ & & & \\
\hline
\end{tabular}

Van de 24 projecten laten zich acht typeren als innovaties en tien andere als beleidsopvolgende vernieuwingen. Dat betekent dat er nog best wat vernieuwing werd geprobeerd. 
Daarentegen blijkt uit de tweede kolom dat bitter weinig evaluatie plaatsvond. Hoe kan het ministerie zo bouwen aan een consistente opgaande beleidslijn?

In de derde kolom zien we erg veel government-oriëntatie. De aanduiding A - betekent dat elementen van governance in combinatie met government optraden. Dat ligt aan de manier van beleidsvoorbereiding (D'gemeenten) of implementatie (Dualisering), aan bepaalde deelprojecten (grotestedenbeleid en ICT-beleid). Soms (B -) had de governance-modus zelfs de overhand in de mix (sociale vernieuwing, Kwaliteitsinstrumenten).

Maar dan volgt de vierde kolom, die in combinatie met de derde onthullend is: juist overal waar elementen van governance-oriëntatie worden geprobeerd, is er geen doorwerking. Dat wil zeggen dat deze denkwijze geen hegemoniale status heeft bereikt, waarvoor immers institutionele verankering nodig is. De combinatie leidt tot de uitkomsten in de voorlaatste kolom: er is geen sprake van de gezochte omslag of shift, want als er een aanvechting tot governance-benadering doorschemert, wordt deze weer spoedig gesmoord.

De laatste kolom indiceert welke projecten het meest een stempel drukten op de dominante bestuurstheorie en in hoeverre zij gaandeweg de invloed van de maatschappelijke omgeving absorbeerden. Behalve wellicht de voortdurend zoekende coördinerende taak is er geen project gevonden, dat zowel invloedrijk als enigszins bij de tijd blijvend kan worden genoemd. Er waren vijf projecten die een langdurig stempel drukten op het bestuursbeleid, vooral in het decentralisatiedossier. Ten slotte waren er zes projecten in de categorie dynamisch praktijkontwikkelingen volgend. Deze kwamen niet onverwacht vooral voor in de dossiers waar kwaliteitsimpulsen voor het lokaal bestuur werden gegeven.

Een paar voorbeelden worden eruit gelicht om de tabel iets meer te laten spreken. De nummering komt overeen met die van de projecten in hoofdstuk 1.

1. De reorganisatie binnenlands bestuur was een echte innovatie, omdat het Rijk voor het eerst sinds de Franse tijd geheel nieuwe provincies ging tekenen, en wel uit oogpunt van bestuurlijke samenhang. Het doel was bij uitstek bestuurscentrisch en dat was ook de aanpak. Die was er één vanuit de ivoren toren. De beleidswerkelijkheid werd rationeelwetenschappelijk opgebouwd. De mislukking was totaal. Evaluatie bleef uit. De achterliggende beleidsambitie bleef echter decennialang hangen.

2. De werkgroep Complementair Bestuur ging uit van een nieuw bestuursconcept (samenwerking), de samenstelling van de werkgroep was divers en eminent. De werkgroep legde een interimrapport neer voor reacties uit het veld. Daarmee houdt het governancegehalte wel op. Relaties met maatschappelijke partners ontbraken in het gezichtsveld van de werkgroep (geen netwerkbestuur) en de focus bleef rationeel-deductief. Het rapport verdween in een diepe la.

5. Dualisering was gericht op onder meer versterking van de lokale representatieve democratie. De verhouding tussen raad en dagelijks bestuur liet de samenleving vrijwel ongemoeid. De structuurverandering is succesvol doorgevoerd, de invoering van de cultuuraanpassing in de Vernieuwingsimpuls was bijzonder in de zin dat ook ambtenaren van Binnenlandse Zaken afdaalden naar de gemeenten. Evaluatie heeft meermaals plaatsgevonden. Er was dus iets van een leerproces.

6. De coördinerende taak was evenals de bestuurlijke reorganisaties uit de jaren zeventig (1, 22) gericht op ordening van het bestuurscentrum, maar dit keer vooral om de gemeentelijke autonomie te beschermen. De doorwerking was maximaal, want dit ziet Binnenlandse Zaken nog steeds als een centrale opgave. Evaluatie in formele zin was er niet, wel voortdurende interne bezinning in de zoektocht naar goed bestuur bij anderen.

9. De Bestuursakkoorden tussen de drie bestuurslagen zijn per definitie horizontaal bestuur, maar de werking bleef voornamelijk steken op Haags niveau. Dit werd in theorie anders bij het Bestuursakkoord-nieuwe stijl, omdat daar de opzet was gericht op gezamenlijke probleemaanpak. Ook daar bleven de meeste onderwerpen, op één na, echter steken op 
Haags papieren werk. Bestuursakkoorden als werkafspraken tussen Rijk, VNG en IPO werden een 'onmisbare' traditie van 1987 tot 2011 zonder dat er veel nieuws van buiten werd ingebracht, want de buitenwacht zat niet aan tafel.

12. De laatste jaren van de twintigste eeuw lieten een opleving zien van zelfreflectie binnen het dossier van de interbestuurlijke betrekkingen: 'Besturen op de tast', 'Decentraliseren met beleid' en 'Op zoek naar samenhang en richting' van Bram Peper. Uitstapjes naar procesmanagement (24) en ketenregie (21) gaven blijk van probleemgerichtheid en prikten bestuurlijke zekerheden door (decentralisatie, politiek primaat). De existentiële beleidstwijfel was alleen van korte duur. De producten bleven zonder gevolg. Na 2000 was het weer decentraliseren en 'accountswerk' as usual (hinderlijk volgen van de vakdepartementen).

13. De korte aanvechting rond 2006 om na te denken over differentiatie in gemeentelijke taakuitoefening werd door de voortijdige val van het kabinet-Balkenende II definitief afgebroken. Deze differentiatie-benadering zou van realiteitszin getuigen als men de problemen vanuit lokaal perspectief benadert, maar voor de ordelijke sturing van rijkswege houdt Binnenlandse Zaken liever vast aan het aloude concept van de uniforme gemeente.

14. Minderhedenbeleid werd bij Binnenlandse Zaken geplaatst, omdat de gemeenten een slag moesten maken met inburgeren. Deze nieuwe loot introduceerde praktische probleemgerichtheid binnen DG Binnenlands Bestuur, maar de directie Minderhedenbeleid bureaucratiseerde te snel, de contacten met de doelgroep bleven steken in overlegorganen. Wetenschappelijk onderzoek was relatief belangrijk, getuige de relatief grote bedragen die hier omgingen. Het beleidsterrein werd in 2001 naar een ander departement overgebracht.

15. Sociale vernieuwing bracht ook voor Binnenlandse Zaken vernieuwing. Voor het eerst trokken de ambtenaren de wijken in. Een golf van elan overspoelde het land, maar deze werd wel gesmoord doordat decentralisatie-doelstellingen gingen overheersen. Het Sociale Vernieuwingsfonds moest worden gevuld en 500 convenanten werden getekend. Evaluatie was goed voorzien. Blijvende effecten voor de organisatie waren er minder. Nog voor het einde van de kabinetsperiode vond de ambtelijke leiding het wel genoeg geweest.

16. De opvolger Grotestedenbeleid miste een aantal tekortkomingen van sociale vernieuwing, maar daartegenover stond vanaf het begin framing van de problemen in het licht van gebrek aan beleidsvrijheid van de steden en de verplichting om integrale meerjarige ontwikkelingsplannen op te stellen (en te toetsen) om geld los te krijgen. Er zijn veel verhalen opgehaald, maar er is minder in het Grote Verhaal doorgedrongen.

17. Tekenend zijn de lotgevallen van een initiatief binnen grotestedenbeleid om bedrijven te betrekken bij de ontwikkeling van de steden. Dit initiatief ontstond door een interessante samenloop van omstandigheden en op bijzondere lokaties ver van hier. Serendipiteit lijkt een aardige indicator te zijn voor de opkomst van interessante innovaties (D'gemeenten, Bedrijfsbetrokkenheid, Ketenregie). Na enige jaren veelbelovend netwerken bleef dit governance-initiatief het werk van een eenling, voor Binnenlandse Zaken een vreemde eend in de bijt. Binnen het bestuursbeleid is nooit meer over bedrijfsbetrokkenheid gehoord.

19. ICT-verkenningen van Binnenlandse Zaken komen nog het dichtst bij de leefwereld van de burger en kunnen ook niet om de realiteit van de netwerksamenleving heen. Binnen deze technologische revolutie gaat de meeste aandacht van het beleid uit naar de organisatie van grote databestanden voor de overheid. Verder valt op dat het meest succesvolle en duurzame project daarbinnen, GBA, strak rationeel en planmatig is opgezet.

20. De kwaliteitsinstrumenten, die gericht waren op 'van buiten naar binnen werken' binnen de gemeentelijke organisatie, hebben alle een beperkte levensduur gehad en hun procesgang is niet geëvalueerd. De rode draad (zoeken naar vraagpatronen) had enige invloed op de bestuurstheorie blijkens de relatief lange voortgang, vooral als bijdrage aan de vermindering van administratieve lasten.

23. Na een aarzelende start stort Binnenlandse Zaken zich met overgave op de verzelfstandiging van uitvoerende diensten. Al gauw overheerst de staatkundige toetsing aan de eisen die de ministeriële verantwoordelijkheid aan de arrangementen stelt boven de interesse in het optimaal functioneren van afzonderlijke publieke diensten binnen hun specifieke omgeving. Daarom een geheide score $A$ en institutionele doorwerking van het beleid. 
24. Aan het eind van de jaren negentig kon Binnenlandse Zaken even snuffelen aan de ontwikkeling van interactieve beleidsvorming (Procesmanagement, regierol van de gemeenten). Dat was weer een kortstondig experiment. Het vernieuwingsgehalte van het veelbelovende Programma Andere Overheid was een farce. Na 2008 is een nieuwe opbloei van het onderwerp burgerparticipatie ontstaan in een beleidseenheid die voor het eerst na Thorbecke het onderwerp democratie problematiseerde en dan vooral de introductie van participatieve democratie. Maar dat valt buiten het bestek van dit boek.

\section{De resultaten van de verkenning}

$\mathrm{Na}$ presentatie van de cases en voorbeelden, die allemaal in potentie een nieuw begin zouden kunnen inluiden, is de vraag of de geformuleerde verwachtingen bevestigd worden. Dat blijkt het geval. Ja, er is een rode draad en dat is duidelijk de government-benadering, maar die is niet zo overheersend dat er geen afwijkingen, of vernieuwende aanpakken mogelijk waren. Doordat deze niet echt doorzetten, kan volgens de omschrijving van Hajer niet gesproken worden van institutionalisering van een nieuw alternatief discours. Dan moet namelijk (in een meerderheid van de gevallen) sprake zijn van het vertalen van een discours of verhaallijn in institutionele arrangementen, geëffectueerd beleid en maatregelen in de institutionele sfeer (Hajer, 1995: 61). Enkele keren bereiken initiatieven met een governance-karakter de fase van officieel beleid, maar zelfs dan is dat een tijdelijke doorbraak, zoals bij de sociale vernieuwing. Meestal komen deze initiatieven niet verder dan de tekentafel of een fiat van een ambtelijke directieraad. Zij blijven steken in de categorie aanvechtingen. Als de resultaten worden uitgezet op de tijdbalk uit hoofdstuk 4 zou wellicht in de periode 1994-2002 een meerderheid van de voorbeelden als modus B of B scoren (nummers 12, 13, 16, 17, 20, 21, 24: dus toch een shift? Niet echt, want niet beklijvend), maar daarna lijkt weer een terugslag te zijn gevolgd (bij nummers $4,7,12,13,20,21$ ). De omwenteling heeft zeker niet doorgezet.

Figuur 10.2 Projecten, getypeerd als A- of B-modus, uitgezet op een tijdbalk (periode-indeling uit hoofdstuk 4)

\begin{tabular}{|c|c|c|c|c|c|c|}
\hline $\begin{array}{l}\text { Periode } \\
\text { Projecten }\end{array}$ & $>1980$ & $1980-' 84$ & 1984-'87 & 1987-'94 & 1994-2002 & 2002-2009 \\
\hline $\begin{array}{l}1 \text { Reorgan. Binn. } \\
\text { Bestuur }\end{array}$ & & & & & & \\
\hline $\begin{array}{l}2 \text { Complementair } \\
\text { Bestuur }\end{array}$ & & & & & & \\
\hline 3 VBO/Stadsprovincies & & & & & & \\
\hline 4 Landsdelen & & & & & & \\
\hline 5 Dualisering & & & & & & \\
\hline 6. Coördinerende Taak & & & & & & \\
\hline 7. Offensief Dec. beleid & & & & & & \\
\hline 8. Specif. Uitkeringen & & & & & & \\
\hline 9. Bestuursakkoorden & & & & & & \\
\hline 10. D'gemeenten & & & & & & \\
\hline $\begin{array}{l}\text { 11.Decentralisatie- } \\
\text { impuls }\end{array}$ & & & & & & \\
\hline 12.Decentr. met beleid & & & & & & \\
\hline
\end{tabular}




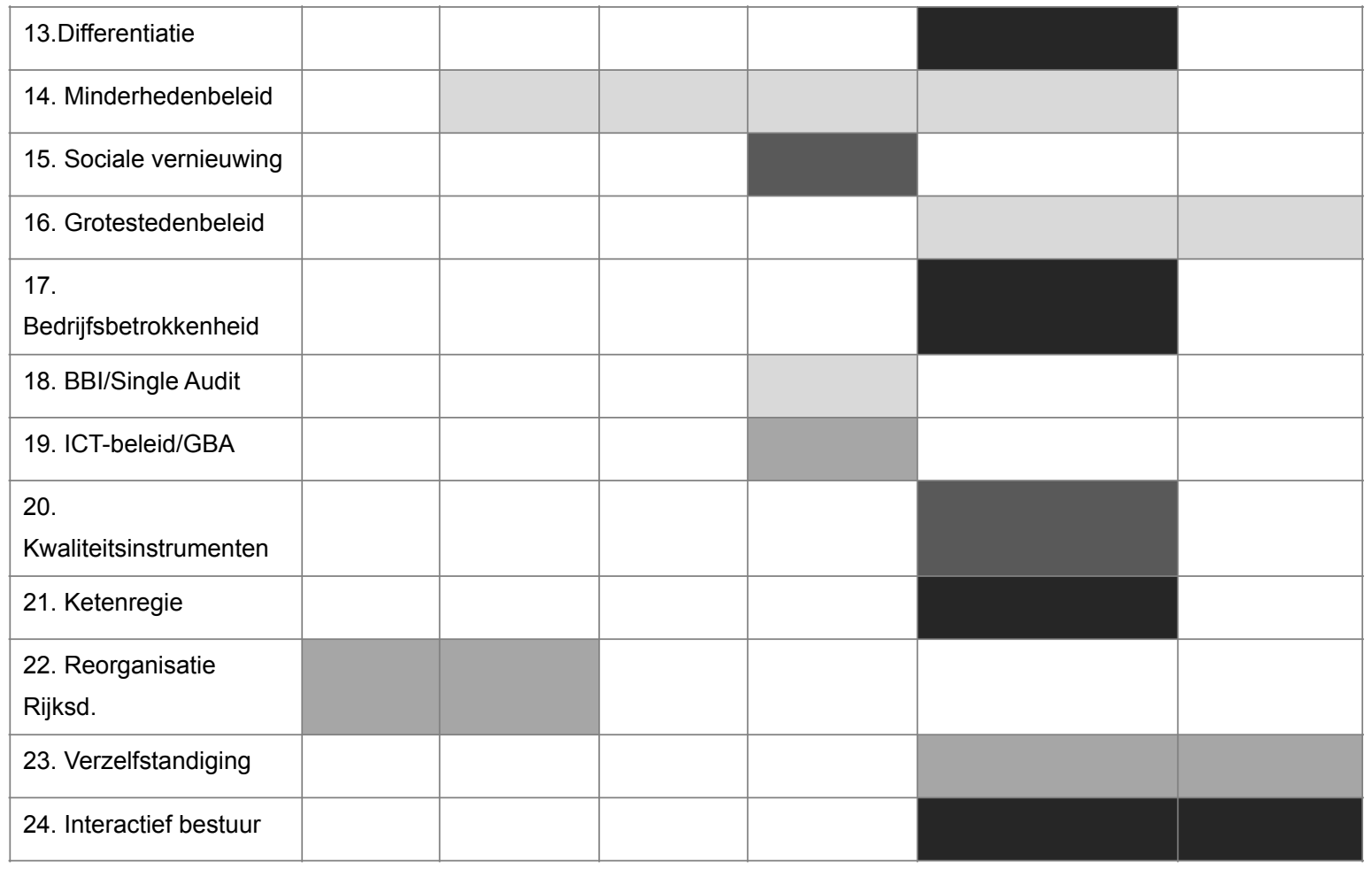

Legenda

\begin{tabular}{|l|l|}
\hline & Modus A \\
\hline & Modus A - \\
\hline Modus B \\
\hline Modus B - \\
\hline
\end{tabular}

Een bewijs uit het ongerijmde is nog te ontlenen aan een interne notitie over bestuurskracht, afkomstig van de genoemde programmadirectie Krachtig bestuur uit ongeveer 2009, met de titel 'Het belang van maatschappelijke organisaties en bedrijfsleven voor bestuurskracht van gemeenten'. De relatie met ons governance-begrip is evident. De discussie als het gaat over bestuurskracht, onder meer in deze directie, ging aanvankelijk over de smalle of de brede definitie ervan. Het smalle bestuurskrachtbegrip zou alleen de prestaties van de overheid zelf in ogenschouw nemen, terwijl de brede bestuurskracht bestaat uit de resultante van de gezamenlijke inspanningen van overheid en samenleving, waarbij de overheid vaak de rol van regisseur of facilitator aanneemt. De laatste opvatting (governance) heeft uiteindelijk gewonnen en wordt nu door het Kwaliteits Instituut Nederlandse Gemeenten met verve uitgedragen, maar dat speelt zich allemaal af na 2008. Tot 2008 zaten adviesbureaus die bestuurskrachtmetingen verrichtten feitelijk vooral op de lijn van government blijkens analyse van ruim 150 rapporten over bestuurskracht (Abma, 2012). Hier gaat het om de volgende passage in deze notitie van 2009: "Het beleid van BZK richt zich tot nu toe vooral op versterking bestuurskracht van gemeenten zelf en van de intergemeentelijke samenwerking. BZK heeft nog geen afzonderlijk beleid op het versterken van de kwaliteit van de samenwerking tussen gemeenten en maatschappelijke organisaties en bedrijfsleven" (interne notitie directie PKB d.d. 5 september 2009).

\section{Conclusie}

Eindconclusies worden pas in hoofdstuk 14 getrokken, maar de kortst mogelijke samenvatting van alle uitkomsten is dus: nee, er is uiteindelijk tussen 1969 en 2009 in het bestuursbeleid geen 
sprake van een door bestuurskundigen veronderstelde omslag (shift) van government naar governance geweest. Ook al waren er hier en daar duidelijke aanvechtingen in die richting (in het schema: B of B -), doordat zij nergens zijn doorgezet of geïnstitutionaliseerd, mag de mainstream in het bestuursbeleid als government-georiënteerd getypeerd worden. Verder is er behoorlijk geïnnoveerd en geëxperimenteerd en opvallend weinig geëvalueerd. Misschien niet verrassend, maar toch niet bevorderlijk voor het leerproces is het gegeven dat de kans op evaluatie evenredig daalt naarmate het project minder succesvol was. De bestuurstheorie is vooral in de jaren zeventig en tachtig ontwikkeld en nauwelijks in wisselwerking met de bestuurspraktijk en de maatschappelijke omgeving geactualiseerd.

\subsection{Overige conclusies, 'bijvangst'}

Het onderzoek heeft behalve antwoorden op de hoofdvragen terloops nog enkele interessante uitkomsten opgeleverd, die hier kort zijn samenvat.

\section{Doelstellingenhiërarchie}

De dossiers en projecten overziende, valt op dat er een zekere hiërarchie in de onderwerpen valt te ontdekken. De projecten die begonnen met een inhoudelijke urgentie, zoals sociale vernieuwing, grotestedenbeleid, minderhedenbeleid en ook complementair bestuur en de reorganisatie van het binnenlands bestuur bleken al gauw ondergeschikt te worden gemaakt aan een kennelijk hoger geacht doel, namelijk decentralisatie. Ook binnen de Financiële Verhouding(en) was de versterking van de gemeentelijke en provinciale autonomie uiteindelijk belangrijker dan nauwkeurige toedeling van middelen. Reden waarom dit dossier zelfs is vereenzelvigd met interbestuurlijke betrekkingen en decentralisatie. Maar decentralisatie mag op zijn beurt weer instrumenteel worden geacht voor een nog belangrijker doel, te weten de versterking van de (lokale) democratie. Wie de doelstellingen van decentralisatiebeleid uit de decentralisatienota's terugleest, ziet dat integrale afweging, de mogelijkheid om lokale eigenheid in de politieke beslissingen tot uiting te brengen en ruimte voor herkenbare en voor de burgers transparante besluiten de boventoon voeren. Dit zijn geen ambtelijke, technocratische overwegingen voor doelmatigheid en doeltreffendheid, maar vooral voorwaarden voor democratische keuzen in politieke organen. Zo was in het beleid ten aanzien van de organisatie van de rijksdienst de ministeriële verantwoordelijkheid ook het hoogste goed. Reden waarom fusie tussen inspecties en diensten over de grenzen van ministeries heen steeds is afgewezen. De verhouding tussen regering en parlement raakt het functioneren van de (representatieve) democratie en dat is uiteindelijk leidraad voor het handelen van het hele bestuursbeleid. Het ministerie kwam echt in rep en roer na signalen dat de representatieve democratie niet naar behoren functioneerde. Verwezen is naar de schok van de teleurstellende opkomst bij de gemeenteraadsverkiezingen van 1991, die de sociale vernieuwing vleugels gaf. Een ander voorbeeld is de schok die het onderzoek door de Universiteit van Twente over de onmacht van gemeenteraadsleden om te gaan met de gemeentelijke jaarstukken teweegbracht, die de aanzet gaf tot het BBI-project. Binnen deze waardenhiërarchie heeft democratie een specifieke inhoud. Rechtstatelijke elementen zijn veel minder prominent dan de genoemde politieke afwegingsprocessen. Privacy, openbaarheid van bestuur, integriteit van bestuurders en ambtenaren zijn thema's die nu en dan wel opkwamen, maar geen permanente aandacht opeisten zoals wel de besluitvorming en controle van politieke meerderheden in de representatieve organen. Zoals hiervoor beschreven, waren rechtstreekse vormen van burgerparticipatie eerder als concurrerende vormen van democratie behandeld dan als zelfstandige bron van collectieve wilsvorming.

\section{De mate van doelbereiking}

Hoewel zij herhaald dat dit boek niet gaat over de mate waarin het ministerie zijn doelstellingen in de maatschappelijke werkelijkheid 'out there' heeft bereikt, kan en passant worden vastgesteld dat van de verschillende dossiers een aantal plannen niet en andere min of meer zijn gelukt.

Zo kan men twisten over de resultaten van de inzet van het bestuursbeleid. De 24 onderzochte voorbeelden overziend, is ongeveer $50 \%$ hiervan succesvol geweest in die zin dat ze het stadium 
van institutionalisering in beleid hebben bereikt. Voor de vraag of dit beleid ook binnen het ministerie is beklijfd valt het percentage nog veel lager uit, omdat veel projecten (sociale vernieuwing, minderhedenbeleid, BBI, et cetera) na verloop van tijd werden losgelaten of afgepakt. De vraag of een andere bestuurstheorie dit slagingspercentage had opgekrikt dringt zich op. Daarover volgt meer in hoofdstuk 14.

\section{Successen}

$\mathrm{Ja}$, het aantal gemeenten is ruim gehalveerd, maar die ontwikkeling is permanent voortgegaan, ook als het ministerie daar geen sturend beleid op zette. Het zelfde is te zeggen van het hoofdthema van al die jaren: decentralisatie. Meermalen is gesteld dat bij veel decentralisatie het eigen belang en inzicht van de vakdepartementen het resultaat beter verklaren dan de aandrang vanuit Binnenlandse Zaken. De meeste vorderingen op dat terrein zijn uit de ministeries zelf voortgekomen. Denk aan het welzijnsbeleid en de stadsvernieuwing. De decentralisatie van de volkshuisvesting is van binnenuit goed beschreven in het proefschrift van Koffijberg (2005) en het is opvallend wat voor bijrol Binnenlandse Zaken in dat boek krijgt toegedicht. De integratie van het minderhedenbeleid is nog relatief mild beoordeeld in het rapport van de commissie-Blok. Het bestuursbeleid ten aanzien van verzelfstandigingen was nogal defensief, maar kreeg wel enige politieke steun.

Grotere vorderingen zijn te melden op twee terreinen: de sanering van bestuursinstrumenten (specifieke uitkeringen, toezichtinstrumenten en planprocedures) en het grotestedenbeleid. Echte klappers waren de GBA en de dualisering van het gemeentebestuur.

\section{Mislukkingen}

Niet succesvol was het herinrichten van de bestuurlijke organisatie op het middenniveau. De herstructurering (opschaling) van het lokale bestuur is in veertig jaar tijd wel gestaag voortgeschreden, al lijkt dit proces haast ongevoelig voor beleid. Of er nu vanuit Den Haag actief wordt bevorderd of dat gemeentelijke herindeling juist wordt ontmoedigd en overgelaten aan eigen initiatief, lijkt nauwelijks verschil te maken voor het tempo van dit proces van schaalvergroting, dat overigens parallel loopt aan ontwikkelingen in andere sectoren, zoals zorg, onderwijs en veiligheid. De resultaten van integratie en gelijkberechtiging van etnische minderheden zijn omstreden. Het minderhedenbeleid is onderwerp geweest van parlementair onderzoek en beloond met een zesminnetje. De effecten van achterstandswijkenbeleid (PCG, sociale vernieuwing, grotestedenbeleid) zijn even ambivalent. Het meest gunstige oordeel lijkt dat de situatie hierzonder ongunstiger was geweest.

Het beleid met betrekking tot informatierelaties was redelijk succesvol (GBA, één-loketbeleid). Ten slotte kan de reorganisatie van de rijksdienst, opgevat als bewaken van de vesting van de ministeriële verantwoordelijkheid (Kaderwet zbo's, inspecties) worden beschouwd als een achterhoedegevecht. Privatisering en verzelfstandiging hebben een grote vlucht genomen. De inspanningen van Binnenlandse Zaken om hieraan condities te verbinden zijn weliswaar aanvaard, maar het saldo-effect is verder afgedreven van de oorspronkelijke opzet van de commissie-Vonhoff om integratie en samenhang binnen de rijksoverheid te versterken.

Waarschijnlijk is het saldo-effect van alle inspanningen die uiteindelijk gericht waren op het versterken van de lokale democratie niet positief te noemen. Ondanks de geslaagde inzet van de dualisering en de redelijke opbrengst van het decentralisatiestreven is het overwegende beeld van raadsleden dat zij steeds minder te zeggen hebben (Binnenlands Bestuur, 5 november 2013). Dit zou grotendeels te wijten zijn aan de voortschrijdende tendens om taken onder te brengen in gemeenschappelijke regelingen.

\section{Ambiguïteit in het discours}

Een van de bijvangsten van dit onderzoek is de ontdekking dat verschillende vertogen ook gelijktijdig binnen eenzelfde organisatie en zelfs binnen één enkele persoon plaatsvinden. Er is een soort dialogue intérieur gaande, waarbij de deelgenoten zich halfbewust nu eens in de ene groef, dan in de andere redeneerlijn begeven. Dit kwam duidelijk naar voren bij het project Complementair bestuur. Dit verschijnsel is niet herkenbaar in de meeste literatuur over beleidstheorieën (casu quo bestuurstheorieën) en discoursanalyse. Deze veronderstellen een eenduidige rationaliteit bij de 
verschillende actoren. Het belang van de veronderstelling dat de werkelijkheid ingewikkelder is, lijkt me dat er meer nodig is dan analyse van teksten en uitspraken om een dominant of hegemoniaal discours van een organisatie vast te stellen. Daarom is in dit onderzoek zoveel nadruk gelegd op andere gegevens, zoals de mate waarin zichtbaar vervolg gegeven wordt aan een idee of project in de vorm van evaluatie, voortzetting in een zo mogelijk verbeterde variant en andere blijken van doorwerking in een continue beleidsontwikkeling.

\section{Ruimte voor ambtenaren}

Bij terugblik op de projecten valt op dat minder dan een derde hiervan valt toe te rekenen aan politiek initiatief (nummers 1, 3, 4, 5, 6, 15, 22). Dit staat in schril contrast met het bij Binnenlandse Zaken gangbare beeld van politiek primaat. Tegelijkertijd onderstreept deze bevinding dat dit ministerie door veel ambtenaren als een paradijs kon worden beschouwd. Je kon nog eens wat bereiken met ideeën en initiatief. Vanuit de gedachtegang van de commissie-Van Rijn, die in 2002 haar zorg uitsprak over de werfkracht van de overheid voor jonge ambtenaren die behoefte voelen maatschappelijke impact tot stand te brengen, kan Binnenlandse Zaken als voorbeeldige organisatie worden beschouwd. Dit bottom-up karakter van de beleidsagenda heeft natuurlijk ook een keerzijde, die hierna volgt.

\section{Fladderend beleid}

Een van de meest opvallende bevindingen is dat het bestuursbeleid zoveel eendagsvlinders heeft gekend. Daarbij is kenmerkend dat de meeste projecten door ambtelijk initiatief en uitwerking worden gedragen en nauwelijks worden geschraagd door een gemeenschappelijk masterplan over wat het ministerie als geheel met het bestuur wil. Dat is ten dele een andere manier om te stellen dat er geen sprake is van een ontwikkelde bestuurstheorie, maar overigens is er sprake van weinig onderlinge cohesie tussen de onderdelen van het ministerie. Evenmin is er sprake van een krachtige en eendrachtige leiding aan de top. leder doet zijn ding en laat de ander begaan, zolang die niet lastig is voor het eigen terrein. Zo kunnen eendagsvlinders vrijelijk opfladderen en afsterven. Provinciale beleidsplanning, ketenregie, complementair bestuur, benchmarking, kwaliteitsinstrumenten, differentiatie in het binnenlands bestuur, proeftuinen, sociale vernieuwing en wijkaanpak, inspraak, beleidsanalyse, good governance, innovatie als zodanig (XPIN, InAxis) allemaal gekomen en gegaan. Waren dit probeersels die voorbestemd waren te stranden? Ontbrak het uithoudingsvermogen om langer dan zeg één kabinetsperiode met eenzelfde thema bezig te blijven, tenzij intussen sterke stakeholders voortzetting steunden (zoals bij het grotestedenbeleid)? Of zijn ze juist na succesvolle lancering in de bestuurspraktijk met een gerust hart losgelaten? Deze laatste veronderstelling behoeft bij de verklaringen die in de volgende paragraaf worden behandeld enige aandacht, omdat de redenering om dominantie van het government-discours vast te stellen zo zwaar leunt op de continuïteit (doorwerking) van een beleidsthema in de organisatie. Als het werkelijk zo zou zijn dat Binnenlandse Zaken bewust zijn governance-projecten als impuls de samenleving in stuurde en dan snel met een volgende impuls begon, zou de asymmetrische behandeling van beide modaliteiten immers niet wijzen op een inhoudelijke voorkeur. Met deze gedachtegang begint de volgende paragraaf dus.

\subsection{Concurrerende verklaringen voor het gevonden patroon}

\subsubsection{Inleiding}

In deze paragraaf zal hoofdzakelijk worden gezocht naar alternatieve verklaringen van de ontkennende - conclusie ten aanzien van de hoofdvraag van dit onderzoek. Het is natuurlijk denkbaar dat er een heel andere redenering ten grondslag gelegd kan worden aan de gevonden uitkomsten van de cases dan dat een shift van government naar governance is uitgebleven. Deze alternatieve redeneringen passeren hieronder eerst de revue en zullen daar ook worden verworpen. Het betreft eerst het idee dat er een diepere gedachte schuilgaat achter het tijdelijk houden van impulsen om het openbaar bestuur te laten oefenen met governance-benaderingen. 
En daarna de veronderstelling dat het versterken van algemene bestuurscentra bij uitstek past bij de taak van Binnenlandse Zaken, waardoor het geen verbazing hoeft te wekken dat governmentdenken hier dominant is.

Hieronder volgt dus eerst een interpretatie van de feiten die de conclusie van dit hoofdstuk mogelijk op losse schroeven kan stellen. Pas in hoofdstuk 14 wordt gezocht naar mechanismen die de wel degelijk standhoudende conclusies kunnen verklaren.

\subsubsection{Discussie over alternatieve verklaringen}

Verklaring uit bewuste veranderstrategie

Op enkele momenten zou in het beleid van Binnenlandse Zaken een houding herkend kunnen worden die past bij een beredeneerde innovatietactiek van korte slagen. Als de overgang naar netwerkbestuur/governance als een innovatie wordt gezien, is het niet gek om deze beweging anders te instrumenteren dan de al bestaande visie. Bij de afdeling Interbestuurlijke Betrekkingen werd in het 'verlichte' tijdvak onder Arie Jan Vos en Berend van der Ploeg een hierop lijkende stelregel afgesproken over de werkwijze van deze afdeling. Omdat de afdeling veel te weinig capaciteit had om meer eigentijdse bestuursarrangementen in de hele rijksdienst voortdurend te ondersteunen, werd een aanpak van korte impulsen afgesproken onder het motto 'ABP':

Agenderen, Begeleiden, Pleite. Daarmee gaven de medewerkers elkaar het signaal niet te lang bij een onderwerp of onderdeel te blijven plakken, omdat er nog zoveel bestuurlijke verbetering of vernieuwing lag te wachten. Een ander voorbeeld van de manier waarop men bij Binnenlandse Zaken aankeek tegen het werken aan innovaties wordt ontleend aan de geschiedenis van het bureau XPIN. Daar spraken de medewerkers elkaar stoer toe met de woorden: "Wij zijn ingesteld voor vier jaar en streven ook niet naar verlenging, want innovatie moet je niet institutionaliseren." Is het denkbaar dat soortgelijke gedachtegangen ook ten grondslag liggen aan de gesignaleerde praktijk dat projecten gericht op vernieuwingen zoals netwerkbestuur/governance, steeds maar een kort leven beschoren zijn? Ligt er soms beleid aan ten grondslag, waardoor de hier gehanteerde indicator voor beklijven 'Doorwerking-of-niet' ontkracht zou worden? Hier pleit een aantal overwegingen tegen.

In de eerste plaats wijst veel erop dat projecten niet volgens een grote strategie tot stand kwamen en weer verdwenen. Het einde van projecten als Complementair bestuur, Bestuursbemiddeling, Bedrijfsbetrokkenheid en Differentiatie in het binnenlands bestuur was volstrekt niet gepland. Ze waren er op een bepaald moment gewoon niet meer. Ook hun begin leek eerder impulsief en toevallig dan gepland. Zo 'strategisch' opereerde het ministerie in het algemeen al helemaal niet. Op de revolte van Parijs 1968 werd ook niet gereageerd in de vorm van een bezinning over wat dit betekende voor de Nederlandse democratie, voor de gezagsverhoudingen. Ook veertig jaar later was het ontbreken van planmatig werken nog steeds zichtbaar toen de opkomst van sociale media bij openbare-orde-incidenten om een soortgelijke brede verkenning vroeg.

In de tweede plaats zou deze verklaring plausibel zijn als de bedoelde vernieuwingsprojecten werden opgevolgd door iets anders, iets mooiers en iets wat liefst ook nog de lessen van het voorafgaande in zich incorporeerde. In de vorige hoofdstukken is steeds duidelijk gemaakt dat dit niet het geval was.

Het argument zou ten slotte ook overtuigen als daadwerkelijk zou blijken dat de impuls van Binnenlandse Zaken zijn werk had gedaan en voortaan zonder begeleiding van het bestuursdepartement zijn weg in de maatschappij had gevonden. Dit is echter moeilijk vol te houden. De impuls van Binnenlandse Zaken met zijn 'maatschappelijke discussie' over Complementair bestuur kan toch moeilijk worden aangewezen als aanstichter van de latere convenantenpraktijk. Dit project is tenminste nog openlijk en met een argumentatie dat decentralisatie te veel bedreigd zou worden stopgezet. De aanbevelingen van de werkgroep Complementair Bestuur (1980) waren veel specifieker en gingen verder (wetgeving!) dan de algemene convenantenpraktijk van daarna. Het is dus niet juist deze praktijk als outcome aan de inspanningen van de werkgroep toe te rekenen. Bedrijfsbetrokkenheid is heus niet de rechtstreekse 
vader van maatschappelijk verantwoord ondernemen, noch zijn de experimenten D'gemeenten dat van het opnieuw in Denemarken ontdekte, vrijwel identieke 'Right to Challenge' (2012) evenmin als bestuursbemiddeling (1985) te verbinden is met publieke beleidsbemiddeling (2012). Zo dun was het 'bedrijfsgeheugen' in het ministerie bij deze onderwerpen, laat staan dat er sprake is van daadwerkelijke beleidscontinuïteit.

\section{Past die governance-benadering wel bij de opgaven van Binnenlandse Zaken?}

Een volgende verdedigingslinie is de stelling dat dit helemaal niet zou passen bij de opdracht van het ministerie. De veronderstelde shift van government naar governance impliceert zoals bekend allerminst de eliminatie van de government-modus en de vervanging door netwerkbestuur in alle situaties. Een zekere verschuiving in die richting binnen de hele samenleving en het hele bestuur laat wel onverlet dat mogelijk 'toevallig' de onderwerpen waar Binnenlandse Zaken voor verantwoordelijk is, overwegend de klassieke benadering vergen. Sterker, deze voorkeur is natuurlijk helemaal niet toevallig, maar de essentie van de herkenbare missie van Binnenlandse Zaken, waarbij dit ministerie zich positioneert tegenover alle gefragmenteerde deelbelangen die worden vertegenwoordigd door vakdepartementen en middenveldorganisaties. Het is de eervolle taak van Binnenlandse Zaken de kernwaarden van de democratische rechtsstaat tegenover deze desintegrerende krachten overeind te houden. Het bijeenhouden van bestuurskracht in democratisch geleide en orde brengende bestuurseenheden met verantwoordelijke bestuurders vanuit het algemeen belang vergt een niet gering tegenwicht tegen alles wat voos en vooringenomen het kleine kortzichtige deelbelang wil dienen. Dat sluit ook aan bij de andere poot van Binnenlandse Zaken, het Veiligheidsbeleid. Daar worden de orde en het staatsgezag gehandhaafd en burgers zijn er vooral onderdaan, zodat governance er zo mogelijk nog meer wezensvreemd is dan in het bestuursbeleid. ${ }^{83}$ Zo verloopt de redenering achter dit ideaal. Daarom vooral past het gelijkwaardig afhankelijkheid erkennen aan overlegtafels van al deze partijen en partijtjes, ook wel stakeholders genoemd, niet bij het dominante discours van Binnenlandse Zaken. En dat moet ook niet. Laat ergens in ons land de democratische grondslag van stevig toegerust en verantwoordelijk bestuur bewaakt worden, aldus een plausibele gedachte over de beleidstheorie van Binnenlandse Zaken-als-tegenwicht.

Op deze eerbiedwaardige stellingname, die voorkeur voor de government-modus niet alleen erkent, maar ook toejuicht, valt op twee manieren af te dingen. In de eerste plaats is bij de afzonderlijke dossiers al her en der vastgesteld dat de gekozen aanpak ook anders en misschien zelfs beter had gekund door gebruik te maken van de governance-benadering. Het meest schrijnende voorbeeld is het Programma Andere Overheid (paragraaf 9.4), dat op klassieke wijze top-down werd vormgegeven als een plan met 67 uitvoeringstaken. Een ander voorbeeld is de zoektocht naar nieuw middenbestuur (paragraaf 5.6), dat ondanks interne voorstellen voor een alternatieve aanpak al gauw verzandde in de zoveelste poging nieuwe provinciegrenzen op de kaart van Nederland te tekenen zonder dat hiervoor voldoende steun was. Meebuigen is soms geen ondergeschiktheid erkennen, maar bittere noodzaak.

Een tweede repliek op deze veronderstelling is dat dit boek niet gaat over de verdedigbaarheid van, laat staan preferentie voor, afzonderlijke producten van Binnenlandse Zaken (waarvan de resultaten overigens niet spectaculair waren), maar over de achterliggende kijk op de hoofdopgaven van het openbaar bestuur als zodanig. De stelling vanuit de bestuurskunde over een shift gaat ervan uit dat in steeds meer, misschien wel de meest belangrijke en urgente, kwesties de governance modus van toepassing is en dat daarom onze opvattingen over wat goed bestuur vereist aangepast moeten worden. In dat geval zou dit toch ook tot uiting moeten komen in de onderwerpskeuze van het ministerie en de wijze waarop deze onderwerpen worden aangepakt. Deze redenering stelt het effectief oplossen van maatschappelijke vraagstukken voorop en dat zou in deze tijd niet anders mogelijk zijn dan door het mobiliseren van alle hoekpunten in de driehoek

\footnotetext{
83 Uitzonderingen daargelaten, zoals veiligheidspreventie en integrale veiligheid in wijken, die nauw aansloten bij Sociale
} vernieuwing. 
overheid - civil society - markt (volgens sommigen een vierhoek met ook kennisinstellingen op een hoekpunt).

Als samenwerken en het op gelijke voet benutten van maatschappelijke krachten, en vooral op maat improviseren, de belangrijkste uitdaging van het bestuur zou zijn om resultaten te bereiken, mag worden verondersteld dat het een majeure inspanning van juist het bestuursdepartement vereist om deze transitie (horizontalisering) te begeleiden en voor te leven. Daarvan is nu juist weinig te merken geweest.

\section{Conclusies}

De conclusie van deze paragraaf is dat andere verklaringsgronden dan die welke in de hoofdvraag centraal staan, slechts zeer ten dele bevredigend antwoord kunnen geven op de vraag waarom de grondhouding van Binnenlandse Zaken zo hardnekkig de government-benadering weerspiegelt. $\mathrm{Nu}$ dat is verkend, blijft er nog heel wat te verklaren over. Dit wordt echter uitgesteld tot hoofdstuk 14, nadat ook de ontwikkelingen in verwante domeinen zijn verkend.

\subsection{Reflectie: op zoek naar het Grote Verhaal achter het bestuursbeleid}

\subsubsection{Impressie uit de verhalen}

\section{Het Verhaal van Binnenlandse Zaken}

$\mathrm{Na}$ de vele verhalen in de voorgaande hoofdstukken is het nu de kunst, dit geheel om te vormen tot één verhaal, het Grote Verhaal van het bestuursbeleid. Dit is de plaats om even terug komen op het verhaal in de gangbare betekenis van het epische sprookje. Wat is de held, het grote conflict en de mogelijke triomf voor het bestuursbeleid, waarna zij nog lang en gelukkig leefden? Als we door de oogharen naar de genoemde voorbeelden kijken, is een overheersend thema de goede ambtenaar van Binnenlandse Zaken die de strijd aanbindt tegen verkokering, tegen deelbelangen en handjeklap binnen sectoren. Hier stelt hij of zij de verlokkingen van integraal bestuur en vooral van eerlijke democratische afweging door een gekozen volksvertegenwoordiging (op drie bestuursniveaus) tegenover. Uiteindelijk is het verhaal van bestuursbeleid tussen 1969 en 2009 een groot gevecht voor de representatieve democratie, die belaagd wordt door centralisme, verkokering en functioneel bestuur. Helaas ontbreekt in veel gevallen het zoet van de victorie, maar de onvermoeibare inzet voor de goede zaak is een belangrijk deel van de beloning, in het bijzonder in de stellige wetenschap dat Binnenlandse Zaken vrijwel alleen strijd levert te midden van een overmacht aan krachten van het kwaad. De fictie dat de lokale autonomie alleen afhankelijk is van de strijd tussen Binnenlandse Zaken en zijn bondgenoten tegenover de boze vakdepartementen zit heel diep, ook al is het beeld aantoonbaar onjuist. CRM was de eerste die dit streven onder woorden bracht en toepaste in de proefgemeenten welzijnsbeleid van de Stuurgroep Ontwikkelingsprojecten (Beck en De Jong, 1990). Ook achterstandenbeleid en interventies in de gemeentelijke informatiehuishouding worden uiteindelijk geframed in deze strijd.

Achterstandsproblemen in wijken zijn uiteindelijk het gevolg van onvoldoende beleidsruimte voor de democratische besturen van de grote steden.

Dit verhaal, dat ervan uitgaat dat Binnenlandse Zaken primair gaat voor (vooral gemeentelijke) autonomie en voor heldere democratische verantwoordelijkheden, is vrijwel synoniem met de government-benadering. Geen wonder dat de concurrerende visie van grillige maatschappelijke samenwerkingsrelaties en complexe probleemoplossingscombinaties die voortkomen uit moeilijk beheersbare maatschappelijke processen met contingente ontwikkelingspatronen weinig poot aan de grond krijgen. Dat wil echter geenszins zeggen dat hier geen aandacht voor is of geen ruimte voor wordt geboden. Misschien is het wel een van de grondeigenschappen van de ruime inborst van Binnenlandse Zaken, dat er zoveel uitstapjes en verkenningen mogelijk zijn. Sommige organisaties houden de beleidslijn strak in de gaten en dulden weinig dissidente geluiden. Bij Binnenlandse Zaken vormen tijdelijke oefeningen buiten de lijnen deel van de cultuur. Moet kunnen, maar wel met zoveel losheid dat men er ook weer snel vanaf kan. 


\subsubsection{Mogelijk patroon in de golfbeweging}

Afstand nemen en toenadering zoeken tot de plaatselijke werkelijkheid

Voor hele volksstammen van Binnenlandse Zaken-ambtenaren is de gemeente een black box. En bovendien (waarschijnlijk daardoor) worden gemeenten als bestuurslaag geïdealiseerd: democratische bestuurslaag dicht bij de burger, integraal bestuur met maatwerk, underdog die voortdurend wordt bedreigd door regelzuchtige departementen, waartegenover maar één instantie die voor hun belangen op de bres staat en dat is Binnenlandse Zaken.

Een tweede ervaringsfeit is dat de meeste Binnenlandse Zaken-ambtenaren in beginsel geen contact hebben met burgers, want dat is het prerogatief van de eerste bestuurslaag. Dit werd pijnlijk duidelijk toen Roger van Boxtel zich de woede van de grote steden op de hals haalde door over hun hoofden heen - een subsidiepot te openen voor burgerinitiatieven in de wijken, het project 'Onze Buurt Aan Zet'.

Uitzonderingen op de genoemde constateringen bevestigen echter de regel.

Interessant is de vraag of bestuursbeleid van Binnenlandse Zaken liever uitgaat van de weerbarstige werkelijkheid in het veld (via samenwerking met gemeenten, in de modder) of van zijn zelf-geconstrueerde bestuursdoctrines.

De lezer herkent hierin wellicht een beetje de spanning tussen het oude BFO en IB uit hoofdstuk 4. De mensen van IB werden in de contacten met de ministeries al wat meer geconfronteerd met praktische vraagstukken die soms moeilijk verenigbaar leken met de opdrachten waarmee zij het veld in gestuurd werden (decentralisatie moet, stadsprovincies, Gemeentefonds). In 1991 kwam daar bij dat zij - voor het eerst - nog verder afdaalden, naar het echte grondvlak in de wijken: de sociale vernieuwing. Voor het eerst gingen Binnenlandse Zaken-ambtenaren zelf de worsteling aan met de lastige, maar ook zeer leuke en inspirerende werkelijkheid van achterstandenbeleid. Inspirerend was vooral de enthousiaste inzet van (sommige, actieve) burgers voor eigen initiatieven. Aan het einde van het kabinet-Lubbers-Kok was het echter gauw afgelopen met het project Sociale vernieuwing. Binnenlandse Zaken zag niet voor niets als de hoofdmissie de autonomie van gemeenten. Daarin paste het niet zo dat Binnenlandse Zaken-ambtenaren zich duurzaam in wijken gingen ophouden en meehelpen met (sub)gemeentelijk beleid.

Het grotestedenbeleid, de opvolger van sociale vernieuwing, ging weer op de meer klassieke manier van start: achter het bureau plannen toetsen. Later, onder Van Boxtel ging Binnenlandse Zaken zowaar weer afdalen naar de wijken. Maar dat was dan ook geen idee van Binnenlandse Zaken, maar van Annette Bertram, toenmalig DG bij VROM. Er werden gemengde teams gevormd van ambtenaren van gemeente en rijk om vanuit de praktische problemen ongeacht ieders sectorale verantwoordelijkheid bij te dragen aan praktische troubleshooting. Eigenlijk een horreur vanuit de Binnenlandse Zaken-doctrine van gescheiden verantwoordelijkheden, maar nood breekt wet.

In de jaren negentig heeft Binnenlandse Zaken de effecten van decentralisatiebeleid laten onderzoeken (Fleurke et al., 1997). Toen is toch maar eens nagegaan of de veronderstelde beleidsvoordelen die de doctrine in het vooruitzicht stelde, ook daadwerkelijk optraden: meer integraal bestuur, maatwerk, efficiency, et cetera. Het bleek bar tegen te vallen. De belangrijkste aanbeveling was dat Binnenlandse Zaken zich dringend moest bezighouden met de bestuurskwaliteit van gemeenten, want Fleurke constateerde dat de meeste gemeenten niet bleken opgewassen tegen al die moeilijke opgaven die zij gedecentraliseerd kregen. Veel liever dan zelf naar plaatselijke omstandigheden en voorkeuren beleid maken, gingen de gemeenten door met het uitvoeren van de regeltjes zoals ze dat altijd gewend waren geweest in medebewindsverhoudingen.

Eigenlijk is de vrij magere geschiedenis van de aandacht vanuit Binnenlandse Zaken voor burgers en burgerbelangen eenzelfde uitzondering op de hoofdregel dat Binnenlandse Zaken in principe halt houdt bij de gemeentegrens. Burgers staan in de hiërarchie onder de gemeente en rijksambtenaren mogen eigenlijk niet met burgers verkeren zonder de competentie van de 
gemeente te schenden. Niet voor niets was in de jaren kort na 2000 IOS de enige die zich binnen DG Openbaar Bestuur bezighield met burgers (democratiebeleid bestond toen nog niet).

Een ander voorbeeld waarin Binnenlandse Zaken even afdaalde in de black box van de gemeente, was de Vernieuwingsimpuls dualisering. Via Actieprogramma Lokaal Bestuur (ALB), onderdeel van de VNG, maar aanvankelijk met rechtstreekse aansturing en ook persoonlijke deelname van Binnenlandse Zaken-medewerkers. Er moest immers een grootschalige cultuuromslag plaatsvinden en zonder een beetje ondersteuning (nogmaals op basis van gelijkwaardigheid, probleemgericht) ging dat niet. Ook deze escapade was na een paar jaar afgelopen. De bemoeienis met VNG/ALB werd allengs minder en zeker vertoonden zich geen ambtenaren van Binnenlandse Zaken meer in de gemeenten.

De doorlichting van Zelfstandige bestuursorganen had, met een analoog voorbeeld op rijksniveau, een aanzet kunnen zijn voor een langduriger inzet van het bestuursbeleid om verbetering aan te brengen in de talloze uitvoeringsorganisaties en het vaak verouderde of verbureaucratiseerde contact tussen overheid en burgers aan het loket en tussen de Haagse beleidskernen en de werkelijkheid van de uitvoerende diensten. Maar ook dit heeft niet zo mogen zijn, omdat Binnenlandse Zaken daarmee weer te dicht op het bevoegdheidsdomein van anderen zou komen. Je gelooft in ministeriële verantwoordelijkheid of je doet dat niet.

Steeds werden kleine pogingen gezien om vanuit Binnenlandse Zaken te 'infiltreren' in de organisatie van anderen (meestal gemeenten): toerusten, ondersteunen, kwaliteitsimpuls, probleemgerichte benadering en burgers helpen in hun bijdrage aan de publieke zaak. Steeds was dat een uitzondering op de regel. Tussen 2002 en 2009 was er weer een dieptepunt, maar onder DG Andrée van Es kwam er daarna weer een bloeiperiode. Na de periode Remkes/Van Halder lijkt er weer een zekere opleving in de denklijn te volgen dat het toch wel nuttig is om vanuit Binnenlandse Zaken de gemeenten te helpen om samen te proberen reële problemen van de bestuurlijke werkelijkheid aan te pakken. Niet om gemeenten te bevoogden, maar om hen te faciliteren. Te noemen zijn drie voorbeelden uit de kabinetsperiode 2007-2010, hoewel deze grotendeels buiten het bestek van dit boek valt.

1. Programma Krachtig bestuur. Wat is goed bestuur, hoe staat het met de bestuurskracht, wat denken gemeenten daar zelf over, kunnen we helpen via onderzoek, gesprek en handreiking?

2. Programma Burgerparticipatie, in het bijzonder In Actie met Burgers! In samenspel met de VNG.

3. De meeste onderwerpen binnen de programmadirectie Dienstverlening, Regeldrukvermindering en Informatiebeleid (en haar voorganger IIOS). Een duidelijk voorbeeld is het project Mediationvaardigheden, waarbij BiZa trainingen en werkwijzen aanreikt die aantoonbaar verbetering aanbrengt in de bejegening van klagende burgers.

Zal deze probleembenadering weer tijdelijk zijn? De organisatievorm van project en programmaeenheden doet zoiets wel vermoeden, maar op zichzelf zegt dat niets. Of zal de hardnekkige BZKreflex ('wij zijn er voor de autonomie van gemeenten', niet voor het helpen oplossen van lastige maatschappelijke vraagstukken, onder meer door ons inzicht in de bestuurlijke werkelijkheid) toch weer zegevieren?

\section{Golfpatroon}

Als men de voorbeelden van de afgelopen dertig, veertig jaar op een rijtje zet, ontrolt zich voor de welwillende waarnemer een vast golfpatroon. Het zou aardig zijn dit verder te onderzoeken, aan de hand van een hypothese dat korte escapades met bevordering van de kwaliteit van het bestuur in gemeenten het maximum is dat Binnenlandse Zaken kan verdragen in het reële spanningsveld tussen het forceren van zijn eigen bestuursdoctrine (autonomie en bottom-up bestuur) en de soms al te opzichtige tekortkomingen van het lokaal bestuur om de problemen zelfstandig te lijf te kunnen. Of minder dramatisch geformuleerd: de evidentie dat het beter kan en moet. Hier volgt de chronologische reeks van perioden met relatief verhoogde interbestuurlijke inzet van Binnenlandse Zaken om de kwaliteit van het (lokale) bestuur te vergroten: 
1976-1980: Veel artikel 12-gemeenten. De Inspectie Gemeentefinanciën was de bron van kwaliteitsimpulsen binnen de gemeenten (financieel. zwakke broeders) en van kritiek op rijksbeleid.

1984-1987: Directie Bestuurszaken (Kapsenberg, Schouten, Hoff, A.J. Vos): Modernisering GBA, Beleids- en beheersinstrumenten (gezamenlijke beweging ter verbetering van gemeentelijke jaarstukken). Abrupt beëindigd in 1987. Ook directie Minderhedenbeleid, waar met gemeenten een infrastructuur voor integratie van etnische minderheden werd opgezet, en probleemcumulatiegebiedenbeleid (PCG) in wijken werd ontwikkeld.

1991-1994: Sociale vernieuwing! Eveneens abrupt gestopt na kabinetsperiode-Lubbers-Kok.

1998-2002: Troubleshooting in grotestedenbeleid, gemengde adoptieteams (rijks- en gemeentelijke ambtenaren), Onze Buurt aan Zet (wijkbudgetten), Vernieuwingsimpuls Dualisering, Kwaliteitsinstrumenten op het terrein van dienstverlening.

2007-2011: Programmadirectie Krachtig Bestuur, project In Actie Met Burgers!, programmadirectie Dienstverlening, Regeldrukvermindering en Informatiebeleid, interventie in bestuurlijk zwakke gemeenten, zoals Delfzijl.

Een bijna wiskundig patroon: 3 à 4 jaar op - 3 à 4 jaar af.

Figuur 10.3 Perioden waarin werd geïntervenieerd in de kwaliteit van het lokaal bestuur

\begin{tabular}{l|l|l|l|l|l|l|l|l|l|}
\hline \multicolumn{7}{|l|}{ Tijdbalk met perioden uit hoofdstuk 4} \\
1976 & 1980 & 1984 & 1987 & 1991 & 1994 & 1998 & 2002 & 2007 & 2011 \\
\hline WEL & & WEL & & WEL & & WEL & & WEL \\
\hline & NIET & & NIET & & NIET & & NIET & \\
\hline
\end{tabular}

Weliswaar bieden de perioden waarin Binnenlandse Zaken het zich veroorlooft om bij gemeenten de boel op orde te komen brengen, meer kansen om iets van de gedifferentieerde werkelijkheid op te snuiven, maar voldoende voorwaarde om de governance-aanpak over te nemen is dit nog niet.

De hoofdvraag van dit onderzoek richtte zich op de mate waarin het discours bij Binnenlandse Zaken toegespitst op de verhouding tussen overheid en samenleving zich onderscheidt van andere bestuurlijk relevante actoren. Die vraag komt nu via korte verkenningen aan de orde bij achtereenvolgens de politieke arena, een vakdepartement, waarbij om verschillende redenen is gekozen voor het ministerie van Landbouw, en het lokaal bestuur. 


\title{
11. Vergelijking met de Tweede Kamer
}

\author{
1. Inleiding
}

Onderscheid tussen algemene politieke uitingen en de specifieke bestuursspecialisten De vergelijking met andere bestuursdomeinen begint met de politieke arena. Dit domein is ongetwijfeld te breed: omvat het alleen regeringscoalitie (de macht) of ook de oppositie? Moeten we alle handelingen van alle commissies et cetera in beschouwing betrekken of concentreren we ons op de Vaste Commissie voor Binnenlandse Zaken? In dit hoofdstuk moet steeds duidelijk onderscheid worden gemaakt naar de positie van de beschreven politieke actoren in relatie met het ministerie van Binnenlandse Zaken. Een aantal van hen is nadrukkelijk betrokken bij het bestuursbeleid van Binnenlandse Zaken, in het bijzonder de Vaste Commissie voor Binnenlandse Zaken. Deze maakt onderdeel uit van het subsysteem dat het bestuursbeleid vormgeeft en dan is verwantschap met Binnenlandse Zaken niet verwonderlijk. Dan nog kan de invloed leidend of volgend zijn, beeldversterkend of -afzwakkend. Andere volksvertegenwoordigers dan de vakspecialisten paraderen in de volgende paragraaf voorbij als exponenten van algemene politieke rationaliteit. Het is interessant om te registreren wat uit het gedrag van beide categorieën politici op te maken is over de heersende bestuurstheorie, het discours over de verhouding tussen overheid en samenleving, in de politieke wereld. Dit hoofdstuk is verdeeld in twee stukken: beelden uit de Tweede Kamer als geheel over de heersende bestuurstheorie en relevante informatie uit de Vaste Commissie Binnenlandse Zaken, die kan worden beschouwd als onderdeel van het beleidssysteem dat het bestuursbeleid bepaalt.

Bronnen zijn naast eigen waarnemingen van de auteur als beleidsambtenaar de talloze egodocumenten van ex-Kamerleden, in het bijzonder Jeekel (1998), een themanummer van Bestuurskunde (2012, nr. 2) en de Handelingen van de Vaste Commissie Binnenlandse Zaken, in het bijzonder alle aangenomen moties tussen 1995 en 2009.

\section{Anekdotische herinneringen}

Het verhaal begint anekdotisch met een persoonlijke beleving van de schok die de tegenstelling tussen government en governance kan oproepen. Deze anekdote voert de lezer terug naar 2002, een jaar van grote politieke beroering.

Op 18 april vond een grote conferentie 'Ketens en Netwerken' plaats in het Kurhaus onder auspiciën van de NSOB en anderen. Hier spraken achtereenvolgens Wouter Bos en Rick van der Ploeg, beiden net afgetreden als staatssecretaris vanuit het tweede paarse kabinet, dat was gevallen over de Srebrenica-schaamte.

Wat hoorden de deelnemers Rick van der Ploeg daar zeggen?

"De oude instituten zijn anders geregeld dan de nieuwe instituten en hebben in veel gevallen een remmende werking op ontwikkelingen. Een conclusie die we daaruit kunnen trekken is dat hiërarchisch georganiseerde bedrijven niet passen in een netwerksamenleving: Van 'bovenaf' een blauwdruk opleggen werkt niet meer. Er dient van onderaf gestimuleerd te worden. Top-down denken verhoudt zich niet met particulier ondernemen. Volgens Adam Smith ontstaat sociaal maatschappelijk gedrag door het eigenbelang van consumenten. Is er dan nog wel een centraal bestuur nodig? Neem als voorbeeld de mieren. Zij hebben geen echte leider. Er is wel 
een koningin maar zij bepaalt niet wat er gebeurt. De natuur bewijst het: netwerken vormen de kracht van de toekomst."84

Bij die gelegenheid is de volgende logboekaantekening gemaakt en binnen XPIN verspreid: "Leuke uitspraken van Wouter Bos. Hij liet zien dat er toch wel wat politici zijn die nadenken over een veranderende samenleving, ketens en netwerken. Zijn stelling was bijvoorbeeld dat het woord 'ketens' alleen in het leven wordt geroepen door ambtenaren op plekken waar het misgaat (de gezondheidszorg, jeugdzorg, vervoer, et cetera)."

Omstanders verbaasde hun optreden nogal. Ze wisten dus donders goed wat er in de samenleving gaande was. Het contrast met hun gedrag als politici in het krampachtig sturende tweede paarse kabinet ('politiek primaat') was treffend. Het leek wel of ze zich door hun aftreden van hun knellende hiërarchische banden bevrijd voelden en nu 'uit de kast' durfden komen. Natuurlijk was dit een subjectieve perceptie en ongetwijfeld zullen de heren zich aangemoedigd hebben gevoeld door het thema van het congres om zo te spreken, maar dit verhaal zegt iets over twee dingen: hoe bijvoorbeeld de medewerkers van XPIN, in die tijd aankeken tegen het politieke bedrijf en dat die politici toch minder wereldvreemd waren dan zij misschien dachten. Die ervaring is later nog meermalen herhaald, bijvoorbeeld in 2003 toen XPIN en anderen met Kamerleden een openbare hoorzitting over '10 jaar motie-Willems' organiseerden of toen Binnenlandse Zaken op pad gestuurd werd door de Kamerleden Anker en Schinkelshoek om experimenten met burgerparticipatie te organiseren. En toch gingen deze ervaringen ook steeds gepaard met tegenstrijdige ervaringen. Als puntje bij paaltje komt, heeft de politiek vooral oog voor de burger als kiezer, als onderdaan of als klant en is de burger als coproducent van beleid een ongewenste concurrent. Van Zuylen en Schrijver hebben in het artikel 'Hoezo kloof?' (2010) hiervan een aantal staaltjes vanuit de Vaste Commissie Binnenlandse Zaken opgenomen. In de volgende paragraaf komen die ter sprake. Eerst echter een presentatie van meer algemene politieke signalen over voorkeursopvattingen die wijzen op een bepaalde bestuurstheorie in de wereld van politiek en volksvertegenwoordiging. Daarna volgen de meer specifieke opvattingen van de directe gesprekspartner van de minister van Binnenlandse Zaken, de Vaste Commissie in de Tweede Kamer.

\subsection{Literatuuronderzoek over bestuursopvattingen in de Tweede Kamer}

\subsubsection{Algemene politieke uitingen die wijzen op een bepaalde bestuurstheorie}

\section{Redeneerlijn}

In het voorjaar van 2010 kwam de Raad voor het Openbaar Bestuur (ROB, 2010) met zijn spraakmakende advies 'Vertrouwen op Democratie'. Hierin stelt de Raad dat de werkelijke 'kloof tussen burger en politiek' geen kwestie is van misverstanden, te moeilijk taalgebruik of van een te grote culturele afstand tussen elite en gewone burgers, maar betrekking heeft op fundamentele systeemkenmerken: het verticale tegenover het horizontale denken. Het advies richt zich in eerste instantie op de politiek, maar betrekt het probleem op de overheid als geheel. De Raad waarschuwt in één adem dat deze kloof het gezag van de overheid aantast:

“De verticaal georganiseerde politieke instituties moeten nieuwe verbindingen met de burgers aangaan. Die opereren niet langs verticale, maar langs horizontale lijnen. De overgang van een partijendemocratie naar een publieksdemocratie is onontkoombaar. Politieke partijen, parlement, media en burgers kunnen ieder vanuit hun eigen verantwoordelijkheid die kloof dichten."

${ }^{84}$ Zie www.ketens-netwerken.nl/verslag/5_netwerksamenleving.htm. 
De stelling is niet gewaagd dat de politici, meer nog dan de overheid, zichzelf zien als het centrum van de macht en als vertegenwoordiger van de publieke zaak. Politici noemen zich niet voor niets volksvertegenwoordigers en hun (her)verkiezing is afhankelijk van de indruk die zij wekken dat de publieke zaak bij hen in goede handen is. Daarbij past niet goed het beeld dat maatschappelijke resultaten in feite mede afhankelijk zijn van maatschappelijke partners, zoals zorgaanbieders, onderwijsgevenden, energieproducenten, projectontwikkelaars, actieve bewoners en vrijwilligers, et cetera.

Deze situatie is althans in Nederland zo. Misschien kan in de Verenigde Staten het politieke klimaat anders zijn, zodat politici er een eer in stellen tegenover de burgers hun eigen rol zo bescheiden mogelijk voor te stellen (Kruiter, 2011), maar dat is ook daar meestal alleen theorie; in Nederland is het zelfs bij de meest liberale of communitaristische partijen niet het geval. Toch kan het altijd nog sterker. In Nederland is het etatisme niet geworteld. In Frankrijk kan men de stelling regelmatig horen verdedigen dat de burgers er voor de staat zijn, trots moeten zijn de Staat (die verheven kroon op de natie) te mogen dienen; in Nederland vindt men een dergelijke stelling ongehoord. Natuurlijk, zo zullen vrijwel alle politici beamen, is het omgekeerd: de staat is er voor de burgers en moet dat besef steeds weer opfrissen om niet af te glijden naar technocratie of paternalisme. Dit is de gangbare opvatting in Nederland, maar dienstbaar zijn aan of werken voor is nog wat anders dan samenwerken met of zelfs luisteren naar.

\section{De houding van de Tweede Kamer als geheel inzake bestuursbeleid}

Als de politieke arena breed wordt beschouwd, dus kamerbreed en niet alleen de VC Binnenlandse Zaken, zijn signalen over de heersende bestuurscultuur moeilijk te vinden. Bestuur en bestuursvisie staan daar veel minder in de belangstelling dan inhoudelijke problemen, uitvoeringsmissers, onbedoelde effecten van beleid. Daar ligt de aandacht van het volk, dus ook die van de volksvertegenwoordigers. Dus decentralisatie als principe kon de hobby zijn van enkele Kamerleden uit de commissie Binnenlandse Zaken, in de Kamer als geheel was de steun voor decentralisatie meestal niet actief. De facto is de politieke betrokkenheid bij bestuur veel meer eclectisch en een uitkomst van toevallige interventies en contingenties dan het lijkt als alleen de agenda van de Vaste Commissie van Binnenlandse Zaken als ijkpunt wordt genomen.

De behandelde periode kenmerkt zich wel door een duidelijk gedragen steun voor ons systeem van representatieve democratie. Staatkundige en bestuurlijke vernieuwingen zijn er niet veel geweest, tenzij men de Europese integratie hier ook bij rekent. Ja, burgemeesters worden in deze eeuw de facto door gemeenteraden gekozen, maar daarmee blijt deze zeggenschap voorbehouden aan de politiek-bestuurlijke elite. In de vorige hoofdstukken is al een aantal keer gesignaleerd dat de behoefte om het politiek primaat te beklemtonen, de ministeriële verantwoordelijkheid te schragen, gedurende deze periode zelfs toenam.

\section{Sturingsbenadering en democratieopvatting}

Bij de behandeling van de cases in de dossiers van het bestuursbeleid is bij de sturingsbenadering vooral gekeken naar de eigen beleidsprocessen die meer het karakter van instructie of van horizontaal overleg kunnen hebben. Binnen het politieke bedrijf is deze keuzeoptie wat minder toepasbaar. Zelden zien we volksvertegenwoordigers een open dialoog openen met de samenleving met een ongewisse uitkomst. In 99\% van de gevallen verlaat het parlement zich op de stukken van de regering of op instructies van de eigen partijprogramma's. Een memorabele uitzondering, die de regel bevestigt, is de commissie-Van Middelkoop die in 1996 een open verkenning startte met hoorzittingen over de ins en outs van de klimaatproblematiek.

Hieronder gaat het er niet zozeer om een beeld te vormen over de eigen sturingsaanpak van de Kamer, maar over de opvattingen over sturing die de politieke beslissers proberen te bevorderen in wetgeving en beleid.

De democratieopvatting van de Tweede Kamer is nogal wiedes: representatieve democratie vooruit! Toch zijn er enkele voorbeelden waarin de Kamer zich inspant om burgerparticipatie als aanvulling op de representatieve democratie meer ruimte te gunnen. Te noemen zijn motie-Willems (1993), motie-Anker en amendement-Schinkelshoek (2007) en motie-Kalma (2008). 
Ook wat betreft sturingsfilosofie en democratieopvatting is het moeilijker de inzet van de Tweede Kamer als geheel te typeren dan alleen die van het smaldeel dat zich bezighoudt met Binnenlandse Zaken. Ten slotte is een wet als de WMO die zich richt op het erkennen en verder spreiden van maatschappelijke verantwoordelijkheid ook een politiek project. En de motie-Feenstra is ook door de Tweede Kamer aangenomen bij de behandeling van de begroting van milieu voor 2002. Daarin werd gesteld dat het milieubeleid meer 'van, voor en door de burger' zou moeten worden. Burgers zouden een meer coproducerende rol moeten krijgen bij de totstandkoming van het Nederlandse milieubeleid (TK 2001-2002, 28000 XI, nr. 21). Vanuit de Commissie Binnenlandse Zaken kan een soortgelijke interventie alleen worden opgetekend in de motie-Anker 2007 en het amendementSchinkelshoek, leidend tot het project 'In Actie met Burgers!', dat al weer over de rand van de onderzochte periode tot 2009 valt. Ja, als de Bijzondere Commissie Vraagpunten inzake staatkundige, bestuurlijke en staatsrechtelijke vernieuwing (zgn. commissie-Deetman) ook in deze koker geplaatst mag worden hebben we nog de beroemde motie-Willems van 1 december 1993. Deze vroeg de regering experimenten te stimuleren met interactieve beleidsvorming. Binnenlandse Zaken wist daar toen geen raad mee, maar Verkeer en Waterstaat pakte dit signaal op als startpunt voor nieuwe beleidsprocessen rond infrastructurele projecten (Infralab, Wegverlichting en alles wat daarop volgde).

\section{Waarnemingen van politici in een veranderende tijd}

Het is op één punt ook binnen de eigen wereld van politiek functioneren duidelijk merkbaar dat we in een andere tijd leven. De chaotische agendavorming, die past bij de hyperige mediacratie van de laatste tijd verraadt dat we inderdaad in een complexe netwerksamenleving zijn aanbeland. Maar dat weerspiegelt zich niet in de verhalen en taaluitingen van de Kamerleden, althans zolang deze in functie zijn.

Op zoek naar aanwijzingen voor het bestaan van opvattingen over de verhouding tussen politiek, overheid en samenleving is van binnenuit wellicht inside-information te krijgen uit publicaties zoals het proefschrift van Guido Enthoven (2011) en de herinneringen van Meili Vos, 'Politiek voor de leek'. Zij dateren echter van na 2008. Wel binnen de periode valt de beste beschrijving van het Kamerbedrijf-van-binnenuit die er is, in het boek 'Niet spreken met de bestuurder' van Gerard van Westerloo (2003), die, als gast uitgenodigd bij de PvdA-fractie, onbarmhartig de fractiediscipline en de verkokering tijdens Paars II neerzet. Als coalitiepartner was alles gericht op beheersing en risico mijden. Hetzelfde gedrag dat in die periode is opgetekend van de andere zijde, van Binnenlandse Zaken-directeur Herman Schartman. Binnen de grote warme deken van de fractiediscipline waarin elke visie en gevoelige uitspraak werd uitgebannen, waren de fractieleden kleine zelfstandigen over hun eigen winkeltje (portefeuille) met een groot tekort aan collegialiteit. Bij zijn afscheid na drie weken gastvrijheid roemt Van Westerloo deze:

"Niemand heeft me narrig iets geweigerd, iedereen heeft me gastvrij onthaald. En toch voelt het vertrek als een ontsnapping: weg uit een wereld waarvan de bewoners zo sterk op zichzelf gericht zijn, in beslag genomen als ze zijn door hun eigen functioneren."

Niet bepaald een typering die past bij een politiek orgaan dat is gericht op open samenwerkingsrelaties met de netwerksamenleving. Dergelijke herinneringen tussen ongeveer 2000 en 2008 zijn allerminst zeldzaam. ${ }^{85}$ Helaas zijn egodocumenten van politici die voor dit boek relevant materiaal opleveren dunner gezaaid. Wat moeten we bijvoorbeeld met de persoonlijke ditjes en datjes van Marjet van Zuylen? De meeste boeken in deze reeks gaan over het politieke bedrijf en de onderlinge verhoudingen en bevatten zelden reflecties over de rol van de overheid en politiek in deze tijd. Een uitzondering is het verslag van Hans Jeekel (1998) in 'Duizend Dagen Kamervragen', dat met kop en schouders boven de andere ijdele boekjes uitsteekt. Het begint al de

\footnotetext{
${ }^{85}$ Marjet van Zuijlen (2000), 'Retour Nijmegen-Den Haag. Dagboek van een politica', Hans Jeekel (1998), 'Duizend dagen Kamervragen', Bert Middel (2003), 'Politiek handwerk', Boris O. Dittrich (2001), 'Een blauwe stoel in paars. Verhalen uit de Tweede Kamer', Paul Rosenmöller (2003), Een mooie hondenbaan, Marcus Bakker (1994), 'Wissels. Bespiegelingen zonder berouw', Jan Nagel (2001), 'Boven het maaiveld', en andere.
} 
eerste dag waar het kersverse Kamerlid meteen geacht wordt volleerd te zijn. Antwoorden "ik oriënteer me nog" werkt niet. "Waar deze ouderwetse macho-ontvangst vandaan komt, weet ik nog niet. Het heeft iets te maken met de persoonlijkheidsstructuur van politici en ook iets met de grote invloed van de media", stelt Jeekel. Een volgende observatie van Jeekel betreft het loopgravengedrag. Omdat Jeekel van het ministerie van Landbouw afkomstig was, is zijn vergelijking met de ontwikkeling daar ook interessant voor het volgende hoofdstuk, waar LNV onder de loep wordt genomen. Jeekel schetst de omslag die hij in de jaren negentig heeft meegemaakt. Nieuwe openheid, die mogelijk werd door veel samenwerken, je inleven in doelen van de ander.

"Nu de Kamer. Daar zag ik heel weinig van die nieuwe cultuur. Sterker: ik zag ouderwetsigheid in de omgang."

Ten slotte beklemtoont Jeekel in zijn analyse de misplaatstheid van de parlementaire dikdoenerij alsof Kamerleden de leidende rol spelen. In het beeld van de muis en de olifant die zo lekker stampen samen, is de muis het parlement en de olifant de bureaucratie. Als bureaucraat had Jeekel overigens bij het voorbereiden van het Natuurbeleidsplan de ervaring dat ambtenaren als publiek ondernemer spin in het web zijn te midden van een maatschappelijk netwerk van stakeholders (governance). Kortom, politici houden de schijn op van politiek primaat, maar misschien omdat er in werkelijkheid niet veel van over is, gebeurt dat vaak net iets te krampachtig. Jeekel schetst de botsing tussen de participatieve beleidsvoorbereiding en de rol van het parlement dat hier geen boodschap aan heeft. Uiteindelijk bepleit Jeekel een heel andere rol voor politici, in navolging van Cees Schuyt: het versterken van het democratisch debat over de morele waarde van politieke besluiten, uitwisseling van argumenten op het niveau van waarden, waar iedereen aan kan meedoen.

"De tweede 'olifant' die de politiek overschaduwt zijn de media. De enorme impact van mediainterventies leiden ertoe dat de politiek in zijn schulp kruipt of juist tot bolle ijdelheid vervalt."

De scherpe waarnemingen van Jeekel tijdens zijn 1000 dagen bevestigen de conclusie dat politici gevangenen zijn van een zeer overheersend systeem en vooral van elkaar als elkaars concurrenten. Gevolg is volgens hem een aantal veiligheidsmechanismen: gedragen taal, enorme gehechtheid aan procedures, onwaarachtige jovialiteit, gewoondoenerigheid en lacherigheid, kortom weinig menselijk gedrag. Weinig voorwaarden voor een open oplossingsgerichte samenwerking. Een volgens Jeekel betreurenswaardig schepsel, die politicus. Een karikatuur misschien, maar als karikatuur komt de positie van politici veel verder nog aan het linker uiterste op de as tussen government en governance dan Binnenlandse Zaken, waar we weliswaar geen shift, maar nog veel ambiguïteit aantroffen.

Dit is natuurlijk maar het beeld van één Kamerlid, want de andere memoires en terugkijkboeken leveren veel minder helderheid op in dit opzicht. Beeld dat overheersend oprijst na lezing van deze lectuur is wel dat van 150 kleine zelfstandigen die enorm druk zijn met hun 'portefeuilles' en 'standpunten' die moeten worden opgewaardeerd tot fractiestandpunten en daarna zelfs Kamermeerderheden. In ieder geval zijn de boeken niet gericht op de vraagstelling die hier voorop staat: 'is er in de politieke arena sprake van een (verborgen) bestuurstheorie?' Nee, een betrouwbare bron vormen de meeste egodocumenten niet. Men moet wel erg tussen de regels doorlezen. Hoogstens kan worden vastgesteld wat er niet in staat. Contacten met lobbyisten, gesprekken met gewone burgers ontbreken in de meeste van deze boeken. Hoewel dat laatste niet helemaal klopt in het boek van Bert Middel, die zijn ervaringen met 'gewone' mensen, oorlogsgetroffenen, vluchtelingen en andere hulpbehoevenden uitgebreid weergeeft als de meest indrukwekkende bijdragen voor zijn standpuntbepalingen. Het boek van Boris Dittrich bestaat zelfs grotendeels uit concrete verhalen van burgers, waarmee het Kamerlid ook wil aantonen dat "de democratie geen abstractie is. De kloof tussen de Tweede Kamer en het volk hoeft niet zo groot te zijn als hij soms wordt afgeschilderd." 
Eigen ervaring in de Tweede Kamer

Op dit punt wil de schrijver nog een persoonlijke ervaring weergeven uit de XPIN-tijd. Samen met het adviesbureau BMC hadden we in 2002 een jaarcongres georganiseerd, waarbij ook een ideeënprijsvraag werd gehouden. Winnaar met het meest innovatieve idee werd een duo, dat onafhankelijk van elkaar een soortgelijke gedachte had ingediend: Leo Klinkers en Froukje Idema. Zij wilden het gesprek op basis van argumentenwisseling, de deliberatie zou je nu zeggen, in de volksvertegenwoordiging stimuleren. Het regeerakkoord tussen partijen aan de top zou vervangen moeten worden door agendering vanuit dialoog met de samenleving. De prijs bestond eruit dat zij, op kosten van BMC, hun idee zelf mochten uitwerken en helpen realiseren. Die uitwerking kwam erop neer dat Kamerleden zouden worden begeleid bij het voeren van open gesprekken, zonder zeepkist, meer luisteren dan zenden. Coen Dierikx van BMC en de schrijver vanuit XPIN fungeerden als facilitators vanuit de opdrachtgevers. ${ }^{86}$ We verwierven de medewerking van de Kamervoorzitter Weisglas en een vijftal Kamerleden wilden wel meedoen met dit experiment. We organiseerden verschillende vormen van gesprek: huiskamergesprek, groepsgesprek, digitaal gesprek, flitsgesprekken tot complete Real Time Branding en interactieve evaluatie met burgers in het hele land. En toen ging het mis. Want vlak voor de afgesproken datum werd steevast door de desbetreffende Kamerleden afgebeld wegens drukke verplichtingen: stemmingen, spreekbeurten, de wachtende burgers teleurgesteld achterlatend. Het experiment moest worden afgebroken, maar het project werd omgebouwd tot een analyse van het achterliggende mechanisme in het politieke bedrijf. Het boekje 'Terug naar Start' werd als spiegel voor de Kamerleden aangeboden aan de Kamervoorzitter. Het onderstaande citaat bevat enkele opvallende uitspraken:

"De kunst om signalen uit de samenleving te vertalen naar een politieke agenda op nationaal niveau is niet eenvoudig, maar lijkt ook niet meer te passen in de functieomschrijving van parlementariërs. Dat heeft de projectleden het meest verbaasd."

"Toen we de zeven gespreksvormen van het meervoudig instrument definieerden hebben wij niet voldoende beseft hoe strak het keurslijf zit. De Kamerleden moeten functioneren binnen de (vergader)orde van de Tweede Kamer en van de fractie. We dachten dat ze inspiratie zouden kunnen krijgen van de open gesprekken in ons plan van aanpak, maar voor inspiratie en verrassingen is in de agenda's van Kamerleden weinig of geen ruimte."

"De inspiratie komt vaak als reactieve impuls na plannen van het kabinet. De Kamerleden hebben een zodanig volle agenda dat onduidelijk is of er nog overzicht is. Door de (over)belasting neemt de flexibiliteit en responsiviteit af. Het kan een maand, een half jaar goed gaan, maar geen vier jaar, laat staan acht of twaalf jaar. De aandacht wordt steeds meer gericht op het kader binnen het regeerakkoord. Of dit (nog) een goede weergave van de maatschappelijke situatie is, wordt niet als maatgevend gezien."

Geconstateerd wordt dat politici worden geleefd door verplichte vergaderingen, voorbereiding van het debat dan wel bestudering van de vergaderdossiers, de contacten met de media, 'de partij' en dat voor het onderhouden van de contacten in het land en de vrij te besteden ruimte voor reflectie en experimenten bitter weinig tijd overblijft. Vanuit de in dit boekje haarfijn geanalyseerde werkwijze van politici kan zo al worden geconcludeerd dat responsiviteit en creatieve oplossingsgerichte interventies minder hoog zullen scoren dan het zijn van radertje in de besluitvormingscarrousel. In de beeldvorming via de media gaat het erom te laten zien hoe belangrijk de rol van politici is en in

\footnotetext{
${ }^{86}$ Leo Klinkers beschrijft dit project op zijn website als volgt: 'Verslag van een mislukt project met de Tweede Kamer. In 2002 won ik met Froukje Idema (LNV) de XPIN/BMC jaarprijs voor het meest innovatieve idee. Met het ter beschikking gestelde bedrag van 30.000 euro ontwierpen wij een meervoudig instrument om Kamerleden het contact met de samenleving te laten hervinden. Ondanks dat geld, onze expertise, netwerken en medewerking van de voorzitter van de Tweede Kamer is dat project niet gelukt. Over de oorzaken daarvan gaat dat boek met bijdragen van Coen Derickx, Froukje Idema, Leo Klinkers, Peter van Noppen en Jan Schrijver.'
} 
het bijzonder de bijdrage van de partij aan het bieden van heilzame voorzieningen en regels. Dit is het bekende politiek primaat, de uitingsvorm van de government-benadering bij uitstek in de politieke arena.

\subsubsection{Houding van de VC-Binnenlandse Zaken in het bestuursbeleid}

Aanwijzingen uit gemeen overleg met het Parlement

De hierboven genoemde stelling over de plaats van het politieke bedrijf als centrum van de wereld lijkt plausibel en de indruk wordt door het politieke taalgebruik dagelijks bevestigd, maar het gaat ook hier uiteindelijk om gedrag. Net als bij de casusbeschrijvingen van Binnenlandse Zaken, is uiteindelijk het doorzetten van een voorstel, het beklijven van een thema de lakmoesproef voor de mate waarin het parlement of afzonderlijke politici naar de ene of andere kant overhellen als het gaat om het onderscheid tussen government- en governance-benaderingen.

In de beschrijving van de casus Procesmanagement (paragraaf 9.4) passeerde al een reeks ervaringen op het beperkte terrein van burgerparticipatie, waaruit ook de relatieve desinteresse van de Tweede Kamer duidelijk bleek.

- Het niet nakomen van de toezegging aan het Kamerlid Schutte, het achterwege blijven van kabinetsreacties op twee adviezen van de Raad voor het Openbaar Bestuur afgescheiden ('Primaat in de Polder', 1999 en 'Burgers Betrokken, Betrokken Burgers', 2005), het uitblijven van de toegezegde Beleidskader Interactieve Beleidsvorming en het afwijzen van de nota over Burgerschap van Programma Andere Overheid zonder dat er enig alternatief werd gevraagd.

Hieraan kunnen nog de volgende voorbeelden worden toegevoegd:

- $\quad$ In samenwerking met de Vaste Commissie van Binnenlandse Zaken organiseerden XPIN, IMI en het bureau van Wilbert Willems DEND eind 2003 een informele hoorzitting over de stand van zaken met interactieve beleidsvorming ' 10 jaar motie-Willems'. Tijdens deze geslaagde parade van deskundigen in het gebouw van de Tweede Kamer werd duidelijk bij de Kamerleden dat juist bij de volksvertegenwoordigers verwachtingen en werkwijzen moeten worden aangepast om vrij baan te geven aan interactief bestuur en burgerparticipatie. De Kamerleden waren vastbesloten aan dit inzicht in moties of anderszins ook formeel in het parlement nog uiting te geven, maar dat is nooit meer gebeurd;

- $\quad$ Dat er nog geen consistente lijn van burgerparticipatie is ingezet is ook te zien aan de lotgevallen van de motie-Kalma/Schinkelshoek over een Charter voor Burgerparticipatie. Op een dikke brief van de staatssecretaris (TK 2008-2009, 30184, nr. 27) is nooit gereageerd door de Tweede Kamer.

Eigenlijk vindt de Tweede Kamer burgerparticipatie een beetje eng: het concurreert in de ogen van volksvertegenwoordigers met de representatieve democratie, maar dat kunnen ze zeker niet hardop zeggen. Het gaat toch ook om hun kiezers. Tekenend hiervoor is dat aan het begin van de demissionaire periode in 2010 het programma Burgerparticipatie op de lijst van controversiële onderwerpen is geplaatst. Een misverstand of een gotspe?

\section{Ervaring in de Tweede Kamer}

In de Tweede Kamer heeft de auteur zelf ook een ervaring opgedaan toen in 1992 werd gevraagd ambtelijke ondersteuning te leveren voor de commissie Decentralisatie binnen de discussies over Staatkundige Vernieuwing (commissie-Deetman). Binnen deze commissie onder leiding van Jan Fransen (VVD) heersten dezelfde ideeën als bij het ministerie over de strijd tussen goed en kwaad die zich rond decentralisatie afspeelt. Deze ideeën kennen we uit de rational choice-bestuurskunde (Buchanan, Downs et al.), die de bureaucratie beschrijven als een calculerend systeem van gericht op budgetmaximalisatie. In die gedachtegang is decentralisatie van binnenuit vrijwel onmogelijk, omdat ambtenaren dan bezig zouden zijn hun eigen banen op te offeren. Het verhaal gaat dan als volgt. 
Alleen door de grootst mogelijke machtsconcentratie kunnen de vakdepartementen gedwongen worden hun speelgoed af te staan. Of door heel slim te werk te gaan. David tegen Goliath. De heldensage van het decentralisatiebeleid van Binnenlandse Zaken. Waar hadden we dat meer gehoord? Het is de Binnenlandse Zaken heldenlegende, maar dan leken de parlementariërs, ongeacht hun partij, bij voorkeur de meest ongepolijste versie te vertellen: "We moeten ze dwingen!" Alleen de meest ervaren accountmanagers bij Interbestuurlijke Betrekkingen wisten wel beter.

Is het niet heel verwonderlijk dat typisch departementale legenden geloofd worden door volksvertegenwoordigers, die toch gekozen worden vanwege hun partijprogramma, vertrouwenwekkende persoonlijkheid of andere kwaliteiten, maar toch niet omdat ze de departementale ideeën over de eigen raison d'être navertellen...? De gedachtegang dat bureaucratieën erop uit zijn zichzelf in stand te houden of te versterken, groepeer ik onder de government-benadering, omdat de organisatie daar als doel op zichzelf wordt beschouwd.

Daartegenover staat governance-denken dat gericht is op het vinden van oplossingen voor - in dit geval bestuurlijke - problemen. Voor dit onderzoek onderstreept het nog eens dat de denkwereld van het ministerie en die van de gelijknamige Vaste Commissie zeer dichtbij elkaar liggen.

\section{Vier criteria}

Laten we nog wat systematischer te werk gaan. In de hoofdtekst werd het onderscheid government- governance geoperationaliseerd aan de hand van vier kenmerken:

\section{Doelstelling van beleid}

Versterken van de centraliteit van het bestuur, scheiding van verantwoordelijkheden, uniformiteit en standaardisatie of samenwerking, delen van verantwoordelijkheden, contingentie en maatwerk.

\section{Sturingsaanpak bij de beleidsvoering}

Hiërarchische command and control-benadering, planmatige fasering, sterke reductie van complexiteit en scheiding tussen beleid en uitvoering versus omgaan met complexiteit, beleidsprocessen als avontuur, zoeken naar ad hoc coalities, open communicatie.

3. Democratieopvatting

Representatieve democratie versus directe participatie van betrokkenen.

4. Informatievergaring

Kortweg aangeduid als Analyse -> Instructie of Variëteit -> Selectie.

Achtereenvolgens wordt de zelfstandige inbreng vanuit de volksvertegenwoordiging op deze assen geplaatst. Eerst bekijken we de bijdrage vanuit de Commissie op het terrein van bestuursbeleid.

\section{Doelstelling}

Bij dit criterium stuiten we meteen al op de pluriformiteit van politieke opvattingen. We kunnen de politieke arena als het gaat om doelstellingen moeilijk over één kam scheren. Het is nu juist het wezen van politieke partijen dat zij zich onderscheiden in hun visie op de gewenste beleidsrichtingen en ook op deze punten van bestuursbeleid lopen de voorkeuren uiteen. In de periode die in dit boek wordt bekeken zijn er echter wel duidelijke meerderheden aanwezig die hun stempel zetten op het bestuursbeleid

Aldus beschouwd is het niet moeilijk om de praktische bijdrage van het parlement in het bestuursbeleid te lokaliseren. Het parlement is net zo verkokerd als de rijksoverheid, dus een politieke inbreng op deze thema's is vooral te vinden in de Commissie voor Binnenlandse Zaken. En deze Commissie hanteert een typisch 'bestuurlijke' invalshoek, dus let meer op de systeemintegriteit van het openbaar bestuur (aantal bestuurslagen, autonomie van gemeenten en provincies, bestuurskracht van overheden, ministeriële verantwoordelijkheid) dan op de bijdrage van het bestuur aan het oplossen van maatschappelijke problemen. Wel is vanuit de vorige hoofdstukken vast te stellen dat het parlement bij sommige dossiers meer sturend en initiërend is geweest dan bij andere: initiatieven voor bestuurlijke organisatie en organisatie rijksoverheid waren 
vaak reacties op aandrang vanuit het politieke domein, terwijl het parlement bij decentralisatie, achterstandenbeleid en informatiesystemen meer volgend was ten opzichte van het bestuur.

Turven van de inbreng vanuit de Vaste Commissie

In de vijf dossiers van bestuursbeleid versterkt de Tweede Kamer de gesignaleerde voorkeur van het ministerie veeleer dan dat zij tegengas geeft. Als Binnenlandse Zaken plannen aankondigt om te decentraliseren, adviesorganen op te schonen, stadsprovincies te vormen en informatierelaties te stroomlijnen zijn de moties en amendementen er in de meeste gevallen op gericht nog een tandje bij te zetten. Slechts 22 van de 118 beogen de verstrakking van de bestuurlijke doctrine af te zwakken.

Tussen $1995^{87}$ en 2009 zijn 118 aangenomen moties en amendementen aangetroffen op het terrein van bestuursbeleid met uitzondering van de zeer populaire thema's Integriteit en beloning ambtsdragers, en gemeentelijke herindelingen. Deze thema's zijn op zichzelf al verantwoordelijk voor minstens een even groot aantal moties en amendementen. Binnen de resterende moties en amendementen zijn er ook weer enkele onderwerpen die elk afzonderlijk een groot aandeel hebben in de oogst. Dat zijn vooral dualisering (36) en zelfstandige bestuursorganen (25), samen goed voor meer dan de helft van de moties en amendementen.

Van de 118 aanvaarde moties en amendementen uit de Tweede Kamer zijn er in totaal 56 te karakteriseren als verder strekkend dan de kabinetsvoorstellen in de richting van government. Bij slechts 22 is de strekking juist invoeren van meer governance in de besluiten en bij 40 is de bedoeling in dit opzicht onbepaald.

Er zijn vanuit het ministerie slechts enkele projecten uit de dossiers van dit boek met een governance-karakter die de Tweede Kamer überhaupt hebben bereikt: sociale vernieuwing, Complementair bestuur en Procesmanagement. Daar is nooit een traan gelaten om het feit dat Binnenlandse Zaken deze projecten heeft stopgezet. De ontbrekende voortgangsbewaking op toezeggingen van de regering op het terrein van burgerparticipatie is hierboven al beschreven.

\section{Informatievergaring}

Het gebruik van wetenschappelijke analyse en onderzoek als basis voor oordeelsvorming lijken in de Tweede Kamer en het politieke domein in brede zin nog het meest te zijn veranderd in de onderzochte periode. Dat komt wellicht nog het meest door de enorme proliferatie van onderzoek, die het mogelijk maakt voor iedere partij om naar haar gading onderzoek uit te zoeken dat bij haar standpunt past. Deze ontwikkeling wordt mooi beschreven in het themanummer van

Bestuurskunde over Informatie en Politiek (Van Montfort en Enthoven, 2012). In dit opzicht lijkt het model Variëteit -> Selectie langzamerhand meer van toepassing dan Analyse -> Instructie, met dien verstande dat een gecondenseerd selectieproces doorgaans ontbreekt.

\subsection{Conclusies over de bestuurstheorie van de Tweede Kamer}

Bestuurstheorie van politici in het algemeen

De informatie hier is naast goed bijgehouden eigen ervaringen (Schrijver en Van Zuylen, 2010) ontleend aan getuigenissen van parlementariërs over hun ervaringen in deze verheven politieke arena. Enkele van deze egodocumenten bieden enige reflectie op de bestuurstheorie die aldaar opgang doet (vooral Jeekel,1998).

Of het nu gaat over de inhoudelijke voorkeursuitingen en vooroordelen van parlementariërs of over de arbeidsvoorwaarden en werkwijzen van Kamerleden, alle tekenen wijzen erop dat de bestuurstheorie daar eerder nog 'ouderwetser' lijkt te zijn dan dat zij al een omslag naar governance-benaderingen gemaakt zou hebben. In de jaren negentig, onder 'paars', werd het politiek primaat zwaar aangezet. De verwachtingen van velen waren dat na de populistische 'opstand' van Fortuyn cum suis een andere wind zou waaien, maar toch hebben de traditionele

87 Vanaf 1995 zijn alle Kamerstukken digitaal te vinden op www.officielebekendmakingen.nl. 
politieke partijen zich spoedig herpakt en is opnieuw een restauratieve terugslag merkbaar geweest.

Bestuurstheorie van de VC-Binnenlandse Zaken

Bovenstaande gegevens geven een beeld over de bijdrage van het 'bestuurlijk smaldeel' in het parlement aan de bestuurstheorie binnen het 'subsysteem' van het bestuursbeleid.

De vooraf verwachte uitkomst over de bestuurstheorie van het parlement was gebaseerd op de proefschriften van Peters en Koppenjan, die constateerden dat Binnenlandse Zaken, meer dan andere ministeries invloed van de politieke arena ondergaat. Dit ministerie zou zich van nature dienstbaar richten op de parlementaire democratie en zich relatief veel gelegen laten liggen aan de wensen van de volksvertegenwoordiging. Deze houding is goed te rijmen met hetgeen is gevonden over de ministeriële verantwoordelijkheid (zie paragraaf 9.3). In de verzamelde gegevens over het gedrag van de Tweede Kamer, culminerend in de vakcommissie, schijnt weinig licht door tussen de bestuurstheorie van Binnenlandse Zaken en van de gelijknamige Vaste Commissie, die de standpunten over bestuursbeleid voorbereidt en in feite bepaalt. De leden van deze commissie zijn overigens niet zelden uit het circuit rond het ministerie afkomstig (ambtenaren,

gemeentebestuurders, consultants). Daarnaast zijn de aangenomen moties en amendementen van de Vaste Commissie Binnenlandse Zaken tussen 1995 en 2009 geturfd met als vraag of zij ten opzichte van kabinetsbeleid verder strekken in de richting van government of juist meer governance willen invoeren. Van de 118 in de telling betrokken moties en amendementen is bijna $50 \%$ te karakteriseren als verder strekkend dan de kabinetsvoorstellen in de richting van government. Bij een kleine $20 \%$ is de strekking juist invoeren van meer governance in de besluiten en bij de rest is de bedoeling in dit opzicht onbepaald.

Deze analyses leiden tot twee conclusies over de stellingen van dit onderzoek:

1. Van een veronderstelde shift van government naar governance is, althans in dit deel van de Tweede Kamer zo mogelijk nog minder te merken dan bij het ministerie al het geval was.

2. De stelling van Peters dat Binnenlandse Zaken van oudsher dicht aanschurkt tegen het parlement heeft dit onderzoek niet kunnen bewijzen, omdat niet is vastgesteld of andere ministeries minder eerbied tonen voor de volksvertegenwoordiging. Het grote belang dat aan het wetgevingsinstrument wordt gehecht zou volgens Peters en anderen een mogelijke verklaring vormen, maar bijzondere aandacht voor wetgeving is in de casussen binnen het bestuursbeleid niet zo opgevallen. Wel is binnen de bestuurstheorie van Binnenlandse Zaken bijzondere aandacht voor de positie van volksvertegenwoordigers merkbaar, tot uiting komend in de leerstukken over ministeriële verantwoordelijkheid, democratische controle en het regionale (democratische) gat. Zo zou de stelling van Peters dat Binnenlandse Zaken bijzondere reverentie voor het parlement toont, nog wel kunnen kloppen, maar om een andere reden dan het belang dat aan wetgeving wordt gehecht.

Via een aantal waarnemingen over relevante indicatoren van bestuursstijl en belangstelling binnen het parlement is hier tot een voorzichtige inschatting gekomen van de kans dat de bestuursopvatting in de politieke wereld de transformatie zou hebben doorgemaakt van government naar governance. Die kans moet bijzonder gering worden geacht. Dus inderdaad evenmin als bij Binnenlandse Zaken het geval bleek. De kans lijkt groter dat vanuit het parlement de geconstateerde voorkeurshouding van het ministerie nog is versterkt. Immers, de meeste ingediende voor het onderwerp relevante moties en amendementen wijzen meer op versterking van de leer dan op afzwakking ervan.

$\mathrm{Nu}$ zal de lezer toch benieuwd zijn of dat bij vakministeries en bij de gemeenten anders zou liggen. 


\section{Vergelijking met een vakdepartement: Landbouw}

\subsection{Inleiding}

In hoofdstuk 1 is aangekondigd dat bij de vergelijking van Binnenlandse Zaken met een ander ministerie de keuze is gevallen op het ministerie van Landbouw ${ }^{88}$ (LNV), omdat daar vrij veel over is geschreven, ook met een langetermijnperspectief. Veel aandacht is uitgegaan naar de ingrijpende verandering in de koers van het ministerie na het aftreden van Gerrit Braks in 1990 als minister. Dit is ook een indicatie dat zich hier misschien, anders dan bij Binnenlandse Zaken, een echte paradigmawisseling kan hebben voorgedaan in de richting die de bestuurswetenschap ons voorhoudt. De periodisering van de bestuurstheorie van LNV betreft dus grofweg twee perioden: de naoorlogse jaren tot circa 1985 en de periode daarna.

Hieronder zal de beschrijving van het discours bij LNV zich baseren op enkele wetenschappelijke studies over het ministerie van Landbouw, die alle ook ingaan op de ideeënontwikkeling binnen dat departement:

- $\quad$ B.J.S. Hoetjes (1993), Landbouw, natuurbeheer en visserij - Profiel van een ministerie, Den Haag;

- $\quad$ C.A.M. Termeer (1993), Dynamiek en inertie rondom mestbeleid; een studie naar veranderingsprocessen in het varkenshouderijnetwerk, Den Haag;

- J. Frouws (1993), Mest en macht; een politiek-sociologische studie naar belangenbehartiging en beleidsvorming inzake mestproblematiek in Nederland vanaf 1970, Wageningen;

- H. Bekke., J. de Vries en G. Neelen (1994), De salto mortale van het ministerie van Landbouw, Natuurbeheer en Visserij, Beleid, organisatie en management op een breukvlak, Alphen aan den Rijn;

- $\quad$ E. Wielinga (2001), Netwerken als levend weefsel, Een studie naar kennis, leiderschap en de rol van de overheid in de Nederlandse landbouw sinds 1945, 's-Hertogenbosch;

- W.J.M. Kickert en F.B. van der Meer (2007), Laat duizend bloemen bloeien, Hoe het ministerie van LNV omgaat met externe veranderingen, Den Haag.

Wetenschappelijk werk over ministeries is dun gezaaid. Er is geen ministerie dat als studieobject zoveel bestuurskundige proefschriften heeft opgeleverd als LNV, andere ministeries moeten het doorgaans met een enkele doen. Daar wordt in deze verkenning dankbaar gebruik van gemaakt.

Wielinga zet in zijn proefschrift verschillende periodiseringen die in de eerder genoemde literatuur worden gehanteerd voor de ontwikkeling van het naoorlogse landbouwbeleid naast elkaar (Wielinga 2001: 44-45). Bekke cum suis noemen de periode van 1945-1980 de 'serene periode'. Termeer beschrijft de aanloop tot het mestbeleid (1970-1975) als 'geen wolkje aan de lucht' en de periode daarna (1975-1983) als 'stilte voor de storm'. Wielinga zelf maakt nog een knip tussen 'Wederopbouw' en 'Bloeiperiode'(1956-1975) en ziet in 1975-1984 al tekenen van 'toenemende onzekerheid'. Hoewel de datering niet helemaal synchroon loopt, is bij alle drie auteurs wel duidelijk dat er iets ingrijpends aan de hand is. Bekke: 1980-1992 'Periode van toenemende crisis', Termeer: 1984-1987 'Donderslag bij zwaarbewolkte hemel' en 1988-1991: 'Zwaar weer op komst'. Wielinga typeert minder dramatisch: 'Uiteenlopende belangen' (1984-1989) en 'Onthechting' (1989-1995).

\footnotetext{
88 Het ministerie heeft in de onderzochte periode verschillende benamingen gehad. Hoewel overkomst van het onderdeel natuurbeheer en recreatie van Cultuur, Recreatie en Maatschappelijk Werk al in 1982 had plaatsgevonden, werd pas in 1989 de N van Natuurbeheer toegevoegd aan Landbouw en Visserij. Misschien tekent dit nog het best de cesuur tussen het oude en het nieuwe ministerie, niet langer één belang in de naam. In de nadagen van zijn bestaan is de $V$ van Visserij nog ingewisseld voor Voedselkwaliteit. De constante is dus Landbouw en de gangbare afkorting in het grootste deel van de periode 1968-2008 was LNV.
} 
Bovenstaande typeringen en de titel 'Salto mortale' van Bekke cum suis zeggen genoeg over de keuze tussen continuïteit of verandering bij LNV. Het is niet zo relevant om al die historische fasen uitgebreid te gaan beschrijven. Het gaat hier om één specifiek aspect: de heersende opvatting over de verhouding tussen overheid en samenleving op de as tussen government en governance. De vraag is of op dit punt ergens halverwege onze onderzoeksperiode, dus rond 1990, een radicale en blijvende omslag heeft plaatsgevonden in de bestuurstheorie die past in de these van veel bestuurskundigen over modern netwerkbestuur/governance.

\subsection{Literatuurverkenning over de bestuurstheorie van LNV}

\subsubsection{De corporatistische traditie, neo-corporatistische staatsopvatting}

\section{Netwerk, maar wel gesloten}

Wat vrijwel meteen opvalt in de eerste periode van ons onderzoek in de jaren zeventig en tachtig, is het grote verschil in bestuursbenadering tussen het ministerie van Binnenlandse Zaken en dat van Landbouw. Hoewel ooit Binnenlandse Zaken en Landbouw van hetzelfde ministerie deel hebben uitgemaakt (Hoetjes, 1993: 23), is dit vakdepartement wel uitzonderlijk ver van het moederdepartement verwijderd geraakt. Ofschoon Binnenlandse Zaken ook zijn vaste clientèle had en heeft (VNG, IPO, de directies bedrijfsvoering en de bestuurlijk-juridische afdelingen van de departementen), heeft LNV lange tijd na de oorlog een hechte symbiotische relatie gehad met het agrarische bedrijfsleven. In dat opzicht zou men kunnen spreken van governance avant la lettre, samenspel tussen de overheid en partners uit de samenleving. De oriëntatie van het ministerie was zeer probleemgericht en werd rechtstreeks gevoed door de samenleving, maar daar houdt de vergelijking op. Volgens de omschrijving in dit boek zijn cliëntelisme en polderende besluitvorming immers niet direct gelijk te stellen aan governance. De relaties met de Landbouw-partners waren zeer hiërarchisch, de boeren waren gezagsgetrouw en de interacties weinig verrassend (Termeer, 1993a).

Wel effectief. Zowel Bekke cum suis (1994: 89) als Jeekel (1998: 22) melden dat het ministerie omstreeks 1980 zeer hoog stond aangeschreven in de pikorde. Als er al sprake was van een netwerk, was het netwerk nogal voorspelbaar en gestuurd. Het pluralistische wezenskenmerk van de governance-benadering was hier afwezig en ook de kennisopvatting was bij uitstek klassiek rationalistisch. Met enige overdrijving werd de Nederlandse landbouw wel beschreven als een variant op het kolchozen-systeem en het ministerie als Stalinistisch bolwerk (met een aardig bijpassend gebouw aan de Bezuidenhoutseweg). De fameuze technologische ontwikkeling van de Nederlandse agrarische industrie ${ }^{89}$ in wisselwerking met de ondernemers verliep via een uitgekiend model van Onderzoek, Voorlichting en Onderwijs (de eigen universiteit van Wageningen, de Landbouwvoorlichting en de landbouwscholen). Resultaten van toegepast onderzoek sijpelden snel en efficiënt door naar de praktijk via de genoemde kanalen. Er was wel kritiek op dit aparte en vrij ongenaakbare bolwerk (het Groene Front), maar het werkte wel en was lange tijd onaantastbaar. In de jaren tachtig en negentig stortte het bestuursmodel echter met een harde klap ineen, wat deze casus zo interessant maakt voor onze studie.

Frouws beschrijft in zijn studie zeer nauwkeurig de kenmerken van corporatisme en neocorporatisme als politieke theorieën. Zonder hier diep in te gaan op het verschil tussen de corporatistische oervorm (autonome zelforganisatie van maatschappelijke partners, subsidiariteit in eigen kring) en de neo-corporatistische variant (sterke verstatelijking, één machtscentrum met sterk georganiseerde belangengroepen) is deze laatste vorm hier vooral van belang. De ontwikkeling

\footnotetext{
89 Hoe een klein landje 's werelds tweede agrarische exporteur kon worden, wel ten koste van het landschap en door de grond in een groot chemisch reservoir te veranderen, waar het ministerie nog tot in de jaren negentig 1000 kilogram kunstmest per hectare voorschreef.
} 
van het landbouwbeleid na de oorlog was namelijk sterk verstatelijkt en het corporatistische karakter moet meer worden gezocht in de instituties binnen de sterke staat dan in de autonomie van de sector. De kern van de neo-corporatistische staatstheorie is de verstrengeling van staat en belangengroepen: de laatste worden een deel van de 'vergrote' staat en delen in de staatsmacht. Aan die autonome staatsmacht wordt door de aanhangers van de neo-corporatistische staatstheorie grote betekenis toegekend.

Vergelijking met Binnenlandse Zaken binnen de government-governance benadering In tegenstelling tot dit maatschappelijk gewortelde ministerie, was Binnenlandse Zaken meer Haags en bezig met afstandelijke politieke en bestuurlijke kwesties. Zelfs achterstandswijken werden, zoals we zagen, doorgaans op gouvernementele wijze via kaders voor gemeentelijke beleidsplanning en bestuurskrachtontwikkeling benaderd.

Een schoksgewijze omslag (shift) naar een ander bestuursparadigma is bij Binnenlandse Zaken ver te zoeken, terwijl de recente geschiedenis van LNV hierdoor juist wordt getekend. In de eerste helft van onze onderzoeksperiode wordt de democratie-opvatting van LNV binnen Binnenlandse Zaken nauwelijks getolereerd. Politieke representatie behoort volgens de naoorlogse opvattingen van de 'bestuurlijke kaste' plaats te vinden op basis van verkiezingen en de botsing van ideologische standpunten, niet op basis van belangenrepresentatie van een selecte afspiegeling van bedrijfsgenoten. Op veel punten waren de tegenstellingen tussen de ministeries groot.

Als Binnenlandse Zaken iets wilde bespreken over de sturingsinstrumenten van LNV, kon men niet om het centrale machtsbolwerk binnen het ministerie heen: de directie Bestuurlijk-Juridische Zaken (BJZ), waar ook de grote mannen van het ministerie, Tjibbe Joustra, Maarten Brabers en anderen, hun loopbaan hadden opgebouwd. Overleg daar was een aparte ervaring. Je kon net zo goed tegen een muur praten, in ieder geval als je enige verandering wilde voorstellen. Het systeem zat onwrikbaar in elkaar, elke regeling was onmisbaar voor boeren en voor de politiek gelegitimeerde beleidsdoelen gelijk. Er was geen speld tussen te krijgen. Als ambtenaar heeft de onderzoeker zelf het twijfelachtig genoegen gehad om tijdens de Decentralisatie-impuls (1991-1993) onderhandelingen te voeren met het 'oude' ministerie van Landbouw over de Landinrichtingsdienst en het natuurbeleid. Op de achterhand was een glashelder rapport van de adviescommissie van drie wijze mannen (Gijs van Aardenne, Cees van Dijk en Walther Etty) beschikbaar, die ondubbelzinnig concludeerden dat veel van dit beleid wel naar de provincies zou kunnen worden gedecentraliseerd. Maar er was geen doorkomen aan. Tot en met de minister-president heeft minister Braks zich verzet en Ruud Lubbers wilde uiteindelijk toch liever zijn kabinet bij elkaar houden dan een voorkeur uit te spreken voor een helder inhoudelijk advies. In paragraaf 6.8 is over de werkwijze van de Decentralisatie-impuls al geschreven. Dat was 1992. In paragraaf 6.6 kwam ook het Bestuursakkoord-Nieuwe Stijl aan de orde, waar in 1998 Landbouw een van de weinige voorbeelden bood waar overeenkomstig de bedoeling werd afgedaald naar concrete beleidspraktijk, in Noord-Limburg. Bart Fokkens had daar vanuit Binnenlandse Zaken een belangrijk aandeel in, maar aan de andere kant werkte hij samen met Nico Beun. Dit was een prettige ambtenaar, die afkomstig was uit het oude ambacht van ruilverkavelen bij de Landinrichtingsdienst, maar in de veranderingsgolf binnen het ministerie kansen kreeg om zijn ware vernieuwende aard te ontplooien. Niet voor niets is Nico nu al weer jaren een van de drijvende krachten in het Innovatienetwerk Groene Ruimte en Agrocluster dat hieronder nog ter sprake komt, maar toen was hij een witte raaf in een duidelijk veranderend klimaat. Andere vernieuwers die de auteur in die periode vlak voor de eeuwwisseling tegenkwam waren Peter Kurstjens (vóór Schrijver secretaris bij het interdepartementale netwerk van de directeuren strategisch omgevingsbeleid en ontwerper van de leergang voor jonge medewerkers bij de fysieke departementen), Wim de Haas (bij de Dienst Landelijk Gebied in Utrecht), Bram van de Klundert (de ondernemende trekker van het Natuurbeleidsplan na Hans Jeekel), Renske Peters en Kees de Ruiter van de directie Plattelandsbeleid en een aantal mensen bij de directie Strategie: Ger Vos (later directeur van het Innovatienetwerk), Katrien Termeer, Jan Dirven (evangelist van de horizontalisering). Er was duidelijk een andere wind opgestoken binnen LNV. Bij XPIN kwam je veel LNV'ers tegen, zoals SG 
Chris Kalden die lid werd van de XPIN-stuurgroep, Henk van Latesteijn, Sander Mager en Jobien Monster, allemaal van Strategie. De laatste jonge ambtenaren kregen kansen om inspirerende projecten te ondernemen, zoals het boekje 'Hollandse Nieuwe'van Sander ten behoeve van een denksessie. Jobien verzorgde met anderen een boeiende presentatie Tina \& the Milk, waar Jobien en anderen het gedachtegoed van de postmoderne filosoof Bruno Latour op kunstzinnige wijze toepasten op de voedselketen en het landbouwbeleid. Ten slotte herinnert menig bestuurskundige zich nog de keynote speech van minister Cees Veerman voor het Festival der Bestuurskunde in 2005, waar hij een vurig pleidooi hield voor een nieuwe rol van de rijksoverheid, passend in de governance-benadering.

Ja, er was binnen LNV veel ruimte voor experimenten, maar toch. Dat trainee Jobien Monster het er niet kon volhouden was een teken aan de wand. Gelovigen als Jan Dirven wisten elkaar wel te vinden en kregen ook wel ruggensteun van de top, maar hun leuke en inspirerende projecten bleven, zoals ook later Foodlink, losse flodders.

Maar in deze periode is toch de overeenstemming tussen beide ministeries voor onze vraagstelling relevanter. Beide ministeries scoorden op de as tussen government en governance op alle drie kenmerken positief als government gericht: uitgaand van centraliteit van de macht, verticale hiërarchische verhoudingen en kennis puttend uit de 'objectieve' werkelijkheid.

\subsubsection{De salto mortale}

Voor een uitgebreide beschrijving van de verandering in het Nederlandse landbouwbeleid in het algemeen, wordt eerst de monografie van Bekke cum suis (1994) ter hand genomen. Deze auteurs leggen de nadruk op organisatie en management. Wielinga (2001) zoomt in op twee belangrijke aspecten, de leiderschapsopvatting en de kennis- en informatiebenadering binnen het ministerie. Beide studies laten goed zien hoe het ministerie in de loop van de jaren tachtig onder toenemende kritiek van de buitenwereld kwam te staan. In 1987 stelde de Tweede Kamer een parlementair onderzoek in naar de visquoteringsregelingen. In 1990 volgde een tweede visserij-affaire en die leidde tot het aftreden van de minister. De mestproblematiek speelde ongeveer gelijktijdig en wordt ook door Bekke cum suis als beleidscasus voor verandering aangehaald.

\section{Drie Beleidsramen voor verandering}

De defensieve, in zichzelf gekeerde groene sector had zijn geloofwaardigheid te midden van de conflicterende belangen van stad en milieu compleet verloren. Een diepgravend proces van zelfreflectie en cultuurverandering volgde hierop. Het boek van Bekke cum suis (1994), dat in opdracht van de bestuursraad van LNV werd geschreven, vormt onderdeel van dit reflectieproces. Voor nu is vooral de vraagstelling naar de organisatieverandering van belang. Net als dit boek gaat Bekke uit van het belang van ideeën voor organisaties, meer dan machtsverhoudingen of de kwaliteit van personen. Net als Koppenjan dat bij Binnenlandse Zaken heeft gedaan, hanteren deze auteurs het theoretisch model van Kingdon voor de agendavorming. Omstandigheden in de omgeving creëren kansen (windows of opportunity, door Bekke cum suis in het Nederlands vertaald als beleidsramen) voor bepaalde oplossingsrichtingen bij nieuw gesignaleerde problemen om de agenda te bereiken en door te breken in beleid. De relevante veranderingen in publieke ideeën worden door Bekke cum suis gerelateerd aan de volgende bestuurskundige analyse:

"De ijzeren driehoek van de landbouwsector (belangengroepen, politici, ambtenaren) is veranderd in een complex en veel meer open strijdpuntennetwerk waarin diverse personen en groepen verschillende ideeën en waarden vertegenwoordigen. De coherente cultuur die was gebaseerd op consensus komt onder druk te staan waardoor de operationele code binnen de beleidsgemeenschap niet langer werkt." (Bekke et al., 1994: 17)

De auteurs maken het optreden van deze omwenteling aannemelijk binnen verschillende relevante omgevingen van het beleid: economie, politieke ontwikkelingen bij partijen en afkalvende 
ideologieën, nieuwe strijdpunten op basis van immateriële waarden. Institutionele vertaling van deze ideeënontwikkeling is de genoemde ontwikkeling van een open strijdpuntennetwerk, waarin men elementen van de governance-benadering herkent. Bekke cum suis reconstrueren drie momenten waarop het beleidsraam voor verandering in de ideeën bij het ministerie werd opengezet: in 1982-1984 de ambtelijke cijfers over melkplassen, overbevissing en mestoverschotten, in 1990 de schok die het vertrek van Braks opleverde en in 1992 de stroomversnelling die in gang werd gezet door een televisie-uitzending van 'NOS-laat' waarin alle elementen (stromen in de theorie van Kingdon) samenkwamen: problemen, oplossingen en politiek. Interpellatie in de Tweede Kamer en instelling van een commissie onder leiding van Neelie Kroes maakte het veranderproces onomkeerbaar. Het gevolg van deze bijzondere momenten is volgens Bekke onmiskenbaar een breukpunt op het terrein van beleid, organisatie en management geweest. Een klassiek hiërarchisch opererende bureaucratie in afbouw, een ondernemende professionele organisatie in opbouw. Naar buiten gericht conditionerend in plaats van dirigerend management. De gesprekken die de onderzoekers met groepen medewerkers hebben gevoerd, detecteren nog hardnekkige resten van 'oude cultuur'. Het optimisme over het verdwijnen van het bestuurscentrisme en de gesloten belangencircuits is bij de leiding weliswaar groter dan bij de medewerkers, maar de richting van de innovatie is onomstreden.

\subsubsection{Drie paradigma's in de landbouwnetwerken}

Eelke Wielinga heeft nog tot circa 2000 verder onderzoek gedaan binnen het ministerie over de ingezette veranderingen. Ook hij constateert dat tot ongeveer 1985 sprake was van een opmerkelijke samenwerkingsrelatie, een netwerk avant la lettre, waarbij de informatie weliswaar stroomde binnen het netwerk, maar dat nog niet paste bij de latere plurale netwerksamenleving van onze governance-these. Dit oude netwerk was tot uitzonderlijke prestaties in staat binnen de condities van het naoorlogse Nederland, dat een wereldspeler werd op de markt van agrarische producten. Maar het raakte in de problemen toen de samenleving complexer werd. Een volgend mirakelstukje is geleverd door een aanpassingsproces aan de nieuwe condities, wat vooral innovatie in leiderschap en kennissystemen vergde. Volgens Wielinga is door de landbouwsector in vrij korte tijd gewerkt aan een nieuw contract met de samenleving. Hij beschrijft dit proces aan de hand van vier stappen, elk met een eigen paradigmatisch verhaal. De eerste drie ziet Wielinga ook in de empirie weerspiegeld. Het vierde paradigma is het vervolg op de geschiedenis, een verhaal dat Wielinga zelf ontwerpt en in de toekomst projecteert.

Het eerste verhaal is het instrumentele paradigma dat kon blijven bestaan zolang men zich binnen het netwerk kon identificeren met een gemeenschappelijk belang. Kennis heeft binnen die context de functie om objectieve wetenschappelijke waarheid te ontwikkelen en te verspreiden ten dienste van de gemeenschappelijke doelen. Die objectieve scheidsrechtersfunctie van de wetenschap kwam te vervallen toen de belangen gingen uiteenlopen. Het tweede, in de periode na 1995 dominante, 'strategische' verhaal projecteerde een machtsarena waarin winnaars en verliezers optreden. De partijen kwamen los uit hun klemmende greep en tegenover elkaar te staan. Wetenschappelijke strijd tussen specialismen ging hiermee hand in hand. De verhoudingen werden er niet beter op. In de onderstroom werd in dezelfde periode na 1995 een derde verhaal zichtbaar. Dit is het communicatieve paradigma waarin niemand meer de waarheid in pacht heeft en alleen interactie en communicatie als wapens overblijven om tot collectieve leerprocessen te komen.

Onderlinge afhankelijkheid tussen vele actoren en ongewisse processen zijn herkenbaar voor de governance-benadering. Wielinga acht ze echter niet stevig genoeg voor een vitaal netwerk. Er ontbreekt namelijk een ijkpunt voor wat in de veelheid van waarheidsclaims goed en wat ziek is. Daarvoor voegt hij een element toe in het vierde en laatste verhaal, het ecologisch paradigma. Dat element is de kwaliteit van de respons op de ecologische en sociale omgeving. Los van deze persoonlijke, nogal normatieve toevoeging werpt zijn analyse van de geschiedenis van het ministerie en de rol van de landbouwvoorlichting in het kennissysteem licht op de stelling dat LNV daadwerkelijk een shift van government naar governance heeft geïnternaliseerd. 
Te midden van de privatiseringsgolf (zie hiervoor paragraaf 9.3) werd in 1989 ook de landbouwvoorlichting geprivatiseerd. De Dienst Landbouwvoorlichting werd een commercieel bedrijf en de cultuuromslag die ermee gepaard ging, leidde tot een grote uittocht van medewerkers. De saamhorigheid van het landbouwkennissysteem brokkelde snel af. Na 1995 trad onder de paarse kabinetten een volgende fase in. Het einde van het eens zo machtige Landbouwschap, geheel vermolmd en omgevallen door een relatieve kleinigheid, markeert deze nieuwe fase. Een andere kenmerkende ontwikkeling was de verbreding van het landbouwbeleid naar plattelandsbeleid. Om de vitaliteit van het platteland te waarborgen moesten naast de landbouw andere functies, zoals natuur, recreatie en kleinschalige economie, worden geïntegreerd in een gebiedsontwikkeling op maat. Plattelandsvernieuwing werd voor LNV een speerpunt van beleid. Termen als vitaal platteland verhullen een enorme versplintering van het middenveld. Intussen woedde in het politieke discours rond 2000 de 'nieuwe flinkheid', die nodig werd geacht om slagvaardigheid op basis van het politiek primaat en het mandaat van de kiezer mogelijk te maken.

Maar het besef dat maatschappelijke problemen niet zijn op te lossen als actoren niet hun eigen verantwoordelijkheid nemen, had binnen LNV wel weerklank gevonden, maar geen echt institutionele vertaling, althans binnen de belangrijke kennisinfrastructuur. Een interessante uitzondering is de oprichting van het Innovatienetwerk Groene Ruimte en Agrocluster, dat samen met betrokken actoren, op afstand van het ministerie op zoek ging naar systeeminnovaties. Het bestaat thans nog steeds, heeft een aantal vernieuwingen op de rails gezet, maar niet veel daarvan zijn ook geïmplementeerd buiten kleine experimentele pilots. Onderzoek, voorlichting en onderwijs waren niet ondergeschikt geworden aan processen van interactieve beleidsvorming (Wielinga 2001: 108). Hoewel voorlichting gemakshalve bij uitvoering werd gerekend, besefte de leiding van het ministerie dat het kennissysteem zich meer gelegen moest laten liggen aan de behoeften vanuit het veld, waarbij dat veld intussen aanmerkelijk complexer en veelvormiger was geworden dan in 'the old days' toen de agrarische producenten de maat sloegen. Het verhaal van het communicatieve paradigma biedt volgens Wielinga uiteindelijk onvoldoende houvast wanneer niet alle partijen bereid zijn elkaars werkelijkheid serieus te nemen. Misschien was dat ook wel te veel gevraagd. Wielinga zoekt de analyse van de feitelijke werking van het systeem in het leiderschap. Dat kan horizontaal en verticaal georiënteerd zijn. Horizontaal als mensen uit verschillende domeinen elkaar kennen en vertrouwen, verticaal leiderschap komt 'van buiten', introduceert op gezaghebbende wijze interventies die het geheel in een bepaalde bedding dwingen. De analyse van Wielinga komt erop neer dat in de eerste periode de landbouwsector excelleerde in horizontaal leiderschap (ons kent ons), maar dat dit in de gefragmenteerde tweede periode te weinig aanwezig was. Daar werd relatief veel verticaal leiderschap binnengebracht ('vreemde' bestuurders als Van

Aartsen, Peper en Kroes), maar de verbindingen die nodig waren voor horizontaal leiderschap waren verstopt geraakt. Wielinga biedt geen recept aan voor een werkzame mix van horizontaal en verticaal leiderschap, maar in zijn vierde 'ecologisch' paradigma is een situationeel bepaalde mix nodig om tot een vitaal energie-genererend netwerk te komen.

\subsubsection{Hoe is de landing na de salto mortale verlopen?}

Konden deze onderzoekers niet verder kijken dan de aanvang van de verandering, de latere ontwikkelingen bevestigen dat de 'salto mortale' (van buiten naar binnen werken) wel is voortgezet, al is uiteindelijk de landing niet heelhuids gelukt, als we tenminste het opheffen van het hele ministerie na 2008 in de beschouwing betrekken. Voor die tijd werden onderwerpen als gebiedsgericht plattelandsbeleid en voedselbeleid belangrijke thema's en heeft minister Veerman het adagium 'Van zorgen voor naar zorgen dat' tot lijfspreuk van het ministerie gemaakt. Een volgende bestuurskundige studie over de veranderingen bij het ministerie van LNV dateert van 2007 en is van de hand van Kickert en Van der Meer, in opdracht van het ministerie. Het boekje behandelt op basis van een groot aantal interviews de wijze waarop het ministerie omgaat met maatschappelijke partners. De meeste geïnterviewden zitten hoog in de boom (vanaf 
directeursniveau), wat enige perspectivische vertekening kan meebrengen. Drie domeinen die elk een sterk verschillende beleidscontext kennen, zijn apart bestudeerd: landbouw, natuur en voedselkwaliteit. Het onderzoek vond plaats in een periode waarin de bestuurlijke en ambtelijke top van het ministerie sterk doordrongen was van het netwerkperspectief in het management. Minister Veerman en SG Kalden droegen actief naar buiten uit dat zij zich gesteld voelden voor de veranderopgave die hoorde bij de omslag 'van zorgen voor naar zorgen dat'. In het boekje valt hierover het volgende te lezen:

"De nieuwe beleidsfilosofie die LNV in 2005 heeft gepubliceerd, is de resultante van een langdurig veranderproces dat is ingezet met de ingrijpende reorganisatie begin jaren negentig. Het ministerie heeft de luiken geopend, is transparanter geworden, luistert meer naar de buitenwereld, staat open voor kritiek, werkt meer samen met anderen. De nieuwe beleidsfilosofie bestaat uit de volgende zeven 'drijfveren' van LNV:

- Niet zorgen voor, maar zorgen dat. De overheid moet stimuleren en faciliteren, dialoog en overleg voeren.

- De burger, de ondernemer en het gebied centraal. De overheid moet van buiten naar binnen werken. Aansluiten op de wensen van de buitenwereld.

- Decentraal wat kan, centraal wat moet. Het Rijk moet hooguit kaders stellen; de regie en uitvoering liggen bij provincies en gemeenten.

- Minder regelgeving, minder bureaucratie, minder lastendruk en minder uitvoeringslast.

- Het draait om de uitvoering. Het gaat niet alleen om beleidsvoorbereiding, maar vooral om een effectieve en efficiënte uitvoering.

- Het draait ook om de naleving. Toezicht en controle moeten een einde maken aan gedogen. Zelfregulering heeft de voorkeur.

- Balans tussen people, profit en planet. Niet alleen economie en ecologie (duurzame landbouw en natuur), maar ook de menselijke kant doet ertoe."

(Kickert en Van der Meer, 2007: 52-53)

De realiteit in deze sectoren dwingt ook wel tot deze draai. Het veld is sterk versnipperd, waardoor de tijd dat het ministerie met een beperkt aantal koepels en belangenorganisaties zaken kan doen definitief voorbij is en effectieve top-down sturing niet meer mogelijk is. De auteurs van het boekje ontmoeten bij het topmanagement in het algemeen een grote mate van herkenning en acceptatie van de nieuwe managementfilosofie. Een andere zaak is de vraag of deze bestuursopvatting ook in alle lagen en geledingen van het ministerie is doorgedrongen en of die al vertaald kan worden in een heel andere houding en werkwijze. Opvallend is dat in de externe omgeving van het ministerie dat nog helemaal niet was opgevallen (Kickert en Van der Meer, 2007:135). Dat geeft te denken, evenals de constatering dat men volgens de onderzoekers er niet in is geslaagd om nieuwe vormen van 'gerichte beïnvloeding' (in plaats van 'sturing') te ontwikkelen. Het omgaan met de nieuwe netwerken stelt bijzondere uitdagingen, misschien wel onmogelijke, als het erom gaat effectief beleid te ontwikkelen. Bij plattelandsbeleid zijn vooral andere actoren aan zet met als gevolg dat niemand erover gaat. In milieu- en natuuraangelegenheden bestaan talloze nauwelijks gekoppelde netwerken naast elkaar en lijkt het ministerie om politieke redenen overbodig geworden. Op het terrein van landbouw bestaan de oude overlegsystemen nog naast de nieuwe innovatieve netwerken. Bij het nieuwe onderwerp voedselveiligheid is LNV nog nauwelijks een geaccepteerde partner. Alles volgens beide bestuurskundigen (Kickert en Van der Meer, 2007: 136).

Het antwoord van het ministerie op deze gesignaleerde onmacht is voorlopig duizend bloemen te laten bloeien. Steeds nieuwe innovatieve netwerken en stimulerings- en faciliteringsprojecten worden in het leven geroepen. Dit is misschien de enig mogelijke, maar tegelijkertijd kwetsbare strategie. Politieke ongedurigheid bij gevoelige kwesties als voedselveiligheid verlangt daadkrachtige sturing. En bij economisch zwaar weer worden goedbedoelde netwerkinitiatieven gauw geslachtofferd. Het ministerie van LNV is dan ook binnen de rijksdienst ongenadig zwaar aangeslagen bij bezuinigingen en de optimistisch innovatieve managementvisie aan het begin van 
deze nieuwe eeuw was geen lang leven beschoren na het vertrek van minister Veerman in 2006. Het ministerie werd in 2006 zelfs geheel opgeheven. ${ }^{90}$

Voedselkwaliteit als illustratie

In 2007 signaleerde het ministerie dat het thema voedsel in de hele samenleving een opmars maakte. Een kleine, maar groeiende groep individuen en maatschappelijke organisaties kwam met initiatieven om de afstand tussen de burger en zijn voedsel te verkleinen en om de kwaliteit van eten in zorginstellingen en op scholen te vergroten. Op scholen werden bijvoorbeeld smaaklessen ontwikkeld, buurtmoestuinen en streekmarkten werden opgericht. Het ministerie wilde graag op deze 'voedselinitiatieven' aanhaken. Een netwerk van enkele medewerkers van de directie Regionale Zaken ging hiermee, naast hun reguliere werk, aan de gang en startte in 2007 Foodlink. De opzet was deze maatschappelijke trend in kaart te brengen, deze verder te stimuleren en om te zorgen dat deze beweging zou bijdragen aan de doelstellingen met betrekking tot duurzaam voedsel. Dit voorbeeld illustreert goed wat hier bedoeld wordt met governance: er wordt aangesloten bij maatschappelijke krachten (bottom-up), beleid is niet vooraf planmatig uitgetekend achter een bureau, maar emergeert op de golven van de serendipiteit: kansen grijpen. Ambtenaren staan met een been in de samenleving en met een been in de bureaucratie, ze springen op ijsschotsen en hun rol is verbinden en ondersteunen: het nieuwe werken in optima forma. De overheid helpt, maar neemt niet over. Samenwerken en permanent leren is de houding. Deze benadering was de laatste jaren bij grote delen van het ministerie in zwang. Althans de manier waarop de algemene leiding van het ministerie (bijvoorbeeld minister Veerman en SG Kalden) naar buiten trad en de projecten die in de etalage werden gezet, deden dit vermoeden. Dit was in ieder geval anders dan bij Binnenlandse Zaken. Maar onderhuids is voor de grote meerderheid van de ambtenaren waarschijnlijk nog weinig veranderd, afgaand op de beschouwingen van Wielinga (2001, die de Communicatieve benadering slechts als onderstroom typeerde) en van Kickert en Van der Meer (2006), die opmerken dat externe partners weinig herkenning toonden van de nieuwe bestuursopvattingen binnen het ministerie.

\subsubsection{Voorbeeld mestbeleid}

\section{Een taboe bepaalde het discours}

Een species van het plattelandsbeleid en het landbouwbeleid is het mestbeleid. Hier kwam de botsing van beleidsvisies in alle hevigheid naar voren en hier was het ministerie van LNV weinig effectief om dit weerbarstige probleem te temmen. In 1993 verschenen maar liefst twee proefschriften op dit terrein over de aanloop van deze problematiek tot dat deze werkelijk acuut werd. Deze periode bestrijkt meer dan twintig jaar, zodat we wel kunnen spreken over lange termijn beleidsontwikkeling. Jaap Frouws schreef een beschouwing over de voorgeschiedenis, waarbij het corporatistische bestuursmodel centraal staat. De boeren hadden het beleidscentrum in de greep en evidente problemen met de mestproductie werden vooruit geschoven met quasi-oplossingen, waarbij de uitweg in de richting van inkrimping van de varkensstapel taboe werd verklaard (Frouws 1993). Deze optie paste tussen 1970 en 1990 niet in de werkelijkheidsdefinitie van overheid en landbouwlobby.

\section{Verklaring van de ommezwaai}

Termeer laat met een variant op de discoursanalyse zien hoe hierin stapsgewijs verandering optrad en waardoor dat kwam.

In navolging van H.J. van Dongen en anderen (1996) ontwikkelde Katrien Termeer de configuratietheorie. Deze auteurs gaan uit van een sociaal-constructivistisch perspectief. De wereld is zoals mensen hem zien en mensen zien hem verschillend. Conflicten, veranderingen, fixaties en organisatievormen zijn te verklaren uit interactie tussen werkelijkheidsbelevingen en spelregels

\footnotetext{
90 Hoetjes noemt dit in zijn vooruitblik uit 1993 nog 'onvoorstelbaar' en onderbrenging bij Economische Zaken een 'monstrum'. Het kan verkeren.
} 
over sociaal gedrag die tussen mensen bestaan. Die interacties zijn te herleiden tot patronen (groepen, netwerken) = configuraties, waarin mensen elkaar duurzaam of tijdelijk ontmoeten. De analyse draait om de altijd aanwezige 'derde' bij de conversatie (dialoog). Conflict is het centrale thema van onderzoek.

Termeer wilde in haar onderzoek momenten opsporen waarin het beleid stagneerde en wanneer veranderingen optraden. $\mathrm{Zij}$ verbond deze fasering aan de interacties van betrokkenen. Wanneer actoren steeds in dezelfde kringen bewegen is hun werkelijkheidsbeleving overeenkomstig gefixeerd. Als er echter meervoudige relatiepatronen ontstaan, worden actoren geconfronteerd met verschillende percepties van dezelfde verschijnselen en uit de botsing hiervan ontstaat ruimte voor verandering.

Figuur 12.1 Configuratie-onderzoek fixaties en verandering

\begin{tabular}{|c|c|c|}
\hline & Cognitief & Sociaal \\
\hline Fixatie & $\begin{array}{l}\text { Werkelijkheidsdefinitie } \\
\text { de>>>>> } \\
\text { dezelfde } \\
\text { CONFIGURATIE }\end{array}$ & $\begin{array}{l}\text { le< } 2<<<\text { Interactieregel, actor } \\
\text { CONGRUENTE INCLUSIES }\end{array}$ \\
\hline Verandering & $\begin{array}{l}\begin{array}{l}\text { Werkelijkheidsdefinitie } \\
\text { >>>>>> } \\
\text { verschillend }\end{array} \\
\text { CONFRONTATIE }\end{array}$ & $\begin{array}{l}<<<<<<<\text { Interactieregel, actor } \\
\text { MULTIPLE INCLUSIE }\end{array}$ \\
\hline Bron: Termeer & & \\
\hline
\end{tabular}

Onderzoek naar deze configuraties en veranderingen daarin vergt een zeer precieze beschrijving van de onderlinge verhoudingen. Daarvoor moet je welhaast onder het schedeldak van de betrokkenen kijken. Termeer is dit in zekere mate gelukt aan de hand van een nauwgezette analyse van gedragingen bij verschillende actoren in het mestbeleid en van kleine veranderingen van relatiepatronen in de tijd. Termeer schrijft verandering in beleid (in haar geval varkensmestregulering bij LNV) toe aan de invloed van personen die in meerdere configuraties tegelijkertijd optreden. Het verschijnen van LNV-functionarissen in bijvoorbeeld milieu-netwerken maakt absorptie van nieuwe ideeën binnen het beleid mogelijk. Vernieuwing ontstaat door grensoverschrijdende contacten, stagnatie is gevolg van naar binnen gerichtheid.

\section{Betekenis van beleidsverandering en bestuurstheorie}

De ontknoping van het twintig jaar oude mestbeleid markeert een kantelpunt bij het ministerie van LNV. Inderdaad is een fundamenteel andere beleidsredenering geïntroduceerd en doorgevoerd in wetgeving en ingrijpende beleidsmaatregelen. Het nieuwe discours is daadwerkelijk geïnstitutionaliseerd. Als gevolg van dit beleid moest het hele Noord-Brabantse platteland op de schop. Dit integrale plattelandsbeleid zette een extra stempel van meervoudigheid en vernieuwing op de ontwikkeling van het ministerie van LNV. Daarmee zou de omwenteling toch wel compleet gemaakt kunnen worden. Naar een ministerie dat in staat is regie te voeren tussen verschillende belangen, dat niet de eigen dogma's centraal stelt, maar de problemen in de samenleving zoals die door verschillende stakeholders worden gepercipieerd en dan in staat is een werkbare en gedragen 
oplossing te (laten) effectueren. En toch lijkt deze 'salto mortale' in de termen van Bekke cum suis uiteindelijk niet te zijn gelukt, zoals we nu weten. Qua structuur (privatisering) en qua leiderschapscultuur (nieuwe flinkheid te midden van een verdeeld en onsamenhangend veld) waren de noodzakelijke ingrediënten voor een vitaal netwerkbestuur (governance) volgens Wielenga in onvoldoende mate aanwezig.

Dit voorbeeld illustreert ook hoe moeilijk wetenschappelijk onderzoek over dergelijke complexe onderwerpen is. Door de vele voorwaarden van de wetenschappelijke methode kan altijd maar een beperkt deel van de werkelijkheid worden belicht. Dat geldt ook voor kwalitatief discoursonderzoek. Het onderzoek van Termeer is vooral gericht op het toetsen van een bepaalde hypothese ter verklaring van veranderingen, waarmee het belang van sociale interactiepatronen en de blootstelling aan verschillende percepties op de werkelijkheid wordt onderbouwd. In vergelijking met ons onderzoek (en bijvoorbeeld dat van Dicke over waterbeleid) wordt duidelijk dat discoursanalyse zich in verschillende gedaanten voordoet. De methode-Dicke zoekt de rode draad op een bepaald kenmerk van beleid door de hoofdlijn van denken op een bepaald thema te typeren in een dichotome 'verhaallijn'. Een partiële inhoudsanalyse. Dat zou macro-discours genoemd kunnen worden. Termeer analyseert het discours op microniveau door minutieuze analyse van de individuele deelnemers en de door hen geproduceerde teksten bij interactie en correspondentie. Het interessante van deze benadering is dat de 'toevallige' ontmoeting van actoren allesbepalend lijkt te zijn voor een emergente beleidswijziging, maar hoe diep gaat die inhoudelijke beleidsverandering? De hardnekkigheid van bepaalde achterliggende denkwijzen (paradigma's) en de bijbehorende machtspatronen, krijgen we zo niet in beeld. Ook bij onze eigen verkenning naar het optreden en beklijven van governance-elementen in de bestuurstheorie van een ministerie kunnen misschien wel verschuivingen worden gevonden, maar de vraag blijt of er ook een duurzaam werkend evenwicht is gecreëerd dat leidt tot productieve resultaten. Dan is er misschien toch een visionaire verkenning van iemand als Wielinga nodig om vast te stellen dat er uiteindelijk maar één criterium is voor bestuurlijke verandering: de vraag of een gezond of ongezond systeem ontstaat. In een ongezond systeem is volgens deze auteur de drempel voor leiderschap hoog en het responsief vermogen dientengevolge laag (Wielinga, 2001). Kortom, een bepaalde bestuurstheorie is geen voldoende voorwaarde voor de vitaliteit van een systeem. Dat relativeert.

\subsection{Conclusies}

\subsubsection{Ontwikkeling van Landbouw in het licht van dit onderzoek}

\section{Afwijkend discours bij vakdepartement}

Wie op zoek is naar een shift kan bij LNV zijn hart ophalen. Dan wordt het contrast met een rustig voortkabbelend departement als Binnenlandse Zaken wel duidelijk. De eerste vraag die in hoofdstuk 1 werd gesteld (deelvraag 8), was of een vakministerie soms een eigen, en afwijkend, discours laat zien. Dat is bij het ministerie van Landbouw zeker wel bevestigend te beantwoorden. Hier was de context, de verhouding met de samenleving, zo anders dat het discours hier heel anders verliep. En ook bleek hier, anders dan bij Binnenlandse Zaken, een ingrijpende verandering, paradigmawisseling, op te treden die nauwelijks nog in modellen van incrementele beleidsontwikkeling te plaatsen is.

\section{Shift van government naar governance bij vakdepartement}

Maar is dit ook een omslag van government naar governance geweest? Op het eerste gezicht heeft het daar wel de schijn van. De deuren zijn opengegooid voor een open dialoog met 'de vijand' (de milieu- en natuurbeweging), een gebiedsgerichte bottom-up benadering op plaatselijk niveau heeft zich in het plattelandsbeleid gemanifesteerd, de leiding put zich uit in de retoriek van het postmoderne meervoudige bestuur. Jeekel beschrijft beeldend het contrast tussen de 'ouderwetse' bestuursopvattingen binnen de Tweede Kamer en zijn eigen recente ervaringen als ambtenaar van 
uitgerekend LNV. Daar had hij ook de periode van hooghartige dominantie van één beleidslijn meegemaakt, later de periode van de ambtelijke loopgravenoorlogen rond de totstandkoming van het Eerste Milieubeleidsplan en daarna zijn eigen vrije rol als ondernemende ambtenaar in de functie van eindredacteur van het Natuurbeleidsplan. Maar wie zegt dat deze laatste ervaring niet net zozeer een eenmalig incident was als de sociale vernieuwing binnen Binnenlandse Zaken? Nu hebben we bij het ministerie van LNV niet een soortgelijke reeks van dossiers over de volle breedte van het beleidsterrein onderzocht. Omdat de onderwerpen bij LNV anders dan bij Binnenlandse Zaken niet per definitie gericht zijn op bestuurlijke verhoudingen, is het ook de vraag of de bestuurstheorie gemakkelijk uit de afzonderlijke beleidsprojecten kan worden afgeleid. Daarom beperken we ons bij LNV tot de hoofdlijnen en tot de organisatieontwikkeling als zodanig. Het discours aan de top van het departement over de verhouding met de samenleving was na de ingrijpende veranderingen rond 1990 inderdaad echt anders dan bij Binnenlandse Zaken. Betrek hierbij echter de kanttekening van Bekke cum suis over de gevoelens bij groepen medewerkers die nog hardnekkige resten van 'oude cultuur' detecteren. Daarnaast wijst Wielinga op nieuwe tekortkomingen in organisatiestructuur, verstopte informatiestromen en afkalvend (horizontaal) leiderschap. Er is zeker geen reden om de veranderingen binnen LNV te idealiseren, maar bij nadere beschouwing zijn er ook te veel contra-indicaties om te kunnen spreken van een ondubbelzinnige omslag van government naar governance. Misschien wel juist omdat het ministerie na 1990 niet meer op een eiland van zelfgenoegzaamheid kon verkeren, kreeg het van de ontwikkelingen in de politiek-bestuurlijke omgeving de nodige invloeden mee. Denk aan de privatiseringsgolf van het New Public Management, de opleving van het publiek primaat. Dezelfde invloeden die bij Binnenlandse Zaken nog veel sterker doorwerkten op de bestuurstheorie hadden bij LNV in ieder geval effecten op de structuur en op het leiderschap. Hierdoor kregen impulsen voor verandering in de verhouding met de samenleving die bij LNV veel krachtiger en langduriger doorwerkten dan bij Binnenlandse Zaken toch niet de kans een duurzaam en vitaal stelsel van netwerkbestuur/governance tot ontplooiing te brengen.

\subsubsection{Vraagtekens bij de 'shift' op rijksniveau}

\section{Dubbelzinnige conclusies}

De hoofdvraag van dit onderzoek richtte zich op de mate waarin het discours bij Binnenlandse Zaken zich onderscheidt van andere politieke actoren, maar die vraag wordt vervolgens toegespitst op de verhouding tussen overheid en samenleving. In ieder geval is de ideeënontwikkeling bij een vakministerie als dat van Landbouw opvallend anders geweest. Maar de analyse van de bestuurstheorie in termen van een shift van government naar governance heeft in dit laatste hoofdstuk twee deuken opgelopen. In de eerste plaats blijkt de vroegere ontwikkeling van het landbouwbeleid nu juist te worden gekenmerkt door een nauwe verwevenheid en wederzijdse afhankelijkheid tussen de overheid, maatschappelijke organisaties en het bedrijfsleven. Dat was nu juist een kenmerk van de vernieuwing die netwerkbestuur/governance in de jaren tachtig en negentig projecteerde! Een dergelijke vernieuwing behoeft dus allerminst lineair verloop te hebben vanuit een government verleden naar een governance toekomst. Wie wat verder teruggaat in de geschiedenis zal al gauw stuiten op de gebruikelijke situatie waarin de publieke zaak werd ingevuld door een combinatie van verschillende maatschappelijke partijen, zoals gilden, schuttersgezelschappen, de Kerk en de overheid (Kickert 2004). Dit moet echter, zoals eerder gesteld, niet zonder meer gelijkgesteld met het veel grilliger netwerkbestuur/governance uit onze internetsamenleving. In de tweede plaats blijkt de ontwikkeling bij Landbouw in hoge mate ambivalent te zijn geweest. We zien een botsing tussen twee bewegingen optreden. Aan de ene kant de inderdaad manifeste beweging die de bestuurskundigen waarnemen: fragmentatie, individualisering en vervaging van grenzen. Deze leidt ertoe dat het bastion van de landbouwwereld wordt opengebroken. Hier zien we een cesuur in de geschiedenis van dit departement die afwijkt van die van Binnenlandse Zaken. Tegelijkertijd zien we aan de andere kant bestuurlijke en organisatorische ontwikkelingen die juist veel overeenstemming vertonen met die we ook in het bestuursbeleid tegenkwamen: de hardnekkigheid van het politiek primaat in de 
communicatie, van het top-down denken, New Public Management, de ontoereikendheid van nieuwe werkvormen en denkwijzen die pluriformiteit kunnen inpassen in het streven naar een gezamenlijk resultaat, kortweg samenwerking.

\section{Omgaan met spanningsvelden}

Deze tweeslachtigheid, enerzijds gedwongen responsief te reageren op specifieke kritiek uit de samenleving, maar anderzijds gevangen blijven in algemene bestuurlijke trends op rijksniveau, is bij LNV uiteindelijk een vrij ongezonde mix gebleken. Wat dat betreft, was Binnenlandse Zaken intern misschien consistenter, maar misschien weer minder responsief ten opzichte van ontwikkelingen in de samenleving. In hoofdlijnen netjes in de pas blijvend bij de politieke cultuur die nogal inert reageerde op ontwikkelingen in de samenleving, maar met een zekere repressieve tolerantie ten opzichte van tijdelijke escapades.

Misschien bood Binnenlandse Zaken steeds net genoeg ruimte voor experimenten, als uitlaatklep, maar dat na enige tijd de oester zich weer sloot. Dat zou dan een meer geleidelijke ontwikkeling als bij Landbouw kunnen verklaren.

Op rijksniveau zijn wel verschillen waar te nemen met een ministerie van Landbouw dat veel meer stormen van maatschappelijke kritiek het hoofd moest bieden dan Binnenlandse Zaken, maar juist op het vlak van bestuurstheorie en organisatiecultuur zijn uiteindelijk de verschillen minder groot. Deze conclusies over Landbouw worden onderstreept door de analyse van Paul Pestman in zijn boek over Verkeer en Waterstaat. Bij zijn studie over de gevolgen van de ervaringen met de Betuwelijn, die een schok door het ministerie deden gaan, stelt hij eveneens vast dat de veranderingen in de procesvoering "(nog) een zwakke institutionele verankering kennen" (Pestman, 2001: 186).

Waarschijnlijk is de rijksoverheid de laatste decennia (als concern) juist homogener geworden. Immers de uitgangssituatie van de vergelijking tussen een corporatistisch (netwerk-)ministerie als Landbouw en het streng gouvernementele Binnenlandse Zaken is erg uiteenlopend, maar na de eeuwwisseling beginnen ze steeds meer op elkaar te lijken.

Nieuw in onze verkenning is dat ook in een situatie waarin vrij massaal vanuit het topmanagement wordt ingezet op netwerkbestuur/governance als bestuurstheorie (anders dan bij Binnenlandse Zaken, waar dit incidenteel gebeurde in enkele projecten), dit toch niet blijkt door te zetten en uiteindelijk stokt. Misschien is het in de politieke context waarin wij nu onderzoek doen, uiteindelijk alleen theoretisch passend, maar in de praktijk geen werkbare optie. In dat geval zou deze uitkomst voor de bestuurskunde aanleiding geven tot zelfreflectie. Het oude denkmodel kan niet meer en het nieuwe model werkt niet. Tel uit je winst.

In het laatste empirische hoofdstuk willen we nog verkennen hoe de ontwikkeling bij een andere bestuurslaag, de gemeenten, is geweest. Is daar de gelijkenis met het moederdepartement, onderdeel van dezelfde bestuurskolom van het binnenlands bestuur, weer groter? Of konden daar, 'dichter bij de burger', juist nieuwe ontwikkelingen in de samenleving eerder vat krijgen op het bestuur? 


\section{Vergelijking met het lokaal bestuur}

\subsection{Inleiding}

In hoofdstuk 1 werd deelvraag 9 als volgt geformuleerd: Is er aanwijzing voor een dominant discours bij de decentrale overheden op hetzelfde terrein van de verhouding tussen openbaar bestuur en samenleving en wijkt dat af van het gevonden resultaat bij Binnenlandse Zaken? Die vraagstelling veronderstelt al in de eerste plaats dat alle gemeenten over één kam te scheren zijn (provincies blijven hier maar liever buiten beschouwing, die wat bijzondere laag van semifunctioneel bestuur). Nu is inderdaad een kenmerk van ons binnenlands bestuur dat Nederlandse gemeenten nogal uniform in de jas gegoten zitten. Dus laten we een poging wagen, in het besef dat we bij elke trend wel een normaalverdeling van koplopers, het grote peloton en achterblijvers zullen aantreffen.

Bij de formulering van een veronderstelde uitkomst is het volgende overwogen:

Er is veel literatuur over lokaal bestuur (nauwgezet bijeengebracht op de website van Korsten), maar daaronder zit opvallend weinig empirisch onderzoek met kwantitatieve indicaties over ingrijpende veranderingen in de kijk van bestuur op de samenleving. Dus in hoeveel gemeenten en in welke breedte van het lokale bestuursdomein is nu werkelijk een kanteling vast te stellen? Enerzijds is er veel casus-beschrijvende en beredenerende kwalitatieve literatuur die hierop wijst, misschien ook een proefschrift als dat van Gerritsen (2011). Anderzijds is er ook nogal wat materiaal dat indiceert dat bij de meeste gemeenten nog weinig ingrijpend is veranderd, bijvoorbeeld het essay 'Bestuurskracht' op terrein van Welzijn, zelfs na de WMO (De Boer en Van der Lans, 2011); ook het proefschrift van Abma (2012), een van de weinigen die het gedrag van gemeenten meet, wijst niet in de richting van een shift van government naar governance.

Hieronder worden deze en andere bronnen verder uitgewerkt ter toetsing van de hypothese dat de kans op een dergelijke shift bij gemeenten waarschijnlijk kleiner zou zijn dan bij het vakdepartement Landbouw. Daarbij worden eerst de aanwijzingen die argumenten bieden voor het optreden voor een shift binnen het lokaal bestuur behandeld en daarna komen de indicaties van het tegendeel aan de orde.

\subsection{Literatuurverkenning over governance bij gemeenten}

\subsubsection{Ons thema binnen de bestuurskundige literatuur over lokaal bestuur}

Met erkentelijkheid wordt hier gebruikgemaakt van de handige bronnenlijst op de website van Korsten. Hij heeft de meest uitgebreide literatuurlijst over de vele onderwerpen die hij heeft behandeld netjes geordend per onderwerp op zijn website arnokorsten.nl gezet. De literatuurlijst lagere overheden bevat duizenden titels, merendeels over bestuurlijke kwesties op gemeentelijk niveau. Als we dan de lijst nader bekijken, blijft er niet veel over waardoor we een betrouwbaar overzicht kunnen krijgen over de feitelijke gang van zaken bij gemeenten, de bestuurscultuur of opvattingen over de rol van het bestuur aldaar. Korsten heeft zelf een alleen op internet gepubliceerd document samengesteld dat goed van pas komt: 'Een halve eeuw lokaal bestuur' (Korsten, 2012). Die titel komt straks terug. Verder is in een groot aantal boeken over lokaal bestuur geprobeerd signalen te vinden voor de beantwoording van de vraag of zich bij gemeenten in de afgelopen veertig jaar werkelijk een verschuiving zou hebben voorgedaan in de verhoudingen tussen overheid en samenleving. 
Eerst de vele aanwijzingen dat er wel degelijks een slag is gemaakt in gemeenteland. Deze indicaties zijn helaas niet afkomstig van systematisch onderzoek van feitelijk gedrag of zelfs van organisatieontwikkelingen binnen alle Nederlandse gemeenten. Idealiter zou men een bekende Scurve willen kunnen tekenen, waarop dan een mooi tipping point (Gladwell, 2000) ergens bij de eeuwwisseling te zien zou zijn. Die grafiek zou de bestuurskundige these ondersteunen door harde statistiek met op de x-as de jaren tussen 1990 en 2005 en op de y-as een percentage van alle Nederlandse gemeenten dat de 'kanteling' naar netwerkbestuur/governance heeft volbracht. Maar welke indicator zou men daarvoor kunnen gebruiken: het aantal bestuursafspraken per gemeente met maatschappelijke partners, de agenda van wethouders en ambtenaren (extern versus intern), of het aandeel coproducties ten opzichte van zelfstandige interventies van gemeenten? Allemaal utopisch, want niemand turft deze gegevens. De aanwijzingen waarmee de lezer zich hier tevreden moet stellen zijn dus allemaal losse voorbeelden en projecten. Verhalen van bestuurders en ambtenaren en natuurlijk bestuurskundigen (maar die kijken dus vaak met een bepaalde bril naar de praktijk).

In de inleiding hierboven stonden al een paar contra-indicaties: het proefschrift van Abma (2012) over bestuurskracht bij gemeenten en het essay 'Burgerkracht' van De Boer en Van der Lans (2011). Men zou hierbij ook nog kunnen noemen het ontluisterende rapport van de Nationale Ombudsman 'We gooien het de Inspraak in!' (2009). Deze en andere publicaties indiceren dat er nog weinig is veranderd in de afstandelijke en top-down verhoudingen tussen overheid en burgers.

Deze indicaties zijn al meer representatief voor de hele populatie van Nederlandse gemeenten. Het proefschrift van Abma, zelf gemeenteambtenaar, is vooral interessant omdat daar anno 2012 nog het enge begrip bestuurskracht wordt gehanteerd. Vooral omdat in de complete inventarisatie van bestuurskrachtmetingen geen ander begrip bestuurskracht wordt gehanteerd. Dat enge begrip bestuurskracht slaat op de capaciteit binnen het gemeentehuis, terwijl een breed bestuurskrachtbegrip kijkt naar het samenspel tussen gemeente en samenleving. In paragraaf 10.3 werd al gesignaleerd dat Binnenlandse Zaken bij monde van de Programmadirectie Krachtig Bestuur in 2009 zich tot het brede begrip heeft bekeerd.

\subsubsection{Aanwijzingen voor een omslag}

\section{Horizontaal bestuur als theoretische noodzaak}

Al in 1987 gebruikt André Hoekema voor het eerst het woord horizontaal bestuur in een bundel met de gelijknamige titel (Von Benda-Beckmann en Hoekema, 1987). Hierin staat ook een artikel van de Haagse gemeenteambtenaar W.E. Doolaard. Deze toont volgens Hoekema aan in hoe sterke mate beleidsvoering van de lagere overheid horizontaal van aard is, waarom dat zo is, volgens welke spelregels het functioneert en wat men ermee bereiken kan. Echt empirisch is de verbreiding van dit verschijnsel helaas niet vastgesteld, maar Doolaard maakt overtuigend duidelijk waarom gemeenten in deze tijd (dus sinds de jaren tachtig) niet anders kunnen dan bij veel onderwerpen volgens de governance-methode te werk te gaan. Daaruit zou men de conclusie kunnen trekken dat dit ook wel de gangbare praktijk in gemeenten zal zijn. Maar pas op: de praktijk houdt zich vaak niet aan de theoretische argumenten, hoe dwingend die ook lijken te zijn. Het feit dat een praktijkman en geen bestuurswetenschapper dit schrijft, legt toch wel enig gewicht in de schaal van overwegingen dat er echt iets veranderd is in gemeenteland. Citaat:

"Gemeentebesturen bemoeien zich met de meest uiteenlopende problemen. De bevoegdheden waarover ze beschikken zijn dan lang niet altijd goed hanteerbaar. Vaak geldt zelfs het tegendeel. Bevoegdheden brengen meestal ook verplichtingen met zich. ledere belanghebbende kan de gemeente daaraan houden. Zeker in wat complexere situaties is het haast onmogelijk om al die verplichtingen na te komen. In elk geval is het vaak zo, dat men allerlei effecten tot stand wil brengen, die met de regels enigszins in strijd zijn maar die toch als wenselijk ervaren worden. Waar men geen rechtstreekse bevoegdheden heeft om de gewenste doelen te bereiken, bestaat 
er altijd de mogelijkheid om met alle betrokkenen te overleggen en te bezien wat er op die wijze bereikt kan worden." (Von Benda-Beckmann en Hoekema, 1987: 12)

Om deze auteur te parafraseren: horizontaal bestuur is eigenlijk een onvermijdelijk voortvloeisel uit de ontwikkeling van de gefragmenteerde samenleving en van de overheidstaak daarin. Hier lijkt geen speld tussen te krijgen. Inderdaad, complexe onderwerpen, gemeenten bemoeien zich bijna overal mee. Uit de theorie vloeit dus de shift naar netwerkbestuur/governance in het lokaal bestuur al zonder meer voort. Nu de praktijk nog. Er dus zullen zich inderdaad talloze conflicten tussen beleidsdoelen en tussen belangen voordoen. Zoals ook het dilemma tussen vrijheid en gelijkheid bijna altijd spanningsvelden oplevert. Maar gelden die contradicties ook tussen formele regels?

Een theoretische benadering die natuurlijk aansluit bij de bestuurskundige these over 'de shift' wordt door Denters en Rose (2004) betrokken op het lokaal bestuur. In heel Europa signaleren zij de volgende ontwikkelingen die het lokaal bestuur wel dwingen tot samenwerking, (publiek-privaat) partnerschap en organiserend vermogen. Het takenpakket van lokale besturen wordt steeds omvangrijker en tendeert alomvattend maatschappelijke reikwijdte aan te nemen. Daarnaast wordt steeds meer dienstverlening van de gemeentehuizen weggehaald en ondergebracht in quasiprivate organisaties. Dan is de ontwikkeling onvermijdelijk waarbij lokale overheden niet langer meer alleenheerschappij hebben en meer 'lokaal bestuur', als primus inter pares, worden.

Tegelijkertijd signaleren deze auteurs een roep om een krachtdadiger en effectiever lokaal bestuur. Hoewel voor hen de 'shift van government naar governance' al voldoende is onderbouwd (Denters en Rose, 2004: 291), kunnen we ons afvragen of de groeiende verwachtingen ten aanzien van het (al dan niet indirecte) prestatievermogen van het lokaal bestuur niet ook bureaucentrische kanten heeft en juist het zicht op de complexe en spontane dynamiek van de samenleving onttrekt.

\section{Exemplarische casusbeschrijvingen}

Een tweede argument uit het ongerijmde valt te ontlenen aan een groot aantal casusbeschrijvingen die duidelijk de toepassing van de governance-aanpak in het lokaal bestuur verraden. Recente publicaties die echter ook praktijken van voor 2009 beschrijven, zijn bijvoorbeeld 'De Slimme Gemeente' (Gerritsen, 2011) over Amsterdam, 'De zucht naar goed bestuur' (Hendriks en Drosterij, 2012) over onder meer Zwolle en Eindhoven. Daarnaast wordt verwezen naar wat oudere publicaties, zoals 'Frontlijnsturing' (Hartman en Tops, 2005) over Rotterdam, 'Verhalen over coproduktie' in Noord-Brabantse gemeenten (Tops et al., 1996) en 'Regiefunctie in gemeenten' (Denters et al., 1999) over besluitvorming in een aantal geanonimiseerde grotere steden voor plannen op het terrein van onderwijsachterstandenbeleid, ruimtelijke ordening en volkshuisvesting, de afstemming van jeugdbeleid met oog op veiligheid. Al deze beschrijvingen zijn zonder meer herkenbaar als illustraties van de governance-aanpak. De onderzoeker zal dat dan ook niet steeds expliciteren bij de samenvatting van de voorbeelden hieronder, omdat de toepassing van het governance-model, qua doelstelling, sturingsfilosofie en informatieproces, evident is. Ze zijn daarop uiteraard ook geselecteerd door de auteurs (nota bene allen bestuurskundigen) met oog op de boodschap in hun boek en mogen dus niet worden beschouwd als representatief voor de algemene praktijk in de gemeenten. Wel gelden ze als aanwijzing voor de stelling dat de governance-aanpak in gemeenten in een breed werkveld voorkomt en dat het niet moeilijk is voorbeelden hiervan te vinden.

De grote lijn van deze casussen volgt nu achtereenvolgens.

\section{Sterke colleges}

In het boek van Korsten en Schoenmaker over sterke colleges (2008) staat het hoofdstuk 'Bestuur met andere partijen of alleen?'. Dat boek geeft niet alleen een enorm overzicht over lokale empirische literatuur maar ook laat dat boek wel zien dat er een beweging is naar governance, vooral bij grote en middelgrote gemeenten. Dat boek bevat tal van citaten van wethouders en anderen. Exemplarisch is de toenmalige wethouder Beurskens van Venlo (later gedeputeerde), die vertelt dat hij PIP-principe toepast: eerst proces, dan informatie en inhoud, dan procedure. Dat 
betekent: netwerkmanagement (interactieve interorganisationele beleidsvorming). De bewustwording bij deze bestuurders is groot dat bij bepaalde problemen, in het bijzonder grote projecten en complexe vraagstukken ('wicked problems'), deze benadering onmisbaar is om niet vast te lopen.

\section{De Slimme Gemeente}

In zijn proefschrift, getiteld 'De slimme gemeente nader beschouwd', belicht Gerritsen de aanpak van ongetemde problemen. Dat zijn niet alleen complexe problemen met veel aspecten en actoren, zoals we bij Doolaard zagen, maar bovendien bestaat hier geen overeenstemming over de in het geding zijnde waarden en doelen. De ideeën over een passende (slimme) aanpak van de gemeente baseert Gerritsen op zijn ervaringen als gemeentesecretaris van Amsterdam tussen 2000 en 2007. De principes die hij in die functie steeds heeft geprobeerd toe te passen zijn:

- een besturingsmodel gericht op richting, ruimte, rekenschap en resultaten (4 $\times \mathrm{R}$ van Paul Schnabel) ter doorbreking van institutionele verlamming;

- $\quad$ ketenregie en herontwerp van processen ten behoeve van het vlottrekken van vastgelopen werkprocessen;

- $\quad$ samenwerking in de bedrijfsvoering ter bevordering van de kwaliteit en minder versnippering;

- $\quad$ burger aan het roer waarbij burgers meer eigen verantwoordelijkheid krijgen voor het bereiken van maatschappelijke resultaten.

Echt 'slim' wordt de aanpak door een veranderkundige mix van verleiding en doorzettingsmacht. Verder is een ketenregisseur nodig die steeds de samenhang in het oog houdt. In de ogen van Gerritsen moeten de principes van de bureaucratie (government) niet worden afgeschaft, maar aangevuld door voortdurende nadruk op samenwerking tussen actoren in het netwerk (governance). Gerritsen analyseert drie casussen: crisisopvang, voortijdig schoolverlaten en multiprobleemgezinnen, die hij stelselmatig aanduidt als succescasussen. Een andere casus (inburgering) noemt hij de faalcasus. Deze typeringen ontleent hij aan interviews met sleutelfiguren. In de faalcasus was er geen sprake van toepassing van de principes van slimmer werken. In de drie succescasussen zijn 'netwerkmanagement' en 'ketenregie' toegepast. In twee ervan heeft 'herontwerp van werkprocessen' bijgedragen aan prestatieverbetering. Een bijdrage van 'samenwerking op de bedrijfsvoering' (eufemisme voor centralisatie of shared services) en 'burger aan het roer' kon op basis van het casusonderzoek niet worden vastgesteld. Gerritsen constateert dat een combinatie van macht en psychologie, ofwel doorzettingsmacht en verleiding noodzakelijk is gebleken voor de effectuering van verandering. "Onderdeel van de strategie is het bewust sturen op interactief leren en het bewust omgaan met toeval en complexiteit, waaronder het incasseren en ruimte laten voor spontane emergentie." Dit licht apologetische verhaal toont aan dat in een stad als Amsterdam in ieder geval gepoogd is (in de "kleedkamers van het politiek-bestuurlijke toneel") op een moderne manier om te gaan met complexe veranderingsprocessen en persoonlijk leiderschap op alle niveaus, het handelingsperspectief van de 'slimme gemeente', dat overigens niet onversneden netwerkbestuur/governance is.

\section{Il buon governo}

Hendriks en Drosterij cum suis (2012) hebben een grootscheeps meerjarig onderzoek uitgevoerd in het kader van het Nicis-programma 'Kennis voor Krachtige Steden'. Hierin gingen zij samen met de acht steden die in een onderzoeksconsortium waren verenigd op zoek naar werkwijzen die in de plaatselijke setting geleid hebben tot een weldadige mix van actoren en factoren: 'il buon governo' uit de schilderijen van Lorenzetti, of 'good governance in de stad' in eigentijdse terminologie. De onderzoekers reflecteren hierbij op de veelbesproken shift van government naar governance. Zij nemen hierbij afstand van een dichotome vervanging van A door B. Zo is er al eeuwen sprake van 'maatschappelijk medebewind' in de vorm van 'persuasie' en 'accommodatie', waarbij ze verwijzen naar de consensustraditie in ons goede vaderland. In ons onderzoek wordt meer uitgegaan van een verschil tussen die algemene kenmerken van de consensusdemocratie en de grilliger kenmerken van netwerkbestuur/governance, zoals gesteld in hoofdstuk 3, bijvoorbeeld in noot 8. 
Ook bij ons is geen sprake van dichotome vervanging van A door $\mathrm{B}$, wel van paradigmatische verschillen tussen beide. Wel zien ook Hendriks en Drosterij een herschikking van het repertoire aan bestuursvormen, waarbij nieuwe én traditionele, informele én formele, horizontale én verticale bestuursvormen in stelling worden gebracht. Ze stellen zelfs dat "in Nederland een dergelijke herschikking duidelijk waarneembaar is" (Hendriks en Drosterij, 2012: 21).

Binnen de vernieuwde arrangementen onderscheiden de auteurs vier modaliteiten door een combinatie van twee keuzen: meer aandacht voor de 'echte' beslissers of juist voor de gewone burgers, en meer nadruk op concurrentie (variatie en selectie) of communicatie (deliberatie). Een van de beschreven casussen betreft weer de Amsterdamse ellende van multiprobleemgezinnen. De periode (> 2010) valt echter na de betrokkenheid van Gerritsen als gemeentesecretaris, dus na de 'slimme gemeente' (en ook na het tijdvak dat ons onderzoek bestrijkt). In weerwil van diens succesverhaal valt in deze beschrijving één ding op: de indruk wordt gewekt dat met ketenregie en netwerksturing in het jeugddomein nog vanaf nul moest worden begonnen. Dit zijn toch bij uitstek rollen voor de gemeentelijke overheid, die verder maar weinig formele macht en bevoegdheden heeft in het jeugddomein. Dit blijft nu verder terzijde.

De 'concurrentie'-optie is te herkennen als kenmerkend voor een netwerkbestuur. Twee voorbeelden uit het onderzoek voldoen hieraan: Brainport Eindhoven en 'Samen maken wij de stad' uit Zwolle. Zij dateren ook beide van vóór 2009. In Eindhoven was er in de jaren negentig een duidelijke sense of urgency door een economische crisis die dit gebied in het bijzonder trof (DAF, Philips). Burgemeester Welschen zocht contact met grote bedrijven en kennisinstellingen en regelde Europese cofinanciering voor een Samenwerkingsverband Regio Eindhoven. Dit maatschappelijke samenwerkingsverband richtte zich op het creëren van een centrum voor toptechnologie. Dit werd in de vorm van een Brainport een groot succes. Bedrijfsleven, kennisinstellingen en overheid (de zogeheten Triple Helix) richtten een stichting op, waar zich organisch een gezamenlijk programma ontwikkelde. Deze constructie kan in navolging van het voorbeeld Atlanta worden aangeduid als regionaal regime. De kracht zit in de informele contacten tussen de relevante actoren, die elkaar vertrouwen en blindelings weten te vinden. Legitimiteit van deze constructie moet vooral gevonden worden in de output van de samenwerking, die tot nu toe inderdaad indrukwekkend is. De regio Zuidoost-Brabant is in 2011 tot de meest intelligente ('de slimste') regio ter wereld benoemd (www.intelligentcommunity.org).

In Zwolle heeft het gemeentebestuur zich ook nadrukkelijk gericht op de maatschappelijke partners. Aanleiding was hier in 2005 een takendiscussie gericht op een slankere gemeente met oog op noodzakelijk geachte bezuinigingen. De gemeente zou zich door verantwoordelijkheden te delen met anderen kunnen beperken tot een verbindende regierol. De uitkomst van dit proces had een verdergaande strekking dan de interne kerntakendiscussie voor grotere efficiency. Het werd een complete sturingsfilosofie met sociale en ideologische trekken: een stedelijke beweging. Anders dan concurrentie en emergentie die in Eindhoven kenmerkende trekken waren, lag in Zwolle de nadruk op communicatie: breed overleg in de stedelijke polder. Bijzonder voor Zwolle is de positie van de stedelijke ideeënmakelaar, intermediair tussen maatschappelijke vraag of initiatief en gemeentelijk aanbod. Ook hier trekken de onderzoekers parallellen met het urban regime in Atlanta. Alleen zitten in Zwolle ook relatief bescheiden machten als de gemeentelijke bibliotheek en (via de ideeënmakelaar) gewone burgers op de eerste rang. Belangrijk is dat Zwolle niet meer is te kwalificeren als toepassing van governance in een paar beperkte sectoren van complexe (of ongetemde) problematiek. Het lijkt het hele gemeentelijke domein te omvatten.

\section{Frontlijnsturing}

Rotterdam heeft altijd wel voorop gelopen als het gaat om bestuurlijke vernieuwing. We zagen in hoofdstuk 7 al de sociale vernieuwing die hier is uitgevonden en de Rotterdamwet voor het concept kansenzones. Nu gaat het zoeklicht naar de kanteling van de organisatie die ontstaat door uitvoeringsproblemen stelselmatig centraal te stellen. Frontlijnsturing doet dat. Wederom is het ' $t$ 
Kenniscentrum Grotestedenbeleid (later Nicis ${ }^{91}$ ) dat de schijnwerper hierop zet (Hartman en Tops, 2005). Als uitvoering de maat aangeeft, komen beleidsprocessen in een ander daglicht te staan.

Elke situatie is anders en creëert grillige verbindingsbehoeften voor de gemeentelijke organisatie. Een zogeheten frontlijnorganisatie met managementbevoegdheden die vanuit de frontlijn worden gedicteerd, zorgt ervoor dat de nodige situationele verbindingen worden gelegd. Beleidssturing blijft hiernaast onontbeerlijk om de frontlijnactiviteiten in een breder kader te plaatsen en om democratische sturing en verantwoording mogelijk te maken. Wederom dus hier de waarschuwing dat governance niet kan worden beschouwd als vervanging voor government, maar wel een nuttige en relatief nieuwe aanvulling vormt. In Rotterdam is de combinatie van bottom-up invloed en topdown beleid tot een eigen systeem verheven, waarbij de figuur van de stadsmarinier landelijke bekendheid heeft verworven. De taakgroep Sociale Infrastructuur onder leiding van René Diekstra stelde in 2000:

"Is het niet vreemd dat het leger zijn best toegeruste mensen (mariniers) in de frontlijn inzet en het openbaar bestuur het tegendeel doet? Hier worden goede mensen juist uít de frontlijn gehaald en ín de lijn gezet. Kortom, de taakgroep pleit voor het mariniersmodel."

In 2002 werden de eerste vijf ingezet in de moeilijkste wijken. Hartman en Tops volgen in hun boekje een aantal frontlijnwerkers op werkveldniveau tot achter de voordeur met aansprekende verhalen. Zij analyseren echter ook de functionele spanningsrelaties die in Rotterdam zijn ingebouwd om te voorkomen dat het systeem uit de bocht vliegt. Ze onderscheiden drie interventiemechanismen bij uitvoeringsprocessen: sturing op regels (voorspelbaar), op prestaties (meetbaar resultaat is wat telt) en op personen (alles is mensenwerk). Alle drie mechanismen kunnen vanuit het beleid (top-down) of vanuit de frontlijn (bottom-up) worden ingevuld. De kunst is de positieve functies van alle zes spanningsvolle perspectieven te behouden en de negatieve te onderdrukken. Dat het introduceren van governance-elementen in het lokaal bestuur noodzakelijk maar niet eenvoudig is, illustreert figuur 13.1, die alle verworvenheden en valkuilen uit de analyse van Hartman en Tops samenvat.

Figuur 13.1 Perspectieven en interventiemechanismen

\begin{tabular}{|l|l|l|l|}
\hline & Regelsturing & Prestaties & Personen \\
\hline $\begin{array}{l}\text { Beleidsperspectief } \\
\text { Positieve functies }\end{array}$ & $\begin{array}{l}\text { Legitimiteit, } \\
\text { rechtsgelijkheid }\end{array}$ & $\begin{array}{l}\text { Transparantie en } \\
\text { meetbaarheid }\end{array}$ & Inzet en vakmanschap \\
\hline Negatieve functies & $\begin{array}{l}\text { Stiptheidsactie (by the } \\
\text { book) }\end{array}$ & Russische spijkerfabriek & $\begin{array}{l}\text { Oncontroleerbaar } \\
\text { Onaanspreekbaar }\end{array}$ \\
\hline $\begin{array}{l}\text { Frontlijnperspectief } \\
\text { Positieve functies }\end{array}$ & $\begin{array}{l}\text { Rugdekking bij moeilijke } \\
\text { boodschap }\end{array}$ & $\begin{array}{l}\text { Realistische } \\
\text { resultaatgerichtheid }\end{array}$ & Prompte actie en reactie \\
\hline
\end{tabular}

Bron: Hartman en Tops, 2005: hoofdstuk 6

Coproducties in Noord-Brabant

91 En sinds medio 2012 Platform31. 
Dezelfde Pieter Tops onderzocht al in 1996 met zijn Tilburgse collega's maar liefst elf voorbeelden in Noord-Brabant van 'co-produkties' in het lokaal bestuur. In grote lijnen zijn de vormen van bestuurlijke en democratische vernieuwing die zij in ruime mate aantreffen te typeren als vormen van inspraak en andere pogingen om burgers bij de lokale politiek te betrekken. De onderzoekers concluderen uit de intenties, wapenfeiten en instrumenten die zij hebben opgetekend "dat in Brabantse gemeenten het thema van co-produktie de aandacht van bestuurders en politici heeft". En daarbij wordt niet alleen instrumentele betekenis, maar ook intrinsiek nut aan de betrokkenheid van burgers gehecht. Bij al deze welwillendheid past wel de kanttekening dat de Brabantse bestuurders niet zover gaan dat ze burgers in staat achten om een gemeente goed te besturen. Daarvoor zouden ze te weinig oog hebben voor de complexiteit van bestuurlijke vraagstukken en zich voornamelijk laten leiden door eigenbelang. In de meeste gevallen is de betrokkenheid louter reactief. Op papier lijken gemeentebestuurders veel waarde te hechten aan een open en vroegtijdige samenwerking als succesfactor voor het welslagen van controversiële projecten. De praktijk is echter weerbarstig. In dat licht zou deze optimistisch getoonzette publicatie bijna als een bewijs voor de ontkenning van netwerkbestuur/governance beschouwd moeten worden. Een schaarse uitzondering is misschien de uitnodiging van de lokale zorgaanbieders en verzekeraars door het gemeentebestuur om gesprekken te voeren over de nieuwe inrichting van de zorg. Dit is dan ook een onderwerp waar de eigen machtspositie van de gemeente vrij beperkt was. In 1996 stond de ontwikkeling in de richting van burgerparticipatie die volgens Tops cum suis zijn oorsprong vond in de gemeenteraadsverkiezingen van 1990 (zie ook sociale vernieuwing, paragraaf 7.4) kennelijk nog in de kinderschoenen. Maar zij was er al wel. Ook kan uit de latere voorbeelden die hierboven werden beschreven, een opgaande lijn in die ontwikkeling worden vastgesteld. De latere voorbeelden zijn duidelijk verstrekkender en meer vernieuwend dan de eerste in dit rapport.

\section{Regierol}

Denters cum suis kregen in 1999 van de Raad voor het Openbaar bestuur de opdracht een studie te schrijven over de regierol van het lokaal bestuur, een term die toentertijd in zwang was om aan te geven dat de sturingscapaciteit van de overheid beperkt is: in plaats van zelf beleid formuleren en uitvoeren kan de gemeente het meeste resultaat behalen door het regisseren van vele actoren (acteurs) op het maatschappelijk toneel. Denters cum suis plaatsen dit verschijnsel vooral in het licht van de verkokering; in elke sector wordt die regierol weer anders ingevuld. Spelers bewegen zich kennelijk nog binnen steeds dezelfde werkverbanden, wat nog niet duidt op een sterke situationele probleemgerichtheid. De Twentse onderzoekers maken gebruik van bestaand onderzoeksmateriaal om stedelijke casussen op drie beleidsvelden te schetsen (onderwijs, jeugd en veiligheid en ruimtelijke ordening en volkshuisvesting) en de praktijken op deze velden te analyseren. Aldus kregen ze enig zicht op de variëteit in de invulling van de regierol in de lokale bestuurspraktijk en de knelpunten die zich in het bestuur voordoen. Bij nadere beschouwing van dit overleg blijkt onder meer het volgende:

- Voor elk beleidsterrein geldt dat de organisatie van het beleidsterrein per gemeente aanzienlijk verschilt.

- In alle cases vormt overleg of onderhandeling kern van de beleidsvorming en is men gericht op het bereiken van overeenstemming.

- Op elk beleidsterrein vindt overleg plaats in de beperkte kring van bestuur, ambtenaren en professionals; beleidsconsumenten ontbreken.

- Inhoudelijk is het overleg per sector op verschillende planelementen gericht (bij jeugd en veiligheid op prestaties, bij volkshuisvesting ook op processen, bij onderwijs worden diverse onderwerpen behandeld).

- De rol van college- en raad(scommissie)leden is veelal marginaal.

In de praktijk van het lokale bestuur is het vervullen van een regierol gangbaar.

Lokale bestuurders scharen zich ook nadrukkelijk achter deze vorm van besturen. Met name onder raadsleden bestaat er een brede steun voor de idee van een regisseursrol bij interactieve 
besluitvorming. Bijna negentig procent vindt overigens dat de raad ook na afloop, bij de uiteindelijke formele beleidsbepaling de vrijheid moet hebben om het interactief gevormde beleid te verwerpen en te amenderen. Of onder deze randvoorwaarden interactieve beleidsvorming mogelijk is, lijkt dubieus. Een belangrijk kenmerk van het concept is immers dat zowel de probleemformulering als de probleemoplossing in samenspraak met betrokken burgers of het middenveld gestalte dienen te krijgen.

Binnen de gemeentelijke overlegpartners blijkt een vermenging van rollen op te treden. Enerzijds is sprake van een inhoudelijke betrokkenheid (die noopt tot materiële sturing); anderzijds behoort er in elk geval ook een zekere procedurele sturing plaats te vinden met het oog op onder meer de democratische kwaliteit van de besluitvorming. Tussen die twee vormen van betrokkenheid bestaat spanning.

De toegankelijkheid aan de kant van de samenleving is vooral beperkt, omdat de deelname aan de beleidsnetwerken in termen van tijd en vereiste deskundigheden de nodige eisen stelt. Tegen de achtergrond van de selectieve toegankelijkheid (en openbaarheid) is het voor Denters cum suis opvallend dat in de beleidsvorming op de onderzochte terreinen zelden wordt stilgestaan bij de vragen omtrent deze aspecten van de democratische kwaliteit. Besluitvaardigheid krijgt relatief veel nadruk bij de respondenten. Tot zover de bevindingen van de Twentse onderzoekers over de regierol van gemeenten.

Op de onderzochte terreinen, waar de gemeente duidelijk geen alleenheerschappij heeft, wordt in ieder geval in 1999 overleg met maatschappelijke partners normaal gevonden. Dat heet dan de regierol. Over de democratische haken en ogen daarvan maakt men zich nog vrij weinig zorgen. Dat gemeenten zich realiseren dat hun positie met zich meebrengt dat hun bijdrage aan maatschappelijke problemen voortvloeit uit een goede waarneming van kansen en omstandigheden in het veld, blijkt nog niet zonneklaar uit deze analyse.

\section{Lokale politiek}

Er zijn twee stromingen in de literatuur als het gaat over de positie van de lokale politiek. De ene beklemtoont dat er eigenlijk nauwelijks zoiets bestaat, omdat het lokaal bestuur voor een groot deel nationaal beleid uitvoert en omdat de lokale verkiezingen niet veel meer zijn dan een peiling voor de nationale politieke verhoudingen (Derksen, Elzinga). Boogers (2007) legt daartegenover de nadruk op andere kenmerken die maken dat lokale politiek wel degelijk eigensoortig is.

Democratische processen in de gemeente zijn inderdaad minder (partij-)politiek, maar lopen eerder over in uitvoeringsprocessen. Doordat de politieke dimensie dichter op de gemeenschap zit, is deze eigensoortig en meer participatief dan de nationale politiek. Naarmate dit het geval is, zal er inderdaad ruimte komen voor een meer organische verhouding tussen gemeenten en de lokale samenleving. Dit moet voor wie het boekje van Boogers goed verstaat, nog wel groeien. Het blijkt bijvoorbeeld in de praktijk erg moeilijk om voor de gemeenteraad een eigen onderscheiden rol te vinden in dit speelveld, zoals in de dualisering was beoogd. De volgende paragraaf komt hierop terug.

\subsubsection{Contra-indicaties}

Korsten: een halve eeuw lokaal bestuur

In zijn overzicht van relevante ontwikkelingen gedurende deze periode op het gebied van de staat, die hun doorwerking vinden in het lokaal bestuur sinds 1958 ziet Korsten achtereenvolgens een ontwikkeling "van welvaartsstaat, via verzorgingsstaat naar de interventiestaat, de terugtredende staat, de verstopte staat, de veiligheidsstaat, de bemoeistaat. Steeds blijken zich actie- en reactieprocessen voor te doen. Na veel aandacht voor planning volgt er discussie over deregulering; na een amorele opstelling (de staat bemoeit zich niet met hoe de burgers zich privé gedragen) volgt een periode waarin de staat nadenkt over morele 'modellering' van de burgers." (Korsten, 2012: 14) In de reeks toelichtingen die volgen, passeert ook een paragraaf 'Interventie door netwerkmanagement'. Daaruit citerend: 
"Bij tal van zaken blijken overheden afhankelijk van elkaar en afhankelijk van semi-overheden en particuliere organisaties. Dat brengt ons bij het concept netwerksturing - ook wel interorganisationeel procesmanagement genoemd. (...) Partijen hebben elkaar dus nodig. In geval van een dergelijk netwerk kan een gemeentebestuur weinig opleggen. Het gemeentebestuur moet met andere partijen werken aan sfeer en aan een gemeenschappelijk perspectief, om vervolgens en dus pas later te komen tot doelverbinding en middelenbundeling. Processen van gedeelde perceptievorming gaan vooraf aan inhoudelijke sturing van gemeenten. Dit besef dringt zeker niet steeds tot gemeenteraden door. Ze zien zich nog te veel als spil van de samenleving. Daar moet men in netwerkcontexten vanaf. Die ontwikkeling wordt wel omschreven als een beweging van bestuurscentrisch denken ('government') naar 'governance'." (Korsten, 2012: 16-17)

In het centrale vijfde hoofdstuk over ontwikkelingen binnen het gemeentebestuur vervolgt Korsten met het noemen van vele verschijnselen als feitelijke veranderingen sinds 1958. In de beleidsvoorbereiding is dat openheid en inspraak, al is democratische vernieuwing in vergelijking met de periode 1975-1995 onmiskenbaar al jaren een daler op de politieke aandachtsladder. Thema's als integratie, inburgering, openbare orde en veiligheid eisten veel meer aandacht op de agenda van het gemeentebestuur op. Wat wel constant hoog scoort, zijn de probleemwijken. In die context is er ook sprake van een verandering in bestuursstijl. Het is typisch een complex onderwerp dat zich leent voor de gemeente als regisseur: een procedurele rol voor het bijeenbrengen van maatschappelijke partners voor kennis en oplossingen. We citeren nu weer Korsten:

"In 1960 had nog geen enkele ambtenaar gehoord van een gemeentebestuur als regisseur, als bestuur voor het toneel en achter de coulissen. De regiefunctie makkte na ongeveer 1990 een opmars door." (Korsten, 2012: 90)

Ook op het vlak van dienstverlening signaleert Korsten ingrijpende veranderingen, 50 jaar geleden was er nog geen sprake van burgergerichtheid, maar er werd ook nauwelijks agressie aan de balie geregistreerd. Rond 1970 werd er nagedacht over laagdrempeliger dienstverlening, maar echt klantgericht werden gemeenten niet. Medio jaren tachtig reageerde een VNG-commissie ter zake dat klantgerichtheid als voornaamste eis voor gemeenten te ver ging. Burgers waren niet uitsluitend klant, ze zijn ook onderdaan, kiezer en citoyen. Met mate is niettemin behoorlijke behandeling toegevoegd aan de nieuwe criteria waaraan gemeentebesturen worden afgemeten, onder meer onder invloed van ombudsmannen. De invloed van het Nieuw Public Management liet zich ook merken in de opmars van planning-en-controlcyclus, benchmarks en bestuurskrachtmetingen, managementinformatiesystemen in de verhouding tussen ambtenaren en bestuur en in competentiegericht personeelsbeleid op weg naar human resource management. Allemaal vernieuwingen die moesten concurreren met de genoemde horizontalisering van bestuur, de regiefunctie bij complexe vraagstukken, waar de bestuurskunde zoveel aandacht aan wijdde en die in dit boek centraal staan. En dan waren er ook nog zoveel zaken die bij het oude bleven. Korsten concludeert dus dat gemeenten in de laatste jaren blootstaan aan veel onbekende reacties uit een ongekende samenleving. Gemeenten voeren nauwelijks strategisch beleid, maar anno 2008 is dat volgens Korsten wel nodig. Ze zijn al tot zoveel verplicht en komen hier eenvoudig niet aan toe. Prestaties leveren in termen van output en outcome is al een uitdaging. Men doet zijn best: inputgerichtheid, dat is al heel wat voor gemeentebesturen, wat overeenkomt met een naar binnen gerichte bestuurscultuur. Dit is toch de wat sombere toon waarmee Korsten zijn overzicht over vijftig jaar stabiliteit en dynamiek in het lokaal bestuur eindigt.

Eerder had Korsten al samen met Schoenmaker het boek 'Sterke Colleges' (2008) geschreven. Hierboven kwam dit boek al langs bij de argumenten voor de omslag in gemeenteland, maar dan vooral bij grote en middelgrote gemeenten. De keerzijde is in hetzelfde boek te vinden, namelijk dat niet elke wethouder zo kijkt. Sommigen wilden direct de inhoud in en liepen dan soms vast. Zij hanteerden dus een government-concept. Bij bepaalde problemen is dat niet erg maar bij wicked 
problems wel, aldus bijvoorbeeld Twan Beurskens, die als voorbeeld werd aangehaald. In kleinere gemeenten kan men nog wel eens zonder dure woorden en bestuurskundige inzichten van nature geneigd zijn met betrokkenen te overleggen in plaats van vanuit het gemeentehuis - met wat inspraakfranje - te decreteren. Er zijn zelfs kleine gemeenten (zoals Helden, later Peel en Maas) die de verhouding met de gemeenschap radicaal gekanteld hebben, maar de meeste kleinere gemeenten hanteren nog een klassieke bestuursopvatting, aldus Korsten.

\section{Bestuurskracht als benadering voor bestuursopvatting}

Interessant materiaal is in dit verband te vinden in het proefschrift van Korstens leerling Abma (Abma 2012). Hij analyseert de bestuurskrachtonderzoeken bij Nederlandse gemeenten en begint met de definitie van het begrip gemeentelijke bestuurskracht. We laten nu Abma (2012: 225) aan het woord:

"Bestuurskrachtmetingen richten zich meer op presteren, verantwoorden en het boeken van resultaten dan op het proces van het bij elkaar brengen van actoren en het bevorderen van samenwerking van relevante actoren bij het aanpakken van wettelijke taken en opgaven en ervaren maatschappelijke uitdagingen en problemen."

Dit betekent dus dat "bestuurskrachtmetingen zijn opgezet vanuit de smalle of bestuurscentrische invalshoek. De mate waarin een gemeentebestuur zelfstandig zijn taken aan kan heeft dan ook de overhand boven het gezamenlijk aanpakken en uitvoeren van de wettelijke en lokale taken en opgaven." Omdat het begrip brede bestuurskracht gedurende zijn onderzoeksperiode tussen 2000 en 2007 volgens Abma meer aanhang verwierf, verwachtte hij gaandeweg meer brede bestuurskrachtonderzoeken tegen te komen. Dat bleek echter niet het geval. Bij de (complete) populatie van 116 bestuurskrachtmetingen vond hij er zegge twee die de brede invalshoek kozen. Abma schrijft zelf hierover:

"Na de eeuwwisseling werden de opvattingen over bestuurskracht breder, althans in de bestuurskundige literatuur. Al in de onderzoeksperiode 2000-2007 verschoof de aandacht van 'government' (overheid staat op zichzelf) naar 'governance' (overheidsfunctioneren moet in een netwerkcontext worden gezien) en daarmee naar de wisselwerking tussen gemeentebestuur en omgeving." (Abma 2012: 225)

Nu horen we het nog eens van een ander, maar voor dit moment is het feitelijk gedrag van gemeenten belangrijker dan het gegeven dat overeenkomstig de hoofdvraag van dit onderzoek de bestuurskundige literatuur deze verandering van opvatting weerspiegelt (een beetje later dan deze omslag in dit onderzoek wordt gepositioneerd). Daarvoor gaan we verder met Abma's tekst:

"Vooral de opvattingen van een groep auteurs rond de Dordtse gemeentesecretaris Wesseling vielen daarbij op: het gemeentebestuur werd daarin opgevat als een schakel in de keten om de maatschappelijke effecten te realiseren. Zij verwierpen daarmee het bestuurscentrisme." (Abma 2012: 225)

Toch was veranderden de invalshoeken bij het bestuurskrachtonderzoek zelfs in de zes Drechtstedengemeenten, waaraan Wesselings eigen gemeente deelnam, niet naar een bredere opvatting. De bestuurscentrische opvatting was ook hier dominant. Dit betekent dat de bestuurskundige Wesseling anders publiceerde dan hij als gemeentebestuurder handelde. Waarom dit zo zou zijn, probeert Abma te verklaren:

"De volgende redenen zijn aan te geven als mogelijke verklaring voor de nagenoeg afwezige brede benadering in de praktijk. Allereerst is de neiging tot gemeente centrisme ('alles draait om het lokaal bestuur') sterk. En: blijkbaar stelden bureaus een bredere benadering niet voor en/of wensten gemeentebesturen een brede benadering niet te financieren en/of schrokken 
gemeentebestuurders terug uit vrees dat de andere actoren (provincies, Rijk) niet erg zaten te wachten op een brede meting (die ze niet zouden willen steunen) en/of drong de visie van pleitbezorgers niet echt door tot de praktijk van beslissers over bestuurskrachtmetingen. Wat we hoorden uit de monden van veel bestuurders is dat het centrisme bijna altijd meespeelt evenals de omvang van het budget en wat bureaus voorstellen." (Abma 2012: 226)

Letterlijk concludeert Abma (2012: 226): "De adepten van de brede 'governance'-benadering van bestuurskrachtmetingen waren in de periode 2000-2007 dus (nog) roependen in de woestijn." A fortiori geldt dit natuurlijk voor de periode hieraan voorafgaand. Nu is bestuurskrachtonderzoek niet hetzelfde als bestuursopvatting in de dagelijkse praktijk van het lokaal bestuur, maar als gemeenten werkelijk hun rol fundamenteel zouden identificeren met hun regiefunctie, zou dit bestuursconcept toch ook wel doordringen in de benadering van bestuurskracht. Samen met de bijkomende informatie die Abma verstrekt, is dit gegeven toch een krachtige aanwijzing ten nadele van de stelling dat het lokaal bestuur ergens tussen 1969 en 2009 een omslag (shift) van government naar governance zou hebben doorgemaakt.

\section{Analyse van collegeprogramma's}

De geraadpleegde literatuur geeft ook maar weinig steun voor het tegendeel. Dat wil zeggen dat er in de eerste plaats maar weinig synoptische studies bestaan over het feitelijk gedrag van alle Nederlandse gemeenten. Flauwe benaderingen hiervan zijn misschien inhoudsanalyses van collegeprogramma's. Boogers en Tops (wederom de Universiteit van Tilburg) hebben in 1998 een dergelijke analyse verricht van 145 collegeprogramma's met als zoekopdracht de termen 'acceptatie', 'draagvlak', 'interactief' en 'samenspraak'. ${ }^{92}$ Zij schetsen een rijk palet van participatieve besluitvormingsprocedures en gaan nader in op:

a. interactief dorps- en wijkbeheer;

b. toekomstdebatten en scenarioworkshops;

c. interactieve projectontwikkeling;

d. teledebatten en andere technologisch geavanceerde interacties;

e. referendum-experimenten;

f. opiniepeilingen, consumentenonderzoek en raadplegingen (Tops et al., 1999: 4-5).

Deze lyrische opsomming geeft een aardig tijdsbeeld van de heersende 'etiquette' (term Tops cum suis) en modieuze praktijken, maar zegt nog weinig over de werkelijke responsiviteit van het bestuur. Bepaalde termen worden 'vaak' (?) gebruikt in collegeprogramma's en de opgesomde praktijken vormen een wild boeket, wat er op wijst dat geen van hen gemeengoed is zoals dat met wettelijke procedures het geval is.

\section{De positie van de wethouder en van de burgemeester}

Als het waar zou zijn dat de gemeente gedurende de afgelopen decennia een heel nieuwe bestuurstheorie is gaan huldigen, dan zou dat toch zeker ook tot uiting moeten komen in de positie en werkwijze van haar bestuurders.

Een bundel over de positie en het functioneren van de wethouder in een veranderend bestuur (Tops et al., 1994) en een veel recenter boek over de burgemeester dito (Korsten et al., 2012) geven hier echter weinig aanwijzingen voor. Over de wethouder vinden we te midden van 31 hoofdstukken er één die een beetje in de buurt komt: 'de wethouder en sociale vernieuwing'. $\mathrm{Na}$ een opsomming van bekende problemen van de kloof tussen de systeemwereld (bureaucratie, macht, procedures) en de leefwereld van de burgers stellen de auteurs Gossink en Van Soomeren:

\footnotetext{
92 NB De oorspronkelijke publicatie is nergens te vinden, zelfs niet bij de opdrachtgever VNG, KB en Nationaal Archief. Opvragen bij de auteurs heeft evenmin resultaat opgeleverd. Dit geeft te denken over ons documentenbeheer in de overgang van het papieren naar volledig digitale tijdperk.
} 
"De wethouder die dit rijtje leest, moet zich ongemakkelijk - of misschien juist uitgedaagd voelen. Hij of zij staat immers middenin de driehoek die gevormd wordt door het bestuur, de bevolking en de gemeentelijke diensten. Het zweet zal de desbetreffende wethouder waarschijnlijk uitbreken als hij of zij zich verdiept in de vraag hoe sociale vernieuwing aangepakt moet worden. Dan blijkt dat er gezocht moet worden naar een totaal andere rolopvatting van het bestuur." En verderop: "Als de enigszins terugtredende overheid haar nieuwe taak - het (re)activeren van burgers en instellingen - serieus neemt, betekent dat twee dingen:

- De overheid zal vaker even pas op de plaats moeten maken;

- De overheid zal niet langer kunnen uitgaan van de eigen probleemdefinitie." (Tops et al., 1994: 328)

Deze verzuchtingen wijzen er alleszins op dat in ieder geval in 1994 deze habitus nog geen gemeengoed was onder de wethouders van Nederland. Ter bevestiging vervolgen de auteurs:

"In 1993 stellen de onderzoekers van het Sociaal en Cultureel Planbureau vast dat de bestuurlijke rivieren in dit land inderdaad traag stromen: 'Zeker daar waar de benodigde veranderingen meer dan marginale gevolgen moeten krijgen, gaat er veel tijd overheen alvorens de burgers iets van de veranderingen merken. Dat wordt bijvoorbeeld duidelijke in de gemeenten die proberen de burgers een permanente stem te geven in het wijkbeheer (...). Naast organisatorische en procedurele aanpassingen vergt dit doorgaans een ware omslag in het denken van de lokale beleidsambtenaren en de politici. Twee jaar na de start van de sociale vernieuwing staat de uitvoering van het integrale wijkbeheer (...) nog in de kinderschoenen (SCP, 1993)." (Tops et al., 1994: 329)

\section{Burgemeesters}

Wat betreft de burgemeesters ligt de situatie wel wat anders. Aan de ene kant is hun portefeuille 'openbare veiligheid' nogal atypisch. Aan de andere kant is hun algemene rol als verbinder en burgervader bij uitstek geschikt om oog te hebben voor de hele samenleving en daarmee verbinding te leggen. In dat licht is het recente boek van Korsten cum suis (2012) illustratief. Binnen zijn eigen portefeuille komen afhankelijkheidsrelaties en samenwerkingsbehoeften regelmatig voor. Korsten zegt hierover dat de burgemeester in de veiligheidsregio overwegend in een klassieke bevelshuishouding zit, maar "hij opereert voor ad hoc kwesties af en toe in netwerken". Dat blijkt bij elke grotere ramp, zoals de Herculesramp, de Schipholbrand. Zoals het proefschrift van de Amsterdamse gemeentesecretaris Gerritsen duidelijk maakt, had ook burgemeester Cohen de Ketenmanagementaanpak nodig om koppelingen te krijgen tussen instellingen, de organisaties te verknopen in aanpak van hangjongeren en aanverwanten. Maar bij sommige zaken heeft een burgemeester doorzettingsmacht en dan kan hij beslissen.

Evident is dat rond voetbalveiligheid de burgemeester moet overleggen met de driehoek en clubs, et cetera. Korsten memoreert in het bijzonder in dit verband:

"De burgemeester van Hengelo zei mij als er een probleem is in de binnenstad kijk ik altijd direct of andere(n) erover gaan, op de een of andere manier. Want dat had hij in de loop der jaren wel geleerd. Hij zei: men kijkt vaak wel naar mij maar soms heb ik niet veel tools en zijn andere op het erf met taken, bevoegdheden en middelen". (Korsten et al., 2012: 6)

Uit de inleiding van het boek is bovendien het volgende te lezen:

"Besturen is ook netwerken. Een burgemeester representeert een gemeentebestuur dat in een netwerksamenleving opgenomen is. Overheden zijn op tal van terreinen afhankelijk van andere organisaties en groepen en dat betekent dat een speciale probleem- en ontwerpaanpak wenselijk is: netwerkmanagement ('governance'). Een gemeente kan dan niet verordonneren, maar zal met 'partners' moeten zoeken naar een gemeenschappelijk perspectief en uitwerking in het verbinden van doelen en middelen. Denk aan het volkshuisvestingsnetwerk: gemeenten 
plannen, corporaties bouwen. Dan ben je als organisaties van elkaar afhankelijk. Een gemeentebestuur moet dus 'on speaking terms' zijn met de corporatiebestuurders. Verdroging in een natuurgebied tegengaan? Je hebt partners nodig als een waterschap, een provinciebestuur, andere gemeentebesturen, de vereniging natuurmonumenten, grondeigenaren, pachters. Ze hebben elkaar dus nodig; alleen kom je als gemeente niet ver. Dat lukt als sprake is van regie en partners die niet gefixeerd zijn op het eigen gelijk, maar zich ook in andere organisaties en belangen kunnen verplaatsen. Burgemeesters kunnen hierin nadrukkelijk een rol vervullen als aanjagers, als sfeermakers, als regisseurs, als personen die een probleem met één slag een andere wending kunnen geven." (Korsten et al., 2012: 6)

We herkennen hier weer het bekende bestuurskundige 'cliché', dat hier ook als uitgangsstelling is gekozen, maar wat betreft de feitelijke impact voor de verbindende rol van de burgemeester komt er niet veel meer dan een mogelijke bijdrage als regisseur. Wie de feitelijke beschrijvingen in het boek van Korsten cum suis op zich laat inwerken, ziet andere ontwikkelingen als meer beeldbepalend naar voren komen. Dan gaat het vooral om de rol van de media, de onbarmhartige tests waaraan de burgemeester in crisissituaties wordt bloot gesteld als alle blikken op hem (of haar) zijn gericht. De kwaliteiten als onverschrokken leider en communicator lijken meer bepalend voor succes of falen van de burgemeester dan zijn verbindende rol in de samenleving. Dien ten gevolge ontkomt ook de burgemeester in het begin van de 21e eeuw niet aan zorgvuldig risicomijdend gedrag, waar de hele politiek-bestuurlijke werkelijkheid door lijkt te worden beheerst en in een regressieve reflex is gedrongen.

\section{De rol van de gemeenteraad}

De positie van de gemeenteraad is stevig beïnvloed door de dualisering, een van de weinige geslaagde structuurinterventies van Binnenlandse Zaken. Hoe de feitelijke oriëntatie van raadsleden zich heeft ontwikkeld, leren we onder meer uit het boek van Pröpper en Kessens, die rond de invoering van de dualiseringsoperatie meer dan honderd gemeenten hebben begeleid (Pröpper en Kessens, 2005). In feite beoogt het boek een handreiking te zijn voor "diegenen bij gemeenten die voorop willen lopen in veranderingsprocessen rond politieke en bestuurlijke vernieuwing". Ook in dit boek, dat natuurlijk niet voor dat doel is geschreven, rijst niet het beeld op van een sterke verschuiving van de arena in de richting van de samenleving. De auteurs bepleiten een duidelijke brugfunctie voor raadsleden: dus niet alleen zichzelf of het eigen standpunt vertegenwoordigen, maar ook niet klakkeloos de nukken van verontwaardigde burgers vertolken.

De praktijk is echter anders: Veel "raadsleden luisteren niet maar zenden." En: "We hebben het zo druk met het veranderingsproces. We vergaderen hoegenaamd elke avond. Helaas hebben we nog geen tijd om met de burgers te praten. Dat moet nog komen." (Pröpper en Kessens, 2005: 61) Responsief bestuur is een van de belangrijkste doelstellingen van de beoogde veranderingen rond de dualisering. In de evaluatiestudies na de dualisering komt dit niet terug als belangrijkste merkbaar effect. In het rapport 'Staat van de dualisering' staat alleen in algemene zin een verwijzing naar "een geleidelijke cultuurverandering", die in grotere gemeenten beter zou zijn gelukt dan in kleinere. Maar of hiermee gedoeld wordt op responsiever bestuur, blijft onbenoemd. Wel staat in hetzelfde rapport dat de volksvertegenwoordigende rol van de raad niet is versterkt. Dan zou men eigenlijk moeten concluderen dat de doelstelling responsief bestuur niet is beoogd met de cultuurverandering na de dualisering. Ook in het jaarrapport van de begeleidingscommissie van de Vernieuwingsimpuls, waarin uitgebreid wordt ingegaan op cultuurverandering, wordt de invloed van dualisering binnen de onderzochte gemeenten vooral gelokaliseerd in de verandering tussen raad en college of tussen de politieke partijen binnen de raad. Niet in de verhouding met de samenleving (Vernieuwingsimpuls, 2006). Sinds de invoering van het dualisme is volgens Boogers (2007: 55) wel duidelijk merkbaar dat de gemeenteraad meer overleg voert met maatschappelijke organisaties. Dat komt omdat deze organisaties na overleg met de wethouder niet meer automatisch verzekerd zijn van steun in de gemeenteraad. 
Als het gaat om een nieuwe rolverdeling tussen overheid en samenleving heeft volgens velen in gemeenteland de raad, de lokale politiek, de sleutel in handen. In de denkbeeldige S-curve die in het begin van dit hoofdstuk is geprojecteerd, is voor het lokaal bestuur een aantal markeerpunten te vinden die als indicator zouden kunnen fungeren voor een daadwerkelijke omslag in de verhoudingen. In de eerste plaats zal bij een 'kantelende' gemeente herkenbaar zijn dat een onderwerp als 'burgerparticipatie' wordt weggehaald bij de afdeling Communicatie, waar het meestal instrumenteel wordt ingevuld: trek nog eens een laatje participatieprocessen open. Daarna zou zichtbaar moeten worden dat externe oriëntatie en samenwerking met belanghebbenden is opgenomen in alle geledingen van de organisatie als deel van het eigen repertoire. En ten slotte mag de transitie geacht worden te zijn voltooid als de gemeenteraad er blijk van geeft de positie van de gemeente te zien als primair coproducent van publieke waarden in plaats van enige bron van publieke diensten.

Hoeveel gemeenteraden in Nederland zouden deze slag al hebben gemaakt? Nul? In relatieve zin komt Almere misschien nog het dichtst in de buurt. De gemeenteraad van Almere staat bekend om zijn stuwende rol bij de organisatie van burgerparticipatie, onder meer via een goedlopend burgerpanel via internet, de regelmatige politieke markten voorafgaand aan raadsvergaderingen en bij een uitgebreide consulatie rond de zogeheten schaalsprong. Als het gaat om het betrekken van de samenleving gaat in Almere meer impuls uit van de raad dan van het college. Maar alles is relatief; Almere staat niet bekend als de meest naar buiten gekeerde gemeente in Nederland (wat ook aan de bevolking kan liggen). Venlo en Oude IJsselstreek worden ook wel genoemd als kandidaten, maar het blijft met een lampje zoeken.

Er zit wel enige beweging in de rol van de gemeenteraad. In de publicatie van Binnenlandse Zaken uit 2010 blijkt dat er al enkele voorbeelden te vinden zijn waarin gemeenteraden incidenteel een andere verkennende en procesgerichte rol kiezen (De Beuk Organisatieadvies, 2010). Die voorbeelden dateren ook van vóór 2009, zoals de toekomstverkenning in de gemeente Hardenberg waarvan de procesregie van begin tot het eind in handen was van de raad. Ook in de gemeente Binnenmaas was de raad bijzonder actief in een soortgelijk proces. Een sterk voorbeeld is ook de rol van de Arnhemse gemeenteraad die zelf het heft in handen nam toen ten aanzien van de gebiedsontwikkeling in Rijnwaarden (Stadsblokken-Meinerswijk) een politieke impasse ontstond. De raad en niet het college ging zelf gesprekken organiseren met alle betrokkenen, waaruit weer een perspectief op een oplossing ontstond.

Dit zijn voorbeelden die laten zien dat een andere rol van de raad mogelijk is, maar het zijn wel incidentele projecten. Uiteindelijk zou men verwachten dat de driehoek gemeenteraad, gemeentebestuur (plus ambtenaren), samenleving gesloten wordt teneinde een soepel samenspel tussen participatieve en representatieve democratie te krijgen. De volgende stap na dualisering zou dan trialisering moeten zijn, maar daarvoor is een minstens zo ingrijpende cultuurverandering nodig als bij de inmiddels ingesleten dualisering.

\subsection{Conclusies over bestuurstheorie van het lokaal bestuur}

In dit laatste vergelijkende hoofdstuk is nog verkend hoe de ontwikkeling bij een andere bestuurslaag, de gemeenten, is geweest. Is daar de gelijkenis met het moederdepartement, onderdeel van de bestuurskolom van het binnenlands bestuur, weer groter? Of konden daar, 'dichter bij de burger', juist nieuwe ontwikkelingen in de samenleving eerder vat krijgen op het bestuur? Ook hier heeft de onderzoeker een literatuurstudie ondernomen om uitspraken te kunnen doen over veranderingen in de bestuurstheorie van het lokaal bestuur gedurende de laatste vijftig jaar. 
Net als bij het vakdepartement Landbouw is vast te stellen dat bij het lokaal bestuur de situatie wel wat afwijkt van die bij Binnenlandse Zaken, maar uiteindelijk toch niet fundamenteel op een doorbraak wijst.

Een theoretische redenering die in de literatuur is aangetroffen over horizontalisering leek onafwendbaar. Dit betreft de conclusie dat de complexiteit van de gemeentelijke bestuursopgave haast dwingt tot onderhandelen (Von Benda-Beckmann en Hoekema, 1987: 12). Hoewel er wel degelijk tekenen zijn van verandering, is er op de theoretische logica wel af te dingen. Immers, gemeentebestuurders kunnen een hoop dilemma's en ongerijmdheid voor lief nemen en uiteindelijk toch opteren voor versimpeling van het probleem naar eigen voorkeur, mits zij daar uiteindelijk mee wegkomen. Dat is waarschijnlijk nog in verreweg de meeste situaties het geval. Slechts zeer zelden zijn er dwingende regels die elkaar echt tegenspreken, en ook is niet vaak de tegenpartij in staat werkelijk beslissende hindermacht te genereren om een spaak tussen de wielen te steken. De laatste jaren is die ruimte zelfs eerder verkleind dan vergroot. Denk aan de doorzettingsmacht bij ruimtelijke planvorming. In hetzelfde domein is de planschaderegeling aangescherpt, waardoor het bestuur meer armslag heeft en de burgers minder hindermacht kunnen ontplooien. In theorie behoort de overheid een evenwichtige belangenafweging te maken en daarbij rekening te houden met omwonenden. Sinds 2008 geldt in de nieuwe wet Ruimtelijke ordening een verzwaarde regeling voor planschade waarbij de omwonenden zich eerst een 'normaal maatschappelijk risico' ter hoogte van $2 \%$ van de waarde van hun onroerend goed moeten laten welgevallen voordat de overheid zich druk hoeft te maken over een tegemoetkoming in de schade. De noodzaak om met de omwonenden om tafel te gaan is er eenvoudigweg niet en dan laten de gemeenten die stap maar liever achterwege. Slechts weinigen hanteren de regels van het zogeheten Strategisch Omgevingsmanagement om te proberen alle stakeholders te contenteren, zoals is gebeurd bij de voorbereiding van de Tweede Maasvlakte en van de herinrichting van de Scheveningse boulevard (Wesselink, 2010). Nederlandse bestuurders lijken hun natuurlijke neiging tot complexiteitsreductie (grote stappen gauw thuis; de volgende verkiezingen wenken weer) nog vergaand te kunnen botvieren zonder grote negatieve gevolgen (anders dan op lange termijn vertrouwensverlies bij de burgers) en maken daar nog dankbaar gebruik van. De bekende kwalificatie van Nederlandse regenten verwijst vooral naar hun koopmansgedrag. Een slimme koopman richt zich op kortetermijnwinst. Als externe kosten later of op anderen kunnen worden afgewenteld, zal de regent dat niet laten. Ook al gaat dit ten koste van duurzaamheid of lange termijn vertrouwen.

\section{Het eigentijds discours binnen en over het lokaal bestuur}

Toch is er wel degelijk veel veranderd, zoals is af te leiden uit de vele casusbeschrijvingen tussen 1994 en 2009. De latere voorbeelden komen toch dichter in de buurt van coproductie dan de voorbeelden die Tops cum suis in 1996 onder die noemer optekenden.

Juist de bestuurskundigen, die immers zo royaal strooien met het cliché dat er een massieve shift van government naar governance plaatsvindt, laten ons als het gaat om de ontwikkeling van het lokaal bestuur wat in de steek. Handboeken over het lokaal bestuur besteden nauwelijks aandacht aan deze transitie. Dan zal er ook wel niet veel van waar zijn?

Het belangrijkste (zo niet enige) handboek voor het lokaal bestuur wordt anno 2010 aangeprezen wegens de grote dynamiek in het lokaal bestuur: interactieve beleidsvorming, veranderende verhoudingen tussen politieke en bestuurlijke actoren, decentralisatie, herindeling en wellicht reorganisatie van het binnenlands bestuur. De lezer herkent hier wel de agenda van Binnenlandse Zaken in, maar weinig shift naar de samenleving (Derksen en Schaap, 2010). Het thema interactieve beleidsvorming hadden Monster en schrijver dezes al in 2005 ten grave gedragen (Monster en Schrijver, 2005). Korsten heeft een overzicht over 50 jaar lokaal bestuur geschreven dat vooral de klassieke thema's etaleert, maar één passage over netwerkmanagement is onthullend: "Gemeenteraden zien zichzelf nog te veel als spil van de samenleving." (Korsten, 2012) 
Daartegenover staat een recent boek van Boogers over lokale politiek, dat wel meer herkenningspunten oplevert (Boogers, 2010). Het dichtst bij een duidelijk signaal voor veranderende inzichten komt echter uit de wereld van de gemeentesecretarissen. De publicaties van de vereniging van deze beroepsgroep ademen duidelijk een grote belangstelling voor alles wat binnen de gemeente naar buiten is gericht. Samen met de Vereniging voor Bestuurskunde heeft zij de volgende publicaties doen verschijnen: 'Maatschappelijke Veerkracht', 'Veerkracht en Democratie' en 'Voorbij de Crisis', die een welsprekende vertolking van de hier bedoelde shift van government naar governance bevatten. Uit de aankondiging van 'Veerkracht en Democratie' volgt dit citaat:

"De derde publicatie van de VGS in samenwerking met de Vereniging voor Bestuurskunde is een pleidooi voor een nieuw 'sociaal contract'. 'Veerkracht en democratie' laat zien dat maatschappelijke organisaties en burgers elkaar steeds beter weten te vinden buiten de overheid om, maar signaleert ook een ernstig verlies aan legitimiteit. Overheid en maatschappelijke organisaties zijn nu aan zet om die nieuwe samenwerkingsvormen een democratische impuls te geven."

Dit is een taalgebruik dat men van het college van secretarissen-generaal niet gauw zal verwachten, laat staan van ons parlement. In contrast met de rijksoverheid, waar binnen de concerngedachte de convergentie tussen ministeries en hun bestuursopvattingen is toegenomen, lijken de verschillen tussen een kopgroep van gemeenten en de achterhoede juist veel groter geworden dan in de tijd van de 'uniforme gemeente' van rond 1975.

\section{Conclusies}

Bij Binnenlandse Zaken lijkt er periodiek initiatief te worden genomen voor beleid in deze richting, maar onder druk van de dominante doctrine van Thorbecke (of wat daarvan in de loop der tijd is gemaakt: autonome bestuurslagen en politiek primaat van de representatieve democratie) zet dit niet door. Bij LNV was er een schokeffect, dat wel degelijk tot een blijvende en majeure verandering heeft geleid, maar ook daar bleef institutionele verankering uit. Verandering bleef vooral steken in verwarring en veel zoeken naar iets nieuws wat niet kwam.

De gemeenten staan het dichtst bij de harde praktijk. Daar beneemt vooral de verscheidenheid, tussen de verschillende gemeenten en tussen de vele beleidsterreinen die daar spelen, het zicht op een doorslaggevende verandering. Toch gloort er op steeds meer terreinen daar wel een aantal tekenen van vernieuwing. De verwachting dat de gemeenten als doelgroep van het bestuursbeleid eenzelfde bestuurstheorie huldigen als Binnenlandse Zaken is hier niet bevestigd. Laten we zeggen dat de overeenstemming in bestuurscultuur tussen Binnenlandse Zaken en de nationale politiek meer dezelfde polsslag slaat dan die bij de gemeenten. Maar in een S-curve op weg naar een transitie zijn de meeste gemeenten (zeker in de periode tot 2009) niet verder dan onderaan de helling gevorderd. Sommige zijn al verder en in bepaalde toonaangevende projecten of praktijken is dat zeker het geval. 


\section{Samenvatting, conclusies, verklaringen en reflectie}

\subsection{Samenvatting en conclusies}

Elk beleid kenmerkt zich door een bepaalde beleidstheorie, de veronderstellingen over de achterliggende causale, finale en normatieve relaties. Zo ook het beleid betreffende de inrichting en werking van het openbaar bestuur: het bestuursbeleid. Deze beleidstheorie heeft zelfs een aparte naam: bestuurstheorie. Deze vormt het onderwerp van deze studie. In hoofdstuk 1 werd de algemene probleemstelling voor deze verkenning aldus geformuleerd:

Hoe heeft binnen het subsysteem van het 'bestuursbeleid' in de periode van 1969 tot 2009 het dominante discours over de verhouding tussen bestuur en samenleving (de dominante bestuurstheorie dus) zich ontwikkeld en hoe is die ontwikkeling te verklaren?

Deze probleemstelling liet zich uitsplitsen in twee hoofdvragen:

a. Was er sprake van systematische ontwikkeling van een bestuurstheorie met een opgaande, aan de praktijk getoetste leercurve?

b. Onderscheidt de bestuurstheorie van Binnenlandse Zaken in de genoemde periode zich van de inzichten in de bestuurswetenschap, namelijk dat er een verschuiving plaatsvindt van government naar governance?

Om het beeld meer reliëf te geven is met behulp van een literatuurstudie verkend hoe de bestuurstheorie van Binnenlandse Zaken zich verhoudt tot die van andere ministeries, gemeenten en politiek in de Tweede Kamer.

Hieronder volgt eerst een resumé met de bevindingen die we onderweg zijn tegengekomen, gerangschikt naar de in hoofdstuk 1 gestelde deelvragen.

1. Wat is bestuursbeleid, welke dossiers vallen hieronder, welke projecten zijn interessant om de discoursontwikkeling te volgen, bijvoorbeeld omdat hier sprake lijkt van beleidsvernieuwing? De keuzen die hiervoor nodig waren, zijn in hoofdstuk 1 verantwoord. Bestuursbeleid werd gedefinieerd als het samenstel van maatregelen gericht op de verbetering van inrichting en werking van het openbaar bestuur als zodanig. De bestuurstheorie is een samenhangend geheel van veronderstellingen over inrichting en werking van het openbaar bestuur, in het bijzonder de verhouding tussen overheid en samenleving.

Vijf beleidsterreinen, hier dossiers genoemd, zijn te onderscheiden, waarbinnen 24 voorbeelden naar voren sprongen van projecten of ideeën die het in zich hadden om vernieuwing teweeg te brengen:

- $\quad$ Bestuurlijke organisatie;

- Decentralisatie;

- $\quad$ Achterstandsgebiedenbeleid (= PCG, sociale vernieuwing, grotestedenbeleid);

- $\quad$ Interbestuurlijke informatievoorziening;

- Organisatie rijksdienst.

De 24 geselecteerde voorbeelden van vernieuwende beleidsinitiatieven op deze terreinen vormen het casusmateriaal voor dit onderzoek. Een zesde potentieel dossier, Financiële verhouding(en), is niet apart in beschouwing genomen, omdat dit onderdeel zich strak conformeert aan de bestuurlijke lijn.

2. Hoe is te onderbouwen dat de dominante verhaallijn over het openbaar bestuur binnen de desbetreffende tak van wetenschap, de bestuurskunde, gaat over de shift van government naar 
governance? Government wordt opgevat als hiërarchisch bestuur op basis van politieke instructies en governance als open verkennend netwerkbestuur. Dit idee wordt zo frequent herhaald in de bestuurskundige wereld dat Hendriks en Drosterij (2012) het als het cliché van de bestuurskunde aanduiden. Ze willen aantekenen dat government natuurlijk niet geheel verdwijnt om te worden vervangen door netwerkgovernance. Dat is ook zo, maar de veronderstelde shift (omwenteling) betreft in dit boek ook niet de absolute afschaffing van verticalisme, maar de primaire kijk op het openbaar bestuur met een nieuwe verhouding tussen overheid en samenleving als een wederzijds verstrengeld vlechtwerk. Verondersteld wordt dat hier een bijzondere uitdaging ligt voor het openbaar bestuur. Het academisch debat over governance is er niet over uit of dit nu een radicaal ander paradigma voor het openbaar bestuur betekent of meer accent legt op een verschijnsel dat er altijd is geweest. In dit boek worden scherp onderscheidende criteria voor governance gehanteerd die duiden op een ten dele geheel nieuw verschijnsel. De onvoorspelbaarheid van relaties, effecten en dwarsverbanden, de variëteit aan potentiële actoren en belangen die het beleid beïnvloeden, stellen ongekende eisen aan het improvisatie- en reflectievermogen van bestuurders, waardoor governance wel degelijk een 'andere overheid' oplevert. Die kijk kan radicale gevolgen hebben voor de beleidsdoelstellingen over de ordening in het binnenlands bestuur (meer improvisatievermogen, meer samenwerking dan taakverdeling, meer experimenten met trial and error, open communiceren: louter maatwerk, afhankelijkheden tussen actoren die elk eigen taken, bevoegdheden en middelen hebben waardoor geen enkele actor alle doorzettingsmacht heeft en actoren dus veroordeeld zijn tot het opruimen van blokkades voor overleg, behoefte aan gemeenschappelijke beeldvorming, verknoping van doelstellingen en middelen nodig).

3. Wat is een passende methode om inhoudelijke typering en vergelijking van bestuursbeleid vast te stellen? Wat is de verhouding tussen taaluitingen (discours) en feitelijk handelen bij dit onderzoek? Er is voor gekozen voort te bouwen op de manier waarop Hajer (1995) en Dicke (2001) discoursanalyse toepassen. Discours is hier gedefinieerd als de typering van taaluitingen en praktijken binnen een vooraf geconstrueerde dichotomie van denkwijzen, waarmee betekenis wordt verleend aan het handelen van beleidsmakers.

Uit de beschreven bestuurstheorieën zijn duidelijk contrasterende verhaallijnen gedestilleerd. Die dichotomie is gebruikt voor de typering van de bestuurstheorie van Binnenlandse Zaken die spreekt uit praktijken en taaluitingen binnen de gekozen casussen.

De praktijken die aan beleidsdocumenten en literatuur zijn ontleend en de verhalen van de projectleiders roepen een beeld op van de dominante bestuursvisie die aan elk initiatief ten grondslag lag en die uiteindelijk heeft gewonnen. Per project is steeds de volgende informatie verzameld:

- de typering van de doelstelling achter het project en de beleidsredenering;

- de typering van de sturingsaanpak;

- de typering van de democratie-opvatting;

- de typering van de wijze van informatievergaring;

- de typering van het vernieuwend gehalte van het project volgens de categorisering van Hogwood en Peters (1984);

- de vraag of evaluatie heeft plaatsgevonden;

- de vraag of het project heeft bijgedragen aan de bestuurstheorie van Binnenlandse Zaken, zo mogelijk geactualiseerd aan de praktijk en met een opgaande leercurve;

- typering van de doorwerking, institutionalisering (het beklijven) van het beleidsinitiatief in het bestuursbeleid.

Per project is een score toegekend als A, A -, B of B - (government- of governance-oriëntatie) en aan het eind is de conclusie over het hele dossier getrokken in het licht van de beantwoording van de hoofdvraag over de shift van government naar governance.

Tezamen een duidelijke indicatie voor het beantwoorden van deelvraag 3 , hier kort samen te vatten als: is binnen het bestuursbeleid iets te merken van een omslag (shift) van government naar governance? 
4. Kan met behulp van het postulaat uit de bestuurskunde over de shift van government naar governance een operationele ideeëndichotomie worden gedestilleerd waarmee het bestuursbeleid kan worden getypeerd? De bedoelde operationalisering is geconstrueerd aan de hand van vier criteria, waarmee kan worden vastgesteld of sprake is van de ene of de andere modus in de bestuurstheorie. Wanneer in een meerderheid van de gevallen in een bepaalde periode sprake is van een governance-modus die bovendien beklijft, dus institutioneel verankerd wordt, concluderen we tot een shift.

5. Zijn bij de bestudeerde dossiers in het bestuursbeleid de verhaallijnen veranderd, is tussen de verschillende dossiers sprake van samenhang en inhoudelijke verwantschap, die een aanwijzing vormen voor de aanwezigheid van een dominante verhaallijn? Uit de in hoofdstuk 4 beschreven organisatiegeschiedenis van Binnenlandse Zaken blijkt dat ongeveer alle mogelijke combinaties van de dossiers binnen het bestuursbeleid in eenzelfde directie bij elkaar hebben gezeten. Dit gegeven toont aan dat er grote inhoudelijke samenhang tussen de onderwerpen moet zijn geweest. Bovendien constateren we een duidelijke doelstellingenhiërarchie, waarbij het decentralisatiestreven de andere doelstellingen overheerste. Dit blijkt uit de manier waarop beleidsdossiers als achterstandenbeleid en bestuurlijke organisatie ten dienste stonden van dit streven. Decentralisatie, bestuurlijke informatierelaties en organisatie van de rijksdienst waren op hun beurt weer dienstbaar aan het nog hogere doel: het versterken van de representatieve democratie. De bestuurstheorie van Binnenlandse Zaken is door enkele projecten gedurende de gehele periode van 1969-2009 beïnvloed. Vooral de ideeën over het regionale gat, de decentralisatie en de sanering van specifieke uitkeringen, de bestuursakkoorden en de behoefte aan coördinatie en samenhang in de rijksdienst (Vonhoff) hebben hun stempel gezet op de bestuurstheorie, ideeën waar weinig aan veranderd is door wisselwerking met de maatschappelijke werkelijkheid. Ook de magere evaluatiepraktijk (vooral bij succesvolle projecten) en de geringe mate waarin projecten voortbouwen op voorafgaande ervaringen wijzen in de richting van een antwoord op vraag 6.

6.a. Is er aanwijzing dat Binnenlandse Zaken lering heeft getrokken uit de confrontaties met de bestuurspraktijk en daarmee bewust een bestuurstheorie heeft ontwikkeld en bijgehouden? In hoofdstuk 1 werd de bestuurstheorie van Binnenlandse Zaken geïntroduceerd als instrumentele leidraad voor het beleidshandelen met een aantal daaraan te stellen kwaliteitseisen: consistentie, langetermijngerichtheid, aansluiting op de ontwikkeling in de samenleving en dus 'passendheid' ter wille van de effectiviteit ervan. De onderzoeksresultaten doen ernstige twijfel rijzen aan het systematisch onderhoud van een dergelijke visie. Pas sinds 2005 , wellicht onder invloed van de instelling van een centrale kenniseenheid voor strategie en onderzoek, werd systematisch gewerkt aan een alternatieve bestuursvisie, maar dat gebeurde weer op te grote afstand van de beleidseenheden en deze poging moest oproeien tegen andere krachten (politieke mediatisering) die zich toen juist lieten gelden.

Enerzijds vertoont het beleidsproces vooral in de jaren negentig sterke tekenen van een onzeker zoekproces. Dat biedt kansen voor leren en vernieuwing wanneer de maatschappelijke werkelijkheid daarom vraagt.

Anderzijds was dit proces te zeer hapsnap en te weinig gericht op verankering om structurele groei van een visie mogelijk te maken.

6.b. Heeft de dominante bestuurstheorie in de afgelopen veertig jaar een shift van government naar governance laten zien? Er is een rode draad en dat is overeenkomstig de verwachting duidelijk de government-benadering, maar die is niet zo overheersend dat er geen afwijkingen, of vernieuwende aanpakken mogelijk waren. Doordat deze niet echt doorzetten, kan echter niet gesproken worden van institutionalisering van een nieuw alternatief discours. De projecten met governance-kenmerken blijven steken in de categorie aanvechtingen. Wat vooral opvalt, is dat er zoveel concepten en aanpakken een tijdje zijn uitgeprobeerd en weer zonder enig spoor verdwenen. Neem een willekeurige greep: Complementair bestuur, Provinciale beleidsplanning, Ketenregie, Interactieve beleidsvorming, Benchmarks, sociale vernieuwing, Bestuursbemiddeling, 
Differentiatie, enzovoort. De opkomst en ondergang van bestuursconcepten bij Binnenlandse Zaken is tekenend voor de onderzochte periode. Dus uiteindelijk heeft het gebrek aan institutionele doorwerking de doorslag gegeven om te komen tot de dubbele conclusie: a. dat bij Binnenlandse Zaken geen shift heeft plaatsgevonden en $b$. dat van de vele beleidservaringen weinig leereffect is uitgegaan dat heeft bijgedragen aan een geactualiseerde duurzame bestuurstheorie.

De thema's en concepten die bleven bestaan (gemeentelijke herindeling, decentralisatie, sanering van specifieke uitkeringen, reorganisatie van het middenbestuur, bundeling en integratie van gemeentelijke samenwerkingsgebieden, ministeriële verantwoordelijkheid, et cetera) hadden allemaal een government karakter gemeen.

Van de 24 vernieuwende projecten heeft bij de helft een vorm van implementatie en institutionele doorwerking plaatsgevonden. Aan dit onderzoek is geen uitspraak te ontlenen of het gebrek aan 'succes' (in de genoemde betekenis van het woord) te maken had met het dominante governmentperspectief. In de eerste plaats is het onderzoek daar niet specifiek op gericht. In de tweede plaats zijn er evenveel government- als governance-projecten gestrand. In de derde plaats is de veronderstelling gerechtvaardigd dat veel government-projecten (bijvoorbeeld de herstructurering van het aantal, takenpakket en de schaal van provincies) met een governance-benadering niet eens begonnen waren. En ten slotte kan het afbreken van projecten ook andere redenen hebben dan een ontoereikende aanpak.

Zo is bekend dat Binnenlandse Zaken veel belang hecht aan de gemeentelijke autonomie. We zagen niettemin hoe Binnenlandse Zaken het soms niet kon nalaten de gemeenten te ondersteunen om de kwaliteit van bestuur te verbeteren als dat nodig was (BBI, kwaliteitsinstrumenten, grotestedenbeleid), maar daarna zich weer in zijn schulp terugtrok. Het (onbewust) afwisselen van perioden met en zonder diepgaande bemoeienis met gemeenten lijkt een passend antwoord te zijn op het duivelse dilemma tussen het eerbiedigen van de lokale autonomie en de noodzaak om het bestuur kwalitatief aan de maat te houden.

We leerden ook hoe heldhaftig het ministerie de strijd kon aangaan tegen veel grotere krachten (VNG, vakdepartementen, referendum in de grote steden) en dan roemloos kon ondergaan (reorganisatie binnenlands bestuur, stadsprovincies, reorganisatie rijksdienst, decentralisatieplan, terugdraaien verzelfstandigingen). Geen wonder dat succes dan uitbleef. Maar later kon een volgende minister weer met een subtielere aanpak terugkomen (kaderwetgebieden, D'gemeenten, Decentralisatie-impuls, overhedenoverleg, kaderwet zbo's).

Per saldo is niet te zeggen hoe de successcore (in de betekenis van het bereiken van de fase van beleidsimplementatie) beter had gekund. Wel dat bij een andere bestuurstheorie andere onderwerpen waren gekozen en daardoor de bijdrage van Binnenlandse Zaken aan de kwaliteit van het openbaar bestuur relevanter had kunnen zijn.

Als de projecten op een tijdbalk worden afgezet, lijkt het ministerie in de periode rond de eeuwwisseling een wending naar een andere bestuursstijl in te zetten, maar die zet niet door. $\mathrm{Na}$ 2002 is een duidelijke verkramping in bestuursstijl waar te nemen. Uit de literatuur, die hierna nog wordt besproken, blijkt dat effect overigens in de hele overheid merkbaar (Kickert, 2005). Experimenten en verkenningen worden ingeruild voor beproefde projecten op het terrein van bestuurlijke organisatie, decentralisatie en bestuursakkoorden. Vooral decentralisatie, sanering van specifieke uitkeringen en gedragscodes voor de interbestuurlijke betrekkingen in bestuursakkoorden bleven hoge prioriteit houden ook al was de noodzaak van interventies van Binnenlandse Zaken ter wille van een evenwicht in het binnenlandsbestuur in feite al overleefd. Men zou kunnen zeggen dat de continuïteit op deze thema's ten koste ging van vernieuwing op andere terreinen. Ook het streven naar bestuurlijke reorganisatie van het middenbestuur kan ondanks de indrukwekkende reeks mislukkingen als een continu thema van het bestuursbeleid worden beschouwd. Of het nu ging om doe-provincies, stadsprovincies, kaderwetgebieden, of zelfs landsdelige provincies, al deze pogingen waren direct of indirect gericht op het creëren of op den duur laten ontstaan van krachtige, democratisch gelegitimeerde, regionale (bovenlokale) besturen in het hele land. 
De hierna volgende vraagstellingen waren aanvullend bedoeld om het beeld met betrekking tot Binnenlandse Zaken meer reliëf te geven. Zij zijn gebaseerd op een literatuurverkenning.

7. Is er een aanwijzing voor een andere bestuurstheorie bij het parlement en bij politieke partijen? De vooraf verwachte uitkomst over het politieke domein was gebaseerd op de proefschriften van Peters (1999) en Koppenjan (1993). Die constateerden dat Binnenlandse Zaken, meer dan andere ministeries, invloed van de politieke besluitvormers ondergaat. Dit ministerie zou zich van nature dienstbaar richten op de parlementaire democratie en zich relatief veel gelegen laten liggen aan de wensen van de volksvertegenwoordiging. Inderdaad schijnt er weinig licht door tussen de bestuurstheorie van Binnenlandse Zaken en van de gelijknamige Vaste Commissie die de standpunten in de Tweede Kamer over bestuursbeleid voorbereidt en in feite bepaalt. Ten aanzien van een veronderstelde shift van government naar governance is hiervan in dit deel van de Tweede Kamer zo mogelijk nog minder te merken dan bij het ministerie al het geval was.

8. Is er een aanwijzing voor een dominant discours bij een of meer andere ministeries als het gaat om de verhouding tussen openbaar bestuur en samenleving en wijkt dat af van het gevonden resultaat bij Binnenlandse Zaken? Anders gesteld: is de shift die nauwelijks zichtbaar was bij het bestuursbeleid in de periode 1969-2009, ook niet te vinden bij een specifiek ander departement? Wegens de beschikbaarheid van onderzoeksmateriaal is voor deze vergelijking het ministerie van Landbouw gekozen in hoofdstuk 12. De verwachte uitkomst van deze vergelijking is dat een dergelijk vakministerie, dat de hete adem van de samenleving direct ondervindt, wel degelijk een shift van government naar governance zou hebben doorgemaakt. Hier leidde bestudering van de empirisch goed gefundeerde literatuur voor het eerst tot een afwijkende conclusie. Weliswaar is de ideeënontwikkeling bij een vakministerie als dat van Landbouw opvallend anders geweest, maar er was wel degelijk sprake van schoksgewijze verandering. De analyse van de bestuurstheorie in termen van een shift van government naar governance heeft echter twee deuken opgelopen. In de eerste plaats blijkt dit ministerie juist een afwijkende historische ontwikkeling te hebben doorgemaakt die niet goed past bij een lineair verloop vanuit een government-verleden naar een governance-toekomst. In de tweede plaats blijkt ook bij Landbouw institutionele vertaling en verankering te zijn uitgebleven. Uiteindelijk zagen we bestuurlijke en organisatorische ontwikkelingen die juist veel overeenstemming vertonen met die welke we ook in het bestuursbeleid tegenkwamen: de hardnekkigheid van het politiek primaat, van het top-down denken, de ontoereikendheid van nieuwe werkvormen en denkwijzen die pluriformiteit kunnen inpassen in het streven naar een gezamenlijk resultaat, kortweg samenwerking. Dus ook hier geen doorgezette shift.

9. Is er aanwijzing voor een dominant discours bij de decentrale overheden op hetzelfde terrein van de verhouding tussen openbaar bestuur en samenleving en wijkt dat af van het gevonden resultaat bij Binnenlandse Zaken? Hoofdstuk 13 gaat hierover. De verwachting uit de theorie was dat de gemeenten net als het moederdepartement naar alle waarschijnlijkheid niet echt de slag hebben gemaakt naar een nieuw bestuursparadigma in de aangegeven zin.

De conclusie aan het eind van het vorige hoofdstuk was wel afwijkend van de veronderstelling. Wellicht geldt deze stelling voor het peloton van gemeenten, maar er zijn toch te veel tekenen van verandering bij een kopgroep en bij een bepaalde categorie actoren (bijvoorbeeld de gemeentesecretarissen) om vol te houden dat aanloop naar een omwenteling hier helemaal niet heeft plaatsgevonden. Er is waarschijnlijk toch minder innige omklemming van Binnenlandse Zaken met zijn doelgroep om te kunnen spreken van een homogeen 'papegaaiencircuit' met dezelfde bestuurstheorie. Misschien geldt zoiets voor de relatie met de VNG (en IPO), maar niet met de gehele categorie gemeenten.

Het belangrijkst uit de literatuurverkenningen over aanpalende bestuursdomeinen is de conclusie dat Binnenlandse Zaken niet alleen staat in zijn bestuursopvattingen. Niet opzienbarend is dat de directe gesprekspartners en strijdmakkers in de Tweede Kamer en VNG soortgelijke bestuurstheorieën huldigen als het moederdepartement. Bijzonderder is dat een vakdepartement 
uit een geheel andere beleidsfamilie als LNV en V\&W, althans in de laatste decennia, helemaal niet afwijken in hun geneigdheid naar government-denken. Nieuw in dit onderzoek zijn de aanwijzingen voor het geleidelijk versterkte magnetisme binnen de rijksdienst.

Het ministerie van Binnenlandse Zaken en dat van Landbouw begonnen de onderzoeksperiode met een diametraal tegengestelde bestuursvisie. Aan het eind van die periode zijn ze, ondanks verwachtingen van 'een salto mortale' (Bekke et al., 1994) geconvergeerd naar gelijksoortige beleidsorganisaties die zich vooral oriënteren op de eisen van de politiek, de risk-society en van de media. LNV heeft ook aanvechtingen gehad in de richting van governance, meer nog dan Binnenlandse Zaken, maar die hebben niet echt de overhand gekregen. De overeenkomsten tussen de ministeries (het 'concern Rijk') zouden, volgens deze studie althans, in de onderzochte veertig jaar groter zijn geworden.

De traditioneel sterke homogeniteit binnen het binnenlands bestuur lijkt daarentegen minder sterk dan die misschien is geweest. De gevonden beschrijvingen geven aan dat gemeenten meer ruimte hebben genomen om een eigen weg te gaan, variërend van een regisserende gemeente die zelfsturing voorop stelt tot klassiek vrij regentesk bestuur.

Gemeenten zouden dan geleidelijk gedurende de onderzochte periode verder uit elkaar zijn gegroeid en daarmee is ook de gelijkenis in denken met het moederdepartement wat afgenomen.

10. Wat zijn mogelijke hypothesen ter verklaring van de opgedane bevindingen? Dat is voer voor het laatste deel van dit hoofdstuk.

Het beleid van Binnenlandse Zaken heeft gedurende de hele onderzochte periode onder invloed gestaan van het werk aan de Nota Bestuurlijke Organisatie, de Reorganisatie van de rijksdienst en de Decentralisatienota. Voor zover de bestuurskunde als toegepaste wetenschap de praktijk terecht voorhoudt dat bepaalde maatschappelijke problemen alleen door inzet van alle hoekpunten van de driehoek (vierhoek) samenleving - markt - overheid - wetenschap met vrucht zijn aan te pakken, is het bestuursbeleid waarschijnlijk door de relatief zware investeringen voor het tot stand brengen van de genoemde nota's in de aanvang van de onderzoeksperiode op een ander been gezet.

In hoofdstuk 10 werden enkele redeneringen over de verklaarbaarheid van het vasthouden aan de government-denklijn, zelfs passendheid daarvan in de beleidsstrategie van Binnenlandse Zaken, al verworpen. Innovatiebevorderend beleid is niet per definitie vluchtig en tijdelijk. En Binnenlandse Zaken is niet per definitie alleen op aarde om structuren te bouwen en te onderhouden, maar om te zorgen dat het bestuur de eisen van de tijd aankan. Tautologische verklaringen en vertekeningen van het eindbeeld die zouden voortkomen uit een verkeerde onderzoeksopzet, zijn in hoofdstuk 10 beredeneerd afgewezen.

In de volgende paragraaf komen we dus toe aan de echte verklaringen van de bevindingen over de bestuurstheorie van Binnenlandse Zaken.

\subsection{Mogelijke verklaringen van het uitblijven van de shift}

\subsubsection{Hypothesen naar aanleiding van de uitkomsten bij Binnenlandse Zaken}

De hieronder geformuleerde hypothesen komen voort uit een logische categorisering van factoren die bepalend zijn voor strategische veranderingen, zoals een omwenteling in het denken. Spiegelbeeldig kunnen zij ook het uitblijven van dergelijke veranderingen binnen organisaties verklaren, zoals in het geval van Binnenlandse Zaken de shift die niet kwam.

A. Interne Factoren

A.1. De organisatierelaties, management en leiderschap

A.2. Human resources, de personen binnen organisaties

B. Externe Factoren, zoals technologie, economie, demografie en politieke machtsfactoren die invloed uitoefenen op de organisatie 
Deze indeling is ontleend aan het bekende handboek voor organisatiewetenschappen van Kreitner en Kinicki (2008: 562).

\section{A. Interne factoren binnen de organisatie}

Verklaring uit de organisatieverhoudingen en managementbeslissingen

Een in de organisatiekunde breed aanvaarde stelling is dat de innovatieve kracht van een organisatie niet is te verwachten van de leiding. Een bijzondere combinatie met onder meer de psychoanalyse levert bij de Britse organisatiekundige Stacey interessante inzichten op voor verklaring van gedrag van mensen en organisaties om te leren en hun overlevingskans te vergroten (Stacey, 1996). Elk individueel of collectief menselijk organisme wordt volgens Stacey gekenmerkt door een harde kern met een kenmerkend dominant en manifest denkschema en een latent schaduwsysteem daaromheen, dat in contact staat met de buitenwereld en dat rivaliserende denkbeelden binnenbrengt.

Dominante systemen kunnen in extreme gevallen grote stabiliteit vertonen, door met succes weerstand te bieden tegen signalen van buiten. Tegenovergesteld zijn situaties waarin rivaliserende ideeën de overhand hebben, wat leidt tot anarchie en chaos en neurotische symptomen in een werkomgeving.

De aanbevolen toestand zit volgens Stacey daartussenin. De tussenvorm waarbij organisaties creatieve ontwikkeling laten zien, is die waarin voldoende centripetale kracht bestaat om een voortdurende staat van onzekerheid en nervositeit in de periferie van de organisatie te dempen, maar anderzijds voldoende gelegenheid wordt geboden om grenservaringen te laten doordringen en die te incorporeren in de dominante 'ideologie' door middel van creatieve destructie. Dat impliceert dat de verbindingen tussen top en werkvloer open en vloeiend moeten zijn. Stacey noemt vijf factoren die bepalen of een organisatie op het scherp van de snede opereert, tussen de luie zekerheid van de comfortzone en chaotische anarchie:

- de kwaliteit van informatiestromen;

- voldoende, maar niet overmatige diversiteit in de organisatie;

- de kwaliteit van verbindingen;

- gecontroleerde nieuwsgierigheid en scoringsdrift;

- ervaren machtsverschillen binnen de organisatie.

Het komt aan op het vinden van het heilzame midden: regelkramp en onderdanigheid zijn net zo schadelijk als ongebreidelde fantasie en hobbyisme. Werkrelaties mogen niet te vluchtig zijn en ook niet te hecht, maar voldoende intensief om vertrouwen te genereren.

Ook bij de beleidsorganisatie Binnenlandse Zaken is de natuurlijke neiging om de eigenheid (boven aangeduid als de doctrine) van de organisatie te bewaken en te bewaren. Zelfs de prachtige missie van Binnenlandse Zaken uit $2008^{93}$ ademt meer het vasthouden ("staat voor", "borgt") dan ontwikkeling en vernieuwing. Ontwikkeling en vernieuwing moeten komen van de wisselwerking tussen de organisatie en haar omgeving. "Aan de Grens wordt men pas Mensch." Zuurstof wordt binnengebracht door blootstelling van de organisatie aan de buitenlucht. Kortom, een flink stuk van de bezigheden van een gezond Binnenlandse Zaken zal alleen al om die reden gewijd moeten zijn aan de gezamenlijke praktische worsteling met bestuurlijke problemen op het lokale vlak.

De wijsheid van het management is volgens deze organisatiekundigen inzicht te hebben in de eigen beperktheid en in de noodzaak systeemcorrecties in de organisatie te brengen door programma's of langduriger opdrachten die bewust zijn gericht op samenwerking, facilitering, ontwikkeling in het veld. In het geval van bestuursbeleid betekent dit contact houden met de ontwikkelingen in de uitvoeringspraktijk, bijvoorbeeld naar aanleiding van bestuurlijke

93 'Binnenlandse Zaken staat voor een goed functionerend openbaar bestuur, een veilige samenleving en een overheid waar burgers op kunnen vertrouwen. Daarmee borgen wij de kernwaarden van onze democratie.' 
tekortkomingen binnen gemeenten. Dat is op gezette tijden ook wel gebeurd, zonder te ontaarden in bevoogding, zoals de meeste voorbeelden laten zien. Denk aan het BBI-project, sociale vernieuwing, Ketenregie en (na 2009) de bezinning op bestuurskracht.

Daarnaast is de uitdaging voor leidinggevenden van een gezonde, toekomstbestendige organisatie om ervoor te zorgen dat de interne wisselwerking tussen invloeden van buiten en de hoofdstroom intensief plaatsvindt. Waar de organisatieleiding niks aan heeft, is een aantal losse eenheden aan de rand van de organisatie die vertwijfeld zoeken naar hun missie en die doldraaien door van het ene interessante probleem naar het volgende mooie project te springen. Ook gemarginaliseerde eenheden die door de leiding met repressieve tolerantie worden gedoogd (kijk ons eens innovatief en coöperatief zijn, gaan jullie lekker in je speeltuin spelen) helpen niet. Een echte wisselwerking en serieus openstaan voor signalen alsmede actief meesturen vanuit het management in prioritering en selectie van interventies zijn nodig voor de effectieve bijdrage aan de organisatieontwikkeling vanuit ervaringen in de omgeving.

Terugdenkend aan analyses die ambtenaren van Binnenlandse Zaken zelf maakten bij werkgroepen rond de reorganisatie Leeuwensprong (2004), lijkt de conclusie eerder dat het ministerie als 'neurotische' organisatie met een relatief weinig krachtige leiding (Stacey, 1996) impulsen volgde en uiteindelijk met talloze losse en half afgemaakte initiatieven opereerde dan dat de leiding de beleidslijnen uitzette en deze met verve bewaakte. De ambtenaren die hierover ervaringen uitwisselden, moesten vaststellen dat zij zelden een werkplan van de top ten uitvoer voorgelegd kregen, maar dat vrijwel altijd omgekeerd de plannen van onderaf kwamen en de leiding de voorstellen fiatteerde. Het effect van beide extreme leiderschapsmodellen is overigens gelijk: gebrek aan verandering.

\section{Typen ambtenaren}

Een andere analyse zoekt oorzaken voor de geneigdheden van het ministerie bij de ambtenaren. Ton Pauka heeft veel geschreven over de waardepatronen bij ambtenaren. In een studie bij het ministerie over de houding van ambtenaren tegenover de ministeriële verantwoordelijkheid in 2001 signaleert hij een indeling in twee archetypische opvattingen over dit onderwerp (Pauka, 2001):

"Type A, die het liefst verantwoording en openheid vermijdt en zich vereenzelvigt met de minister. Hij ziet het tot zijn taak de risico's voor de minister te minimaliseren. Type B voelt als ambtenaar een aparte verantwoordelijkheid tegenover de samenleving, en ervaart spanning met het politieke domein. Archetype B is minder geneigd tot autonome ambtelijke risicomijding dan archetype A."

De rapportage vervolgt met de vaststelling dat ambtenaren van het type $B$, de durvers, vooral zijn te vinden onder de categorie niet-leidinggevende medewerkers. Daarnaast valt bij Binnenlandse Zaken op dat de medewerkers die nieuw binnenkomen op BZK nagenoeg zonder uitzondering van het type B (durvers) zijn. Hij verklaart dit uit het gegeven dat waarden uit archetype B dichter bij de in de maatschappij gangbare opvattingen liggen. De B-ambtenaren zien hun leidinggevenden als behorende tot het A-type. Hoe hoger in de hiërarchie, hoe sterker de A-kenmerken aanwezig zijn, zo menen zij. Die perceptie lijkt logisch. Daar zit men dichter bij de minister, de top moet hem uit de wind houden. De heersende veronderstelling is dus dat om carrière te maken, een beweging van $B$ naar A nodig is. Pauka beveelt aan om de grijstinten tussen de extreme posities A en B op te zoeken en om hierover intern meer te communiceren. Maar hij ontkent het bestaan van deze beelden niet. Dat gegeven alleen kan de uitkomst van veel gedrag binnen BZK mede verklaren.

Talloze ooggetuigenverslagen uit de laatste decennia stellen dat de verhouding tussen ambtenaren en politici sinds de tweede helft van de jaren negentig nog krampachtiger is geworden. Ook Docters van Leeuwen haalt dit naar voren in een interview, maar hij was zelf slachtoffer in een van de bekende affaires (Van Liempt en Westing, 2000). Ook Kickert memoreert deze ontwikkeling in zijn rondgang langs een aantal spelers rond de reorganisaties in de rijksdienst (Kickert, 2005: 32). Het paarse kabinet maakte het politiek primaat tot hoofdpunt van beleid. Kickert tekende onder meer de volgende uitspraken op: 
"De politiek heeft een disciplineringsbeweging uitgevoerd, ook omdat ze zelf zo onzeker is over wat goed is."

"De politiek-ambtelijke verhoudingen zijn harder geworden. Ambtenaren vallen ministers niet meer in het openbaar af en ook achter de schermen is de mondigheid verminderd."

"Er is een tijd geweest dat de ambtenaar mondiger moest worden en meer politiek ondernemer. Hierdoor ontstond strijd tussen politici en ambtenaren. Nu zie je er niets meer van."

Deze typering van BiZa-ambtenaren zou betekenen dat voor zover de ambtenaren zich zouden kenmerken als relatief weinig ondernemend, de blik omhoog gericht, dus niet direct in de horizontale oplossingsgerichte staand met een maatschappelijke oriëntatie, dit zou samenhangen met de habitus van hun politieke bazen zoals in de vorige alinea werd belicht. Dit is overigens niet het beeld van de ambtenaren van Binnenlandse Zaken dat in het voorgaande relaas vooral is te associëren met veelal initiatiefrijke trekkers van vernieuwende projecten. Misschien is de hele samenleving wat conservatiever geworden, na de Sturm und Drang van de jaren zestig en zeventig.

Er zijn ook mensen die het gebrek aan bestuurlijke vernieuwing wijten aan een bepaalde beroepsgroep binnen Binnenlandse Zaken, de (wetgevings)juristen. Juristen zouden niet goed uit de voeten kunnen met governance. Wetgeving is belangrijk op rijksniveau, maar het kan niet volgehouden worden dat Binnenlandse Zaken de laatste decennia door juristen werd overspoeld. Zoals in hoofdstuk 4 en 6 uiteengezet, werden eind jaren zeventig vooral sociale wetenschappers aangetrokken. Eind jaren negentig is de wetgevingsfunctie geconcentreerd bij de stafafdeling Constitutionele Zaken en Wetgevingsaangelegenheden, waardoor (wetgevings)juristen binnen de beleidsafdelingen nog dunner gezaaid werden. Daarbij komt dat lang niet alle juristen zich wars tonen van bestuurlijke vernieuwing, zoals het vooroordeel doet geloven. Van de veertig voor dit onderzoek geïnterviewde personen hebben er twaalf de meestertitel, maar daar zitten mensen bij die in de verhalen als vernieuwers uit de voorhoede naar voren komen.

\section{B. Externe verklaringsfactoren}

\section{Technologische ontwikkelingen}

Vooral ICT-ontwikkelingen hebben op de werkwijze binnen het ministerie een enorme invloed gehad in de hier onderzochte periode. Maar dat betrof toch vooral de kantoorautomatisering. De eerste decennia werden nota's door secretaresses uitgetypt of in de centrale typekamer in Winschoten. Er kon wel een week overheen gaan voordat een stuk heen en weer was gegaan. In de jaren tachtig kwamen de eerste computers en in vrij korte tijd werden de ambtenaren geacht geheel zelf hun producten te verzorgen.

De tweede invloed van ICT is in hoofdstuk 8 beschreven en betrof vooral de grote basisregistraties die de digitale administratieve verwerking van data mogelijk maakten. Hier is beleidsmatig veel energie in gestoken, en met succes, zoals in paragraaf 8.3 naar voren kwam.

Veel minder aandacht kreeg de derde en misschien maatschappelijk meest diep ingrijpende ontwikkeling, namelijk die van het internet en de sociale media. Dit is vooral de ontwikkeling die voor netwerkvorming en spontane associaties binnen de samenleving van doorslaggevend belang is geweest en nog is. Dat Binnenlandse Zaken daarvan geen project heeft gemaakt is wel te begrijpen, want er zijn weinig aangrijpingspunten voor directe interventies op dit domein. De impact op het bestuursbeleid is vooral indirect en weinigen kunnen de ingrijpende portee van deze ontwikkeling overzien. Niettemin zou het voor de ontwikkeling van de bestuurstheorie van Binnenlandse Zaken van belang kunnen zijn geweest om een aantal goeroes op dit terrein binnen te halen en samen de effecten op democratie en bestuur te verkennen. Een poging die enigszins in deze richting ging, betrof de commissie-Docters van Leeuwen, die in haar eindfase door een 
ongelukkige communicatie (zie paragraaf 8.4.2) een slechte ontvangst binnen het ministerie heeft gekregen. De voorzitter van deze commissie komt hieronder aan het woord.

\section{Factor macht}

Dit aspect wordt meestal aangehaald als het gaat om het verklaren van conservatisme. Dat geldt overigens even goed voor veranderingen in de richting van versterking van centrale sturing als van netwerksamenwerking. Als voorbeeld van het eerste wordt vaak de verklaring van alle mislukkingen bij de reorganisatie van het middenbestuur aangehaald. Die verklaring luidt dat uiteindelijk de politieke partijen hun calculaties maken en vaststellen dat zij in termen van politieke macht en baantjes erop achteruit gaan en dan de stekker eruit trekken of berusten in de status quo, onder verwijzing naar een gebrek aan draagvlak in de samenleving.

In het advies van de commissie-Docters van Leeuwen staat de verhouding tussen overheid en burger centraal. De commissie gebruikt voor de typering van die relatie het volgende schema (raamwerk; zie figuur 14.1), waarbij de ontwikkelingsrichting is van boven naar beneden op de transactionele as en van links naar rechts op de ordenende as.

Figuur 14.1 Relaties tussen overheid en burger volgens de commissie-Docters van Leeuwen

De overheid beslist,

de burger bewaakt

De burger als belanghebbende

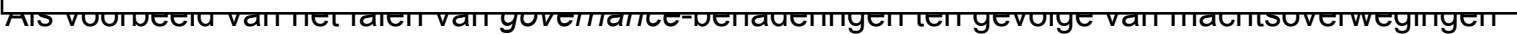
spreekt Arthur Docters van Leeuwen die door de Raad voor het Openbaar Bestuur is geïnterviewd ${ }^{94}$ ten behoeve van het advies 'Trias Informatica' (Raad Openbaar Bestuur, 2003). Hij stelt daar dat 'ze' (de machthebbers, de beleidsmakers) selectief redeneren in de richting van wat in hun straatje past. Hoewel alle adviezen en rapporten hameren op de ontwikkeling in de richting van één kwadrant van het raamwerk (rechtsonder), worden ze stelselmatig niet opgevolgd. Dat hangt samen met de machtsfactor. De overheid blijft in aanbodstermen denken, in de 'wij bepalen'termen. Afscheid nemen van het model overheid-onderdaan doet pijn. Een andere houding en manier van werken wordt volgens Docters van Leeuwen als heel bedreigend ervaren.

De boodschap is duidelijk, onder aftrek van de mogelijke frustratie van een commissievoorzitter wiens advies net terzijde is gelegd: misplaatste machtsaspiraties van politici (en hoge ambtenaren) staan noodzakelijke hervormingen in de richting van meer horizontale samenwerkingsrelaties met de samenleving in de weg, en deze weerstand wordt zelfs de laatste jaren groter in weerwil van de toegenomen noodzaak tot verandering. Op rijksniveau is de beschreven reflex in sterke mate aanwezig, meer dan bij gemeenten en zbo's. Binnenlandse Zaken zou dan extra gevoelig zijn voor deze politieke sentimenten.

\section{Tegenstrijdige tendensen}

Bestuur en politiek zijn niet alleen onderhevig aan tendensen die in dezelfde richting wijzen. Dat maakt het in de praktijk moeilijk om een duidelijke stijl te omarmen. Hier volgen twee voorbeelden van 'anti-governance'-krachten.

\footnotetext{
94 Interview met Arthur Docters van Leeuwen in 'Elf over twaalf, Interviews over ICT en Overheid' door Pieter Nieuwenhuijsen, Den Haag, 2003.
} 
Willem Trommel (2010) wees in zijn oratie op de paradox van 'gulzig bestuur'. Terwijl het geloof in maatschappelijke maakbaarheid vrij algemeen achterhaald is verklaard, lijkt de bemoeizucht met ons persoonlijk leven alleen maar toe te nemen. De overheid lijkt in onze risicosamenleving (term van Ulrich Beck, die erop duidt dat mensen weinig risico's meer voor lief nemen) gedwongen te worden 'preventief' en 'integraal' steeds meer 'maatregelen' te nemen om onheil te voorkomen. Tragische bijkomstigheid is dat hiermee juist veel nieuw onheil wordt opgeroepen, want het goed bedoelde beleid leidt bijna altijd tot onbedoelde neveneffecten die soms erger zijn dan de kwaal (Frissen, 2013). De lezer zal zich herinneren hoe het sociale vernieuwingsbeleid tegelijkertijd mikte op empowerment van burgers of maatschappelijke organisaties en ook de integrale bestuurspretentie van de overheid aanwakkerde. De tweede kracht is duidelijk werkzaam in het politieke speelveld.

\section{Politieke cultuur}

In 2011 werd de jaarlijkse Van Slingelantlezing van de Vereniging van Bestuurskunde gehouden door Paul 't Hart ('t Hart en Van der Steen, 2012). Hij heeft een aantal jaren in Australië gedoceerd en had van zijn ervaringen in dat land een andere kijk op de Nederlandse politiek overgehouden. In vergelijking met Australië staat Nederland aan het andere uiterste van een spectrum waarmee het politieke bedrijf getypeerd kan worden: populistisch versus establishment, machtsstrijd versus consensusgericht, personalistisch versus technocratisch, et cetera. Ondanks Fortuyn en Wilders is de Nederlandse politiek nog uiterst gemoedelijk van aard. Wilders zou in Australische verhoudingen een 'watje' zijn. Zijn stelling was dat door allerlei maatschappelijke en technologische ontwikkelingen de Nederlandse bestuursstijl onherroepelijk meer de Australische kant opgaat. Simplificering van tegenstellingen, keiharde machtsstrijd tussen twee blokken en Mediacratie met een hoofdletter.

Ongeacht de vraag of men deze toekomstverwachting van 't Hart deelt, kunnen we de afgelopen jaren al een stukje van deze ontwikkeling waarnemen. Verkiezingen gaan bijvoorbeeld om de vraag wie van twee partijen de grootste zal worden, de entertainment- en wedstrijdelementen lijken het te winnen van de inhoud en de flanken winnen ten koste van de middenpartijen. Naarmate dergelijke elementen de overhand krijgen, mogen we van de (nationale) politiek weinig bescheidenheid en samenwerkingsgeneigdheid verwachten. De op massale kijkcijfers en applaus gerichte media houden de politici in de greep van een machocultuur en simpele verwachtingen. Hierboven werd al gerefereerd aan soortgelijke tendensen die de beleidsontwikkeling in hun greep hebben. Er is nog geen begin van een aanwijzing dat de samenleving wijzer en meer bezonken gaat worden, wat wel een voorwaarde lijkt voor netwerkbestuur/governance. Met deze conclusie moeten we het voorlopig doen.

\subsubsection{Hypothesen naar aanleiding van de uitkomsten buiten Binnenlandse Zaken}

\section{Homogener rijksniveau}

De motor voor de geconstateerde interne cohesie binnen de rijksdienst is afkomstig van de werkwijze van het politieke bedrijf en de innige omstrengeling met de media. De medialogica werkt op nationaal niveau in tegengestelde richting ten opzichte van de these over een shift van government naar governance. Risicomijdend gedrag en verstrikt blijven in de gevoelde noodzaak om stoerheid en centraliteit uit te stralen, zijn te verklaren uit 'populistische' tendensen die waarschijnlijk sterker zijn dan de veronderstelde shift van government naar governance. Dit verklaart voor een belangrijk deel de haperende paradigmashift, althans op rijksniveau. Politiek en media voelen zich door koop-, kijk- en kiezerscijfers gedwongen tot het aanbieden van simpele boodschappen die appelleren aan sentimenten van grote aantallen. Dit kan wel eens een sleutelfactor vormen, waarbij een themanummer van het blad Bestuurskunde illustratief is. Het gedrag van commissies die in het leven worden geroepen om misstanden en ongewenste effecten van beleid te onderzoeken is tekenend voor de tendens om complexiteit te onderdrukken (Bestuurskunde 2013, nr. 4). Zij kunnen zich volgens de redacteuren van het themanummer eenvoudig niet permitteren om werkelijke oorzaken (waarom-vragen) en achtergronden te achterhalen, omdat de maatschappelijke onrust niet gedempt wordt door complexe meervoudige 
oorzaken te reconstrueren. Daarvoor past het beter om eenduidige schuldigen en (met kennis van nu) foute beslissingen in de top aan te wijzen. Dit gedrag is ook mutatis mutandis herkenbaar bij beleidsontwikkeling (Bronneman, 2013). Beleid dat op een verantwoorde (ambtelijke) manier problemen analyseert en stakeholders betrekt, komt wellicht verder met passende oplossingen, maar deze werkwijze heeft twee belangrijke politieke nadelen:

- Hoe communiceer je een heldere boodschap aan het volk?

- Hoe krijg je binnen vier jaar een resultaat?

De politieke rationaliteit biedt dus een krachtige verklaring voor gedrag dat afwijkt van bestuurskundige idealen. Die rationaliteit sluit helemaal aan bij de government-modus. De meer nuance en pluralisme toelatende 'ambtelijke' of beleidswetenschappelijke rationaliteit zou dan passen bij netwerkbestuur/governance.

Politiek drukt in die redenering een veel groter stempel op de rijksorganisatie dan gerechtvaardigd wordt door het aantal werkelijk politieke beslissingen dat primaat en sturing nodig heeft. Het leeuwendeel van de beleidsonderdelen is immers hetzij verkennend hetzij uitvoerend bezig. Daar zijn processen op het grondvlak, tussen dienstverlener en klant, tussen citoyen en beleidsmaker, tussen toezichthouder en regeltoepassing enzovoort, minstens zo belangrijk als die tussen principaal en agent. De overheid heeft te werken met een veelheid aan interactiepatronen en bijbehorende interventierepertoires. Dat verschijnsel vergt met een term uit de ICT-wereld een 'agile overheid' (Price Waterhouse Coopers, 2012), een overheid die voor elke situatie een passend repertoire uit de hoed tovert. Pas als ons democratiebegrip meervoudig is geworden en onze politieke bestuurders zich navenant opstellen, valt een verandering te voorzien. Het moet ooit mogelijk zijn deze boodschap (de 'Agile Overheid') bij de meeste kiezers uit te leggen.

\section{Divergerend lokaal niveau}

Binnen de gemeenten is deze ontwikkeling veel minder sterk voelbaar. Weliswaar zijn burgemeesters en wethouders merkbaar vaker slachtoffer van publieke crisis en kritiek, maar de tucht van de media is toch veel minder sterk dan op nationaal niveau. Men kan relatief in de luwte de maatschappelijke ontwikkeling volgen. Het sterk toegenomen takenpakket van gemeenten (vrucht van decentralisatie, al dan niet dankzij Binnenlandse Zaken), heeft de vermaatschappelijking van de gemeentelijke bestuurspraktijk bevorderd. In veel gevallen zijn de verhoudingen blijven steken in het oude polderen: het overlegmodel met vaste maatschappelijke partners, niet de verbinding met spontaan opkomende netwerken en belangengroepen uit onverwachte hoek. Denk hierbij vooral aan de sociale sector, waar de Wet maatschappelijke ondersteuning en in mindere mate de Wet werk en bijstand de verbindingen met partners in de samenleving hebben gestimuleerd. In de fysieke sfeer is de verzelfstandiging van de volkshuisvesting een belangrijke factor, omdat gemeenten de positie van de woningcorporaties als gelijkwaardige partners in het middenveld niet konden miskennen. Dit gold altijd al voor het onderwijs. In het veiligheidsdomein is de politie meer partner en geen onderdeel van de gemeentelijke organisatie meer. In een aantal gemeenten is de verdergaande stap gezet naar het opengooien van de communicatie naar alle burgers. Hierdoor kwam een onbepaalde groep betrokkenen het gemeentehuis binnen en worden gezamenlijk met krachten uit de lokale samenleving de probleemdefinities en bijbehorende oplossingsrichtingen bepaald. Zo wordt anders dan op rijksniveau in een aantal voorhoedegemeenten een langzame, maar onmiskenbare trend naar vermaatschappelijking ingezet (SCP, 2013), maar in de overheid als geheel is de shift van government naar governance niet bepaald overtuigend.

Conclusie: de zoektocht van dit boek is gericht op de vraag of Binnenlandse Zaken in dit opzicht misschien wel afwijkt van andere sectoren, zoals politiek, vakdepartementen en lokaal bestuur. Dat beeld is zeker niet bevestigd met deze studie.

\subsubsection{Weging}


Per saldo lijkt invloed van het politieke bedrijf zich vooral in de laatste periode het sterkst te doen gevoelen binnen het ministerie. De rol van de samenstelling van het ambtenarenapparaat en de houding van ambtenaren (human resources) lijkt onvoldoende bij te dragen aan het verklaren van het conservatisme. Eerder werden de ambtenaren als initiatiefrijk en ondernemend gekenschetst. Ministers en staatssecretarissen hebben als personen vooral door hun korte politieke levensduur weinig stempel kunnen zetten op de organisatie. Daarom is de conclusie gewettigd dat vooral het ambtelijk management en de invloed die het onderging van het politieke klimaat (meer dan de personen van de ministers) de belangrijkste factor vormt voor het gevonden patroon. De periode aan het eind van de twintigste eeuw was aanleiding om een grondige ideeënverandering te verwachten, maar de periode die daarop volgde zette daar een domper op. Dan richten de hypothesen zich onwillekeurig op het politieke en maatschappelijke klimaat dat na 2000 zijn stempel zette op de Nederlandse samenleving. Dat effect van de mediacratie herkennen we uit de beschrijvingen in hoofdstuk 11 en 12 .

Er is wel iets vreemds met de machtsfactor. Het is van tweeën één: of de maatschappelijke verhoudingen zijn daadwerkelijk verschoven zodat de overheid wegens sterke afhankelijkheid van maatschappelijke partners niet meer om samenwerking en onderhandelend bestuur heen kan, of die machtsafhankelijkheid valt nogal mee. Hiermee komen we terug op het begin van deze studie, op de uitgangsstelling van de bestuurskunde over een bestuurlijke en maatschappelijke ontwikkeling naar (meer) netwerkbestuur. Wat blijft daarvan over? Niet zo heel veel als ook wordt vastgesteld dat het openbaar bestuur in Nederland ondanks alles nog heel behoorlijk functioneert (Korsten, 2010).

\subsection{Hoe nu verder}

\subsubsection{Wat kan het bestuursbeleid met deze uitkomsten?}

Een discrepantie tussen vanuit de bestuurswetenschap gesignaleerde tendens en de praktijk van het bestuursbeleid hoeft niet meteen alarmerend te zijn.

Het is niet gezegd dat de omslag naar een andere kijk op het bestuur ook altijd heilzaam zou zijn. Dit caveat is al in paragraaf 2.3.2 duidelijk naar voren gebracht. Daarbij moet natuurlijk onderscheid worden gemaakt tussen de intrinsieke onbruikbaarheid van een netwerkconcept in bepaalde bestuurssituaties en de onvolkomen toepassing van een dergelijk concept, waar dit wel zou kunnen werken. Tussen deze uitersten ligt nog een groot grijs gebied, waar de toepassing op dit moment niet passend is, onder meer omdat politici, bestuurders en samenleving nog te veel verslingerd zijn aan oude denkmodellen en schijnwerkelijkheden. Maar ook zijn er sommige vraagstukken waar een minister ook helemaal niet naar governance-methoden hoeft te grijpen. Een zorgtoeslag verhogen, bij voorbeeld, dat wordt besloten terwijl niemand eraan te pas komt.

Er is natuurlijk een spanning tussen de behoefte aan eenduidige bevelslijnen, overzichtelijke en voorspelbare verantwoordelijkheden en de eisen van de complexe werkelijkheid met zijn afhankelijkheden en onzekerheden. Daarbinnen zijn verschillende keuzen verdedigbaar. Misschien was door eenzijdige nadruk op netwerkbestuur/governance bijvoorbeeld nooit iets terechtgekomen van een gestandaardiseerde communicatie-infrastructuur bij de politie. De oekaze-Kok, die vanuit opvattingen over politiek primaat rechtstreekse contacten tussen parlementariërs en beleidsambtenaren verbood, was in een bepaalde context wellicht nodig om te voorkomen dat elke afdeling van de rijksoverheid bureaupolitiek lobbywerk in het parlement ging plegen ten bate van zijn eigen beleidsbelangen. Zolang een democratische samenleving bij de collectieve besluitvorming geen alternatief heeft voor een gekozen volksvertegenwoordiging, moet zij het misschien maar voor lief nemen dat de gekozenen onwennig reageren op rechtstreekse zeggenschap van burgers en maatschappelijke organisaties. Om maar een paar voorbeelden te noemen.

Er zijn dus goede redenen voor het bevestigen van centraliteit, aangezien we niet zonder kunnen. 
Misschien is het juist goed als het bestuur wat tegenwicht blijft leveren in een turbulente en gefragmenteerde wereld met multi-interpretabele denkbeelden. En Binnenlandse Zaken kan bij uitstek de hoeder zijn van enige vastigheid op dit terrein. Daarnaast zijn er genoeg voorbeelden waarin de overheid wel degelijk governance-methoden gebruikt, alleen omdat het niet anders kan. Soms na eerst met schade en schande dit vastgesteld te hebben, zoals bijvoorbeeld bij de Tweede Maasvlakte gebeurde. Maar dat netwerkbestuur/governance hier en daar wordt toegepast, is nog iets anders dan een omwenteling, een andere kijk op de verhouding tussen overheid en samenleving, die ons in het vooruitzicht was gesteld.

De vraag is hoe groot de spanning kan worden tussen de wenselijkheid een ordelijk en democratisch gelegitimeerd bestuurscentrum te koesteren en de feitelijke afhankelijkheid die een dergelijk centrale actor van andere partijen ondervindt. Het lijkt niet gezond als de kloof tussen de maatschappelijke en bestuurlijke werkelijkheid (relatieve bestuurskracht van de overheid, verplaatsing van politiek, netwerkkarakter van de samenleving, serieuze

representativiteitsproblemen en niet vanzelfsprekende legitimiteit van beleid) en de bestuurstheorie van de overheid te groot wordt. Elke organisatie die niet beantwoordt aan een maatschappelijke behoefte is op den duur gedoemd te verdwijnen, al kan een overheidsorganisatie het in dit opzicht langer volhouden dan een marktorganisatie. En toch. De politieke realiteit laat zien dat de overheid langer dan vele bestuurskundigen verwachtten, in staat is een aparte status hoog te houden. Gaandeweg is in dit onderzoek naar aanleiding van de uitkomsten het idee gegroeid, dat een shift van government naar governance misschien plausibel kan zijn, maar dat in praktijk sterkere krachten in een andere richting werkzaam zijn. Het feit dat ook in andere domeinen, in het bijzonder in het parlement en vakdepartementen, de shift wordt tegengehouden door wat hier kortweg het politiek primaat-denken wordt genoemd, is tekenend.

Wat als...?

De gesignaleerde ervaring over de wijze waarop bij Binnenlandse Zaken beleidsplannen tot stand komen (zelden vanuit de top gestuurd), onderlijnt het beeld van een wispelturig, maar uiteindelijk conservatief ministerie. De vraag is of de gevolgen van de (impliciet) gemaakte keuzen ernstig zijn. De resultaten zijn in de eerste plaats over die veertig jaar niet om over naar huis te schrijven, zoals we zagen. Had Binnenlandse Zaken met een andere bestuurstheorie of met een sterker management betere resultaten bereikt? Door zich niet vast te bijten in onhaalbare of overleefde projecten (middenbestuur reorganiseren, de laatste specifieke uitkering uitroeien) was er misschien ruimte vrijgemaakt om dichter 'op de bal te zitten', Had Binnenlandse Zaken het hele binnenlands bestuur kunnen begeesteren met nieuwe concepten zoals complementair bestuur, brede bestuurskracht of bedrijfsbetrokkenheid als men daarmee serieus was doorgegaan? Had Binnenlandse Zaken de inspirator kunnen vormen van innovatie in het openbaar bestuur? Is het erg dat dit steeds weer in de kiem is gesmoord (InAxis, Andere Overheid, sociale vernieuwing)? Het stellen van 'what if'-vragen, is niet erg vruchtbaar. De padafhankelijkheid van gemaakte keuzen is in deze branche nu eenmaal erg groot (Kingdon, 1995).

Misschien zijn er ook onbezonnenheden voorkomen door vast te houden aan de vertrouwde thema's. In ieder geval kan worden geconstateerd dat de heersende bestuurstheorie van het ministerie een voorkeursbehandeling inhield voor de zogenoemde 'makkelijke' taken. De taken waarbij de zeggenschap van het bestuur onomstreden is: het toekennen van straatnamen, de uitgifte van paspoorten, de handhaving van de strafwet, enzovoort. De dominante opvatting over de opgave van het bestuur impliceert dus een bias ten nadele van de minder voorspelbare, meer complexe taken met veel actoren en variabelen. Dat lijkt een zwaktebod, omdat in deze tijd de complexe vraagstukken en de rol van de overheid als regisseur en facilitator meer uitdagingen oproept. Daarvoor is toch een bestuursdepartement nodig. Een geluid dat vaak wordt gehoord met betrekking tot een andere bestuurstheorie is: je kunt er toch geen beleid mee maken! Men bedoelt dan: het leent zich niet voor wetgeving; samenwerkingsgerichtheid en omgevingsgerichtheid vergen vooral een bepaalde houding. Zoals cultuurverandering kun je het niet sturen. Met permissie, dit lijkt een uiting van een gebrek aan fantasie. Projecten als Prettig Contact met de overheid, wijkenaanpak, overheidsloket 2000 en burgerparticipatie in gemeenten tonen het 
tegendeel aan. Men bedoelt misschien: het is moeilijk om hier bepaalde streefcijfers aan te verbinden waarmee politici kunnen scoren. En dan is de cirkel weer rond.

Was het nu en dan de vrije teugel laten aan een tijdelijk innovatief project een uiting van repressieve tolerantie van de leiding, een semi-bewust beleid? Wie zal het zeggen? Afgemeten naar de beperkte strategische sturing die van het topmanagement lijkt uit te gaan is deze complottheorie weinig aannemelijk. Wel duidelijk is dat door gebrek aan langere adem en absorberen van leereffecten veel kennis en ervaring is verspild, waarop de organisatie beter wat langer had kunnen voortbouwen. Dat Binnenlandse Zaken de shift niet heeft omarmd, is niet zonder maatschappelijke relevantie, omdat dan wellicht meer succes was bereikt en minder projecten waren mislukt. Wellicht waren meer relevante bijdragen aan het oplossend vermogen van het openbaar bestuur geleverd.

Uiteindelijk kan in de gegeven omstandigheden niemand het ministerie verwijten dat het te veel uit de pas heeft gelopen, omdat het niet ten volle de shift heeft meegemaakt die de bestuurskunde voorzag, hoewel het even leek dat die in de euforie van het fin de siècle was ingezet. Daarvoor geldt nu dat het voluit en van harte doorzetten van deze ontwikkeling tegelijkertijd maatschappelijk onvermijdelijk lijkt en maatschappelijk onmogelijk blijkt. Voer voor de complexiteitstheorie? Wellicht, maar eenvoudiger is de verklaring dat het openbaar bestuur verschillende doelgroepen moet bedienen: insiders en outsiders, afzijdige en participerende burgers. In het laatste decennium laat het bestuur de oren meer naar de outsiders hangen. Dat komt voor het ministerie en zijn klassieke bestuurstheorie goed uit. Wat wel anders had gemoeten, was een betere benutting van de vele ervaringen die zijn opgedaan in de contacten met het veld in de beschreven projecten ten behoeve van een cumulatieve ontwikkeling van de eigen bestuurstheorie: wat was daarvan te leren over de verhouding tussen bestuur en samenleving en voor het bestuursbeleid? In verschillende opzichten paste de dominante bestuurstheorie niet op de bestuurspraktijk van haar tijd. Enkele zijn te noemen:

- de karikaturale beelden van het Huis van Thorbecke (drie autonome bestuurslagen buiten de Europese Unie, democratie enkel door representatie in verkiezingen);

- $\quad$ de blinde vlek voor bedrijven, instellingen en netwerken als reële actoren in het publieke domein (zie onder meer paragraaf 5.8);

- $\quad$ de wereldvreemde (woorden van Bierman, zie paragraaf 6.10) hang naar uniformiteit en standaardisatie die ook in het internettijdperk nog werd volgehouden;

- $\quad$ het misplaatste Calimerobeeld dat BiZa de enige hoeder voor de lokale democratie zou zijn en voortdurend de vijandige en oppermachtige vakdepartementen moet bevechten;

- de rabiate afkeer van specifieke uitkeringen als bekostigingswijze en de onevenredige energie die wordt gestoken in brede doeluitkeringen (zie paragraaf 7.3 en 7.4) alsof daarmee de maatschappelijke problemen opgelost worden;

- de behoefte om als organisatie de schijn van alwetendheid op te houden, dus liever de tong af te bijten dan te vragen aan deskundigen of burgers hoe zij het zien.

Veel van deze kenmerken of attitudes leefden ook in de 'klantenkring' van het ministerie (gemeenten, provincies en vooral de Tweede Kamerleden in de Vaste Commissie Binnenlandse Zaken). Dus daarom zou het ministerie door de steven te wenden wellicht risico lopen te veel leiderschap te tonen, te ver voor de troepen uit te lopen. Dat moet dan maar als men tenminste de taakopvatting meer zoekt in het helpen oplossen van maatschappelijke problemen dan in het verdedigen van posities. Of is dat een politieke stellingname?

\section{Neigingen van bestuurders}

Leiderschap? Dat moet wel kunnen. Kan een meer pragmatisch en oplossingsgericht bestuurder zich aan de politieke druk van de mediacratie (RMO, 2003) ontworstelen? Misschien wel voor een deel, maar betekent dit dat bestuurders ook geneigd zullen zijn de weg van open probleemverkennend en onderhandelend bestuur ten volle te kiezen in plaats van shortcuts naar snelle oplossingen en het doorzetten van eigen plannen? Bestuurders moeten al een stuk bewegingsmarge claimen van de hijgerige politiek om niet als een olifant door de porseleinkast te 
gaan, maar zichzelf 'wegcijferen in maatschappelijke processen' is weer het andere uiterste. Dat zien we ook niet vaak in Nederland. Het bestuur wordt door krappere randvoorwaarden harder, sommige projecten worden met procedurele zorgvuldigheid omgeven, maar vaker is een bestuurder erop uit om belangen en perspectieven van derden over te slaan en kan hij daarmee binnen de Nederlandse bestuurscultuur vaak nog steeds wegkomen.

Als al een meer communicatieve houding op langere termijn loont in termen van vertrouwen en constructieve inzet van de kant van burgers, weegt dit nog niet op tegen de voordelen van kortetermijngewin. Dat de afhankelijkheid van derden tot cocreatie zou dwingen is nog niet aangetoond. Wie nog het meeste aanvechting tonen tot een andere aanpak zijn de ambtenaren. De meeste innovaties in de richting van procesmanagement en coproductie zijn door vooruitstrevende ambtenaren bedacht en uitgevoerd. Ook daar zit dus weer ruimte voor experimenterend gedrag in het stelsel. Maar mainstream wordt het pas als de politieke smaakmakers, die de meeste magneetwerking op het systeem uitoefenen, de draai gaan maken. Volgens Paul 't Hart kunnen we dat dus (voorlopig) vergeten. Als we naar andere dan nationale bestuursniveaus kijken (lokaal, provinciaal en Europees) is er meer kans, waarschijnlijk omdat de mediacratie daar minder haar stempel op het politieke domein drukt. Een andere kans op verandering is er als door bezuinigingen en saneringen de rol van de overheid geleidelijk minder sterk wordt, zodat de pretenties van bestuurscentrisme nog minder geloofwaardig worden of de samenleving in toenemende mate heeft geleerd buiten de overheid om problemen aan te pakken.

Dit type verklaringen maakt goed duidelijk dat de systeemdwang voor de gesignaleerde voorkeursopties bij Binnenlandse Zaken en anderen sterk is. Het feit dat de keuzen van de organisatie zo hardnekkig in de richting van government-denken gaan, kan niet zomaar aan de persoonlijke karakteristieken van de hoofdrolspelers worden toegeschreven. Zij hadden meestal niet veel keus.

Zolang dit duurt zullen degenen die (voor)zien dat we een shift beleven van government naar governance nog meer (dan de afgelopen veertig jaar) geduld moeten hebben en kan deze stelling nog een tijdje in de ijskast. Intussen zou de bestuurskunde zich misschien moeten bezinnen op het empirisch gehalte van haar uitspraken.

\subsubsection{Wat kan de bestuurskunde met deze uitkomsten?}

Reflectie op de government-governance these

Misschien zullen sommigen in dit boek bevestiging vinden van hun opvatting dat die governancethese sterk overtrokken is. Enkele auteurs die wel de hier gehanteerde terminologie gebruiken, kwamen al tot de conclusie dat er uiteindelijk geen sprake is van een werkelijke paradigmaverandering of shift (Zimmer, 2007; Maintz, 1999). De kenmerken van de governancebenadering worden dan geabsorbeerd in de hoofdgedachte achter government, waarbij de overheid uiteindelijk de boventoon voert. Anderen verwerpen om deze reden principieel het gemaakte onderscheid, omdat dat te veel de suggestie wekt dat de overheid een van de vele gelijkwaardige partners zou zijn in plaats van de behartiger van een hoger collectief belang. Ook zij stellen dat nieuwe configuraties tussen overheid, markt en samenleving weliswaar zichtbaar zijn, maar tegelijkertijd de rol van de overheid als waarborger van tegenwichten en van elementaire waarden onverlet laat. Een echt nieuwe bestuursleer is niet uit alle eigentijdse ontwikkelingen van individualisering en horizontalisering voortgevloeid (Fleurke et al., 2009: 133).

\section{Government-governance revisited}

Aan het eind van deze zoektocht gekomen is het goed om de relatie tussen de government- en governance-benadering in het openbaar bestuur opnieuw te bezien. De volgende inzichten dringen zich op:

- Volgens de bekende $80-20$-regel is $80 \%$ van het overheidshandelen (inclusief uitvoering) nog steeds gericht op routine en $20 \%$ behelst verkenning van nieuwe wegen. 
- Van die laatste $20 \%$ is $80 \%$ een interactieve wisselwerking met de omgeving, maar valt ook nog steeds $20 \%$ terug op de vertrouwde gezagspositie van de overheid, die op het juiste moment impasses kan doorbreken of bijeenkomsten kan convoceren.

- De hier als polaire tegenstellingen gepresenteerde werkvormen treden dus vrijwel altijd gemengd op.

- Het is waarschijnlijk dat politiek en bestuur moeite hebben met de overgang naar nieuwe vormen van werken die bij veel complexe ('moeilijke') taken nodig zijn - zie bijvoorbeeld het debacle van het megaproject de Tweede Maasvlakte toen het bij de Raad van State strandde.

- Maar uiteindelijk is de Nederlandse overheid soms ook flexibel genoeg om de draai te maken zie bijvoorbeeld ditzelfde megaproject, dat in tweede instantie op geheel andere leest werd geschoeid, waarbij met succes alle stakeholders werden opgezocht om consensus te bereiken (Wesselink, 2010).

- De hoofdreflex van het openbaar bestuur is vaak ten onrechte 'wij gaan erover, wij zijn de baas', maar het kan op enig moment onmisbaar zijn dat een dergelijk legitimerend idee wordt ingeroepen.

- Dat maakt het ongewenst om de government-modus radicaal overboord te gooien en stelt de critici die menen dat er au fond geen reden is voor een radicaal nieuwe bestuursleer in het gelijk.

- De stelling dat het vaak passender is om het politiek primaat te vervangen door politiek ultimaat (Rob, 2010), lijkt in veel gevallen recht te doen aan de reële verhoudingen, niet aan de politieke. Bij het overnemen van deze stelling zou er meer ruimte ontstaan voor een open verkennende beleidsvoorbereidingsfase.

- Er zijn individuele bestuurders met een natuurtalent voor een eigentijdse aanpak in controversiële en multi-stakeholder projecten, maar voor het systeem als geheel is diepere doordringing van de implicaties van de hedendaagse verhoudingen in de samenleving wenselijk, in termen van toerusting, openheid, flexibiliteit en communicatievormen.

- Dit begint met een goed doordachte en breed gedeelde visie op het bestuur: bestuurstheorie.

\section{Reflectie op de bestuurskunde}

Deze zoektocht betrof het vergelijken van de feitelijke gang van zaken binnen het bestuursbeleid met een breed aanvaarde stelling in de bestuurskunde. Dit blijkt nu niet te werken, omdat deze stelling grotendeels op drijfzand blijkt te zijn gefundeerd. In de eerste plaats is de politieke werkelijkheid sterker dan een idee over onvermijdelijke afhankelijkheden en onzekerheden die aanleiding geven de oplossing te zoeken in netwerkbestuur/governance. In de tweede plaats heeft dit idee ook zijn zwakheden en tegenstrijdigheden, die door weer andere (soms zelfs dezelfde) bestuurskundigen naar voren worden gebracht. Het sterkst is de stelling van (nota bene) Paul Frissen dat governance tot de duivel leidt, omdat het gebaseerd is op een onbestaanbare isomorfie tussen overheid en samenleving en omdat het uitgaat van dezelfde rationele verlichtingsidee dat alle maatschappelijke problemen uiteindelijk door kennis en interactie opgelost kunnen en moeten worden. Uiteindelijk blijft over de conclusie dat niet alleen de overheid 'een toontje lager moet zingen', maar dat dit ook en vooral voor de kennis over het openbaar bestuur geldt. Deze wetenschap heeft als geen ander te kampen met de onvolkomenheden van discoursen: men praat elkaar na, maar daarmee is het nog niet waar. De enige zekerheid die we na een lange zoektocht in handen lijken te hebben is dat vooral ons politiek systeem moeite heeft gelijke tred te houden met de mate van complexiteit waarin onze samenleving zich ontwikkelt.

Mede afgaand op de conclusie die we aan het eind van paragraaf 14.2.1 formuleerden - dat een voorwaarde voor netwerkbestuur/governance is dat de samenleving wijzer en bezonkener gaat worden - zou de bestuurskunde (die sommigen integrerende bestuurswetenschap noemen) meer kennis over de samenleving moeten omvatten. 


\section{Literatuur}

Aa, A. van der, en T. Konijn (2001), Ketens, ketenregisseurs en ketenontwikkeling: het ontwikkelen van transparante en flexibele samenwerkingsverbanden in netwerken, Lemma, Den Haag.

Aardema, H. (2002a), Doorwerking van BBI, BMC, Leusden.

Aardema, H. (2002b), Pas op voor de veertien ongewenste neveneffecten van bedrijfsmatig werken!, in: B\&G, jrg. 29, nr. 12, blz. 16-19.

Aardema, H. (2004), Verbindend leiderschap, Elsevier, Den Haag.

Aardema, H. (2005), Stille waarden, Open Universiteit/BMC, Den Haag (oratie).

Aardema, H., W. Derksen, M. Herweijer en P. de Jong (red.) (2010), Meerwaarde van de bestuurskunde, Liber Amicorum voor prof. dr. Arno F.A. Korsten, Boom Lemma, Den Haag.

Aardema, H., A. Korsten, C, Riezebos en M. van Dam (2011), De vallende wethouder - Een onderzoek naar de vertrekredenen van onvrijwillig teruggetreden wethouders in de bestuursperiode 2006-2010, BMC/Open Universiteit, Amersfoort/Heerlen.

Aarts, H.J.B. (1967), Centralization or decentralization of Population Register Systems, in: The Netherlands Conference Proceedings International Symposium on The Automation of Population Register Systems, 25-28 September, blz. 279-284.

Aarts, M. en H. te Molder (1998), Over natuur gesproken - Een discoursanalytische studie van een debat, Rathenau Instituut, Sdu, Den Haag.

Abma, K. (2012), Beoordelen van gemeenten, Wolf Legal Publishers, Oisterwijk.

Abma, T. (1996), Responsief evalueren - Discoursen, controversen en allianties in het postmoderne, Eburon, Delft.

Abma, T. en R.J. in 't Veld (red.) (2001), Handboek beleidswetenschap, Boom, Amsterdam.

Adriaansens, H.P.M. (1980), Talcott Parsons and the Conceptual dilemma, Routledge \& Kegan Paul, London.

Adviescommissie sanering planprocedures (1986), Caranavalsoptocht der planprocedures, Den Haag.

Arend, S. van der (2007), Pleitbezorgers, procesmanagers en participanten - Interactief beleid en de rolverdeling tussen overheid en burgers in de Nederlandse democratie, Eburon, Delft.

Argyris. C. \& D. Schön (1974), Theory in practice - Increasing personal effectiveness, Jossy-Bass, San Francisco.

Assche, K. van (2006), Over goede bedoelingen en hun schadelijke bijwerkingen - Essay over flexibiliteit, ruimtelijke ordening en systeemtheorie, Innovatienetwerk, Utrecht.

Axelrod, R. (1976), Structure of decision: The cognitive maps of political elites, Princeton Press, Princeton.

Bak, P. (2004), Een souverein leven - Biografie van W.F. de Gaay Fortman, Mets \& Schilt, Amsterdam.

Baumgartner, R. \& B.D. Jones (eds.) (2002), Policy Dynamics, The University of Chicago Press, Chicago. 
Beck, W. en A. de Jong (1990), Lessen voor sociale vernieuwing - Analyses van het experiment met proefgemeenten inzake gedecentraliseerd welzijnsbeleid, VUGA, Den Haag.

Bekke, A.J.G.M. (1990), De betrouwbare bureaucratie, Leiden (oratie).

Bekke, H. (2003), Duurzaamheid en dynamiek - Over het nut van het veranderen van instituties en organisaties, Leiden (afscheidscollege).

Bekke, H., J. de Vries en G. Neelen (1994), De salto mortale van het ministerie van Landbouw, Natuurbeheer en Visserij, Samsom H.D. Tjeenk Willink, Alphen aan den Rijn.

Bekker, R. (2012), Marathonlopers rond het Binnenhof, Boom Lemma, Den Haag.

Bekkers, V. (2012), Beleid in beweging, Boom Lemma, Den Haag.

Benda-Beckmann, K. von, en A.J. Hoekema (1987), Horizontaal bestuur, VUGA, Den Haag.

Benz, A., S. Lütz, U. Schimank \& G. Simonis (Hrsg.) (2007), Handbuch Governance - Theoretische Grundlagen und empirische Anwendungsfelder, VS Verlag, Wiesbaden.

Berg, H. van den (2004), Discoursanalyse, in: Kwalon, jrg. 9, nr. 2, blz. 29-39.

Bestuurskunde (2004), Themanummer over het avontuur bestuurskunde, jrg. 13, nr. 1.

Bestuurskunde (2012), Themanummer over informatie en politiek, jrg. 21, nr. 2.

Bestuurskunde (2013), Themanummer over de rol van onderzoekscommissies, jrg. 22, nr. 4.

Bestuurskunde (2014), Themanummer Deliberatie over wicked problems, jrg. 23, nr. 2.

Bevir, M. \& R.A.W. Rhodes (2006), Governance Stories, Routledge, London.

Boer, N, de, en J. van der Lans (2011), Burgerkracht - De toekomst van het sociaal beleid in Nederland, RMO, Den Haag.

Boerboom, H. en J. Nijenhuis (2013), Het BIF-stuk - Samenwerken aan een goed financieel beleid, Ministerie van Binnenlandse Zaken en Koninkrijksrelaties, Den Haag.

Boin, A., F. Hendriks en S. Zouridis, (red.) (2004), Het avontuur bestuurskunde, Themanummer bij het afscheid van redactievoorzitter prof. dr. A.F.A. Korsten, in: Bestuurskunde, jrg. 13, nr. 1, blz. 1-37.

Boogers, M. (2010), Lokale politiek in Nederland - De logica en dynamiek van plaatselijke politiek, Lemma, Den Haag.

Boogers, M. en F. Hendriks (2005), Middenbestuur in discussie - Analyse van en reflectie op de naoorlogse discussie over middenbestuur in Nederland, Universiteit van Tilburg.

Boonstra, J.J. (2000), Lopen over water - Over dynamiek van organiseren, vernieuwen en leren, Vossiuspers, Amsterdam (oratie).

Bovens, M.A.P., P. 't Hart en M.W.J. van Twist (2012), Openbaar bestuur - Beleid, organisatie en politiek, Kluwer, Alphen aan den Rijn, achtste druk.

Bovens, M.A.P., P. 't Hart, M.W.J. van Twist en U. Rosenthal (2001), Openbaar bestuur - Beleid, organisatie en politiek, Kluwer, Alphen aan den Rijn, zesde druk.

Breed, K., M. van Haeften en K. Veldhuijsen (red.) (2009), Het wegen van publieke waarden, Rob, Den Haag. 
Breeman, G.E., W.J. van Noort en M.R. Rutgers (red.) (2012), De bestuurlijke kaart van Nederland, Uitgeverij Coutinho, Bussum.

Bressers, J.Th.A. \& L.J. O'Toole (1998), The selection of policy instruments: a network-based perspective, in: Journal of Public Policy, vol. 3, nr. 3, blz. 213-239.

Bressers, J.Th.A. en M.M. Kuks (2001), Governance patronen als verbreding van het beleidbegrip, in: Beleidswetenschap, jrg. 15, nr. 1, blz. 76-103.

Bressers, J.Th.A. en P.J. Klok (2008), De inhoud van beleid, in: A. Hoogerwerf en M. Herweijer, (red.), Overheidsbeleid, Kluwer, Alphen aan den Rijn, blz. 181-204.

Breunese, J.N. (1982), Bestuurlijke organisatie: een spel zonder grenzen, in: Acta Politica, jrg. 17, nr. 3, blz. 343-367.

Breunese, J.N. (1983), Bestuurlijke organisatie: een spel zonder grenzen, in: Acta Politica, jrg. 18, nr. 4, blz. 453-468.

Breunese, J.N. en H.-A. van der Heijden (1979), Bestuurlijke reorganisatie in Nederland: een spel zonder grenzen, in: Acta Politica, jrg.14, nr. 4, blz. 509-539.

Breunese, J.N. en L.J. Roborgh (red.) (1992), Ministeries van algemeen bestuur, Spruyt, Van Mantgem \& De Does, Leiden.

Brewer, G. \& P. DeLeon (1983), The foundations of policy analysis, Dorsey Press, Homewood.

Brink, G. van den (2002), Mondiger of moeilijker: een studie naar de politieke habitus van hedendaagse burgers - Voorstudies en achtergronden, Wetenschappelijke Raad voor het Regeringsbeleid, Den Haag.

Bronneman-Helmers, R. (2013), Lessen uit het Parlementair Onderzoek Onderwijsvernieuwingen, in: Bestuurskunde, jrg. 22, nr. 4, blz. 37-46.

Bruijn, H. de, E. ten Heuvelhof en R.J. in 't Veld (2002), Procesmanagement, Academic Service, Schoonhoven.

Bruijn, H. de, E. van Bueren en F. Keiken (2012), Framing en reframing in het klimaatdebat, in: Bestuurskunde, jrg. 21, nr. 4, blz. 54-64.

Bruijn, J.A. de, P. de Jong, A.F.A. Korsten en W.P.C. van Zanten (red.) (1996), Grote projecten Besluitvorming en management, Samsom H.D. Tjeenk Willink, Alphen aan den Rijn.

Cachet, A. en E.R. Muller (1991), Beslissen over voetbalvandalisme: een permanent probleem, Gouda Quint, Arnhem.

Campbell, J.L. (2002), Institutional Analysis and the Role of Ideas in Political Economy, in: Theory and Society, jrg. 27, blz. 377-409.

Castells, M. (1996). The Rise of the Network Society - The Information Age: Economy, Society and Culture, Vol. 1, Blackwell, Cambridge/Oxford.

Commissie Toekomst Lokaal Bestuur (Commissie-Bovens) (2006), Wil tot verschil - Gemeenten in 2015, VNG, Den Haag.

Commissie-Blok (2004), Rapport Integratie Etnische Minderheden, Tweede Kamer 2003-2004, 28689.

Commissie-Bovens (2006), zie Commissie Toekomst Lokaal Bestuur.

Commissie-Docters van Leeuwen (2001), zie Eenmalige Adviescommissie ICT en Overheid. 
Commissie-Duivesteijn (2004a), Grote projecten uitvergroot - Een infrastructuur voor besluitvorming, Den Haag.

Commissie-Duivesteijn (2004b), Het project Zuiderzeelijn - Toetsing met terugwerkende kracht, Den Haag.

Commissie-Franssen (1993), Over decentralisatie is nog nooit een vers geschreven, Deelrapport van de Parlementaire Commissie Vraagpunten staatkundige vernieuwing, Tweede Kamer 21427, nrs. 42-43.

Commissie-De Grave (2005), Je gaat erover of niet, Ministerie van Binnenlandse Zaken en Koninkrijksrelaties, Den Haag.

Commissie-Geelhoed (2002), Op schaal gewogen, Interprovinciaal Overleg, Den Haag.

Commissie-Kok (2006), Advies commissie versterking Randstad, Ministerie van Binnenlandse Zaken en Koninkrijksrelaties, Den Haag.

Commissie-Kohnstamm (2004), Een herkenbare staat - Investeren in de overheid, Ministerie van Binnenlandse Zaken en Koninkrijksrelaties, Den Haag.

Commissie-Montijn (1989), Grote steden, grote kansen, Sdu, Den Haag.

Commissie-Sint (1994), Verantwoord verzelfstandigen, Ministerie van Binnenlandse Zaken, Den Haag.

Commissie-Vonhoff (1984), zie Adviescommissie sanering planprocedures.

Commissie-Wallage (2001), In dienst van de Democratie - Rapport van de Commissie Toekomst overheidscommunicatie, Ministerie van Algemene Zaken, Den Haag.

Cörvers, R.J.M., P. Glasbergen \& A.F.A. Korsten (2003), Netwerksturing bij natuurontwikkeling, in: Bestuurswetenschappen, jrg. 57, nr. 3, blz. 205-228.

Davies, B. \& R. Harré (1990), Positioning: The Social Construction of Selves, in: Journal for the Theory of Social Behaviour, vol. 20, blz. 43-63.

De Beuk Organisatieadvies (2010), De raad en burgerparticipatie - leder in zijn rol en in zijn kracht, Publicatiereeks Burgerparticipatie ministerie van Binnenlandse Zaken, Den Haag.

DeLanda, M. (2006), A New Philosophy of Society, Continuum, London.

Deleon, P. (1978). Public policy termination: An end and a beginning, in: Policy Analysis, jrg. 4, blz. 369-392.

Denters B. \& L.E. Rose (2004), Van lokale overheid tot onderdeel van het lokaal bestuur?, Serie Veranderend lokaal bestuur in vergelijkend perspectief, in: Bestuurswetenschappen, jrg. 57, nr. 4, blz. 277-294.

Denters, S.A.H. (1996), Het succes van falend beleid: Het politiek-bestuurlijk succes van gemeentelijk herindelingsbeleid, in: Bestuurswetenschappen, jrg. 50, nr. 6, blz. 439-455.

Denters, S.A.H., M.J.I. van der Haar, H.M. de Jong en R.M. Noppe (1999), Preadvies: De regiefunctie in gemeenten, Raad voor het openbaar bestuur, Den Haag.

Derksen, W. en A.F.A. Korsten (red.) (1989), Lokaal bestuur in Nederland, Samsom H.D. Tjeenk Willink, Alphen aan den Rijn.

Derksen, W., J.A. van der Drift, R. Giebels, C. Terbrack (1987), De bestuurskracht van kleine gemeenten, Onderzoekscentrum Sturing van de samenleving, Leiden. 
Dewey, J. (1927), The Public and its Problems, Holt, New York.

Dicke, W. (2000), Narratieve analyse van de watersector, in: N.J.M. Nelissen et al. (red.), Bestuurlijk vermogen, Coutinho, Bussum, blz. 77-103.

Dicke, W. (2001), Bridges \& Watersheds - A narrative analysis of watermanagement in England, Wales and the Netherlands, Aksant, Amsterdam.

Dijstelbloem, H. (2008), Politiek vernieuwen - Op zoek naar publiek in de technologische samenleving, Amsterdam, Van Gennep.

Directie Interbestuurlijke Betrekkingen en Informatievoorziening (1997), Kabinetsreactie op het advies 'Besturen op de tast' van de Raad voor het binnenlands bestuur, Ministerie van Binnenlandse Zaken en Koninkrijksrelaties, Den Haag.

Directie Interbestuurlijke Betrekkingen en Informatievoorziening (1998a), Rapportage werkgroep procesmanagement, Ministerie van Binnenlandse Zaken en Koninkrijksrelaties, Den Haag.

Directie Interbestuurlijke Betrekkingen en Informatievoorziening (1998b), De effectiviteit van het openbaar bestuur, Ministerie van Binnenlandse Zaken en Koninkrijksrelaties, Den Haag.

Dongen, H.J. van, W.A.M. Maas en A.J.J.A. de Laat (1996), Een Kwestie van verschil - Conflictbenadering en onderhandeling in een configuratieve integratietheorie, Eburon, Delft.

Doolaard, W.E. (1987), De onderhandelende gemeente, in: K. von Benda-Beckmann en A.J. Hoekema (red.), Horizontaal bestuur, VUGA, Den Haag, blz. 13-29.

Doorn, J.A.A. van (1985), Over beleidstheorieën - Een technologische en sociologische interpretatie, in: Beleid en Maatschappij, jrg. XII, nr. 5, blz. 107-116.

Douglas, M. \& A. Wildavsky (1982), Risk and Culture: An Essay on the Selection of Technical and Environmental Dangers, University of California Press, Berkeley/London.

Dror, Y. (1971), Design for policy sciences, Elsevier, New York.

Dryzek, J.S. (1997), The Politics of the Earth - Environmental Discourses, Oxford University Press, Oxford.

Duivenboden, H. van, M. van Twist, M. Veldhuizen en R. in 't Veld (red.) (2000), Ketenmanagement in de publieke sector, Lemma, Utrecht.

Dunn, W.N. (2012), Public Policy Analysis, Pearson, Boston.

Eberg, J. (1997), Waste Policy and Learning - Policy Dynamics of Waste Management and Waste Incineration in the Netherlands and Bavaria, Eburon, Delft.

Edelenbos, J., E.H. Klijn en B. Steijn (2011), Vertrouwen in governance netwerken, in: Bestuurskunde, jrg. 20, nr. 3, blz. 80-94.

Eenmalige Adviescommissie ICT en Overheid (2001), Burger en overheid in de informatiesamenleving - De noodzaak van institutionele innovatie, Ministerie van BZK, Den Haag.

Eeten, M. van (1999), Dialogues of the Deaf - Defining New Agendas for Environmental Deadlocks, Eburon, Delft.

Engels, J.W.M. en M.J. Fraanje (2013), De bestuurlijke organisatie van Nederland - Historie, grondslagen, werking en debat, Kluwer, Deventer.

Expertisegroep Architectuurstudie Modernisering GBA (2002), Architectuur GBA - Modernisering GBA, 25 september 2002 Versie 1.4 Status Definitief, via www.minbzk.nl in september 2008. 
Fischer, F. (2003), Reframing Public Policy - Discursive Politics and Deliberative Practices, Oxford University Press, Oxford.

Fischer, F. (2006), Participatory governance as deliberative empowerment - The cultural politics of discursive space, in: American Journal of Public Administration, vol. 36, nr. 1, blz. 19-40.

Fischer, F. \& J. Forester (red.) (1993), The Argumentative Turn in Policy Analysis and Planning, Duke University Press, London.

Fischer, F. \& M. Hajer (eds.) (1999), Living with Nature - Environmental Politics as Cultural Discourse, Oxford University Press, Oxford.

Fleurke, F. en F.D. Huizenga (1988), Methodische aspecten van beleidstheorie, in:

Bestuurswetenschappen, jrg. 42, nr. 7, blz. 467-486.

Fleurke, F., J. van der Schaar en F. van Wijk (2009), Ontwikkelingspaden voor woningcorporaties, RIGO Research en Advies, Amsterdam.

Fleurke, F., J.R. Hulst en P.J. de Vries (1997), Decentraliseren met beleid, Sdu, Den Haag.

Fredrickson, H.G. (2005), Whatever happened to public administration? Governance, governance, everywhere, In: E. Ferlie, L.E. Lynn jr. \& C. Pollitt (eds.), The Oxford Handbook of Public management, Oxford University Press, Toronto, blz. 282-304.

Frissen, P.H.A. (2007), De staat van verschil - Een kritiek van de gelijkheid, Van Gennep, Amsterdam.

Frissen, P.H.A. (2013), De fatale staat - Over de politiek noodzakelijke verzoening met tragiek, Van Gennep, Amsterdam.

Frouws, J. (1993), Mest en macht - Een politiek-sociologische studie naar belangenbehartiging en beleidsvorming inzake mestproblematiek in Nederland vanaf 1970, Wageningen.

Frouws, J. (1998), The Contested Redefinition of the Countryside - An Analysis of Rural Discourses in the Netherlands, in: Sociologica Ruralis, vol. 38, nr. 1, blz. 54-68.

Gee, J.P. (1999), An Introduction to Discourse Analysis - Theory and Method, Routledge, London.

Gerritsen, E. (2011), De slimme gemeente nader beschouwd, Nicis Institute/AUP, Amsterdam.

Geul, A. (2006), Pragmatisme en pragmatiek - Perspectieven op beleidsconstructie, Lemma, Utrecht.

Gladwell, M. (2000), The Tipping Point: How Little Things Can Make a Big Difference, Little Brown, New York.

Glasbergen, P. (1989), Beleidsnetwerken rond milieuproblemen - Een beschouwing over de relevantie van het denken in termen van beleidsnetwerken voor het analyseren en oplossen van milieuproblemen, VUGA, Den Haag (oratie).

Goverde, H. (2000), Waardeconflicten over rurale ontwikkeling, in: N. Nelissen et al. (red.), Bestuurlijk vermogen, Coutinho, Bussum, 2000, blz. 43-76.

Grin, J. (2004), De politiek van omwenteling met beleid, Vossiuspers UvA, Amsterdam.

Guba, E.G. \& Y.S. Lincoln (1989), Fourth generation evaluation, Sage, Newbury Park, CA.

Gunsteren, H. van (1976), The quest for control - A critique of the rational-central-rule approach in public affairs, Wiley, London. 
Gunsteren, H.R. van (1994), Culturen van besturen, Boom, Amsterdam/Meppel.

Gunsteren, H. van (2006), Vertrouwen in de democratie, Van Gennep, Amsterdam.

Gunsteren, H.R. van, en E. van Ruyven (red.) (1995), Bestuur in De Ongekende Samenleving, Sdu, Den Haag.

Habermas, J. (1989), De nieuwe onoverzichtelijkheid en andere opstellen, Boom, Meppel.

Hajer, M.A. (1989), Discourscoalities in politiek en beleid, in: Beleidswetenschap, nr. 3, blz. 242-263.

Hajer, M. (1993), Discourse Coalitions and the Institutionalization of Practice - The Case of Acid Rain in Great Britain, in: F. Fischer \& J. Forrester (eds.), The Argumentative Turn in Policy Analysis and Planning, Duke University Press, Durham, blz. 43-77.

Hajer, M.A. (1995), The politics of environmental discourse - A study of the acid rain controversy in Great Britain and the Netherlands, Oxford University Press, Oxford.

Hajer, M. (2000), Politiek als vormgeving, Vossiuspers AUP, Amsterdam (oratie).

Hajer, M. (2001), Infrastructuur als discursieve politiek: de 'Transeuropese Netwerken' nader beschouwd, in: T. Abma en R. in 't Veld (red.), Handboek beleidswetenschap, Boom, Amsterdam, blz. 382-393.

Hajer, M. (2003), Policy without Polity - Policy Analysis and the Institutional Void, in: Policy Sciences, vol. 36, nr. 3, blz. 175-195.

Hajer, M. (2005), Mijn favoriete klassieker: John Dewey, the public and its problems, 1927, in: Bestuurswetenschappen, jrg. 58, blz. 363-365.

Hajer, M.A. (2009), Authoritative Governance - Policy Making in the Age of Mediatization, Oxford University Press, Oxford.

Hajer, M. \& H. Wagenaar (eds.) (2003), Deliberative Policy Analysis - Understanding governance in the network society, Cambridge University Press, Cambridge.

Hajer, M.A. \& D. Laws (2006), Ordering through Discourse, in: M. Moran, M. Rein \& R.E. Goodin (eds.), The Oxford Handbook of Public Policy, Oxford University Press, Oxford, blz. 251-269.

Hajer, M. \& J. Uitermark (2007), Performing Authority: Discursive politics after the assassination of Theo van Gogh, in: Public Administration, vol. 86, nr. 1, blz. 5-19.

Hall, P. (1993), Policy paradigms, social learning and the state - The case of economic policylearning in Great Britain, in: Comparative Politics, vol. 25, nr. 3, blz. 275-296.

Hart, P 't, P. de Jong en A.F.A. Korsten (red.) (1991), Groepsdenken in het openbaar bestuur Cruciale beslissingen in kleine groepen, Samsom, Alphen aan den Rijn.

Hart, P. 't, en M. van der Steen (2012), Politiek-ambtelijke verhoudingen in de 2.0-wereld - Nieuwe uitdagingen en overzeese lessen (Van Slingelandtlezing 2011), in: Bestuurskunde, jrg. 21, blz. 71 82.

Hartman, C. en P. Tops (2005), Frontlijnsturing - Uitvoering op de publieke werkvloer van de stad, Kenniscentrum Grote Steden, Den Haag.

Havermans, A.J.E. (1984), Artikel 12-gemeenten, VUGA, Den Haag. 
Heffen, O. van (2003), Beleidstheorieën uit de beleidspraktijk, in: A. Hoogerwerf en M. Herweijer, (red.), Overheidsbeleid: een inleiding in de beleidswetenschap, Kluwer, Alphen aan den Rijn, blz. 225-239.

Heffen, O. van, P.J. Klok en M.S. de Vries (red.) (1996), Culturele dynamiek en beleidsontwikkeling in Nederland, Van Gorcum, Assen.

Heijden, G.M.A. van der, en J. Schrijver (red.) (2002), Representatie en participatie - Dubbele democratie, Eburon, Delft.

Heijden, G.M.A. van der (red.) (2005), Recombinaties van samenleving en bestuur - Denken over innovatieve beleidsvorming, Eburon, Delft.

Heijden, H. van der, et al. (red.) (1985), Succes- en faalfactoren bij bestuurlijke reorganisaties, Wolters-Noordhoff, Groningen.

Heijden, H.-A. van der (1990), Tussen wetenschap en politiek - Een verkenning van vertoogtheorie en politicologische paradigma's en een vertoogtheoretisch-politicologische analyse van bestuurlijke reorganisatie en ruimtelijke planning in Nederland 1973-1989, Mondiss, Kampen.

Hendriks, F. (2006), Vitale democratie - Theorie van democratie in actie, Amsterdam University Press, Amsterdam.

Hendriks, F. en G. Drosterij (red.) (2012), De zucht naar goed bestuur in de stad - Lessen uit een weerbarstige werkelijkheid, Boom Lemma, Den Haag.

Hendriks, F. \& Th. A.J. Toonen (eds.) (2001), Polder politics, Ashgate, Aldershot.

Hisschemöller, M. (1993), De democratie van problemen, VU Pers, Amsterdam.

Hoekema, A.J., N.F. van Manen, G.M.A. van der Heijden, I.C. van der Vlies en B. de Vroom (red.) (1998), Integraal bestuur - De behoorlijkheid, effectiviteit en legitimiteit van onderhandelend bestuur, VUGA, Den Haag.

Hoetjes, B.J.S. (1993), Landbouw, natuurbeheer en visserij - Profiel van een ministerie, VUGA, Den Haag.

Hoetjes, B.J.S. (2004), De grenzen van de Nederlandse overheid - een politieke en bestuurlijke beschouwing, Haagse Hogeschool, Den Haag (intreerede).

Hogwood, B. \& B.G. Peters (1983), Policy Dynamics, Wheatsheaf Books, Brighton.

Hommes, D.W. (1994), Sociale vernieuwing - Opkomst en ondergang van een politiek motto van het kabinet-Lubbers-Kok, Uitgeverij SWP, Utrecht.

Hoogerwerf, A. (1976), Een regeringsnota in een beleidsproces: mobilisatie van steun?, in: Beleid en Maatschappij, jrg. 3, nr. 2, blz. 73-82.

Hoogerwerf, A. (1977), De groei van de overheid in Nederland sinds 1900, in:

Bestuurswetenschappen, juli/aug., blz. 243-265.

Hoogerwerf, A. (1984), Beleid berust op veronderstellingen: de beleidstheorie, in: Acta Politica, okt., blz. 493-532.

Hoogerwerf, A. (1986), Vanaf de top gezien, Bert Bakker, Amsterdam.

Hoogerwerf, A. (1987), Het ontwerpen van overheidsbeleid, in: P.B. Lehning en J.B.D. Simonis (red.), Handboek beleidswetenschap, Boom, Meppel, blz. 54-68. 
Hoogerwerf, A. (1987a), Beleid berust op veronderstellingen: de beleidstheorie, in: P. Lehning en J. Simonis (red.), Handboek beleidswetenschap, Boom, Meppel, blz. 23-40.

Hoogerwerf, A. (1989), De beleidstheorie uit de beleidspraktijk: een tussenbalans, in: Beleidswetenschap, jrg. 3, nr. 4, blz. 320-342.

Hoogerwerf, A. (1993), Een kwart eeuw beleidswetenschap: ontwikkeling, stand van zaken en uitdagingen, in: Beleidswetenschap, nr. 3, blz. 215-238.

Hoogerwerf, A. (1999), Het eerste kabinet-Kok beoordeeld vanuit de eigen doeleinden, in: Beleidswetenschap, nr. 1, blz. 3-26.

Hoogerwerf, A. en M. Herweijer (red.) (2003), Overheidsbeleid, Samsom, Alphen aan den Rijn, 2003 (zevende druk).

Hoppe, R. (1988), Voor moed, beleid en ... betrouwbare beleidstheorie?, in: Beleid en Maatschappij, jrg. 15, nr. 1, blz. 55-65.

Hoppe, R. (1989), Het beleidsprobleem geproblematiseerd, Uitgeverij Coutinho, Bussum (oratie).

Hoppe, R. (1996), Omgaan met ongestructureerde problemen in beleid en bestuur, in: A. Ringeling, H. Berg, A. Korsten et al. (red.), Strategie en beleid in de publieke sector, Samsom H.D. Tjeenk Willink, mei, zevende aanvulling D1300.

Hoppe, R. (1998), De broosheid van debat en argumentatieve beleidsanalyse, UTwente, Enschede (oratie).

Hoppe, R. (2010), From 'knowledge use' to 'boundary work': sketch of an emerging new research programme for science/policy interactions, in: R.J. in 't Veld (ed.), Knowledge Democracy Consequences for Science, Politics and Media, Springer, Heidelberg, blz. 169-186.

Hoppe, R. (2010/11), Institutional constraints and practical problems in deliberative and participatory policy making, in: Policy \& Politics, Vol. 39, nr. 2, blz. 163-183.

Hoppe, R. (2011), The Governance of Problems - Puzzling, Powering, Participation, Policy Press, Bristol/Portland.

Hoppe, R. (2012). Waarom uitvechten uitdenken overtroeft, in: Bestuurskunde, nr. 2, blz. 7-17.

Hoppe, R. en A. Peterse, (red.) (1998), Bouwstenen voor argumentatieve beleidsanalyse, Elsevier, Den Haag.

Hoppe, R., M. Jeliazkova, H. van de Graaf en J. Grin (1998), Beleidsnota's die (door)werken, Uitgeverij Coutinho, Bussum.

Hoppe, R., T. Hoppe, J. Woldendorp \& N.C. Bandelow (2011), The Netherlands, in: Bertelsmann Stiftung (ed)., Sustainable Governance Indicators 2011 - Policy Performance and Governance Capacities in the OECD, Verlag Bertelsmann Stiftung, Gütersloh, blz. 219-221.

Hoven J. van den, en A. van de Bogaard (2006), Waardengevoelig ontwerp en de automatiserende overheid - Het voorbeeld van identiteitsinfrastructuur, TU Delft, Delft.

Idenburg, Ph.A. (1999), Het gaat om mensen - Excellente veranderaars in organisaties, Balans, Amsterdam.

IJsselmuiden, P.G. van (1988), Binnenlandse Zaken en het ontstaan van de moderne bureaucratie in Nederland 1813-1940, J.H. Kok, Kampen.

Instituut voor Bestuurswetenschappen (1972-1975), Onderzoek naar de bestuurlijke organisatie. 2 Volumes, Staatsuitgeverij, Den Haag. 
Jeekel, H. (1998), Duizend dagen kamervragen, Sdu, Den Haag.

Kettl, D.F. (2002), The Transformation of Governance: Public administration for the twenty-first century America, Johns Hopkins University Press, Baltimore/London.

Kickert, W.J.M. (1979), Fuzzy theories on decision-making: a critical review, Martinus Nijhoff Social Sciences Division, Leiden.

Kickert, W.J.M. (1993), Complexity, Governance and Dynamics - Conceptual Explorations of Public Network Management, in: J. Kooiman (ed.), Modern Governance, Sage, London, blz. 191-204.

Kickert, W.J.M. (1993a), Overheidssturing, in: W.J.M. Kickert (red.), Veranderingen in management en organisatie bij de rijksoverheid, Samsom H.D. Tjeenk Willink, Alphen aan den Rijn, blz. 49-64.

Kickert, W.J.M. (2004), History of Governance in the Netherlands - Continuity and exceptions, Reed Elsevier, Den Haag.

Kickert, W.J.M. (2005), Lessen uit het verleden - Onderzoek naar veranderoperaties bij de overheid, Programma Andere Overheid, Ministerie van BZK, Den Haag.

Kickert, W.J.M. (2008), The Study of Public Management in Europe and the United States - A Comparative Analysis of National Distinctiveness, in: Der moderne Staat - Zeitschrift für Public Policy, Recht und Management, Heft 1, blz. 221-234.

Kickert, W.J.M. en F.B.L. van der Meer (2007), Laat duizend bloemen bloeien - Hoe gaat het ministerie van $L N V$ om met externe veranderingen: verschillende beelden en meningen, Reed Elsevier, Den Haag.

Kickert, W.J.M., E.H. Klijn \& J.F.M. Koppenjan (1997), Managing Complex Networks, Sage, London.

Kickert, W.J.M., H.J. Aquina en A.F.A. Korsten (red.) (1985), Planning binnen perken - Nieuwe zienswijzen op planning in het openbaar bestuur, Kerckebosch, Zeist.

Kiel, L.D. (1994), Managing chaos and complexity in government - A new paradigm for managing change, innovation, and organisational renewal, Jossey-Bass, San Francisco.

Kingdon, J. (1995), Agendas, alternatives and public policies, Harper Collins, New York.

Kjaer, A.M. (2004), Governance, Cambridge University Press, Cambridge.

Kleistra, Y. (2002), Hollen of stilstaan - Beleidsveranderingen bij het Nederlands ministerie van Buitenlandse Zaken, Eburon, Delft.

Klinkers, L. (2000), Beleid begint bij de samenleving - Een zoektocht naar de menselijke maat, Over de essentie van interactief beleid maken, Lemma, Utrecht.

Knaap, P. van der, A. Korsten, K. Termeer en M. van Twist (red.) (2004), Trajectmanagement Beschouwingen over beleidsdynamiek en organisatieverandering, Lemma, Utrecht.

Koffijberg, J. (2005), Getijden van beleid. Omslagpunten in de volkshuisvesting - Over de rol van hiërarchie en netwerken bij grote veranderingen, Delft University Press, Delft.

Kooiman, J. (ed.) (1993), Modern governance - New government - Society Interactions, Sage, London.

Kooistra, R. (2009), De rijksdienst is nooit af, in: SER-magazine, januari 2009. 
Koopmans, R. (2009). Multicultureel beleid in Nederland: voer voor historici of actualiteit? in: Beleid en Maatschappij, jrg. 36, nr.1, blz. 59-71.

Koppenjan, J.F.M. (1993), Management van de beleidsvorming - Een studie naar de totstandkoming van beleid op het terrein van het binnenlands bestuur, EUR, Rotterdam.

Koppenjan, J.F.M. en J.F. Zaaijer (1997), Beslissen over de Rotterdamse stadsprovincie - Wie leidt de dans rond de 'garbage can'?, in: Bestuurskunde, jrg. 6, nr. 5, blz. 213-221.

Korsten, A.F.A. (1979), Het spraakmakende bestuur - Een studie naar effecten van participatie in relatie tot demokratiemodellen en sociale ongelijkheid, VUGA, Den Haag.

Korsten, A.F.A. (1985), Uitvoeringsgericht ontwerpen van overheidsbeleid, in: Bestuur, nr. 8, blz. 12-20.

Korsten, A.F.A. (1988), Bestuurskunde als avontuur, Kluwer, Deventer.

Korsten, A.F.A. (1992), Geschiedenis van de bestuurskunde, in: http://www.arnokorsten.nl/PDF/ Bestuurskunde/Geschiedenis\%20van\%20de\%20bestuurskunde.pdf, geraadpleegd 27 januari 2014.

Korsten, A.F.A. (1993), Beëindiging van beleid, in: A. Hoogerwerf (red.), Overheidsbeleid, Samsom, Alphen aan den Rijn.

Korsten, A.F.A. (2004), Dynamisch bestuur, in: P. van der Knaap et al. (red.), Trajectmanagement Beschouwingen over beleidsdynamiek en organisatieverandering, Lemma, Den Haag, blz. 231-251.

Korsten, A.F.A. (2005), Grote Klasse! - Op zoek naar excellente ambtenaren en leiderschap, Beljon + Westerterp/Open Universiteit, Heerlen.

Korsten, A.F.A. (2008a), Discoursanalyse: Beleid als ideeënpolitiek en discoursanalyse als hulpmiddel voor het begrijpen van controverses, de beleidsinhoud en beleidsverschuivingen, in: http://www.arnokorsten.nl/PDF/Beleid\%20veranderen\%20of\%20stoppen/Discoursanalyse.pdf, geraadpleegd 15 januari 2014.

Korsten, A.F.A. (2008b), Change that's what we want - Beschouwing over beleidsdynamiek en beleidsbeëindiging, in: http://www.arnokorsten.nl/PDF/Beleid\%20veranderen\%20of\%20stoppen/ beleid\%20veranderen\%20of\%20stoppen.pdf, geraadpleegd 15 januari 2014.

Korsten, A.F.A (2010), Deugdelijk bestuur, Open Universiteit, Heerlen (afscheidsrede).

Korsten, A.F.A. (2012), Een halve eeuw lokaal bestuur, op: www.arnokorsten.nl/downloads.html.

Korsten, A.F.A. (2013), Wat evaluatoren van kritiek kunnen leren, in: Beleidsonderzoek online, http://www.beleidsonderzoekonline.nl/tijdschrift/bso/2013/12/Beleidsonderzoek-D-12-00030, geraadpleegd 15 januari 2014.

Korsten, A.F.A. en Th.A.J. Toonen, (red.) (1988), Bestuurskunde: hoofdfiguren en kernthema's, Stenfert Kroese, Leiden.

Korsten, A.F.A. en A. Ringeling (1993), Beleidsbeëindiging en strategische beleidsverandering, in: Berg, A., e.a., (red.), Handboek strategie en beleid in de publieke sector, Samsom, Alphen aan den Rijn, blz. 1-25.

Korsten, A.F.A. en P.W. Tops, (red.) (1998), Lokaal bestuur in Nederland, Samsom, Alphen aan den Rijn.

Korsten, A., J.H.H. Lucassen en S. van der Schaaf (2000), Single Audit! - Het einde van de specifieke accountantsverklaring?, in: B\&G, jrg. 27, nr. 4, blz. 31-33. 
Korsten, A.F.A. en G. Leers (2005). Inspirerend leiderschap in de risicomaatschappij, Lemma, Den Haag.

Korsten, A.F.A. en P. de Goede (red.) (2006), Bouwen aan vertrouwen in het openbaar bestuur, Elsevier, Den Haag.

Korsten, A.F.A. en R. Hoppe (2006), Van beleidswetenschap naar kennissamenleving - Voortgang, vooruitgang en achteruitgang in de beleidswetenschap, in: Beleidswetenschap, jrg. 30, nr. 4, blz. 34-72.

Korsten, A.F.A., K. Abma en J.M.L.R. Schutgens (2007), Bestuurskracht van gemeenten, Eburon, Delft.

Korsten, A.F.A., P. de Jong en C.J.M. Breed (2010), Regeren met programma's Interdepartementale kabinetsprogramma's van het kabinet-Balkenende IV: voortgang en samenwerking, Boom Lemma, Den Haag.

Korsten, A.F.A., M. Schoenmaker, H. Bouwmans en A. Resoort (2012), Onder burgemeesters Finesses van het burgemeesterschap, Boom Lemma, Den Haag.

Krapels, J.T.W. (1978), De coördinerende rol van het ministerie van binnenlandse zaken, Bestuurswetenschappen, nr. 6, blz. 429-442.

Krapels, J.T.W. (1992), Openbaar besturen pragmatisch-analytisch benaderd, dissertatie, Laren.

Kreitner, R. \& A. Kinicky (2008), Organizational behavior, McGraw Hill//rwin, New York.

Kroon, O. (1994), Ministerie in crisis - Over visfraude, milieubehoud en boerenbelang, Uitgeverij L.J. Veen, Amsterdam.

Kroonenburg, J.G.P.M. van, J.P.A. Pouwels, A.F.A. Korsten, J.A. Kropman, D.J. van Houten, A.M.J. Kreukels et al. (1981), Provinciale beleidsplanning, ITS/Vakgroep Planning en Beleid, Utrecht/ Nijmegen.

Kruiter, A.J., J. de Jong, C. Hijzen en J.Taal (2008), RU Experienced, Leren van experimenten in het openbaar bestuur, InAxis, Den Haag.

Kuik, F. van (1986), Zeven jaar Minderhedenbeleid, in: Bestuur, jrg. 4, blz. 118-123.

Kuhlmann, S. \& H. Wollmann (2014), Introduction to Comparative Public Administration Administrative Systems and Reforms in Europe, Edward Elgar, London.

Kuks, S.M.M. (2004), Water governance and institutional change, Universiteit Twente, Enschede.

Kuypers, G. (1981), Beginselen van beleidsontwikkeling, Uitgeverij Coutinho, Muiderberg.

Lasswell, H.D. (1971), A pre-view of policy sciences, American Elsevier, New York.

Latesteijn, H.C. van (2001), Hoe inspiratie georganiseerd kan worden - De Zuidvleugel van de Randstad: instituties en discoursen, in: Stuurgroep toekomstonderzoek en strategisch omgevingsbeleid, Handorakel voor toekomstonderzoek, Lemma, Utrecht, blz. 61-69.

Laws, D. \& M. Rein (2003), Reframing practice, in: M. Hajer \& H. Wagenaar (eds.), Deliberative policy Analysis - Understanding Governance in the Network Society, Cambridge University Press, Cambridge, blz.172-209.

Laws, D., H. Wagenaar, G.M.A. van der Heijden, A. Kramer en D. Hogendoorn (2012), Publieke Beleidsbemiddeling, Amsterdams Centrum voor Conflictstudies/Ministerie van Binnenlandse Zaken, Amsterdam/Den Haag. 
Lemstra, W., C.J.N.Versteden en W.J. Kuijken (red.) (1996), Handboek voor

Overheidsmanagement, Samson H.D. Tjeenk Willink, Alphen aan den Rijn.

Liempt, A. van, en G. van Westing (2000), Klem in de draaideur - Arthur Docters van Leeuwen en het ministerie van Justitie 1995-1998, Balans, Amsterdam.

Lindblom, C.E. \& D.K. Cohen (1979), Usuable knowledge, social science and social problem solving, Yale University Press, New Haven/London.

Logister, L. (2005), John Dewey - Een inleiding tot zijn filosofie, Uitgeverij DAMON, Budel.

Luhmann, N. (1995), Social systems, Stanford University Press, Stanford.

Lulofs, K., H. Bressers en A. Boeren (2005), Schokgolven in het openbaar bestuur na 'Enschede', Lemma, Utrecht.

March, J.G. \& J.P. Olsen (1995), Democratic Governance, Free Press, New York.

Mastenbroek, W. (1996), Conflicthantering en organisatieontwikkeling - Verandermanagement door betere sturing en meer zelforganisatie, Kluwer/Samsom, Alphen aan den Rijn.

Mayntz, R. (1999), Nieuwe uitdagingen voor de governance theory, in: Beleid en Maatschappij, jrg. 26, nr. 1, blz. 2-12.

Meer, F.M. van der, en E.J.T. van den Berg (1992), Het ministerie van Binnenlandse Zaken, in: J.N. Breunese en L.J. Roborgh (red.), Ministeries van algemeen bestuur, Spruyt, Van Mantgem \& De Does, Leiden, blz. 155-167.

Meuleman, L. (2008), Public management and the metagovernance of hierarchies, networks and markets - The feasibility of designing and managing governance style combinations, PhysicaVerlag, Heidelberg.

Mierlo, J.G.A. van (red.) (1988), Pressiegroepen in de Nederlandse politiek, Hooiberg, Epe, Stichting maatschappij en onderneming.

Ministerie van Binnenlandse Zaken en Koninkrijksaangelegenheden (2004), leder zijn rol - Een heroriëntatie op de interbestuurlijke verhoudingen. Gespreksnotitie met daarin de kabinetsvisie op de interbestuurlijke verhoudingen tussen rijk en lagere overheden, Den Haag.

Ministerie van Binnenlandse Zaken en Koninkrijksrelaties (2006), Scenario's gemeentelijk belastinggebied in relatie tot de bestuurlijke verhoudingen, TK 2006-2007, 30096, nr. 26, Den Haag.

Ministerie van Binnenlandse Zaken en Koninkrijksrelaties (2010), De Staat van het bestuur 2010, Ministerie van BZK, Den Haag.

Ministerie van Binnenlandse Zaken en Koninkrijksrelaties, IPO en VNG (2005), Code Interbestuurlijke Verhoudingen, Den Haag.

Monster J. en J. Schrijver (2005), Interactieve beleidsvorming, een naschrift, in: Bestuurskunde, jrg. 14, nr. 2, blz. 11-20.

Montfort, C. van (2004), Ruimte voor Goed Bestuur. Tussen prestatie, proces en principe - Essay ten behoeve van rapport Bewijzen van Goede Dienstverlening, webpublicatie, WRR, Den Haag.

Montfort, C. van, en G. Enthoven (2012), Thema Informatie en Politiek, in: Bestuurskunde, jrg. 21, nr. 2, blz. 2-49.

Moran, M., M. Rein \& R.E. Goodin (eds.) (2008), The Oxford Handbook of Public Policy, Oxford University Press, Oxford. 
Muijen, M.L. van, en J. A. Wolthuis (2006), De code interbestuurlijke verhoudingen - Impuls voor good governance van rijk, provincies en gemeenten, Mediawerf Uitgevers, Amsterdam.

Nelissen, N.J.M., T.Ikink en A.W. van de Ven (red.) (1996), In staat van vernieuwing Maatschappelijke vernieuwingsprocessen in veelvoud, Coutinho, Bussum.

Nelissen, N.J.M., P. de Goede en M.J.W. van Twist (2004), Oog voor openbaar bestuur - Een beknopte geschiedenis van de bestuurskunde, Elsevier, Den Haag.

Nieuwenkamp, R. (2013), Schaduwpolitici, bontkragen en blokkendozen - Een onderzoek naar de politiek-ambtelijke verhoudingen in Nederland, CAOP, Den Haag.

Noordegraaf, M. (1993), Bestuursraad op BiZa, SZW en O\&W, in: Kickert, W.J.M. (red.), Veranderingen in management en organisatie bij de rijksoverheid, Samsom H.D. Tjeenk Willink, Alphen aan den Rijn, blz. 151-167.

Noordegraaf, M. (1999), Zinloze wanorde - Publiek management te midden van ambiguïteit, in: Bestuurskunde, jrg. 8, nr. 7, blz. 300-310.

Noordegraaf, M. (2000), Attention! Work and Behavior of Public Managers amidst Ambiguity, Eburon, Delft.

Noordegraaf, M. en W.J.M. Kickert (1993), Binnenlands bestuur in beweging, in: Kickert, W.J.M. (red.), Veranderingen in management en organisatie bij de rijksoverheid, Samsom H.D. Tjeenk Willink, Alphen aan den Rijn, blz. 105-119.

Noordegraaf, M., K. Peters en B.C. de Wit (2005), Reflectie als reflex - Denker in publieke dienst: Herman Tjeenk Willink, in: Bestuurskunde, jrg. 14, nr. 7-8, blz. 56-67.

Noordegraaf, M., K. Geuijen en A. Meijer (red.) (2011), Handboek publiek management, Boom Lemma, Den Haag.

Osch, H. van (2010), Bram Peper - Man van contrasten, Boom, Amsterdam.

Parsons, W. (1995), Public Policy, Edward Elgar, Aldershot.

Pauka, T. (2001), Verslag 1e fase project 'Ministeriële verantwoordelijkheid en ambtelijke professie', Ministerie van Binnenlandse Zaken, Den Haag.

Pennen, A.W. van der, en E. ter Borg (1996), Welzijn en sociale vernieuwing - Een onderzoek naar de bijdrage van het lokale welzijns- en sociale vernieuwingsbeleid aan achterstandsbestrijding, SCP/VUGA, Rijswijk/Den Haag.

Pennen, A.W. van der, V. Veldheer, E. ter Borg en M. Kunst (1998), Sociale Vernieuwing - Van plan naar praktijk, SCP, Den Haag.

Penninx, R. (1979), Naar een algemeen etnisch minderhedenbeleid? Wetenschappelijke Raad voor het Regeringsbeleid, deel B van rapport 17, Den Haag.

Peper, B. (1999), Op zoek naar samenhang en richting, NRC, 12 juli 1999.

Pestman, P.K. (2001), In het spoor van de Betuwelijn, Rosenberg Publishers, Amsterdam.

Peters, K. (1999), Verdeelde macht - Een onderzoek naar invloed op rijksbesluitvorming in Nederland, Boom, Amsterdam.

PIVOT 113 (2003), Coördinatie integratiebeleid minderheden - Institutioneel onderzoek naar het taakveld van de Directie Coördinatie Integratiebeleid Minderheden 1978-1999 (samenstelling: drs. C.R. van Troost, ISBN 90-5909-036-5), 's-Gravenhage. 
PIVOT 143 (2003), Organisatie Rijksoverheid - Institutioneel onderzoek naar het beleidsterrein organisatie van de rijksoverheid 1945-1999 (samenstelling: Petra Honnef, Mathilde Kors, Paul Spierenburg, Hanno de Vries), 's-Gravenhage, niet in druk verschenen.

PIVOT 92 (2003), Overheidsinformatievoorziening - Een institutioneel onderzoek naar het handelen van de overheidsorganen op het beleidsterrein overheidsinformatievoorzieningen, 1945-1999 (samenstelling: P. Fijnheer, ISBN 90-5909-035-7), 's-Gravenhage.

Plaat, A., G. van Os en M. Noordegraaf (red.) (2012), Rijk met wetenschap, Boom Lemma, Den Haag.

Poorthuis, A.M. (2003), Ketens en netwerken, Een zoektocht naar samenhang, Lemma, Den Haag.

Pouw, R. (1999), 50 jaar nationaal sportbeleid - Van vorming buiten schoolverband tot sociale vernieuwing, Universiteit van Tilburg, Tilburg.

Pree, J.C.I. de (1997), Grenzen aan verandering: de verhouding tussen reorganisatie en structuurprincipes van het binnenlands bestuur, WRR, Den Haag (dissertatie).

Price Waterhouse Coopers (2012), De Agile Overheid, Visiedocument over de transformatie naar de overheid van de toekomst, Den Haag.

Pröpper, I. en H. Kessens (2005), Tussen pluche en politiek - Lokale politiek in de praktijk, Coutinho, Bussum.

Publieke Zaak, de (2007), 21minuten.nl, editie 2007, http://www.21minuten.nl/21minuten/images/ 21minuten_2007_rapport.pdf.

Putten, J. van (1980), Haagse machten - Verslag van een politicologisch onderzoek naar de totstandkoming van acht regeringsmaatregelen, Sdu, Den Haag.

Putten, N. van (2006), Terug naar de stad - Kleine geschiedenis van het grotestedenbeleid, Ministerie van Binnenlandse Zaken en Koninkrijksrelaties, Den Haag.

QANU (2005), Rapportage van de Visitatie Nederlandse bestuurskunde-opleidingen o.I.v. prof. R. Maes, www.qanu.nl.

Raad voor de Territoriale Decentralisatie (1979), Reorganisatie van het binnenlands bestuur (advies), RTD, Den Haag.

Raad voor het binnenlands bestuur (1984), De D'trein ontspoord - Brochure over het decentralisatiebeleid, RBB, Den Haag.

Raad voor het binnenlands bestuur (1987), Advies over decentralisatie, Den Haag.

Raad voor het binnenlands bestuur (1988), Medebewind van autonome waarde, Tweede advies over decentralisatie, Den Haag.

Raad voor het binnenlands bestuur (1991), Bestuur in stadsgewesten, Afrondend advies over bestuur in grootstedelijke gebieden, Den Haag.

Raad voor het binnenlands bestuur (1996), Besturen op de tast, advies + kabinetsreactie, TK 1997, 25665, nr. 1.

Raad voor het openbaar bestuur (2000), Bestuurlijke samenwerking en democratische controle, Rob, Den Haag. 
Raad voor het openbaar bestuur (2003), Trias Informatica - ICT en overheid in vogelvlucht, Rob, Den Haag.

Raad voor het openbaar bestuur (2003a), Politiek en media - Pleidooi voor een LAT-relatie, Rob, Den Haag.

Raad voor het openbaar bestuur (2004), Cultuur met een FORS postuur - rijksdienst tussen rechtsstaat en flexibiliteit, Rob, Den Haag.

Raad voor het openbaar bestuur (2006), Bestuur op maat - Advies over middenbestuur, Rob, Den Haag.

Raad voor het openbaar bestuur (2008), Bestuur over grenzen - Opgave voor alle bestuurslagen, Rob, Den Haag.

Raad voor het openbaar bestuur (2009), Slagvaardig bestuur - Advies over integraliteit en vertrouwen in het openbaar bestuur, Rob, Den Haag.

Raad voor het openbaar bestuur (2010), Vertrouwen in Democratie, Rob, Den Haag.

Raad voor Maatschappelijke Ontwikkeling RMO (2002), Bevrijdende Kaders - Sturen op verantwoordelijkheid, RMO, Den Haag.

Raad voor Maatschappelijke Ontwikkeling RMO (2003), Medialogica, RMO, Den Haag.

Rathenau Instituut (2001), Hoe oordelen we over de veehouderij?, Den Haag.

Rhodes, R.A.W. (1997), Understanding governance: policy networks, governance and accountability, Open University Press, Buckingham.

Rijnja, G. en R. van der Jagt (2004), Storytelling - De kracht van verhalen in communicatie, Communicatie dossier nr. 24, Kluwer, Deventer.

Ringeling, A.B. (1975), Reorganisatie van het binnenlands bestuur, in: Beleid en Maatschappij, jrg. 2, nr. 10, blz. 283-288.

Ringeling, A.B. (1993), Het imago van de overheid, VUGA, Den Haag.

Roe, E. (1994), Narrative policy analysis, Duke University Press, Durham.

Roost, M.A.R. van, en H. Verheul (2002), Mobiliteit in beleid - Oorzaken van de paradigmawisseling in het verkeers- en vervoersbeleid, in: Bestuurswetenschappen, jrg. 55, nr. 1 , blz. 31-45.

Rosenthal, U, A.B. Ringeling, P. 't Hart en M.W.J. van Twist (1996), Openbaar bestuur, Samsom H.D. Tjeenk Willink, Alphen aan den Rijn (vijfde druk).

Ruiter, D.W.P. (1975), Gewest en territoriale decentralisatie, Samsom, Alphen aan den Rijn.

Ruiter, D.W.P. (1976), Reorganisatie van het binnenlands bestuur - Een overzicht van de ontwikkelingen sinds 1975, in: Acta Politica, jrg.11, nr. 3, blz. 365-382.

Ruller, H. van, en J.F. Schrijver (1986), Decentralisatie als onderdeel van de grote operaties, in: F.K.M. van Nispen en D.P. Noordhoek (red.), De grote operaties - De overheid onder het mes of het snijden in eigen vlees, Kluwer, Deventer, blz. 113-140.

Sabatier, P.A. \& H.C Jenkins-Smith (1999), The advocacy-coalition-framework, in: Sabatier, P. (ed.), Theories of the policy process, Westview Press, Boulder, blz. 117-168. 
Salamon, L. (ed.) (2002), The Tools of Government - A Guide to the New Governance, Johns Hopkins University Press, New York.

Scharpf, F.W. (1997), Games real actors play: Actor-centered institutionalism in policy research. Westview Press, Boulder.

Scholten, P. en A. Timmermans (2004), Doorbraken en zachte landingen in het Nederlands immigrantenbeleid - Een theoretische analyse van beleidsdynamiek, in: Beleidswetenschap, jrg. 18, nr. 1, blz. 3-30.

Schein, E.H. (2006), De bedrijfscultuur als ziel van de onderneming - Zin en onzin over cultuurverandering, Scriptum, Rotterdam.

Schön, D. \& M. Rein (1994), Frame reflection - Towards the resolution of intractable policy controversies, Basic Books, New York.

Schrijver, J.F. (1983), Je geld en je leven (financiën en decentralisatie), In:

Bestuurswetenschappen, jrg. 37, blz. 379-392.

Schrijver, J.F. (1984), Decentralisatie in het netwerk gevangen?, in: A.J.G.M. Bekke en U. Rosenthal (red.), Netwerken rond het openbaar bestuur, Geschriften van de Vereniging voor Bestuurskunde, Alphen aan den Rijn, blz. 38-62.

Schrijver, J.F. (1985), De andere helft van het Rijk, een organisatorische dwarsdoorsnede door de rijksoverheid? gedeconcentreerde rijksdiensten, in: Bestuur, jrg. 4, nr. 7, blz. 2-8.

Schrijver, J.F. (1987), Calculaties bij decentralisatie, in: Tijdschrift voor Openbaar Bestuur, jrg. 13, nr. 3, blz. 63-67.

Schrijver, J.F. (1989), Decentralisatie en differentiëring van taken, in: W. Derksen en A.F.A. Korsten (red.), Lokaal bestuur in Nederland - Inleiding in de gemeentekunde, Samsom H.D. Tjeenk Willink, Alphen aan den Rijn, blz. 384-396.

Schrijver, J. (1990), Nieuwe taken voor de gemeenten - Het decentralisatiebeleid belicht, Stichting Burgerschapskunde, Leiden.

Schrijver, J. (1992), Het D'project, regie van het toeval, in: Openbaar Bestuur, jrg. 2, nr. 3, blz. 2-7.

Schrijver, J. (1996), Relaties tussen overheden, in: W. Lemstra, C.J.N.Versteden en W.J. Kuijken (red.), Handboek voor Overheidsmanagement, Samsom H.D. Tjeenk Willink, Alphen aan den Rijn, blz. 321-364.

Schrijver, J. (1998), Bestuur op zoek naar balans, in: Openbaar bestuur, jrg. 8, nr. 12, blz. 9-13.

Schrijver, J. (2008), Zou burgerparticipatie het vertrouwen in de politiek vergroten? in: Bestuurskunde, jrg. 17, nr. 2, blz. 102-112.

Schrijver, J. (2009), Dertig jaar bestuursbeleid van Binnenlandse Zaken, 1976-2006: government of governance?, in: Bestuurswetenschappen, jrg. 62, nr. 4, blz. 65-86.

Schrijver J.F. en F.J. van Bork (1980), De bijdragespiraal, dynamiek van specifieke uitkeringen en mogelijke alternatieven, in: Bestuurswetenschappen, jrg. 34, blz. 357-374.

Schrijver J.F. en H. van Ruller (1986), Decentralisatie als onderdeel van de grote operaties, in: D.P. Noordhoek en F.K.M. van Nispen (red), De grote operaties, Kluwer, Deventer, blz. 113-140.

Schrijver, J.F. en P.R. Heij (1991), Decentralisatie, in: C.A. de Kam en J. de Haan (red.), Terugtredende overheid, realiteit of retoriek?, Academic Service economie en bedrijfskunde, Schoonhoven, blz. 55-75. 
Schrijver, J. en J. Monster (2005), Interactieve beleidsvorming, een naschrift, in: Bestuurskunde, jrg. 14, nr. 2, blz. 11-20.

Schrijver, J. en J. van Zuylen (2010), Hoezo kloof? - De worsteling van Binnenlandse Zaken met de burger, in: I. Verhoeven en M. Ham, (red.), Brave Burgers gezocht, TSS jaarboek, Van Gennep, Amsterdam, hoofdstuk 10.

Schuppert, F. (2007), Was ist und wozu Governance?, in: Die Verwaltung, Band 40, Heft 4, blz. 463-511.

Schutgens, J.M.L.R., A.J.C. Maessen en A.F.A. Korsten (2009), Beoordeling van gemeenten, Eburon, Delft.

Scott, J. (1998), Seeing Like a State - How Certain Schemes to Improve the Human Condition Have Failed, Yale University Press, New Haven.

Seinstra, A. en H. Sietsma (2012), Provincies van binnen en van buiten, Uitgeverij Réunion, Nieuwegein.

Simon, H.A. (1997), Administrative Behavior, The Free Press, New York.

Smaal, M. (2012), Politieke strijd om de prijs van automobiliteit, De geschiedenis van een langdurend discours: 1895-2010, Eburon, Delft.

Snellen, I.Th.M. (1987), Boeiend en geboeid - Ambivalenties en ambities in de bestuurskunde, Katholieke Universiteit Brabant, Zwolle (oratie).

Snellen, I.Th.M. (2007), Grondslagen van de bestuurskunde, Lemma, Den Haag.

Soeterbroek, F. (2004), 'Go with the flow': meebewegen, overleven en sturen bij bestuurlijke drukte, in: Bestuurswetenschappen jrg. 57, nr. 2, blz. 118-135.

Sonnenschein, L. (2010), Innovatie bij de overheid - Een buitenboordmotor voor innovatie in het openbaar bestuur, Cahier 14, Inaxis, Den Haag.

Sörensen, E. (2002), Democratic theory and Network governance, in: Administrative Theory \& Praxis, blz. 693-709.

Stacey, R.D. (2007), Strategic management and organizational dynamics, Prentice Hall, Harlow.

Steen, M. van der (2009), Een sterk verhaal - Een analyse van het discours over vergrijzing, Lemma, Den Haag.

Stuurgroep doorlichting specifieke uitkeringen (Stuurgroep-Brinkman) (2004), Anders gestuurd, beter bestuurd - De specifieke uitkeringen doorgelicht, Ministerie BZK, Den Haag.

Stuurgroep Toekomstonderzoek \& Strategisch Omgevingsbeleid (2001), Zijlicht op toekomstonderzoek, 4 casus, WRR-vooronderzoek, Den Haag.

Susskind, L., P. Field, M. van der Wansem \& J. Peyser (2005), Integrating Scientific Information, Stakeholder Interests, and Political Concerns in Resource and Environmental Planning and Management in Fostering Integration: Concepts and Practice, in: K.S. Hanna \& D.S. Slocombe (eds.), Resource and Environmental Management, Oxford University Press, Don Mills, Canada, blz. 181-203.

Tas, P.A. en S. B. Luitjens (1993), Informatisering bij de overheid, in: L.A. Ten Horn, J.H.M. Stroeken en F.R.H. Zijlstra (red.), Informatietechnologie in de maatschappij, wisselwerking en sturing, Kluwer, Deventer, blz. 32-46.

Teisman, G. (2005). Publiek management op de grens van chaos en orde, Sdu, Den Haag. 
Tennekes, J. (2005), Wat donoren zien in good governance - Discoursanalyse van het ontwikkelingsbeleid van Nederland en Duitsland, UT Twente, Enschede.

Termeer, C.J.A.M. (1993), Dynamiek en inertie rondom mestbeleid - Een studie naar veranderingsprocessen in het varkenshouderijnetwerk, VUGA, Den Haag.

Termeer, C.J.A.M. (1993a), Cultuurverstarring op Landbouw, Natuurbeheer en Visserij, in: W.J.M. Kickert (red.), Veranderingen in management en organisatie bij de rijksoverheid, Samsom H.D. Tjeenk Willink, Alphen aan den Rijn, blz. 275-285.

Termeer, C.J.A.M. en B. Kessener (2007), Revitalizing Stagnated Policy Processes, Using the Configuration Approach for Research and Interventions, in: Journal of Applied Behavioral Science, vol. 43, nr. 2, blz. 256-272.

Thijn, E. van (1994), Retour Den Haag, Van Gennep, Amsterdam.

Throgmorton, J.A. (1991), The rethorics of policy analysis, in: Policy Sciences, vol. 24, blz. 133-179.

Throgmorton, J.A. (1996), Planning as Persuasive Storytelling: the Rethorical Construction of Chicago's Electric Future, University of Chicago Press, Chicago.

Toonen, Th.A.J. (1982), Denken over binnenlands bestuur, VUGA, Den Haag.

Toonen, Th.A.J. (2004), Bestuurskunde in de kennissamenleving: Van 'Art of the State' naar 'State of the Art', in: Bestuurskunde, Themanummer over het Avontuur Bestuurskunde, jrg. 13, nr. 1, blz. 27-37.

Tops, P.W. (1985), Machine of machinatie? - De reorganisatie van het binnenlands bestuur 1969-1983, Uitgeverij van de VNG, Den Haag.

Tops, P.W. (2007), Regimeverandering in Rotterdam - Hoe een stadsbestuur zichzelf opnieuw uitvond, Atlas, Amsterdam.

Tops, P.W., A.F.A. Korsten en C.A.T. Schalken (1994), De wethouder - Positie en functioneren in een veranderend bestuur, VUGA, Den Haag.

Tops, P.W., M. Boogers, F. Hendriks en R. Weterings (1999), Omtrent interactieve besluitvorming Een inventariserend onderzoek naar nieuwe vormen van politieke participatie in de 'alledaagse democratie', Katholieke Universiteit Brabant, Tilburg.

Tops, P.W., P.F.G. Depla en P.J.C. Manders (red.) (1996), Verhalen over co-produktie - De praktijk van politieke en bestuurlijke vernieuwing in Noord-Brabantse gemeenten, Katholieke Universiteit Brabant, Tilburg.

Trommel, W. (2010), Gulzig bestuur, Boom Lemma, Den Haag (oratie).

Twist, M.J.W. van (1993), De beleidstheorie vanuit de wetenschapspraktijk: Van 'hoe ver?' naar 'hoe verder?', in: Beleidswetenschap, jrg. 7, nr. 1, blz. 34-47.

Twist, M.J.W. van (1995), Verbale vernieuwing, VUGA, Den Haag.

Twist, M.J.W. van, M. van der Steen, Ph.M. Karré, R. Peeters en M. van Ostaijen (2009), Vernieuwende verandering - Continuïteit en discontinuïteit van de vernieuwing van de rijksdienst, NSOB, Den Haag.

Valk, I. van der (2001), Het politieke vertoog over immigratie en asiel - De parlementaire debatten in Frankrijk en Nederland, in: Justitiële Verkenningen, jrg. 27, nr. 8, blz. 91-106. 
Veenswijk, M. (1996), Departementale cultuur - IJzeren kooi, bron van versplintering of politiek werktuig, Eburon, Delft.

Veenswijk, M. en W. Kickert (1993), Departementale cultuur, in: W.J.M. Kickert (red.),

Veranderingen in management en organisatie bij de rijksoverheid, Samsom H.D. Tjeenk Willink, Alphen aan den Rijn, blz. 237-254.

Veld, R.J. in 't (2001), De sturingsconceptie van Paars, in: F. Becker et al. (red.), Zeven jaar paars, Wiardi Beckman Stichting / De Arbeiderspers, Amsterdam, blz. 164-197.

Veld, R. in 't (2007), De vloek van het succes - Over de ontwikkeling van democratie, Rede voor het Huis van de Democratie van Hogeschool InHolland, Dordrecht.

Veld, R. in 't (2010), Kennisdemocratie - Opkomend Stormtij, Sdu, Den Haag.

Veld, R. in 't (2014), Uitleiding, in: Bestuurskunde, Themanummer Deliberatie over wicked problems, jrg. 23, nr. 2, blz. 46-48.

Veldheer, V. en A. van Kalmthout (1989), De beleidstheorie als instrument voor evaluatieonderzoek, in: Beleidswetenschap, jrg. 3, nr. 2, blz. 165-179.

Verkruisen, W.G. (1975), Herziening van de bestuurlijke organisatie. Maar hoe?, in: EconomischStatistische Berichten, jrg. 60, nr. 17, blz. 431-438.

Vernieuwingsimpuls Dualisme en Lokale democratie (2003), Handreiking Interactieve Beleidsvorming voor een dualistische raad, 25 vragen en antwoorden, VNG + Ministerie van BZK, Den Haag.

Vernieuwingsimpuls Dualisme en Lokale democratie (2006), Culturen rond besturen Bestuurskracht en bestuurscultuur in gedualiseerde gemeenten, Vierde jaarbericht van de Begeleidingscommissie Vernieuwingsimpuls Dualisme en lokale democratie, Sdu, Den Haag.

Vickers, G. (1965), The art of judgment - A study of policy making, Basic Books, New York.

Vries, J. de (2001), Paars en de managementstaat - Het eerste kabinet-Kok (1994-1998), Garant, Amersfoort.

Vries, J. de, en M. van Dam (1998), Politiek-bestuurlijk management, Samsom, Alphen aan den Rijn.

Wagenaar, H. (1997a), Beleid als fictie: over de rol van verhalen in de bestuurlijke praktijk, in: Beleid en Maatschappij, jrg. 24, nr. 1, blz. 7-21.

Wagenaar, H. (1997b), Verhalen in de beleidspraktijk, in: Beleid en Maatschappij, jrg. 24, nr. 1, blz. 2-7.

Wagenaar, H.C. (2005), Stadswijken, complexiteit en burgerbestuur, Vlugschrift 5, XPIN, Den Haag.

Walraven, G (1991), De kwaliteit van de beleidstheorie - Visies vanuit de beleidspraktijk, UTwente, Enschede.

Werkgroep Complementair Bestuur (1977), Complementair bestuur verkend, Staatsuitgeverij, Den Haag.

Werkgroep Complementair Bestuur (1980), Eindrapport van de werkgroep complementair bestuur, Staatsuitgeverij, Den Haag.

Wessel, J. (1979), Beïnvloedings- en temperingsinstrumenten, in: Tijdschrift voor Openbaar Bestuur, jrg. 5, nr. 6, blz. 311-314. 
Wesselink, M. (2010), Handboek Strategisch Omgevingsmanagement, met de casus Maasvlakte 2 door R. Paul, Kluwer, Deventer.

Westerloo, G. van (2003), Niet spreken met de bestuurder, De Bezige Bij, Amsterdam.

Wetenschappelijke Raad voor het Regeringsbeleid WRR (1990), Van de stad en de rand, Den Haag.

Wetenschappelijke Raad voor het Regeringsbeleid WRR (1995), Orde in het binnenlands bestuur, Den Haag.

Wetenschappelijke Raad voor het Regeringsbeleid WRR (2004), Bewijzen van goede dienstverlening, Den Haag.

Wetenschappelijke Raad voor het Regeringsbeleid WRR (2005), Vertrouwen in de buurt, Den Haag.

Wetenschappelijke Raad voor het Regeringsbeleid WRR (1998), Ruimtelijke Ontwikkelingspolitiek, Rapporten aan de Regering nr. 53, Sdu, Den Haag.

Wielinga, E. (2001), Netwerken als levend weefsel - Een studie naar kennis, leiderschap en de rol van de overheid in de Nederlandse landbouw sinds 1945, Uilenreef, 's-Hertogenbosch.

Willemse, R. (2001), Het bestaansrecht van de gemeente, Eburon, Delft.

Winsemius, A. (1945), De opbouw van het bestuursapparaat, Elsevier, Amsterdam.

Wolfson, D. (2005), Transactie als bestuurlijke vernieuwing, WRR, Den Haag.

Wolthuis, J.A. (2006), Bestuurlijke drukte: van verkenning naar beleidsinzet - Een beknopte weergave van gesprekken over het thema 'bestuurlijke drukte', 10 augustus 2006, intern document afdeling IB, niet gepubliceerd.

Woltjer, J. (2000), Consensus Planning - The relevance of communicative planning theory in Dutch infrastructure development, Ashgate, Aldershot.

Wouden, R. van der, M. Ruinaard, R. Kwekkeboom, E. ter Borg, P. Voogt en W. Wiertsema (1994), Evaluatie Sociale Vernieuwing: het eindrapport, SCP/VUGA, Rijswijk/Den Haag.

Wouden, R. van der, E. ter Borg, B. Cordia, P. Voogt en W. Wiertsema (m.m.v. R. Kwekkeboom) (1993), Evaluatie Sociale Vernieuwing: een tussenrapport, SCP/VUGA, Rijswijk/Den Haag.

XPIN (2005), Mensen en ideeën rond XPIN, XPIN, Den Haag.

Yanow, D. (1993), How does a policy mean? Interpreting Policy and Organizational Action, Georgetown University Press, Washington, DC.

Yanow, D. (1999), Conducting Interpretive Policy Analysis, Sage, London.

Zimmer, A. (2007), Governance and Civil Society, working paper: http://nez.uni-muenster.de/ download/Zimmer_Civ_Gov.pdf.

Zuijderhoudt, R. (2004), De adaptieve organisatie, in: Holland Management Review, nr. 94, blz. 76-84.

Zuijderhoudt, R. (2007), Op zoek naar synergie - Omgaan met onoplosbare problemen, Bussum.

Zwanikken, T. (2001), Ruimte als voorraad - De consequenties van discoursen rondom 'ruimte als voorraad' voor het rijks ruimtelijk beleid, Katholieke Universiteit Nijmegen, Nijmegen. 


\section{Summary}

'The turning point that did not come', Exploring Internal Affairs Policies of the Ministry of the Interior 1969 - 2009

\section{Subject matter and method of enquiry}

In order to improve our insight in public policy making, this book presents the results of extensive research into the polity-theory of the policy making sub-system around the Dutch Ministry of the Interior in the period between 1969 and 2009.

A polity-theory is a species of policy theories, i.e. the (often implicit) set of beliefs and reasonings of policy makers about the fundamental character and relationships of their subject matter. When this subject matter concerns the nature of public governance itself we speak about a polity-theory.

The main research question is: how did the polity-theory of those participants of the political sub-system dealing with the structure and functioning of public administration in the Netherlands develop? We call these dealings (meta-policies) Internal Affairs. Do these fundamental ideas follow the actual developments in society or are the Ministry and its allies pursuing a logic of their own?

These developments are described by political scientists. Many scholars of public administration adhere to academic views (theories) about the empirical developments between government and society.

Thus we could reformulate our research question to the following: to what extent does the mainstream polity-theory of Internal Affairs reflect the predominant academic theory on the structure and functioning of public administration.

This query presupposes the focused development of a consistent polity-theory within the Ministry.

Additional research questions are therefore: were there systematic efforts to update the ideas about governing in this period when the world changed dynamically? And were these theoretical views reflected in the practical policies of the Ministry? All these questions are about organisational learning.

Furthermore, the study explores other policy making domains surrounding the Ministry of Internal Affairs in order to question the often heard suggestion that this (sub)system had specific inclinations that discerned it from other systems. These domains are:

the political scene in parliament and relevant parliamentary committees, a spending department like the Ministry of Agriculture, and the practice in local government.

First, we look for a point of reference to which the development of the polity-theory can be compared. For this purpose (in chapter 2) we turn to the the mainstream discourse within academic theories about public administration. About the science of public administration within the Netherlands, which dates back to roughly the same period as is covered by this study, several historical overviews have been published (e.g. QANU, 2005; Boin, e.a., 2004; Snellen, 2007). In these studies we found as predominant the above mentioned central thesis about a shift from government to governance, which was first developed in Rotterdam University in the nineties. It can also be recognised in public policy literature worldwide (Scharpf, 1994; March and Olsen, 1995; Rhodes, 1997; Maintz, 1999; Peters and Pierre, 2000; Salamon, 2002; Kjaer, 2004; Folke Schuppert, 2007; Fischer, 2006). Kjaer (2004: 41) even refers to 'The Dutch school of governance'. This theory implies that for a growing number of complex issues topdown bureau-centric policy making is no longer possible. The traditional working methods of hierarchy and vertical instructions 
following pre-arranged political plans are not suitable in areas of high uncertainty and characterized by mutual interdependence of many actors.

It is self-evident that in many respects government institutions and practices are influenced by this development. At the same time it is clear that the traditional government-mode' is still useful in many situations and remains tempting for public officials, because it leads to swift and seemingly rational decisions. The postulated shift refers to a relative change in the relationship between government and society, which challenges the traditional attitudes within the administration.

In this present study the distinction between government and governance modus is being elaborated on in a number of operational criteria to test whether the policies of the Ministry concerning the structure and functioning of public administration reflects the same shift.

How does a set of ideas, a policy theory or polity-theory, reveal itself in day-to-day practice of public policy making? Chapter 3 is devoted to methodology. The analysis of the discourse within the subsystem offers an appropriate method for this purpose. In this study the stories that are told and the language in the documents of the different projects are analysed in order to classify the type of policy theory that lies behind these texts, but discourse does not limit itself to language, it also contains practices. Discourse is defined here as 'classification of language and practices within a preset dichotomy of ideas, that give meaning to the activities of policy makers'.

Discourse analysis is a well developed research method within social sciences. Here the approach of Maarten Hajer and Willemijn Dicke, who applied discourse analysis in a specific manner in their research (Hajer, 1993; Dicke, 2001) is followed, They make a distinction between different clear cut 'story-lines' with which the policy approaches in the field can be classified.

Here is where the distinction between the two modes, government and governance, comes in. We classify the discourse in a number of new projects that have come up in the Ministry of the Interior to change the system of government by characterising them as either government or governance oriented. For this purpose four criteria are used:

1. the goal of the policy is directed to consolidation of power and well discerned responsibility in central polities or it is aimed to enhance coproduction and cooperative problem solving capacity;

2. the steering approach in the project is hierarchical or horizontal;

3. the stance on democracy is favouring representative forms of democracy or also opening up to participative democracy;

4. the gathering of information is based on the rational causal relationships epistemology or relies on learning by doing and experiments. Van Gunsteren (2006) makes the distinction between reasoning from Analysis to Instruction and reasoning from Variety to Selection.

Each of these preferences revealed in the discourse of the projects corresponds with either a government- or a governance-inclination. Some projects show a mixed outcome, with some elements of the opposite approach. To conclude the research, all projects were assigned a score to categorise their approach: $A$ = government; $A$ - =government with some governance-elements; $B=$ governance; $\mathrm{B}$ - = governance with some government-elements. If during a certain period more than half of the projects switched from $A$ to $B$ and if this orientation continued for a longer period (institutionalised), we conclude that the postulated 'shift' took place.

Furthermore, this study establishes the extent to which each project appears to be sustainable and is institutionalised in the legal system of the Dutch public sector. We assume that the polity-theory which is connected with projects that are implemented and institutionalised is likely to be the hegemonial or mainstream theory of the Ministry and its allies.

From the developments of the discourse in the subsequent new projects and its sustainability in the institutions the changing pattern of the dominant polity-theory can be deducted.

In order to establish the nature of innovation in the different projects the concepts developed by Hogwood and Peters (1993) are applied. Some projects represent completely new issues and approaches in the policies of the Ministry, others are adaptations or replacements of already ongoing policies. 
Finally, of each project an assessment is made whether evaluation has taken place, and if so whether this was done in a way that implies organisational learning. Subsequently, conclusions can be drawn about the existence of a dynamic and vital system of polity-theory development within the sub-system of Internal Affairs.

The contribution of each project to the polity-theory is assessed in four categories:

large impact and dynamically updated by external influences (1);

large impact but stable regardless of developments in the environment (2);

little impact, but dynamically subject to external influences by updating (3);

little impact and relatively inert from external influences (4).

This methodology was applied to cases where important new projects and policy

innovations were introduced. We found 24 examples in five different fields of Internal Affairs. It is important to stress that these cases were not a random selection, but contained virtually all projects where the Ministry made a significant turn to new ideas or new methods. If anywhere, possible shifts could be found here. These policy fields are:

organisational structure of government (municipalities, provinces);

intergovernmental relations and decentralisation of responsibilities between tiers of government; qualitative impulses in local government to cope with disadvantaged areas;

qualitative impulses in local government on information systems;

organisation of central government.

The investigations of the projects are based on documents, interviews and literature and are focused on stories, factual developments, descriptions and evaluations. These are characterised according to the criteria of this research described above. A discussion of the analysis of these projects is presented in chapters 5 to 9 .

\section{Empirical data about projects in Internal Affairs}

Before elaborating on the 24 projects an overview is given of the internal organisation of the Ministry (chapter 4).

The systematic development of constructive policies about the structure and functioning of government goes back to around 1969. In that year a 'green paper' on the organisation of local government appeared, based on extensive scientific research and developing a blueprint for a coherent subdivision of the country in new tiers of government. In the same period a committee of experts appointed by the Dutch government reported on the fundamental problems of ministerial coordination within central government and came with proposals for a new division of tasks between Ministries.

Between 1969 and 2009, seven substantial internal reorganisations within the Ministry of the Interior took place, as a result of which the different departments of the Ministry have been put together in the same directorate for one or more periods of time. This implies two things: a. there is a close coherence between the departments so that their configuration seems to be interchangeable; $b$. the frequent reorganisations suggest that the management must have been uncertain about the best course of action.

Another fact highlighted in this study is the frequent changes of political leadership. During the 40 years this study spans 25 ministers came into office. Among them only one minister stayed for more than 4 years, although taking part in three different cabinets. Presumably, not much political steering can be expected with such volatile presence of less than 2 years per minister. Some staatssecretarissen (junior ministers) had a better track record and are told to have been more influential, notably mr. Wim Polak (1974-1978) and mrs. Dieuwke de Graaff-Nauta (1986-1994).

In terms of organisational culture a tension is found between two kinds of civil servants: the 'doctrine-developers' and the 'coordinators in the field'. The latter civil servants were confronted with different contingent arrangements in different sectors of government, whereas the first type of civil servants clung to the uniform standards for the government as a whole. Of course the coordinating civil servants also had to bring the message about the standard doctrine of the 
Ministry, but they were naturally more inclined to see the historical and pragmatic reasons for tailormade solutions in their area of work.

\section{Description of the cases}

\section{Field 1. Organisational structure of local government (municipalities, provinces)}

This chapter studies the attempts to restructure local government. These projects aimed at reformulating the institutional framework for local government, three of which tried to define new entities for the middle tier of local government and two others worked on the modes of cooperation between and within local government. Only the latter project succeeded.

Three major attempts have been made in 1976-1983, 1992-1994 and 2005-2007 respectively to fundamentally change the size, tasks and position of the provinces, the middle tier of Dutch government. All of them failed. The first two of these projects succeeded in getting legislation passed, but were aborted in the last stage of implementation. The latter did not even reach the stage of parliamentary approbation. The first two were based on the idea of transferring operational tasks from (often cooperating) municipalities to a compact regional entity (,do-province') on a scale of large agglomerations or coherent regions. The latter was heading to large regions, combining several existing provinces to five parts of the Netherlands, creating a competitive relationship between provincial and state level.

One project was an exploratory study in a special expert committee about co-operative government, regulations that would be necessary in order to make arrangements and to foster agreements between different public stakeholders on fields that transcend each organisation's competence. Also, this project lead to a report and entailed some interesting discussion among experts, but not to any institutional effect. Even the concept ('complementary governance') that was used in the title of the report has become obsolete in present-day jargon.

Remarkable is that, although all projects were directed to more effective problem solving in collective issues, none of these projects involved participation of the private sector or of midfield social organisations, e.g. social welfare institutions, schools and hospitals, which are essential coproducers for collective services.

One reformative project that was studied in this field dealt with intra-governmental relations between councils and boards (around 2000). This project was a success. It resulted in legislation and implementation within the timeframe of one cabinet period. This project improved the checks and balances between local government and the councils by separating responsibilities. This 'Dualisation' process had specific care for a fitted implementation process in each municipality. A team in which also civil servants of the Ministry of the Interior participated, went to the town halls and learned about the practical situation in in the field of local government. This was one of the few instances where the link between The Hague and local practice was established, thereby fulfilling a criterion for the governance-type of information-gathering. On the other hand, the concept of democracy in the Dualisation project referred to representative democracy only.

For the rest, the scores based on the four research criteria in all the projects of this field were government-oriented, even though in this field, a less technocratic and top down approach in preparing and implementing policies could have been possible. The project about Complementary governance might be considered an exception to the government approach, although the report was mainly a product of technocratic administrative thinking. Moreover, the complete failure of this report to be turned into law, and the arguments to keep it that way, reveal the predominant inclination of the Ministry. Striking is the fact that of all these projects only the successful Dualisation-legislation was evaluated, even extensively, and none of the others was.

Field 2. Intergovernmental relations and decentralisation of responsibilities between tiers of government 
This field contains one general innovation to start a coordinating activity to intervene in the products of other Ministries concerning local government activities, one project which introduced general covenants between the national associations of local governments and central government, four new methods to promote decentralisation and one project that reflected on the effects of decentralisation. A last innovative project focused on the extent to which differentiation between municipalities would be possible and advisable.

Around 1980 the Ministry changed its mission from being a passive spectator and executive of centralising legislation in all sectors to a coordinator of intergovernmental relations and a protagonist of decentralisation in the domain of other Ministries. The adoption of this objective was one of the major changes in the position and ideology of the Ministry and a very influential leading rationale for most of its activities, also in other fields.

Specific projects for decentralisation succeeded each other with different methods and approaches. For this study a few of these changing strategies were analysed. Some of them were not top down, experimental even, like the 'D'project'. This project accepted proposals by individual municipalities or provinces, but in the end this project only headed towards universal realisation of proposals favoured by some local governments. Another project called Decentralisation-impulse, consisted of real negotiations between local and central government, to transfer more power to local authorities in exchange for the acceptance of budget-cuts.

Both projects implied a broadening of the playground, introduction of more committed players and more serendipity in the process than simple proposing new decentralisation options within the cabinet, from the one Ministry to the other.

For the purpose of this research it is interesting to see the translation in the D'-project of the Scandinavian Frikommuner concept in the Dutch context of standardised government: free zones where the municipality could select its own regime to experiment with and more experimenting with differentiated regulation than national legislative proposals. The Dutch project made reverse choices. The powerful Dutch Association of Dutch Municipalities VNG is not keen to differentiate by allowing privileges to some of its members.

Since 1987, Central Government, the VNG and the Interprovincial platform (IPO) pledge their common insights about intergovernmental relations in General Covenants. In 1994 they tried to switch to more specific covenants about urgent issues. The products of these covenants were mostly worded in general terms, i.e. did not consist of tailor-made local or regional negotiations with individual municipalities and provinces about their specific problems.

The policy on intergovernmental relations was remarkably consistent during most of the research period. Decentralisation programs, combining and shifting specific grants to the General Grant for local government funding and general codes of conduct in Covenants were repeated over and over again, even when the original urgency was long gone. Nevertheless, there was a period between 1995 and 2000 when the spirit of innovation was at its peak within the department for intergovernmental relations.

A study about the effects of decentralisation (Fleurke cum suis 1997) pointed out that the presupposed effects of decentralisation were not reached automatically: promises like integrated democratic decision making, tailor-made solutions and more citizens' participation require adequate local government capabilities, which are often not available. Fleurke advised that central government should accompany decentralisation with efforts to help effective implementation. This evaluation study made the Ministry reflect upon its decentralisation policies so far and led to the project 'Decentralisation with care', focusing on the specific requirements of each social problem rather than working with standardised arrangements and facilitating local government to take appropriate action. As it turned out, this view did not last and was abandoned at the beginning of the 21st century.

This present study adds that ideas for such experimentation, exchange of experiences between local politicians and local civil servants were often tried by Internal Affairs, but prematurely came to an end after some time. 
In general, we conclude that ambitions in the field of intergovernmental relations was high and at the same time predominantly aimed at strengthening or restoring the government-modus of public administration: clear cut responsibilities and more power to local centers of public decision making, fostering local representative democracy and standardised arrangements for the whole country. Civil society or the market sector was hardly ever a partner in this policy field. Of the eight projects in this field six obtained an A or A - score. There were also two B's ('Decentralisation with care' and 'Differentiation', but these did not reach the institutionalisation phase.

Evaluation and theorisation of the challenges of intergovernmental relations did at some point take place, but hardly influenced the polity-policy of the Ministry.

\section{Field 3. Qualitative impulses in local government to cope with disadvantaged areas}

The next two chapters deal with projects which intervened in the policies of local governments, assisting them to cope with new challenges and deprivations. Field 3 focuses on deprivations, field 4 deals with challenges offered by information and communication technologies (ICT's).

In 1980 a first large task that emerged from new social challenges of modern society was allocated to the Ministry of the Interior: integration of ethnic minority groups. This challenge was perceived first and foremost on the local level. Municipalities had to be prepared for this task. The activities were not confined to a single sector such as housing, education, social wefare, etcetera, but included them all. This was the main reason why it was considered an administrative challenge and why Internal Affairs was selected as the locus for this policy. The directorate for the integration of Minorities was founded in 1980 with ample means and, possibly as a result of that, soon became over bureaucratised. The project from this directorate which was selected for this study, the Policy for Neighbourhoods with Cumulating Problems ('PCG'), shows the influence of its placement between local government policies. The project concluded that problems of ethnic minorities could best be coped with by impulses in specific neighbourhoods. So plans, money and freedom to act, with less interference from central sectorial regulations would be the instruments for these neighborhoods. The PCG-project was gradually developed since 1985, but soon overtaken by successive policy projects elaborating on the same theme: Social Renewal and Big Cities Programs. These projects are among those examined here.

'Social Renewal' was a major project of the Centre left Lubbers-Kok government which intended to show responsiveness to the citizens after the harsh budget-cuts of the eighties. The initial efforts were quite innovative for the Ministry and involved many contacts with grassroot neighbourhood activities. After two years, the project became contaminated with bureaucracy, because most effort was devoted to preparing covenants with all municipalities about their utilisation of the combined grants for deprived areas and to ensure correct accounting for the way this money was spent. The combined grants from different Ministries were seen as preceding transfer to the general grant in the Municipality Fund, administered by Internal Affairs.

A similar strategy is found in the Big Cities Program. After the Social Renewal project, lessons were learned and the program concentrated on a smaller number of municipalities with deprivation problems rather than covering all of them. Now only the big cities with real problems took part in the program, although their number soon increased from 15 to 27 (later 32), all epitomised 'Big'. Again, the problems of deprivation were pictured as curable by giving more freedom and responsibility to the city councils, while at the same time pushing them to make midterm integrated plans for tackling the complex problems. Collecting and judging all these plans (often showing surprising similarity), cost a lot of administrative energy, but beside this yearly routine there was ample opportunity for innovation.

One of the innovations was an initiative to persuade private companies located within the cities to join the efforts for rehabilitating neighbourhoods. The idea was borrowed from a similar initiative in Minneapolis in the United States, and the promoter, Mike Brinda, was introduced by the Dutch project-leader in Rotterdam to circles of entrepreneurs in order to inspire them. Although associations of Corporate Social Responsibility were founded in some cities, Internal Affairs did not sustain its efforts and after a few years the idea of company involvement in Big Cities development 
was abandoned. Such efforts, evidently of the governance type, were soon aborted and seemed alien to the policy sphere of Internal Affairs. In the end, the whole project for Big Cities Policies was taken away from the Ministry of the Interior, as had happened earlier in 2002 with integration of ethnic minorities. The Ministry had been successful in the sense that the spending Ministries were no longer hostile to each other so that one of them could be made responsible for coordinating the project, but this eventually meant that these tasks were taken away from the Ministry of the Interior.

This field produced interesting experiences: mixed adoption teams, composed of municipal and multi-departmental members, went troubleshooting in neighbourhoods; citizens were encouraged to take initiatives and get subsidies for their plans in deprived areas directly from the Ministry. Such activities may have helped to give the civil servants a better sense of practices on the ground level, but again all these instruments were temporary and they did not have lasting influence in a polity-theory of the Ministry. Scores were divided equally among A's and B's, but no governance-oriented projects lasted.

Evaluation has taken place more frequently in this field, although the focus of these assessments was more directed at the results of the efforts than at the process within the organisation.

\section{Field 4 qualitative impulses in local government on information systems}

Another field where Internal Affairs felt the urge to intervene into the activities of local government was that of information systems. Two large innovative projects (BBI and GBA) investigated into old routines of local government that urgently needed modernisation. Two other projects were devoted to better service delivery to citizens with modern ICT-related methods (Quality instruments and Management of Chains).

The first project concerned the production of yearly budgetary reports. A study by Twente University in 1985 pointed out that local councils were hardly able to understand these products of their financial departments. An ambitious project from Internal Affairs about Policy and Control Instruments (BBI), alarmed by this threat to the major democratic functions to make budget decisions and to achieve transparency of spending, aimed at upgrading the quality of these financial reports. This again suggests that Internal Affairs was highly sensitive to threats of representative democracy. The project also had governance-like aspects, because civil servants of the Ministry made a tour of municipalities and had more contact with the local practice to see what really happened there, and why. However after a few years, in 1988, the implementation of the jointly developed Policy and Control Instruments was left to the market of consultancy and the lifeline between local practicalities and the policy center in The Hague was cut.

Another large project was the automation of the population registers. The core choice was between a central register or decentralied registration of the population by municipalities within a common framework and with possibilities to exchange data. After two years of study, the second option was chosen and translated into a system design, logical design and into complete legislation. GBA (Municipal Population Administration) became one of the few successes of the Ministry. The process was topdown and based upon rational planning, but left executive power and direct control on the ground level to local government.

The two preceding projects scored $\mathrm{A}$ - and the next two $\mathrm{B}$ - on the scale from government to governance.

Other quality improvement projects were more temporary and experimental. For example, quality safeguards in service provision were sought by concentrating service delivery to a single counter in the municipality. Also the development of explicit service standards was promoted. Following New Public Management ideas, the customer approach was introduced by exchanging best practice between pioneering local governments.

A last example examined here is the so called Management of Chains project, which portrayed public services as a chain of different government professionals adding value to a single individual person or group rather than a one-to-one service delivery. This vision implied cooperation between a network of professionals, a working method that sharply distinguished itself from the contemporary silo-organisation of public service. In order to promote chain management, Internal 
Affairs installed a knowledge center and invited all relevant partners to join and to learn from each other. This method is typical for all projects where Internal Affairs tried to introduce and stimulate new methods of governance.

Similarly typical is the pattern that all these projects (half of them were ended long before a substantial number of local governments had adopted and implemented these new governance methods. This resulted in a series of novelties endorsed by the Ministry for a limited period of time and then left aside again. The pattern, occurring over and over again, adds to the impression that the mainstream polity policy of the Ministry is government- rather than governance-oriented. Moreover, it leads to the conclusion that no substantive change of the polity-theory based on ongoing developments in society and public administration has taken place. Neither is there any sign of systematic efforts to develop and update the polity-theory by making use of evaluation and feedback studies.

\section{Field 5. The organisation of central government}

In this field three projects, or rather clusters of activities following a core idea about central government, were investigated. The first was the reorganisation, or rather rationalisation, of central government in the $80 \mathrm{~s}$. The second followed in the $90 \mathrm{~s}$ and was directed at privatisation and autonomisation of public service organisations. The third concerned the idea that representative democracy is no longer the only way to legitimise decisions, which idea entails processmanagement and interactive policy making.

One of the first issues of Internal Affairs tackled by public policies was the organisation and coordination of central government. In the $60 \mathrm{~s}$ and 70 s the welfare state had produced a large and multi-departmental bureaucracy where coordination and integration of multiple government policies were the biggest problems. Three state committees were formed around these issues, which strongly influenced the polity-theory of the Ministry in the earliest days of policy development. The main views of the largest of these committees, named after its chair Vonhoff-committee (1980), were considered to be outdated even at that time (Van der Heijden, 1990: 207) and did not go beyond traditional ideas of rational planning and concentration of policy development in large coherent areas. As a result, hardly any of the recommendations of this Vonhoff-commission were implemented. A remarkable fact is that the Government Commissioner, Herman Tjeenk Willink, who had been added to the commission and stayed as a guest at the Ministry for a few more years to look after implementation, had been giving authoritative advice with quite a different outlook on $f$ state problems. He stressed the network character of policy making and the importance of fostering relations with civil society. This governance type message did however not influence the main decision makers and after some time Tjeenk Willink moved to even higher offices.

The important wave of change that did have some influence followed in the 90's after the New Public Management school arrived on the European continent. This stood for privatisation and the formation of agencies detached from the policy center. This innovation, however, did not start in the Ministry of the Interior, but with the Ministry of Finance, which aimed at more efficiency in public services. It was only a few years later that Internal Affairs took over, but from another perspective: better functioning of the core policy center and of ministerial responsibility, which was often overloaded with operational details.

In this field, the Ministry found itself trapped into one of the paradoxes of its own theory. In order to be effective as a watchdog or even a leading advisor for improvement in the operation of services and policy making it would be forced to meddle into the affairs of other ministries, which would conflict with one of its own principles of ministerial responsibility. Here again, its dealings with the reorganisation processes of major public service provision- and control-institutions remained too superficial and general in nature to influence polity-theory. The starting point, ministerial responsibility towards democratic representation, and the method of intervention, legislation and general guidelines, suited government better than governance. The Ministry remained constantly doubtful about this privatisation and autonomisation of public service organisations and at one point 
even an expert committee advised to bring them all under direct supervision of ministers again, but by this time (2004) this was far too late. The process had become irreversible.

Another subject Internal Affairs tried to deal with, was citizens' participation. Here, the Ministry was not the first and most important policy maker. The Ministries of Transportation and Water Management, of Housing, Planning and Environment and of Agriculture and Nature Management had started pilot projects with citizen's participation before. Because this topic related to public policy making, the Ministry of Internal Affairs felt tempted to step into this field, which was a clear example of the governance approach. At the same time, however, the Ministry, being closely related to parliamentary politics, felt reluctant to fully express its support for participative democracy. This is shown on many occasions where the Ministry did not answer questions on the subject from the House of Commons. This in itself is quite uncommon, but on these occasions Parliament itself failed to ask for follow up. In the political arena, citizens' participation appeared to be an uneasy subject, if not a taboo. Nevertheless, on the administrative level the Ministry pursued learning activities with municipalities to exchange experiences and new practices for citizens participation, also in cooperation with other Ministries. This field of exploration looked promising for helping develop an up to date polity-theory, because it opened up relationships with of civil society and other stakeholders than government. However, for this purpose sustainable influx of new ideas about the relationship between government and society within the organisation must be established. And so far (2009) this did not occur.

To conclude findings in this field, two projects were of the A type and one $B$, of which the latter did not reach institutional status yet.

\section{Concluding on the polity-theory of Internal Affairs}

The combined results of the discourse analysis in all 24 projects are shown in this table.

Field 1 Organisational structure of government (municipalities, provinces)

\begin{tabular}{|c|c|c|c|c|c|c|}
\hline Project & $\begin{array}{l}\text { I } \\
\text { Type of } \\
\text { change }\end{array}$ & $\begin{array}{l}\text { II } \\
\text { Evaluato } \\
n\end{array}$ & $\begin{array}{l}\text { III } \\
\text { Character } \\
\text { of Polity- } \\
\text { theory }^{1} \text { ) }\end{array}$ & $\begin{array}{l}\text { IV } \\
\text { Follow up; } \\
\text { institutio } \\
\text { nalisation }\end{array}$ & $\begin{array}{l}\text { V } \\
\text { Indication } \\
\text { for shift } \\
\text { (combining } \\
\text { columns } \\
\text { I, II en III) }\end{array}$ & $\begin{array}{l}\text { VI } \\
\text { Contribution } \\
\text { to } \\
\text { Polity theory } \\
\left.{ }^{2}\right)\end{array}$ \\
\hline $\begin{array}{l}1 \text { Reorgan. do-provinces } \\
2 \text { Complementary co-op. } \\
3 \text { Urban provinces } \\
4 \text { Combined provinces } \\
5 \text { Dual checks/balances }\end{array}$ & $\begin{array}{l}\text { successio } \\
\mathrm{n} \\
\text { innovation } \\
\text { adaptation } \\
\text { successio } \\
\mathrm{n} \\
\text { adaptation }\end{array}$ & $\begin{array}{l}- \\
- \\
- \\
- \\
+\end{array}$ & $\begin{array}{l}A \\
A- \\
A \\
A \\
A-\end{array}$ & $\begin{array}{l}- \\
- \\
- \\
- \\
+\end{array}$ & $\begin{array}{l}\text { No } \\
\text { No } \\
\text { No } \\
\text { No } \\
\text { Not really }\end{array}$ & $\begin{array}{l}2 \\
4 \\
4 \\
4 \\
3\end{array}$ \\
\hline
\end{tabular}

Field 2 Intergovernmental relations and decentralisation 


\begin{tabular}{|l|l|l|l|l|l|l|}
\hline 6. Coördinating Role & innovation & $-?$ & A & + & No & 1 \\
7. Offensive & adaptation & + & A & + & No & 2 \\
Decentr.policy & adaptation & - & A & + & No & 2 \\
8. Specific Grants & successio & + & A & + & Not really & 2 \\
9. Covenants & $\mathrm{n}$ & \pm & A & - & No & 4 \\
10. Dutch Frikommuner & adaptation & - & A & - & No & 4 \\
11.Decentralis.- Impulse & adaptation & - & B & - & No & 3 \\
12.Decentr.reconsidered & successio & - & B & - & No & 4 \\
13.Differentiation & $\mathrm{n}$ & & & & &
\end{tabular}

Field 3\&4 Qualitative interventions in local government in disadvantaged areas and information systems

\begin{tabular}{|l|l|l|l|l|l|l|} 
14. Minorities integration & $?$ & \pm & $\mathrm{A}-$ & $\pm /-$ & No & 4 \\
15. Social Renewal & succession & + & $\mathrm{B}-$ & $\pm /-$ & No & 3 \\
16. Big Cities Policy & adaptation & + & $\mathrm{A}-$ & + & Not really & 3 \\
17. CSR in cities & innovation & + & $\mathrm{B}$ & + & No & 4 \\
18. BBI/Single Audit & adaptation & - & $\mathrm{A}-$ & + & No & 4 \\
19. ICT-policies/GBA & adaptation & - & $\mathrm{A}-$ & + & Not really & 2 \\
20. Quality instruments & succession & - & $\mathrm{B}-$ & - & No & 3 \\
21. Chain Management & innovation? & - & $\mathrm{B}$ & - & No & 4
\end{tabular}

Field 5 Organisation of central government

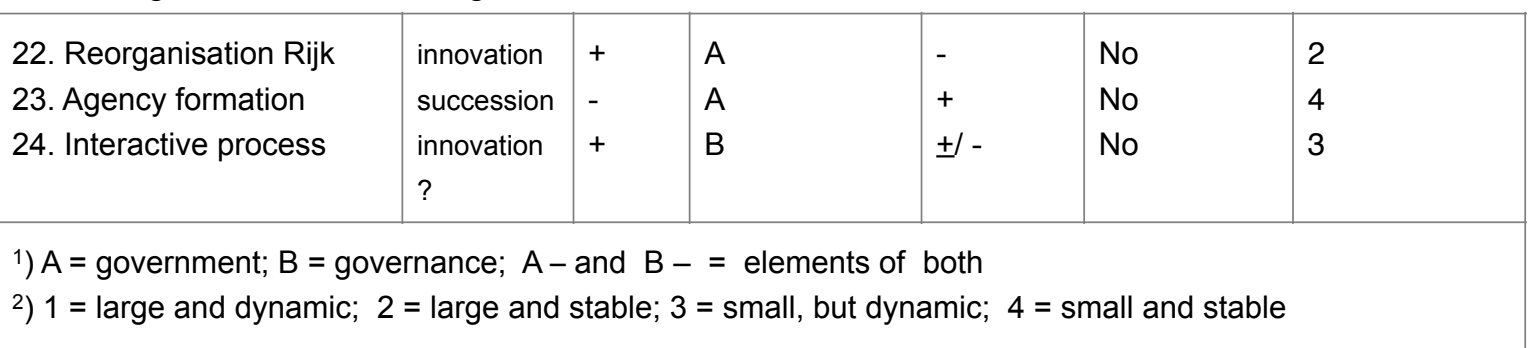

Of the 24 cases about half were successful, in the sense that they reached the stage of institutionalisation and implementation. One case (number 13) did hardly reach the stage of official policy-making, although an official project about differentiation was started in 2006, but at the brink of a new cabinet in 2007 it was abolished again. The idea of one standard-type of municipality is deeply rooted in the Dutch administrative system, another symptom of government-thinking.

This $50 \%$ score does not mean that the projects that were institutionalized also had a sustainable influence on the polity-theory (vision) of the Ministry. In order to reach that stage, it would have been necessary to evaluated and reflected on the impact for the relation between government and society and on the implications for the mission and organisation of the Ministry. As column I b shows, this seldom was the case. The the lack of evaluation studies indicate that all these new projects with their often disruptive confrontations with reality were not used as building bricks for the steady development of a sustainable polity-theory. Moreover column $\mathrm{V}$ suggests that projects that effectively had influence on the polity-theory of the Ministry were relatively petrified, not updated by the confrontation with external influences on the ground. 
Remarkable is that almost all governance projects were a once-off experiment. Even those that were successful or sometimes returned much later in a different shape or in a different Ministry, as Wijkaanpak (empowered neighborhoods), which was a lookalike of Social renewal 20 years later, was developed in the Ministry of the Environment VROM.

Discourse in the ministerial system, revealed by both examined language and performed practices, indicates that the turmoil created by individualisation, emancipation, fragmentation, complexity hardly had substantive influence on the development of a new polity-theory. Certainly no shift has taken place from government to governance, as predicted by the academic side of the public administration community.

It seems that the basic ideas of the Ministry were solidly founded in the seventies, an era where rational planning bloomed, and have never really changed since. When split up in periods of time according to chapter 4 , one period (1994 - 2002) shows a majority of new projects of a governance nature, but because they did not last through durable institutionalisation, also this period did not contribute to a real shift. It was no more than a try. These projects were efforts and signs of a changing tide, but they were overruled by other developments: new public management, political populism and mediacracy, to name a few. Hierarchical ties were fastened and short term straightforward solutions prevailed. However, alternative ways of thinking went on, but outside the mainstream discourse of the Ministry and its related sub-system.

It is remarkable that only 8 of the 24 cases were politically instigated. There was ample opportunity for civil servants to start innovative projects. In terms of Hogwood and Peters (1993) the inclination towards innovation was quite high. Many new projects however, especially those tending to a governance mode ended prematurely, never to restart again. This means that the need for experimentation with alternative polity-theories was felt, but at the same time the incorporation of governance elements in the mainstream polity-theory failed during the research period 1969-2009. Many examples of network governance in these projects tended to fade away over time, straddled by bureaucratic elements. For instance, in Social renewal and Integration of ethnic minorities this mechanism was pre-eminent.

In short, yes, there were tendencies to introduce network-governance elements in new policy projects, but they were not incorporated into the mainstream polity-theory of the Ministry.

Before continuing our main line of argument, we respond to possible reasoning which state that other mechanisms are at work than those obstructing a shift from government to government. The line of reasoning could be that the Ministry acts purposefully in these projects. For instance, the inclination towards the government approach would coincide with the sheer purpose of the Ministry to foster the general interest, upholding the democratic maintained by a strong government against partial interests in public organisations and against centrifugal tendencies in society. This natural preference might account for its inclination to structure-building with concentrated responsibilities. Another suggestion would be that the Ministry deliberately jumps from the one innovative impulse to the next, leaving further implementation to local partners and not sticking to a single method for too long until the stage of routinisation, which would be at odds with innovation. Several objections against such explanations can be made.

Firstly, the policies of the Ministry does not support the impression of such strategic planning, neither has there been a neatly complementary succession of projects, in order to absorb insights progressively in the same line of thought. Most projects just come and go.

Secondly, even deliberate policies aiming at a strong bureaucentric government, would have to take into account that these objectives can only be reached effectively when they incorporate real developments in society, including co-creation in networks, participative tendencies in democracy, notably uncertainties and interdependencies in public decision making.

During our research, we noticed that policy makers thought ambiguously about politytheories. We saw that very clearly in the position of the director-general Brinkman, who advocated Complementary policy making but finally chose to kill his darling in favour of decentralisation and the creation of new provinces. This ambiguity in human thinking is considered to be an amendment to the discourse analysis practice, that suggests that the position of actors can be assessed unequivocally by the language they use (Van der Arend, 2007: $27 \mathrm{ff}$ ). 
Looking more closely, we found an interesting regularity in the moments where the Ministry of the Interior intervened on a large scale in the practices of local governments contrasted with periods where it abstained from such activities. These periods of approximately three years seem to alternate, which can be explained by the tension between the necessity to correct defects in local government and the doctrine of local autonomy, professed by the Ministry. The coincidental pattern of alternation could be regarded as a rather elegant way to tackle this dilemma.

\section{Comparison with other domains of policy making}

In the next chapters (11 to 13), the available relevant literature has been analysed to find indications of a possible shift from government to governance in three different domains adjacent to Internal Affairs:

- politicians in parliament,

- a spending department: in case Agriculture and

- local government, the natural grass root-supporters of the Ministry.

Unlike the research on the cases in the Ministry of the Interior, these comparative studies are merely based on the available literature.

\section{Domain politicians in parliament}

Politicians whose ideas are described here are divided between those observant politicians reflecting on their particular profession and the members of the parliamentary commission on Internal affairs, taking a specific stand on the issues the Ministry dealt with.

The memoirs and other documents about the first group (notably Jeekel, 1998; Enthoven, 2011) revealed that in general the culture in parliament was less open and innovative than in the Ministries.

The second group tended to ask the Ministry to be even stricter, in a vertical government sense. Especially when it came to participative forms of democracy, the interaction between the Ministry and parliament appears to have been quite touchy (Schrijver and Van Zuylen, 2010). Quite a few promises made by the Ministry to elaborate on this subject were never realized, but parliament did not come back to it.

\section{Domain spending department: in case Agriculture}

The Ministry of Agriculture was selected for comparison, because so many academic studies have been devoted to this Ministry (Hoetjes, 1993; Frouws, 1993: Termeer, 1993, Bekke e.a., 1994; Wielinga, 2001; Kickert \& Van der Meer, 2007). It is interesting to see that the history of this Ministry has been so different compared to the Ministry of the Interior. After World War II, Agriculture was a network organisation, firmly related to one sector of the economy: farmers and fishermen. In the eighties this politically uneasy coalition came in a crisis when the minister covered up a fishermen's fraud too long. The minister had to resign and the Ministry experienced a somersault ('salto mortale', Bekke, 1994). New ministers brought the organisation back on track, opening up relationships with environmentalists and focusing on food safety and sustainability. More crises had to be overcome, like a manure problem and an epidemic of pig disease.

Although some interesting innovations started in this Ministry, like the Innovation Network Agribusiness and the Agency to service land and water-management, working on integrated landscaping, the Ministry's policy center in The Hague soon felt the pressure of the political process in a mediatised environment. Civil servants reported the restored discipline of hierarchy after 2000 (Kickert \& Van der Meer, 2007). Wielinga (2000) describes a communicative (governance) paradigm from 1995 only as underflow behind the mainstream 'strategic' (power-struggle) paradigm. In the end, the whole Ministry was discarded and taken over by the Ministry of Economic Affairs.

\section{Domain local government}


About Dutch local government in the last 50 years a large number of studies is available (Gerritsen, 2011; De Boer en Van der Lans, 2011; Abma, 2012 Korsten, 2012). Apart from some general studies describing overall tendencies, many descriptions of new experiments can be found in recent literature (Tops et al., 1996; Denters et al., 19989 Hendriks \& Drosterij, eds, 2012). The general descriptions either virtually ignore tendencies in the social context of mutual interdependence and uncertainties for local government, or overenthusiastically state that there is no alternative for local government than negotiating its way to co-productive decision making (Doolaard in Beckmann \& Hoekema eds., 1987: 12).

From the many publications on specific municipalities engaging into experimental practices, it may be deduced that at least part of local government has been taking advantage of alternative methods of network governance. However, the general picture of all municipalities in the Netherlands is far from an overall application of interactive government throughout the organisation (Boogers \& Tops, 1998; Pröpper \& Kessens, 2005; Abma, 2012; Korsten, 2012). Many municipalities keep presenting themselves as rather autocratic and self-contained.

Our conclusion is that local government has gradually become very diverse, with some progressive forerunners, a larger section of pioneering experimenters and the peloton lagging behind. The diversity between local governments may have increased during the last forty years, starting with the standardised municipality, as Internal Affairs had molded it, and finally showing individual approaches of local problem solving, whereas in the same period Central government became more homogeneous. Nowadays the Dutch central government calls itself 'concern Rijk' with one logo, merging many staff functions in one single Central agency. The practice of policy making in the core offices in The Hague has become more integrated, since processes are all guided by mass-media and populist politics.

\section{Conclusive reflections}

In concluding, what possible explanations can we suggest to explain the fact that the policy theory Internal Affairs actually did not change to the extent academics in the field have predicted. There have been three possible explanations for the fact that 'the shift' did not happen? Following Kreitner and Kinicki (2008: 562), we distinguish between two internal factors (organisational relations, leadership and human resources) and external factors (like economic development and political power).

Organisation theory often finds conserving tendencies in the managing core compared to the more dynamic fringe processes of field workers in the organisation (Stacey, 1996). Our investigations in Internal Affairs, suggested that here leadership is relatively weak, leaving field workers freedom to experiment, but bringing little cohesiveness and sustainability in the activities.

Explanations about human relations stress the effects of an auto-selection process for types of civil servants, possibly more inclined to risk avoidance and diligence towards the minister (Pauka, 2001). In the Ministry of the Interior, this last explanation is not corroborated by the facts.

Power based explanations look for interest groups who benefit from keeping positions as they are. Docters van Leeuwen (Raad openbaar bestuur, 2003) ascribes the conserving tendencies in the polity- theory to power pressures. Moreover, the centripetal effects of the Risk society (Tommel, 2010) and a harsher political culture (Bestuurskunde, 2013, nr. 4) are pointing in the same direction.

The chapters 11 to 13 have pointed out that Internal Affairs has not been diverging from other domains of policy making, because it was more submissive to the legislative process. This study even suggests that the opportunities to switch to a governance paradigm were limited. So, would alternative policies have been feasible? The Ministry has not been protected from serious problems of effectiveness by ignoring strong contextual tendencies in society. If not by changing topics and objectives, the Ministry could at least have adjusted its methods in a complex environment that demands responsiveness to multiple actors and different perspectives. Two recent examples illustrate what went wrong here: the program 'Different Government' (Andere overheid) and the project 'Big middle tier of government' (Middenbestuur) could have benefited from another 
bottom-up approach, the use of which was even advised to the Ministry at the time. Of course it is difficult to prove afterwards that these projects would have successful if they had tried a governance mode of conduct, but it is suggested that adaptation of the polity-theory to the circumstances of times is prerequisite for any success in policy making.

At the same time, a peculiar conclusion imposes itself from the facts presented here. On the one hand, social developments seem to demand (post-)modern ways of conduct, while on the other hand political conditions seem to prevent acting that way. Scientists of public administration (exceptions excluded) may have ignored that even stronger forces (notably mediatised politics) were exerted to prevent the shift from government to governance from happening. In that case our study ends with the conclusion that the choices by Internal Affairs were not so disconnected as seemed at first sight, although its inability to find a suitable polity-theory remains a substantial drawback in the decades we explored.

At the same time, the expectation of a shift from government to governance was based on existent fundamental changes in society like individuation and fragmentation. These developments exerted real challenges to an agile public administration. Obviously our political system and human society had trouble in keeping pace with the level of complexity required by these developments, which indicates a real impasse in present-day public administration. 


\section{BIJLAGE 1}

\section{Lijst van geïnterviewde personen}

\begin{tabular}{|c|c|c|c|}
\hline Naam & Functie (hier relevant) & Datum & Plaats \\
\hline Simon Bakker & Beleidsmedew. IB/GSB & $30-08-2007$ & Den Haag \\
\hline Marbeth Bierman & Dir. IBI & $17-07-2007$ & Heemstede \\
\hline \multicolumn{4}{|c|}{ Voorz. Werkgr. Procesmanagement } \\
\hline Hessel Boerboom & Hoofd Afd. FO (BFO) & 09-08-2007 & Den Haag \\
\hline Frans van Bork & $\begin{array}{l}\text { Beleidsmedew. CB } \\
\text { Secr. Agenda Overleg }\end{array}$ & $21-08-2007$ & Den Haag \\
\hline Wouter Bringmann & Co-projectleider Soc. Vern. & 06-09-2007 & Den Haag \\
\hline Elco Brinkman & DG Binnenlands Bestuur & 07-09-2007 & Zoetermeer \\
\hline \multicolumn{4}{|c|}{ Secr. Werkgroep Compl. Bestuur } \\
\hline Ger Ebbeling & Directeur Minderheden CRM & 09-01-2008 & Delft \\
\hline Bart Fokkens & Beleidsmedew. IB & 01-08-2007 & Den Haag \\
\hline Martin van Haeften & Projectleider Nat. Conventie & $16-07-2007$ & Den Haag \\
\hline Leon van Halder & Directeur GSIB, DGKB & 09-02-2009 & Den Haag \\
\hline Jan Hendrikx & DG Openbaar Bestuur & 02-08-2007 & Zwolle \\
\hline Johan Hoff & $\begin{array}{l}\text { Hoofd Bur. Bijz. Adviezen } \\
\text { Projectleider BBI }\end{array}$ & 24-07-2007 & Den Haag \\
\hline Gerard Houterman & $\begin{array}{l}\text { leider VBO } \\
\text { eam GSB }\end{array}$ & 02-08-2007 & Utrecht \\
\hline Han Kapsenberg & $\begin{array}{l}\text { Plv. dir. DCM, } \\
\text { Plv. dir. Bestuurszaken, }\end{array}$ & 09-06-2008 & Amsterdam \\
\hline Tom Keek & Beleidsmedewerker Afd. IB & $16-08-2007$ & Den Haag \\
\hline Meine Henk Klijnsma & Secretaris Cie Elzinga & $26-07-2007$ & Den Haag \\
\hline Jan Krapels & Secretaris Stafbureau DGBB & $17-08-2007$ & Den Haag \\
\hline \multirow[t]{2}{*}{ Frank van Kuik } & nedew. DCM & 01-08-2007 & Den Haag \\
\hline & Beleidsmedew. DIBI & $10-09-2007$ & Den Haag \\
\hline Grada Lautenbach & Beleidsmedew. IB & $16-08-2007$ & Den Haag \\
\hline Tom Leeuwestein & Projectleider Eur. Stedenbeleid & $31-07-2007$ & Den Haag \\
\hline Lute v.d. Linde & Plv. dir. DCM & $23-07-2007$ & Den Haag \\
\hline Marie-Louise v. Muijen & $\begin{array}{l}\text { Projectleider BANS, } \\
\text { Hoofd Afd. IB }\end{array}$ & $27-07-2007$ & Den Haag \\
\hline Jiska Nijenhuis & Projectleider Single Audit & 06-09-2007 & Den Haag \\
\hline Floris Plate & Directeur CB & 04-09-2007 & Den Haag \\
\hline Berend van der Ploeg & Hfd Afd. IB & $11-09-2007$ & Den Haag \\
\hline Maarten Prinsen & Projectleider Democratie & 07-08-2007 & Den Haag \\
\hline Jan van Schagen & Projectleider Burgerforum & $12-09-2007$ & Den Haag \\
\hline Herman Schartman & Directeur GSIB & $15-08-2007$ & Den Haag \\
\hline Ciska Scheidel & Secretaris BANS & $31-07-2007$ & Den Haag \\
\hline Jeroen den Uyl & Beleidsmedew. IB & $06-08-2007$ & Amsterdam \\
\hline Roel in 't Veld & Lid Werkgroep Compl. Bestuur & $24-08-2007$ & Den Haag \\
\hline Marjolein Vermeeren & Projectleider Ketenregie & $25-07-2007$ & Den Haag \\
\hline
\end{tabular}


Lodewijk van Vliet

Arie Jan Vos

Govert van Wesel

Eduard de Wilde

Hans Wilmink

Jan de Winter

Pien Zaaijer

Harry van Zon
Projectleider Soc. Vernieuwing 30-07-2007 Hoofd Afdeling CB

20-08-2007

06-09-2007

Specialist zbo's

Beleidsmedew. Best. Organisatie 08-08-2007

Co-projectleider Soc. Vern.

07-08-2007

Projectleider zbo's

Projectleider Decentralisatie

31-08-2007

19-07-2007

Projectleider VBO

Secretaris Commissie-Wiegel

Directeur IOS

21-08-2007

Projectleider GBA

Voorzitter Ambtel. regiegr. DI
Den Haag

Den Haag

Den Haag

Den Haag

Den Haag

Den Haag

Den Haag

Den Haag 


\section{BIJLAGE 2}

\section{Opzet interviews bij verhalen over bestuursbeleid}

Naam:

Tijdstip: $\quad$ Plaats:

Doel: Bijdrage aan casestudies op het terrein van bestuursbeleid t.b.v. bestuurskundig proefschrift over adaptieve beleidsvormingsprocessen in een complexe omgeving.

U bent belangrijke informant i.v.m. sleutelrol bij 1 of meer van de cases.

Gesprek zal ongeveer anderhalf uur duren, geluidsopname louter voor eigen gebruik, informatie wordt niet als quote weergegeven, tenzij met uitdrukkelijke toestemming.

Focus:

Welke factoren zorgen in een veranderende omgeving voor de vitaliteit van het bestuursbeleid, dat wordt gedefinieerd als 'bijdragen aan goed bestuur'? Hoe wordt geleerd van eerdere ervaringen om effectief te zijn met beleid dat ertoe doet? Mijn interesse gaat uit naar de spanning tussen dynamiek, ontwikkeling en vernieuwing enerzijds, en de kracht en beperkingen van een gevestigde (politieke) organisatie anderzijds (slagkracht, positie, keurslijf, fixatie). De noodzaak van lerende, adaptieve ontwikkeling van beleid en organisatie is voor mij een gegeven in deze dynamische tijd en bij dit complexe onderwerp.

Operationalisering:

Vitale $=$ lerende, adaptieve organisatie

1. opwaartse spiraal

- $\quad$ draagt bij aan differentie, gevarieerde praktijken, netwerken en referentiekader;

- $\quad$ van het een komt het ander; wat men aanpakt heeft behalve rechtstreeks (beoogd?) resultaat, ook altijd spin-off effect: leren over de werkelijkheid, nieuwe ideeën;

- $\quad$ contacten met de omgeving leveren informatie dicht bij de bron, over enerzijds bruikbare aanpakken, werkwijzen en instrumenten en anderzijds actuele contingente issues die kansrijk zijn voor de politieke agenda;

2. toets voor maatschappelijk belang, relevantie (geen dynamiek als zodanig, maar wie zit erop te wachten?)

- $\quad$ top-down: politieke steun

- $\quad$ bottom-up: door de 'klanten' gewenst (gemeenten? stakeholders?)

- $\quad$ succesvol, resultaat, scoort.

Dus Variabelen:

Adaptief of niet, lerend van verleden, bron voor de toekomst, dedifferentiatie of differentiatie, netwerkverbreding, rol van toeval en avontuur, omgevingsgerichtheid, samenwerkingsgerichtheid, flexibiliteit, relevante steun, synergie, resultaat als target of als uitkomst van proces, vernieuwingsgehalte, gebondenheid aan gevestigde belangen, invloed politiek, politici, 
volksvertegenwoordiging, spanning met veld en andere stakeholders, werkelijkheidsgehalte, overeenkomstig de tijdgeest of anticyclisch?

Vraagstelling in interview bij verhalen over dynamische organisatieontwikkeling bij bestuursbeleid van het ministerie van Binnenlandse Zaken

1. Het gaat me om onderwerp in de episode waarbij u betrokken was als...

- Hoe kijkt u daarop in hoofdlijnen terug?

- Wat voor gevoel krijgt u erbij?

- Wat is u het meest bijgebleven?

- Wat hebt u ervan geleerd?

- Wat was het leidende idee vanuit het beleid?

- Kende dit project volgens u een doorbraak?

- Wat was echt nieuw?

- Hebt u ergens een eyeopener ervaren?

- Was het project een succes?

- Kon u dat succes herleiden aan een bepaald idee achter het project?

- Misschien succes niet in het direct beoogde resultaat, maar indirect door neveneffecten?

- Kon u succes afmeten aan politieke steun?

- Werd het belang van het project erkend door de klanten, afnemers, stakeholders?

- Wat zou u nu achteraf anders doen?

- Leverde dit traject duurzame versterking op van de positie van Binnenlandse Zaken?

- In hoeverre was het een product van zijn tijd?

2. Relaties

- Welke relaties zijn voor het project van belang geweest? (....... Positief?)

- Waren er ook belemmerende relaties?

- $\quad$ Aan welke ontbrekende relaties had u behoefte?

- Welke nieuwe typen relaties zijn gecreëerd dankzij het project?

- Welke relaties zijn bewust uitgesloten?

- Hoe liepen relaties met de politiek (actieve steun, weerstand, onverschilligheid)?

- $\quad$ Relaties met bazen in de lijn?

- $\quad$ Relaties met het veld?

- Voldeed het beleid/idee aan behoefte daar, of was er weerstand?

- Hoe waren de relaties met andere directies?

- Met andere departementen?

- Wat was het belang van informele relaties, netwerken, klankborders?

- Is het relatienetwerk van Binnenlandse Zaken duurzaam verruimd? 


\section{BIJLAGE 3}

\section{Lijst van afkortingen}

$A B D$

$A B P$

ALB

ARB

ARD

AZ

BANS

B\&W

BB

$\mathrm{BBI}$

BFO

BIBIT

$\mathrm{BiZa}$

BON

BVK

BZK

CB

CDA

CdK

CPA

CPB

CRM

CUMI (nota)

DB

DCB

DCIM

DCM

DG

DGBK

DGKB

DRI

DG

EU

EZ

FAMO

\section{FEZ}

Fin

FOBB

FV

G4, G15, G21 enz.

GAll

GBA

GSB

GSIB

HSL

IBP

ICBB

ICES

ICM

ICT

IMI

IND
Algemene Bestuursdienst

'Aanjagen, laten Beklijven en Pleite' (werkwijze van IB)

Actieprogramma Lokaal Bestuur

Adviesunit Resultaatgericht Beleid

Adviescommissie (Reorganisatie) Rijksdienst

(Ministerie van) Algemene Zaken

Bestuursakkoord Nieuwe Stijl

(Afdeling) Bestuur en Wetgeving

(Directie) Binnenlands Bestuur

Beleids- en beheersinstrumentarium

(Directie) Bestuurlijke en Financiële Organisatie

(Afdeling) Bevordering Interbestuurlijke Informatica Toepassingen

(Ministerie van) Binnenlandse Zaken

Bestuur op Niveau

(Minister van) Bestuurlijke Vernieuwing en Koninkrijksrelaties

(Ministerie van) Binnenlandse Zaken en Koninkrijksrelaties

(Directie, later: Afdeling) Coördinatie Bestuursbeleid

Christen-Democratisch Appel

Commissaris der Koningin

Centrale Persoonsadministratie

Centraal Planbureau

(Ministerie van) Cultuur, Recreatie en Maatschappelijk werk

(Nota) Culturele Minderheden

Directie Bestuurszaken

Directie Coördinatie Bestuursbeleid

Directie Coördinatie en Integratie Minderhedenbeleid

Directie Coördinatie Minderhedenbeleid

Directeur-Generaal

Directoraat-Generaal Bestuur en Koninkrijksrelaties

Directoraat-Generaal Koninkrijksrelaties en Bestuur

Directie Dienstverlening, Regeldrukvermindering en Informatiebeleid

Directeur-Generaal

Europese Unie

(Ministerie van) Economische Zaken

Federatie van Algemene Middelenmanagers bij de Overheid

Directie Financieel-Economische Zaken

(Ministerie van) Financiën

(Afdeling) Financiële Organisatie Binnenlands Bestuur

(Afdeling) Financiële Verhouding(en)en

Grote steden (aantal) erkend als deelnemers in het grotestedenbeleid

(Beroepsopleiding) Gemeenteambtenaar diploma hoogste niveau

Gemeenschappelijke (of Gemeentelijke) Bevolkingsadministratie

Grote Stedenbeleid

(Directie) Grotestedenbeleid en Interbestuurlijke Betrekkingen

Hoge Snelheids Lijn

Interbestuurlijke Begeleidingscommissie Privatisering

Interdepartementale Commissie Binnenlands Bestuur

Interdepartementale Commissie Economische Structuurversterking

Interdepartementale Coördinatiecommissie Minderhedenbeleid

Informatie- en Communicatietechnologie

Instituut voor Maatschappelijke Innovatie

Immigratie- en Naturalisatie Dienst 


\begin{tabular}{|c|c|}
\hline IOS & (Directie) Informatiebeleid Openbare Sector \\
\hline IPO & Interprovinciaal Overleg \\
\hline IULA & International Union of Local Authorities \\
\hline IWP & Interdepartementale Werkgroep Privatisering \\
\hline KABNA & Kabinet der Nederlandse Antillen \\
\hline KING & Kwaliteits Instituut Nederlandse Gemeenten \\
\hline LNV & (Ministerie van) Landbouw, Natuurbeleid en Visserij \\
\hline LSA & Landelijk Samenwerkingsverband Aandachtswijken \\
\hline MITACO & Ministeriële Commissie Taakverdeling en Coördinatie \\
\hline MKB & Midden- en Kleinbedrijf \\
\hline MOP's & Meerjaren ontwikkelingsplannen (Grotestedenbeleid) \\
\hline MOS & (Directoraat-Generaal) Management en Personeelsbeleid Openbare Sector \\
\hline MVO & Maatschappelijk Verantwoord Ondernemen \\
\hline Nivra & Nederlands Instituut van Registeraccountants \\
\hline NSOB & Nederlandse School voor Openbaar Bestuur \\
\hline O\&A & (Directie) Organisatie en Automatisering \\
\hline O\&W & (Ministerie van) Onderwijs en Wetenschappen \\
\hline OBD & (Directie) Openbaar Bestuur en Democratie \\
\hline OESO & Organisatie voor Economische Samenwerking en Ontwikkeling \\
\hline OFA & Overleg Fysieke Aangelegenheden \\
\hline OGA & Operationele Gebiedsaanwijzing \\
\hline OKR & (Afdeling) Organisatie en Kwaliteit Rijksdienst \\
\hline OL2000 & Overheidsloket 2000 \\
\hline OPS & Ondernemings Platform Stedelijke vernieuwing \\
\hline OSCA & Overleg Sociaal-culturele aangelegenheden \\
\hline OSEA & Overleg Sociaal-economische aangelegenheden \\
\hline PCG & Probleemcumulatiegebiedenbeleid \\
\hline PKB & Programmadirectie Krachtig Bestuur \\
\hline POIR & (Directie) Personeel, Organisatie en Informatievoorziening Rijksdienst \\
\hline PvdA & Partij van de Arbeid \\
\hline RBB & Raad voor het binnenlands bestuur \\
\hline $\mathrm{RCC}$ & Rijkscomputercentrum \\
\hline ROA & Regionaal Orgaan Amsterdam \\
\hline $\mathrm{ROB}$ & Raad voor het openbaar bestuur \\
\hline SCO & Servicecentra voor de overheid \\
\hline SDU & Staatsdrukkerij en Uitgeverij \\
\hline SER & Sociaal-Economische Raad \\
\hline SG & Secretaris-Generaal \\
\hline iaS & \\
\hline SKO & Strategische Kennisontwikkeling \\
\hline SMART & Specific, Measurable, Achievable, Realistic and Timely \\
\hline SOAG & $\begin{array}{l}\text { Samenwerkingsverband voor de Overkoepeling van de Automatisering bij } \\
\text { de Gemeenten }\end{array}$ \\
\hline SZW & (Ministerie van) Sociale Zaken en Werkgelegenheid \\
\hline UvA & Universiteit van Amsterdam \\
\hline V\&W & (Ministerie van) Verkeer en Waterstaat \\
\hline VBO & Vernieuwing Bestuurlijke Organisatie \\
\hline VBTB & Van Beleidsbegroting Tot Beleidsverantwoording \\
\hline Vinex & Vierde Nota (Ruimtelijke Ordening) Extra \\
\hline VNG & Vereniging van Nederlandse Gemeenten \\
\hline VNO & Vereniging van Nederlandse Ondernemingen \\
\hline VRO & (Ministerie van) Volkshuisvesting en Ruimtelijke ordening \\
\hline VROM & (Ministerie van) Volkshuisvesting, Ruimtelijke ordening en Milieubeheer \\
\hline VU & Vrije Universiteit \\
\hline VVD & Volkspartij voor Vrijheid en Democratie \\
\hline VWS & (Ministerie van) Volksgezondheid, Welzijn en Sport \\
\hline WGR & Wet gemeenschappelijke regelingen \\
\hline WRR & Wetenschappelijke Raad voor het Regeringsbeleid \\
\hline WVC & (Ministerie van) Welzijn, Volksgezondheid en Cultuur \\
\hline XPIN & Expertisebureau Innovatieve Beleidsvorming \\
\hline zbo & Zelfstandig bestuursorgaan \\
\hline
\end{tabular}




\section{Curriculum vitae}

Jan Schrijver werd in 1949 in Utrecht geboren, waar hij vanaf 1961 de gymnasium bèta-opleiding volgde en in 1967 voltooide. Hij studeerde aansluitend aan de Universiteit van Amsterdam en behaalde daar zijn doctoraalexamen Nederlands recht in 1975 en het doctoraalexamen Politieke en sociale wetenschappen in 1976.

Vanaf 1976 werkte hij in verschillende functies bij het ministerie van Binnenlandse Zaken, altijd aan de vernieuwing van het openbaar bestuur. Het eerste deel van zijn loopbaan was hij vooral belast met het opzetten van decentralisatiebeleid.

Vanaf eind jaren negentig was zijn werkterrein vooral de verhouding tussen overheid en samenleving. In dat verband was hij medeoprichter van het interdepartementale Expertisebureau voor Innovatieve beleidsvorming XPIN, waar hij tweede man werd.

$\mathrm{Na}$ terugkeer binnen het ministerie verdeelde Schrijver van 2005-2013 zijn activiteiten over twee domeinen: beleidsmedewerker bij verschillende projecten betreffende participatieve democratie (laatstelijk het thema doe-democratie) en gedetacheerd gastdocent bij zijn alma mater, de afdeling politicologie van de Universiteit van Amsterdam. In die periode noemde hij zich Verkenner van governance.

Hij publiceerde veel artikelen en boekhoofdstukken waarvan de meeste in de literatuurlijst hiervoor vermeld zijn.

Binnen het ministerie waren zijn belangrijkste bijdragen gewijd aan de volgende projecten:

- Meerjarenplanning bij gemeenten en provincies;

- Decentralisatienota en Decentralisatieplan;

- Project D'gemeenten en D'provincies;

- Decentralisatie-impuls;

- Rapport van de werkgroep Procesmanagement;

- Samenwerking en studium generale van de directeuren Strategisch Omgevingsbeleid;

- De internationale conferentie Borders to Cross I en II;

- De Nationale Conventie;

- Voorbereiding van een nieuw beleidsonderdeel voor Democratie en burgerschap;

- De kabinetsnota Doe-democratie.

Sinds 1973 getrouwd met Klaske Wijkstra. Zij hebben drie kinderen. 


\section{Valorisatie}

Artikel 23 van het Promotiereglement van de Universiteit van Maastricht vraagt om een valorisatie van de studie. Deze behoort gericht te zijn op een bezinning ten aanzien van het maatschappelijk, bestuurlijk en eventueel economisch nut of - voorzichtiger - de betekenis van het onderzoek. Het universiteitsbestuur neemt heden ten dage, onder invloed van discussies bij regering en parlement, geen genoegen meer met kennis omwille van de kennis, met onderzoek als l'art pour l'art, maar vraagt naar reflectie op eventueel nut voor openbaar bestuur en samenleving in meest brede zin. Deze beschouwing biedt een poging hiertoe.

Hierna zal eerst een korte samenvatting van het onderzoek worden gepresenteerd, waarin al aanzetten ten aanzien van de praktische betekenis te vinden zijn. Vervolgens komen enkele praktische toepassingsmogelijkheden voor drie verschillende doelgroepen aan de orde. Ten slotte volgt nog een aanduiding van het innovatief gehalte van het onderzoek.

\section{'De omwenteling die niet kwam'}

In deze studie is een uitgebreide verkenning gedaan naar veertig jaar bestuursbeleid van het ministerie van Binnenlandse Zaken en wel in de periode 1969-2009. Bestuursbeleid slaat op de inspanningen vanuit het ministerie om de inrichting en werking van het openbaar bestuur naar 'eisen van de tijd' te beïnvloeden. Het begin van een dergelijk beleid dateert in systematische vorm van ongeveer 1969. Het onderzoek dat van die veertig jaar verslag doet, is om praktische redenen in 2009 afgesloten.

Bij de bestudering van dit bestuursbeleid is vooral gezocht naar de zogeheten bestuurstheorie. Een dergelijke theorie wordt omschreven als het geheel van - al dan niet expliciet gemaakte veronderstellingen achter het (extern gericht) overheidsbeleid dat betrekking heeft op de relaties tussen overheid en samenleving. De aanname is dat er achter afzonderlijke vormen van overheidsbeleid een algemenere bestuurstheorie schuilgaat. Maar als dit verondersteld wordt, hoelang blijft eenzelfde visie op de relatie tussen overheid en samenleving houdbaar en hoelang blijft die visie desondanks voortbestaan?

Voorstelbaar is dat opeenvolgende bewindslieden van Binnenlandse Zaken projecten van eerdere ministers of in het ministerie ontwikkelde projecten erven en doorzetten ter wille van 'betrouwbaar bestuur' of aanpassen. Maar het is ook denkbaar dat bewindslieden na elke kabinetsformatie met eigen - nieuwe - voornemens komen (policy innovation) en de overige doorontwikkelen (policy succession), onmiddellijk stoppen (policy termination), gedeeltelijk of geheel afbouwen (phasing out) of negeren of ongemoeid laten (maintenance). Daarbij moet worden beseft dat ook vanuit het departement zelf thema's op de agenda worden gezet en voorstellen worden gedaan. We zouden dus een dynamische beleidsontwikkeling verwachten, maar is deze ook ingebed in een stelselmatig ontwikkelde, aan de praktijk getoetste visie op bestuur en samenleving, die ook gelijke tred houdt met inzichten in de wetenschap?

Om deze bestuurstheorie op het spoor te komen, is niet aansluiting gezocht bij de oude staatsleer van 'Thorbecke', maar is gekozen voor een actuelere aansluiting, namelijk bij een al sinds de jaren negentig veel gehoorde stelling in de nationale en internationale bestuurskunde dat er sprake zou zijn van een shift van government naar governance. Daarmee wordt gedoeld op een door maatschappelijke en bestuurlijke omstandigheden aangewezen noodzaak om steeds meer klassieke verticale en hiërarchische verhoudingen vanuit politiek gelegitimeerde 'instructies' (command and control) te verlaten en over te stappen op een meer open, verkennende bestuursstijl, gericht op samenwerking met vele betrokkenen binnen en buiten het openbaar 
bestuur. We kunnen spreken van een omwenteling van (meer) hiërarchisch bestuur naar (meer) deliberatief netwerkbestuur. Planning en controle versus interactie en verbinding. De vraag werd dus: bestaat er een bestuursbeleid bij het ministerie in de periode van onderzoek, en gaat achter een dergelijk bestuursbeleid een omwenteling (lees: verschuiving) van government naar governance schuil? Komt governance als dominante bestuurstheorie in de plaats van een government-gerichte oriëntatie of is slechts sprake van voorzichtige of ontbrekende pogingen? Men moet 'in de plaats komen' niet zo opvatten dat alle vormen van hiërarchisch bestuur worden uitgebannen. Dat zou onmogelijk zijn in ons vergaand gereguleerde land. En dat is ook onnodig bij de vele relatief eenvoudige routinetaken van de overheid. Het gaat om het verleggen van het hoofdaccent, vooral in het bestuursbeleid. Welke opgaven stellen het bestuur voor zodanige uitdagingen dat het moederdepartement een handje moet helpen? Welke maatschappelijke problemen (doorgaans de complexe, wicked problems met veel onzekerheid en afhankelijkheden) maken de relatie tussen overheid en samenleving tot een avontuur? En richt het ministerie daar ook zijn beleidsaandacht op?

Hoe systematisch en expliciet was de bestuurstheorie van het ministerie en zijn bondgenoten - uit onder andere de wereld van gemeenten, provincies en waterschappen - eigenlijk gedurende de onderzoeksperiode 1969-2009? Werd stelselmatig geleerd van ervaringen in het beleid en uit contacten met de omgeving van de overheid en leidde dit tot een cumulatief leereffect, zodat de beleidsinterventies trefzeker en bij de tijd konden blijven? Voor het beantwoorden van deze laatste vraag was het van belang om goed te kijken naar de wijze waarop het ministerie zijn informatie vergaart en naar het gebruik van evaluaties van beleidsprojecten. Maar ook uit de opeenvolging van projecten en uit de mate waarin nieuwe initiatieven voortbouwden op voorafgaande beleidservaringen kon veel worden afgeleid over de bestuurlijke lijn ('if any') en de invloed van relevante omgevingsfactoren op een groeiende beleidsvisie, in casu bestuurstheorie.

Voor de beantwoording van de eerste gestelde vraag over de inhoud van de bestuurstheorie, in het licht van het postulaat uit de bestuurskunde over government en governance, is een eigen variant van discoursanalyse ontwikkeld. Deze variant bouwt voort op de werkwijze van Hajer (1995) en Dicke (2001), die beleid typeren op basis van verhaallijnen (storylines). 'Discours' is in dit onderzoek gedefinieerd als de typering van taaluitingen en praktijken binnen een vooraf geconstrueerde dichotomie van denkwijzen, waarmee betekenis wordt verleend aan het handelen van beleidsmakers. De genoemde dichotomie is in dit onderzoek de tegenstelling tussen government en governance.

Van belang is verder dat niet alleen taaluitingen bij de reconstructie van 'de werkelijkheid' bepalend waren, maar ook praktijken en feitelijke omstandigheden. Wat betreft de taaluitingen is, behalve van een veelheid van beleidsdocumenten, gebruikgemaakt van interviews met sleutelfiguren in toonaangevende projecten van het bestuursbeleid. Deze projecten vormen niet een willekeurige steekproef uit veertig jaar bestuursbeleid, maar gepoogd is alle projecten te beschrijven die een substantiële vernieuwing in het beleid van Binnenlandse Zaken introduceerden $(\mathrm{N}=24)$. De verhalen door de sleutelfiguren ('helden' genoemd) konden worden getypeerd als meer of minder government- en governance-georiënteerd. In combinatie met de verdere lotgevallen van de projecten kon een voorkeursoriëntatie van het ministerie als geheel worden gereconstrueerd. Als in een bepaalde periode meer dan de helft van de projecten zou 'verschieten van kleur' en dit bovendien in de volgende periode zou beklijven, in de zin van institutionalisering in beleid en organisatie, dan zou sprake zijn van een shift van government naar governance.

Wat bleek? Een dergelijke omslag bleek zich gedurende de onderzoeksperiode niet voor te doen. Niet omdat er geen projecten waren die als deliberatief netwerkbestuur (governance) getypeerd konden worden, maar vooral omdat deze (circa een derde van de populatie aan projecten) op het ministerie niet beklijfden. Denk daarbij aan sociale vernieuwing, Bedrijfsbetrokkenheid, Decentralisatie met beleid, Differentiatie tussen gemeenten, Procesmanagement en Interactief 
bestuur, en Ketenregie. Dit waren projecten die pasten in een governance-gerichtheid. Daarentegen waren de projecten van het type government juist nogal hardnekkig. Zozeer dat zij vaak voortgezet werden zonder dat zij veel invloed ondervonden van de gewijzigde tijdsomstandigheden. Denk aan de Reorganisaties van het middenbestuur, Offensief decentralisatiebeleid, Sanering van specifieke uitkeringen, Bestuursakkoorden met VNG en IPO en de Aanpak van de rijksdienst (reorganisatie rijksdienst).

De studie laat zien dat van een systematisch doorontwikkelde bestuurstheorie in departementaal handelen ten aanzien van het openbaar bestuur nauwelijks sprake was, wel van vasthouden aan opvattingen die in de jaren zeventig al waren ontwikkeld.

Ook het gebruik van evaluaties in het bestuursbeleid is tekenend. Deze blijken vrijwel uitsluitend te zijn gehouden bij de (weinige) succesvolle projecten. Dat falende projecten niet zijn geëvalueerd, zegt dat het opdoen van leerervaringen blijkbaar in de onderzochte periode van veertig jaar niet de belangrijkste drijfveer was voor evalueren op het vlak van bestuursbeleid. Daarbij is aan te tekenen dat de evaluatie zelden gericht was op de eigen werkwijze van het ministerie, maar alleen op de effecten bij andere organisaties.

Het hier gehanteerde postulaat, dat ontleend is aan de bestuurskunde, over een eventuele shift werd ook nog verkend in aanpalende bestuursarena's, namelijk de Tweede Kamer, een vakdepartement (Landbouw) en het lokaal bestuur. Was daar wel sprake van een omwenteling? Ook daar werd de omwenteling, individuele uitschieters daargelaten, over het algemeen niet aangetroffen. Alleen in de laatste categorie, die van de gemeenten, is beweging zichtbaar in de aangegeven richting van deliberatief netwerkbestuur; althans bij een voorhoede van de gemeenten, lang niet bij allemaal. De indruk bestaat volgens de auteur dat de gemeenten een grotere verscheidenheid is gaan vertonen en dat de rijksministeries juist meer op elkaar zijn gaan lijken.

In de studie is gezocht naar mogelijke verklaringen van het uitblijven van 'de omwenteling' (in het bestuursbeleid uit de periode 1969-2009) en daarmee verbonden bevindingen. Hiervoor zijn voor de rijksoverheid zowel interne als externe factoren verkend. Een factor is het denken in termen van het politiek primaat en niet los kunnen laten ter wille van constitutie en productiviteit van netwerken van actoren. Maar deze factor verklaart maar beperkt. De belangrijkste reden waarom in de rijksoverheid als geheel de aanzetten naar deliberatief netwerkbestuur, die er (vooral vlak voor de eeuwwisseling) wel degelijk waren, niet op brede schaal zijn doorgezet, wordt door de auteur niet zozeer gezocht in de houding en opvattingen van departementsambtenaren, maar meer geweten aan externe tendensen die zich gelijktijdig met de bekende trends van individualisering, fragmentering in de samenleving voordeden: populisme, de 'risk-society' en mediacratie. De wederzijdse omstrengeling van media en politiek (mediacratie) leidde frequent tot een verkrampte houding van risicomijding, waarbij de overheid 'zijn verantwoordelijkheid moest tonen' en dat ook deed door middel van wat door de WRR wel betiteld is als de risicoregelreflex. Naast alle bekende ontwikkelingen die horen bij de genoemde trends, waaronder mondiger en beter opgeleide burgers, is op te merken dat niet voldaan is aan een voorwaarde voor netwerkbestuur (governance), namelijk dat de samenleving wijzer en bezonkener is geworden. Het gevolg hiervan kan - ceteris paribus - zijn dat het van een echte omwenteling voorlopig ook nog niet zal komen.

De uitkomsten van dit onderzoek betekenen ook iets voor de bestuurskunde, waarvan vele vertegenwoordigers immers de stelling over de op handen zijnde omwenteling richting governance hebben verdedigd. In deze studie wordt aanbevolen dat de bestuurskunde meer kennis over de maatschappij zou moeten incorporeren om dergelijke uitspraken over de verhouding tussen overheid en samenleving in de toekomst onderbouwd te kunnen doen.

\section{Toepassingsmogelijkheden van de onderzoeksresultaten}


Dit proefschrift heeft verschillende kanten, die allemaal kansen bieden voor productieve uitwerking en toepassing, en wel bij drie doelgroepen:

1. het ministerie van Binnenlandse Zaken en andere ontwerpers van bestuursbeleid;

2. de betrokkenen bij politieke besluitvorming in het algemeen;

3. de beoefenaren van de bestuurswetenschap.

\section{Ad 1. Voor de beleidsgemeenschap: het maken van bestuursbeleid}

Deze studie biedt een breed overzicht van het gevoerde beleid gedurende een lange periode, wat op zichzelf al meerwaarde biedt voor het leggen van verbanden en het leren kennen van leerzame ervaringen in het bestuursbeleid. In het boek zijn verschillende voorbeelden genoemd van wielen die opnieuw worden uitgevonden zonder dat de beleidsmakers zich zelfs maar bewust zijn dat (nagenoeg) hetzelfde concept al eerder is beproefd. Een gebrek aan geheugen blijkbaar of in andere termen 'zwak kennismanagement'. Een recent voorbeeld is de 'uitvinding' van een idee uit de Deense bestuurspraktijk voor gebruik in Nederland (right to challenge) om met aanpassing van regelgeving te experimenteren zonder dat men wist van een soortgelijk al veel eerder toegepast, eveneens uit Scandinavië ontleend idee voor experimenten in D'gemeenten.

Belangrijker nog is de grote lijn die uit het onderzoek naar voren komt over de toepassing van evaluaties en de ontwikkeling van beleid dat voortbouwt op een opgaande leercurve. Daaraan heeft het blijkens het fladderende beleid met de talloze voortijdig afgebroken of in ieder geval bij niet voortgezette projecten vooral ontbroken. De meest productieve les voor het ministerie lijkt dus te zijn: ontwikkel een bestuurstheorie, bijvoorbeeld stelselmatig voortbordurend op het idee van deliberatief netwerkbestuur, en verbindt aan concrete beleidsprojecten in de bestuurspraktijk de verdere verfijning en uitwerking van een dergelijke bestuurstheorie. Zo kunnen nu meestal zonder enig (departementaal) vervolg doodgelopen projecten als Ketenregie, Complementair bestuur, sociale vernieuwing, Bedrijfsbetrokkenheid, Differentiatie in het binnenlands bestuur, Burgerparticipatie en vele andere ingebed worden in een steeds verder verdiept inzicht in de wijze waarop het openbaar bestuur zijn belangrijkste taak kan vervullen, namelijk het bijdragen aan de oplossing van meer of minder heftige maatschappelijke vraagstukken. Hieraan gerelateerd zal het ministerie door deze studie meer weloverwogen dan klaarblijkelijk intuïtief al is gebeurd, een evenwicht weten te vinden tussen de nu en dan noodzakelijke interventie in de gang van zaken van andere overheden en publieke organisaties enerzijds en het grote goed van de autonomie en zelforganisatie van die organisaties in ons staatsbestel anderzijds.

De gedachtevorming over de kernelementen van het binnenlands bestuur zelf heeft door dit onderzoek een impuls gekregen, met grote mogelijkheden voor praktische doorwerking in onze bestuurspraktijk. Het betreft dan onder meer de volgende kernbegrippen:

- de gedecentraliseerde eenheidsstaat;

- de invloed van de toevoeging van de Europese Unie als extra bestuurslaag aan het Huis van Thorbecke;

- interactief bestuur en de verhouding tussen representatieve en participatieve democratie;

- de werkelijke betekenis van autonomie van lokaal bestuur in de 21e eeuw;

- nieuwe ijking van beginselen betreffende gelijkheid en verscheidenheid in deze tijd;

- en vooral de rol van bedrijven, instellingen en van (beleids)netwerken als reële actoren in het publieke domein.

Kortom, het advies aan Binnenlandse Zaken dat uit deze studie opklinkt, is: laat een overkoepelend denkkader, dus een omvattende bestuurstheorie, formuleren voor en door de onderdelen die verantwoordelijk zijn voor het bestuursbeleid, dat neerkomt op:

a. de vaststelling dat op bijna geen enkel vlak één overheid alleen nog in staat is om extern gericht beleid te ontwikkelen én zelf te realiseren (afhankelijkheden en verstrengelingen bestaan; schaarste van situaties en omstandigheden dat één overheid zaken kan regelen); 
b. oog hebben voor van elkaar afhankelijke overheden die taken, bevoegdheden en middelen op heel veel terreinen met elkaar delen en zullen willen en moeten verbinden (netwerken bestaan); c. erop vertrouwen dat netwerkpartners elkaar opzoeken en komen tot arrangementen en eventueel tot zelforganisatie (netwerken moeten productief worden; rol voor procesmanagement); d. omarmen van de complexiteit (niet te snel in de regelreflex schieten, consortia uitnodigen voor ideeënontwikkeling, experimenteren met verschillende oplossingen, de beste uitkiezen) als manier om het evenwicht tussen overheid en samenleving te herstellen.

Breng innovatieve (in netwerken groeiende) projecten die op deze bestuursvisie zijn gebaseerd gerust tot een goed einde, maar leer van de ervaringen in het licht van een dergelijke bestuurstheorie en zorg voor een zinnige voortzetting met een project dat op die ervaringen voortbouwt. Zolang het ministerie dit soort geluiden steeds alleen in kleine, kortstondige en geïsoleerde initiatieven blijft uitdragen, blijt het als organisatie onmachtig met de kenmerken van in zichzelf verdeeld los zand. Evalueer wat binnen een netwerk van de grond komt, ook binnen dat netwerk, maar houdt daarbij bovengenoemde omvattende bestuurstheorie in het vizier. Zo gezien wreekt zich het gebrek aan evaluatie van de afgelopen veertig jaar. De beleidsmakers uit die jaren wisten niet wat ze deden, teweegbrachten en waarom.

Het is zaak om deze bestuursvisie in overeenstemming te brengen met de conclusies betreffende de stand van de politieke besluitvorming in het algemeen, die hierna aan de orde komt.

\section{Ad 2. Voor de betrokkenen bij politieke besluitvorming in het algemeen}

De politieke gemeenschap zal in deze studie geïnteresseerd (kunnen) zijn, omdat het resultaat een spiegel voorhoudt voor de betrokkenen bij politieke besluitvorming die zich in een moeilijke overgangsfase bevindt. Het lijkt wel alsof men het nooit goed doet. Het politieke systeem is duidelijk niet (langer) vanzelfsprekend in staat voldoende weerklank te vinden in de samenleving. Steeds meer mensen keren de politieke partijen de rug toe, als lid en als trouwe kiezer, om maar een belangrijke indicator te noemen. Verkiezingen zijn steeds meer een soort sportwedstrijd geworden en de volatiliteit van de uitslagen is nooit hoger geweest. In de periode na 2000 is er veel publieke discussie geweest over het afgenomen vertrouwen van burgers in politiek en bestuur.

Wat heeft deze studie aan deze discussie toe te voegen? Er is immers geen onderzoek aan de kant van de burgers geweest. De onderhavige studie beperkt zich tot het kamp van gezagsdragers en ambtenaren in het openbaar bestuur. Daar en in de politicologie heerst in brede kring de mening dat de responsiviteit van het politiek-bestuurlijk systeem tekortschiet, waardoor de burgers in hun verwachtingen teleurgesteld worden. Hoewel het vertrouwen van burgers in het openbaar bestuur niet eenvoudig is vast te stellen, getuige de studie 'Bouwen aan vertrouwen in het openbaar bestuur' (Korsten en De Goede, 2006), zou dit het teruglopend vertrouwen in politiek en bestuur mede kunnen verklaren. Die veronderstelling raakt aan de ideeën over deliberatief netwerkbestuur (governance), die in dit onderzoek centraal staan. De open interactie met belanghebbende partners en onthechte burgers, het erkennen van participatieve democratie als nevengeschikte en serieus te nemen aanvullende bron voor politieke steun en inhoudelijke inbreng bij collectieve besluitvorming naast die van de gekozen volksvertegenwoordiging of als alternatief, en het centraal stellen van maatschappelijke problemen boven organisatorische drijfveren zijn kenmerken van deze veronderstelde mega-trend. De uitkomst van het onderzoek is dat deze mega-trend niet de doorbraak heeft meegemaakt die velen, ook in de wetenschap ervan verwachtten. En dit resultaat beperkt zich niet tot het werkveld van Binnenlandse Zaken. De verklaring die wordt geopperd, is dat er ook tegengestelde krachten zijn die dit effect tot heden verhinderen, die zelfs de laatste jaren zich sterker doen gelden dan in de optimistische fin-de-siècle-periode.

De auteur van dit boek liet en laat er geen twijfel over bestaan dat hij zelf tot de aanhangers van de governance-idee behoorde en behoort. Ook hij komt nu echter tot de conclusie dat een 'omwenteling' in deze richting in deze tijd niet van de grond komt of vanzelfsprekend werkt. 
Daarmee is het politieke systeem dus nog niet uit de brand, maar de studie helpt bij de diagnose van de huidige situatie, die als een soort impasse of patstelling gekwalificeerd kan worden. De gemaakte analyse doet vermoeden dat het samenspel van een zeer groot aantal factoren, waaronder een zeer gemêleerde samenstelling van de bevolking met uiteenlopende en zeker niet afnemende verwachtingspatronen, maakt dat het openbaar bestuur en de politieke actoren voorlopig niet zullen omslaan naar een totaal ander besturingsparadigma, omdat dit nu op landelijk niveau niet werkt. Het gegeven dat in een vrij groot aantal gemeenten wel degelijk een merkbare verandering in bestuursstijl zichtbaar werd en wordt (zonder verbindingen geen beleidsresultaten), wijst op het mogelijke belang van twee factoren: de aard van de te nemen besluiten, waarbij lokale kennis en betrokkenheid een grote rol spelen, en de relatieve luwte voor media-opwinding ten opzichte van landelijke kwesties.

De praktische waarde van deze analyse is 'rust in de tent'. Er zijn voor verschillende groepen in de Nederlandse samenleving waarschijnlijk alternatieve mogelijkheden om hun preferenties te uiten dus om hun ei kwijt te kunnen - maar voor de meerderheid is er geen noodzaak om op dit moment wild aan de knoppen van het politiek-maatschappelijke systeem te gaan draaien.

Van de analyse gaat de suggestie uit dat in een verdere fase van ontwikkeling van het digitale tijdperk wellicht minder druk uitgaat van de huidige factoren die belemmerend werken voor een systeemsprong. Het heeft geen zin deze nu te forceren. In dit opzicht (geen omwenteling) hebben Binnenlandse Zaken en de andere direct verantwoordelijken voor de inrichting van ons politiek systeem in de afgelopen veertig jaar het nog niet zo gek gedaan. Een geruststellende gedachte.

Is dit een uitnodiging tot zelfgenoegzaamheid? Zeker niet. Vanuit een positie waarin men zich niet opgejaagd voelt, is het goed mogelijk te werken met experimenten en geleidelijke ontwikkeling voorwaarts. Dit is ook de reden dat aan Binnenlandse Zaken de aanbeveling werd gedaan te werken aan een op verandering gerichte bestuurstheorie. Immers, van het bestuursdepartement, dat Binnenlandse Zaken nog steeds pretendeert te zijn, mag men verwachten voorop te lopen. Zeker is: overheden zijn voor tal van zaken afhankelijk van andere overheden en actoren uit de samenleving. Op tal van terreinen en bij tal van vraagstukken is er geen overheid te vinden die alleen doorzettingsmacht heeft. Er is geen overheid die alle taken, bevoegdheden en middelen heeft om pakweg over brandende kwesties als windenergie volledig zelf te beslissen. Er bestaan reeksen en kluwens van afhankelijkheden (vele zijn in wetten te vinden) en daarom kan alleen door middel van verbindingen resultaat worden geboekt. Het kan niet anders dan dat het governanceconcept relevantie blijft houden. De onvermijdelijkheid van governance is ook voor bestuurskundigen geen wensbeeld maar op zijn minst rond een aantal kwesties een empirisch feit, zoals het boek 'The Governance of Problems' van Rob Hoppe (2009) ook nog eens duidelijk maakt.

\section{Ad 3. Wetenschappelijk onderzoek en onderwijs}

De meeste bouwstenen voor de wetenschap die door dit onderzoek zijn aangedragen, komen terug in de volgende rubriek over innovatie. Hier kan worden volstaan met een hoofdaanbeveling aan de bestuurswetenschap waar dit boek mee afsloot.

Wil de bestuurskunde bestuurlijke en maatschappelijk relevante theorie ontwikkelen, dan kan zij in deze tijd niet volstaan met het hoofdzakelijk bestuderen van het binnenste van het openbaar bestuur, ook al is er hier en daar ruimte voor deliberatief netwerkmanagement en interactief bestuur. Daarom is de aanbeveling aan onderwijs en onderzoek in de bestuurswetenschappen, en in het bijzonder aan de integrerende bestuurswetenschap die zich bestuurskunde noemt, om haar domein te verbreden. Het kan een verdienste van deze studie worden geacht de noodzaak van deze verbreding nog meer te hebben aangetoond. Immers, de meerderheid van de Nederlandse bestuurskundigen postuleerde de overgang naar deliberatief netwerkbestuur (governance) zonder daarbij voldoende rekening te houden met de remmende krachten die binnen bestuur en 
samenleving werkzaam zijn. Daarnaast is er voor degenen die blijven hameren op een op handen zijnde omwenteling (shift), temeer reden om het werkveld van de bestuurskunde te verbreden, zoals ook het begrip bestuurskracht inmiddels bij de meeste kenners van dat begrip is verbreed tot 'vaardigheid om in wisselwerking met de samenleving maatschappelijke problemen op te lossen'. Maar ook hier geldt de paradox: lokale helden dragen netwerkgerichte bestuurskrachtanalyses uit, maar gemeentelijke overheden geven zelf geen opdracht voor netwerkanalyses op het vlak van bestuurskrachtanalyse. Ze trekken zich terug op een enger perspectief en financieel beperktere opdracht (Abma, 2012). Zelden geeft een netwerk van partners opdracht tot een analyse ten behoeve van het gehele netwerk. Maar evaluatief gerichte visitaties komen voor, bijvoorbeeld van veiligheidsregio's.

\section{Innovatief gehalte}

Met een proefschrift moet een promovendus tonen zelfstandig wetenschappelijk verantwoord onderzoek te kunnen doen. Dat onderzoek moet bij voorkeur een wetenschapsgebied verder brengen, met een kleine of een iets grotere stap. Is dergelijk onderzoek werkelijk vernieuwend? Vernieuwen betekent iets doen wat nog niet eerder is gedaan. En er moet sprake zijn van originaliteit. Dan wordt het al moeilijker. Maar bovendien moet het nieuwe idee, de uitvinding zo men wil, beproefd zijn. Een idee in het hoofd, hoe geniaal ook, is nog geen innovatie.

De originaliteit van deze studie schuilt allereerst in de uitgebreide beschrijving en analyse van een beleidsveld, want dit is voor het bestuursbeleid nog niet eerder gedaan. Analyses van de ontwikkeling van beleid op langere termijn zijn nog betrekkelijk schaars, maar ze komen incidenteel overigens wel voor, zoals over vijftig jaar sportbeleid. Er zijn echter twee andere innovatiepogingen die in dit onderzoek zijn ondernomen en zeker vermeldenswaard zijn. De ene is de gebruikte methode van discoursonderzoek en de andere is de operationalisering van de begrippen government en governance.

Discoursanalyse is als methode aantrekkelijk voor kwalitatief onderzoek. Een dergelijke analyse biedt voordelen door de mate van diepgang die bij de beschrijving van casuïstiek met deze methode mogelijk is. Het is voor veel onderzoekers van casus aanlokkelijk om grotere verbanden te presenteren uit de door hen verzamelde taaluitingen en hieraan conclusies te verbinden over algemene tendensen. Daarvoor zijn vernuftige technieken ontwikkeld (Van der Arend, 2007: 27 e.v.; Korsten, 2008a). De onderhavige studie waarschuwt overigens tegen het trekken van te snelle conclusies uit geregistreerde taaluitingen, zeker als het beleidsonderzoek betreft. Taalgebruik in een beleidsomgeving is uiterst flexibel en retoriek wordt er niet geschuwd. Daarom is in dit onderzoek een aantal waarborgen ingebouwd, die voor herhaling vatbaar lijken. In de eerste plaats zijn 'verhalen' niet over een vrij willekeurige groep casus bijeengebracht, maar is geprobeerd een limitatieve verzameling van alle relevante casus in een bepaalde periode onder de loep te nemen. In de tweede plaats is niet alleen gekeken naar verbale uitingen en interpretaties van betekenissen in gedrag, maar is een tweede maatstaf aangelegd om te concluderen of daadwerkelijk sprake is van een betekenisvolle en duurzame verandering in beleid (in dit geval de bestuurstheorie van Binnenlandse Zaken). Daarvan kon volgens de onderzoeker alleen sprake zijn als ook institutionele verankering (implementatie, opneming in wet en regelgeving, voortgezette aandacht in organisatieeenheden die met de uitwerking en uitvoering belast zijn) van een bepaald idee geconstateerd kon worden. Het is dus niet voldoende als in een aantal gevallen initiatieven van een bepaald type gesignaleerd worden, zij moeten ook beklijven. Als in de meerderheid van de gevallen aan beide voorwaarden voldaan was, zou sprake zijn van een daadwerkelijke shift, een paradigmatische verandering in het denken binnen het ministerie. Deze methode bleek goed uitvoerbaar en leidde ook tot heldere conclusies, terwijl alleen afgaan op de inhoudelijke typering van de voorbeelden in een bepaalde periode tot een andere conclusie zou hebben geleid dan de combinatie van beide voorwaarden. 
Innovatief was ook de operationele ijking van de begrippen government en governance. Zoals bij meer vindingen het geval is, is dit idee bij toeval, inductief zo men wil, ontstaan. Achteraf is de gekozen vierdeling van criteria uit paragraaf 3.5.2 echter goed te verantwoorden. Er schuilt een logische verdeling achter, volgens de cellen van een matrix: met op de assen intern - extern en instrumenteel - inhoudelijk. Ook deze typologie is in de praktijk goed toepasbaar gebleken. Het kostte weinig moeite om uit het onderzoeksmateriaal met de aangegeven criteria de typering als government of governance gericht te onderbouwen. 